\title{
Environmental Report 1996
}

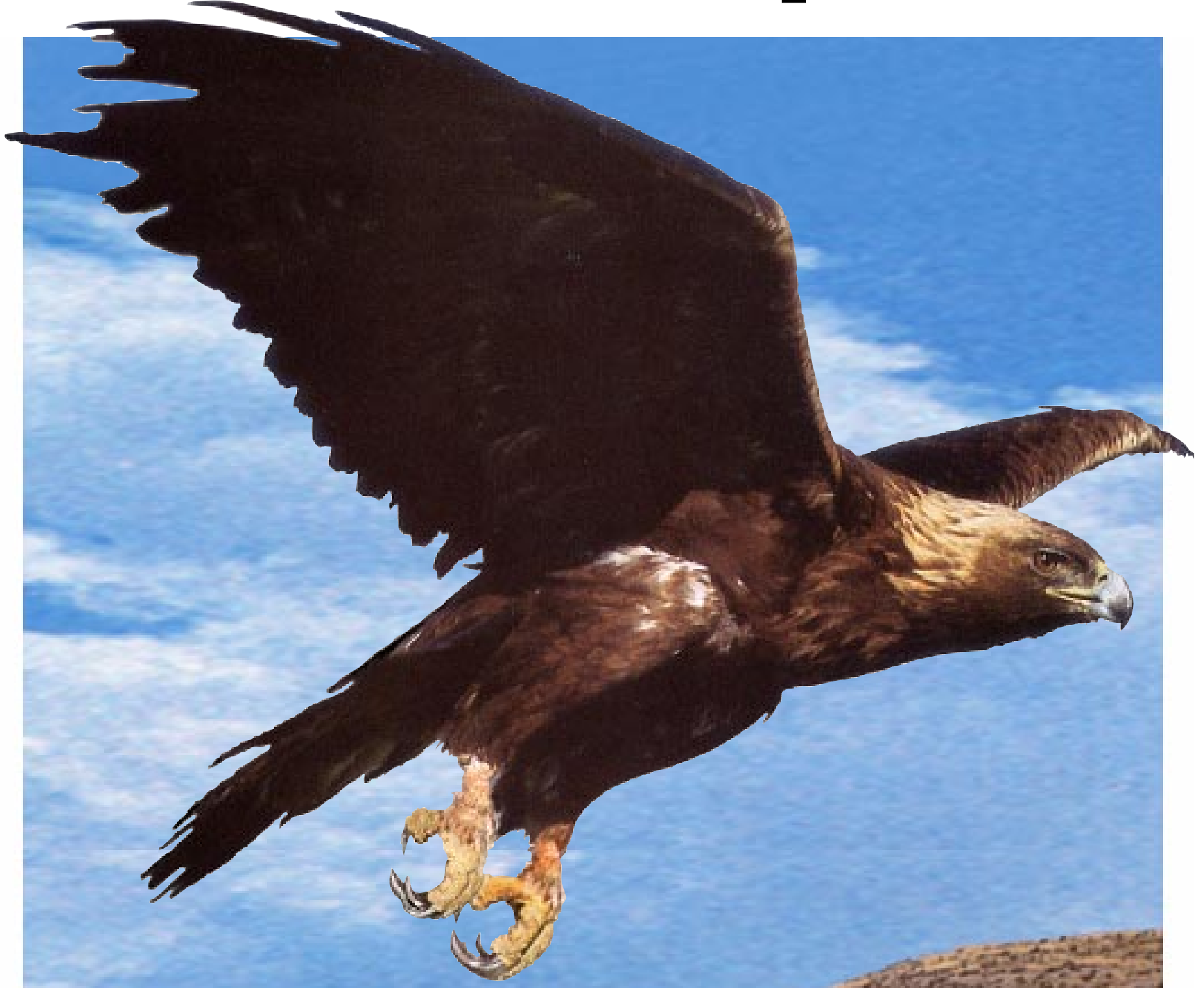




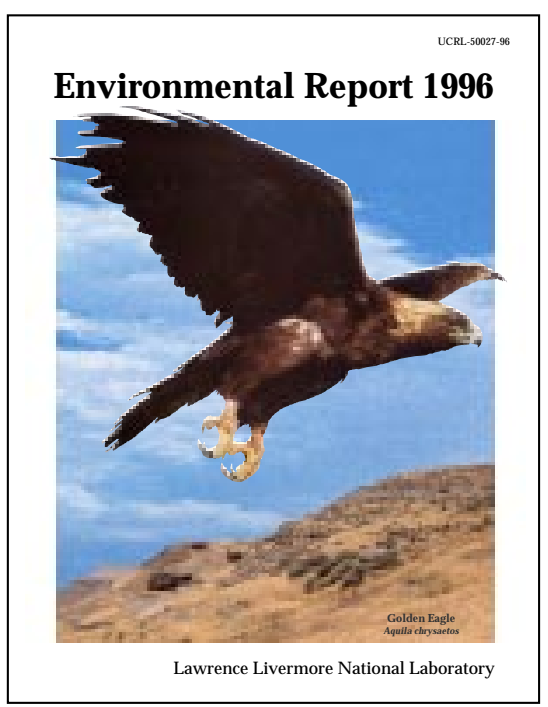

\section{Lead Compositor}

Beverly L. Chamberlain

\section{Art and Design}

Lee A. Dravidzius

\section{Proofreader}

Jill S. Sprinkle

\author{
Publication Services \\ Brenda M. Staley
}

\section{Cover}

The golden eagle (Aquila chrysaetos), a species protected by federal and state law, has long made its home in the coastal hills of California, foraging in grassland areas now part of both the Livermore site and Site 300 of the Lawrence Livermore National Laboratory. In 1996, the first documented breeding pair of golden eagles nested on a live power pole at Site 300. Eggs were laid and incubated in the nest, but it was abandoned. Laboratory personnel then moved the nest to a newly constructed platform with hope that the eagle pair will use it in the spring of 1998.

This year's cover was designed by Lee A. Dravidzius of LLNL's Technical Information Department. The editors thank Tom and Pat Leeson, noted photographers of North American eagles, for the use of their photograph.

For further information about this report contact: Bert Heffner, LLNL Public Affairs Department, P.O. Box 808, Livermore, CA 94550, (510) 424-4026. This report can be accessed on the Internet at http:/ / www.llnl.gov.saer. It is also available to DOE and DOE contractors from: Office of Scientific and Technical Information, P.O. Box 62, Oak Ridge, TN 37831 and to the public from: National Technical Information Service, U.S. Department of Commerce, 5285 Port Royal Road, Springfield, VA 22161.

\section{DISCLAIMER}

This document was prepared as an account of work sponsored by an agency of the United States Government. Neither the United States Government nor the University of California nor any of their employees, makes any warranty, express or implied, or assumes any legal liability or responsibility for any apparatus, product, or process disclosed, or represents that its use would not infringe on privately owned rights. References herein to any specific commercial products, process or service by trade name, trademark, manufacturer, or otherwise, does not necessarily constitute or imply its endorsement, recommendation, or favoring by the United States Government or the University of California. The views and opinions of authors expressed herein shall not be used for advertising or product endorsement purposes. 


\section{Environmental Report 1996}

\section{Authors}

Robert J. Harrach Gretchen M. Gallegos

Paula J. Tate Eric Christofferson Erich R. Brandstetter Jennifer M. Larson Arthur H. Biermann Barbara C. Fields Lucinda M. Garcia Kris A. Surano

\section{Editors}

Howard L. Lentzner

Mary M. Napolitano

\section{Contributing Authors}

Robert J. Vellinger

Sabre J. Coleman

Karen J. Folks

Richard A. Brown John Celeste

Donald H. MacQueen

Frank J. Gouveia Michael J. Taffet Richard G. Blake

Paris Althouse

Winifred Burks-Houck

Sandra Mathews
Shari L. Brigdon

Allen R. Grayson Constance E. DeGrange Joseph M. Woods Willie E. Montemayor $\mathrm{H}$ Keith Otsuki Charlotte Van Warmerdam Ellen Eagan-McNeill Stephen P. Harris Jamie M. Bennett Matthew L. Mlekush Saverio P. Mancieri
Jim S. Woollett, Jr. Kenneth C. Zahn Tina M. Carlsen Joseph R. Mc Intyre David W. Rice, Jr. William G. Hoppes Charlene H. Grandfield C. Susi Jackson Glenn A. May Jack Sims

Richard Ragaini
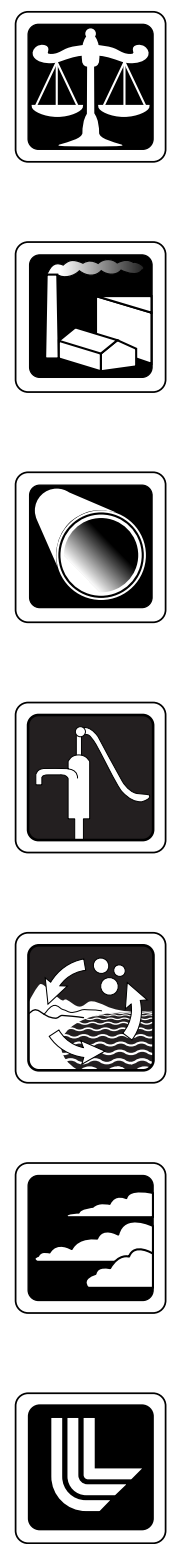



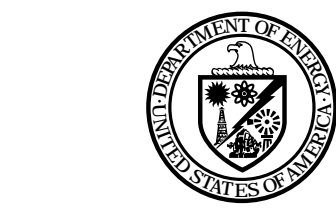

\section{Department of Energy}

Oakland Operations Office 1301 Clay Street

Oakland, California 94612-5208

(date)

Subject: 1996 Site Annual Environmental Report (SAER) for

the Lawrence Livermore National Laboratory (LLNL)

This report, prepared by LLNL for the U.S. Department of Energy, Oakland Operations Office (DOE/OAK), provides a comprehensive summary of the environmental program activities at LLNL for calendar year 1996. Site Annual Environmental Reports (SAERs) are prepared annually for all DOE sites with significant environmental activities, and distributed to relevant external regulatory agencies and other interested organizations or individuals.

To the best of my knowledge, this report accurately summarizes the results of the 1996 environmental monitoring, compliance, impacts assessment, and restoration program at LLNL. This assurance can be made based on DOE/OAK and LLNL review of the SAER, and quality assurance protocols applied to monitoring and data analyses at LLNL.

A reader survey form is provided with the SAER to provide comments or suggestions for future versions of the report. Your response is appreciated. Questions or comments regarding this report may also be made directly to DOE/OAK, by contacting Steve Black of the Environment, Safety, and Health Division at (510) 637-1595, or by mail to the address above.

Sincerely,

James T. Davis

Associate Manager for

Environmental Management 



\section{Preface}

The Environmental Report 1996 is prepared for the U.S. Department of Energy (DOE), as required by DOE Order 5400.1 and DOE Order 231.1, by the Environmental Protection Department (EPD) at the Lawrence Livermore National Laboratory (LLNL). The results of LLNL's environmental monitoring and compliance effort and an assessment of the impact of LLNL operations on the environment and the public are presented in this publication.

To produce a more readable and useful document for our diverse readership-including regulators, scientists and engineers, educators, the media, public interest groups, and interested citizens - we have, as in the past two years, divided this report into two volumes. The first describes LLNL's environmental impact and compliance activities and features descriptive and explanatory text, summary data tables, and plots showing data trends. The summary data include measures of the center of data, their spread or variability, and their extreme values. The first volume contains the Executive Summary and the Compliance Summary; it features individual chapters on monitoring of air, sewage, surface water, ground water, soil and sediment, vegetation and food stuff, and environmental radiation; and it contains chapters on site overview, environmental program information, radiological dose assessment, and quality assurance. Information on both the Livermore site and Site 300 are presented in each chapter.

The second volume, supporting Volume 1 summary data, is essentially a detailed data report that provides the individual data points, where applicable. Some summary data are also included in Volume 2, and more detailed accounts are given of sample collection and analytical methods.

Volume 1, which can be read without access to Volume 2, contains all information of interest to most of our readers. Volume 1 will be distributed as usual, but Volume 2 will be sent only upon request; a card for this purpose is included on the last page of Volume 1. Both volumes are available on the Internet at the address of LLNL's home page (http:/ / www.llnl.gov) under the heading "Publications," under the subheadings "Institutional Publications" and "Technical Papers." Alternatively, one can use the address given on the inside front cover of this report.

As in our previous annual reports, data are presented in Système International (SI) units. In particular, the primary units we use for radiological results are becquerels and sieverts for activity and dose, respectively, with curies and rem used secondarily $\left(1 \mathrm{~Bq}=2.7 \times 10^{-11} \mathrm{Ci} ; 1 \mathrm{~Sv}=100 \mathrm{rem}\right)$. Units are discussed in Supplement 12-1 of Chapter 12, Radiological Dose Assessment, in Volume 1. 
This document is the responsibility of the Operations and Regulatory Affairs Division of EPD.

Monitoring data were obtained through the combined efforts of the Operations and Regulatory Affairs Division, Environmental Restoration Division, the Chemistry and Materials Science Environmental Services laboratories, and the Hazards Control Department of LLNL. Special recognition is deserved for the dedication and professionalism of the technicians who carried out environmental monitoringGary A. Bear, David J. Castro, Paul C. Dickinson, David L. Graves, Marion Heaton, Renee Needens, Terrance W. Poole, Donald G. Ramsey, Rebecca J. Ward, Rhonda L. Welsh, and Robert Williams - and to the data management personnel-Jennifer Clark, Doris H. Ryon, Kimberly A. Stanford, and Suzanne Chamberlain. Special thanks to Judith L. Kelly for secretarial support and collation and distribution of drafts.

In addition, the following people made significant contributions to this report:

\begin{tabular}{lll} 
Nancy A. Allen & Everett B. Guthrie & Duane W. Rueppel \\
Bryan B. Bandong & Richard K. Henry & Adrienne Ridolfi \\
Michael E. Barnett & Joy M. Hirabayashi & Wayne H. Runnalls \\
Jeanne M. Bazan & G. Bryant Hudson & Ann M. Ruth \\
Nicholas A. Bertoldo & Thomas T. Kato & Sterling R. Sawyer \\
Rita Ann Brösius & Steven A. Kreek & William W. Schwartz \\
Karl Brunckhorst & Albert L. Lamarre & Gary L. Seibel \\
Janice Butler & Richard K. Landgraf & Rohit K. Shah \\
Brett Clark & Mary Ann Lee & Donald C. Shepley \\
C. Loren Comen & Susan C. MacLean & Richard L. Shonfeld \\
MaryAnne R. Cox & Sharlene Markow & Elizabeth L. Silva \\
Lisa Dorenkamp & Grace Massa & Judith C. Steenhoven \\
William L. Edwards, Jr. & William A. McConachie & Paula Stithem \\
Harry L. Galles & Dianne D. McGovern & Janet Tanaka \\
Keith V. Gilbert & Michael P. Meltzer & David G. Trombino \\
Raymond W. Goluba & Patricia L. Ottesen & Kent L. Wilson \\
Margorie A. Gonzalez & John Paolini & Fowzia N. Zaka \\
Curtis L. Graham & Ellen Raber & John P. Ziagos \\
& & \\
\hline
\end{tabular}




\section{Table of Contents}

List of Figures................................................................................................................. x xiii

List of Tables .................................................................................................................. x xvii

Executive Summary …................................................................................................ EX-1

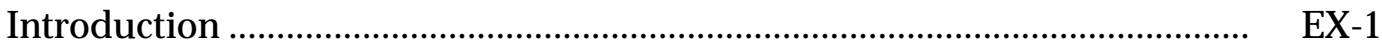

Environmental Monitoring Results .............................................................. EX-1

Radiological Dose Assessment .................................................................... EX-5

Environmental Compliance and Program Activities ..................................... EX-6

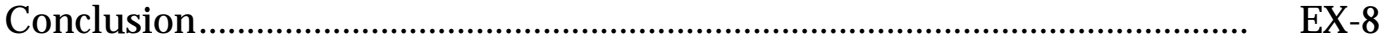

1. Site Overview .......................................................................................... 1-1

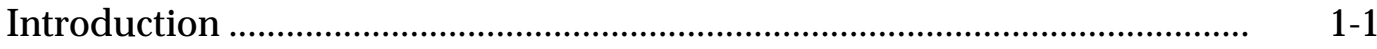

Operations ................................................................................................. $1-1$

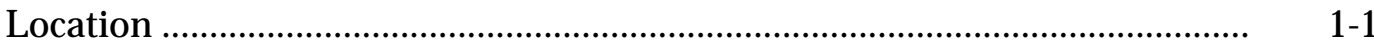

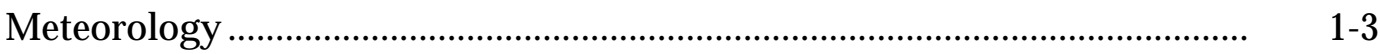

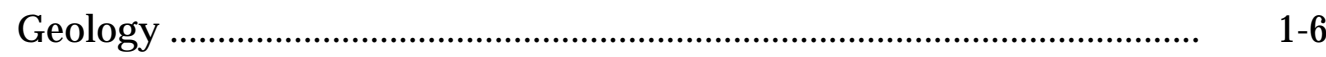

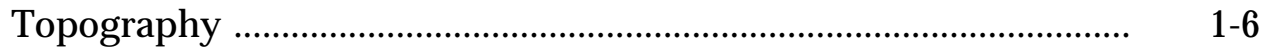

Hydrogeology .....................................................................................

Livermore Site …………………………………………………...

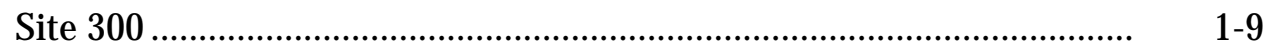

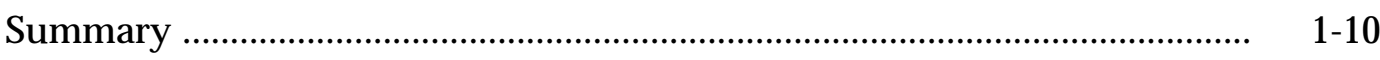

2. Compliance Summary ................................................................................. 2-1

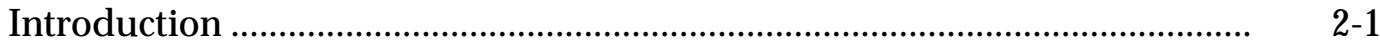

CERCLA/SARA, Title I.................................................................................

Livermore Site Ground Water Project ..................................................... 2 2-1

Documentation ……………………………………………....... 2-3

Milestones and Activities ....................................................................... 2-. 2-3

Community Relations ........................................................................ 2- 2-5

Site 300 Environmental Restoration Program ………………………...... 2- 2-6

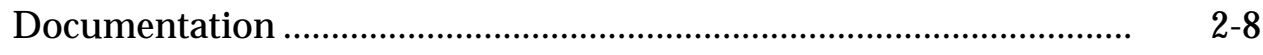

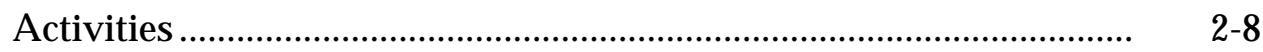

Community Relations ...................................................................... 2-. $2-11$

SARA, Title III .......................................................................................... 2

Activities Requiring Permits ...................................................................... $\quad 2-12$

Clean Air Act—Air Quality Management Activities ..................................... 2 2-16

National Emission Standards for Hazardous Air Pollutants .................. 2 2-16

Clean Water Act and Related State Programs............................................... 2 2-17

Ground Water and Surface Water .......................................................... 2- 2-18

Sewerable Water ………………………………………………….... 2-. 
Streambed Alteration Agreements and 404 Nationwide Permits

Injection Wells

Spill Prevention Control and Countermeasures Plan ............................. . 2-22

Tank Management ....................................................................................... 2-22

Tank Systems ................................................................................... 2-22

Tank Integrity Testing ........................................................................... 2-22

Closure and Leak Documentation........................................................... 2-23

Tank Upgrade Project .............................................................................. 2-24

Remedial Activities ......................................................................... 2-24

Resource Conservation and Recovery Act .................................................. 2.. 2-24

Hazardous Waste Permits .................................................................... 2-25

Hazardous Waste Reports for 1995 and 1996 ......................................... . 2-26

Hazardous Waste Transport Registration ................................................. 2 2-26

Waste Accumulation Areas ...................................................................... 2 2-27

Medical Waste ............................................................................................ 2-27

Building Inspections .......................................................................... 2-28

Site Evaluations Prior to Construction.......................................................... 2-28

Federal Facility Compliance Act .................................................................... 2-29

Toxic Substances Control Act ............................................................................ 2-29

National Environmental Policy Act................................................................ 2-29

Environmental Assessments .............................................................. 2-20

Floodplain Management and Wetland Protection ................................... 2 2-30

California Environmental Quality Act............................................................. 2-30

National Historic Preservation Act........................................................... 2 2-30

Endangered Species Acts and Sensitive Natural Resources ......................... 2 2-31

Environmental Occurrences .................................................................... 2-32

Contributing Authors Acknowledgment ..................................................... 2 2-35

3. Environmental Program Information............................................................ 3-1

Introduction .................................................................................................

Integrated Environmental, Safety, and Health Management System ........... 3-1

Work Smart Standards .............................................................................

Environmental Protection Department........................................................ 3-3

Operations and Regulatory Affairs Division ........................................... 3 3

Hazardous Waste Management Division ................................................. 3-5

Environmental Restoration Division ........................................................ 3

Performance Measures Summary ................................................................ 3-6

DOE Pollution Prevention Goals .................................................................. 3-6

Waste Minimization/Pollution Prevention ................................................... 3-. 3

Nonhazardous Solid Waste Minimization .............................................. 3-10

Diverted Waste ............................................................................ $\quad$ 3-10

Source Reduction and Pollution Prevention ............................................ 3-12 
Toxic Reporting Inventory Information............................................. 3-12

Additional Pollution Prevention Program Elements ……………………….. 3-12

Implementing Cost-Saving P2 Projects ................................................. 3-12

Review of New Processes or Experiments ............................................. 3-13

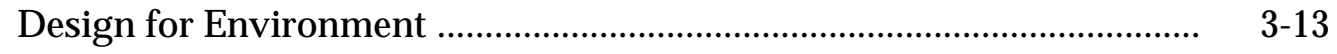

Implementing P2 Employee Training and Awareness Programs .......... 3 3-14

Current Return on Investment Projects ..................................................... 3-15

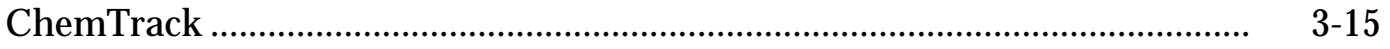

Current Issues and Actions ......................................................................... 3-16

Miniature Optical Lair Explorer …………………………………….... 3-16

Leaking Underground Fuel Tank Studies ................................................ 3-17

Initiative to Improve VOC Cleanup Process by Using Historical

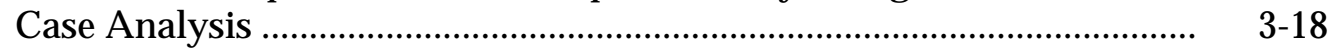

Cal/EPA Environmental Technology Certification Program .................. 3- 3-18

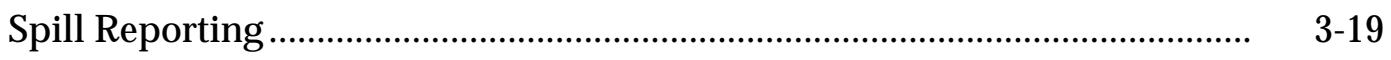

Response to Spills and Other Environmental Emergencies ........................... 3-19

Environmental Training ……………………………………………...... $\quad 3-20$

LLNL's Other Environmental Programs ...................................................... 3-. 3-20

Contributing Authors Acknowledgment ........................................................ 3-. 3-21

4. $\quad$ Air Monitoring................................................................................................. 4-1

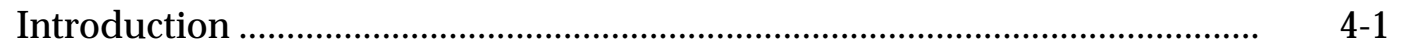

Methods .............................................................................................

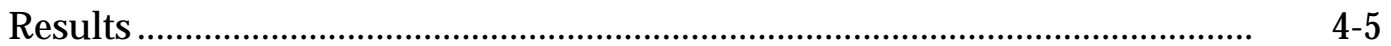

Livermore Site .....................................................................................

Airborne Radioactivity ................................................................... $4-5$

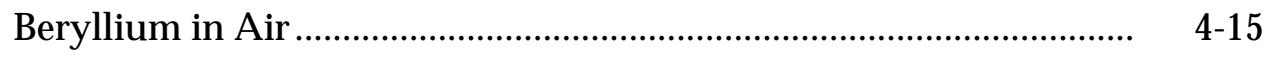

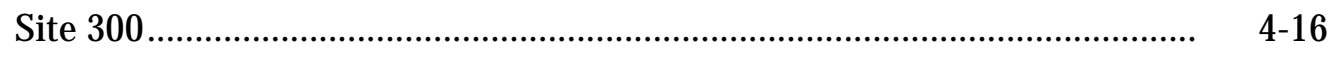

Airborne Radioactivity ………………………………………….... $4-16$

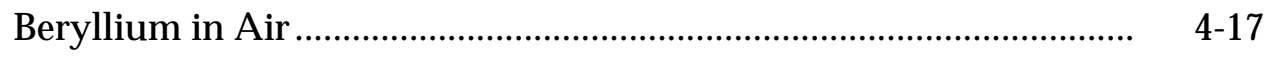

Environmental Impact ............................................................................... 4. $4-17$

Radioactive Materials ............................................................................... $4-18$

Nonradioactive Materials ………………………………………….... $4-18$

5. Air Effluent Monitoring …………………………........................................... 5-1

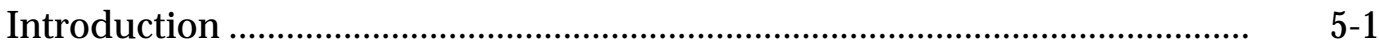

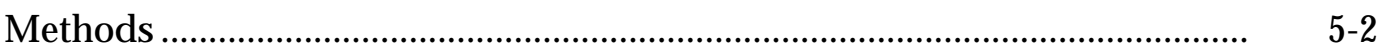

Measured Radioactive Air Emissions ……………………………………...

Livermore Site ...................................................................................

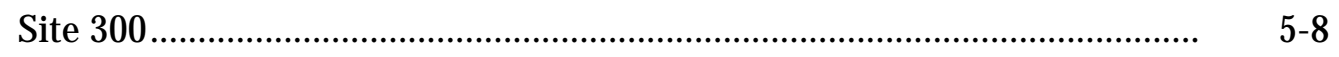

All Potential Sources for Emissions .................................................................. 5-8

Livermore Site Radioactive Emissions ......................................................

Site 300 Radioactive Emissions …………………………………….... 
Nonradioactive Effluents .............................................................................. 5-9

Environmental Impact ............................................................................ $\quad 5-10$

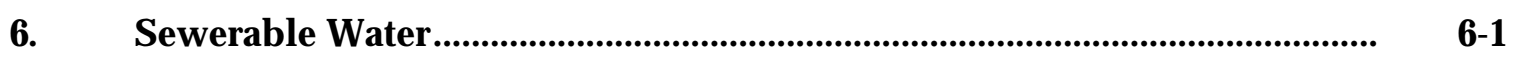

Introduction ........................................................................................

Preventive Measures ............................................................................ 6-1

Continuous Monitoring ..................................................................... $6-2$

Diversion System ................................................................................ $6-3$

Satellite Monitoring .......................................................................... $6-3$

Pretreatment and Categorical Discharges ................................................... $6-4$

Radioactive Pollutants in Sewage ........................................................... $6-7$

Monitoring Results .............................................................................. $\quad 6-7$

Environmental Impact of Radioactive Pollutants in Sewage .................. 6-9

Nonradioactive Pollutants in Sewage .......................................................... $\quad 6-15$

Monitoring Results .............................................................................. $\quad 6-15$

Environmental Impact of Nonradioactive Liquid Effluents .................. 6-17

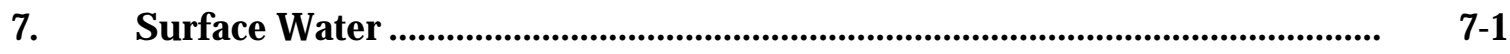

Introduction .......................................................................................... $\quad$ 7-1

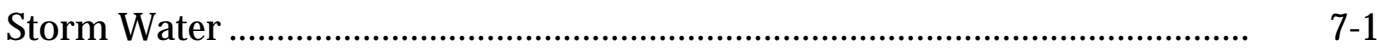

Livermore Site ..........................................................................

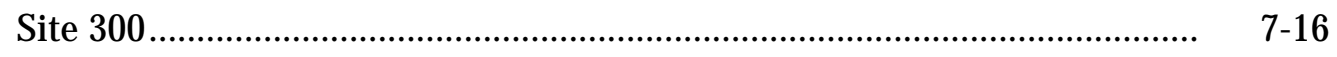

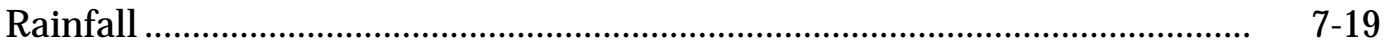

Livermore Site ................................................................................. $\quad$ 7-19

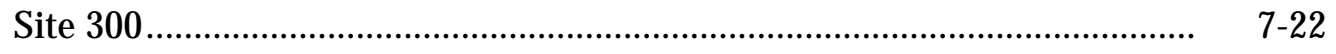

Livermore Site Drainage Retention Basin ….............................................. $\quad$ 7-23

Treatment Facilities ................................................................................. $\quad$ 7-34

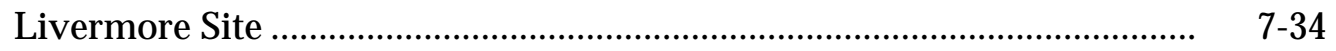

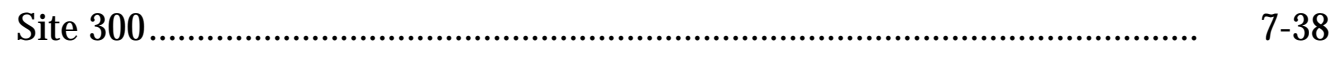

General Services Area ..................................................................... 7-38

Cooling Towers ............................................................................. $\quad$ 7-40

Other Waters ….......................................................................................... $\quad$ 7-44

Environmental Impacts ..........................................................................

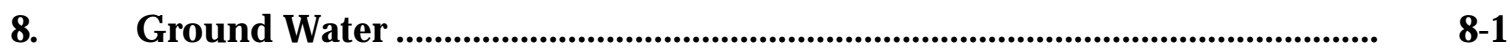

Introduction .................................................................................

Ground Water Regime ................................................................... 8 8

Livermore Site ............................................................................ $8-2$

Physiographic Setting ............................................................. $8-2$

Drainage Retention Basin ............................................................... 8 8

Hydrogeology …....................................................................... $8-3$

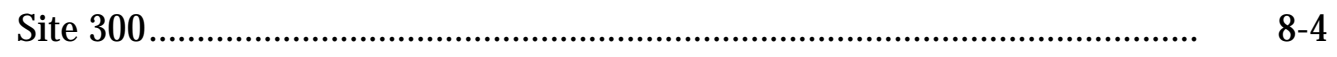

Physiographic Setting ................................................................ $8-4$ 
Hydrogeology ............................................................................. 8

Surveillance Ground Water Monitoring of Livermore Valley ……………..... $\quad 8-8$

Livermore Site ..................................................................................

Monitoring Results …………………………………………….... 8

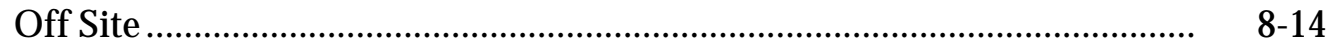

Surveillance Ground Water Monitoring of Site 300 ………………………..... $\quad$ 8-15

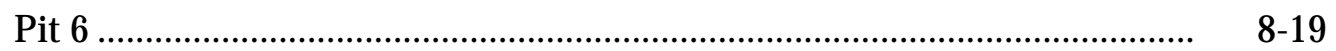

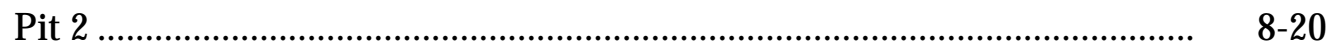

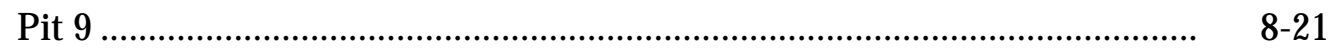

Elk Ravine Drainage Area ……………………………………………. $\quad$ 8-22

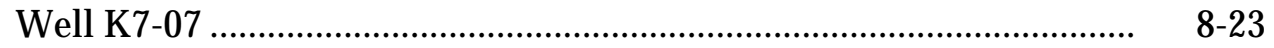

Wells NC7-61 and NC7-69 …………………………………….... $\quad 8-23$

Wells K2-04D, K2-04S, and K2-01C .................................................. 8-24

Wells NC2-11D and NC2-12D ......................................................... $\quad 8-25$

812CRK (Spring 6) and Well NC2-07 ………………………............ 8-25

Wells 18 and 20 ................................................................................ $\quad 8-25$

Off-Site Supply Wells .......................................................................... 8- 8-26

Compliance Ground Water Monitoring at Site 300 ....................................... 8 $\quad$ 8-27

Landfill Pits 1 and 7 ………………………………………………….. $\quad 8-28$

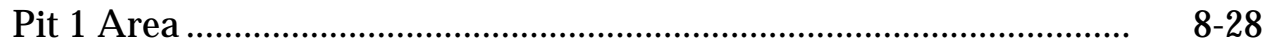

Pit 7 Complex Area ……………………………………………... $\quad 8-30$

Surface Impoundments ....................................................................... 8-. $8-34$

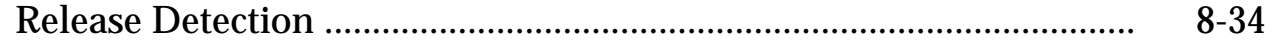

Influent Monitoring …………………………………………….... $8-38$

Sewage Evaporation and Percolation Ponds ………………………….... 8. 8-39

Ground Water Remediation........................................................................ $\quad 8-40$

Livermore Site ……………………………………………………... $\quad 8-40$

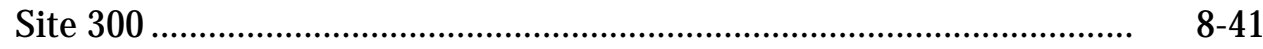

Ground Water Protection Management Program ......................................... $\quad 8-44$

Areas of Special Concern ....................................................................... 8- 8-44

Soil and Sediment Surveillance Monitoring ……………………….... 8-45

CERCLA Remedial Actions........................................................................ 8-46

Livermore Site ……………………………………………….... $8-46$

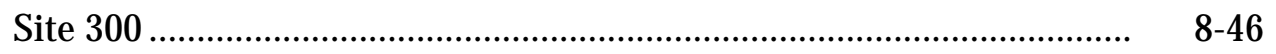

Environmental Impacts ............................................................................ 8- 8-47

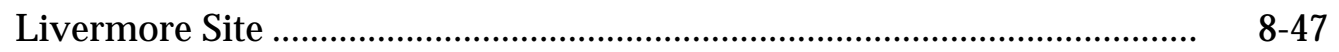

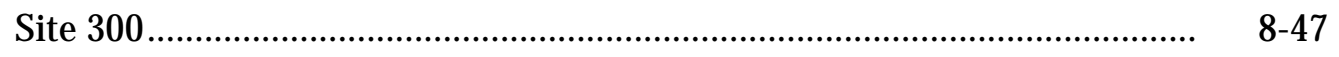

9. Soil and Sediment Monitoring ........................................................................ 9-1

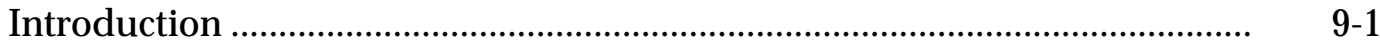

Methods ............................................................................................. 9

Livermore Valley Results ............................................................................. 9... 9-4 


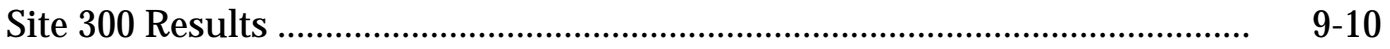

Environmental Impact...................................................................... $\quad 9-12$

Livermore Site …............................................................................... 9

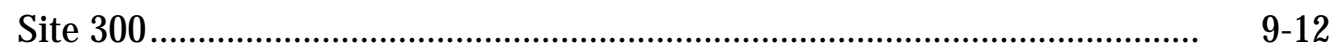

10. Vegetation and Foodstuff Monitoring …................................................... 10-1

Introduction ........................................................................................ 10 1

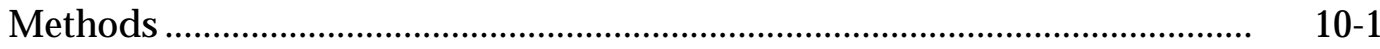

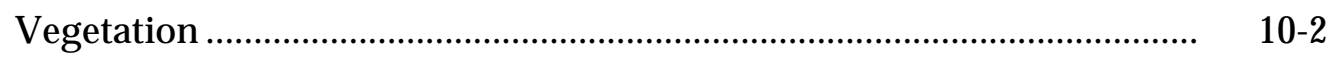

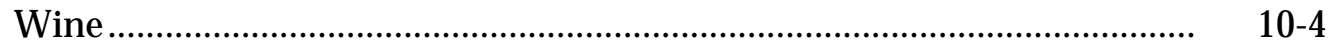

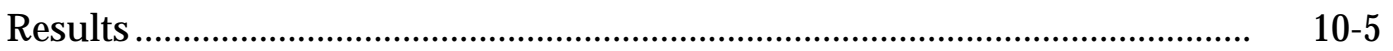

Livermore site ........................................................................... 10-5

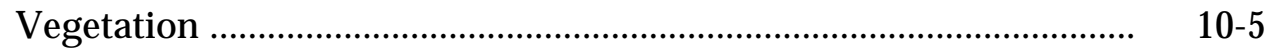

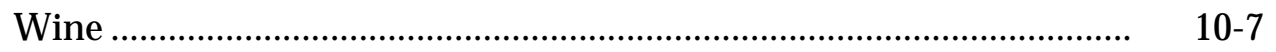

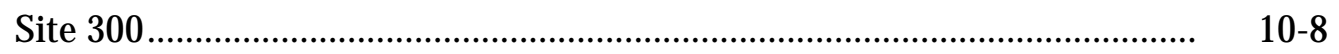

Vegetation ............................................................................. $10-8$

Environmental Impact .................................................................. 10-10

Livermore Site ............................................................................ 10-10

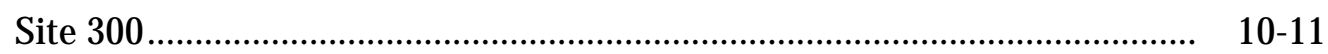

11. Environmental Radiation Monitoring ........................................................ 11-1

Introduction ......................................................................................... 11

Monitoring Locations …...................................................................... 11-1

Results of Gamma Monitoring …............................................................ 11-2

Livermore Site ........................................................................................ 11-3

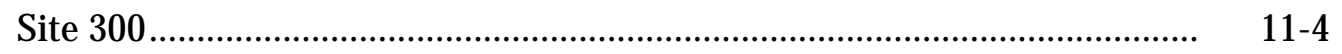

Environmental Impact ........................................................................ 11-6

12. Radiological Dose Assessment .......................................................................... 12-1

Introduction ................................................................................ $12-1$

Radiation Protection Standards............................................................... $12-1$

Modeling Code and LLNL Data Files ........................................................ 12-2

Maximally Exposed Individuals and Populations ....................................... 12 $12-5$

Monitored and Inventoried Sources........................................................... 12-6

Inventoried Sources ...................................................................... $12-6$

Monitored Sources....................................................................... $12-7$

Effluent Monitoring .................................................................. $12-7$

Surveillance Monitoring ............................................................... 12-8

Estimate of Total Radioactivity Released ............................................. 12-9

Calculations of Radiological Dose .............................................................. 12-9

Dose Breakdown by Facility .............................................................. 12-9

Unplanned Releases ............................................................................ 12-12

Doses to Site-Wide Maximally Exposed Individuals ............................. 12-13 
Collective Doses to Exposed Populations ................................................ 12-16

Summary and Conclusion ........................................................................ 12-18

Supplement 12-1: Radiation Basics ......................................................... 12-19

Supplement 12-2: Radiation Control Measures at LLNL ............................ 12-23

Supplement 12-3: Modeling Explosives Experiments at Site 300 ............... 12-24

13. Quality Assurance ................................................................................................. 13-1

Introduction ..................................................................................... 13-1

Quality Assurance Activities .................................................................. 13-2

Analytical Laboratories ............................................................................ 13-2

Participation in Laboratory Intercomparison Studies ............................ 13-2

Duplicate Analyse s.................................................................................... 13-3

Deviations and Changes to the Sampling Program ..................................... 13-7

Changes to Environmental Monitoring Networks .................................. 13-7

Explanation of Missing Samples.............................................................. 13-10

Statistical Methods ................................................................................ 13-13

Radiological Data .............................................................................. 13-14

Nonradiological Data ............................................................................ 13-14

Statistical Comparisons ................................................................. 13-14

Summary Statistics ............................................................................. 13-14

Radiation Units ......................................................................... 13-15

Appendix A. 1996 EPD Publications.................................................................. A-1

Appendix B. Methods of Dose Calculations .................................................................... B-1

References ............................................................................................................................ R-1

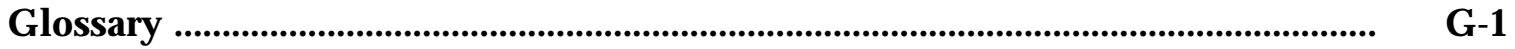





\section{List of Figures}

Figure 1-1. Locations of LLNL Livermore site and Site 300 ................................ $1-2$

Figure 1-2. Wind rose showing the average annual wind speed, frequency

of occurrence, and direction at the Livermore site, 1996 ..................... 1-4

Figure 1-3. Wind rose showing the average annual wind speed, frequency of occurrence, and direction at Site 300, 1996 ...................................... 1-6

Figure 1-4. Approximate ground water and surface elevation contours, Livermore site and vicinity ............................................................ $1-9$

Figure 1-5. Approximate ground water elevations in principal continuous

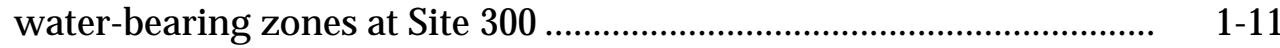

Figure 2-1. Location of existing and planned ground water treatment facilities

Figure 2-2. Environmental restoration study areas and activities at Site $300 \ldots . . .$.

Figure 4-1. Air particulate and tritium sampling locations, Livermore site, 1996.

Figure 4-2. Air particulate and tritium sampling locations, Livermore Valley, 1996

Figure 4-3. Air particulate sampling locations, Site 300, 1996

Figure 4-4. Monthly median gross alpha concentrations in particulate air samples from LLNL perimeter, Livermore Valley, and Site 300 sampling locations, 1996.

Figure 4-5. Monthly median gross beta concentrations in particulate air samples from LLNL perimeter, Livermore Valley, and Site 300 sampling locations, 1996

Figure 4-6. Median plutonium concentrations in air particulate samples at two locations, SALV and FCC, 1982 to 1996

Figure 4-7. Median concentration of beryllium in air particulate samples, Livermore site perimeter, 1974 to 1996

Figure 5-1. Buildings at the Livermore site having air monitoring systems for effluent gas streams

Figure 5-2. Tritium Facility emission (HTO and HT) between 1981 and 1996.

Figure 6-1. Sewer monitoring network

Figure 6-2. Historical trend in tritium concentration in LLNL sewage

Figure 6-3. Historical trends in plutonium and cesium concentration in LLNL sewage 
Figure 6-4. Average monthly concentrations of 12 metals in LLNL sanitary sewer effluent showing trends between 1994 and 1996.

Figure 6-5. Concentrations of metals in 24-hour and weekly composite samples of LLNL sewage compared to effluent pollutant levels (EPLs) during 1996.

Figure 7-1. Storm water runoff sampling locations, Livermore site and vicinity, 1996

Figure 7-2. Annual median gross alpha in LLNL storm water compared with the maximum contaminant level (MCL)

Figure 7-3. Annual median gross beta in LLNL storm water compared with the maximum contaminant level (MCL).

Figure 7-4. Annual median tritium concentrations in LLNL storm water

Figure 7-5. Chromium in LLNL storm water, compared with the maximum contaminant level (MCL) and ambient water quality criterion (AWQC) values

Figure 7-6. Annual median gross copper in LLNL storm water compared with the benchmark and ambient water quality criterion (AWQC) values

Figure 7-7. Annual median zinc concentrations in LLNL storm water compared with the benchmark and ambient water criterion (AWQC) values

Figure 7-8. Rain and storm water runoff sampling locations, Site 300 and vicinity, 1996.

Figure 7-9. Relationship of storm water gross alpha and gross beta to total suspended solids .....

Figure 7-10. Rain sampling locations, Livermore site and Livermore Valley, 1996

Figure 7-11. Trends of median tritium activity in rain and total stack emissions of HTO from LLNL and SNL/California, 1990 to 1996.

Figure 7-12. Sampling locations within the Drainage Retention Basin, 1996

Figure 7-13. Monthly average dissolved oxygen vs temperature at each depth location in the Drainage Retention Basin from January through December 1996.

Figure 7-14. Correlation between concentration of chlorophyll-a and turbidity and alkalinity at monitoring point CDBE

Figure 7-15. Water discharged from the Drainage Retention Basin in 1996

Figure 7-16. Location of existing and planned treatment facilities 
Figure 7-18. Surface and drinking water sampling locations, Livermore Valley, 1996

Figure 8-1. Hydrostratigraphic cross section for the Livermore site

Figure 8-2. Site 300 stratigraphy

Figure 8-3. Locations of surveillance ground water monitoring wells at the Livermore site, 1996

Figure 8-4. Map showing distribution of VOCs for 154 sampling locations in Hydrostratigraphic Unit 2 (HSU2), at Livermore site and vicinity, 1996

Figure 8-5. Locations of surveillance ground water monitoring wells in the Livermore Valley

Figure 8-6. Locations of surveillance ground water wells and springs, Site 300, 1996

Figure 8-7. Locations of surveillance ground water monitoring wells, Pit 6, 1996.

Figure 8-8. Locations of surveillance ground water monitoring wells, Pit 9, 1996.

Figure 8-9. Locations of compliance ground water monitoring wells, Pit 1 (K1-01C, -07, -02B, -03, -04, -05, -08, and -09) and Pit 2 surveillance wells (K1-01A and B, K1-02A, K2-01A and B, and K2-02A and B).

Figure 8-10. Map showing distribution of tritiated ground water extending from the Pit 7 Complex valley to Doall Ravine and Elk Ravine, 1996.

Figure 8-11. Locations of compliance ground water monitoring wells, Pit 7 Complex.

Figure 8-12. Map of the Pit 7 Complex showing two shallow ground water plumes where uranium is in excess of the California MCL for drinking water

Figure 8-13. Locations of compliance ground water monitoring wells in the Explosives Process Area

Figure 8-14. Locations of compliance ground water monitoring wells in the area of the sewage ponds

Figure 9-1. Soil sampling locations, Livermore Valley, 1996 .................................. $\quad 9-3$

Figure 9-2. Site 300 soil sampling locations, 1996 ................................................ $9-4$

Figure 9-3. Arroyo and drainage basin sediment sampling locations, 1996.......... 9-5

Figure 9-4. Median ${ }^{239+240} \mathrm{Pu}$ activities in surface soils, 1976 to 1996 .................... 
Figure 9-5. Median tritium concentrations in sediments $(\mathrm{Bq} / \mathrm{L}$ of recovered water), 1988 to 1996 ......

Figure 9-6. Uranium-238 activities in surface soils, 1976 to 1996 .......................... 9-11

Figure 10-1. Livermore Valley vegetation sampling locations, 1996 ....................... 10-2

Figure 10-2. Site 300 vegetation sampling locations, 1996 ....................................... 10-3

Figure 10-3. Median tritium activities in Livermore Valley vegetation samples, 1971 to 1996

Figure 10-4. Mean tritium in retail wines, 1977 to 1996, plotted by sampling year (error bars are \pm 1 standard error).

Figure 10-5. Mean tritium in retail wines, vintages 1980 to 1996 values are decay-corrected and plotted by vintage year (error bars are \pm 1 standard error)

Figure 10-6. Median tritium activities in vegetation at Site 300 sampling locations, 1971 to 1996 ...

Figure 11-1. Gamma dosimeter locations, Livermore site, 1996 ….......................... 11-2

Figure 11-2. Gamma dosimeter locations, Livermore Valley, 1996 ......................... 11-3

Figure 11-3. Gamma dosimeter locations, Site 300 and vicinity, 1996 .................... 11-4

Figure 11-4. Gamma measurements at the Livermore site perimeter, Livermore Valley, and Site 300, 1988 to 1996

Figure 11-5. Frequency distribution of external gamma radiation at 23 Livermore Valley locations in 1996

Figure 12-1. Dose to the sitewide maximally exposed individual member of the public, 1990 to 1996 .

Figure 12-2. Typical annual radiation doses from natural and man-made sources

Figure 13-1. Tritium concentration in air from collocated samples

Figure 13-2. Total alkalinity concentration in ground water from collocated samples

Figure 13-3. Plutonium-239 concentration on air filters from collocated samples 


\section{List of Tables}

Table 1-1. Wind rose data for LLNL's Livermore site at the 10-m level for 1996

Table 1-2. Wind rose data for LLNL's Site 300 at the 10-m level for 1996

Table 2-1. Volatile organic compounds (VOCs) removed from ground water at the Livermore site

Table 2-2. Major constituents of concern found in soil, rock, and ground water at Site 300

Table 2-3. Volatile organic compounds (VOCs) removed from ground water and soil at Site 300

Table 2-4. Summary of LLNL compliance with EPCRA in 1996

Table 2-5. Livermore site, SARA, Title III, Section 311, Chemical List

Table 2-6. Site 300, SARA, Title III, Section 311, Chemical List

Table 2-7. Summary of permits

Table 2-8. Inspections and tours of LLNL facilities by external agencies in 1996.

Table 2-9. Summary of discharges to surface water relative to NPDES permits.

Table 2-10. Summary of compliance with LWRP permit limits for discharges to the sanitary sewer

Table 2-11. Summary of streambed alteration agreements and 404 nationwide permits.

Table 2-12. Status of in-service tanks, December 31, 1996

Table 2-13. Tabulation of environmental occurrences reported under the Occurrence Reporting System, 1996

Table 3-1. DOE environmental protection performance measures

Table 3-2. Waste generation totals, 1990 to 1996 (in tons)

Table 3-3. Waste reduction, 1996

Table 3-4. Nonhazardous landfill totals (in tons) in 1996.

Table 3-5. Waste diversion summary table for 1996.

Table 3-6. EPD training courses.

Table 4-1. Gross alpha and gross beta in air particulate samples summarized by month, 1996 .....

Table 4-2. Gamma activity in air particulate samples, Livermore site perimeter and Site 300, 1996 
Table 4-3. Plutonium activity in air particulate samples (in $10^{-15} \mathrm{~Bq} / \mathrm{mL}$ ), 1996

Table 4-4. Uranium mass in air particulate samples, 1996

Table 4-5. Tritium in air samples (in 10-9 Bq/mL), 1996

Table 4-6. Beryllium in air particulate samples (in $\mathrm{pg} / \mathrm{m}^{3}$ ), Livermore site perimeter and Site 300, 1996.

Table 5-1. Air effluent sampling locations and systems

Table 5-2. Measured radiological air effluent emissions for the Livermore site, 1996

Table 5-3. Calculated radioactive air emissions from the Livermore site for 1996

Table 5-4. Calculated radioactive air emissions from Site 300 for 1996.

Table 5-5. Nonradioactive air emissions, Livermore site and Site 300, 1996

Table 6-1. Limits under permit 1250 for discharges into the municipal sewer .....

Table 6-2. Discharge limits for nonradioactive pollutants in wastewaters at point of discharge into LLNL sewer

Table 6-3. LLNL's internal discharge limits for radioisotopes in wastewaters .....

Table 6-4. Compounds detected in water discharged to the sanitary sewer in 1996 under permits 1508 and 1510 .

Table 6-5. Estimated total radioactivity in LLNL sanitary sewer effluent, 1996

Table 6-6. Various radionuclides in sanitary sewer effluents, LLNL and Livermore Water Reclamation Plant (LWRP), 1996

Table 6-7. Sewer discharge release limits for ${ }^{3} \mathrm{H},{ }^{137} \mathrm{Cs}$, and ${ }^{239} \mathrm{Pu}$

Table 6-8. Radioactive liquid effluent releases from the Livermore site, 1987 to 1996.

Table 6-9. Monthly results for metals in LLNL sanitary sewer effluent (in $\mathrm{mg} / \mathrm{L}$ ), 1996 summary

Table 6-10. Positively detected physical and chemical parameters in LLNL sanitary sewer effluent, 1996.

Table 6-11. Inadvertent discharges detected by the continuous monitoring system in 1996 .

Table 7-1. Requested analyses for storm water samples, 1996

Table 7-2. Storm water nonradioactive comparison criteria, Livermore site, 1996

Table 7-3. Radioactivity (in Bq/L) in storm water runoff, Livermore site, 1996 
Table 7-4. Nonradioactive constituents above comparison criteria in storm water runoff, Livermore site, 1996 .

Table 7-5. Radioactivity in storm water runoff at Site 300 (in Bq/L), 1996

Table 7-6. Tritium activities (in Bq/L) in rainfall for the Livermore site and Livermore Valley .

Table 7-7. Treated ground water and Drainage Retention Basin discharge limits identified in CERCLA ROD as amended for outfalls CDBX, TFB, TFC, TFD, TFE, TFF, TFG, TF406, and TF518.

Table 7-8. Routine water quality management levels for the Drainage Retention Basin

Table 7-9. Drainage Retention Basin monitoring event in which the concentration of metals exceeded discharge limits at CDBX shown with associated metal concentration at WPDC

Table 7-10. Results of Drainage Retention Basin monitoring at sampling location $\mathrm{CDBE}$

Table 7-11. General Services Area ground water treatment system surface discharge effluent limitations

Table 7-12. Summary data from compliance monitoring of Site 300 primary cooling towers, 1996

Table 7-13. Summary data from operational monitoring of Site 300 primary cooling towers, 1996

Table 7-14. Radioactivity (in Bq/L) in surface and drinking water in the Livermore Valley, 1996

Table 8-1. Water quality objectives for organic compounds, 1996

Table 8-2. Water quality objectives for inorganic compounds, 1996

Table 8-3. Water quality objectives for radioactive compounds

Table 8-4. Treated ground water discharge limits identified in WDR Order No. 88-075 for TFA

Table 8-5. Site 300 Building 834 ground water treatment surface discharge effluent limitations

Table 9-1. Summary of soils and sediment analytical data, 1996

Table 10-1. Tritium in vegetation (in Bq/L), 1996

Table 10-2. Tritium (Bq/L) in retail wine, 1996

Table 11-1. Summary statistics for gamma monitoring at all sites in 1996 (in $\mathrm{mSv}$ )

Table 11-2. Annual dose by year at the Livermore site perimeter due to direct gamma radiation 
Table 12-1. Sources of radiation dose from LLNL releases to air: stacks (on buildings containing radioactive materials management areas) and diffuse area sources

Table 12-2. Annual dose to the SW-MEI from explosives experiments on firing tables at Site 300, 1990-1996, related to the total quantity of depleted uranium used in the experiments and the total quantity of high explosives (HE) driving the detonations .....

Table 12-3. Major contributors to LLNL's radiation dose via airborne emissions, 1996.

Table 12-4. Doses (in $\mu \mathrm{Sv}$ ) calculated for the site-wide maximally exposed individual for the Livermore site and Site 300, 1990 to 1996

Table 12-5. Comparison of background and LLNL radiation doses, 1996 $12-17$

Table 13-1. Quality assurance duplicate sampling

Table 13-2. Quality assurance duplicate sampling

Table 13-3. Quality assurance duplicate sampling

Table 13-4. Changes to environmental monitoring networks in 1996

Table 13-5. Sampling completeness in 1996, Livermore site and Site 300 $13-13$ 


\section{Executive Summary}

Robert J. Harrach

Howard L. Lentzner

\section{Introduction}

Lawrence Livermore National Laboratory (LLNL), a U.S. Department of Energy (DOE) facility operated by the University of California, serves as a national resource of scientific, technical, and engineering capabilities. The Laboratory's mission focuses on nuclear weapons and national security, and over the years has been broadened to include areas such as strategic defense, energy, the environment, biomedicine, technology transfer, the economy, and education. The Laboratory carries out this mission in compliance with local, state, and federal environmental regulatory requirements. It does so with the support of the Environmental Protection Department, which is responsible for environmental monitoring and analysis, hazardous waste management, environmental restoration, and assisting Laboratory organizations in ensuring compliance with environmental laws and regulations.

LLNL comprises two sites: the Livermore site and Site 300. The Livermore site occupies an area of 3.28 square kilometers on the eastern edge of Livermore, California. Site 300, LLNL's experimental testing site, is located 24 kilometers to the east in the Altamont Hills, and occupies an area of 30.3 square kilometers. Environmental monitoring activities are conducted at both sites as well as in surrounding areas.

This summary provides an overview of LLNL's environmental activities in 1996, including radiological and nonradiological surveillance, effluent and compliance monitoring, remediation, assessment of radiological releases and doses, and determination of the impact of LLNL operations on the environment and public health.

\section{Environmental Monitoring Results}

During 1996, the Environmental Protection Department sampled air, sewerable water, ground water, surface water, soil and sediment, vegetation and foodstuffs, and measured environmental radiation. Over 20,300 environmental samples were taken and analyses were conducted for more than 310,000 analytes. These numbers represent increases of $9 \%$ and $25 \%$, respectively, over the previous year. 
LLNL's sampling networks undergo constant evaluation; changes are made, as necessary, to ensure adequate, cost effective monitoring of all environmental media potentially affected by LLNL operations. Once samples are collected, they are analyzed for radioactive and nonradioactive substances using standard methods such as analytical procedures approved by the U.S. Environmental Protection Agency (EPA), special systems such as the continuous monitoring system for Livermore site sewage, or special analytical techniques designed to measure very low levels of radionuclides. Environmental radiation is also measured directly using dosimeters.

\section{Air Monitoring}

Air surveillance monitoring was performed for various airborne radionuclides (including particles and tritiated water vapor) and beryllium at locations on the Livermore site, Site 300, throughout the Livermore Valley, and in Tracy. Concentrations of all monitored radionuclides and beryllium at all of these locations were well below levels that would endanger the environment or public health, according to existing regulatory standards. As examples: the concentration of plutonium on air filter samples collected at LLNL on-site locations, perimeter locations, and Livermore Valley locations showed median values, respectively, of only $0.02 \%, 0.02 \%$, and $0.002 \%$ of the federal Derived Concentration Guide (DCG), which specifies the concentration of radionuclides that could be inhaled continuously 365 days a year without exceeding the DOE radiation protection standard for the public. Median concentrations of tritiated water vapor at Livermore Valley sampling locations showed a highest median value of $0.001 \%$ of the DCG, while the highest median values on the Livermore site perimeter and within the site boundaries were, respectively, $0.007 \%$ and $0.2 \%$ of the DCG. The highest median concentration of beryllium on the Livermore site perimeter was $0.1 \%$ of the guideline level established by the Bay Area Air Quality Management District and the EPA. Similar results (small fractions of guideline levels) were found at air surveillance monitoring locations at Site 300 and its environs.

\section{Stack Effluent Monitoring}

Stack air effluent was monitored continuously at nine buildings on the Livermore site. These included the Tritium Facility (Building 331), the Plutonium Facility (Building 332), the Heavy Element Facility (Building 251), and four buildings involved with Laser Isotope Separation program activities. This directly measured data on source emissions provides an accurate, time resolved measure of the quantity of radionuclides released from these major facilities, and provides realistic source terms to improve the quality and credibility of our air dispersion and dose assessment modeling. 


\section{Executive Summary}

\section{Wastewater Monitoring}

Discharges of radioactive and hazardous materials to the combined sanitary and industrial sewer at the Livermore site are controlled by limiting the disposal of those materials, implementing engineering controls, and routing some discharged material to retention tanks for later characterization and treatment. Flow-proportional samples of discharged wastewater are regularly collected and analyzed to assure that LLNL's sewage effluent meets the requirements of the permit granted by the City of Livermore. In addition, effluent is monitored continuously for $\mathrm{pH}$, selected metals, and radioactivity. Should concentrations be detected above warning levels, LLNL's sewer diversion system is automatically activated. The diversion system captures all but the first few minutes of wastewater flow that causes an alarm, thereby protecting the Livermore Water Reclamation Plant (LWRP) and minimizing any required cleanup.

In 1996, the Livermore site discharged an average of 0.94 million liters per day of wastewater to the City of Livermore sewer system, an amount that constitutes $4.6 \%$ of the total flow to the system (about $20 \%$ of this flow was generated by Sandia National Laboratory/California). LLNL achieved greater than 99\% compliance with LWRP permit limits covering discharges into the sanitary sewer during the year. One daily analytical result for mercury exceeded the discharge limit in LLNL's Wastewater Discharge Permit, but was not considered a permit violation because it fell within the range of uncertainty in the effluent pollutant level. Concentrations of other metals in LLNL's sewer effluent were below discharge limits. Seven $\mathrm{pH}$ excursions occurred in 1996 and were reported to the LWRP. Only one of the incidents warranted a sewage diversion, and the diverted wastewater was released back to the sanitary sewer when analysis showed it was within acceptable limits. The LWRP issued two Letters of Concern for the $\mathrm{pH}$ excursions. However, in March 1997, LLNL was issued a notice of violation (NOV) for $\mathrm{pH}$ and silver exceedances occurring in February 1997. The NOV specifically targeted these two discharges, but treated the $\mathrm{pH}$ exceedance as a continuation of the $1996 \mathrm{pH}$ exceedances. All pH incidents were short-duration, relatively small-volume discharges.

\section{Water Monitoring}

Surface water sampling and analysis are a large part of the LLNL surveillance and compliance monitoring effort for the Livermore site, Site 300, and their surrounding regions. The waters monitored include storm water runoff; rainfall; reservoirs and ponds, including the swimming pool and Drainage Retention Basin at the Livermore site; tap water; treated ground water discharges; wastewater discharges from cooling towers at Site 300; and drinking water supply wells. Depending on location, the samples may be analyzed for gross alpha and gross beta radiation, tritium, uranium, and nonradioactive pollutants, including solvents, metals, high explosives, and pesticides and other properties such as total suspended solids, conductivity, and $\mathrm{pH}$. 
In August 1996, EPA awarded LLNL the national first place award in the industrial category for its excellent storm water management program.

Ground water in the Livermore Valley and the Altamont Hills is monitored to assess the progress of remediation efforts in areas of known contamination, to test that LLNL operations do not significantly impact local water sources, and to comply with numerous federal, state, and local permits. Ground water samples are routinely measured for tritium, uranium, and other radioisotopes, gross radioactivity, toxic metals, a wide range of organic chemicals and other general contaminant indicators. Special consideration is given to monitoring those dissolved elements and organic compounds that are known to be toxic in trace amounts. In 1996 at the Livermore site, no ground water in monitored off-site wells exceeded primary drinking water maximum contaminant levels (MCLs) for any of the monitored constituents. At Site 300, tritiated water and depleted uranium have been released to ground water in the past, but boundaries of the contaminated water lie within the site boundaries, and this water is not used for agriculture nor consumed by people or cattle. Fate and transport modeling predicts the tritium will decay to activity levels below the drinking water MCL before site boundaries are reached, and maximum uranium activities that could reach potential exposure points are estimated to be small compared to the California MCL for uranium in drinking water. Trichloroethylene (TCE) has been released to ground water at numerous locations at Site 300 in the past. With the exception of a plume extending off site from the Eastern General Services Area, all of the TCE-bearing ground water is on site. Water in the off-site plume is being pumped back to the site and cleansed of TCE.

\section{Soil and Sediment Monitoring}

Soil and sediment sample analyses for the Livermore site in 1996 indicated that the impact of Laboratory operations on these media were insignificant and unchanged from previous years. The highest measured level of plutonium (isotopes 239 and 240) represented $6.5 \%$ of the EPA preliminary remediation goal for commercial or industrial sites; this occurred at the LWRP. At Site 300, the concentrations of radionuclides and beryllium in soil samples were representative of background or naturally occurring levels, as in previous years, with the exception of one sampling location. Elevated concentrations of uranium-238 and beryllium found at location $812 \mathrm{~N}$ in 1996 were attributed to contamination by debris from firing table experiments.

\section{Vegetation and Foodstuffs Monitoring}

Area vegetation and foodstuffs are monitored for their tritium content. Tritium concentrations in samples taken near the Livermore site were found to be higher than those in samples taken from more distant locations, consistent with the trend of data over the last 15 years. The tritium concentrations in vegetation in 1996 were not 


\section{Executive Summary}

significantly different than those reported in 1995. In 1996, as in the past, tritium concentrations in Livermore Valley wines were slightly above those for wines tested from Europe and other locations in California; but the tritium levels are quite low. Mean levels for the 1996-sampling-year data from all areas were not significantly different from those reported for the 1994 and 1995 sampling years. Even the highest detected value, 5.6 becquerels per liter (152 picocuries per liter), represents only $0.8 \%$ of the amount of tritium California allows in drinking water (no health standards exist for radionuclides in wine).

\section{Estimates of Releases Based on Monitoring and Inventory Data}

The foregoing monitoring data, supplemented by radionuclide inventory data from LLNL's radioactive materials management areas, provide estimates of the total quantity and type of radionuclides released from the Laboratory during operations in 1996. The amount of radioactivity released from LLNL was slightly higher than in 1995, but was typical of levels over the last five years, and well below the those seen in 1991 and earlier years.

The most significant radiological effluent for the Livermore site continues to be tritium, the radioactive isotope of hydrogen. The source of nearly all tritium emissions is air emissions from Building 331, the Tritium Facility. Increased decontamination and decommissioning activities in this facility accounted for the higher emissions compared to the previous year. At Site 300, the dominant radioactive effluent is depleted uranium, which contains isotopes with atomic weights 238,235 , and 234 in the weight percentages $99.8,0.2$, and 0.0005 , respectively. The primary sources of these emissions were experiments on the firing tables adjacent to Buildings 801 and 851, resulting in estimated releases of the three isotopes that were about 1.6-times higher than those in 1995, but within the range of variation seen from year to year due to changes in the level of operations at the firing tables. The impact of these releases on public health is summarized in the next section. Nonradioactive air emissions from exempt and permitted sources at LLNL are quite small; for example, total emission of nitrogen oxides from the Livermore site is $58 \mathrm{~kg} /$ day, which is $0.012 \%$ of the amount for the total Bay Area; corresponding numbers for reactive organics are $30 \mathrm{~kg} /$ day and $0.006 \%$.

\section{Radiological Dose Assessment}

Radiological dose-assessment modeling, using EPA-mandated computer models, actual LLNL meteorology, population distributions appropriate to the two sites, and 1996 radionuclide inventory and monitoring data, was conducted this past year for each key facility and each new or modified emission point at the Livermore site and Site 300. 
The public doses we report result from air releases of radionuclides during routine operations and (when applicable) from accidents. The principal exposure pathways are taken into account: internal exposures from inhalation of air and ingestion of foodstuffs and drinking water, and external exposures from contaminated ground and immersion in contaminated air. Releases of radioactivity from LLNL via the water pathway do not contribute to the public dose, since they are not consumed by any individual.

The calculated total potential dose for the sitewide maximally exposed individual (SW-MEI), i.e., a hypothetical member of the public having the greatest possible exposure from Livermore site operations in 1996, was 0.93 microsievert (0.093 millirem) for the Livermore site. This exceeds last year's value by 0.52 microsievert ( 0.052 millirem), primarily because of increased decontamination and decommissioning activity in the Tritium Facility. Trends in this dose over the last seven years are generally downward from the 2.40 microsievert ( 0.24 millirem) level in 1990; these are small radiation quantities, exhibiting large percentage fluctuations from one year to the next.

The calculated total potential dose to a hypothetical person having the greatest possible exposure at Site 300 during 1996 was 0.33 microsievert (0.033 millirem). Explosive tests at the Building 801 and Building 851 firing tables accounted for practically this entire amount. This total dose is about $43 \%$ larger than the previous year's value, reflecting the use of greater quantities of depleted uranium in the explosives experiments. Trends in annual dose levels from Site 300 operations show that this magnitude of year-to-year fluctuation is typical.

The doses to the maximally exposed public individual from Livermore site and Site 300 emissions, respectively, amounted to about $0.9 \%$ and $0.3 \%$ of the EPA National Emission Standards for Hazardous Air Pollutants (NESHAPs) standard. These doses are a small fraction (about 1/3000) of the doses received by these populations from natural background radiation. Thus, the potential radiological doses from LLNL operations in 1996 were well within regulatory limits and were very small compared to doses from natural background radiation sources.

\section{Environmental Compliance and Program Activities}

LLNL works to ensure that its operations comply with all environmental laws and federal, state, and local regulatory guidelines. Many activities related to water, air, waste, waste reduction, community "right to know," and other environmental issues were addressed in 1996. 


\section{Ground Water Remediation}

Both the Livermore site and Site 300 are Superfund sites under the jurisdiction of the Comprehensive Environmental Response, Compensation and Liability Act (CERCLA) and are undergoing remedial activities. The primary treatment technology used at the Livermore site to remediate contaminated ground water is pump-and-treat technology. In 1996, nine treatment facilities at the Livermore site processed over 400 million liters of ground water, removing approximately 80 kilograms of volatile organic compounds (VOCs) plus smaller quantities of dissolved fuel hydrocarbons (FHCs). These efforts at control and remediation have stopped the off-site westward migration of VOC plumes from the Livermore site and have reduced plume size. The feasibility of using passive bioremediation in Treatment Facility F (TFF) was demonstrated to the satisfaction of regulating agencies in 1996. Significant progress also occurred at Site 300, where more than 15 kilograms of VOCs were removed from soil and ground water in four treatment areas. Since initiating cleanup, the extension of a VOC plume beyond Site 300 boundaries in the General Services Area, for example, has decreased from 1200 meters to 300 meters.

\section{Waste Minimization and Pollution Prevention}

In its annual review of waste minimization and pollution prevention activities, LLNL developed a new, weighted ranking system to prioritize and evaluate its waste streams. Rather than simply considering total waste volume as previously, the new criteria also consider cost, type of waste, and operational aspects. The 20 waste stream components having highest priority under the new system contrast sharply with the corresponding set under the old; transuranic and transuranic-mixed and low-level wastes now rank as highest priority for LLNL, even though their quantities are rather low.

The trend in routine waste generation at LLNL over the past seven years shows dramatic reductions in all four categories: radioactive, mixed, hazardous, and sanitary. Comparing 1996 to 1990 levels, these categories have undergone reductions of 77\%, 89\%, $81 \%$, and $29 \%$, respectively. The total waste diverted from landfills in 1996 was more than 20,000 tons, almost five times the total for the previous year; beneficial reuse of soil on site was responsible for this large increase. LLNL has reduced its nonhazardous solid waste stream by $30 \%$ since 1990 . The Laboratory has been chosen to receive a National DOE P2 (pollution prevention) award for its achievements in solid waste recycling of construction and demolition debris.

Chemical inventories at LLNL are tracked through the use of bar codes, laser scanners, and customized software in an inventory system called ChemTrack. The 1996 inventory featured 185,000 chemical containers ranging from 210-liter drums to gram-quantity vials, and was the most accurate and efficient to date because of the addition of new 
hand-held bar code scanners. ChemTrack minimizes the purchase of new chemicals, thereby reducing procurement costs and the generation of hazardous waste.

\section{Air, Wastewater, and Water Compliance}

LLNL continued to perform all activities necessary to comply with clean air and clean water requirements. In 1996, the Bay Area Air Quality Management District (BAAQMD) issued or renewed 194 permits to operate for the Livermore site. The San Joaquin Valley Unified Air Pollution Control District issued or renewed 43 permits for Site 300 operations. LLNL has permits for underground and aboveground storage tanks and for discharge of treated ground water, industrial and sanitary sewage, and storm water. Site 300 has additional permits for inactive landfills, cooling tower discharges, operation of the sewer lagoon, septic tanks, and leach fields. The Laboratory complies

with all requirements for self-monitoring and inspections associated with these permits.

\section{Environmental Occurrences}

Notification of environmental occurrences at the Laboratory is required under a number of environmental laws, regulations, and DOE orders. LLNL responded to 14 incidents that required federal and/or state agency notification during 1996. None of these caused adverse impact to human health or the environment.

\section{Endangered Species}

LLNL must meet the requirements of both U.S. and California Endangered Species Acts. Examples of 1996 actions in this area concern the large-flowered fiddleneck (Amsinckia grandiflora), a federally listed endangered plant species, and the red-legged frog (Rana aurora dragtonii), the largest frog native to California and presently under the federal status "threatened." Two of the three known natural populations of Amsinckia grandiflora occur at Site 300, which has been designated as a critical habitat for the plant. In 1996, the number of fiddleneck plants at the site increased, owing to a reduction in exotic grass cover. Also at Site 300, two new populations of the red-legged frog were found at wetlands locations.

\section{Conclusion}

The current techniques used at the Laboratory for environmental monitoring are very sensitive, allowing detection at extremely low levels of constituents. The combination of surveillance and effluent monitoring, source characterization, and computer modeling show that radiological doses to the public caused by LLNL operations are less than $1.0 \%$ of regulatory standards and are about 3000 times smaller than the doses received from background radiation. The analytical results and evaluations generally show continuing 
low contaminant levels, reflecting both decreased operations and the responsiveness of the Laboratory in controlling pollutants.

In 1996, significant achievements were made in environmental compliance activities related to water, air, waste, and waste reduction. National awards were received for LLNL's storm water management program and for achievements in solid waste recycling of construction and demolition debris. Ground water remediation activities have stopped the westward migration of plumes at the Livermore site; waste minimization efforts have significantly reduced the amount of waste generated in LLNL operations; recycling efforts have diminished the quantity of waste sent to landfills; and efforts at waste reduction and pollution prevention have capitalized on a variety of opportunities to reduce or eliminate, recover, or recycle potential pollutants.

In summary, the results of the 1996 environmental programs demonstrate that LLNL is committed to protecting the environment and ensuring that its operations are conducted in accordance with applicable federal, state, and local laws and regulations. The environmental impacts of LLNL operations are minimal and pose no threat to the public or the environment. 



\section{Site Overview}

\section{Introduction}

Kris A. Surano

Frank J. Gouveia

Richard G. Blake

Michael J. Taffet

Meteorology and geography can play primary roles in how the environment is affected by human actions. Dispersal of particles in air, for example, is influenced by the wind and rain, which in turn are influenced by geographical characteristics. Similarly, the movement of ground water is constrained by the particular geology of a site. Thus, knowledge of wind, rainfall, geology, and geographical characteristics are used to model the effects that operations at LLNL might have on the surrounding environment. Some history and a description of these characteristics help us understand the importance of the Laboratory's meteorological and geographic setting.

\section{Operations}

The mission of LLNL is to serve as a national resource in science and engineering, with a special responsibility for nuclear weapons. Laboratory activities focus on global security, energy, global ecology, biomedicine, economic competitiveness, and science and mathematics education. The Laboratory's mission is dynamic and has been broadened over the years to meet new national needs.

LLNL is a full-service research laboratory with the infrastructure-engineering, maintenance, and waste management activities, as well as security, fire, and medical departments—necessary to support its operations and about 8000 personnel.

\section{Location}

LLNL consists of two sites-the main laboratory site located in Livermore, California (Livermore site) in Alameda County, and the Experimental Test Site (Site 300) located near Tracy, California, in San Joaquin and Alameda Counties (Figure 1-1). Each site is unique, requiring a different approach for environmental monitoring and protection. 


\section{Site Overview}

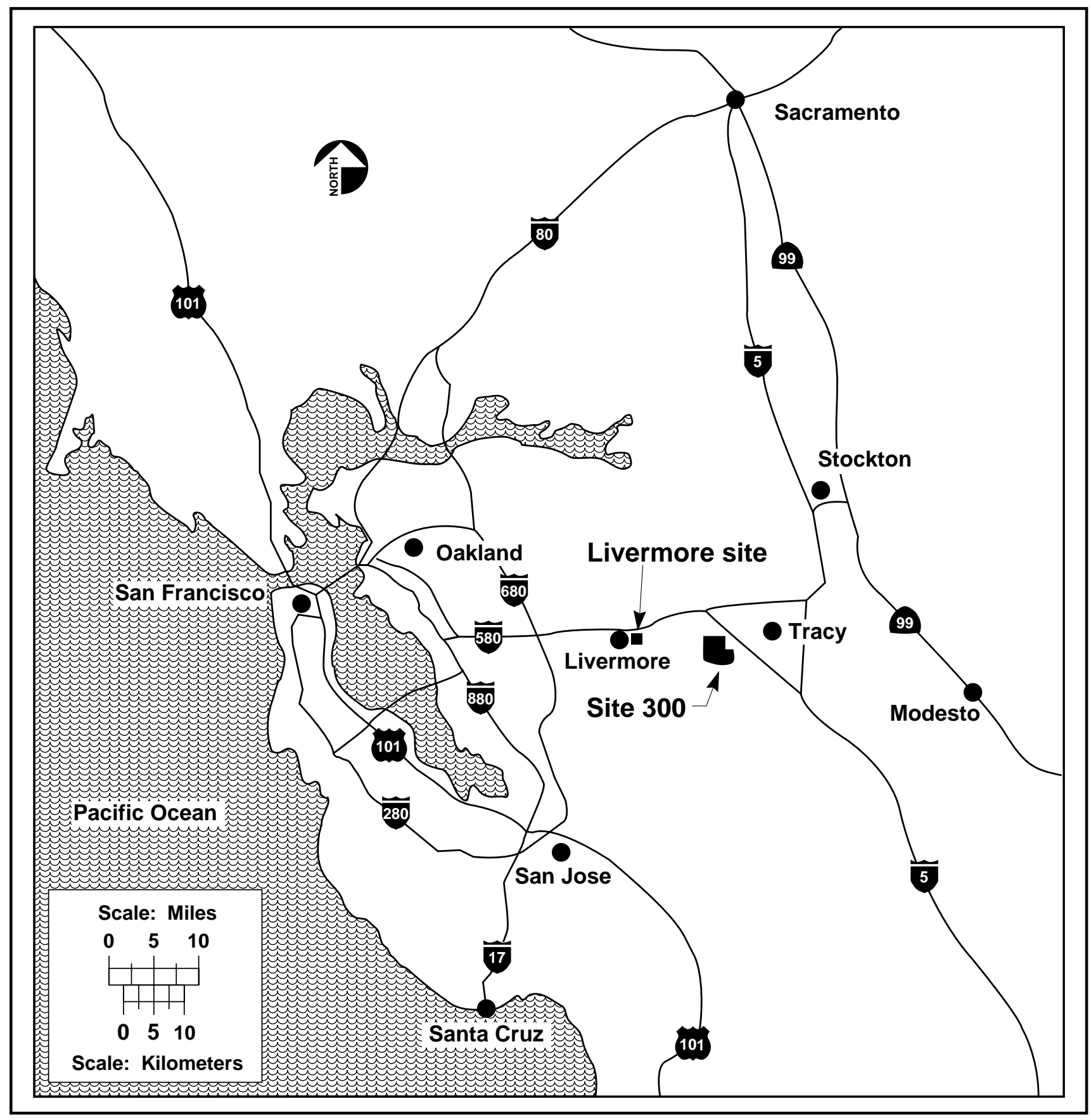

Figure 1-1. Locations of LLNL Livermore site and Site 300.

LLNL was founded at the Livermore site in 1952 at a former U.S. Navy training base. At that time the location was relatively isolated, being approximately $1.6 \mathrm{~km}$ from the Livermore city limits. Over time, Livermore evolved from a small town of fewer than 7000 people when the Laboratory began to its present population of about 66,000 . 
The economy diversified from being primarily agricultural to include light industry and business parks. Within the last few years, low-density, single-family residential developments have begun to fill the formerly vacant fields. Livermore residences are now near LLNL's western boundary.

LLNL's Livermore site occupies an area of $3.28 \mathrm{~km}^{2}$, including the land that serves as a buffer zone around the site. Immediately to the south is Sandia National Laboratories (SNL)/California, operated by Lockheed-Martin under DOE contract. SNL/California provides research and development associated with nuclear weapons systems engineering, as well as related national security tasks. Although their primary missions are similar, LLNL and SNL/California are separate entities, each with its own management and each reporting to a different DOE operations office.

To the south of LLNL, there are also some low-density residential areas and agricultural areas devoted to grazing, orchards, and vineyards. A business park lies to the southwest. Farther south, property is primarily open space and ranchettes, with some agricultural use. A very small amount of low-density residential development lies to the east of the Livermore site, and agricultural land extends to the foothills that define the eastern margin of the Livermore Valley. A business park is located to the north, and a 200-hectare parcel of open space to the northeast has been rezoned to allow development of light industry.

Site 300, LLNL's Experimental Test Facility, is located $20 \mathrm{~km}$ east of the Livermore site in San Joaquin County in the Altamont Hills of the Diablo Range; it occupies an area of $30.3 \mathrm{~km}^{2}$. It is in close proximity to two other testing sites: PRIMEX/Physics International operates a testing site that is adjacent and to the east of Site 300, and SRI International operates another site, located approximately $1 \mathrm{~km}$ south of Site 300 . The Carnegie State Vehicular Recreation Area is located south of the western portion of Site 300 , and wind turbine generators line the hills to the northwest. The remainder of the surrounding area is in agricultural use, primarily as grazing land for cattle and sheep. The nearest residential area is the town of Tracy (population 45,000), located $10 \mathrm{~km}$ to the northeast.

\section{Meteorology}

Meteorological data (including wind speed, wind direction, rainfall, relative humidity, solar radiation, and air temperature) are continuously gathered at both the Livermore site and Site 300. Mild, rainy winters and warm, dry summers characterize the climate of the Livermore Valley. A detailed review of the climatology for LLNL can be found in 


\section{Site Overview}

Gouveia and Chapman (1989). The mean annual temperature for 1996 was $15^{\circ} \mathrm{C}$.

Temperatures range from $-5^{\circ} \mathrm{C}$ during some predawn winter mornings to $40^{\circ} \mathrm{C}$ during some summer afternoons.

Both rainfall and wind exhibit strong seasonal patterns. Annual wind data for the Livermore site are given in Figure 1-2 and Table 1-1. These data show that greater than $50 \%$ of the wind pattern comes from the south-southwest to westerly direction.

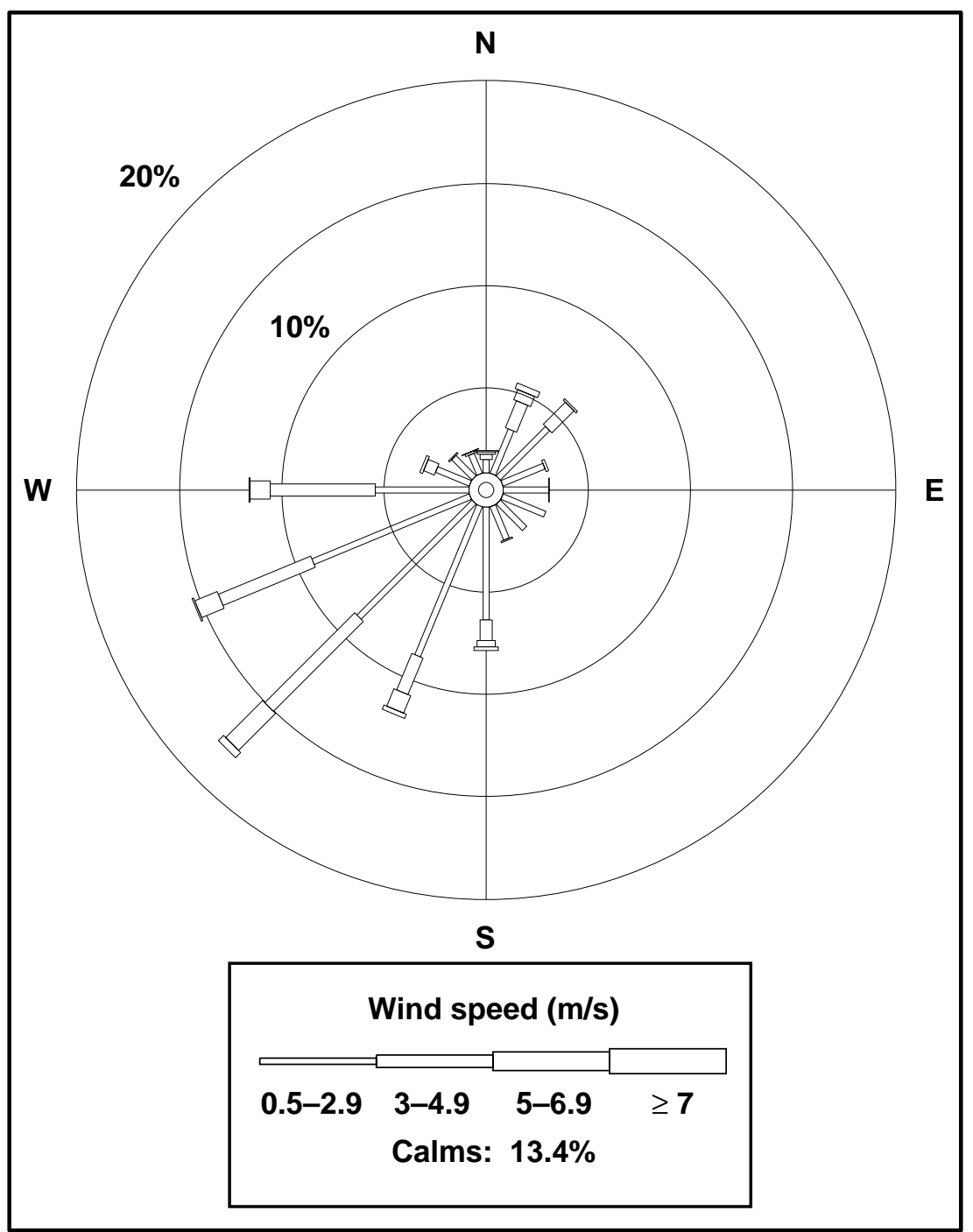

Figure 1-2. Wind rose showing the average annual wind speed, frequency of occurrence, and direction at the Livermore site, 1996. 
Table 1-1. Wind rose data for LLNL's Livermore site at the 10-m level for 1996. Values are frequency of occurrence (in percent). Columns and rows may not exactly sum to the listed totals due to rounding.

\begin{tabular}{|l|c|c|c|c|c|c|}
\hline \multirow{2}{*}{ Direction } & \multicolumn{7}{|c|}{ Wind speed range (m/s) } \\
\cline { 2 - 7 } & $\mathbf{0 . 0 - 0 . 4}$ & $\mathbf{0 . 5 - 2 . 9}$ & $\mathbf{3 . 0 - 4 . 9}$ & $\mathbf{5 . 0 - 6 . 9}$ & $\mathbf{7} . \mathbf{0}$ & Total \\
\hline NNE & 0.84 & 2.34 & 1.42 & 0.53 & 0.29 & 5.4 \\
NE & 0.84 & 3.41 & 1.52 & 0.10 & 0.00 & 5.9 \\
ENE & 0.84 & 2.22 & 0.13 & 0.00 & 0.00 & 3.2 \\
E & 0.84 & 2.23 & 0.00 & 0.00 & 0.00 & 3.1 \\
ESE & 0.84 & 2.26 & 0.00 & 0.00 & 0.00 & 3.1 \\
SE & 0.84 & 1.82 & 0.00 & 0.00 & 0.00 & 2.7 \\
SSE & 0.84 & 1.76 & 0.07 & 0.00 & 0.00 & 2.7 \\
S & 0.84 & 5.51 & 1.01 & 0.31 & 0.18 & 7.9 \\
SSW & 0.84 & 7.93 & 1.93 & 0.92 & 0.22 & 11.8 \\
SW & 0.84 & 7.95 & 6.21 & 2.56 & 0.35 & 17.9 \\
WSW & 0.84 & 8.32 & 4.88 & 1.19 & 0.08 & 15.3 \\
W & 0.84 & 4.58 & 5.13 & 0.99 & 0.05 & 11.6 \\
WNW & 0.84 & 1.78 & 0.57 & 0.14 & 0.00 & 3.3 \\
NW & 0.84 & 1.40 & 0.07 & 0.00 & 0.00 & 2.3 \\
NNW & 0.84 & 1.05 & 0.11 & 0.02 & 0.00 & 2.0 \\
N & 0.84 & 0.65 & 0.26 & 0.12 & 0.06 & 1.9 \\
\hline Total & $\mathbf{1 3 . 4}$ & $\mathbf{5 5 . 2}$ & $\mathbf{2 3 . 3}$ & $\mathbf{6 . 9}$ & $\mathbf{1 . 2}$ & $\mathbf{1 0 0}$ \\
\hline
\end{tabular}

These wind patterns tend to be dominated by the thermal draw of the warm San Joaquin Valley that results in wind blowing from the cool ocean toward the warm valley, increasing in intensity as the valley heats up. The wind blows from the northeast primarily during the winter storm season. Most precipitation occurs between October and April, with very little rainfall during the warmer months. The highest and lowest annual rainfalls on record are 812 and $122 \mathrm{~mm}$. The average annual rainfall is $368 \mathrm{~mm}$. In 1996, the Livermore site received $456 \mathrm{~mm}$ of rain.

The meteorological conditions at Site 300, while generally similar to the Livermore site, are modified by higher elevation and more pronounced relief. The complex topography of the site significantly influences local wind and temperature patterns. Annual wind data are presented in Figure 1-3 and Table 1-2. The data show that these winds are more consistently from the west-southwest and reach greater speeds than at the Livermore site. The increased wind speed and elevation of much of the site result in afternoon temperatures that are typically lower than those for the Livermore site. Rainfall for 1996 was $363 \mathrm{~mm}$ at Site 300. 


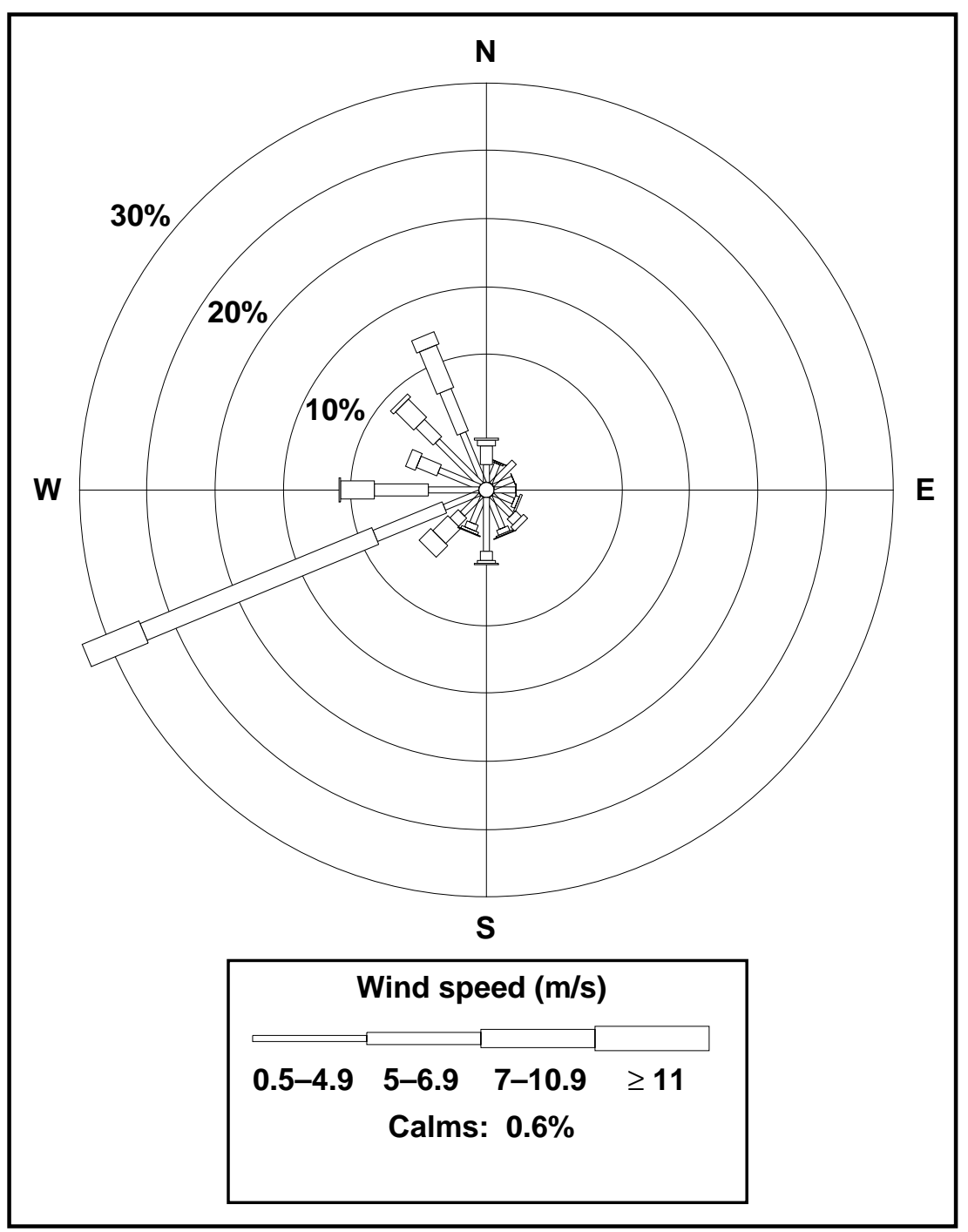

Figure 1-3. Wind rose showing the average annual wind speed, frequency of occurrence, and direction at Site 300, 1996.

\section{Geology}

\section{Topography}

The Livermore site is located in the southeastern portion of the Livermore Valley, a topographic and structural depression oriented east-west within the Diablo Range of the California Coast Range Province. The Livermore Valley, the most prominent valley in the Diablo Range, is an east-west trending structural and topographic trough that is 
Table 1-2. Wind rose data for LLNL's Site 300 at the 10-m level for 1996. Values are frequency of occurrence (in percent). Columns and rows may not exactly sum to the listed totals due to rounding.

\begin{tabular}{|l|c|c|c|c|c|c|}
\hline \multirow{2}{*}{ Direction } & \multicolumn{7}{|c|}{ Wind speed range (m/s) } \\
\cline { 2 - 7 } & $\mathbf{0 . 0 - 0 . 4}$ & $\mathbf{0 . 5 - 4 . 9}$ & $\mathbf{5 . 0 - 6 . 9}$ & $\mathbf{7 . 0 - 1 0 . 9}$ & $\geq \mathbf{1 1 . 0}$ & Total \\
\hline NNE & 0.04 & 1.53 & 0.11 & 0.04 & 0.00 & 1.7 \\
NE & 0.04 & 2.33 & 0.00 & 0.00 & 0.00 & 2.4 \\
ENE & 0.04 & 1.56 & 0.00 & 0.00 & 0.00 & 1.6 \\
E & 0.04 & 1.60 & 0.04 & 0.00 & 0.00 & 1.7 \\
ESE & 0.04 & 1.59 & 0.29 & 0.15 & 0.00 & 2.1 \\
SE & 0.04 & 2.05 & 0.60 & 0.41 & 0.00 & 3.1 \\
SSE & 0.04 & 2.49 & 0.39 & 0.11 & 0.04 & 3.1 \\
S & 0.04 & 3.97 & 0.67 & 0.22 & 0.09 & 5.0 \\
SSW & 0.04 & 2.09 & 0.47 & 0.20 & 0.06 & 2.9 \\
SW & 0.04 & 1.94 & 0.86 & 1.56 & 1.21 & 5.6 \\
WSW & 0.04 & 2.80 & 5.51 & 18.47 & 4.53 & 31.4 \\
W & 0.04 & 3.72 & 3.98 & 2.49 & 0.11 & 10.3 \\
WNW & 0.04 & 3.22 & 1.62 & 0.77 & 0.00 & 5.7 \\
NW & 0.04 & 4.55 & 1.80 & 1.89 & 0.31 & 8.6 \\
NNW & 0.04 & 3.99 & 3.36 & 3.37 & 0.97 & 11.7 \\
N & 0.04 & 1.31 & 1.38 & 0.42 & 0.15 & 3.3 \\
\hline Total & $\mathbf{0 . 6}$ & $\mathbf{4 0 . 7}$ & $\mathbf{2 1 . 1}$ & $\mathbf{3 0 . 1}$ & $\mathbf{7 . 5}$ & $\mathbf{1 0 0}$ \\
\hline
\end{tabular}

bounded on the west by Pleasanton Ridge and on the east by the Altamont Hills. The valley floor is covered by alluvial, lake, and swamp deposits consisting of gravels, sands, silts, and clays, at an average thickness of about $100 \mathrm{~m}$. The valley is approximately $25-\mathrm{km}$ long and averages $11 \mathrm{~km}$ in width. The valley floor is at its highest elevation of $220 \mathrm{~m}$ above sea level along the eastern margin and gradually dips to $92 \mathrm{~m}$ at the southwest corner. The major streams passing through the Livermore Valley are Arroyo del Valle and Arroyo Mocho, which drain the southern highlands and flow intermittently.

The topography of Site 300 is much more irregular than that of the Livermore site; a series of steep hills and ridges is oriented along a generally northwest-southeast trend and is separated by intervening ravines. The Altamont Hills, where Site 300 is located, are part of the California Coast Range Province and separate the Livermore Valley to the west from the San Joaquin Valley to the east. The elevation ranges from approximately $538 \mathrm{~m}$ above sea level at the northwestern corner of the site to approximately $150 \mathrm{~m}$ in the southeast portion. 


\section{Site Overview}

\section{Hydrogeology}

\section{Livermore Site}

The hydrogeology and movement of ground water in the vicinity of the Livermore site have been the subjects of several investigations (Stone and Ruggieri 1983; Carpenter et al. 1984; Webster-Scholten and Hall 1988; and Thorpe et al. 1990). This section has been summarized from the reports of these investigations and from data supplied by Alameda County Flood Control and Water Conservation District Zone 7, the agency responsible for ground water management in the Livermore Valley basin (San Francisco Bay RWQCB 1982a and 1982b).

The Livermore Formation (and overlying alluvial deposits) contains the aquifers of the Livermore Valley ground water basin, an important water-bearing formation. Natural recharge occurs primarily along the fringes of the basin and through the arroyos during periods of winter flow. Artificial recharge, if needed to maintain ground water levels, is accomplished by releasing water from Lake Del Valle or from the South Bay Aqueduct into arroyo channels in the east. Ground water flow in the valley generally moves toward the central east-west axis of the valley and then westward through the central basin. Ground water flow in the basin is primarily horizontal, although a significant vertical component probably exists in fringe areas, under localized sources of recharge, and in the vicinity of heavily used extraction (production) wells.

Beneath the Livermore site, the water table varies in depth from about 10 to $40 \mathrm{~m}$.

Figure 1-4 shows a contour map of water-table elevations (meters above mean sea level) for the Livermore site area. Although water-table elevations vary slightly with seasonal and year-to-year differences in both natural and artificial recharge, the qualitative patterns shown in Figure 1-4 are generally maintained. At the eastern edge of the Livermore site, ground water gradients (change in vertical elevation per unit of horizontal distance) are relatively steep, but under most of the site and farther to the west, the contours flatten to a gradient of approximately 0.003. Ground water flow under most of the site is southwesterly. This flow direction diverges from the generally westward regional flow and from flow patterns demonstrated for the site in the 1980s. This shift in flow direction is a consequence of ground water recovery and remediation in the southwest portion of the site and agricultural pumping. Aquifer tests on monitoring wells in the vicinity of the Livermore site indicate that the hydraulic conductivity of the permeable sediments ranges from 1 to $16 \mathrm{~m} /$ day (Isherwood et al. 1991). This, in combination with the observed water table gradients, yields an average ground water velocity estimate of $20 \mathrm{~m} / \mathrm{y}$ (Thorpe et al. 1990). The range in these values reflects the heterogeneity typical of the more permeable of the alluvial sediments that underlie the area. 


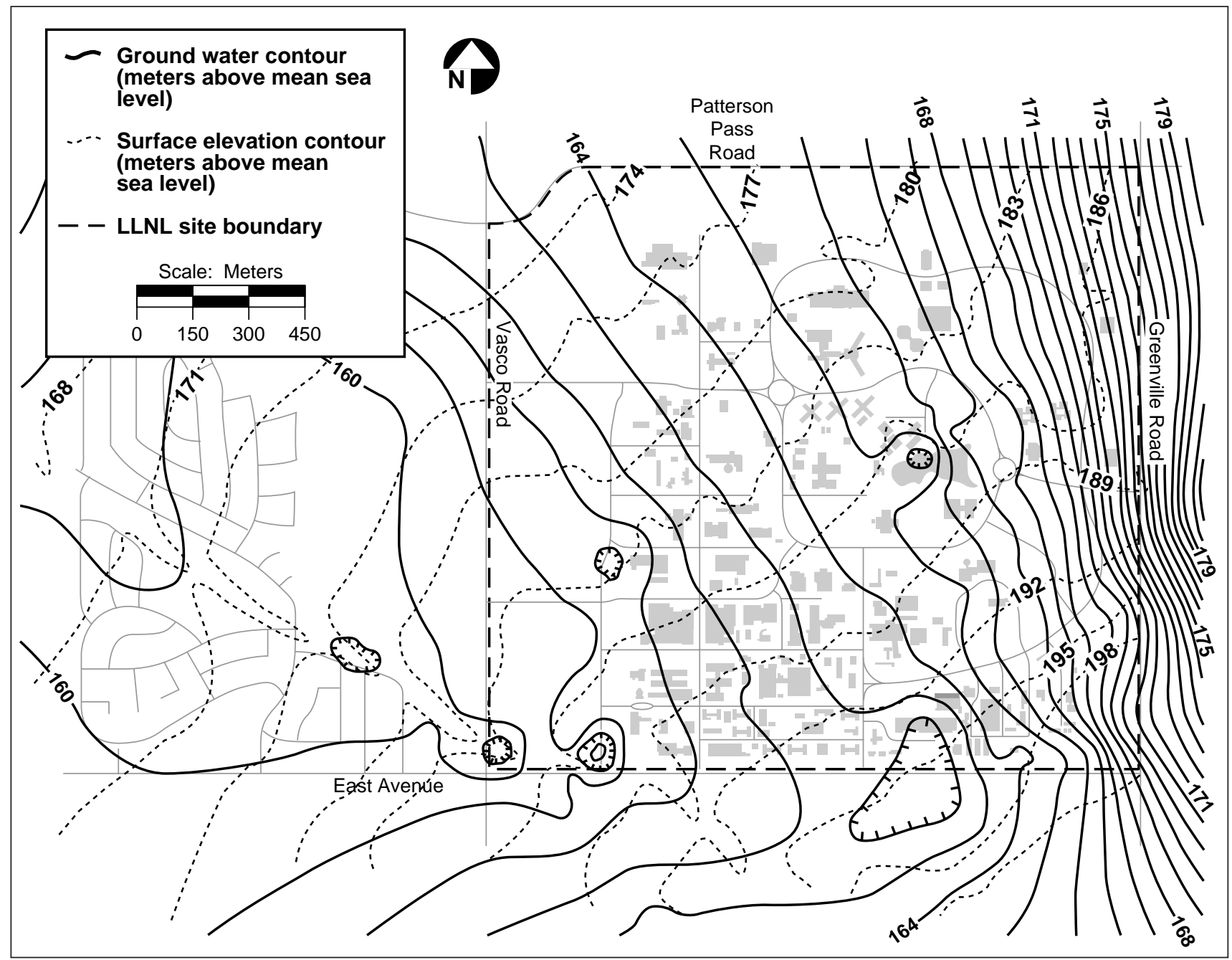

Figure 1-4. Approximate ground water and surface elevation contours, Livermore site and vicinity.

\section{Site 300}

Gently dipping sedimentary bedrock dissected by steep ravines generally underlies Site 300. The bedrock is made up primarily of interbedded sandstone, siltstone, and claystone. Most ground water occurs in the Neroly Formation upper and lower blue sandstone aquifers. Significant ground water is also locally present in permeable Quaternary alluvium valley fill. Much less ground water is present within perched aquifers in the unnamed Pliocene nonmarine unit. Perched aquifers contain unconfined water separated from an underlying main body of water by impermeable layers; normally they are discontinuous and highly localized. Because water quality generally is poor and yields are low, these perched water-bearing zones do not meet the State of California criteria for aquifers that are potential water supplies. 


\section{Site Overview}

Fine-grained siltstone and claystone interbeds may confine the ground water and act as aquitards, confining layers, or perching horizons. Ground water is present under confined conditions in parts of the deeper bedrock aquifers, but is generally unconfined elsewhere.

Ground water flow in most aquifers follows the attitude of the bedrock. In the northwest part of Site 300, ground water in bedrock generally flows northeast except where it is locally influenced by the geometry of alluvium-filled ravines. In the southern half of Site 300, ground water in bedrock flows roughly south-southeast, approximately coincident with the attitude of bedrock strata.

The thick Neroly lower blue sandstone, stratigraphically near the base of the formation, generally contains confined water. Wells located in the western part of the General Services Area are completed in this aquifer and are used to supply drinking and process water.

Figure 1-5 shows the elevation contours for water in the regional aquifer at Site 300. This map of the piezometric surface (the elevation to which water rises in a well that penetrates a confined or unconfined aquifer) is based primarily on water levels in the Neroly lower blue sandstone aquifer.

Recharge occurs predominantly in locations where saturated alluvial valley fill is in contact with underlying permeable bedrock, or where permeable bedrock strata crop out because of structure or topography. Local recharge also occurs on hilltops, creating some perched water-bearing zones. Low rainfall, high evapotranspiration, steep topography, and intervening aquitards generally preclude direct vertical recharge of the bedrock aquifers.

Further information on the hydrology of both the Livermore site and Site 300 can be found in the ground water protection information in Chapters 8 and 9.

\section{Summary}

LLNL recognizes the importance of our geology, hydrogeology, climate, and geographical relationships with our neighbors in assessing potential impacts of operations at the Livermore site and Site 300. Each year additional information is gained to allow us to better predict, interpret, and avoid potential impacts. Each environmental medium that is discussed in this document-air, soil, water, vegetation, and foodstuffmay be affected differently. The environmental scientists at LLNL take into account the unique locations of the Livermore site and Site 300 to tailor sampling and analysis programs for each medium used to monitor the environment. 


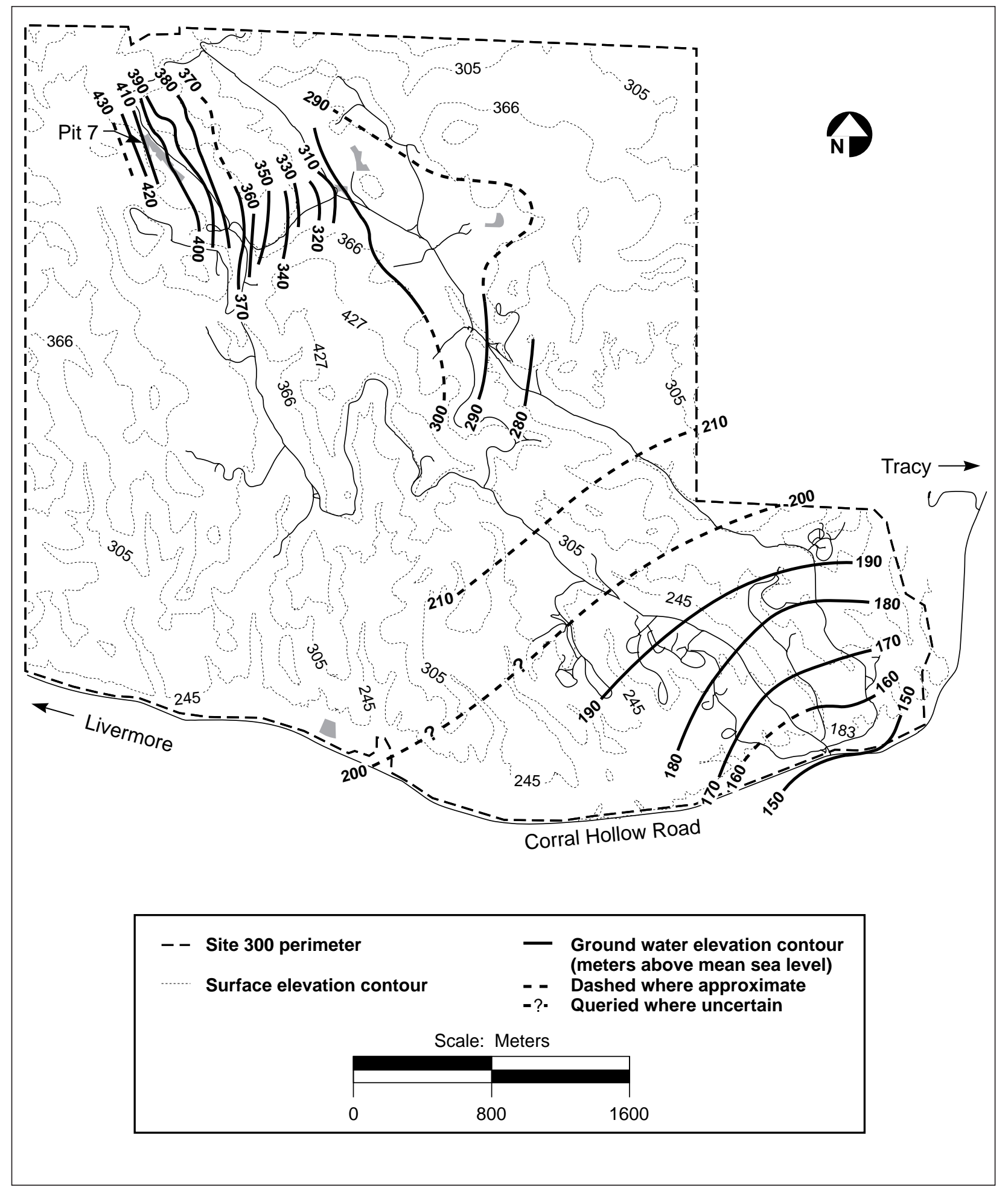

Figure 1-5. Approximate ground water elevations in principal continuous water-bearing zones at Site 300. 



\section{Compliance Summary}

\section{Introduction}

During 1996, Lawrence Livermore National Laboratory (LLNL) participated in numerous activities to comply with federal, state, and local environmental regulations as well as internal requirements and Department of Energy (DOE) Orders. Activities related to air, water, waste, waste reduction, community "right to know," and other environmental issues were carried out at the Livermore site and Site 300. Many documents concerned with these activities and other environmental issues are available for public viewing at the LLNL Visitors Center and the Livermore and Tracy Public Libraries. A wide range of compliance activities are summarized in the following sections. A significant achievement in 1996 was EPA's awarding to LLNL a National First Place Award in the industrial category for its excellent storm water management program.

\section{CERCLA/SARA, Title I}

LLNL has two projects that are under the jurisdiction of the Comprehensive Environmental Response, Compensation and Liability Act (CERCLA)/ Superfund Amendment and Reauthorization Act (SARA), Title 1. These are the Livermore Site Ground Water Project and the Site 300 Environmental Restoration Program.

\section{Livermore Site Ground Water Project}

The Ground Water Project (GWP) complies with provisions specified in a federal facility agreement (FFA) entered into by the Environmental Protection Agency (EPA), DOE, the California EPA's Department of Toxic Substances Control (DTSC), and the San Francisco Bay Regional Water Quality Control Board. As required by the agreement, the project addresses compliance issues through investigations of potential contamination source areas (such as suspected old release sites, solvent handling areas, and leaking underground tank systems), continued monitoring of ground water, and remediation. The ground water constituents of concern are volatile organic compounds (VOCs), primarily trichloroethylene (TCE) and tetrachloroethylene (PCE). These contaminants are present primarily within the site boundary but to some extent at the site boundary and beyond, mainly to the west and south of the site. Treatment facilities are generally situated in areas of high concentrations of VOCs (see Figure 2-1). However, Treatment Facilities A and B (TFA and TFB) are located at areas of lower contaminant concentrations downgradient from high concentration "hot spots" to aid in remediation of contaminated ground water at and beyond the site boundary. 


\section{Compliance Summary}

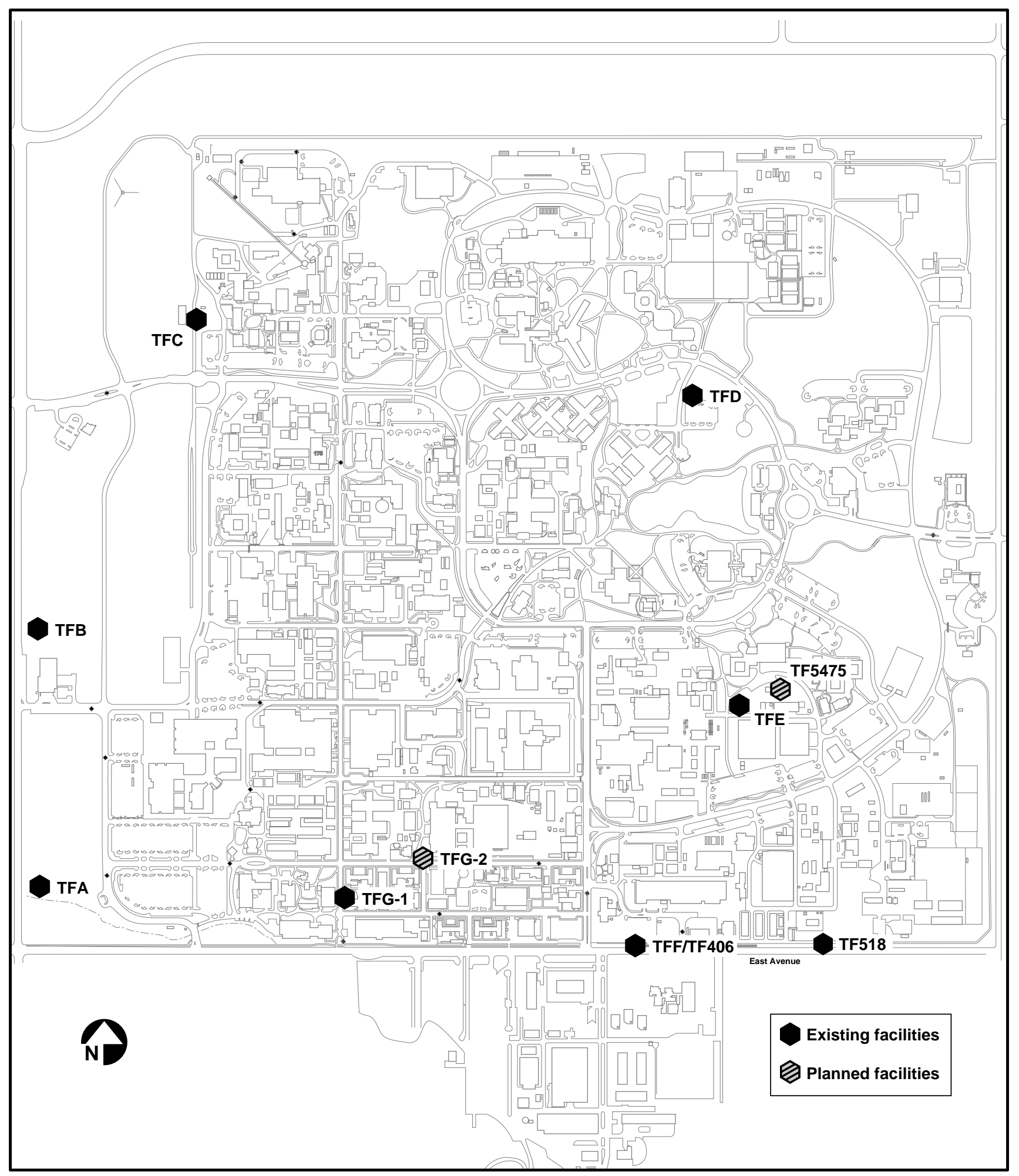

Figure 2-1. Location of existing and planned ground water treatment facilities. 


\section{Compliance Summary}

The primary treatment technology employed at the Livermore site to remediate contaminated ground water is ground water pump-and-treat. This technology employs a dense network of ground water extraction wells, monitoring wells, pipelines, and surface treatment facilities.

\section{Documentation}

During 1996, DOE/LLNL issued two final CERCLA documents for the Livermore site according to the amended schedule in the Remedial Action Implementation Plan (RAIP) (Dresen et al. 1993). The Compliance Monitoring Plan (Nichols et al. 1996) was issued on January 25, 1996, and the Contingency Plan (McKereghan et al. 1996) was issued on November 15, 1996.

As required by the Federal Facility Agreement, DOE/LLNL issued the LLNL Ground Water Project, 1995 Annual Report (Bainer et al. 1996). DOE/LLNL also submitted summaries of 10 Remedial Project Managers' Meetings; the March (McConachie and Brown 1996), July (Ko and Lamarre 1996), September (Littlejohn and Lamarre 1996), and December (Littlejohn and Lamarre 1997) summaries included quarterly selfmonitoring data.

\section{Milestones and Activities}

All seven of the milestones set out in the amended 1996 RAIP (Dresen et al. 1993) for the Livermore site were reached. In addition to RAIP milestones, DOE/LLNL conducted source investigations at Treatment Facility G1 (TFG1) and completed and activated the Treatment Facility C (TFC) North Pipeline on September 26, 1996. (See Figure 2-1 for locations of treatment facilities at the Livermore site.) Ground water remediation activities at the Livermore site are summarized in Table 2-1 and discussed in greater detail in Chapters 7 and 8.

Ground Water Project activities in 1996 also included the following:

- $\quad$ Negotiated the Bay Area Air Quality Management District permit conditions for portable treatment units (PTUs). (See description of PTUs later in this chapter.)

- $\quad$ Revised LLNL's Environmental Project Standard Operating Procedures (Dibley and Depue 1996).

- $\quad$ Received regulatory approval to modify treatment facility effluent discharge limits for metals and sampling frequencies (Bessette Rochette 1996). 


\section{Compliance Summary}

- $\quad$ Received regulatory approval on an outline for the Five-Year Review, due August 5, 1997 (Littlejohn and Lamarre 1996).

- Submitted Application for Containment Zone for the Livermore Site Hydrocarbon Impacted Zone at Treatment Facility F (Happel et al. 1996) on July 17, 1996, and received regulatory approval for "No Further Action" for the fuel hydrocarbons on October 30, 1996 (San Francisco Bay RWQCB 1996).

- $\quad$ Issued the report Simulation of Soil Vapor Extraction at Building 518 (Vogele et al. 1996) to the regulatory agencies.

- $\quad$ Agreed to a revised Livermore Site Consensus Statement/Priority List and the RAIP schedule on September 19, 1996 (Ko et al. 1996).

In addition, DOE and LLNL started to prepare two Explanation of Significant Differences reports for changes to the remedial action plan described in the Record of Decision (U.S. Department of Energy 1992). One request is for a change to air stripping only at TFA and TFB, and the other is for changes in the metals discharge limits. A revised Site Safety Plan is also being prepared.

Table 2-1. Volatile organic compounds (VOCs) removed from ground water at the Livermore site.

\begin{tabular}{|c|c|c|c|c|c|}
\hline \multirow[b]{2}{*}{$\begin{array}{c}\text { Treatment } \\
\text { facility }\end{array}$} & \multirow[b]{2}{*}{$\begin{array}{l}\text { Startup } \\
\text { date }\end{array}$} & \multicolumn{2}{|c|}{1996} & \multicolumn{2}{|c|}{ Cumulative totals } \\
\hline & & $\begin{array}{l}\text { Water treated } \\
(\mathrm{ML})^{(\mathrm{a})}\end{array}$ & $\begin{array}{c}\text { VOCs removed } \\
(\mathrm{kg})\end{array}$ & $\begin{array}{l}\text { Water treated } \\
(\mathrm{ML})^{(\mathrm{a})}\end{array}$ & $\begin{array}{l}\text { VOCs removed } \\
(\mathrm{kg})\end{array}$ \\
\hline TFA & $9 / 89$ & 348 & 16.8 & 992 & 75 \\
\hline TFB & $10 / 90$ & 57 & 7.7 & 182 & 20 \\
\hline TFC & $10 / 93$ & 17 & 2.4 & 49 & 6 \\
\hline TFD & $9 / 94$ & 41 & 12 & 49 & 18 \\
\hline TFE & $11 / 96$ & 1.9 & 0.8 & 1.9 & 0.8 \\
\hline $\operatorname{TFF}^{(b)}$ & - & - & - & - & - \\
\hline TFG1 & $4 / 96$ & 3.4 & 0.2 & 3.4 & 0.2 \\
\hline TF406 & $8 / 96$ & 1.5 & 0.2 & 1.5 & 0.2 \\
\hline TF518 $8^{(\mathrm{c})}$ & 9/95 & - & 42 & - & 66 \\
\hline
\end{tabular}

a $\mathrm{ML}=1$ million liters.

b In June, water was extracted for 6 hours to evaluate concentrations of fuel hydrocarbons in ground water. Further treatment was deemed unnecessary. Ground water extraction and treatment were discontinued.

c Volatile extraction well only—no water was extracted during 1996. 


\section{Compliance Summary}

Portable Treatment Units. Portable treatment units (PTUs) are used as part of LLNL's strategy for optimizing its environmental restoration program. These relatively inexpensive, units provide an alternative to fixed ground water treatment facilities, and are used for hydraulic testing and contaminant mass removal throughout the Livermore site. PTUs are planned for future use at Site 300. An entire PTU, including particulate filters, an air stripper for removing VOCs from ground water, a granular activated carbon canister for removing VOCs from the air stream produced by the air stripper, and ion-exchange resin for removing metals is contained in a $20-\mathrm{ft}$ cargo container. PTUs can be easily moved to the appropriate extraction wells to optimize contaminant mass removal. Because PTUs use the same treatment technologies as fixed facilities, and can remediate ground water faster and more cost-effectively, the regulatory agencies are receptive to their use.

Passive Bioremediation in TFF. In 1996, the feasibility of using passive bioremediation in the TFF area was demonstrated to the satisfaction of the regulating agencies. Ground water extraction and treatment for residual dissolved fuel hydrocarbons from hydrostratigraphic units $3 \mathrm{~A}$ and $3 \mathrm{~B}$ were permanently discontinued. Before its permanent shutdown, TFF operation was interrupted for 194 days as a result of storm damage that occurred on December 8, 1995. During June 1996, ground water was extracted and treated at TFF for a total of 6 hours to evaluate fuel hydrocarbon (FHC) concentrations in ground water extracted from hydrostratigraphic unit (HSU) 3B well GEW-816. No rebound of FHC concentrations was observed in ground water from GEW-816. Following submittal of Application for Containment Zone for the Livermore Site Hydrocarbon Impacted Zone at Treatment Facility F (Happel et al. 1996), "No Further Action" status was granted by the regulatory agencies on October 30, 1996 (San Francisco Bay RWQCB 1996). As part of the terms of this agreement, wells in this area will be sampled and analyzed for FHCs on a semiannual basis.

\section{Community Relations}

The Community Work Group (CWG) met twice in 1996 to discuss cleanup progress, DOE budget issues, evaluation of new technologies, the Priority List-Consensus Statement, and the Contingency Plan. Correspondence and communication with CWG members continued throughout the year.

Other Livermore site community relations activities in 1996 included communicating and meeting with local interest groups and other community organizations; giving public presentations, including those to local realtors and international student and business groups; producing and distributing the Environmental Community Letter; maintaining the Information Repositories and the Administrative Record; conducting tours of the site environmental activities; organizing a Treatment Facility G1 (TFG1) ribbon cutting ceremony; and responding to public and news media inquiries. DOE/LLNL also began meeting with members of Tri-Valley Citizens Against a 


\section{Compliance Summary}

Radioactive Environment (CAREs) and their technical advisor prior to the renewal of their EPA Technical Assistance Grant.

\section{Site 300 Environmental Restoration Program}

At Site 300, remedial investigations, feasibility studies, engineering evaluation and cost analyses, and remedial actions are ongoing. Site 300 investigations and remedial actions are conducted under the joint oversight of the EPA, Central Valley RWQCB, and DTSC and the authority of an FFA for the site (there are separate agreements for Site 300 and the Livermore site). During November 1996, an addendum containing updated scope and milestone due dates was added to the FFA after approval by the regulatory agencies (U.S. Department of Energy 1996a). The study areas and major constituents of concern at Site 300 are shown in Figure 2-2 and Table 2-2.

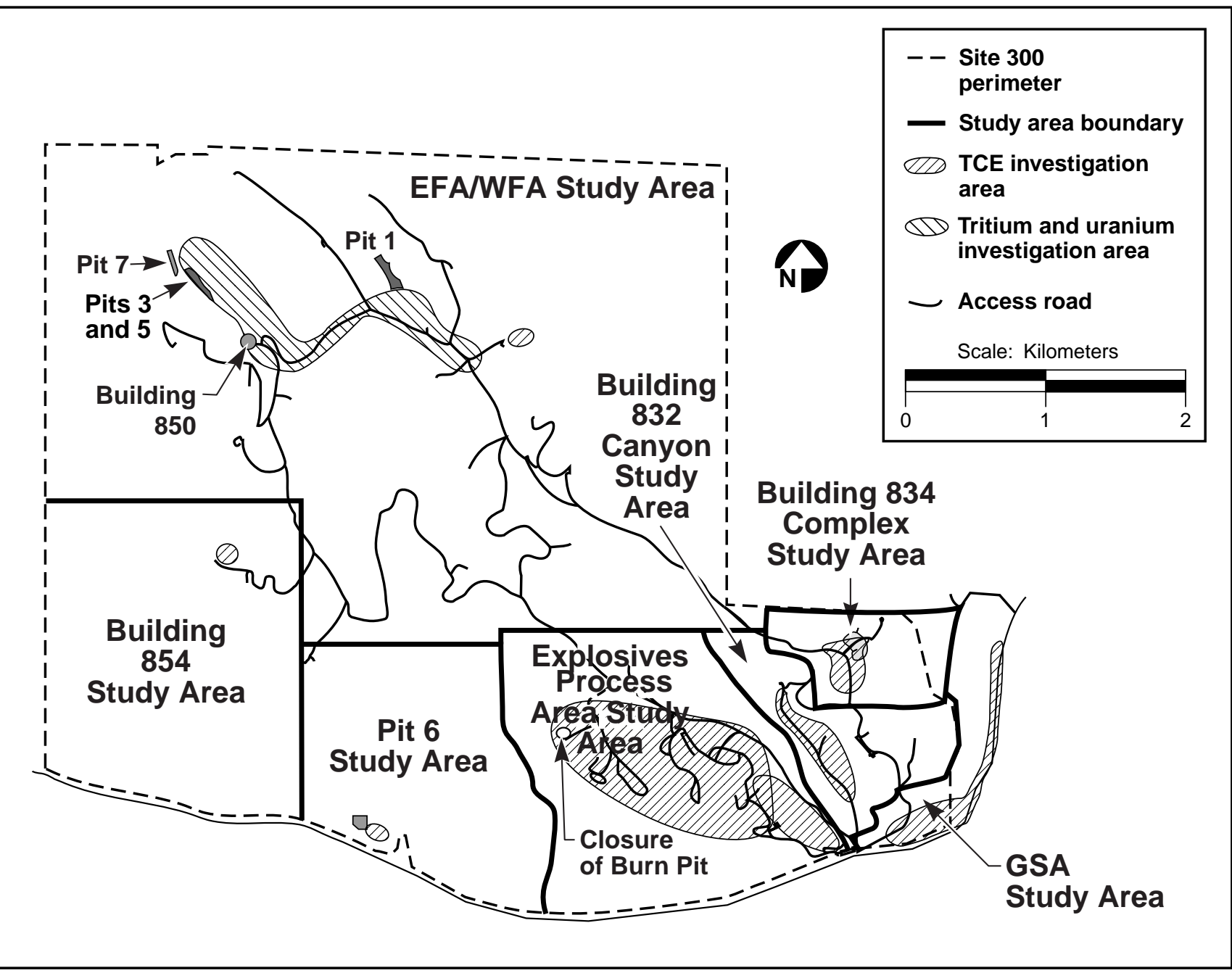

Figure 2-2. Environmental restoration study areas and activities at Site 300. 


\section{Compliance Summary}

Table 2-2. Major constituents of concern found in soil, rock, and ground water at Site 300 .

\begin{tabular}{|l|l|}
\hline \multicolumn{1}{|c|}{ Study area } & \multicolumn{1}{c|}{ Constituent of concern } \\
\hline General Services Area (GSA) & VOCs (primarily TCE) \\
\hline Building 834 Complex & TCE \\
\hline Explosives Process Area & $\begin{array}{l}\text { VOCs (primarily TCE) } \\
\text { HE }^{(a)} \text { (primarily HMX and RDX) }\end{array}$ \\
\hline East and West Firing Areas (EFA/WFA) & $\begin{array}{l}\text { Tritium } \\
\text { Depleted uranium } \\
\text { VOCs (primarily TCE) }\end{array}$ \\
\hline Building 854 & VOCs (primarily TCE) \\
\hline Pit 6 & VOCs (primarily TCE) \\
\hline Building 832 Canyon & TCE \\
\hline
\end{tabular}

a $\mathrm{HE}=$ high explosives.

$\mathrm{HMX}=$ octahydro-1,3,5,7-tetranitro-1,3,5,7-tetrazocine.

RDX = hexahydro-1,3,5-trinitro-1,3,5-triazine.

Table 2-3. Volatile organic compounds (VOCs) removed from ground water and soil at Site 300 .

\begin{tabular}{|c|c|c|c|c|c|}
\hline \multirow[b]{2}{*}{$\begin{array}{c}\text { Treatment } \\
\text { area }\end{array}$} & \multirow[b]{2}{*}{$\begin{array}{c}\text { Startup } \\
\text { date }\end{array}$} & \multicolumn{2}{|c|}{1996} & \multicolumn{2}{|c|}{ Cumulative totals } \\
\hline & & $\begin{array}{l}\text { Water treated } \\
(M L)^{(a)}\end{array}$ & $\begin{array}{c}\text { VOCs removed } \\
(\mathrm{kg})\end{array}$ & $\begin{array}{l}\text { Water treated } \\
(M L)^{(a)}\end{array}$ & $\begin{array}{c}\text { VOCs removed } \\
(\mathrm{kg})\end{array}$ \\
\hline \multicolumn{6}{|l|}{ General Services } \\
\hline Eastern GWTF(b) & $6 / 91$ & 49.7 & 0.34 & 313 & 4.6 \\
\hline Central GWTF & $4 / 93$ & 0.8 & 1.18 & 2.6 & 4.5 \\
\hline \multirow[t]{2}{*}{ Building 834} & $10 / 95$ & 0.16 & 10.7 & 0.17 & 11.5 \\
\hline & & $\begin{array}{l}\text { Soil vapor } \\
\text { treated }\left(\mathrm{m}^{3}\right)\end{array}$ & $\begin{array}{l}\text { VOCs removed } \\
(\mathrm{kg})\end{array}$ & $\begin{array}{l}\text { Soil vapor } \\
\text { treated }\left(\mathrm{m}^{3}\right)\end{array}$ & $\begin{array}{c}\text { VOCs removed } \\
(\mathrm{kg})\end{array}$ \\
\hline \multicolumn{6}{|l|}{ General Services } \\
\hline Central & 1994 & 226,038 & 5 & 398,697 & 29.6 \\
\hline
\end{tabular}

a $\mathrm{ML}=$ million liters.

b GWTF = ground water treatment facility. 


\section{Compliance Summary}

During 1996, LLNL submitted all regulatory documents and performed all actions stipulated in the FFA on schedule. Table 2-3 summarizes remediation activities at Site 300 .

\section{Documentation}

During 1996, LLNL submitted the following documents pertaining to the Site 300 Environmental Restoration Program to the regulatory agencies:

- $\quad$ Addendum to the Site-Wide Remedial Investigation Report, Building 850/Pit 7 Complex Operable Unit (Taffet et al. 1996).

- $\quad$ "Tritium Geochemistry and Ground Water Treatment Technology for the Building 850/Pit 7 Complex Operable Unit letter report" (LLNL 1996a).

- $\quad$ Draft Final and Final Proposed Plan for the General Services Area (LLNL 1996b and c).

- Draft and Draft Final Record of Decision for the Site 300 General Services Area (LLNL 1996d and e).

- $\quad$ Pit 6 EE/CA Fact Sheet (LLNL 1996f).

- Addendum to the Pit 6 Engineering Evaluation/Cost Analysis, Lawrence Livermore National Laboratory Site 300 (Berry 1996).

- $\quad$ "Addendum 2 to the Site 300 Federal Facility Agreement and Appendix A: FFA Schedule of Deliverables" letter (U.S. Department of Energy 1996a).

\section{Activities}

Background for LLNL activities at the following locations can be found in previous Environmental Reports (Harrach et al. 1996 and 1995) and the Final Site-Wide Remedial Investigation Report, Lawrence Livermore National Laboratory Site 300 (Webster-Scholten 1994).

General Services Area. In 1996, the air-sparging treatment system used to treat ground water in the eastern GSA was replaced by aqueous-phase carbon adsorption treatment units. The aqueous-phase carbon adsorption units were demonstrated to be effective in removing VOCs from ground water, less complex in both design and operation than airsparging technology, and less expensive. Before cleanup was initiated, the VOC plume extended about $1200 \mathrm{~m}$ off site; it now extends only $300 \mathrm{~m}$ off site. LLNL estimates that 9 more years of ground water extraction and treatment will be required to achieve and 


\section{Compliance Summary}

maintain ground water VOC concentrations below maximum contaminant levels (MCLs) at the eastern GSA.

During 1996, VOCs were removed from extracted soil vapor at the central GSA. An estimated additional 9 years of soil vapor extraction and 54 years of ground water extraction are required to achieve and maintain ground water VOC concentrations below MCLs at the central GSA.

Details of 1996 activities are contained in the following reports: Draft Final Proposed Plan for Remediation of the Lawrence Livermore National Laboratory Site 300 General Services Plan (Landgraf and Rueth 1996a and b), Draft Record of Decision for the General Services Area Operable Unit, Lawrence Livermore National Laboratory Site 300 (Rueth and Ziagos 1996), and Draft Proposed Plan for the General Services Area Operable Unit, Lawrence Livermore National Laboratory Site 300 (LLNL 1995).

Building 834 Complex. The extraction system underwent extensive expansion and upgrading during 1996. Nine additional wells were plumbed into the manifold, bringing the total number of extraction wells to 15. A number of engineering modifications were implemented to simplify management of off-gas scrubbing and associated monitoring. A sheltering roof was erected over the treatment apparatus, which allows diversion of rainwater away from the area of highest subsurface contamination, greatly reducing recharge in that area. An economical plan was also developed for further drainage improvements and road surface repairs to further reduce recharge into the contaminated area. (See Chapter 8 for a more complete discussion of 1996 monitoring activities at the Building 834 Complex.)

Explosives Process Area. Continued assessment of chemical data indicated that although natural attenuation is reducing the extent and maximum concentration of VOCs at the Building 815 operating unit, contaminants continue to migrate towards the Site 300 boundary. During 1996, the regulatory agencies agreed that the CERCLA pathway for the Building 815 operating unit was a removal action, and thus work began on the engineering evaluation/cost analysis (EE/CA) report for the Building 815 operating unit. The removal action strategy to be evaluated in this report is plume control using ground water pumping and treatment with granular activated carbon. (See Chapter 8 for a more complete discussion of 1996 monitoring activities at the Explosives Process Area.)

East and West Firing Area Study Area. Indications are that at Building 850, tritium was released to the subsurface by percolation of rainfall runoff and dust-control water through contaminated Building 850 firing-table gravels to ground water (Taffet et al. 1989b, Taffet et al. 1996). In the Pits 3 and 5 areas, tritium was released to ground water 


\section{Compliance Summary}

from Pits 3 and 5 by heavy winter rains in 1982-1983, 1986-1987, 1991-1992, 1993-1994, and 1995-1996, and by the resulting rising water tables. Conservative computer modeling of the fate and transport of the tritium indicates that by the time the tritiated ground water reaches the Site 300 boundary, the tritium will have decayed to near background activity levels.

During 1996, total uranium activities in excess of the California MCL of $0.74 \mathrm{~Bq} / \mathrm{mL}$ $(20 \mathrm{pCi} / \mathrm{L})$ continued to be measured in ground water samples from several monitoring wells at the Pits 3 and 5 areas; several of these wells also yielded water samples bearing isotopic ratios indicative of depleted uranium. Conversely, samples of ground water from several wells in the area contain uranium activities that exceed the state MCL but bear natural-uranium isotopic signatures. Analyses of ground water samples from several wells adjacent to Building 850 also indicate depleted-uranium signatures; these samples do not exceed the California MCL for uranium. Additional field work was conducted during 1996. As a result, we have defined three small plumes of uranium in ground water that emanate from each of Pits 5 and 7 and the Building 850 firing table. Conservative ground water fate and transport modeling indicates that total uranium activity will be at background levels by the time any depleted-uranium-bearing ground water reaches the Site 300 boundary.

Small contaminant plumes exist in other portions of the study area. TCE occurs in a small ground water plume below MCL concentrations at the Building 801 firing table. Freon 113 at ground water concentrations significantly below the California MCL of 1.2 ppm is present near Pit 1 and is the result of spills at Building 865 (Advanced Testing Accelerator). Characterization plans for the Building 812 firing table and the Sandia Test Site portions of the East and West Firing Areas were submitted to the regulatory agencies during 1994. Remedial investigations for these areas and Building 865 are planned for 1998 and 1999.

See Chapter 8 for an expanded discussion of 1996 monitoring in this area.

Building 854 Study Area. By the end of 1996, 11 wells had been completed in the Building 854 area, and 35 boreholes had been drilled for soil, rock, and soil vapor sampling and analysis. Air samples were also collected and analyzed for VOCs. Maximum concentrations of TCE in ground water are on the order of several hundred parts per billion.

Pit 6 Area. The source of the TCE plume is the southeast corner of the Pit 6 landfill. Because of natural volatilization of affected ground water at the springs, concentrations of VOCs in the plume have declined more than an order of magnitude since 1992. The Final Feasibility Study Report for the Pit 6 Operable Unit (Devany et al. 1994) discusses 


\section{Compliance Summary}

options for remediation in this area. The regulatory agencies agreed to accept this document as an EE/CA report for a removal action. The Addendum to the Pit 6 Engineering Evaluation/Cost Analysis, Lawrence Livermore National Laboratory Site 300 (Berry 1996) was submitted to the regulatory agencies in 1996. The addendum presents revisions to the accepted capping removal action, which include installation of an impermeable cover, a surface drainage diversion system, and several additional monitoring wells. Title I design began on June 12, 1996. The Pit 6 EE/CA Fact Sheet (LLNL 1996f) was issued on December 17, 1996. The Title II design package was submitted to the regulatory agencies on December 18, 1996. A public meeting was held on January 15, 1997. The removal action construction is scheduled for completion by December 1, 1997.

Building 832 Canyon Study Area. Characterization tasks in 1996 included drilling 34 boreholes, installing 17 ground water monitor wells and 4 soil vapor monitoring wells, and collecting and analyzing soil vapor, air, surface soil, and surface water samples. Ground water samples contained TCE and nitrates at concentrations in excess of MCLs. The maximum concentration of TCE reported in ground water was $7 \mathrm{ppm}$. Samples of surface water and water from shallow wells indicate that a plume of TCE in ground water has reached the southern Site 300 boundary.

\section{Community Relations}

The Site 300 CERCLA project maintains proactive communication with the surrounding communities of Tracy and Livermore. Community relations activities conducted during 1996 included continued dialogue with Tri-Valley CAREs, maintenance of the information repositories and administrative records, Site 300 tours for scientists and students from universities and local public schools, support for off-site, private wellsampling activities, and preparation of Site 300 Fact Sheet Number 3 (Heffner 1996).

A Public Meeting on April 24, 1996, provided a forum for public comment on the planned remedial strategy (continued pump-and-treat) for the General Services Area.

\section{SARA, Title III}

Title III of the Superfund Amendment and Reauthorization Act (SARA) of 1986 is known as the Emergency Planning and Community Right-to-Know Act (EPCRA). It requires owners or operators of facilities that have certain hazardous chemicals on site to provide information on the release, storage, and use of those chemicals to organizations responsible for emergency response planning. Executive Order 12856, signed by 


\section{Compliance Summary}

President Clinton on August 3, 1993, directs all federal agencies to comply with the requirements of EPCRA, including the SARA 313 Toxic Release Inventory Program.

EPCRA requirements and LLNL compliance are summarized in Table 2-4. Tables 2-5 and 2-6 identify those chemicals reported by LLNL for the Livermore site and Site 300 under Section 311 during 1996.

Table 2-4. Summary of LLNL compliance with EPCRA in 1996.

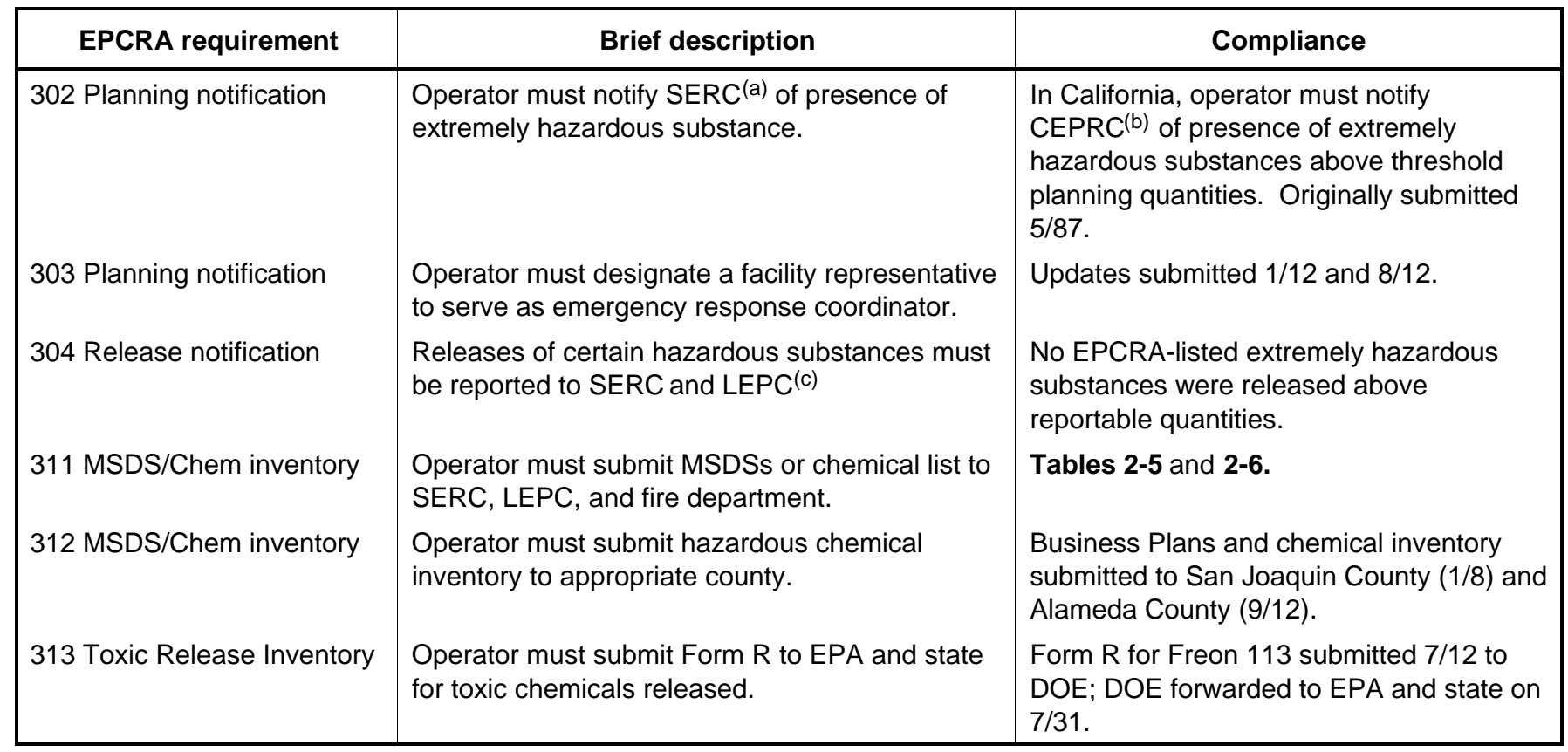

a State Emergency Response Commission.

b Chemical Emergency Planning and Response Commission.

c Local Emergency Planning Committee.

\section{Activities Requiring Permits}

Permits are required for a number of LLNL environmental activities related to air, water, hazardous waste, sewerable waste, storage tanks, and medical waste. Table 2-7 summarizes these permits. Inspections by the permitting agencies in 1996 are summarized in Table 2-8. 
Table 2-5. Livermore site, SARA, Title III, Section 311, Chemical List.

\begin{tabular}{|c|c|c|c|c|c|}
\hline \multirow{2}{*}{$\begin{array}{l}\text { Livermore site } \\
\text { chemicals }\end{array}$} & \multicolumn{3}{|c|}{ Physical hazards } & \multicolumn{2}{|c|}{ Health hazards } \\
\hline & Fire & Pressure & Reactivity & Acute & Chronic \\
\hline Argon & & $x$ & & $x$ & \\
\hline Carbon monoxide & & $x$ & & $x$ & \\
\hline Diesel fuel & $x$ & & & & \\
\hline Ethylene glycol & & & & $x$ & \\
\hline Freon 11 & & & & $x$ & \\
\hline Freon 12 & & & & $x$ & \\
\hline Freon 113 & & & & $x$ & \\
\hline Gasoline & $x$ & & & $x$ & $x$ \\
\hline Helium & & $x$ & & $\mathrm{x}$ & \\
\hline Hydrofluoric acid & & $\begin{array}{c}\text { Some } \\
\text { containers }\end{array}$ & $x$ & $x$ & $\mathrm{x}$ \\
\hline Hydrogen peroxide (>52\%) & & & $x$ & & \\
\hline Lead (bricks and ingots) & & & & $x$ & $x$ \\
\hline Nitric acid & $x$ & & $x$ & $x$ & $x$ \\
\hline Nitric oxide & & $x$ & $x$ & $x$ & \\
\hline Nitrogen & & $x$ & & $x$ & \\
\hline Oxygen & & $x$ & $x$ & & \\
\hline Paint & $x$ & & & & \\
\hline Phosphorous pentoxide $(\mathrm{a})$ & & & $x$ & $x$ & \\
\hline Propane & $x$ & & & & \\
\hline Sodium hypochlorite/bleach & & & & $x$ & $x$ \\
\hline Stoddard solvent/thinner & $x$ & & & $x$ & \\
\hline Sulfuric acid & & & $x$ & $x$ & $x$ \\
\hline
\end{tabular}

a Phosphorous pentoxide is no longer listed as an extremely hazardous substance (EHS) under SARA Title III regulations.

Table 2-6. Site 300, SARA, Title III, Section 311, Chemical List.

\begin{tabular}{|c|c|c|c|c|c|}
\hline \multirow{2}{*}{$\begin{array}{c}\text { Site } 300 \\
\text { chemicals }\end{array}$} & \multicolumn{3}{|c|}{ Physical hazards } & \multicolumn{2}{|c|}{ Health hazards } \\
\hline & Fire & Pressure & Reactivity & Acute & Chronic \\
\hline Chlorine & & $x$ & & $x$ & \\
\hline $\begin{array}{l}\text { Bis (2,2-dinitro-2-fluoroethyl) formal in } \\
\text { methylene chloride }\end{array}$ & -(a) & & -(a) & $x$ & $x$ \\
\hline Diesel fuel & $x$ & & & & \\
\hline Gasoline & $\mathrm{X}$ & & & $x$ & $x$ \\
\hline High explosives & & & $x$ & & \\
\hline Lead (bricks) & & & & $\mathrm{X}$ & $X$ \\
\hline
\end{tabular}

a Dangerous fire or explosion risk in neat form (solvent evaporates). 


\section{Compliance Summary}

Table 2-7. Summary of permits. (a)

\begin{tabular}{|c|c|c|}
\hline $\begin{array}{l}\text { Type of } \\
\text { permit }\end{array}$ & Livermore site & Site 300 \\
\hline Air & $\begin{array}{l}194 \text { permits from BAAQMD. Various equipment, including } \\
\text { boilers, emergency generators, cold cleaners, ultrasonic } \\
\text { cleaners, degreasers, printing press operation, manual wipe } \\
\text { cleaning operations, metal machining and finishing } \\
\text { operations, silk screening operation, silk screen washers, } \\
\text { paint spray booths, adhesives operations, diamond turning } \\
\text { machine cleaning operation, image tube fabrication, optic } \\
\text { coating operations, gravity retort, storage tanks containing } \\
\text { volatile organic compounds (VOCs) in excess of 10\%, } \\
\text { planetary mixers, plating tanks, drum crusher, } \\
\text { semiconductor operations, diesel air compressor engines, } \\
\text { ground water air strippers, soil vapor extraction unit, dryers, } \\
\text { ovens, material handling equipment, sewer diversion } \\
\text { system, wave soldering machine, oil and water separator, } \\
\text { fire test cells, oil shale hopper and preheater, oil shale } \\
\text { combuster, gasoline dispensing operation, resin mixing } \\
\text { operation, paper pulverizer system, and firing tanks. }\end{array}$ & $\begin{array}{l}43 \text { permits from SJVUAPCD. Various equipment, } \\
\text { including boilers, emergency generators, paint spray } \\
\text { booth, ground water air strippers, soil vapor extraction } \\
\text { units, woodworking cyclone, gasoline dispensing } \\
\text { operation, and drying ovens. }\end{array}$ \\
\hline Water & $\begin{array}{l}\text { WDR Order No. 88-075 for discharges of treated ground } \\
\text { water from TFA to percolation pits and recharge basin. } \\
\text { WDR Order No. 95-174, NPDES Permit No. CA0030023 for } \\
\text { discharges of storm water associated with industrial } \\
\text { activities and low-threat non-storm water discharges to } \\
\text { surface waters. } \\
\text { WDR Order No. 92-08-DWQ, NPDES General Permit } \\
\text { No. CAS000002, Bldg. 132, Site ID No. 201S300881, } \\
\text { DWTF Site ID No. 201S305140, and North Buffer } \\
\text { Improvement Project Site ID No. } 2015305529 \text {, for } \\
\text { discharges of storm water associated with construction } \\
\text { activities impacting } 2 \text { hectares or more. } \\
\text { Four projects completed under Army Corps of Engineers } \\
\text { Nationwide Permit and } 401 \text { Waiver of Water Quality } \\
\text { Certification, } 5 \text { streambed alteration agreements. } \\
\text { FFA, ground water investigation/remediation. }\end{array}$ & $\begin{array}{l}\text { WDR Order No. 93-100 for post closure monitoring } \\
\text { requirements for two Class I landfills. } \\
\text { WDR Order No. 94-131, NPDES Permit No. CA0081396 } \\
\text { for discharges of storm water associated with industrial } \\
\text { activities and from cooling towers. } \\
\text { WDR Order No. 96-248 (replaced WDR Order No. } \\
\text { 85-188) for operation of two Class II surface } \\
\text { impoundments, a domestic sewage lagoon, and } \\
\text { percolation pits. } \\
\text { WDR Order No. 91-052, NPDES Permit No. CA0082651 } \\
\text { for discharges of treated ground water from the eastern } \\
\text { General Services Area treatment unit. } \\
\text { Two streambed alteration agreements. FFA ground } \\
\text { water investigation/remediation. } 52 \text { registered, Class V } \\
\text { injection wells. }\end{array}$ \\
\hline $\begin{array}{l}\text { Hazardous } \\
\text { waste }\end{array}$ & $\begin{array}{l}\text { ISD CA2890012584. } \\
\text { Authorization to perform waste resin mixing in Unit CE231-1 } \\
\text { and Unit CE443-1 under conditional exemption tier. }\end{array}$ & $\begin{array}{l}\text { Part B CA2890090002-Building } 883 \text { and Explosives } \\
\text { Waste Storage Facility. } \\
\text { Docket HWCA 92/93-031. } \\
\text { Open burning of explosives waste-pending. }\end{array}$ \\
\hline Sewer & $\begin{array}{l}\text { Discharge Permit Nos. } 1250 \text { (96-97), 1508G (96-97), and } \\
\text { 1510G (96-97) for discharges of wastewater to the sanitary } \\
\text { sewer, discharges of sewerable ground water from TFF, } \\
\text { and ground water discharges from restoration treatability } \\
\text { studies (in order of numbers as indicated). }\end{array}$ & \\
\hline Tanks & $\begin{array}{l}12 \text { underground petroleum and hazardous waste storage } \\
\text { tank permits. }\end{array}$ & $\begin{array}{l}\text { One permit covering five underground petroleum product } \\
\text { tanks. }\end{array}$ \\
\hline Other & ACEHS medical waste permit for treatment and storage. & \\
\hline
\end{tabular}

a Permit numbers are based on actual permitted units maintained and renewed by LLNL during 1996. 
Table 2-8. Inspections and tours of LLNL facilities by external agencies in 1996.

\begin{tabular}{|c|c|c|c|c|}
\hline Medium & Description & Agency & Date & Finding \\
\hline Air & Emission sources & BAAQMD & $\begin{array}{c}5 / 9 \\
11 / 7 \\
11 / 19 \\
12 / 3 \\
12 / 11\end{array}$ & No violations \\
\hline $\begin{array}{l}\text { Storm water/ } \\
\text { streambeds }\end{array}$ & Wetlands management, streambed alteration & CDFG & $\begin{array}{c}1 / 9 \\
8 / 27 \\
10 / 8\end{array}$ & No violations \\
\hline Tanks & Installation and closure of USTs & ACEHS & $\begin{array}{l}2 / 16 \\
4 / 24 \\
4 / 30 \\
6 / 20 \\
6 / 27 \\
7 / 22 \\
8 / 22 \\
10 / 2\end{array}$ & No violations \\
\hline Waste & $\begin{array}{l}\text { Three hazardous waste management facilities and one waste } \\
\text { accumulation area }\end{array}$ & DTSC & $2 / 14-2 / 15$ & No violations \\
\hline \multirow{2}{*}{ Wastewater } & Wastewater sources & LWRP/EPA & $10 / 17$ & No violations \\
\hline & Ground water treatment facilities & LWRP & $12 / 5$ & No violations \\
\hline \multicolumn{5}{|c|}{ Site 300} \\
\hline \multirow[t]{2}{*}{ Air } & Emission sources & SJVUAPCD & $2 / 9$ & No violations \\
\hline & Asbestos in buildings scheduled for demolition & SJVUAPCD & $8 / 20$ & No violations \\
\hline $\begin{array}{l}\text { Storm water/ } \\
\text { streambeds }\end{array}$ & Wetlands management, streambed alteration & CDFG & $9 / 11$ & No violations \\
\hline Waste & Vehicles used for transportation of hazardous material & $\mathrm{CHP}$ & $12 / 10$ & 5 violations ${ }^{(b)}$ \\
\hline Wastewater & Permitted operations & CVRWQCB & $5 / 8$ & No violations \\
\hline
\end{tabular}

a Storage above $0^{\circ} \mathrm{C}$ for longer than 7 days. See Chapter 2, Medical Waste.

b Violations included such things as missing side reflectors, inoperative brake lamps, and a discharged fire extinguisher. See Chapter 2 , Hazardous Waste Transport Registration. 


\section{Compliance Summary}

\section{Clean Air Act-Air Quality Management Activities}

Air permits are obtained from the Bay Area Air Quality Management District (BAAQMD) for the Livermore site and from the San Joaquin Valley Unified Air Pollution Control District (SJVUAPCD) for Site 300. In 1996, BAAQMD issued or renewed air permits for 194 air emission sources for the Livermore site. For 1996, SJVUAPCD issued or renewed air permits for 43 air emission sources for Site 300 (see Table 2-7). During 1996, air district inspectors found no deficiencies at either Site 300 or the Livermore site.

\section{National Emission Standards for Hazardous Air Pollutants}

Demonstration of compliance with the National Emission Standards for Hazardous Air Pollutants (NESHAPs) for radionuclide emissions to air (Radionuclide NESHAPs, 40 CFR 61, Subpart H) requires that all potential sources be evaluated to determine the potential radiological dose to the maximally exposed individual (MEI) member of the public.

Compliance with two dose limits must be evaluated. First, the integrated dose to the MEI from all sources of radionuclide emissions to air at a site must not exceed 100 microsieverts per year ( $\mu \mathrm{Sv} / \mathrm{y})(10$ millirem per year $[\mathrm{mrem} / \mathrm{y}])$. Second, each source (stack) with the potential for unmitigated emissions resulting in any dose greater than $1 \mu \mathrm{Sv} / \mathrm{y}(0.1 \mathrm{mrem} / \mathrm{y})$ must be continuously monitored using systems that meet requirements stated in the regulations.

The LLNL NESHAPs 1996 Annual Report (Gallegos and Biermann 1997) reported to DOE and EPA the total calculated sitewide MEI radiological doses for the Livermore site and Site 300 to be $0.93 \mu \mathrm{Sv} / \mathrm{y}(0.093 \mathrm{mrem} / \mathrm{y})$ and $0.33 \mu \mathrm{Sv} / \mathrm{y}(0.033 \mathrm{mrem} / \mathrm{y})$, respectively. The reported doses include contributions from both point sources and diffuse sources. Modeling was based on a combination of effluent monitoring data and radionuclide inventory data. The totals are well below the $100 \mu \mathrm{Sv} / \mathrm{y}(10 \mathrm{mrem} / \mathrm{y})$ dose limits defined by the NESHAPs regulations. The details of these data are included in this report (see Chapter 12, Radiological Dose Assessment). These 1996 dose values are higher than those reported for 1995, which were $0.41 \mu \mathrm{Sv} / \mathrm{y}(0.041 \mathrm{mrem} / \mathrm{y})$ for the Livermore site and $0.23 \mu \mathrm{Sv} / \mathrm{y}(0.023 \mathrm{mrem} / \mathrm{y})$ for Site 300 . There was one unplanned atmospheric radionuclide release from the Livermore site in 1996. The resulting dose to the sitewide maximally exposed individual was a minuscule $4.9 \times 10^{-8} \mu \mathrm{Sv}$ $\left(4.9 \times 10^{-9} \mathrm{mrem}\right)$. There were no unplanned atmospheric releases at Site 300 in 1996.

In 1996, LLNL maintained continuous radionuclide emissions monitoring of Building 331 (the Tritium Facility), Building 332 (the Plutonium Building), the seismically strengthened portion of Building 251, and six other buildings (see Chapter 12). 


\section{Compliance Summary}

On May 28, 1996, the U.S. EPA, Region IX conducted a Compliance Evaluation Investigation at Buildings 332, 255, 253, and 331. LLNL personnel summarized stack monitoring systems, the HEPA filter testing program, the Hazards Control Radiological Measurements Laboratory operations, Building 332 operations overview and facility tour, and NESHAPs compliance overview. LLNL was found to be in compliance with 40 CFR 61 Subpart $\mathrm{H}$, and no additional compliance activities were required.

On July 25, 1996, LLNL requested an exemption for uranium from the temperaturebased physical state assumption that all materials heated in excess of $100^{\circ} \mathrm{C}$ are in a gaseous physical state. U.S. EPA accordingly granted approved alternative emissions factors for elemental uranium (see Chapter 12).

In December 1996, LLNL held an informational meeting with U.S. EPA Region IX staff to discuss planned construction of the Decontamination and Waste Treatment Facility at the Livermore site and Contained Firing Facility at Site 300. Potential NESHAPs issues and plans for monitoring at the facilities were discussed. Additional subjects covered at the meeting included periodic confirmatory measurements, the potential for the use of de minimis values in determining NESHAPs compliance, and the status of the delegation of NESHAPs regulatory oversight to the State of California.

\section{Clean Water Act and Related State Programs}

Preserving clean water is the subject of local, state, and federal regulations. The National Pollutant Discharge Elimination System (NPDES) under the Federal Clean Water Act establishes permit requirements for discharges into navigable waterways. In addition, the State of California requires permits, known as Waste Discharge Requirements (WDRs), for any discharges of wastes affecting the beneficial uses of waters of the state. The Regional Water Quality Control Boards (RWQCBs) are responsible for issuing and enforcing both permits. The Livermore Water Reclamation Plant (LWRP) requires permits for discharges of sewerable water to the city sanitary sewer system. The Army Corps of Engineers (ACOE) issues permits for work in navigable waterways below the normal high water mark and for controlling dredge and fill operations in waters of the United States. The State Water Resources Control Board (SWRCB) issues water quality certifications for this work if the Regional Water Quality Control Boards do not waive the requirement for the water quality certification. The California Department of Fish and Game (CDFG) under the Fish and Game Code Section 1601 et seq. requires streambed alteration agreements for any work that may disturb or impact rivers, streams, or lakes. Finally, the Safe Drinking Water Act (SWDA) requires registration and management of injection wells to protect ground water sources of drinking water. Water permits are summarized in Table 2-7 and discussed in detail in Chapters 6, 7, and 8. 


\section{Compliance Summary}

\section{Ground Water and Surface Water}

Discharges of treated ground water to surface water drainage courses and percolation ponds at LLNL are governed by NPDES permits, WDRs, and CERCLA Records of Decision (see Table 2-7). Details of surface water discharges are found in Chapter 7 of this report. Details of ground water monitoring are found in Chapter 8 of this report, the LLNL Ground Water Project 1996 Annual Report (Hoffman et al. 1997), and the LLNL Ground Water Project Quarterly Reports (McConachie and Brown 1996; Ko and Lamarre 1996; Littlejohn and Lamarre 1996; and Littlejohn and Lamarre 1997). LLNL discharges storm water associated with industrial activities, low-threat non-storm water, and various process waters discharging to surface impoundments and a sewer lagoon under NPDES permits and WDRs (see Chapters 7 and 8). LLNL was in compliance with its four NPDES permits and received no notices of violations (NOVs) in 1996. However, permit discharge limit excursions occurred in two of the four permits. NPDES discharges are summarized below in Table 2-9.

Table 2-9. Summary of discharges to surface water relative to NPDES permits.

\begin{tabular}{|c|c|c|c|c|}
\hline $\begin{array}{l}\text { Permit } \\
\text { No. }\end{array}$ & Outfall & Nonconformance & $\begin{array}{l}\text { Date(s) } \\
\text { exceeded }\end{array}$ & $\begin{array}{l}\text { Description- } \\
\text { solution }\end{array}$ \\
\hline CAS000002 & Arroyo Las Positas (Livermore site) & $\begin{array}{l}\text { DWTF: Non-permitted } \\
\text { storm water discharge }\end{array}$ & $1 / 96$ & Revised SWPPP(a) \\
\hline CAS000002 & Arroyo Las Positas (Livermore site) & $\begin{array}{c}N B Z(b) \text { : Required } \\
\text { inspection not performed }\end{array}$ & $4 / 30$ & Revised SWPPP \\
\hline CAS000002 & Arroyo Las Positas (Livermore site) & $\begin{array}{l}\text { NBZ: Required inspection } \\
\text { not documented }\end{array}$ & $5 / 7$ & Revised SWPPP \\
\hline CA0030023 & $\begin{array}{c}\text { Arroyo Las Positas and Arroyo Seco } \\
\text { (Livermore site) }\end{array}$ & none & none & none \\
\hline CA0081396 & Corral Hollow Creek (Site 300) & none & none & none \\
\hline CA0082651 & Corral Hollow Creek (Site 300) & TCE & $8 / 21$ & $\begin{array}{l}\text { Increased the retention time } \\
\text { in the treatment system and } \\
\text { cleaned the sparge tank. }\end{array}$ \\
\hline
\end{tabular}

a SWPPP $=$ Storm Water Pollution Prevention Plan.

b $\quad$ NBZ $=$ North Buffer Zone.

LLNL continued construction operations for two projects and started operations for one other project at the Livermore site, activities that are covered by the California General Construction Activity permit (see Table 2-7). Continuing operations included construction of Building 132 and the nonhazardous waste portions of the Decontamination and Waste Treatment Facility (DWTF). In 1996, LLNL submitted a Notice of Intent (NOI) to regrade 36 acres of the North Buffer Zone (NBZ) to improve drainage and maintenance. 


\section{Compliance Summary}

In September 1996, the Central Valley RWQCB issued WDR Order No. 96-248 (amends WDR Order No. 85-188) for the operation of the domestic sewage ponds, the Class II surface impoundments, and five percolation pits at Site 300. On July 30, 1996, the Central Valley RWQCB waived waste discharge requirements for the operation of septic tanks and leach fields (previously permitted under WDR85-188) based on the finding that wastewater discharges to the septic tanks will not adversely affect water quality.

LLNL submitted a permit application to renew WDR Order No. 91-052 (NPDES Permit No. CA0082651) to the Central Valley RWQCB on February 7, 1996. The Central Valley RWQCB has not yet acted on this permit application.

In August 1996, the EPA awarded LLNL the national first place award for an excellent Storm Water Management Program in the Industrial Category. The National Storm Water Control Program Excellence Award acknowledges municipalities and industries that demonstrate their commitment to the protection and improvement of the nation's waters through the operation of innovative, cost-effective storm water control programs or projects. The selection was the result of an extensive national competition. EPA based the selection on LLNL's demonstrated innovative and cost-effective achievements for improving storm water quality.

\section{Sewerable Water}

The Livermore site's sanitary sewer discharges are sampled continuously, daily, weekly, and monthly to satisfy permit compliance requirements. The monitoring results for the LLNL effluent are reported monthly to the LWRP. In 1996, LLNL achieved greater than 99\% compliance with LWRP permits covering discharges into the sanitary sewer. Although no NOVs were written for the sanitary sewer, two letters of concern (LOCs) were issued concerning $\mathrm{pH}$ excursions. In March 1997, LLNL was issued an NOV for a pH exceedance on February 12 and a silver exceedance on February 5. The NOV specifically targeted these two discharges, but treated the $\mathrm{pH}$ exceedance as a continuation of the low $\mathrm{pH}$ exceedances in 1996. LWRP permit exceedances are summarized in Table 2-10 and discussed in detail in Chapter 6 .

In 1996, LLNL continued to seek an EPA exemption from continued compliance with the Categorical Standards because of the belief that the categorical wastewater standards were not written or intended for research and development facilities. The LWRP suspended the requirements for self-monitoring of categorical processes through 1996 while the applicability of the categorical standards was evaluated. With the permit renewal of permit number 1250 (96-97), LWRP and EPA determined LLNL was not eligible for the exemption. However, the permit renewal resulted in a reduced number of processes subject to categorical requirements. Self-monitoring of these processes will begin in 1997 as required in the permit. 


\section{Compliance Summary}

Table 2-10. Summary of compliance with LWRP permit limits for discharges to the sanitary sewer.

\begin{tabular}{|c|c|c|c|c|}
\hline $\begin{array}{l}\text { Permit } \\
\text { No. }\end{array}$ & Outfall & Exceedance & $\begin{array}{c}\text { Date }(\mathbf{s}) \\
\text { exceeded }\end{array}$ & $\begin{array}{l}\text { Description- } \\
\text { solution }\end{array}$ \\
\hline \multirow[t]{3}{*}{1250} & \multirow[t]{3}{*}{ City sewer } & Low $\mathrm{pH}$ & $\begin{array}{l}1 / 31 \\
3 / 22 \\
8 / 12 \\
8 / 26 \\
9 / 11\end{array}$ & $\begin{array}{l}\text { Continue investigating for sources and } \\
\text { provide enhanced education to the } \\
\text { Laboratory's population regarding proper } \\
\text { disposal of wastewater. }\end{array}$ \\
\hline & & High pH & $\begin{array}{c}5 / 17 \\
6 / 3\end{array}$ & $\begin{array}{l}\text { Continue investigating for sources and } \\
\text { provide enhanced education to the } \\
\text { Laboratory's population regarding proper } \\
\text { disposal of wastewater. (a) }\end{array}$ \\
\hline & & Mercury & $11 / 27$ & Not applicable $(\mathrm{b})$ \\
\hline $1508 \mathrm{G}$ & City sewer & none & none & none \\
\hline $1510 \mathrm{G}$ & City sewer & none & none & none \\
\hline
\end{tabular}

a LWRP chose not to enforce these exceedances because they did not exceed the duration criteria of 40 CFR 401.17 .

b LWRP did not consider this exceedance a permit violation (see Chapter 6 for details).

LLNL renewed permits 1508G and 1510G issued by the LWRP for discharge of sewerable waste from TFF and for discharges from sitewide treatability studies. Discharges from TFF to the sanitary sewer are monitored quarterly and reported semiannually to the LWRP. Discharges from the sitewide treatability study are reported annually. These self-monitoring programs and the associated analytical results documenting compliance with the self-monitoring provisions of these permits are detailed in Chapter 6.

The LWRP toured the Building 391 large neutron-scintillating array pit on August 2, 1996, as part of their determination that it was appropriate to discharge ground water seeping into the pit to the sanitary sewer. On October 2 and 3, LWRP collected split samples of site effluent from Building 196 as part of the annual compliance sampling. The U.S. EPA and LWRP staff jointly inspected LLNL on October 17. This inspection was a follow-up to a series of inspections in 1995 that were part of the U.S. EPA's characterization of nondomestic wastewater sources, evaluation of whether source controls ensure compliance with the Clean Water Act, and review of the LWRP permit. EPA's conclusion was that LLNL was well operated and properly configured to comply with the Clean Water Act. LWRP staff additionally inspected the ground water treatment facilities on December 5, 1996. Results of EPA and LWRP inspections are summarized in Table 2-8. 


\section{Streambed Alteration Agreements and 404 Nationwide Permits}

California Department of Fish and Game (CDFG) issued six streambed alteration agreements for construction and maintenance projects within arroyos near Livermore site facilities during 1996 (see Table 2-11). Four of these projects were also subject to Clean Water Act Section 404 permitting requirements and were covered by Army Corps of Engineers (ACOE) nationwide permits. The San Francisco Bay RWQCB issued waivers from 401 Water Quality Certification for each project covered by a nationwide permit.

Table 2-11. Summary of streambed alteration agreements and 404 nationwide permits.

\begin{tabular}{|l|l|l|c|}
\hline \multicolumn{1}{|c|}{ Project } & \multicolumn{1}{c|}{ Location } & \multicolumn{1}{c|}{ Agency } & $\begin{array}{c}\text { Date } \\
\text { submitted }\end{array}$ \\
\hline Bank stabilization & Arroyo Seco & CDFG & $1 / 19 / 96$ \\
Erosion repair & & $\begin{array}{l}401 \text { waiver } \\
\text { Nationwide permit 13 }\end{array}$ & $\begin{array}{l}4 / 17 / 96 \\
4 / 17 / 96\end{array}$ \\
\hline Bank stabilization & Arroyo Las Positas & $\begin{array}{l}401 \text { waiver } \\
\text { Nationwide permit 13 }\end{array}$ & $1 / 29 / 96$ \\
& & CDFG & $1 / 30 / 96$ \\
\hline Maintenance & Arroyo Los Positas & Arroyo Seco & $5 / 17 / 96$ \\
\hline Channel maintenance & Arroyo Las Positas & CDFG & \\
Culvert removal & & 401 waiver & $7 / 22 / 96$ \\
\hline Easement road crossing & & Nationwide permit 13 & \\
Culvert & Arroyo Mocho & CDFG & $8 / 5 / 96$ \\
& & Nationwide permit 14 & $8 / 2 / 96$ \\
\hline Maintenance (5-year agreement) & Site 300 drainage & CDFG & 1995 \\
\hline Cutting vegetation & culverts & & $9 / 20 / 96$ \\
\hline
\end{tabular}

At Site 300, LLNL continued to operate under a 5-year CDFG streambed alteration agreement issued in 1995 for maintenance of drainage channels. CDFG issued a streambed alteration agreement on May 20,1996, for the installation of monitor wells in the stream channel near Building 832. LLNL requested consultation with the Central Valley RWQCB, CDFG, and ACOE under CERCLA for remediation work impacting Elk Ravine as a result of remediation activities at the Building 834 complex.

\section{Injection Wells}

LLNL continues to operate injection wells registered with EPA. LLNL has 32 active and 20 inactive Class V injection wells at Site 300. The majority of the active injection wells are sanitary septic systems and percolation pits receiving small volumes of equipment wastewater, such as boiler blowdown and cooling tower blowdown. 


\section{Compliance Summary}

\section{Spill Prevention Control and Countermeasures Plan}

LLNL's Spill Prevention Control and Countermeasures Plans (SPCC) for the Livermore site and Site 300 comply with the Federal Oil Pollution Prevention Regulation, Title 40, CFR Part 112 and Division 20, Chapter 6.67 of the California Health and Safety code. In addition, the Plans comply with 40 CFR 761.65(b) and (c), which regulates the storage of polychlorinated biphenyls (PCBs). LLNL first published the SPCC plan in November 1991. The plan was updated in December 1995 as required by 40 CFR 112.5, which requires that an SPCC Plan be amended whenever changes to a facility increase or decrease the possibility of oil being discharged into navigable waters. Since the publication of the original plan in November 1991, LLNL has decreased the possibility of a spill by improving its facilities. No significant changes were made to the technology or practices documented in the SPCC Plan. The revised plans were implemented in June 1996.

\section{Tank Management}

LLNL manages its underground storage tanks (USTs) and aboveground storage tanks (ASTs) through the use of underground tank permits, monitoring programs, operational plans, closure and leak documentation, the Tank Upgrade Project, remedial activities, and inspections. Those topics are discussed in the following sections.

\section{Tank Systems}

Underground tanks contain diesel fuel, gasoline, waste oil, and contaminated wastewater; aboveground tanks contain diesel fuel, insulating oil, TCE, and contaminated wastewater. Some of the wastewater systems are a combination of underground storage tanks and aboveground storage tanks. Table 2-12 tabulates the status of the Livermore site and Site 300 tanks as of December 31, 1996. The number of USTs requiring tank operating permits during all or part of 1996 at the Livermore site decreased by 6 .

\section{Tank Integrity Testing}

Under the tank leak-tightness testing program, single-walled hazardous waste and hazardous product USTs are tested to determine their structural integrity in accordance with requirements established in state and federal regulations. The Tank Upgrade Project has replaced all single-walled hazardous waste and hazardous product USTs with doublewalled tanks that have continuous leak detection or double-walled ASTs. Therefore, tank integrity testing for USTs at the Livermore site and Site 300 is no longer needed. 
Table 2-12. Status of in-service tanks, December 31, 1996.

\begin{tabular}{|l|c|c|c|c|c|c|}
\hline \multirow{2}{*}{ Tank type } & \multicolumn{3}{|c|}{ Livermore site } & \multicolumn{3}{c|}{ Site 300 } \\
\cline { 2 - 6 } & Permitted & $\begin{array}{c}\text { No } \\
\text { permits } \\
\text { required }\end{array}$ & Total & Permitted & $\begin{array}{c}\text { No } \\
\text { permits } \\
\text { required }\end{array}$ & Total \\
\hline $\begin{array}{l}\text { Underground storage tanks } \\
\text { Diesel fuel }\end{array}$ & 7 & 0 & 7 & 4 & 0 & 4 \\
Gasoline & 2 & 0 & 2 & 1 & 0 & 1 \\
Waste oil & 1 & 0 & 1 & 0 & 0 & 0 \\
Wastewater & 2 & 38 & 40 & 0 & 10 & 10 \\
$\quad$ Subtotal & $\mathbf{1 2}$ & $\mathbf{3 8}$ & $\mathbf{5 0}$ & $\mathbf{5}$ & $\mathbf{1 0}$ & $\mathbf{1 5}$ \\
\hline Aboveground storage tanks & & & & & & \\
Diesel fuel & 0 & 26 & 26 & 0 & 15 & 15 \\
Product & 0 & 15 & 15 & 0 & 4 & 4 \\
Wastewater & 7 (a) & 75 & 82 & 0 & 15 & 15 \\
$\quad$ Subtotal & $\mathbf{7}$ & $\mathbf{1 1 6}$ & $\mathbf{1 2 3}$ & $\mathbf{0}$ & $\mathbf{3 4}$ & $\mathbf{3 4}$ \\
\hline TOTAL & $\mathbf{1 9}$ & $\mathbf{1 5 4}$ & $\mathbf{1 7 3}$ & $\mathbf{5}$ & $\mathbf{4 4}$ & $\mathbf{4 9}$ \\
\hline
\end{tabular}

a These seven tanks are located at the LLNL Treatment, Storage, and Disposal Facility and are operated under interim status as part of the RCRA Part B permit application.

\section{Closure and Leak Documentation}

Closure requirements for hazardous USTs include the preparation and approval of closure plans, quarterly reports if leaks have been identified, and a report upon completion of closure activities. The closure plans must include a detailed review of the uses of the tank, a sampling plan, a site plan, and other information to verify that no environmental contamination has occurred or, if it has occurred, to ensure its cleanup. Hazardous waste ASTs must also meet regulatory requirements for closure plans, field activities, and closure reports.

A total of eight closure plans were prepared in 1996 for tank systems (or portions of systems) that were taken out of service, previously removed (but not officially closed), or expected to be removed from service. Three of these closure plans were for regulated hazardous product, hazardous waste, or mixed waste USTs and were submitted to regulatory agencies. (A mixed waste UST stores waste that has the characteristics of both hazardous and radioactive waste.) All three closure plans have been approved. The five remaining closure plans were prepared for aboveground hazardous product and nonhazardous waste tank systems as a part of LLNL's best management practices.

Upon completion of closure activities, closure reports for hazardous product, hazardous waste, and mixed waste USTs must be submitted to the regulatory agencies for review 


\section{Compliance Summary}

and approval. Ten closure reports for hazardous product, hazardous waste, or mixed waste USTs were submitted to regulatory agencies for review in 1996. Nine of these were approved, and the one remaining is awaiting approval. Eleven closure reports were prepared in 1996 for aboveground hazardous product and hazardous waste tanks as a part of LLNL's best management practices. Thirteen ASTs and seven USTs were closed during 1996.

\section{Tank Upgrade Project}

In 1992, LLNL began to upgrade or close wastewater retention tanks (for nonhazardous, hazardous, mixed, and radioactive waste) and product retention tanks (for petroleum products) in accordance with existing local, state, and federal tank regulations or to decrease the potential for environmental contamination as the result of a release from a tank or its appurtenances. As of December 1996, construction has been completed for 153 tanks and construction is in progress for 4 tanks.

\section{Remedial Activities}

In June 1996, during pipe removal activities associated with the closure of USTs 419-R1U4/R1U5, beads of elemental mercury were found underneath the floor of Building 419. Two of four samples that were collected and analyzed for metals and radioactivity showed mercury in quantities above the California hazardous waste total threshold limit concentration (TTLC) limit. All soil samples showed tritium radioactivity, which was considered added radioactivity. The piping was removed and all the visible mercury-contaminated soil was excavated. DTSC and the Alameda County Department of Health Services agreed that no further excavation or sampling was necessary. The tritium contamination will be handled according to the Record of Decision for the Lawrence Livermore National Laboratory Livermore Site (U.S. Department of Energy 1992). Three source investigation piezometers have been installed downgradient of the west side of Building 419 to monitor any movement of the tritium contamination.

For every installation and closure of hazardous waste, mixed waste, and hazardous product USTs, there is an inspection in which a representative from Alameda County Environmental Health Services (ACEHS) (for the Livermore site) or San Joaquin County Public Health Services (for Site 300) participates. Inspections are summarized in

Table 2-8.

\section{Resource Conservation and Recovery Act}

The Resource Conservation and Recovery Act (RCRA) provides the framework at the federal level for regulating the generation and management of solid wastes, including 


\section{Compliance Summary}

wastes designated as hazardous. Similarly, the California Hazardous Waste Control Act (HWCA) sets requirements for managing hazardous wastes in California. RCRA and HWCA also regulate hazardous waste treatment, storage, and disposal facilities, including permit requirements. Because RCRA program authorization was delegated to the State of California in 1992, LLNL now works solely with California Department of Toxic Substances Control (DTSC) on compliance issues and in obtaining hazardous waste permits.

\section{Hazardous Waste Permits}

The Livermore site hazardous waste storage and treatment management units continued to operate under interim status provisions (ISD CA2890012584) while DTSC continued to review and consider the latest modification to the Livermore site Part B permit application. Waste management units include container storage, tank storage, and various treatment processes (e.g., wastewater filtration, blending, and size reduction).

LLNL submitted a revised Part B application on June 28, 1996. This application includes some existing hazardous waste facilities as well as the proposed Decontamination and Waste Treatment Facility (DWTF). The DWTF will be constructed in order to consolidate, replace, upgrade, and augment existing LLNL waste management capabilities. The revised Part B application, if approved by DTSC, will provide a mechanism for LLNL to operate portions of the existing hazardous waste facilities under interim status until DWTF is permitted and fully functional. The remaining portion of existing facilities will continue to operate under the Part B permit. A revised Health Risk Assessment was developed to supplement the Part B application and was submitted to DTSC in February 1997.

The Site 300 Building 883 hazardous-waste-container storage area operates under the provisions of the Part B permit (Part B CA28990090002) issued by DTSC in November 1989 and renewed in May 1996. The renewed permit also authorized the construction and operation of the Explosives Waste Storage Facility, which augments the storage capability at Site 300 by providing a separate dedicated facility to store explosives waste. It is anticipated that this facility will be operational in July 1997.

A new, open-burning, open-detonation facility called the Explosives Waste Treatment Facility (EWTF) was proposed for Site 300 . The proposed facility will replace the existing Building 829 Open Burn Facility. A Part B permit application for the proposed EWTF was submitted to DTSC in May 1993 and last revised in September 1995. The Part B application was supplemented by an Environmental and Exposure Assessment (EEA) submitted in May 1993 and last revised in September 1996. LLNL anticipates issuance of the EWTF permit in fiscal year 1997. 


\section{Compliance Summary}

The Building 829 Open Burn Facility for explosives waste continues to operate under a stipulation order issued by DTSC in September 1993. Upon issuance of the EWTF permit, the Building 829 Open Burn Facility will undergo formal interim status closure, pending approval of the closure plan by DTSC. A closure plan was submitted to DTSC in July 1993, and a revised plan submitted to DTSC in April 1997. The closure will involve removal of all equipment and capping and grading of the area, in compliance with regulatory requirements for in-situ closure of a hazardous waste unit.

On February 14 and 15, 1996, DTSC Region 2 conducted a Compliance Evaluation Inspection at the Livermore site.

DTSC reviewed the following types of records and documents: inspection logs, hazardous waste manifests, land disposal restriction notifications, stored waste inventory, hazardous waste container tracking system, hazardous waste hauling license, interim status document, hazardous waste facility operating logs, two conditionally exempt resin mixing treatment unit operating logs, contingency plans, training records, Hazardous Waste Management Waste Analysis Plan, engineering certifications for HWM tanks, and closure plans. No violations were issued (see Table 2-8).

\section{Hazardous Waste Reports for 1995 and 1996}

Biennial reports, Hazardous Waste Report-Mainsite and Hazardous Waste Report-Site 300, are required under 40 CFR 262.41, 264.75, and 265.75. These reports were completed and delivered to EPA on March 29, 1996, by the adjusted deadline. The corresponding annual reports, which cover 1996 waste-handling information, will be completed and submitted to meet DTSC's adjusted June 30, 1997, deadline. The annual reports are required under 22 CCR 66264.75 and are on file at LLNL.

\section{Hazardous Waste Transport Registration}

Transportation of hazardous waste over public roads (e.g., from one LLNL site to another) requires DTSC registration (22 CCR 66263.10). Conditions for registration include annual inspections of transport vehicles and trailers by the California Highway Patrol (CHP), biennial terminal inspections, special training and annual physical examinations for drivers, and annual submission of lists of transport vehicles and trailers to DTSC. The registration was renewed by DTSC in November 1996.

The California Highway Patrol inspected the Livermore site and Site 300 on November 19-20 and December 10, 1996, respectively. As part of the November vehicle safety compliance check, eight vehicles assigned to the Livermore site were inspected. Twelve violations were identified on five vehicles that may transport hazardous material. An additional citation was issued for a vehicle recordkeeping violation. The December inspection was conducted at LLNL's Site 300 and included a total of eight additional 


\section{Compliance Summary}

vehicles. Site 300 received five violations involving four vehicles that may carry hazardous material. All but two of the violations have been corrected. The remaining deficiencies involve driver time-keeping records and vehicle marking issues. Current LLNL policies are being modified to address these final findings.

A certificate commending LLNL for three consecutive satisfactory safety compliance ratings since January 7, 1992, was awarded to LLNL at the conclusion of this inspection.

\section{Waste Accumulation Areas}

Beginning in January 1996, there were 41 waste accumulation areas (WAAs) at the Livermore site and one at the Livermore Airport. During the year, 4 WAAs were taken out of service and 1 WAA was put into service, leaving a total of 38 WAAs at the Livermore site and $1 \mathrm{WAA}$ at the Livermore Airport. Program representatives conducted formal inspections at least weekly at all WAAs to ensure that WAAs were operated in compliance with regulatory requirements. More than 2100 formal WAA inspections were conducted at the Livermore site and 52 at the Livermore Airport WAA. In addition, Environmental Protection Department (EPD) personnel conducted informal, biweekly, routine checks at all WAAs for such things as capacity, labeling, and secondary containment to help ensure that programs managed their WAAs and wastes in compliance with state and federal requirements. EPD personnel performed 1028 biweekly WAA walkthroughs at the Livermore site and 24 biweekly WAA walkthroughs at the Livermore Airport during 1996.

At the beginning of 1996, there were two WAAs at Site 300. During the year, two WAAs were taken out of service and two WAAs were put into service, leaving a total of two WAAs at Site 300. EPD personnel performed 51 biweekly WAA walkthroughs at Site 300 during 1996.

\section{Medical Waste}

LLNL generates several types of medical wastes (previously identified as infectious wastes). In July 1991, LLNL registered with the Alameda County Environmental Health Services (ACEHS) as a large-quantity generator of medical waste and submitted an application for a medical-waste treatment permit for the Livermore site. Site 300 is a small-quantity generator and is therefore exempt from medical-waste registration.

The Livermore site generator registration and treatment application contained detailed information concerning the management and treatment of medical wastes generated by LLNL's Biology and Biotechnology Research Program, Forensic Science Center, Medical Photonics Laboratory, and Health Services facilities. The registration (No. M71049 B-1) 


\section{Compliance Summary}

for medical waste generation is issued annually and is currently valid through July 1997. The treatment permit (No. M71049 C) for on-site steam sterilization, originally issued in August 1991, was renewed in August 1996 and is valid through July 2001.

During an inspection of LLNL's medical waste generator and treatment facilities on September 4, 1996, an ACEHS inspector issued one report of violation to LLNL's Health Services Department for storing a small amount of medical waste (cotton swabs, bandages, and gauze pads) longer than the maximum 7 days above $0{ }^{\circ} \mathrm{C}$. Immediately after the violation was received, a self-assessment of medical waste compliance was conducted, additional training was provided, and revised medical-waste management procedures were implemented. These corrective actions were reported to ACEHS in a letter dated October 3, 1996.

\section{Building Inspections}

Formal, detailed building inspections for each LLNL facility are conducted based on a schedule established by the Facility Manager and the appropriate Environmental, Safety, and Health (ES\&H) Team. The ES\&H Teams are made up of environmental, safety, and health discipline specialists who assist LLNL in maintaining compliance with ES\&H requirements.

The inspections scrutinize handling and management of hazardous and radioactive wastes and waste streams; management and maintenance of WAAs; potential release pathways to the environment (e.g., storm and sanitary-sewer drains and air); hazardous product storage areas; wastewater retention tank systems; operating equipment (e.g., vacuum pumps, transformers, capacitors, and baghouses); and laboratory and machine shop areas. An inspection report is prepared for a program or department, and follow up checks are conducted to ensure implementation of recommendations or corrections. During 1996, the ES\&H teams conducted 160 formal building inspections at the Livermore site. At Site 300, the team conducted 28 formal building inspections. Building inspections include buildings, trailers, and tents. EPD conducted 11 audits of HWM facilities at the Livermore site and 10 audits of the HWM container storage facility at Site 300. Informal walkthrough inspections are conducted on an as-needed basis.

\section{Site Evaluations Prior to Construction}

Soil and debris from construction sites are evaluated for reuse and disposal. Rubble may be surveyed for radioactivity or analyzed, depending on the outcome of the 


\section{Compliance Summary}

evaluation. The soil is sampled and analyzed for potential radioactive or hazardous contamination. Soil is reused when possible (depending on analytical results) or disposed of according to established procedures. During 1996, environmental analysts conducted preconstruction site evaluations for 76 construction projects.

\section{Federal Facility Compliance Act}

In 1995 and 1996, the DOE negotiated terms of a Site Treatment Plan (STP) for management of mixed waste at LLNL with DTSC. DTSC assessed the potential environmental impacts associated with this action under the California Environmental Quality Act (CEQA) and issued a CEQA initial study, a draft Negative Declaration and proposed site treatment plan for public comment starting September 24, 1996. The final STP was approved in February 1997.

\section{Toxic Substances Control Act}

In August 1996, DOE, EPA, and the U.S. Naval Nuclear Propulsion Program signed a National Federal Facility Compliance Agreement to address the storage and treatment of radiological waste containing PCBs. LLNL will comply with the terms of this agreement, which requires DOE to submit annual reports on the status of this waste.

\section{National Environmental Policy Act}

The National Environmental Policy Act (NEPA—42 U.S.C. 4321 et seq.) established federal policy for protecting environmental quality. The major method for achieving established NEPA goals is the requirement for preparing an Environmental Impact Statement (EIS) for any major federal or federally funded project that may have significant impact on the quality of the human environment. If the need for an EIS is not clear, or if the project does not meet DOE's criteria for requiring an EIS, an Environmental Assessment (EA) is prepared. A finding of no significant impact (FONSI) is issued when the EIS is determined to be unnecessary.

Certain groups of actions that do not have a significant effect on the environment either individually or cumulatively can be categorically excluded from a more in-depth NEPA review (i.e., preparation of either an EA or EIS). DOE NEPA implementing procedures (57 FR 15122), as changed in 1996 (61 FR 36222), identify those categorical exclusions and the eligibility criteria for their application. If a proposed project does not clearly fit one of 


\section{Compliance Summary}

the exclusion categories, DOE determines which type of assessment document may be needed. During 1996, 23 categorical exclusions were submitted to and approved by DOE.

\section{Environmental Assessments}

In 1996, DOE issued FONSIs for EAs of the proposed Decontamination and Waste Treatment Facility (DWTF) and the Explosives Waste Treatment Facility (EWTF).

DOE also issued a Record of Decision (ROD) in December 1996 for a Final Programmatic Environmental Impact Statement (PEIS) for Stockpile Stewardship and Management (SSM). This PEIS contained project-specific NEPA analyses for the National Ignition Facility (NIF) (SSM , App. I) and the Contained Firing Facility (CFF) (SSM PEIS, App. J) for which the ROD served as the final NEPA review determination. Both were noted in the ROD as facilities to be constructed and operated at LLNL.

\section{Floodplain Management and Wetland Protection}

In 1996, there were no proposed actions at LLNL that required separate DOE floodplain or wetlands assessments.

\section{California Environmental Quality Act}

No Initial Study or Environmental Impact Report (EIR) documents were completed by the University of California (UC) in 1996 on proposed projects at LLNL for which UC was the principal decision-making (lead) agency.

In November 1992, UC and LLNL made a commitment to implement 67 mitigation measures identified by the 1992 Final Environmental Impact Statement and Environmental Impact Report for Continued Operation of Lawrence Livermore National Laboratory and Sandia National Laboratories, Livermore (U.S. Department of Energy and University of California 1992a and b) and to provide annual reports on their implementation. The measures are being implemented in accordance with the approved 1992 Mitigation Monitoring and Reporting Program associated with that EIS/EIR. The fiscal year 1995 annual report was published in April 1997; the next annual report will cover fiscal year 1996 activities.

\section{National Historic Preservation Act}

The National Historic Preservation Act (NHPA), as amended through 1992, requires federally operated and funded installations such as LLNL to balance agency missions with cultural values by integrating historic preservation into federal agency programs. 


\section{Compliance Summary}

Federal agencies must take into account the effects their projects may have on "historic properties" (cultural resources), and they must allow a reasonable time period for the Advisory Council on Historic Preservation (the Council) to comment.

In 1996, LLNL continued to assist DOE's Oakland Field Office in its consultations with the California State Historic Preservation Office and the Council to develop terms of a Programmatic Agreement to help LLNL resolve short term compliance issues and to develop a Cultural Resource Management Plan (CRMP). Final review and comment by the two agencies and the public in order to fulfill and complete the consultation process as required by NHPA regulations is expected in 1997. Examples of activities performed in 1996 while awaiting final approval of the Programmatic Agreement include the following:

- $\quad$ Continued work to prepare a survey report on the Site 300 Annual Fire Trail Grading Project to comply with Section 106 of the NHPA. Eight isolated finds and three previously identified cultural resources, now redefined archaeological sites, were located as a result of the survey. The isolated finds and sites are all historic and pertain to the Corral Hollow Industrial Period of 1858-1918 and the Carnegie Town and Manufacturing site. In addition, the isolated finds and the Carnegie Town site will be evaluated for significance, according to Section 106 requirements of the NHPA, in order to determine whether the project impacts the significance of the identified cultural resources.

- $\quad$ Continued participation in public outreach programs such as making presentations to schools and local groups (e.g., historical societies and service organizations) about cultural resources within the LLNL area.

\section{Endangered Species Acts and Sensitive Natural Resources}

LLNL must meet the requirements of both the U.S. Endangered Species Act and the California Endangered Species Act as they pertain to endangered or threatened species and other species of special concern that may exist or are known to exist at the LLNL sites. For example, in implementing the Mitigation Monitoring and Reporting Program in 1996, biological assessment surveys were performed for special-status species at 67 LLNL project construction (ground disturbance) areas. Presence data for the San Joaquin kit fox (Vulpes macrotis mutica), American badger (Taxidea taxus), and burrowing owl (Speotyto cunicularia) were collected at each project location, and other applicable mitigation measures were implemented when required. 


\section{Compliance Summary}

During 1996, no active San Joaquin kit fox dens were discovered, but three potential dens were found. Fifteen occupied American badger dens were discovered, and four unoccupied dens were identified. Twelve active burrowing owl dens were discovered (four at the Livermore site and eight at Site 300), and two potential dens were identified. In addition, two new populations of the federally listed red-legged frog (Rana aurora draytonii) and the federal candidate species California tiger salamander (Ambystoma tigrinum) were found at wetlands locations at Site 300. One new population of California tiger salamander was observed at the LLNL Treatment Facility discharge point at SNL/California. One special-status animal species, the red-shouldered hawk (Buteo lineatus), not previously known to occur on LLNL property, nested at the Livermore site in 1996.

Two of the three known natural populations of the large-flowered fiddleneck (Amsinckia grandiflora), a federally listed endangered plant species, occur at Site 300. A portion of Site 300 has been designated as critical habitat for the plant. Between 1992 and 1995, LLNL investigators established new experimental populations of the large-flowered fiddleneck at Site 300, and attempted to determine the causes of the species decline. The scientists were successful in establishing one new experimental population of the plant at Site 300. In 1996, it was found that the numbers of fiddleneck plants had increased owing to the reduction of exotic grass cover.

\section{Environmental Occurrences}

Notification of environmental occurrences is required under a number of environmental laws, regulations, and the 5000 series of DOE Orders including DOE Order 5000.3B, Occurrence Reporting and Processing of Operations Information, and DOE Order 5484.1, Environmental Protection, Safety, and Health Protection Information Reporting Requirements. Effective February 22, 1993, DOE Order 5000.3B provided guidelines to contractor facilities regarding categorization and reporting of environmental occurrences to DOE. The Order divided occurrences into three categories: emergencies, unusual occurrences, and off-normal. On August 8, 1996, DOE Order 232.1, Occurrence Reporting and Processing of Operations Information, was accepted by the UC Regents, thus replacing DOE Order 5000.3B. DOE Order 232.1 divides occurrences into two categories: unusual and off-normal occurrences. This Order refers to DOE Order 151.1, Comprehensive Emergency Management System, for the categorization of all emergencies. However, the UC Regents have not accepted DOE Order 151.1; thus, all emergency categorizations are determined using the 5500 series DOE Orders.

The Environmental Protection Department responded to 14 incidents that required regulatory agency notification during 1996. The EPD response to environmental 


\section{Compliance Summary}

occurrences is part of the larger LLNL On-Site Emergency Response Organization that also includes representatives from Hazards Control, Health Services, Plant Engineering, Public Affairs, Safeguards and Security, and Site 300. Thirteen of the incidents were categorized as off-normal occurrences according to either DOE Order 5000.3B or DOE Order 232.1 implementing procedures. One, the previously mentioned storage of medical waste longer than 7 days above $0^{\circ} \mathrm{C}$, was categorized as an unual occurrence. None of the incidents, summarized in Table 2-13, caused any adverse impact to human health or the environment. Agencies notified of these incidents included DOE, Alameda County Health Care Services Agency, San Joaquin County Public Health Services, San Francisco Bay RWQCB, Central Valley RWQCB, Office of Emergency Services, and DTSC.

Table 2-13. Tabulation of environmental occurrences reported under the Occurrence Reporting System, 1996.

\begin{tabular}{|c|c|c|}
\hline Date $(a)$ & $\begin{array}{c}\text { Occurrence } \\
\text { category }\end{array}$ & Description \\
\hline $\operatorname{Jan} 5$ & Off-Normal & $\begin{array}{l}\text { A manifest was returned from an off-site treatment, storage, and disposal facility (TSDF) in } 49 \text { days } \\
\text { instead of the required } 45 \text {-day regulatory requirement. An Exception Report was submitted to the } \\
\text { state. A written report to outside agencies in a nonroutine format meets the requirements for an Off- } \\
\text { Normal Occurrence. }\end{array}$ \\
\hline Jan 19 & Off-Normal & $\begin{array}{l}\text { Fuming nitric acid was accidentally discharged in the High Bay in Building } 431 \text { when shipping boxes } \\
\text { containing ten } 1-\mathrm{L} \text { bottles of fuming nitric acid ignited (possibly because of acid leakage from one or } \\
\text { more of the bottles onto the cardboard). The ensuing combustion heated, melted, and shattered the } \\
\text { remaining bottles of acid. Approximately } 1500 \text { gal }(5682 \mathrm{~L}) \text { of contaminated sprinkler water used to } \\
\text { douse the fire was discharged to the ground via the gravel pit. The release was reported, under the } \\
\text { requirements of the business plan, to the OES and to the San Francisco Bay RWQCB as required in } \\
\text { NPDES permit CA0030023, WDR 95-174. A written report to outside agencies in a nonroutine } \\
\text { format meets the requirements for an Off-Normal Occurrence. }\end{array}$ \\
\hline April 9 & Off-Normal & $\begin{array}{l}\text { Approximately } 11,000 \text { gal }(42,000 \mathrm{~L}) \text { of potable water were discharged because of a leak in a 10-in. } \\
\text { water main in the vicinity of the DWTF construction area. The release was reported to the San } \\
\text { Francisco Bay RWQCB as required in NPDES Permit CA0030023, WDR 95-174. A written report to } \\
\text { outside agencies in a nonroutine format meets the requirements for an Off-Normal Occurrence. }\end{array}$ \\
\hline May 24 & Off-Normal & $\begin{array}{l}\text { Because of a malfunctioning pump, which normally automatically pumps the contents of the } \\
\text { Building } 817 \text { retention tank to the surface impoundments, the tank overflowed onto the ground from } \\
\text { the top access port. The discharge flowed off the concrete retention tank pad and percolated into } \\
\text { the ground. The majority of the wastewater in the tank at the time of the discharge was cooling } \\
\text { water used to cool another pump in the } 817 \text { complex. The discharge of untreated wastewater was } \\
\text { reported to the Central Valley RWQCB as required in WDR } 85-188 \text {. A written report to outside } \\
\text { agencies in a nonroutine format meets the requirements for an Off-Normal Occurrence. }\end{array}$ \\
\hline June 11 & Off-Normal & $\begin{array}{l}\text { During activities associated with the closure of Building } 865 \text {, wood pallets used to store lead shot } \\
\text { and brick at the Building } 865 \text { corp yard were transported to Salvage. Soil samples were obtained } \\
\text { from the corp yard to determine if lead had contaminated soil beneath the pallets. Results indicated } \\
\text { that surface samples were contaminated to } 12 \mathrm{mg} / \mathrm{L} \text { based on the soluble threshold limit } \\
\text { concentration (STLC), and } 120 \mathrm{mg} / \mathrm{kg} \text { based on the total threshold limit concentration (TTLC). Soil } \\
\text { at } 1.5 \mathrm{ft} \text { was below detection for STLC. The CERCLA reportable quantity for lead is } 10 \mathrm{lb} \text {. The } \\
\text { quantity of lead in the soil exceeded half of the CERCLA reportable quantity, meeting the } \\
\text { requirements of an Off-Normal Occurrence. }\end{array}$ \\
\hline
\end{tabular}




\section{Compliance Summary}

Table 2-13. Tabulation of environmental occurrences reported under the Occurrence Reporting System, 1996 (continued).

\begin{tabular}{|c|c|c|}
\hline Date $(\mathrm{a})$ & $\begin{array}{c}\text { Occurrence } \\
\text { category }\end{array}$ & Description \\
\hline June 20 & Off-Normal & $\begin{array}{l}\text { Approval was received from Alameda County to close the piping associated with underground } \\
\text { storage tank } 419-\mathrm{R} 1 \mathrm{U} 4 / \mathrm{R} 1 \mathrm{U} \text {, which was located underneath Room } 167 \text { of Building } 419 \text {. An LLNL } \\
\text { sampling technician was beginning to excavate underneath the piping to collect soil samples when } \\
\text { he observed that there were small beads of elemental mercury in the first shovel of soil. A small } \\
\text { portion of the soil was removed to assess the extent of the contamination and to remove the } \\
\text { mercury. During this excavation, additional elemental mercury was discovered. The Alameda } \\
\text { County Health Care Services Agency was notified of the release. A written report to outside } \\
\text { agencies in a nonroutine format meets the requirements for an Off-Normal Occurrence. }\end{array}$ \\
\hline June 21 & Off-Normal & $\begin{array}{l}\text { A drum being returned to LLNL containing solidified depleted uranium, D-38, and turnings shipped } \\
\text { from SEG Inc., exceeded the certification ratings for Department of Transportation shipping } \\
\text { requirements. Evidence of improper selection or assembly of a hazardous material package off site } \\
\text { meets the requirements of an Off-Normal Occurrence. }\end{array}$ \\
\hline Aug 22 & Off-Normal & $\begin{array}{l}\text { Two 5-gal (19-L) containers of waste described as non-RCRA formaldehyde, } \mathrm{pH} 4-7 \text { were shipped } \\
\text { to ENSCO. ENSCO notified LLNL that both containers had a pH }<2 \text { upon receipt. Errors made by } \\
\text { the shipper in material descriptions meet the requirements of an Off-Normal Occurrence under the } \\
\text { Transportation Section. }\end{array}$ \\
\hline Aug 25 & Off-Normal & $\begin{array}{l}\text { During a routine QA record review by LLNL personnel, it was discovered that an ignitable solid waste } \\
\text { was transported to ENSCO West Disposal facility as an ignitable liquid waste. The ENSCO facility } \\
\text { was able to accept ignitable solids and the waste was not returned to LLNL. Errors made by the } \\
\text { shipper in material descriptions meet the requirements of an Off-Normal Occurrence under the } \\
\text { Transportation Section. }\end{array}$ \\
\hline Sept 5 & Off-Normal & $\begin{array}{l}\text { During a County Medical Waste inspection, Health Services received a notice of violation (NOV) for } \\
\text { storing medical waste for over } 7 \text { days above } 0^{\circ} \mathrm{C} \text { on at least two occasions. This violation was } \\
\text { discovered during a record review by the regulator during an inspection. Receipt of an NOV meets } \\
\text { the requirements of an Off-Normal Occurrence. }\end{array}$ \\
\hline Sept 25 & Off-Normal & $\begin{array}{l}\text { A waste container holding corrosive material was inadvertently shipped to an off-site treatment } \\
\text { facility with improper classification during a loading operation. When it became known that the } \\
\text { container was loaded on the vehicle, the transporter was notified. The driver corrected his manifest. } \\
\text { Errors made by the shipper in material descriptions meet the requirements of an Off-Normal } \\
\text { Occurrence under the Transportation Section. }\end{array}$ \\
\hline Sept 26 & Off-Normal & $\begin{array}{l}\text { During a routine maintenance operation, the LLNL Pipe Shop Crew discovered some mercury in the } \\
\text { storm drain catch basin adjacent to Building } 253 \text {. Using a mercury sniffer, it was determined that } \\
\text { mercury was present in } 8 \text { of the } 10 \text { catch basins in the immediate vicinity. Any detection of a } \\
\text { hazardous material in a storm sewer where the amount is unrepresentative of natural levels for } \\
\text { LLNL meets the requirements of an Off-Normal Occurrence. }\end{array}$ \\
\hline Oct 17 & Off-Normal & $\begin{array}{l}\text { Approximately } 88,000 \mathrm{gal}(333,000 \mathrm{~L}) \text { of swimming pool water were discharged to the ground } \\
\text { because of a leak in the swimming pool at the Livermore site. The leak was repaired during the } \\
\text { week of September } 26,1996 \text {. The release was reported to the San Francisco Bay RWQCB as } \\
\text { required in NPDES permit CA0030023, WDR 95-174. A written report to outside agencies in a } \\
\text { nonroutine format meets the requirements for an Off-Normal Occurrence. }\end{array}$ \\
\hline
\end{tabular}




\section{Compliance Summary}

Table 2-13. Tabulation of environmental occurrences reported under the Occurrence Reporting System, 1996 (concluded).

\begin{tabular}{|l|c|l|}
\hline Date $^{(a)}$ & $\begin{array}{l}\text { Occurrence } \\
\text { category }\end{array}$ & Description \\
\hline Nov 16 & Off-Normal & $\begin{array}{l}\text { Approximately } 1000 \text { gal }(3800 \mathrm{~L}) \text { of sewage were discharged to the ground because of an overflowing } \\
\text { sewage manhole adjacent to Building 298. Rags and debris had clogged the stationary sewage } \\
\text { monitoring equipment and restricted its flow, thus causing the overflow. The release was reported to } \\
\text { the San Francisco Bay RWQCB as required in NPDES permit CA0030023, WDR 95-174. A written } \\
\text { report to outside agencies in a nonroutine format meets the requirements for an Off-Normal } \\
\text { Occurrence. }\end{array}$ \\
\hline
\end{tabular}

a The date indicated is the date the occurrence is categorized, not the date of its discovery.

\section{Contributing Authors Acknowledgment}

Many authors significantly contributed to this large and diverse chapter. We acknowledge here the work of Jamie Bennett, Richard Blake, Winifred Burks-Houck, Tina Carlsen, Connie DeGrange, Ellen Eagan-McNeill, Karen Folks, Gretchen Gallegos, Allen Grayson, Robert Harrach, Steve Harris, Bill Hoppes, Saverio Mancieri, Sandra Mathews, Joe Mc Intyre, Matthew Mlekush, Willie Montemayor, Keith Otsuki, Michael Taffet, Charlotte Van Warmerdam, Robert Vellinger, Joseph Woods, and Kenneth Zahn. 



\section{Environmental Program Information}

\section{Introduction}

LLNL is committed to operating in a manner that preserves the quality of the environment. The Environmental Protection Department (EPD) leads this effort in the areas of environmental compliance and accountability. This chapter begins with a description of LLNL's integrated Environmental, Safety, and Health (ES\&H) Management System, continues with the development of Work Smart Standards and missions, and describes activities of EPD and its three divisions. Performance measures (PMs) used by DOE to evaluate the Laboratory's environmental protection efforts are then summarized. The bulk of the chapter is devoted to an account of LLNL's activities and progress in waste minimization and pollution prevention in 1996. Following descriptions of current issues and actions in the environmental programs arena, this chapter concludes with a brief discussion of spill response and EPD environmental training.

\section{Integrated Environmental, Safety, and Health Management System}

The ES\&H Program at LLNL employs a process of assessing hazards and the environmental implications of our work; designing and implementing standards-based methods intended to control risks; and complying with the applicable ES\&H regulations. This process is implemented using a graded approach, which increases the level of risk management as the hazard increases. An overview of the Laboratory's ES\&H Program and a general description of how the Laboratory manages ES\&H activities can be found in The Environmental, Safety, and Health Program at Lawrence Livermore National Laboratory (LLNL 1996g).

On October 15, 1996, the Department of Energy issued DOE Policy 450.4: Safety Management System Policy. This policy provides a formal, organized process whereby employees plan, assess, and improve safety in their work. In this policy statement the term "safety" is used comprehensively to include environment and health. The policy was developed taking into consideration various consensus management standards such as International Standards Organization (ISO) 14000, Voluntary Protection Program (VPP), and Recommendation 95-2 from the Defense Nuclear Facility Safety Board. Embracing ISO 14000 by using the major components of the standard, while not 


\section{Environmental Program Information}

adopting it in total, allows flexibility in various management systems while not requiring adoption of a standard for adoption's sake. This policy lets the field of ISO 14000 develop such that if documented cost benefits can be demonstrated (in a command and control environment), a facility could elect to utilize the standard in total by implementing an integrated safety management system (ISMS). Integrated ES\&H management systems are defined as having five functions: to define the scope of work, analyze hazards, develop and implement standards-based controls, perform work, and provide feedback and improvement. The current LLNL ES\&H management process reflects requirements of these five functions. Therefore, to satisfy the DOE's ISMS requirement, LLNL's primary task will be to update our guidance documents and formalize the standard set through the Work Smart Standard Closure Process.

Additionally, documentation of our ES\&H management system will be updated to reflect the concepts defined in ISMS. Implementation of a fully documented ISMS is scheduled to begin in 1998.

\section{Work Smart Standards}

Work Smart Standards (WSS) will improve both safety and the working relationship between the DOE and its contractors and is expected to become part of the DOE contract with the University of California. DOE made the Safety Management System both a policy (DOE Policy 450.4) and an acquisition regulation (Clause 970.5204-2). Implementation of the ISMS at LLNL will take 2 years, but the WSS will be completed in fiscal year 1997.

The WSS process (DOE M450.3-1) requires an understanding of the work, an analysis of the hazards associated with the work, and the selection of standards from which hazards controls are developed to minimize the hazards. LLNL has traditionally identified and controlled hazards to protect the worker, the public, and the environment, but WSS differs from the past in that responsibility for selection of appropriate and necessary standards is in the hands of both the DOE field office and the contractor. This process empowers LLNL and local DOE staffs, through consensus, to focus on the work being performed and to select sitewide ES\&H standards that are based on the actual work being conducted, not on compliance with generalized requirements.

Standards are approved at the management level closest to the work. Others cannot approve the set, require concurrence, or second-guess the standards selected. The LLNL Director and DOE Oakland Operations Office Manager will approve the final set of sitewide standards. This action will align LLNL with industry practice, establish 
common ES\&H expectations for the DOE and UC, help LLNL meet DOE's commitment to the Defense Nuclear Facility Safety Board, and facilitate the tailoring of requirements to streamline and increase the effectiveness of ES\&H management at LLNL. Existing ES\&H methodologies and documentation will support the completion of the process.

\section{Environmental Protection Department}

As the Laboratory's environmental support organization, EPD prepares and maintains environmental plans and guidelines, provides environmental guidance and support to Laboratory personnel, informs management about pending changes in environmental regulations pertinent to LLNL, represents the Laboratory in day-to-day interactions with regulatory agencies, and assesses the effectiveness of pollution control programs.

EPD monitors air, water, soil, and foodstuffs; evaluates possible contaminant sources; and models the impact of LLNL operations on humans and the environment. In 1996, 20,343 samples were taken from air, sewage, ground water, surface water, soil, sediments, vegetation, and foodstuffs. More than 310,292 analytes were tested. These numbers represent increases of $9 \%$ and $25 \%$, respectively, compared to 1995 values. The type of samples collected at a specific location depends on the site and the potential pollutants to be monitored; see the specific chapters of this report for discussions of each environmental medium.

A principal part of EPD's mission is to work with LLNL programs to ensure that operations are conducted in a manner that limits environmental impacts and is in compliance with regulatory guidelines. EPD helps LLNL programs manage and minimize hazardous, radioactive, and mixed wastes; determines the concentrations of environmental contaminants remaining from past activities; cleans up environmental contamination to acceptable standards; responds to emergencies in order to minimize and assess any impact on the environment and the public; and provides training programs to improve the ability of LLNL employees to comply with environmental regulations.

LLNL programs are supported by EPD's four Environmental Support Teams (ESTs). The ESTs are integrated into the Environmental Safety and Health Teams (ES\&H Teams) at the Laboratory through the Environmental Analyst who chairs the ESTs. Each EST includes representatives from environmental specialties within the Operations and Regulatory Affairs Division (ORAD), along with a field technician from the Hazardous Waste Management (HWM) Division. Some ESTs also include a representative from the Environmental Restoration Division (ERD), the ES\&H Teams, or the organizations 


\section{Environmental Program Information}

supported by the ESTs. These teams evaluate operations, determine potential environmental impacts, and provide guidance on environmental regulations and DOE orders for existing and proposed projects. ESTs assist programs in planning, implementing, and operating projects and in understanding and meeting their environmental obligations. When permits are obtained from regulatory agencies, ESTs aid the program in evaluating the permit conditions and implementing recordkeeping requirements.

The four Environmental Support Teams (ESTs) assist LLNL programs with environmental issues through the appropriate ES\&H team. Each EST consists of individuals specializing in specific environmental disciplines such as the National Environmental Policy Act (NEPA), permits, pollution prevention, or waste management. Support is available either directly from the EST discipline or through the ES\&H team environmental analysts. Environmental analysts serve as liaisons between the ESTs and ES\&H teams.

\section{Operations and Regulatory Affairs Division}

ORAD currently consists of eight groups that specialize in environmental compliance and monitoring and provide laboratory programs with a wide range of information, data, and guidance to make more informed environmental decisions.

ORAD prepares the environmental permit applications and related documents for submittal to federal, state, and local agencies and provides the liaison between LLNL and regulatory agencies conducting inspections; tracks chemical inventories; prepares National Environmental Policy Act (NEPA) documents and conducts related field studies for DOE; oversees wetland protection and floodplain management requirements; coordinates cultural and wildlife resource protection and management; facilitates and provides support for the pollution prevention and recycling programs; teaches numerous environmental training courses; coordinates the tank environmental compliance program; conducts compliance and surveillance monitoring; and provides environmental impact modeling and analysis, risk assessment, and reporting.

ORAD also actively assists in responding to environmental emergencies such as spills. During normal working hours, an Environmental Analyst from the ORAD Environmental Operations Group responds to environmental emergencies and notifies a specially trained Environmental Duty Officer (EDO). EDOs are on duty 24 hours a day and coordinate with LLNL's ES\&H Team and other first responders or environmental specialists. 


\section{Hazardous Waste Management Division}

All hazardous, radioactive, and mixed wastes generated at LLNL facilities are managed by the Hazardous Waste Management (HWM) Division in accordance with state and federal requirements. HWM processes, stores, packages, solidifies, treats, and prepares waste for shipment and disposal, recycling, or discharge to the sanitary sewer.

As part of its waste management activities, HWM tracks and documents the movement of hazardous, mixed, and radioactive wastes from waste accumulation areas (WAAs) located near the waste generator to final disposition; develops and implements approved standard operating procedures; decontaminates LLNL equipment; ensures that containers for shipment of waste meet the specifications of the U.S. Department of Transportation (DOT) and other regulatory agencies; responds to emergencies; and participates in the cleanup of potential hazardous and radioactive spills at LLNL facilities. HWM prepares numerous reports, including the annual and biennial hazardous waste reports required by the state and federal environmental protection agencies. HWM also prepares waste acceptance criteria documents, safety analysis reports, and various waste guidance and management plans.

HWM meets regulations requiring the treatment and disposal of LLNL's mixed waste in accordance with the requirements of the Federal Facility Compliance Act. The schedule for this treatment is negotiated with the State of California and involves developing new on-site treatment options, as well as finding off-site alternatives.

HWM is responsible for implementing a program directed at eliminating the backlog of Legacy Waste (waste that is not presently certified for disposal). This effort includes a large characterization effort to identify all components of the waste, as well as a certification effort, which will provide the disposal site with appropriate documentation.

\section{Environmental Restoration Division}

The Environmental Restoration Division (ERD) was established to evaluate and remediate contaminated soil and ground water resulting from past hazardous materials handling and disposal and from leaks and spills that have occurred at the Livermore site and Site 300, both prior to and during LLNL operations. At both the Livermore site and Site 300, ERD investigates field sites to characterize the existence, extent, and impact of contamination. ERD evaluates and develops various remediation technologies, makes recommendations, and implements actions for site restoration. ERD is responsible for managing remedial activities, such as soil removal and ground water extraction, and for assisting in closing inactive facilities in a manner designed to prevent environmental contamination. 


\section{Environmental Program Information}

In dealing with CERCLA compliance issues, ERD plans, directs, and conducts assessments to determine both the impact of such releases on the environment and the restoration activities needed to reduce contaminant concentrations to protect human health and the environment. ERD is responsible for interacting with the community on these issues. Several public meetings are held each year as required in the ERD CERCLA Community Relations Plans. To comply with CERCLA ground water remedial actions at the Livermore site, ERD designed and constructed six ground water treatment facilities and associated pipeline networks and wells (see Chapters 7 and 8). At Site 300, ERD designed and implemented two soil vapor/ground water extraction and treatment systems and one ground water extraction and treatment system. ERD also capped two inactive mixed-waste landfills. ERD is actively designing, testing, and applying innovative remediation and assessment technologies to contaminant problems at the Livermore site and Site 300. ERD also provides the sampling and data management support for ground water surveillance and compliance monitoring activities.

\section{Performance Measures Summary}

Since 1992, the contract for the University of California to manage and operate LLNL for DOE has contained Performance Objectives, Criteria, and Measures. Six of these Performance measures evaluated LLNL's environmental protection activities in 1996. The status of these measures is described in this report at the location referenced in Table 3-1.

In their evaluation of LLNL's fiscal year 1996 self-assessment, DOE and UC reported that LLNL met or exceeded all of the environmental performance measures for the reporting period. Data for calendar year 1996 will be included in the annual self-assessment and evaluation conducted August through October 1997.

\section{DOE Pollution Prevention Goals}

The Secretary of Energy has committed the Department to the following Pollution Prevention (P2) goals, which are to be achieved throughout the complex by December 31, 1999, using 1993 as a baseline:

1. Reduce total releases and off-site transfers for treatment and disposal of Emergency Planning and Community Right-to-Know Act (EPCRA) 313 toxic chemicals from routine operations by $50 \%$.

2. Reduce the generation of radioactive waste from routine operations by $50 \%$. 


\section{Environmental Program Information}

3. Reduce the generation of low-level mixed waste from routine operations by $50 \%$.

4. Reduce the generation of hazardous waste from routine operations by $50 \%$.

5. Reduce the generation of sanitary waste (after recycling) from routine operations by $33 \%$.

6. Divert $33 \%$ of sanitary waste from all operations for recycling.

7. Increase the affirmative procurement of Environmental Protection Agency (EPA)-designated recycled products to $100 \%$.

Table 3-1. DOE environmental protection performance measures.

\begin{tabular}{|c|c|c|}
\hline $\begin{array}{c}\text { P.M. } \\
\text { designator }\end{array}$ & Performance measure & Location in this report \\
\hline 1.1.b & $\begin{array}{l}\text { Radiation Protection of the Public } \\
\text { Public radiation doses to the maximally exposed individual from DOE } \\
\text { operations will be measured or calculated and controlled to assure } \\
\text { that applicable federal limits are not exceeded. An effective ALARA } \\
\text { (as low as reasonably achievable) program shall be in place to } \\
\text { manage dose to the public. }\end{array}$ & $\begin{array}{l}\text { Chapter 12: Radiological Dose } \\
\text { Assessment; section on Radiological } \\
\text { Doses from Air Emissions. } \\
\text { Chapter 2: National Emission Standards } \\
\text { for Hazardous Air Pollutants. }\end{array}$ \\
\hline 1.2.a & $\begin{array}{l}\text { Waste Reduction and Recycling } \\
\text { The Laboratory continues to progress towards meeting the DOE's } \\
\text { pollution prevention goals for the year } 2000 \text {. }\end{array}$ & $\begin{array}{l}\text { This chapter, section on Waste } \\
\text { Minimization/Pollution Prevention. }\end{array}$ \\
\hline 1.2.b & $\begin{array}{l}\text { Pollution Prevention } \\
\text { The Laboratory continues to survey on-site operations for } \\
\text { opportunities to reduce waste and pollutant releases to all media. } \\
\text { Specific opportunities are identified, and success in project } \\
\text { implementation and achievement of the agreed-to waste or pollutant } \\
\text { reduction project goal(s) are tracked. }\end{array}$ & $\begin{array}{l}\text { This chapter, section on Waste } \\
\text { Minimization/Pollution Prevention. }\end{array}$ \\
\hline 2.1.a & $\begin{array}{l}\text { Tracking and Trending of Environmental Findings and Violations } \\
\text { The number of validated environmental violations and findings } \\
\text { resulting from inspections by regulatory agencies and formal audits } \\
\text { will be tracked and trended. A downward trend is expected for each } \\
\text { category from the } 1993 \text { base year. }\end{array}$ & $\begin{array}{l}\text { Chapter 2: Compliance Summary, } \\
\text { Table 2-8. }\end{array}$ \\
\hline 2.1.b & $\begin{array}{l}\text { Tracking and Trending of Environmental Releases } \\
\text { Reportable occurrences of environmental releases exceeding } \\
\text { regulatory or permitted levels imposed by local, state or federal } \\
\text { agencies will be determined and trended. A downward trend is } \\
\text { expected. Changes in regulatory procedures after the } 1993 \text { base } \\
\text { year that increase or decrease the level of occurrence reporting shall } \\
\text { be brought to the attention of UC and DOE as soon as possible and } \\
\text { adjustments made to the base year figure, as appropriate. }\end{array}$ & $\begin{array}{l}\text { Chapter 2: Compliance Summary, } \\
\text { Table 2-9, Table 2-12. }\end{array}$ \\
\hline 5.1.a & $\begin{array}{l}\text { External Customers } \\
\text { The Laboratory measures and evaluates the environment, safety } \\
\text { and health expectations of its external customers and incorporates } \\
\text { the input into Laboratory programs as appropriate. }\end{array}$ & $\begin{array}{l}\text { This chapter. } \\
\text { Chapter 2: Compliance Summary, } \\
\text { section on CERCLA/SARA, Title I. }\end{array}$ \\
\hline
\end{tabular}




\section{Environmental Program Information}

Progress toward achieving these goals is reported annually to the Secretary of Energy in LLNL's Annual Report on Waste Generation and Waste Minimization Progress.

The DOE's Pollution Prevention Program Plan 1996 (U.S. Department of Energy 1996b) establishes six immediate priorities, due to be implemented by fiscal year 1998, which will help DOE Headquarters, the Operations Offices, and the sites focus resources on the most critical aspects of DOE's P2 program.

The six priorities are to:

1. Establish senior management commitment to P2 implementation.

2. Set quantitative, site-specific waste reduction and recycling goals.

3. Institute performance measures.

4. Implement cost-saving P2 projects.

5. Design P2 into new products, processes, and facilities.

6. Ensure that site programs comply with federal, state, and DOE requirements.

LLNL prepares a P2 Plan, which meets the requirements of (1) DOE Orders 5820.2A and 5400.1; (2) RCRA, Sections 3002(b) and 3005(h); and (3) Title 22 of the California Code of Regulations. This Plan is reviewed annually and updated every 3 years; it was last updated and submitted to the DOE in May 1997 (Celeste 1997). The Plan reviews past and current pollution prevention activities and states the objectives of LLNL's waste minimization and pollution prevention efforts.

The P2 Program at LLNL is an organized, comprehensive, and continuing effort to systematically reduce solid, hazardous, radioactive, and mixed waste generation. The P2 Program is designed to eliminate or minimize pollutant releases to all environmental media from all aspects of the site's operations. These efforts offer increased protection of public health and the environment by reducing or eliminating waste management and compliance costs, resource usage, inventories and releases of hazardous chemicals, and civil and criminal liabilities under environmental laws.

In accordance with EPA guidelines and DOE policy, a hierarchical approach to waste reduction (i.e., source elimination or reduction, material substitution, reuse and recycling, and treatment and disposal) has been adopted and is applied to all types of waste. 


\section{Waste Minimization/Pollution Prevention}

LLNL is required by the UC Contract performance measures $1.2 \mathrm{a}$ and $\mathrm{b}$ to annually review its waste generation for P2 opportunities and to propose implementation projects. Previously, waste streams at LLNL were evaluated in terms of the total quantities of waste generated. However, the waste streams of greatest concern are not necessarily those having the largest volume. Each process that generates waste must be considered, as well as the individual characteristics of the components within each waste stream.

To better rank the waste streams and to improve the prioritization of waste minimization efforts, LLNL has developed a new, alternative, weighted ranking system. The methodology assigns to each waste stream three weighting factors in addition to a factor based on quantity of waste generated annually. The three additional weighting factors use the following criteria: cost, waste type (which includes compliance and liability considerations), and operational aspects (such as routine vs nonroutine). This is discussed in Reassessment of LLNL Waste Generation for Calendar Year 1995 (Celeste 1995).

In general, the 20 waste stream components having the highest priority (ranked by summing the four weighting factors) are entirely different from the top 20 source codes ranked by quantity only. For example, transuranic waste (TRU)/TRU mixed and lowlevel wastes, which are problematic at LLNL, are now ranked as having the highest priority, though their relative quantities are somewhat low.

Routine waste generation by waste category, from 1990 through 1996, is shown in Table 3-2. The trend from 1990 on shows a dramatic reduction in all waste categories, which is the result of a proactive P2 program at LLNL.

Table 3-2. Waste generation totals, 1990 to 1996 (in tons).

\begin{tabular}{|l|r|r|r|r|r|r|r|}
\hline \multicolumn{1}{|c|}{ Waste category } & $\mathbf{1 9 9 0}$ & $\mathbf{1 9 9 1}$ & $\mathbf{1 9 9 2}$ & $\mathbf{1 9 9 3}$ & $\mathbf{1 9 9 4}$ & $\mathbf{1 9 9 5}$ & $\mathbf{1 9 9 6}$ \\
\hline Radioactive & 441 & 267 & 296 & 307 & 188 & 143 & 101 \\
Mixed & 202 & 80 & 153 & 46 & 26 & 36 & 23 \\
Hazardous & 1880 & 1148 & 1200 & 740 & 510 & 368 & 351 \\
Sanitary & 2820 & 2295 & 2300 & 2379 & 2465 & 2246 & 2001 \\
\hline \multicolumn{1}{|c}{ LLNL totals } & 5343 & 3790 & 3949 & 3472 & 3189 & 2793 & 2476 \\
\hline
\end{tabular}

Table 3-3 presents the percent reductions for 1996 compared to 1995, the 1993 baseline, and 1990 for a historic perspective. Decreases in radioactive, mixed, and hazardous waste generation in 1996 have already met the 50\% reduction goal for the performance measure. 


\section{Environmental Program Information}

Table 3-3. Waste reduction, 1996.

\begin{tabular}{|l|c|c|c|}
\hline $\begin{array}{c}\text { Waste } \\
\text { category }\end{array}$ & $\begin{array}{c}\text { Reduction 1996 vs } \\
\mathbf{1 9 9 5}(\%)\end{array}$ & $\begin{array}{c}\text { Reduction 1996 vs } \\
\mathbf{1 9 9 3}(\%)\end{array}$ & $\begin{array}{c}\text { Reduction 1996 vs } \\
\mathbf{1 9 9 0}(\%)\end{array}$ \\
\hline Radioactive & 29.3 & 67.1 & 77.1 \\
Mixed & 36.9 & 50.7 & 88.8 \\
Hazardous & 2.4 & 51.4 & 80.9 \\
Sanitary & 10.9 & 15.9 & 29.0 \\
\hline
\end{tabular}

\section{Nonhazardous Solid Waste Minimization}

In 1996, LLNL sent 6136 tons of nonhazardous waste, including routine and nonroutine, i.e., sanitary waste in the above tables, to a landfill. The routine portion was 2001 tons and the nonroutine portion was 4135 tons. The breakdown is shown in Table 3-4.

Table 3-4. Nonhazardous landfill totals (in tons) in 1996.

\begin{tabular}{|l|c|}
\hline & $\mathbf{1 9 9 6}$ total \\
\hline Routine & 1881 \\
Livermore compacted & 27 \\
Site 300 compacted & 93 \\
Industrial (TWMS)(a) & 2001 \\
Routine subtotal & \\
\hline Nonroutine & 4109 \\
Construction demo & 26 \\
Industrial (TWMS) & 4135 \\
Nonroutine subtotal & 6136 \\
\hline LLNL total & \\
\hline
\end{tabular}

a TWMS is the acronym for the HWM's Total Waste Management System.

\section{Diverted Waste}

The total waste diverted from landfills in 1996 was 20,259 tons. This large increase from last year is due to the beneficial reuse of soil on site (9000 tons), soil that is used at the landfill for daily cover (3606 tons), and asphalt that is used for road base material at the landfill (4090 tons). The waste diversion summary is shown in Table 3-5.

For 1996, the total of the diverted waste and nonhazardous waste sent to landfill is $20,259+6136=26,395$ tons. The recycling rate for nonhazardous waste is calculated by dividing the diverted waste by the landfill and the diverted waste total. This results in a recycling rate of $77 \%$ for the nonhazardous waste for 1996 . This far exceeds the DOE-stated goal of achieving a 33\% recycling rate of nonhazardous waste by December 31, 1999. 
For LLNL's UC contract, the goal is to reduce the routine nonhazardous (compactible and industrial) waste (2465 tons) by 33\% by December 31, 1999. As shown in Table 3-4, LLNL reduced the routine, nonhazardous waste generated in 1996 by 19\%, to 2001 tons.

Table 3-5. Waste diversion summary table for 1996.

\begin{tabular}{|c|c|c|}
\hline Description & $\begin{array}{l}1995 \text { total } \\
\text { (tons) }\end{array}$ & $\begin{array}{c}\text { Cumulative } 1996 \text { total } \\
\text { (tons) }\end{array}$ \\
\hline \multicolumn{3}{|l|}{ Paper recycling } \\
\hline Unbaled & 254 & 266 \\
\hline Paper, baled (classified) & 116 & 56 \\
\hline Paper, subtotal & 369 & 321 \\
\hline Asphalt & 686 & 4090 \\
\hline Batteries & 38 & 21 \\
\hline Wood & 406 & 398 \\
\hline Metals, ferrous & 1121 & 1837 \\
\hline Metals, nonferrous & 181 & 193 \\
\hline Metals, copper & 78 & 73 \\
\hline Cardboard & 151 & 159 \\
\hline Compost & NA & 37 \\
\hline \multicolumn{3}{|l|}{ Diverted soil } \\
\hline Off-site daily cover & 794 & 3606 \\
\hline On-site reuse & NA & 9000 \\
\hline Diverted soil subtotal & 794 & 12,606 \\
\hline Food & - & 1 \\
\hline Magazines & 4 & 3 \\
\hline Non-LLNL phone books & 8 & 7 \\
\hline Newspaper & 6 & 3 \\
\hline Tires, scrap & 30 & 24 \\
\hline Trailers $^{(a)}$ & - & 97 \\
\hline Toner cartridges & $<1$ & 6 \\
\hline HWM recycled materials & 314 & 384 \\
\hline LLNL diversion total & 4186 & 20,259 \\
\hline
\end{tabular}

a The recycled steel frames from trailer demolition were separately tracked after the third quarter of FY96.

LLNL has been required by California Law to reduce nonhazardous solid waste by $50 \%$ between 1990 and 2000. Significant reductions have already been achieved; this waste stream has been reduced by $30 \%$ since 1990 . 


\section{Environmental Program Information}

In fiscal year 1997, LLNL has been chosen to receive a National DOE P2 award for its achievements in solid waste recycling of construction and demolition debris.

\section{Source Reduction and Pollution Prevention}

The Laboratory surveyed its operations for opportunities related to source reduction and pollution prevention in 1995. Annually, effective as of fiscal year 1996, the Laboratory will continue to survey on-site operations for opportunities to eliminate, reduce, recover, or recycle potential pollutants to all media, including air, water, soil, sediments, and biota.

\section{Toxic Reporting Inventory Information}

At LLNL only one chemical, Freon 113 (also known as CFC 113), is tracked and reported as part of the Toxic Chemical Release Inventory (TRI) for CY1996. This reporting is required by the Emergency Planning and Community Right-to-Know Act (EPCRA). All other chemicals are in quantities below the threshold reporting levels or are in a form that does not require reporting.

Freon 113, a chlorofluorocarbon (CFC), is an ozone depleting substance whose consumption and production is slated for elimination by the year 2000. For this reason, the replacement and recycling of Freon 113 is a high priority at LLNL.

\section{Additional Pollution Prevention Program Elements Implementing Cost-Saving P2 Projects}

Pollution Prevention Opportunity Assessments (PPOAs) are conducted before the implementation of P2 projects. The purpose of PPOAs is to characterize waste streams and identify those P2 options that can be cost effectively implemented. After a process has been selected for evaluation, the PPOA team contacts program personnel for a series of information gathering meetings, including walkthroughs, demonstrations, brainstorming sessions, and individual discussions. Included in the LLNL PPOA methodology is a return on investment (ROI) calculation and cost assessment of the options for all PPOAs. Results or recommendations are developed in cooperation with program personnel and are thus technically evaluated for cost, ROI, technical feasibility, and feasibility of implementation.

The DOE provides competitively allocated funding to P2 projects through the High ROI P2 Program. This program encourages proposals for the implementation of P2 projects that provide a high ROI through reducing waste and associated waste management 
costs. LLNL participates in this program to obtain funding for cost-effective P2 implementation projects. Over $\$ 2$ million in High ROI projects have been proposed to DOE and to date LLNL has received over $\$ 1.7$ million in funding for these projects. LLNL additionally uses ROI calculations and estimates of project cost-effectiveness to prioritize P2 projects for resource allocation and implementation at the Laboratory.

\section{Review of New Processes or Experiments}

Many organizations at LLNL use a "front end" review process that applies to new programs, projects, or experiments that could have a significant impact on the environment. In this review process, the initial hazardous materials projected to be used are identified, and concentrations of both the starting materials and the wastes produced are estimated. The possibility for chemical substitution, process changes, and recycling is then addressed. If an opportunity for P2 is identified, Pollution Prevention Group (PPG) will assist the generator in the evaluation of options. Researchers and project managers are encouraged to implement alternatives that are less hazardous or nonhazardous.

In general, P2 activities are covered by the pertinent directorate's P2 Plan. New activities are reviewed to identify possible P2 techniques. Projects and experiments performed by LLNL are evaluated for P2 opportunities. All personnel are encouraged to implement reasonable $\mathrm{P} 2$ opportunities that have been identified.

\section{Design for Environment}

Design for Environment (DfE) is a fairly nascent field, with a number of methodologies and definitions. In general, any means of accomplishing the goal of minimizing environmental life cycle impacts can be thought of as an element of DfE. The DfE concept involves developing an understanding of and consideration for minimizing environmental impact over the lifetime of a project, and mitigating potential environmental impacts by overlaying this understanding directly onto the design of the project. Federal facilities are now required, under Executive Order (EO) 12856, to apply life-cycle analysis and total cost accounting principles to the greatest extent practicable when estimating P2 opportunities. Both of these can be considered elements of a new federally funded facility. In addition, EO 12873 requires federal facilities to implement P2 by giving preference to the purchase of environmentally preferable products. In light of these developments, traditional methods and tools employed for management and accounting may not be sufficient or effective enough in and of themselves to meet the requirements of $\mathrm{EO} 12856$.

The Pollution Prevention Group, in conjunction with the National Ignition Facility (NIF) project management, has undertaken a DfE evaluation of the opportunities within the 


\section{Environmental Program Information}

NIF Project and has made recommendations for focused studies that might also have the most immediate impact in areas of greatest concern to project management (such as P2, environmental compliance, and cost). Approximately 20 potential study areas have been identified, and several are being actively pursued, including the development of cleaning concepts and identification of P2 opportunities during special equipment design.

Additionally, P2 measures that are technically and economically practicable are being considered in the design of the Site 300 Contained Firing Facility (CFF). Lists from architectural information exchanges and from P2 design documents are provided to the CFF design team for evaluation. The CFF project has an individual designated as the P2 coordinator for the project.

\section{Implementing P2 Employee Training and Awareness Programs}

P2 awareness information, which covers all disciplines, is disseminated in the following forums:

- New Employee-Contractor Orientation

- $\quad$ EST meetings

- $\quad$ LLNL's Waste Minimization Steering Committee

- Presentations to the Environmental subcommittee

- Employee participation at DOE's P2 conferences and workshops

- $\quad$ Facility walkthroughs

- $\quad$ Earth Day

- $\quad$ Energy Fair

- $\quad$ Posters and videos

- Individual or group training sessions with generators

- $\quad$ Presentations to waste management personnel

- $\quad$ EP0006, a required waste generator training class

- Documents such as the Waste Acceptance Criteria, PPG brochure, and PPG Web page.

P2 awareness is also promoted through Newsline (LLNL's weekly newspaper) articles and administrative memos. PPG has developed a Web site to electronically distribute P2 information and also prepares brochures that briefly describe the P2 program at LLNL. 
PPG also conducts monthly reviews of the HWM's Total Waste Management System (TWMS) database. This database tracks waste generation, and it affords PPG the opportunity to identify potential problem waste streams for each directorate and address issues in real time.

\section{Current Return on Investment Projects}

Some of the PPOAs led to the preparation of High Return-on-Investment (ROI) P2 Project Proposals in 1996. The major ROIs that were completed or were ongoing in 1996 follow:

- Microwave Digestion Equipment-Installation of equipment for the analytical laboratory, to replace acid-digestion methods.

- Technical Information Department Digital Photography Equipment —Purchase of digital imaging components.

- $\quad$ Photomicrographs, Building 321-Purchase of electronic imaging system.

- $\quad$ Ultra-High Vacuum-Removal of low-particulate contamination for ultra-high vacuum and clean room applications with nonhazardous solvents.

- Digital Acquisition System-Purchase of electronic imaging system for the transmission electron microscope.

- $\quad$ Nondestructive Analysis Waste Sampling-Purchase of equipment for field analyses and development of methods to reduce number of samples collected.

- High Explosives Water Recycling System-Installation of waste water recycling systems for Site 300 .

- Uranium Cutting Tools-Purchase of equipment and development of methods to produce high-quality machine cutting tools capable of dry machining materials.

\section{ChemTrack}

ChemTrack, a computerized chemical inventory system, is an important tool for ensuring compliance with SARA Title III and California Business Plan reporting requirements, and for improving the overall management of hazardous materials at LLNL. ChemTrack tracks chemical inventories at LLNL through the use of bar codes, laser scanners, and customized software and enhances LLNL's ability to obtain the toxic release information necessary to complete SARA 313 submittals. With the addition of 


\section{Environmental Program Information}

new, hand-held bar code scanners, the 1996 inventory was the most accurate and most efficient to date. It is expected that these new scanners, with revised software, will continue to significantly improve inventory accuracy while reducing operating costs over the next 2 years. ChemTrack currently has an inventory of approximately 185,000 chemical containers ranging from 210-L drums to gram-quantity vials.

In addition, ChemTrack includes a chemical locating service that allows LLNL researchers to find and share chemicals. This minimizes the purchase of new chemicals, thereby reducing procurement costs and the generation of hazardous waste. Also, ChemTrack data is being used by various LLNL organizations to improve emergency response planning and management of Material Data Safety Sheets (MSDSs), to more closely track specific high-hazard chemicals and other regulated substances, and as a screening tool for conducting preliminary hazard analyses of selected LLNL facilities.

\section{Current Issues and Actions}

Many current issues and actions are described in this report according to chapter subjects. This section lists several not covered elsewhere.

\section{Miniature Optical Lair Explorer}

In 1994, the Operations and Regulatory Affairs Division (ORAD) developed and began using the Miniature Optical Lair Explorer (MOLE) to perform biological assessment studies at Site 300. The MOLE is a miniature tracked vehicle with a tiny camera that allows scientists to investigate subterranean tunnel systems of special-status wildlife species to determine animal presence and numbers. At LLNL, surveys for the San Joaquin kit fox, burrowing owl, and American badger are done before startup of ground-disturbing activities in order to ensure their protection, if present.

The MOLE was used successfully at LLNL in 1996 to survey for the presence of several special-status species with subterranean habits: the burrowing owl, American badger, California tiger salamander, and California red-legged frog. In addition, the MOLE was taken by an international environmental assessment team to Lake Baikal, Siberia, to help evaluate the health of the area's ecosystem. Further studies are projected for fiscal year 1998.

In 1996, improvements were made to the MOLE, including an infrared lighting system for more effective surveillance, a backpack design for versatility and field handling efficiency, and improved monitor resolution. Further development and use of the MOLE will continue in 1997. 


\section{Leaking Underground Fuel Tank Studies}

In 1995, LLNL led a team of researchers from LLNL and four University of California campuses in a collaborative study of underground contamination from leaking underground fuel tanks (LUFTs). The study, performed for the California State Water Resources Control Board (SWRCB), found that once fuel leak sources have been removed, fuel contamination generally does not spread far from the leak site. Given time, naturally occurring microbes in the soil and ground water will usually break down most of the pollutants before they can reach a source of drinking water. On the basis of this study, the SWRCB is revising its overall ground water cleanup policy, ranking cleanup sites by their risk to drinking water sources, and selecting appropriate cleanup techniques based on risk.

One of the important recommendations of the study was to identify a series of LUFT demonstration sites and to form a panel of experts made up of scientific professionals from universities, private industry, and federal and state regulatory agencies. This panel would provide professional interpretations and recommendations regarding LUFT evaluations and closures at demonstration sites.

As a result of this recommendation, ten Department of Defense (DoD) sites were selected in 1996. Site selection was coordinated through the California Military Environmental Coordination Committee Water Process Action Team. Sites were selected to represent each branch of the military services with bases in California, as well as a number of Regional Water Quality Control Boards (RWQCBs) and the diverse hydrogeologic settings in California where fuel hydrocarbon contaminant cleanup problems occur. The sites selected and their corresponding RWQCB regions are: Army Presidio at San Francisco, San Francisco RWQCB; Barstow Marine Corps Logistic Center, Lahontan RWQCB; Camp Pendleton Marine Corps Base, San Diego RWQCB; Castle Air Force Base, Central Valley RWQCB; China Lake Naval Weapons Center, Lahontan RWQCB; El Toro Marine Corps Air Station, San Diego RWQCB, George Air Force Base, Lahontan RWQCB; Port Hueneme Naval Construction Battalion Center, Los Angeles RWQCB; Travis Air Force Base, San Francisco RWQCB; and Vandenberg Air Force Base, Central Coast RWQCB.

Recommendations will be made by the Expert Oversight Panel formed as part of the demonstration project for an appropriate risk-management strategy at each site and the set of actions needed to achieve site closure, based on the concept of developing conceptual models that identify potential hazards associated with sources, pathways, and receptors. The recommendations will also include site-specific findings regarding natural attenuation potential and discussion with regulators. 


\section{Environmental Program Information}

\section{Initiative to Improve VOC Cleanup Process by Using Historical Case Analysis}

The goal of this initiative is a nationwide historical case evaluation that uses a large number of cases to identify common volatile organic compound (VOC) release conditions that pose low risks and can be managed with minimal effort and cost, versus release conditions that pose higher risks and warrant larger expenditures of money. The key to this initiative is a cross-cutting evaluation of the large amount of VOC case data that is available.

As part of this initiative, two groups have been formed: a Working Task Force (WTF) and a Peer Review Panel (PeerRP). The WTF will focus on technical issues of historical VOC case data collection and analysis as well as preparing draft findings and conclusions based on the data analysis. The PeerRP will be called upon to review key deliverables; raise technical issues; and review and comment on draft findings, conclusions, and any recommendations. WTF includes members from the DOE, DoD U.S. Navy and Air Force, U.S. EPA, California Regional Water Quality Control Boards, and the Western Governors Association Working Group on Interstate Technology and Regulatory Cooperation.

Data collection has begun, and the PeerRP and WTF are formed and are meeting regularly. Data collection should be complete by August 1997, findings and conclusions should be prepared by December 1997, and recommendations should be prepared by March 1998.

\section{Cal/EPA Environmental Technology Certification Program}

In 1995, the California Environmental Protection Agency (Cal/EPA), through the Department of Toxic Substances Control (DTSC), contracted with LLNL to provide performance evaluations for its hazardous waste environmental technology certification program. The program was created for two principal reasons: to simplify and expedite the permitting of new technologies for cleanup in California and to assist California environmental companies in selling their products and services. DTSC is looking toward LLNL as a source of scientific expertise in certain technical areas to (1) evaluate and verify a proponent's technology, and (2) provide peer review evaluation reports. The LLNL site is also available for private companies to test their technologies for certification.

DTSC reviews each vendor application to determine whether the technology is ready to be certified and estimates the cost of certification. Then DTSC collects the fee from the vendor, selects members and a chairperson for the teams, and organizes the evaluation and peer review efforts. 
Two technologies, a field immunoassay system for polynuclear aromatic hydrocarbons and a zinc-manganese rechargeable battery, were evaluated by LLNL in 1995. During 1996, LLNL began evaluations on two more technologies. The first of these is the development of criteria for certification of cleaners and cleaning systems that are alternatives to chlorinated solvents. The second technology is a passive soil vapor survey technology.

\section{Spill Reporting}

The federal government and the State of California have several distinct statutory and regulatory provisions that require responsible persons to report releases or threatened releases of hazardous materials or pollutants into the environment. DOE has also established various Orders that require reporting of incidents to DOE Headquarters. These provisions have varying requirements regarding the types of releases that must be reported, the timing of the report or notification (immediate and follow-up), the content of the report (e.g., source of the release, nature of the material, and the quantity released), and the particular agencies that must be notified. Many releases must be reported under more than one provision, and compliance with one provision will not necessarily satisfy another applicable provision.

Under authority of the San Francisco Bay Water Quality Control Plan, the San Francisco Bay RWQCB requires a report of all releases to the ground or surface waters that are not specifically allowed in permits. LLNL followed a reporting procedure established by the San Francisco Bay RWQCB that identifies the types of spills that must be reported, and specifies when the spills are considered to be of so little consequence that records can be kept on file and noted in the routine quarterly reports. If a spill of a reportable quantity of material occurs or the material is not contained, the appropriate agencies are contacted immediately.

\section{Response to Spills and Other Environmental Emergencies}

All spills and leaks (releases) that are potentially hazardous to the environment are investigated and evaluated. The release response process includes identifying the release, shutting off the source (if safe to do so), eliminating ignition sources, contacting appropriate emergency personnel, cordoning off the area containing the released material, absorbing and neutralizing the released material, assisting in cleanup, determining if a release must be reported to regulatory agencies, and verifying that cleanup (including decontaminating and replenishing spill equipment) is complete. Environmental analysts provide guidance to the programs on preventing spill recurrence. 


\section{Environmental Program Information}

To maximize efficient and effective emergency environmental response, EPD established a 7-days-a week, 24-hours-a-day, on-call rotational position entitled the Environmental Duty Officer (EDO). Specialized EDO training includes simulated accidents to provide the staff with the experience of working together to resolve environmental issues within the regulatory structure. The on-duty EDO can be reached by pager or cellular phone at any time.

During normal work hours, Laboratory employees report all environmental incidents to the Environmental Operations Group (EOG) environmental analyst assigned to support their program area. The EOG environmental analyst then notifies the on-duty EDO of the incident and together they determine applicable reporting requirements to local, state, and federal regulatory agencies and to the DOE. The EDO and the EOG environmental analyst also notify and consult with program management, and have 7-days-a-week, 24-hours-a-day access to the office of Laboratory Counsel for questions concerning regulatory reporting requirements.

During off-hours, Laboratory employees report all environmental incidents to the Fire Dispatcher, who, in turn, notifies the EDO and possibly the Fire Department. The EDO then calls out additional EPD support to the incident scene as necessary, and follows the same procedures as outlined above for normal work hours.

\section{Environmental Training}

Major efforts are ongoing to provide LLNL employees with training on environmental topics aimed at improved compliance. Training tasks address both specialized training for environmental professionals and training in a variety of environmental topics for employees at all levels throughout LLNL. Courses presented by EPD's Training Section are listed in Table 3-6.

\section{LLNL's Other Environmental Programs}

Integral to LLNL's environmental research is the Environmental Programs Directorate that conducts multidisciplinary research to assess and mitigate environmental and human risk from natural and man-made hazards and to develop and demonstrate new tools and technologies for environmental restoration. This work includes studies in the design, analysis, and testing of advanced waste-treatment technologies; in-situ environmental remediation using natural and engineered processes; pathway, dosimetry, and risk analysis of radioactive and toxic substances; atmospheric dynamics; subsurface imaging and characterization; and seismic processes. 

Table 3-6. EPD training courses.

\begin{tabular}{|l|}
\hline Administrative Operations Pollution Prevention \\
\hline Diversity Training \\
\hline Environmental Law and Regulation \\
\hline Waste Retention Tank Management \\
\hline Hazardous Waste Generation and Certification \\
\hline Hazardous Waste Transportation \\
\hline Hazardous Waste Generation and Certification Review \\
\hline Low-Level Waste Certification Overview \\
\hline Spill Prevention, Control and Countermeasure Training \\
\hline Overview of Environmental Law and Regulation \\
\hline Placarding: Hazardous Waste Transport \\
\hline Radioactive Materials \\
\hline RCRA Operations \\
\hline SWPP \\
\hline National Environmental Policy Act (NEPA) Compliance \\
\hline Separation for Highway Transport \\
\hline TRU Waste Generation and Certification \\
\hline Waste Accumulation Area Operations \\
\hline
\end{tabular}

\begin{tabular}{|l|}
\hline Air Source Management \\
\hline Environmental Duty Officer Briefings \\
\hline New Hire Orientation \\
\hline Petroleum Product Storage Tank Management \\
\hline Hazardous Waste Sampling \\
\hline Identification of Hazardous Material \\
\hline Land Disposal Restriction \\
\hline Low-Level Waste Generation and Certification \\
\hline Marking of Packages \\
\hline Packaging Operations \\
\hline Pollution Prevention for Facility Design \\
\hline RCRA Facility Management \\
\hline Waste Disposal Requisition Training \\
\hline SARA/OSHA Refresher Training \\
\hline SARA/OSHA Training 40 Hour \\
\hline Shipping Papers \\
\hline Waste Management Unit Inspection, Procedures, and \\
Emergency Response \\
\hline
\end{tabular}

While EPD plays a central role, every directorate at LLNL is responsible for environmental compliance and minimizing the impacts of its operations. Several directorates have taken particularly noteworthy steps in this direction. These include the plans for Defense Nuclear Technologies Program's Contained Firing Facility at Site 300 that will move explosive tests inside a facility where the debris is contained, the Laser Program's efforts to design the National Ignition Facility to have minimal environmental impact, Engineering's Metal Finishing Group's efforts to reduce waste and substitute less hazardous chemicals in many of their processes, and Education Program's efforts to enhance environmental education.

\section{Contributing Authors Acknowledgment}

Major contributors to this diverse chapter were John R. Celeste, Sabre J. Coleman, Winifred A. Burks-Houck, James S. Woollett, Jr., C. Susi Jackson, Constance E. DeGrange, Jack Sims, David Rice, Glenn A. May, Jamie S. Bennett, Stephanie S. Goodwin, and Richard C. Ragaini. 


\section{Air Monitoring}

Paula J. Tate

Paris E. Althouse

\section{Introduction}

Air surveillance monitoring is performed to evaluate compliance with local, state, and federal regulations and to ensure that human health and the environment are protected from hazardous and radioactive air emissions. LLNL complies with local, state, and federal environmental air quality laws and DOE regulations, including 40 CFR 61, the National Emissions Standards for Hazardous Air Pollutants (NESHAPs) section of the Clean Air Act, and DOE Orders 5400.1, General Environmental Protection Program, and 5400.5, Radiation Protection of the Public and the Environment. The Environmental Regulatory Guide for Radiological Effluent Monitoring and Environmental Surveillance (U.S. Department of Energy 1991) provides the guidance for implementing DOE Orders 5400.1 and 5400.5. Other laws governing air quality include 22 CCR 67264.700 and 66265.710, Environmental and Compliance Monitoring, and the California Air Toxics "Hot Spots" Information and Assessment Act of 1987 (AB2588). In general, the constituents that LLNL analyzes (in order to determine environmental impact) are at levels far below the regulatory standards.

LLNL conducts surveillance monitoring of ambient air to determine if airborne radionuclides or hazardous materials are being released by Laboratory operations, what the concentrations are, and what the trends are in the LLNL environs. In the air monitoring program, particles are collected on filters and vapor is chemically trapped on a collection medium. Concentrations of various airborne radionuclides (including particles and tritiated water vapor) and beryllium are measured at the Livermore site, Site 300, at off-site locations throughout the Livermore Valley, and at an off-site location in Tracy. In addition, some point sources and diffuse, or nonpoint sources, are monitored to fulfill NESHAPs requirements (Gallegos and Biermann 1997).

\section{Methods}

For air surveillance monitoring, two networks monitor the air particulates in the environs of the Livermore site, and one network monitors particulates in the environs of Site 300, including one sampler in the city of Tracy. All these networks use continuously operating, high volume samplers located as shown in Figures 4-1, 4-2, and 4-3. 


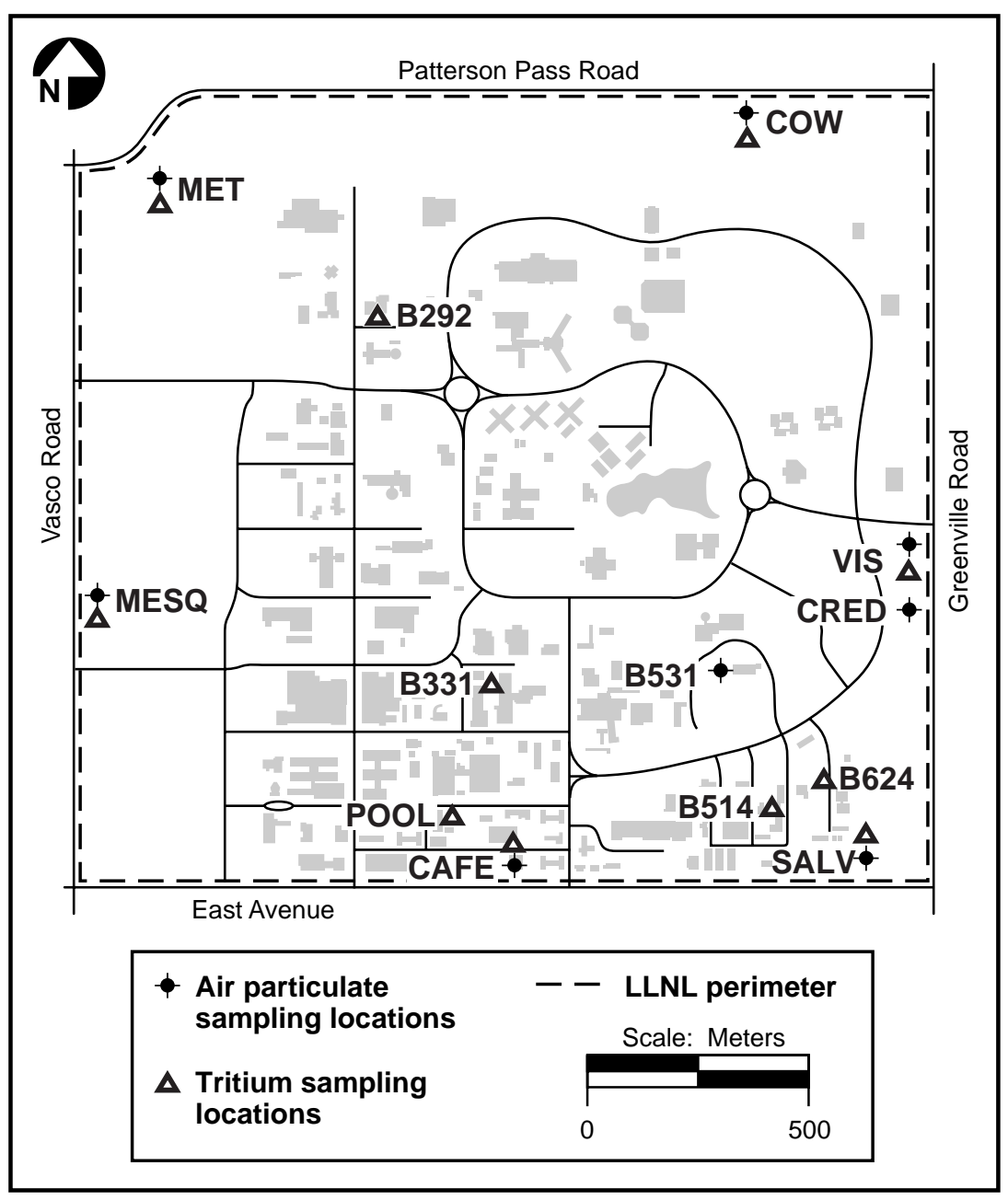

Figure 4-1. Air particulate and tritium sampling locations, Livermore site, 1996.

The Livermore site perimeter air particulate network consists of six samplers at the perimeter and two at areas of special interest (B531, CRED). The Livermore Valley network consists of samplers located in all compass directions. For the purposes of data analysis, four samplers located in the least prevalent wind directions (FCC, FIRE, HOSP, and $\mathrm{RRCH}$ ) are considered to be upwind or representative of background locations and four samplers located in the most prevalent downwind directions (PATT, ZON7, TANK, and ALTA) are considered most likely to be impacted by Laboratory operations. An additional sampler is located in an area of special interest, the Livermore Water Reclamation Plant (LWRP), because of a plutonium release to the sanitary sewer system in 1967 with subsequent soil contamination and potential resuspension (see Results section below). These air samplers are positioned to provide reasonable probability that any significant concentration of radioactive particulate or beryllium effluents from LLNL operations will be detected should it occur. The geographical details of the 


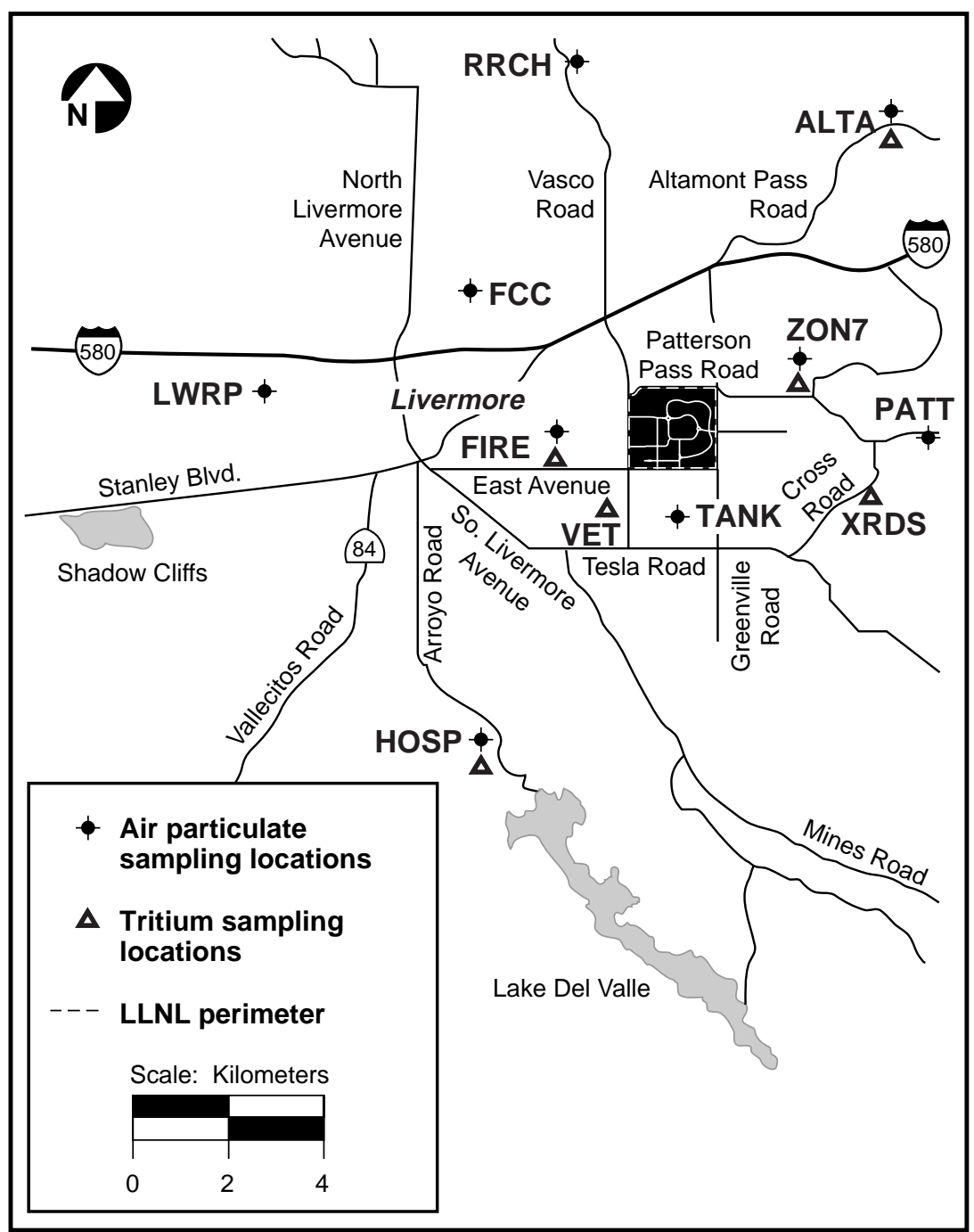

Figure 4-2. Air particulate and tritium sampling locations, Livermore Valley, 1996.

particulate sampling locations are outlined in a procedure in Appendix A of the Environmental Monitoring Plan (Tate et al. 1995).

LLNL also maintains 11 continuously operating airborne tritium samplers on the Livermore site (Figure 4-1) and 6 samplers in the Livermore Valley (Figure 4-2). In November 1996, one tritiated water vapor sampling site (HOSP) was added to the network. This site is located upwind. Four of the Livermore site locations (B331, B292, B514, and B624) monitor diffuse tritium emissions. The tritium sample locations are detailed in Appendix A of the Environmental Monitoring Plan (Tate et al. 1995). 


\section{Air Monitoring}

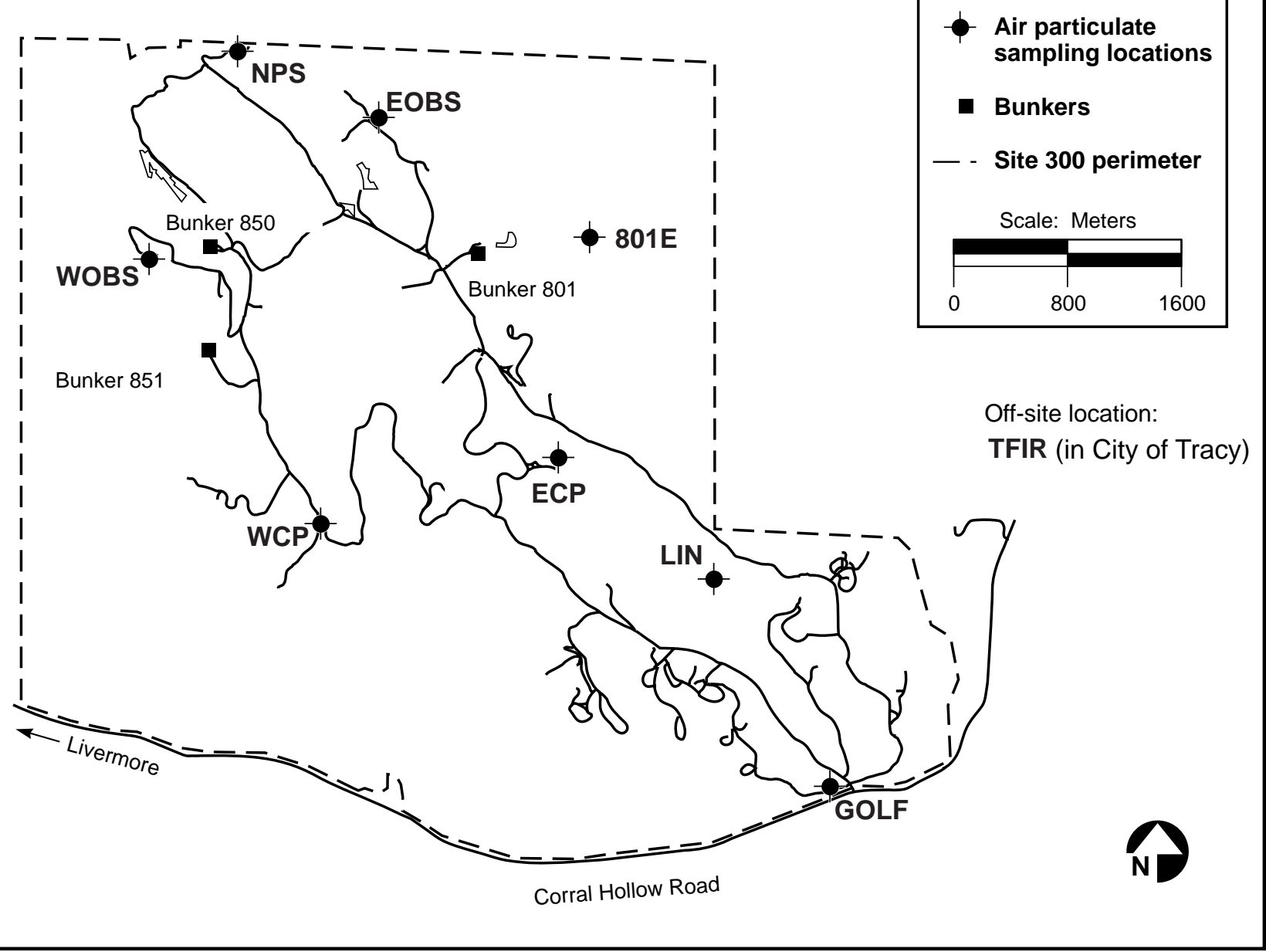

Figure 4-3. Air particulate sampling locations, Site 300, 1996.

Particulate filters are changed each week at all locations, and tritium samples are changed every two weeks. Duplicate quality control samplers are operated for 2 months in parallel with the permanent sampler at a given site, and samples are analyzed to confirm results.

As outlined in the Environmental Regulatory Guide for Radiological Effluent Monitoring and Environmental Surveillance (U.S. Department of Energy 1991), gross alpha and gross beta air filter results are used as trend indicators; specific radionuclide analysis is done for plutonium, uranium, and gamma emitters. All analytical results are reported as a measured concentration per volume of air, or at the minimum detection limit (MDL) when no activity is detected. In all cases, the MDL is more than adequate for demonstrating compliance with the pertinent regulatory requirements for radionuclides that may be or are present in the air sample and for evaluating LLNL-induced environmental impacts. Particle size distributions are not determined because the 
estimated effective dose equivalent to the maximally exposed individual is well below the $0.01 \mathrm{mSv}$ ( $1 \mathrm{mrem}$ ) allowable limit as discussed in the above mentioned Environmental Regulatory Guide. Further details of the surveillance monitoring methods are included in Volume 2, Chapter 4.

\section{Results}

This section discusses the air monitoring results at the Livermore site and at Site 300 .

\section{Livermore Site}

\section{Airborne Radioactivity}

Table 4-1 summarizes the monthly gross alpha and gross beta results for the LLNL perimeter, Livermore Valley, and Site 300 sampling locations. Medians, interquartile ranges (IQR), and maximum values for each network are included. (See Volume 2, Tables 4-1 and 4-2 for detailed location results for all networks for gross alpha and gross beta concentrations.) The monthly median gross alpha and gross beta concentrations are plotted in Figures 4-4 and 4-5, respectively. The gross beta results follow a similar pattern to previous years' data.

The gross alpha data are much more variable because of the nature of the standard analytical method capabilities, and most of the data are at or below the minimum detection limit of the method.

Typical gross alpha activity (median value) for the LLNL perimeter network is $6.3 \times 10^{-12} \mathrm{~Bq} / \mathrm{mL}\left(1.7 \times 10^{-22} \mathrm{Ci} / \mathrm{mL}\right)$; for the upwind Livermore Valley stations the value is $1.4 \times 10^{-12} \mathrm{~Bq} / \mathrm{mL}\left(3.7 \times 10^{-23} \mathrm{Ci} / \mathrm{mL}\right)$; and for the downwind Livermore Valley stations the value is $1.2 \times 10^{-11} \mathrm{~Bq} / \mathrm{mL}\left(3.2 \times 10^{-22} \mathrm{Ci} / \mathrm{mL}\right)$. Negative values occur when the activity of the analytical background filters is higher than the activity on the filters being analyzed. Typical gross beta activity (median value) for the LLNL perimeter is $3.9 \times 10^{-10} \mathrm{~Bq} / \mathrm{mL}\left(1.1 \times 10^{-20} \mathrm{Ci} / \mathrm{mL}\right)$; for the upwind Livermore Valley stations the value is $3.7 \times 10^{-10} \mathrm{~Bq} / \mathrm{mL}\left(1.0 \times 10^{-20} \mathrm{Ci} / \mathrm{mL}\right)$; and for the downwind Livermore stations the value is $3.7 \times 10^{-10} \mathrm{~Bq} / \mathrm{mL}\left(1.0 \times 10^{-20} \mathrm{Ci} / \mathrm{mL}\right)$. These values are similar to those obtained from previous monitoring data during the past several years. The primary sources of the alpha and beta activities are the naturally occurring radioisotopes of uranium and thorium, and any residual fallout from atmospheric weapons testing and the Chernobyl reactor accident in 1986. 
Table 4-1. Gross alpha and gross beta in air particulate samples summarized by month, 1996. (a)

\begin{tabular}{|c|c|c|c|c|c|c|}
\hline & \multicolumn{3}{|c|}{ Gross alpha $\left(10^{-12} \mathrm{~Bq} / \mathrm{mL}\right)$} & \multicolumn{3}{|c|}{ Gross beta $\left(10^{-12} \mathrm{~Bq} / \mathrm{mL}\right)$} \\
\hline & Median & $\begin{array}{c}\text { Interquartile } \\
\text { range }\end{array}$ & Maximum & Median & $\begin{array}{l}\text { Interquartile } \\
\text { range }\end{array}$ & Maximum \\
\hline \multicolumn{7}{|c|}{ LLNL perimeter } \\
\hline Jan & 1.63 & 49.8 & 68.0 & 252 & 525 & 996 \\
\hline Feb & 3.52 & 49.0 & 109 & 381 & 487 & 794 \\
\hline Mar & 4.32 & 39.1 & 65.8 & 357 & 207 & 574 \\
\hline Apr & -4.64 & 30.8 & 42.6 & 491 & 157 & 981 \\
\hline May & 28.0 & 70.4 & 192 & 400 & 417 & 846 \\
\hline June & 0.117 & 56.6 & 85.6 & 258 & 226 & 693 \\
\hline July & 13.7 & 55.5 & 145 & 423 & 152 & 644 \\
\hline Aug & 27.8 & 46.9 & 145 & 424 & 146 & 838 \\
\hline Sept & 17.7 & 59.3 & 112 & 424 & 181 & 855 \\
\hline Oct & -5.03 & 66.6 & 58.8 & 418 & 236 & 1110 \\
\hline Nov & -8.80 & 60.5 & 242 & 426 & 518 & 1270 \\
\hline Dec & 2.30 & 35.6 & 92.8 & 187 & 150 & 712 \\
\hline \multicolumn{7}{|c|}{ Livermore Valley upwind } \\
\hline Jan & -14.4 & 44.6 & 37.9 & 259 & 515 & 923 \\
\hline Feb & 2.89 & 44.0 & 85.5 & 284 & 470 & 769 \\
\hline Mar & -7.29 & 39.5 & 95.8 & 331 & 80.7 & 510 \\
\hline Apr & -4.44 & 14.2 & 44.4 & 466 & 225 & 685 \\
\hline May & 44.4 & 51.2 & 109 & 468 & 340 & 775 \\
\hline June & 9.82 & 46.0 & 123 & 279 & 219 & 655 \\
\hline July & 21.7 & 55.2 & 129 & 368 & 122 & 736 \\
\hline Aug & 16.2 & 36.6 & 99.5 & 437 & 192 & 775 \\
\hline Sept & -7.38 & 59.9 & 49.8 & 363 & 269 & 706 \\
\hline Oct & -9.91 & 31.1 & 112 & 450 & 401 & 1060 \\
\hline Nov & 27.9 & 57.6 & 123 & 428 & 566 & 2080 \\
\hline Dec & -1.16 & 43.4 & 102 & 195 & 82.5 & 622 \\
\hline
\end{tabular}


Table 4-1. Gross alpha and gross beta in air particulate samples summarized by month, 1996(a) (concluded).

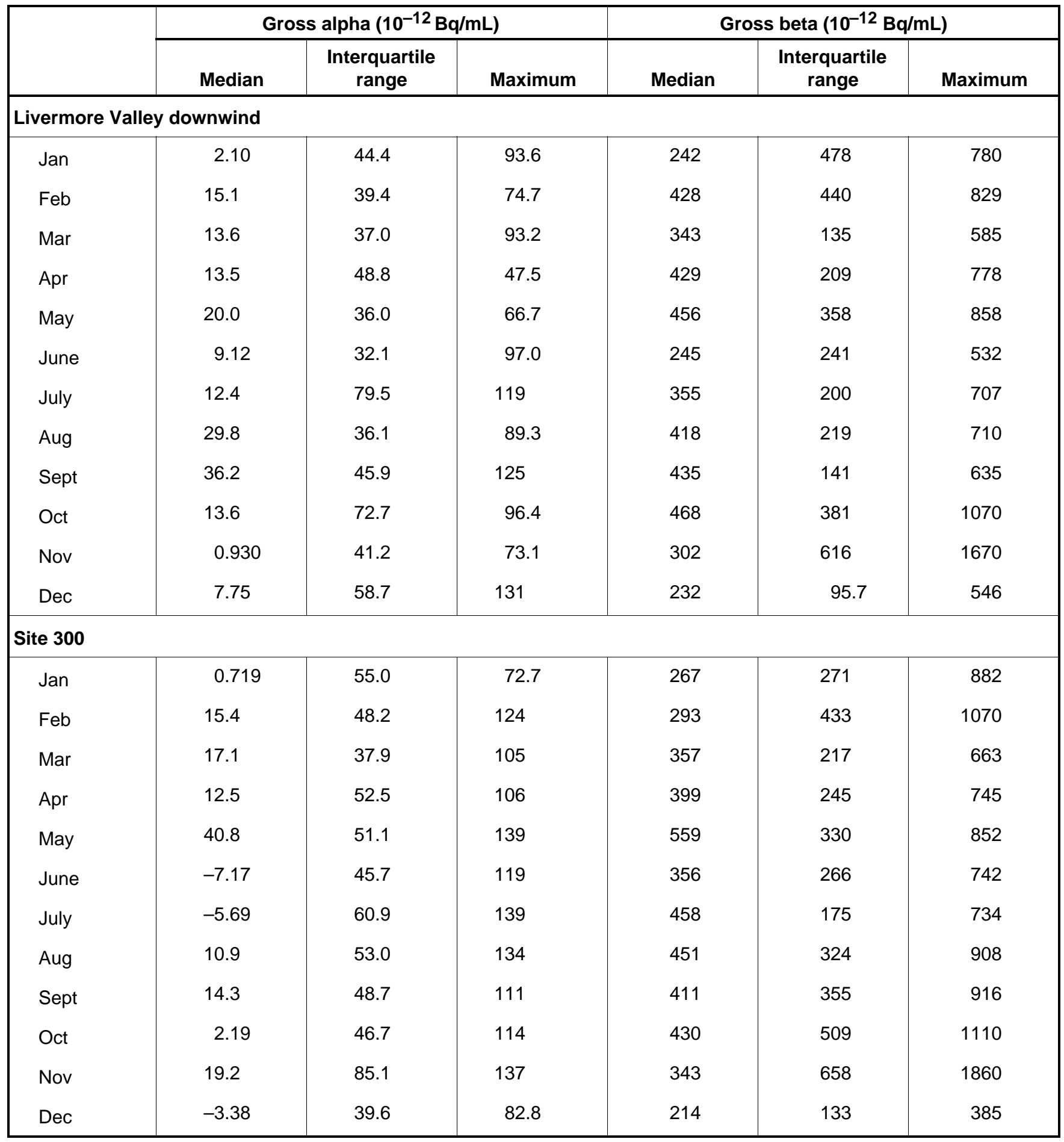

a Negative values indicate that at least half of the samples had activity of the background greater than that of the sample. 


\section{Air Monitoring}

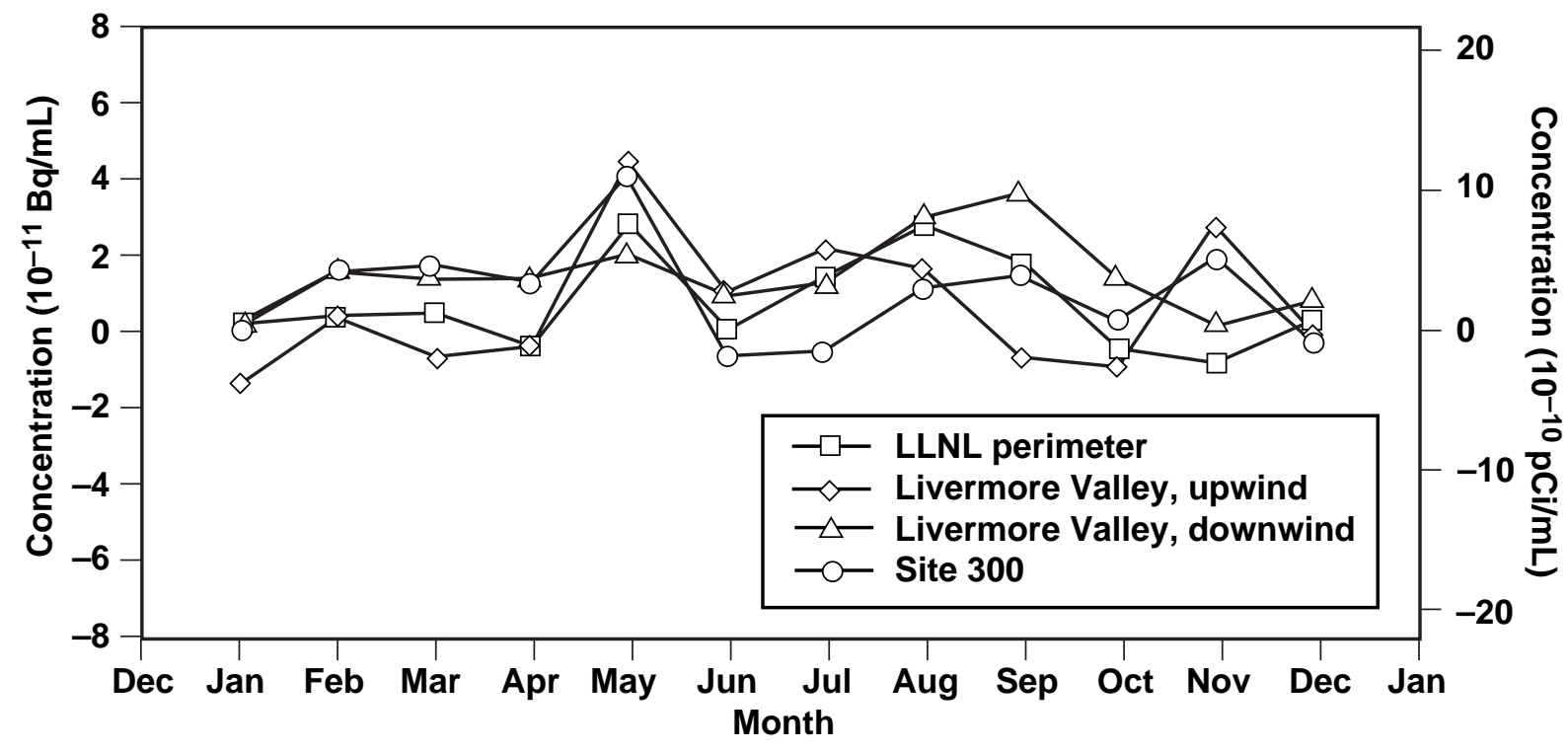

Figure 4-4. Monthly median gross alpha concentrations in particulate air samples from LLNL perimeter, Livermore Valley, and Site 300 sampling locations, 1996.

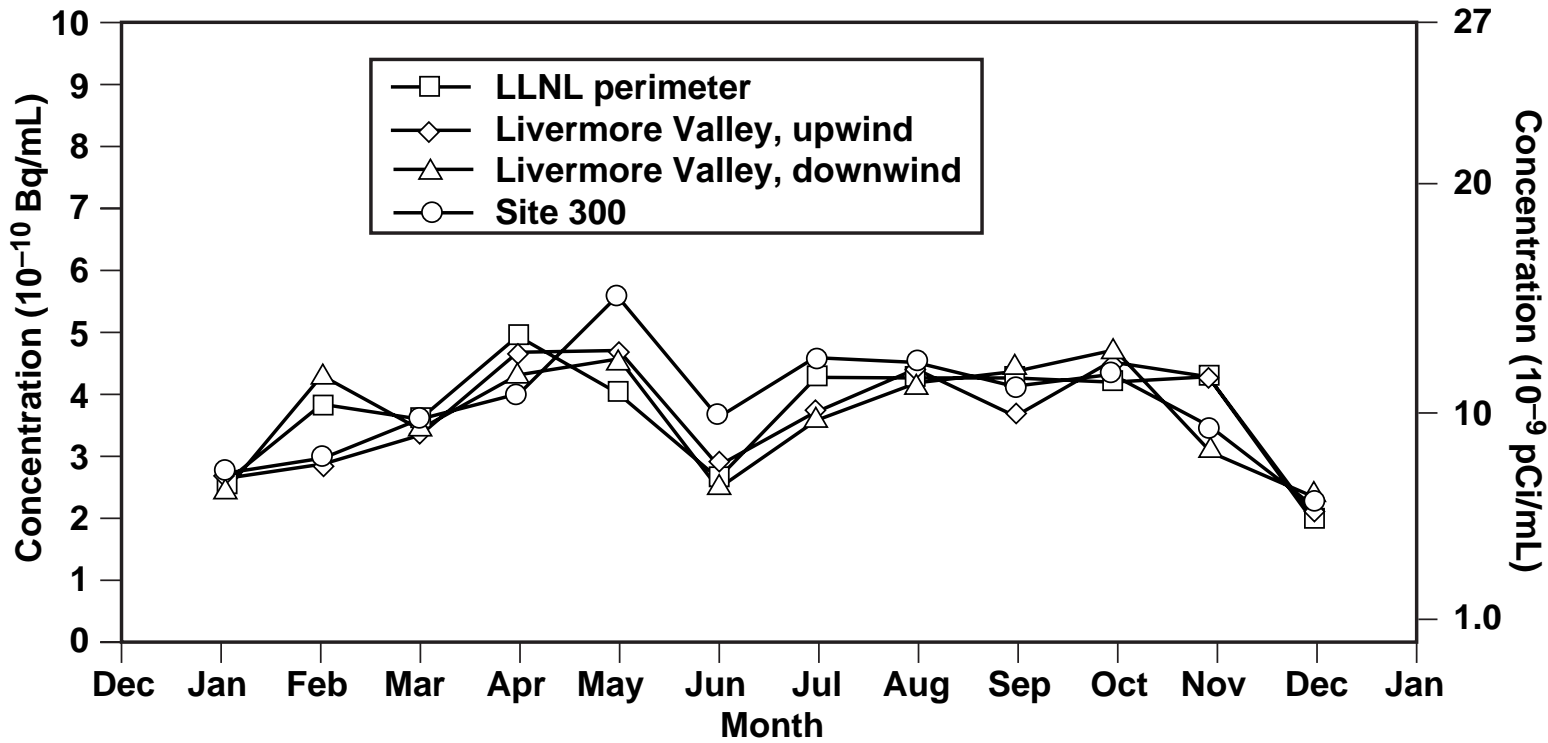

Figure 4-5. Monthly median gross beta concentrations in particulate air samples from LLNL perimeter, Livermore Valley, and Site 300 sampling locations, 1996. 
Gamma-emitting radionuclide concentrations in air that contribute to the activity in the Livermore site perimeter samples are summarized in Table 4-2. (See Volume 2, Table 4-4 for monthly gamma data.) Of the nuclides tabulated, ${ }^{7} \mathrm{Be},{ }^{40} \mathrm{~K},{ }^{226} \mathrm{Ra},{ }^{228} \mathrm{Ra}$, and ${ }^{228} \mathrm{Th}$ occur naturally. The primary source of ${ }^{137} \mathrm{Cs}$ is long-term global fallout and fallout resuspension.

Table 4-2. Gamma activity in air particulate samples, Livermore site perimeter and Site 300, 1996.

\begin{tabular}{|c|c|c|c|c|c|c|c|}
\hline & ${ }^{7} \mathrm{Be}$ & ${ }^{40} \mathrm{~K}$ & ${ }^{137} \mathrm{Cs}$ & ${ }^{22} \mathrm{Na}$ & ${ }^{226} \mathrm{Ra}$ & ${ }^{228} \mathrm{Ra}$ & ${ }^{228} \mathrm{Th}$ \\
\hline & $\left(10^{-9} \mathrm{~Bq} / \mathrm{mL}\right)$ & \multicolumn{6}{|c|}{$\left(10^{-12} \mathrm{~Bq} / \mathrm{mL}\right)$} \\
\hline \multicolumn{8}{|l|}{ Livermore perimeter } \\
\hline Median & 4.9 & $<6.3$ & $<0.2$ & $<0.3$ & $<0.6$ & $<1.4$ & $<0.7$ \\
\hline Interquartile range & 1.6 & -(a) $^{(\mathrm{a})}$ & —(a) $^{(\mathrm{a}}$ & —a) $^{(\mathrm{a})}$ & -(a) & -(a) & -(a) \\
\hline Maximum & 6.8 & 29.4 & $<0.3$ & 0.9 & $<2.8$ & 2.9 & 1.8 \\
\hline $\begin{array}{l}\text { Median fraction of } \\
D G^{(b)}\end{array}$ & $3.3 \times 10^{-6}$ & $<1.9 \times 10^{-7}$ & $<1.3 \times 10^{-8}$ & $<7.8 \times 10^{-9}$ & $<1.5 \times 10^{-5}$ & $<1.2 \times 10^{-5}$ & $<4.6 \times 10^{-4}$ \\
\hline \multicolumn{8}{|l|}{ Site 300} \\
\hline Median & 5.8 & $<4.8$ & $<0.1$ & 0.6 & $<0.4$ & $<0.9$ & $<0.4$ \\
\hline Interquartile range & 3.7 & $-^{(\mathrm{a})}$ & - $^{(\mathrm{a})}$ & $-^{(a)}$ & - $^{(\mathrm{a})}$ & -(a) & -(a) \\
\hline Maximum & 7.4 & 14.8 & $<0.3$ & 1.0 & $<1.5$ & $<1.7$ & $<1.2$ \\
\hline Median fraction of DCG & $3.9 \times 10^{-6}$ & $<1.4 \times 10^{-7}$ & $<1.0 \times 10^{-8}$ & $<1.6 \times 10^{-8}$ & $<9.7 \times 10^{-6}$ & $<7.8 \times 10^{-6}$ & $<2.8 \times 10^{-4}$ \\
\hline DCG (Bq/mL) & $1.5 \times 10^{-3}$ & $3.3 \times 10^{-5}$ & $1.5 \times 10^{-5}$ & $3.7 \times 10^{-5}$ & $3.7 \times 10^{-8}$ & $1.1 \times 10^{-7}$ & $1.5 \times 10^{-9}$ \\
\hline
\end{tabular}

a No measure of dispersion calculated. See Chapter 13, Quality Assurance.

b Derived Concentration Guide.

In addition to providing baseline data on global fallout, analysis of these radionuclides enables LLNL to monitor the containment of the small inventories of mixed fission products and radiochemical tracers used at LLNL. The Derived Concentration Guides (DCGs) for these radionuclides are also shown in Table 4-2. For air, DCGs specify the concentrations of radionuclides that could be inhaled continuously 365 days a year without exceeding the DOE primary radiation protection standard for the public, which is $1 \mathrm{mSv} / \mathrm{y}$ (100 mrem/y) effective dose equivalent (DOE Order 5400.5). (Chapter 12 on Radiological Dose Assessment provides an explanation of this and other units of dose.) Finally, the fraction of the DCGs is presented. These values demonstrate that levels of gamma activity present in air at the Livermore site perimeter are far below the DCGs. Air monitoring data are compared to the DOE DCG in 5400.5, and compliance with the EPA 10 mrem standard (40 CFR 61) is demonstrated by modeling. 


\section{Air Monitoring}

Table 4-3 shows the median, IQR, maximum, and median fraction of DCG for concentration of plutonium on air filter samples collected in the Livermore Valley. (See Volume 2, Table 4-6 for monthly data.) The highest off-site median concentration of ${ }^{239} \mathrm{Pu}$ occurred at the Livermore Water Reclamation Plant (LWRP). Soils near the LWRP contain some detectable plutonium, principally resulting from sludgespreading operations following an estimated $1.2 \times 10^{9} \mathrm{~Bq}(32 \mathrm{mCi})$ release to the sewer in 1967 (see Chapter 9, Soil and Sediment Monitoring). Resuspension of these soils probably accounts for the slightly higher median ${ }^{239} \mathrm{Pu}$ in air concentrations observed. However, the median observed value is $<0.00003$ of the DCG.

Table 4-3. Plutonium activity in air particulate samples (in $10^{-15} \mathrm{~Bq} / \mathrm{mL}$ ), 1996.

\begin{tabular}{|c|c|c|c|c|}
\hline $\begin{array}{l}\text { Sampling } \\
\text { Iocation(a) }^{(a)}\end{array}$ & Median & $\begin{array}{c}\text { Interquartile } \\
\text { range }\end{array}$ & Maximum & $\begin{array}{c}\text { Median fraction } \\
\text { of } \mathrm{DCG}^{(\mathrm{b})}\end{array}$ \\
\hline \multicolumn{5}{|c|}{ Livermore Valley downwind locations } \\
\hline ALTA & 2.7 & 4.9 & 9.6 & $3.6 \times 10^{-6}$ \\
\hline PATT & 0.38 & 9.8 & 28 & $5.1 \times 10^{-7}$ \\
\hline TANK & 0.14 & 4.7 & 10 & $1.8 \times 10^{-7}$ \\
\hline ZON7 & -4.7 & 15.4 & 12 & $-6.4 \times 10^{-6}$ \\
\hline \multicolumn{5}{|c|}{ Livermore Valley upwind locations } \\
\hline FCC & 3.1 & 7.7 & 16 & $4.2 \times 10^{-6}$ \\
\hline FIRE & 8.4 & 13 & 29 & $1.1 \times 10^{-5}$ \\
\hline HOSP & 6.6 & 6.0 & 27 & $8.9 \times 10^{-6}$ \\
\hline $\mathrm{RRCH}$ & 9.6 & 8.5 & 17 & $1.3 \times 10^{-5}$ \\
\hline \multicolumn{5}{|l|}{ Special interest } \\
\hline LWRP & 18 & 26 & 51 & $2.4 \times 10^{-5}$ \\
\hline \multicolumn{5}{|l|}{ LLNL perimeter } \\
\hline CAFE & 24 & 22 & 70 & $3.2 \times 10^{-5}$ \\
\hline cow & 21 & 20 & 43 & $2.8 \times 10^{-5}$ \\
\hline MESQ & 15 & 18 & 41 & $2.1 \times 10^{-5}$ \\
\hline MET & 14 & 8.1 & 36 & $1.9 \times 10^{-5}$ \\
\hline SALV & 18 & 9.4 & 150 & $2.4 \times 10^{-5}$ \\
\hline VIS & 24 & 22 & 84 & $3.2 \times 10^{-5}$ \\
\hline \multicolumn{5}{|c|}{ Diffuse on-site sources } \\
\hline B531 & 130 & 340 & 940 & $1.7 \times 10^{-4}$ \\
\hline CRED & 11 & 14 & 34 & $1.5 \times 10^{-5}$ \\
\hline Site 300 & 3.7 & 2.8 & 10 & $4.9 \times 10^{-6}$ \\
\hline Tracy & 2.2 & 4.7 & 15 & $2.9 \times 10^{-6}$ \\
\hline
\end{tabular}

a See Figures 4-1, 4-2, and 4-3 for sampling locations.

b Derived Concentration Guide $=7.4 \times 10^{-10} \mathrm{~Bq} / \mathrm{mL}\left(2 \times 10^{-14} \mu \mathrm{Ci} / \mathrm{mL}\right)$ for ${ }^{239} \mathrm{Pu}$ activity in air. 
Table 4-3 also shows the concentrations of airborne ${ }^{239} \mathrm{Pu}$ on air filters from the LLNL perimeter locations. (See Volume 2, Table 4-7 for the detailed location monthly data.) The highest concentration was registered at location SALV in September 1996; the concentration value is reported as $1.5 \times 10^{-13} \mathrm{~Bq} / \mathrm{mL}\left(4.1 \times 10^{-24} \mathrm{Ci} / \mathrm{mL}\right)$, which represents 0.0002 of the DCG. This concentration may be due to the construction activities in the area, which included significant grading and dirt movement, thereby increasing the resuspension probability. The median concentration at location SALV is $1.8 \times 10^{-14} \mathrm{~Bq} / \mathrm{mL}\left(4.9 \times 10^{-25} \mathrm{Ci} / \mathrm{mL}\right)$, which is just slightly lower than the previous year.

Figure 4-6 shows the annual median concentrations of ${ }^{239} \mathrm{Pu}$ for locations SALV (on site) and FCC (off site) from 1982 to 1996. Location FCC represents a typical upwind background location, and SALV represents the perimeter location having the highest annual average for most of this 14-year period. The higher values in the past at SALV may be attributed to historical activities at LLNL; improvements in operational processes in the immediate work area have contributed to the observed downward trend of the data.

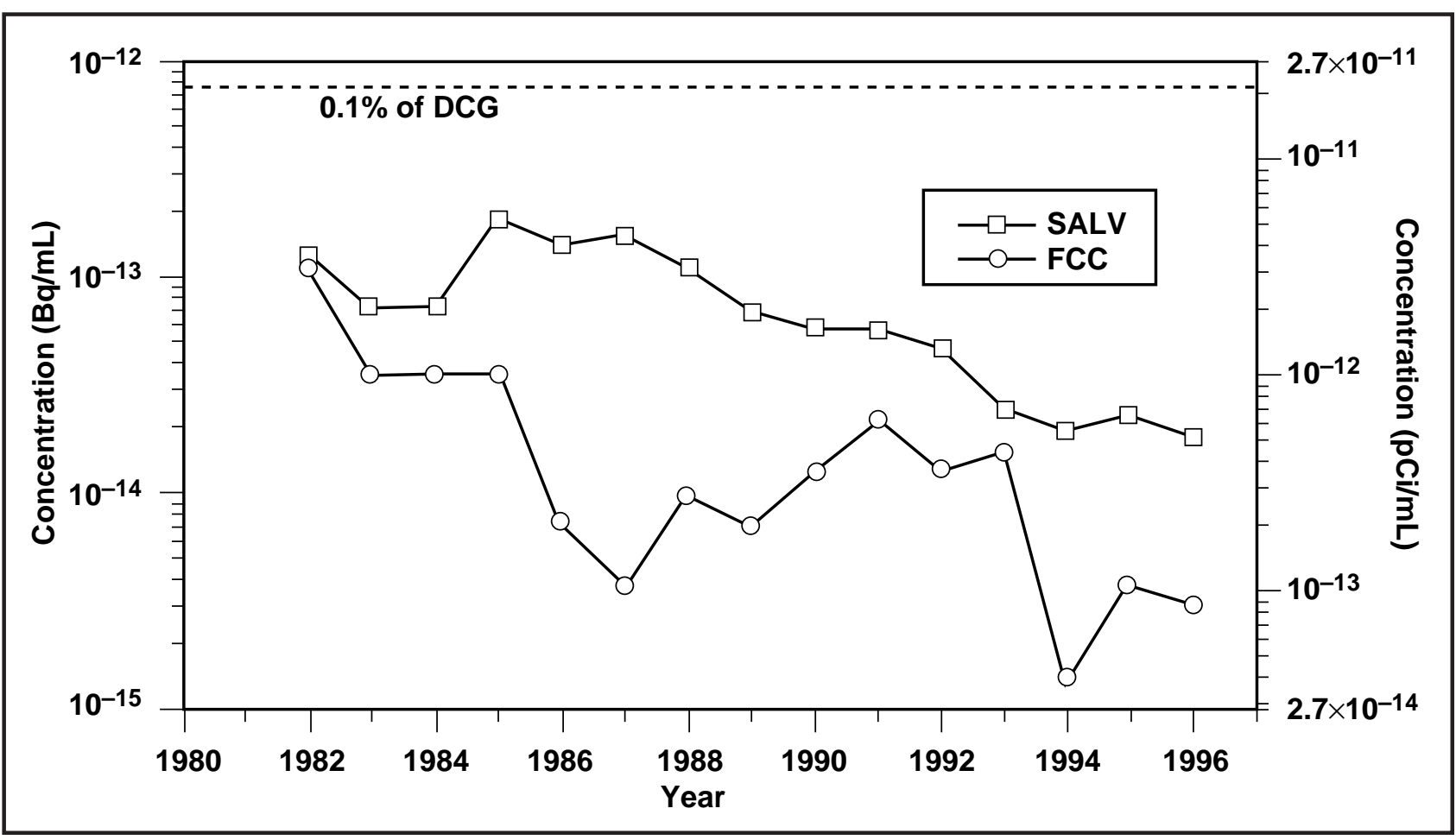

Figure 4-6. Median plutonium concentrations in air particulate samples at two locations, SALV and FCC, 1982 to 1996 (DCG $\left.=7.4 \times 10^{-10} \mathrm{~Bq} / \mathrm{mL}\right)$. 


\section{Air Monitoring}

In June 1991, two air particulate sampling locations (B531 and CRED) were added as part of a special study to investigate the somewhat elevated levels of plutonium in air and surface soil in the southeast quadrant of the Livermore site (see Chapter 9, Soil and Sediment Monitoring, for general background on this study). These sampling locations are now part of our routine monitoring network and provide data for diffuse source dose assessments. Table 4-3 shows the median concentrations of airborne ${ }^{239} \mathrm{Pu}$ at these two locations. (See Volume 2, Table 4-8 for monthly data.) The median concentration of $1.3 \times 10^{-13} \mathrm{~Bq} / \mathrm{mL}\left(3.4 \times 10^{-24} \mathrm{Ci} / \mathrm{mL}\right)$ at location $\mathrm{B} 531$ is higher than the median concentration for any of the other air particulate sampling locations but is still only 0.0002 of the DCG.

The median ${ }^{235} \mathrm{U}$ and ${ }^{238} \mathrm{U}$ concentrations in air samples from the Livermore site perimeter are shown in Table 4-4. (See Volume 2, Table 4-10 for monthly data.) The maximum measured concentration of ${ }^{238} \mathrm{U}$ is less than 0.0009 of the DCG. All ${ }^{235} \mathrm{U} /{ }^{238} \mathrm{U}$ median ratios are as expected for naturally occurring uranium; however, monthly data in Volume 2 shows some unexpected ${ }^{235} \mathrm{U} / 238 \mathrm{U}$ ratios, indicating other than natural uranium around the Livermore site perimeter. While no significant environmental impact stems from the observed ratios, their cause is not known but they have occurred sporadically in the past.

Table 4-5 shows the median concentrations of tritiated water vapor for the Livermore Valley sampling locations. (See Volume 2, Table 4-12 for biweekly data for each location.) The highest annual median concentration was observed at location ZON7. At approximately $4.3 \times 10^{-8} \mathrm{~Bq} / \mathrm{mL}\left(1.2 \times 10^{-18} \mathrm{Ci} / \mathrm{mL}\right)$, this concentration represents 0.00001 of the DCG. The highest biweekly concentration was observed in October at ZON7. If it were a yearly average, this concentration, $5.1 \times 10^{-7} \mathrm{~Bq} / \mathrm{mL}$ $\left(1.4 \times 10^{-17} \mathrm{Ci} / \mathrm{mL}\right)$, would be 0.0001 of the DCG. The 1996 tritium values are generally similar to those reported last year.

Table 4-5 also shows the median concentrations of tritiated water vapor that were observed at the Livermore site perimeter sampling locations. (See Volume 2, Table 4-13 for biweekly data.) The highest annual median concentration was observed at location POOL, which was $2.4 \times 10^{-7} \mathrm{~Bq} / \mathrm{mL}\left(6.5 \times 10^{-18} \mathrm{Ci} / \mathrm{mL}\right)$, or 0.00007 of the DCG.

Diffuse sources of tritium on the Livermore site are monitored at air tritium sampling locations B331, B292, B514, and B624. Table 4-5 shows the median concentrations of tritiated water vapor for these sampling locations. (See Volume 2, Table 4-14 for biweekly data.) The highest median concentration was observed at location B624. This concentration was $6.3 \times 10^{-6} \mathrm{~Bq} / \mathrm{mL}\left(1.7 \times 10^{-16} \mathrm{Ci} / \mathrm{mL}\right)$ and represents 0.002 of the DCG. The highest biweekly tritium concentration, $2.1 \times 10^{-5} \mathrm{~Bq} / \mathrm{mL}$ $\left(5.7 \times 10^{-16} \mathrm{Ci} / \mathrm{mL}\right)$, was observed in October at location B331. If it were a yearly average, this concentration would represent 0.006 of the DCG. 
Table 4-4. Uranium mass in air particulate samples, 1996.

\begin{tabular}{|c|c|c|c|}
\hline $\begin{array}{l}\text { Sampling } \\
\text { Iocation(a) }^{(a)}\end{array}$ & $\begin{array}{c}{ }^{238} \mathrm{U}^{(\mathrm{b})} \\
\left(10^{-5} \mu \mathrm{g} / \mathrm{m}^{3}\right)\end{array}$ & $\begin{array}{c}{ }^{235} \mathrm{U}^{(\mathrm{c})} \\
\left(10^{-7} \mu \mathrm{g} / \mathrm{m}^{3}\right)\end{array}$ & $\begin{array}{c}{ }^{235} U /^{238} U^{(d)} \\
\left(10^{-3}\right)\end{array}$ \\
\hline \multicolumn{4}{|l|}{ LLNL perimeter } \\
\hline \multicolumn{4}{|l|}{ CAFE } \\
\hline Median & 4.56 & 3.29 & 7.09 \\
\hline Interquartile range & 4.79 & 3.14 & 0.22 \\
\hline Maximum & 9.41 & 6.56 & $N A^{(e)}$ \\
\hline Median fraction of DCG & $1.5 \times 10^{-4}$ & $7.0 \times 10^{-6}$ & NA \\
\hline \multicolumn{4}{|l|}{ cow } \\
\hline Median & 6.15 & 4.52 & 7.25 \\
\hline Interquartile range & 13.7 & 9.77 & 0.20 \\
\hline Maximum & 26.1 & 18.7 & NA \\
\hline Median fraction of DCG & $2.1 \times 10^{-4}$ & $9.6 \times 10^{-6}$ & NA \\
\hline \multicolumn{4}{|l|}{ MESQ } \\
\hline Median & 3.99 & 2.77 & 7.18 \\
\hline Interquartile range & 6.36 & 4.42 & 0.08 \\
\hline Maximum & 14.0 & 10.1 & NA \\
\hline Median fraction of DCG & $1.3 \times 10^{-4}$ & $5.9 \times 10^{-6}$ & NA \\
\hline \multicolumn{4}{|l|}{ MET } \\
\hline Median & 4.33 & 2.88 & 7.16 \\
\hline Interquartile range & 4.38 & 3.13 & 0.15 \\
\hline Maximum & 8.13 & 5.81 & NA \\
\hline Median fraction of DCG & $1.4 \times 10^{-4}$ & $6.1 \times 10^{-6}$ & NA \\
\hline \multicolumn{4}{|l|}{ SALV } \\
\hline Median & 4.01 & 2.91 & 7.16 \\
\hline Interquartile range & 5.70 & 3.97 & 0.19 \\
\hline Maximum & 8.48 & 6.06 & NA \\
\hline Median fraction of DCG & $1.3 \times 10^{-4}$ & $6.2 \times 10^{-6}$ & NA \\
\hline \multicolumn{4}{|l|}{ VIS } \\
\hline Median & 4.20 & 2.93 & 7.17 \\
\hline Interquartile range & 3.54 & 2.55 & 0.09 \\
\hline Maximum & 11.1 & 7.92 & NA \\
\hline Median fraction of DCG & $1.4 \times 10^{-4}$ & $6.2 \times 10^{-6}$ & NA \\
\hline \multicolumn{4}{|l|}{ Site 300 (composite) } \\
\hline Median & 4.49 & 2.82 & 6.42 \\
\hline Interquartile range & 5.39 & 3.51 & 1.45 \\
\hline Maximum & 20.2 & 4.95 & NA \\
\hline Median fraction of DCG & $1.5 \times 10^{-4}$ & $6.0 \times 10^{-6}$ & NA \\
\hline
\end{tabular}

a See Figures 4-1 and 4-3 for sampling locations.

b Derived Concentration Guide $=0.3 \mu \mathrm{g} / \mathrm{m}^{3}$ for ${ }^{238} \mathrm{U}$ activity in air.

c Derived Concentration Guide $=0.047 \mu \mathrm{g} / \mathrm{m}^{3}$ for ${ }^{235} \mathrm{U}$ activity in air.

d Naturally occurring uranium has a ${ }^{235} \mathrm{U} / /^{238} \mathrm{U}$ ratio of $7.1 \times 10^{-3}$.

e $\quad \mathrm{NA}=$ Not applicable. 
Table 4-5. Tritium in air samples (in 10-9 Bq/mL), 1996.

\begin{tabular}{|c|c|c|c|c|c|c|}
\hline $\begin{array}{l}\text { Sampling } \\
\text { location (a) }^{(2)}\end{array}$ & $\begin{array}{l}\text { Detection } \\
\text { frequency }\end{array}$ & Median & $\operatorname{IQR}^{(\mathbf{b})}$ & Maximum & $\begin{array}{c}\text { Median } \\
\text { fraction of } \\
\text { DCG(c) }\end{array}$ & $\begin{array}{c}\text { Median } \\
\text { dose } \\
(\mathrm{mSv})^{(\mathrm{d})}\end{array}$ \\
\hline \multicolumn{7}{|c|}{ Livermore Valley } \\
\hline ZON7 & $24 / 26$ & 43.3 & 41.8 & 514 & $1.2 \times 10^{-5}$ & $9.3 \times 10^{-6}$ \\
\hline ALTA & $18 / 26$ & $<18.5$ & 一(e) $^{(\mathrm{n}}$ & 165 & $<5.0 \times 10^{-6}$ & $4.0 \times 10^{-6}$ \\
\hline FIRE & $13 / 26$ & $<17.7$ & -(e) & 99.5 & $<4.8 \times 10^{-6}$ & $3.8 \times 10^{-6}$ \\
\hline XRDS & $14 / 26$ & $<18.4$ & -(e) & 171 & $<5.0 \times 10^{-6}$ & $4.0 \times 10^{-6}$ \\
\hline VET & $19 / 25$ & 24.8 & -(e) & 205 & $6.7 \times 10^{-6}$ & $5.3 \times 10^{-6}$ \\
\hline HOSP & $1 / 3$ & $<23.4$ & —(e) & 24.3 & $<6.3 \times 10^{-6}$ & $5.0 \times 10^{-6}$ \\
\hline \multicolumn{7}{|c|}{ Livermore perimeter } \\
\hline SALV & $26 / 26$ & 81.4 & 96.3 & 514 & $2.2 \times 10^{-5}$ & $1.7 \times 10^{-5}$ \\
\hline MESQ & $23 / 26$ & 38.9 & 53.3 & 463 & $1.1 \times 10^{-5}$ & $8.3 \times 10^{-6}$ \\
\hline CAFE & $26 / 26$ & 160 & 126 & 892 & $4.3 \times 10^{-5}$ & $3.4 \times 10^{-5}$ \\
\hline MET & $22 / 25$ & 43.7 & 42.3 & 178 & $1.2 \times 10^{-5}$ & $9.4 \times 10^{-6}$ \\
\hline VIS & $26 / 26$ & 150 & 63.8 & 1100 & $4.0 \times 10^{-5}$ & $3.2 \times 10^{-5}$ \\
\hline cow & $25 / 25$ & 86.2 & 88.4 & 759 & $2.3 \times 10^{-5}$ & $1.8 \times 10^{-5}$ \\
\hline POOL & $23 / 23$ & 241 & 223 & 1480 & $6.5 \times 10^{-5}$ & $5.2 \times 10^{-5}$ \\
\hline \multicolumn{7}{|c|}{ Diffuse on-site sources } \\
\hline B292 & $25 / 25$ & 145 & 119 & 511 & $3.9 \times 10^{-5}$ & $3.1 \times 10^{-5}$ \\
\hline B331 & $23 / 23$ & 729 & 707 & 21300 & $2.0 \times 10^{-4}$ & $1.6 \times 10^{-4}$ \\
\hline B514 & $24 / 24$ & 392 & 555 & 3890 & $1.1 \times 10^{-4}$ & $8.4 \times 10^{-5}$ \\
\hline B624 & $25 / 25$ & 6250 & 5220 & 19800 & $1.7 \times 10^{-3}$ & $1.3 \times 10^{-3}$ \\
\hline
\end{tabular}

a See Figures 4-1 and 4-2 for sample locations.

b Interquartile range.

c Derived Concentration Guide $=3.7 \times 10^{-3} \mathrm{~Bq} / \mathrm{mL}\left(1 \times 10^{-7} \mu \mathrm{Ci} / \mathrm{mL}\right)$.

d $1 \mathrm{mSv}=100 \mathrm{mrem}$.

e Interquartile range not calculated. See Chapter 13, Quality Assurance.

The B331 location is near the Tritium Facility (Building 331), in which LLNL personnel have reduced operations in recent years and performed significant inventory reduction and cleanup activities. During this process, tritium-contaminated equipment slated for disposal is stored in a waste accumulation area before being sent to Hazardous Waste Management facilities. During 1996, outgassing from such waste processing released an estimated $0.11 \times 10^{12} \mathrm{~Bq}(3 \mathrm{Ci}$ ) of tritium to the atmosphere outside of Building 331 .

The B624 location is situated in the Building 612 yard, which is dedicated to hazardous waste, radioactive waste, and mixed-waste management activities. The yard consists of several areas where waste containers that are outgassing tritium are stored outdoors. Probably, as a result of increased legacy waste repackaging at a location within $60 \mathrm{~m}$ of the sampler, the median concentration at B624 is almost 7 times higher than 1995. 
The B514 sampling location is in a hazardous waste management area where tritiumcontaminated waste is treated, and the B292 location is near an underground retention tank that had previously leaked. The 1996 median concentrations at B292 are similar to the median concentrations in 1995.

\section{Beryllium in Air}

The median concentrations of airborne beryllium for the Livermore site perimeter sampling locations are shown in Table 4-6. (See Volume 2, Table 4-15 for monthly data.) The highest value of $43.4 \mathrm{pg} / \mathrm{m}^{3}$ occurred in the July composite at location COW. The median concentration for this location is 0.001 of the monthly ambient concentration guide (ACG) of 10,000 pg/m³ established by the Bay Area Air Quality Management District (BAAQMD) and the Environmental Protection Agency (EPA).

Table 4-6. Beryllium in air particulate samples (in $\mathrm{pg} / \mathrm{m}^{3}$ ), Livermore site perimeter and Site 300, 1996.

\begin{tabular}{|l|c|c|c|c|}
\hline $\begin{array}{c}\text { Sampling } \\
\text { location (a) }\end{array}$ & $\begin{array}{c}\text { Detection } \\
\text { frequency }\end{array}$ & Median & $\begin{array}{c}\text { Interquartile } \\
\text { range }\end{array}$ & Maximum \\
\hline Livermore perimeter & \multicolumn{5}{|l|}{} \\
\hline SALV & $12 / 12$ & 3.7 & 6.8 & 16.2 \\
MESQ & $12 / 12$ & 6.0 & 8.2 & 19.5 \\
CAFE & $12 / 12$ & 7.7 & 5.8 & 13.6 \\
MET & $12 / 12$ & 8.3 & 7.9 & 16.4 \\
VIS & $11 / 12$ & 6.1 & 4.1 & 14.8 \\
COW & $12 / 12$ & 10.6 & 14.9 & 43.4 \\
\hline Site 300 & \multicolumn{5}{|l}{} \\
\hline EOBS & $12 / 12$ & 3.6 & 6.4 & 12.9 \\
ECP & $12 / 12$ & 4.6 & 4.8 & 11.1 \\
WCP & $12 / 12$ & 4.8 & 6.5 & 10.1 \\
LIN & $12 / 12$ & 5.6 & 5.3 & 10.6 \\
GOLF & $12 / 12$ & 4.9 & 5.5 & 19.1 \\
TFIR & $12 / 12$ & 7.6 & 12.6 & 30.2 \\
NPS & $12 / 12$ & 4.2 & 4.6 & 12.1 \\
WOBS & $12 / 12$ & 3.8 & 5.3 & 10.9 \\
801E & $12 / 12$ & 6.6 & 9.1 & 15.6 \\
\hline
\end{tabular}

a See Figures 4-1 and 4-3 for sampling locations.

Figure 4-7 is a plot of the median beryllium concentration at the Livermore site perimeter from 1974 through 1996. The overall median concentration during this time period was calculated to be 0.002 of the ACG. Unless there is a change in LLNL's operations, it is expected that the beryllium levels will remain unchanged. 


\section{Air Monitoring}

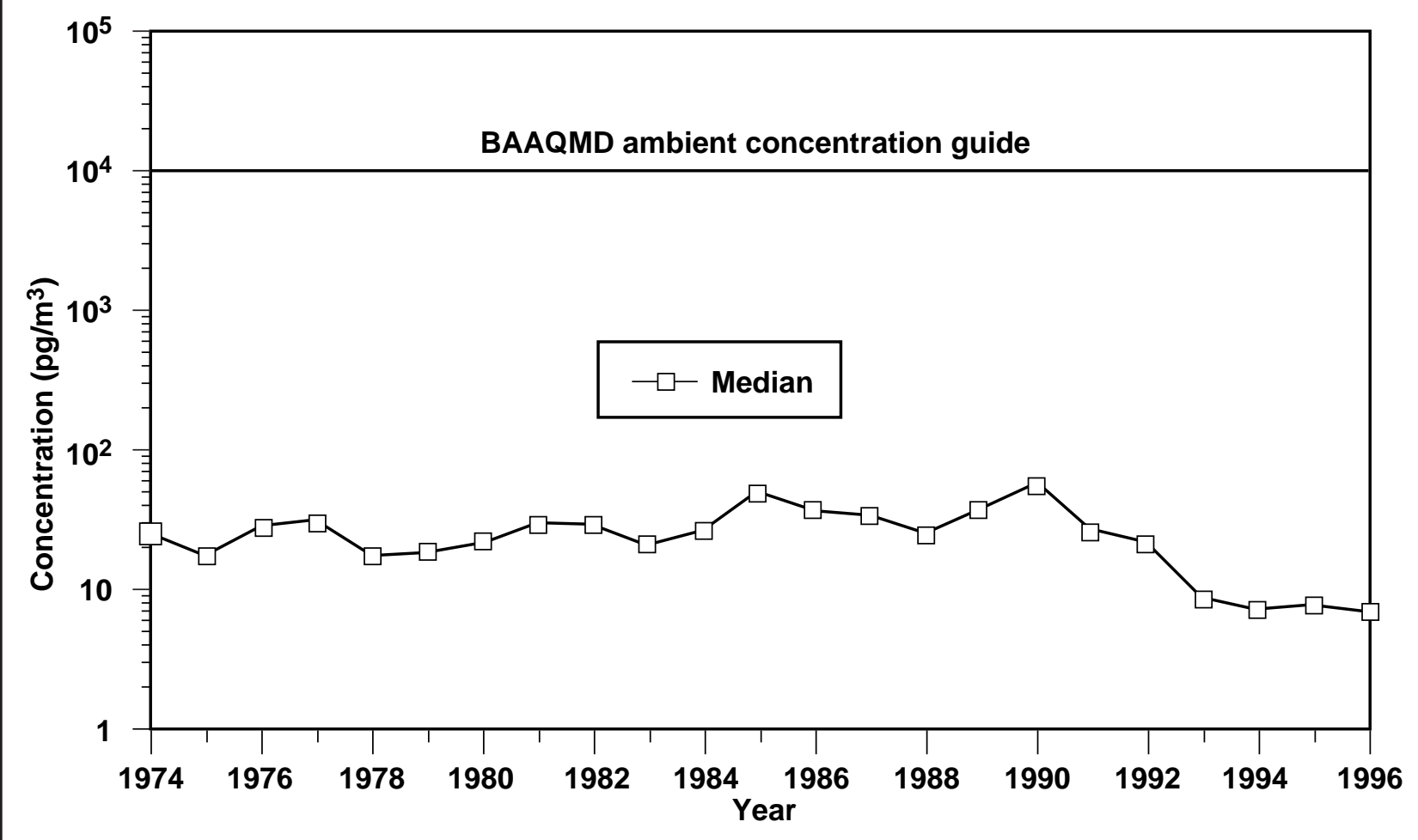

Figure 4-7. Median concentration of beryllium in air particulate samples, Livermore site perimeter, 1975 to 1996.

\section{Site 300}

\section{Airborne Radioactivity}

Most gross alpha determinations at Site 300 were at or near the analytical limit of detection for the method. Table 4-1 shows the monthly gross alpha and gross beta median, IQR, and maximum for sampling locations at Site 300. (See Volume 2, Table 4-3 for monthly data.) The monthly median gross alpha and gross beta concentrations are shown in Figures 4-4 and 4-5. The Site 300 gross beta results show a similar pattern to those found at the Livermore site. Typical gross alpha activity is $9.8 \times 10^{-12} \mathrm{~Bq} / \mathrm{mL}$ $\left(2.6 \times 10^{-22} \mathrm{Ci} / \mathrm{mL}\right)$.

Typical gross beta activity is $3.7 \times 10^{-10} \mathrm{~Bq} / \mathrm{mL}\left(1.0 \times 10^{-20} \mathrm{Ci} / \mathrm{mL}\right)$. The primary sources of observed gross alpha and gross beta activity are naturally occurring radioisotopes of uranium and thorium and their decay products, and any residual fallout from atmospheric weapons testing and the Chernobyl reactor accident (1986). 
Table 4-2 lists the annual median activities, IQR, maximum, the fraction of the DCG, as well as the DCG, of gamma-emitting radionuclides in samples from Site 300. (See Volume 2, Table 4-5 for monthly data.) All these radionuclides were measured at concentrations significantly below the DCGs. Of the nuclides tabulated, ${ }^{7} \mathrm{Be},{ }^{40} \mathrm{~K},{ }^{226} \mathrm{Ra}$, ${ }^{228} \mathrm{Ra}$, and ${ }^{228} \mathrm{Th}$ are naturally occurring. The primary source of ${ }^{137} \mathrm{C}$ s normally is longterm global fallout and resuspension.

Table 4-3 shows the median concentration of ${ }^{239} \mathrm{Pu}$ on air-filter samples collected from Site 300. (See Volume 2, Table 4-9 for monthly data.) The highest concentration of ${ }^{239} \mathrm{Pu}$ was observed in the September composite at a level of $1.0 \times 10^{-14} \mathrm{~Bq} / \mathrm{mL}$ $\left(2 . \times 10^{-25} \mathrm{Ci} / \mathrm{mL}\right)$, or 0.00001 of the DCG. Table $4-4$ shows the median concentration of ${ }^{238} \mathrm{U},{ }^{235} \mathrm{U}$, and the ${ }^{235} \mathrm{U} / 238 \mathrm{U}$ ratio on air samples from Site 300. (See Volume 2, Table 4-11 for monthly data.) The highest concentration of ${ }^{238} \mathrm{U}$ was observed in the November composite at a level of $2.0 \times 10^{-4} \mu \mathrm{g} / \mathrm{m}^{3}$ (0.0007 of the DCG). The highest concentration of ${ }^{235} \mathrm{U}$ was observed in the September composite at a level of $5.0 \times 10^{-7} \mu \mathrm{g} / \mathrm{m}^{3}$ (0.00001 of the DCG). The overall levels were essentially the same as those reported in previous years.

The ratio of ${ }^{235} \mathrm{U}$ to ${ }^{238} \mathrm{U}$ can be used to identify the source of the uranium. Both ${ }^{235} \mathrm{U}$ and ${ }^{238} \mathrm{U}$ occur naturally in the area, but only $0.7 \%$ of the naturally occurring uranium is $235 \mathrm{U}$, and the remainder is almost entirely $238 \mathrm{U}$. Because Site 300 operations use depleted uranium that contains very little $235 \mathrm{U}$, it follows that if the ratio remains constant and near $0.7 \%$ (within the limit of sampling and analytical error), then the $238 \mathrm{U}$ measured is from natural sources. The $235 \mathrm{U} / 238 \mathrm{U}$ ratios in April, July, and November are less than expected for natural sources, which indicate some impact from operations at Site 300. The median concentration of $238 \mathrm{U}$ for 1996 , however, is only 0.0001 of the DCG (DOE Order 5400.5).

\section{Beryllium in Air}

The detection frequency, median, IQR, and maximum concentrations of airborne beryllium for the Site 300 sampling locations are shown in Table 4-6. (See Volume 2, Table 4-16 for monthly data.) The highest beryllium concentration of $30.2 \mathrm{pg} / \mathrm{m}^{3}$ occurred in October at location TFIR. The median concentration for this location is 0.0008 of the federal and state ambient concentration limit, which is $10,000 \mathrm{pg} / \mathrm{m}^{3}$.

\section{Environmental Impact}

The environmental impacts from both radioactive and nonradioactive effluents are described in this section. 


\section{Air Monitoring}

\section{Radioactive Materials}

LLNL operations involving radioactive materials had little impact on radionuclide concentration in ambient air in 1996. Radionuclide concentrations in air at the Livermore site and in the Livermore Valley are well below levels that would cause concern to the environment or public health according to existing regulatory standards.

The diffuse tritium sources at B292, B331, B514, and B624 have a localized effect; the tritium concentrations in October at all the site perimeter and off-site locations were elevated. Higher than average emissions from the tritium facility occurred during late September and early October primarily as a result of glovebox decontamination and decommissioning activities.

The concentrations of radionuclides measured around Site 300 and in the City of Tracy were well below all standards and, except for uranium isotopes, reflect background or naturally occurring levels of these chemicals. (See Chapter 12, Radiological Dose Assessment, for discussion of estimated dose from these data.) The $235 \mathrm{U} / 238 \mathrm{U}$ ratios in April, July, and November are less than the ratio of naturally occurring concentrations of these isotopes, which suggests that LLNL-introduced depleted uranium is present in air samples from Site 300. These kinds of results can occur when tests using depleted uranium are conducted at Site 300.

\section{Nonradioactive Materials}

The concentrations of beryllium at both sites can be attributed to resuspension of surface soil containing naturally occurring beryllium. Local soils contain approximately $1 \mathrm{ppm}$ of beryllium, and the air of the Livermore area and Central Valley typically contains 10 to $100 \mu \mathrm{g} / \mathrm{m}^{3}$ of particulates. Using a value of $50 \mu \mathrm{g} / \mathrm{m}^{3}$ for an average dust load and $1 \mathrm{ppm}$ for beryllium content of dust, a conservative airborne beryllium concentration of $50 \mathrm{pg} / \mathrm{m}^{3}$ can be predicted. The overall annual medians for the Livermore site and Site 300 are $6.8 \mathrm{pg} / \mathrm{m}^{3}$ and $4.7 \mathrm{pg} / \mathrm{m}^{3}$, respectively. These data are lower than predicted, well below standards, and do not indicate the presence of a threat to the environment or public health. 


\section{Air Effluent Monitoring}

Arthur H. Biermann

Paula J. Tate

\section{Introduction}

Air effluent emissions from facility operations are assessed to evaluate compliance with local, state, and federal regulations and to ensure that human health and the environment are protected from radiological and nonradiological air emissions. LLNL complies with local, state, and federal environmental air quality laws and DOE regulations previously discussed in Chapter 4. In general, LLNL analyzes for most constituents at levels that are far below regulatory standards in order to determine any environmental impact. Air surveillance measurements (see Chapter 4) are also made to help assess LLNL's environmental impact.

Assessment of air effluent emissions is performed by monitoring emissions and/or evaluating potential emissions. Currently, the air effluent sampling program measures only radiological emissions. LLNL has operations with nonradiological discharges; however, permits for these operations are obtained through local agencies having enforcement authority for the Clean Air Act, and monitoring of the effluent is not required. The agencies with oversight for LLNL compliance with air regulations are EPA Region IX, the Bay Area Air Quality Management District (BAAQMD) for the Livermore site and the San Joaquin Valley Unified Air Pollution Control District (SJVUAPCD) for Site 300.

Historically, monitoring of radionuclide air effluents at LLNL has been implemented according to the DOE ALARA (as low as reasonably achievable) policy. This policy is meant to ensure that DOE facilities have capabilities consistent with the types of operations to monitor routine and nonroutine radiological releases, so that the dose to members of the public can be assessed and so that doses are ALARA. In addition, the National Emission Standards for Hazardous Air Pollutants (NESHAPs) 40 CFR 61, Subpart $\mathrm{H}$ regulations require that monitoring of facility radiological air effluents must be performed if the potential off-site dose equivalent is greater than $1 \mu \mathrm{Sv} / \mathrm{y}$ $(0.1 \mathrm{mrem} / \mathrm{y})$, as calculated using the EPA-mandated air dispersion dose model and assuming no emission control devices. For air discharge points that are monitored, the results of the monitoring provide the actual source term for modeling to ensure that the NESHAPs standard, $100 \mu \mathrm{Sv} / \mathrm{y}(10 \mathrm{mrem} / \mathrm{y})$ total site effective dose equivalent, is not exceeded. Discharges from operations that have the potential to release radionuclides but that are not monitored are also evaluated according to the NESHAPs regulations, 


\section{Air Effluent Monitoring}

and the corresponding doses are added to those obtained by modeling monitored emissions to determine radiological NESHAPs compliance.

Air effluent monitoring of atmospheric discharge points determines the actual radionuclide releases from individual facilities and processes during routine and nonroutine operations, confirms the operation of facility emission control systems, and can corroborate and aid in the resolution of air surveillance measurement results for the site. (The relationship can also work the other way as well-air surveillance measurements can corroborate effluent monitoring.)

A variety of radioisotopes are used for research purposes at LLNL; these include uranium, transuranics, biomedical tracers, tritium, and mixed fission products. The major radionuclide released to the atmosphere from the Livermore site is tritium. In addition to effluent sampling for tritium, a number of facilities at the Livermore site have air effluent samplers to detect the release of uranium and transuranic aerosols. The air effluent sampling systems described in this chapter apply to stationary and point source discharges. Diffuse, or nonpoint sources, are also monitored to fulfill NESHAPs requirements. Sampling methods to evaluate LLNL diffuse sources are described in Chapter 4, Volume 2. Summary data from these diffuse sources can be found in Chapter 4 of this volume.

\section{Methods}

Air effluent monitoring involves the extraction of a measured volume of air from the exhaust of the facility or process and subsequent collection of particles in the extracted volume by filters or of vapors by a collection medium. After collection, the various radionuclides in the sample are measured by appropriate analytical methods.

In all, LLNL maintains 103 radionuclide samplers on air exhausts at 9 facilities at the Livermore site (see Figure 5-1). These systems are listed in Table 5-1 along with the analytes of interest, the type of sampler, and the number of samplers and discharge points monitored. Sampling for particles containing radionuclides is conducted in eight of the facilities; sampling for tritium is conducted in one facility. All sampling systems operate continuously. Samples are collected weekly or biweekly depending on the facility. Most air samples for particulate emissions are extracted downstream of high-efficiency particulate air (HEPA) filters and prior to the discharge point to the atmosphere. Particles in the extracted air are collected on sample filters and analyzed for gross alpha and beta activity. Tritium is collected using molecular sieves. In addition to sample collection for environmental reporting, some facilities have real-time monitors (also listed in Table 5-1) 
at discharge points to provide faster notification in the event of a release of radioactivity. Analytical results from the continuous samplers are reported as a measured concentration per volume of air, or at the minimum detection concentration (MDC) when no activity is detected. In all cases, the MDC is more than adequate for demonstrating compliance with the pertinent regulatory requirements for radionuclides that are present or may be present in the sampled air. Further details of LLNL air effluent sampling systems are included in Chapter 4 of the Environmental Monitoring Plan (Tate et al. 1995).

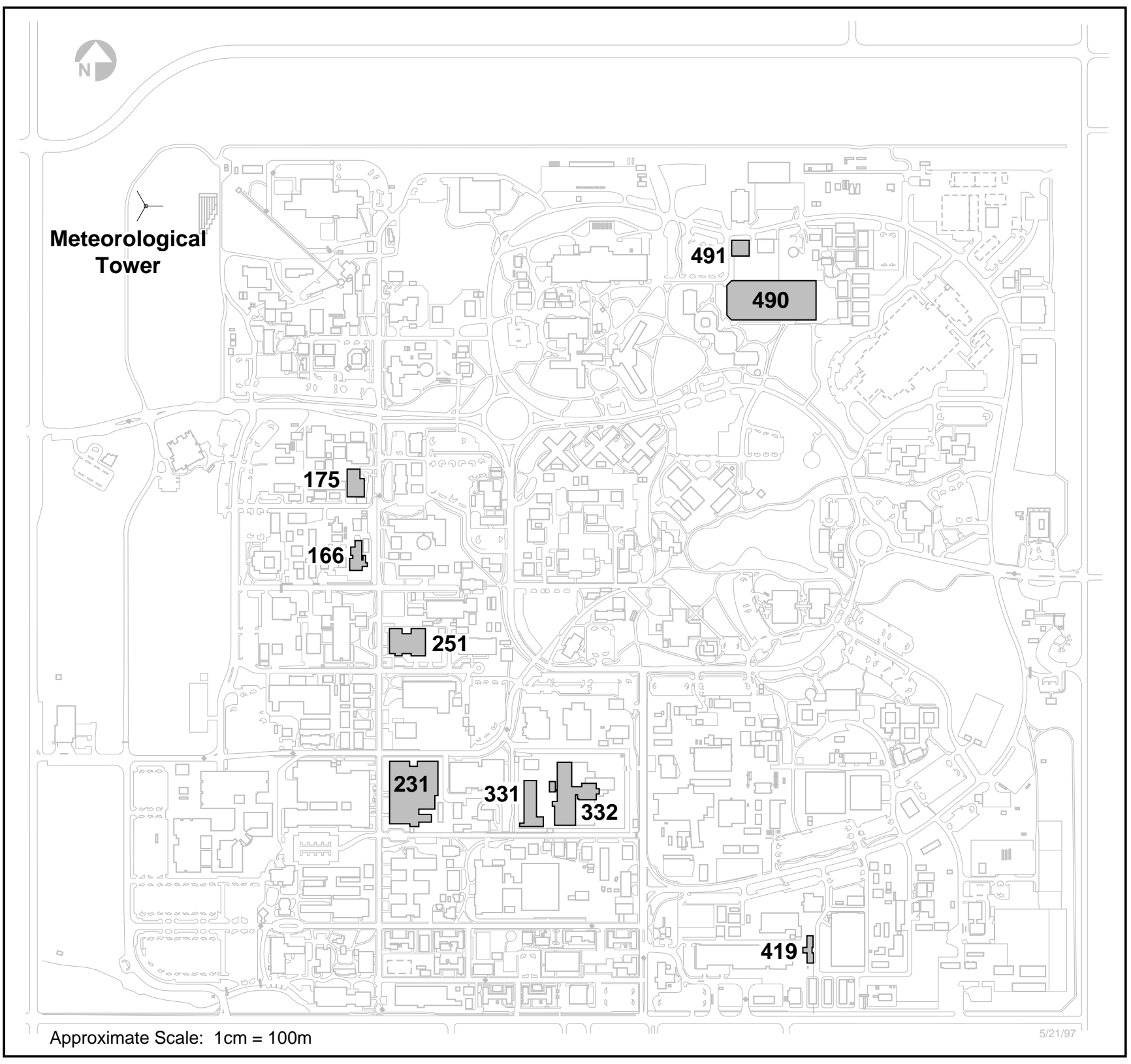

Figure 5-1. Buildings at the Livermore site having air monitoring systems for effluent gas streams. 


\section{Air Effluent Monitoring}

Table 5-1. Air effluent sampling locations and systems.

\begin{tabular}{|c|c|c|c|c|c|}
\hline Building & Facility & Analytes & $\begin{array}{c}\text { Sampler } \\
\text { type }\end{array}$ & $\begin{array}{c}\begin{array}{c}\text { Number } \\
\text { of } \\
\text { samplers }\end{array} \\
\end{array}$ & $\begin{array}{c}\text { Number of } \\
\text { discharge } \\
\text { points }\end{array}$ \\
\hline 166 & $\begin{array}{l}\text { Pyrochemistry } \\
\text { demonstration facility }\end{array}$ & Gross $\alpha, \beta$ on particles & Filter & 1 & 1 \\
\hline 175 & MARS & Gross $\alpha, \beta$ on particles & Filter & 6 & 6 \\
\hline 231 & Vault & Gross $\alpha, \beta$ on particles & Filter & 1 & 1 \\
\hline \multirow[t]{4}{*}{251} & Heavy elements & & & & \\
\hline & Unhardened area & Gross $\alpha, \beta$ on particles & Filter & 44 & $55^{(\mathrm{a})}$ \\
\hline & Hardened area & Gross $\alpha, \beta$ on particles & $\mathrm{CAM}^{(\mathrm{b})}$ & 4 & 4 \\
\hline & & Gross $\alpha, \beta$ on particles & Filter & 4 & 4 \\
\hline \multirow[t]{2}{*}{331} & Tritium & Tritium & Ionization chamber ${ }^{(b)}$ & 4 & 2 \\
\hline & & $\begin{array}{l}\text { Gaseous tritium and } \\
\text { tritiated water vapor }\end{array}$ & Molecular sieves & 4 & 2 \\
\hline \multirow[t]{2}{*}{332} & Plutonium & Gross $\alpha, \beta$ on particles & CAM & 12 & 11 \\
\hline & & Gross $\alpha, \beta$ on particles & Filter & 16 & 11 \\
\hline 419 & Decontamination & Gross $\alpha, \beta$ on particles & Filter & 2 & 2 \\
\hline 490 & $\begin{array}{l}\text { Laser isotope } \\
\text { separation }\end{array}$ & Gross $\alpha, \beta$ on particles & Filter & 4 & 4 \\
\hline 491 & $\begin{array}{l}\text { Laser isotope } \\
\text { separation }\end{array}$ & Gross $\alpha, \beta$ on particles & Filter & 1 & 1 \\
\hline
\end{tabular}

Note: "CAM" denotes Eberline continuous air monitors.

a Alternate blower system measured by the same sampler.

b Alarmed systems.

The need for continuous air effluent monitoring at other air discharge points that can potentially release radionuclides to the atmosphere is evaluated according to the NESHAPs regulations. The evaluation is based on estimated releases using radionuclide inventories specific to individual discharge points and does not take into account reduction by emission control systems (according to the regulations). The most recent NESHAPs evaluation for LLNL operations is reported in the LLNL NESHAPS 1996 Annual Report (Gallegos and Biermann 1997). Many of the existing sampling systems now in place (Table 5-1) are not required by regulation; however, LLNL has continued to operate these systems as a best management practice.

Currently, nonradiological emissions (with the exception of beryllium) are permitted through the local air districts, and monitoring of them is not required. The California Air Toxics "Hot Spots" legislation requires facilities to prepare an air toxics emissions inventory and risk assessment, which LLNL has completed. Based on these data, the BAAQMD and the SJVUAPCD have ranked LLNL as a low-risk facility. 


\section{Measured Radioactive Air Emissions}

This section discusses the radiological air emissions from facilities that have continuously monitored discharge points.

\section{Livermore Site}

Tritium emissions from operations in the Tritium Facility (Building 331) account for nearly all the radioactive discharges to the atmosphere from monitored facilities. In 1996, operations in Building 331 released a total of $8.0 \times 10^{12} \mathrm{~Bq}(210 \mathrm{Ci})$ of tritium. Of this, approximately $6.7 \times 10^{12} \mathrm{~Bq}(180 \mathrm{Ci})$ were released as tritiated water $(\mathrm{HTO})$. The remaining tritium released, $1.2 \times 10^{12} \mathrm{~Bq}(34 \mathrm{Ci})$, was elemental tritium gas. The highest single weekly stack emission from the facility was $1.05 \times 10^{12} \mathrm{~Bq}(28.4 \mathrm{Ci})$, of which $1.03 \times 10^{12} \mathrm{~Bq}(27.7 \mathrm{Ci})$ was tritiated water. The potential dose from tritium gas is approximately 25,000 times lower than the dose from a comparable release of tritiated water. Therefore, the tritiated hydrogen gas did not contribute significantly in calculations of the overall tritium dose. Reduced operations in the facility after 1991 continue to result in lower emissions than in past years (see Figure 5-2).

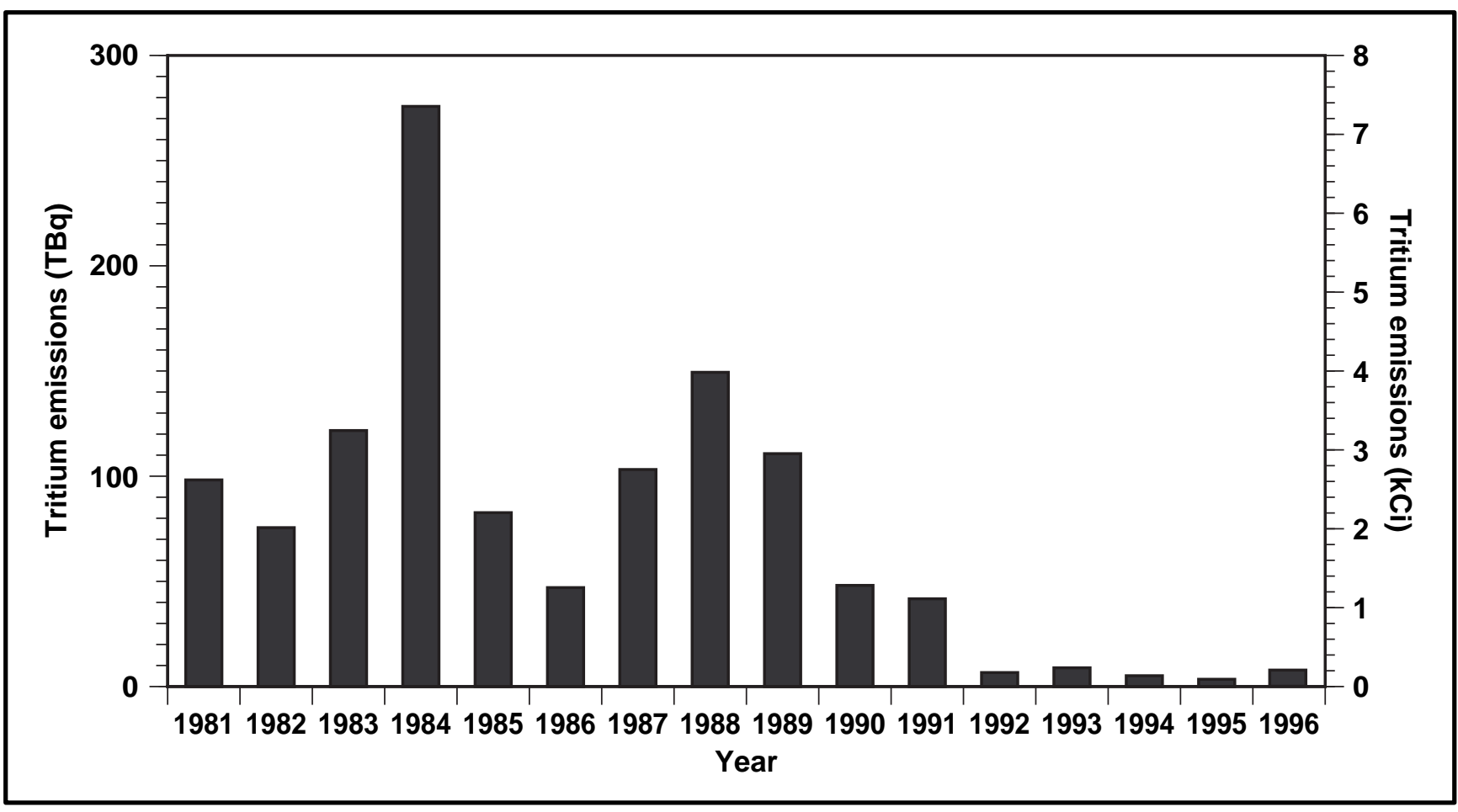

Figure 5-2. Tritium Facility emission (HTO and HT) between 1981 and 1996. 


\section{Air Effluent Monitoring}

For most of the continuously sampled discharge points having the potential for particulate radionuclide releases, sample results are below the MDC of the analysis. Sometimes as few as 1 to 4 samples (out of 25 to 50 samples per year) have concentrations greater than the MDC. Generally, these few samples having results above the MDC are only marginally above the MDC. Use of zero values for this type of data can be justified based on facility knowledge, the use of HEPA filters in all significant release pathways, and alpha-spectroscopy-based isotopic analyses of selected air-sampling filters. These isotopic analyses have demonstrated the presence of naturally occurring radionuclides, such as radon daughters, e.g., polonium, on airsampling filters. In addition, because of exhaust configurations at some facilities, the monitoring systems sometimes sample air from the ambient atmosphere in addition to the HEPA-filtered air from facility operations, which gives rise to background atmospheric radioactivity being collected. Because of these considerations, the emissions from such facility operations are reported as zero. Furthermore, even if the MDC values were to be used in calculations of the emission estimates for these facilities, which would be an extremely conservative approach, the total dose to a member of the public attributable to LLNL activities would not be significantly affected.

In 1996, samples from eight emission points at three facilities, three in Building 175, three in 251 (the unhardened area) and two in 419, yielded gross alpha results greater than the MDC on a significant number of the samples collected throughout the year. We use gross alpha as the primary indicator of potential emissions for operations, such as those at Buildings 175, 251, and 419, that involve the use of uranium and transuranic materials. Gross beta results are used as a further corroboration of those gross alpha results having concentrations above the MDC. The gross alpha monitoring concentrations for these buildings ranged from $-4.0 \times 10^{-4} \mathrm{~Bq} / \mathrm{m}^{3}\left(-1.1 \times 10^{-14} \mathrm{Ci} / \mathrm{m}^{3}\right)$ to $3.2 \times 10^{-3} \mathrm{~Bq} / \mathrm{m}^{3}\left(8.5 \times 10^{-14} \mathrm{Ci} / \mathrm{m}^{3}\right)$. Because of the number of samples with values above the MDC, we have taken a conservative approach and are reporting gross alpha and gross beta measurements as actual emissions. The gross alpha and gross beta emissions for Building 175 were determined to be $3.8 \times 10^{3} \mathrm{~Bq} / \mathrm{y}\left(1.0 \times 10^{-7} \mathrm{Ci} / \mathrm{y}\right)$ and $3.9 \times 10^{4} \mathrm{~Bq} / \mathrm{y}\left(1.1 \times 10^{-6} \mathrm{Ci} / \mathrm{y}\right)$; for Building $251,1.8 \times 10^{4} \mathrm{~Bq} / \mathrm{y}\left(4.9 \times 10^{-7} \mathrm{Ci} / \mathrm{y}\right)$ and $2.9 \times 10^{5} \mathrm{~Bq} / \mathrm{y}\left(7.9 \times 10^{-6} \mathrm{Ci} / \mathrm{y}\right)$; and for Building $419,5.9 \times 10^{3} \mathrm{~Bq} / \mathrm{y}\left(1.6 \times 10^{-7} \mathrm{Ci} / \mathrm{y}\right)$ and $9.2 \times 10^{4} \mathrm{~Bq} / \mathrm{y}\left(2.5 \times 10^{-6} \mathrm{Ci} / \mathrm{y}\right)$. Table 5-2 lists total radiological emissions as determined from the continuous sampling of exhausts for 1996.

We have looked into possible causes of the emissions being reported from Building 419 operations. We found that the physical configuration of the sampling system and faulty seals in the samplers caused some air from the workplace decontamination and decommissioning operations to be sampled by the continuous air samplers. New samplers were installed in October, and since that time no gross alpha or gross beta analyses reported from the new samplers have indicated concentrations above the MDC. 
Therefore, the estimated emissions listed in Table 5-2 are not indicative of emissions from the facility. Actual emissions are now expected to be less than the MDC.

Table 5-2. Measured radiological air effluent emissions for the Livermore site, 1996.

\begin{tabular}{|c|c|c|c|}
\hline \multicolumn{4}{|c|}{ Tritium } \\
\hline Building & Facility & $\begin{array}{c}\text { Elemental, } \mathrm{HT} \\
(\mathrm{Bq})\end{array}$ & $\begin{array}{c}\text { Tritiated water, HTO } \\
\text { (Bq) }\end{array}$ \\
\hline B331 & Tritium & $1.2 \times 10^{12}$ & $6.7 \times 10^{12}$ \\
\hline \multicolumn{4}{|c|}{ Gross alpha and gross beta } \\
\hline Building & Facility & $\begin{array}{l}\text { Gross alpha } \\
\text { (Bq) }\end{array}$ & $\begin{array}{l}\text { Gross beta } \\
\text { (Bq) }\end{array}$ \\
\hline B175 & MARS & $3.8 \times 10^{3}$ & $3.9 \times 10^{4}$ \\
\hline B251 & Heavy Element & $1.8 \times 10^{4}$ & $2.9 \times 10^{5}$ \\
\hline B419 & Decontamination & $5.9 \times 10^{3}$ & $9.2 \times 10^{4}$ \\
\hline Total & Livermore site & $2.8 \times 10^{4}$ & $4.2 \times 10^{5}$ \\
\hline
\end{tabular}

Similarly, the emissions reported for Buildings 175 and 251 have not been confirmed to be emissions from facility operations. As in the case of Building 419, further investigation into the reported emissions is continuing and will include isotopic analyses of selected samples and special air sampling. So it is possible that these emissions from Buildings 175 and 251 are due to naturally occurring, or background, radioactivity, or to the facility exhaust configuration as previously mentioned. In any case, assessment of the gross alpha and gross beta emissions being reported here indicates the radiological dose is only $0.33 \%$ of the dose due to all other emissions at the Livermore site and only $0.003 \%$ of the NESHAPs standard. Consequently, these reported emissions are not a significant contributor to the dose from Livermore site operations to the public.

Radioactive effluent concentrations from individual discharge points at all facilities being monitored are reported in Chapter 5, Volume 2. Activity concentrations are comparable to the concentrations of gross alpha and gross beta activities as measured by LLNL air surveillance samplers and reported in Chapter 4.

\section{Site 300}

Currently, there is no requirement for air effluent monitoring of facilities at Site 300. Air surveillance monitoring is performed for Site 300, and results are reported in Chapter 4. 


\section{Air Effluent Monitoring}

\section{All Potential Sources of Emissions}

This section discusses the evaluation of all sources of radionuclide emissions to air at the Livermore site and Site 300. All discharge points having a potential to release radionuclides to the air are evaluated according to 40 CFR 61, Subpart H of the NESHAPs regulations. This evaluation, performed on an annual basis, uses radionuclide inventories and/or monitoring data along with EPA-accepted release factors for operations and EPAsuggested reduction factors for emission control devices to estimate the potential release for each individual discharge point. Results for 1996 have been published in LLNL NESHAPs 1996 Annual Report (Gallegos and Biermann 1997).

\section{Livermore Site Radioactive Emissions}

An abbreviated isotope summary of measured and calculated (or potential) emissions for 1996 is presented in Table 5-3. Emissions from 41 buildings were evaluated; these buildings, their operations, and effective dose equivalents to a member of the public are listed in Chapter 12 (Radiological Dose Assessment). The estimated release for tritium from both point and diffuse sources was $8.2 \times 10^{12} \mathrm{~Bq}(220 \mathrm{Ci})$. Measured emissions from the Tritium Facility account for $97 \%$ of the total estimated emissions for tritium. Operations involving tritium at facilities other than the Tritium Facility had estimated releases totaling $1.4 \times 10^{11} \mathrm{~Bq}$ (3.7 Ci) during 1996. These releases were assumed conservatively to be HTO. Primary diffuse sources of tritium release are those from Hazardous Waste Management operations at Buildings 514 and 612. These tritium sources have a localized effect. (See Chapter 4.)

A complete isotope listing of calculated emissions appears in Volume 2, Table 5-1.

\section{Site 300 Radioactive Emissions}

The estimated radioactive air emissions from Site 300 for 1996 are presented in Table 5-4. The estimated uranium releases were point source releases from explosives testing operations at Buildings 801 and 851 . The estimated tritium release, $3.5 \times 10^{10} \mathrm{~Bq}(0.94 \mathrm{Ci})$, was from diffuse sources, including subsurface tritium contamination. Estimates of a diffuse source of uranium from contaminated soil resuspension were also made. Details of the calculations and assumptions involved in obtaining the soil resuspension estimates are contained in the LLNL NESHAPs 1996 Annual Report (Gallegos and Biermann 1997).

Both tritium and uranium contamination are from previous explosives testing. 
Table 5-3. Calculated radioactive air emissions from the Livermore site for 1996.

\begin{tabular}{|l|c|c|c|}
\hline Radionuclide $^{(a)}$ & $\begin{array}{c}\text { Calculated } \\
\left.\text { emissions }^{(\mathbf{b})} \mathbf{( B q}\right)\end{array}$ & Radionuclide & $\begin{array}{c}\text { Calculated } \\
\text { emissions (Bq) }\end{array}$ \\
\hline${ }^{3} \mathrm{H}(\mathrm{HTO})^{(\mathrm{c})}$ & $7.0 \times 10^{12}$ & ${ }^{15} \mathrm{O}$ & $8.5 \times 10^{10}$ \\
${ }^{234} \mathrm{U}$ & $9.5 \times 10^{5}$ & ${ }^{238} \mathrm{Pu}$ & $6.4 \times 10^{2}$ \\
${ }^{228} \mathrm{Th}$ & $3.3 \times 10^{5}$ & ${ }^{137} \mathrm{Cs}$ & $5.9 \times 10^{6}$ \\
${ }^{238} \mathrm{U}$ & $2.2 \times 10^{5}$ & ${ }^{32} \mathrm{P}$ & $1.9 \times 10^{7}$ \\
${ }^{239} \mathrm{Pu}$ & $3.9 \times 10^{4}$ & Gross beta & $2.6 \times 10^{5}$ \\
${ }_{\mathrm{Gross}}$ alpha & $(\mathrm{c}, \mathrm{d})$ & $30 \mathrm{Sr}$ & $1.4 \times 10^{5}$ \\
${ }^{13} \mathrm{~N}$ & $3.5 \times 10^{4}$ & ${ }^{226} \mathrm{Ra}$ & $2.2 \times 10^{3}$ \\
${ }^{235} \mathrm{U}$ & $1.6 \times 10^{11}$ & ${ }^{232} \mathrm{Th}$ & $3.9 \times 10^{1}$ \\
${ }^{243} \mathrm{Am}$ & $8.8 \times 10^{3}$ & ${ }^{3} \mathrm{H}(\mathrm{HT})^{(\mathrm{c})}$ & $1.2 \times 10^{12}$ \\
${ }^{241} \mathrm{Am}$ & $1.6 \times 10^{3}$ & ${ }^{57} \mathrm{Co}$ & $3.7 \times 10^{5}$ \\
\hline
\end{tabular}

a Radionuclides have been ordered by weighting the emissions according to the inhalation dose rate conversion factor for the isotope.

b Calculated emissions are estimates made according to NESHAPs 40 CFR 61, Subpart $\mathrm{H}$ except those noted as measured. Values are considered to be conservative.

c Includes measured emissions from continuously monitored facilities.

d Gross alpha and gross beta activities are reported in inventories where specific isotopic content is not determined.

Table 5-4. Calculated radioactive air emissions from Site 300 for 1996.

\begin{tabular}{|c|c|}
\hline Radionuclide $^{(\mathbf{a})}$ & Calculated emissions $^{(\mathbf{b})}(\mathbf{B q})$ \\
\hline${ }^{238} \mathrm{U}$ & $3.3 \times 10^{9}$ \\
${ }^{234} \mathrm{U}$ & $3.1 \times 10^{8}$ \\
${ }^{235} \mathrm{U}$ & $4.3 \times 10^{7}$ \\
${ }^{3} \mathrm{H}(\mathrm{HTO})$ & $3.5 \times 10^{10}$ \\
\hline
\end{tabular}

a Radionuclides have been ordered by weighting the emissions according to the inhalation dose rate conversion factor for the isotope.

b Calculated emissions are estimates made according to NESHAPs 40 CFR 61, Subpart H. Values are considered to be conservative.

\section{Nonradioactive Effluents}

The Livermore site currently emits approximately $100 \mathrm{~kg}$ /day of criteria air pollutants (nitrogen oxides, sulfur oxides, particulate matter [PM10], carbon monoxide, and lead). The largest sources of criteria pollutants from the Livermore site are surface coating operations, internal combustion engines, solvent operations, and, when grouped together, boilers (oil and natural gas fired). 


\section{Air Effluent Monitoring}

The estimated releases from exempt and permitted sources of air pollutants at the Livermore site can be compared to the most recent estimated 1995 daily release of air pollutants for the entire Bay Area. For example, the total emissions of oxides of nitrogen released in the Bay Area is approximately $4.8 \times 10^{5} \mathrm{~kg}$ /day compared to an estimate for LLNL releases of $58 \mathrm{~kg}$ / day for the Livermore site (0.012\% of total Bay Area emissions). The BAAQMD estimate for reactive organic emissions is $5 \times 10^{5} \mathrm{~kg} /$ day, versus Livermore site's estimated releases of $30 \mathrm{~kg} /$ day ( $0.006 \%$ of total Bay Area emissions) in 1996. Table 5-5 lists the estimated Livermore site 1996 total airborne releases for criteria pollutants.

Certain operations at Site 300 require permits from San Joaquin Valley Unified Air Pollution Control District. The total estimated air emissions during 1996 from operations (permitted and exempt air sources) at Site 300 are given in Table 5-5. Criteria sources at Site 300 include internal combustion engines, boilers, a gasoline dispensing operation, open burning, paint spray booths, drying ovens, and soil vapor extraction.

Table 5-5. Nonradioactive air emissions, Livermore site and Site 300, 1996.

\begin{tabular}{|l|c|c|}
\hline \multirow{2}{*}{\multicolumn{1}{|c|}{ Pollutant }} & \multicolumn{2}{c|}{ Estimated releases (kg/day) } \\
\cline { 2 - 3 } & Livermore site & Site 300 \\
\hline Organics/volatile organics & 30 & 1.8 \\
Oxides of nitrogen & 58 & 0.72 \\
Carbon monoxide & 10 & 0.17 \\
Particulates (PM10) & 5.5 & 0.50 \\
Oxides of sulfur & $8.1 \times 10^{-1}$ & $4.0 \times 10^{-2}$ \\
\hline
\end{tabular}

\section{Environmental Impact}

Radioactive air effluents from the Livermore site and Site 300 operations for 1996 are well below levels that should cause concern for the environment or public health according to existing regulatory standards. The doses to the hypothetical maximally exposed members of the public due to measured and potential air emissions, as reported in Chapter 12 (Radiological Dose Assessment), are $0.93 \mu \mathrm{Sv}(0.093 \mathrm{mrem})$ for the Livermore site and $0.33 \mu \mathrm{Sv}(0.033 \mathrm{mrem})$ for Site 300 . When compared to the NESHAPs standard of $100 \mu \mathrm{Sv} / \mathrm{y}(10 \mathrm{mrem} / \mathrm{y})$ and dose from naturally occurring radiation, the estimated doses due to the LLNL radionuclide air emissions reported here are minimal. Nonradioactive air effluents, which are also very small compared to emissions in surrounding areas, are well below standards and do not indicate threats to the environment or public health. 


\section{Sewerable Water}

Jennifer M. Larson Robert J. Vellinger

Shari L. Brigdon

Allen E. Grayson

\section{Introduction}

In 1996, the Livermore site discharged approximately 1 million liters (ML) per day of wastewater to the City of Livermore sewer system, an amount that constitutes $4.6 \%$ of the total flow to the system. This volume includes wastewater generated by Sandia National Laboratories/California (SNL/California), which is discharged to the LLNL collection system and combines with LLNL sewage before it is released at a single point to the municipal collection system. In 1996, SNL/California generated approximately $20 \%$ of the total effluent discharged from the Livermore site. LLNL's wastewater contains sanitary sewage and industrial wastewater and is discharged in accordance with permit requirements and the City of Livermore Municipal Code, as discussed below in the Pretreatment and Categorical Discharges section.

The effluent is processed at the Livermore Water Reclamation Plant (LWRP). As part of the Livermore-Amador Valley Wastewater Management Program, the treated sanitary wastewater is transported out of the valley through a pipeline and discharged into San Francisco Bay. A small portion of this treated wastewater is used for summer irrigation of the adjacent municipal golf course. Sludge from the treatment process is disposed of in sanitary landfills.

LLNL receives water from two suppliers. LLNL's primary water source is the HetchHetchy Aqueduct. Secondary or emergency water deliveries are taken from the Alameda County Flood Control and Water Conservation District Zone 7. This water is a mixture of ground water and water from the South Bay Aqueduct of the State Water Project. Water quality parameters for the two sources are obtained from the suppliers and are used to evaluate compliance with the discharge permit conditions that limit changes in water quality between receipt and discharge.

\section{Preventive Measures}

Administrative and engineering controls at the Livermore site are designed to prevent potentially contaminated wastewater from being discharged directly to the sanitary sewer. Waste generators receive training on proper waste handling. LLNL personnel review facility procedures and inspect processes for inappropriate discharges. Retention 


\section{Sewerable Water}

tanks collect wastewater from processes that might release contaminants in quantities sufficient to disrupt operations at the LWRP. Ground water generated from remediation treatment, hydraulic tests, and volatile organic compound (VOC) treatability studies is analyzed for pollutants of concern and must meet permitted criteria or LWRP approval must be obtained before it can be discharged to the sanitary sewer. Finally, to verify the success of training and control equipment, wastewater is sampled and analyzed not only at the significant points of generation, as defined by type and quantity of contaminant generated, but also at the point of discharge to the municipal sewer system.

To ensure the integrity of the wastewater collection system, LLNL completed an aggressive assessment and rehabilitation program in 1995. Begun in 1992, the program tested all known building drains to determine their points of discharge. Identified deficiencies, considered to be illicit connections, were classified and corrected; major deficiencies were immediately remedied. Finally, preparatory to relining with a synthetic sock, the major laterals of the sanitary sewer system were videotaped and evaluated. Major line failures were repaired. In addition, retention tanks have undergone comprehensive evaluation and rehabilitation.

For facilities with installed retention tank systems, collected wastewater is discharged to the sanitary sewer only if analytical laboratory results show that pollutant levels are within allowable limits (Grandfield 1989). LLNL developed internal discharge guidelines for specific sources and operations to ensure that sewer effluent for the entire site complies with LLNL's waste discharge permit. If pollutant levels exceed permissible concentrations, the wastewater is treated to reduce pollutants to the lowest levels practical and below LLNL guidelines, or it is shipped to an off-site treatment or disposal facility. Liquids containing radioactivity are handled on site and may be treated using processes that reduce the activity to levels well below those required by DOE Order 5400.5. Internal guidelines for retention tank systems and specific sources and operations are discussed below in the "Pretreatment and Categorical Discharges" section.

For the year as a whole, the monitoring data reflect the success of LLNL's discharge control program in preventing any significant impact on the operations of Livermore's treatment plant and are generally consistent with past values.

\section{Continuous Monitoring}

LLNL's sanitary sewer discharge permit requires continuous monitoring of the effluent flow rate and $\mathrm{pH}$. Samplers collect flow-proportional composite samples and instantaneous grab samples that are analyzed for metals, radioactivity, toxic chemicals, and water-quality parameters. In addition, as a best management practice, the outflow to the municipal collection system is sampled continuously and analyzed in real time for conditions that might upset the LWRP treatment process or otherwise impact the public welfare. The effluent is continuously analyzed for $\mathrm{pH}$, selected metals, and 


\section{Sewerable Water}

radioactivity. If concentrations above warning levels are detected, an alarm is registered at the LLNL Fire Dispatcher's Station, which is attended 24 hours a day. The monitoring system provides a continuous check on sewage control and, since July 1990, automatically notifies the LWRP in the event that contaminants are detected. Trained staff respond to all alarms to evaluate the cause and take appropriate action.

A major upgrade to the continuous monitoring system was completed in the final quarter of 1996. Analyzers for continuous monitoring of metals were redesigned to increase the operational safety of the system and to decrease the length of downtime in the continuous monitoring of metals. The redesign included replacement of $x$-ray tubes and power supplies used in the analyzers, reconfiguration of $\mathrm{x}$-ray shielding to accommodate the physical characteristics of the new $x$-ray tubes, and installation of an enclosure that surpasses safety mandates.

\section{Diversion System}

In 1991, LLNL completed construction of a diversion system that is automatically activated when the monitoring system sounds an alarm. The diversion system ensures that all but the first few minutes of the affected wastewater flow is retained at LLNL, thereby protecting the LWRP and minimizing any required cleanup. Up to $775,000 \mathrm{~L}$ of potentially contaminated sewage can be held pending analysis to determine the appropriate handling method. The diverted effluent may be returned to the sanitary sewer (if the liquid is not hazardous or after it is treated, depending on analytical results), shipped for off-site disposal, or treated at LLNL's Hazardous Waste Management Facility. All diverted sewage in 1996 was returned to the sanitary sewer.

\section{Satellite Monitoring}

In 1991, LLNL completed the implementation of a system of 10 satellite monitoring stations that operates in conjunction with the sewer monitoring system (Figure 6-1). The satellite monitoring stations are positioned at strategic locations within the main sewer system to help pinpoint the on-site area from which a release might have originated. Each station consists of an automatic sampler that collects samples on a timeproportional basis. If there is a release, these samples are analyzed. However, early in 1994, all but two (86B and 51A) of the satellite monitoring stations were taken off line pending ergonomic reengineering of the equipment used during routine maintenance. In 1995, one satellite monitoring station (163A) was restored to operation. In 1996, no changes were made to the satellite monitoring system. This satellite monitoring station is located at the point of discharge of SNL/California wastewater to the LLNL collection system. The low number of unacceptable releases to the sewer (those which might upset the LWRP treatment process or otherwise impact the public welfare) has lowered the priority for reengineering the satellite monitoring stations. 


\section{Sewerable Water}

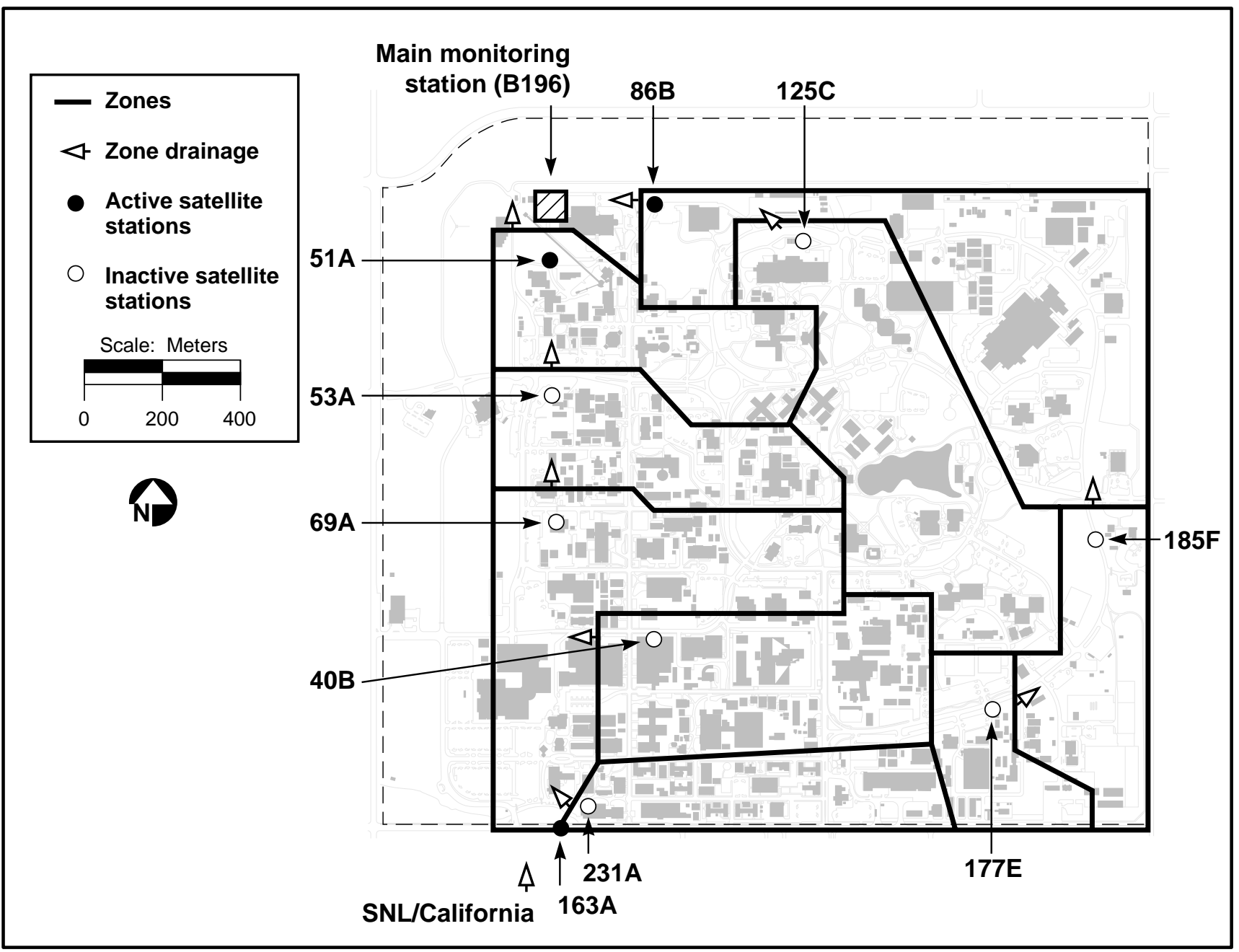

Figure 6-1. Sewer monitoring network.

\section{Pretreatment and Categorical Discharges}

Self-monitored pretreatment programs are required at both the Livermore site and Site 300 by the Livermore Water Reclamation Plant (LWRP) under the authority of San Francisco Bay Regional Water Quality Control Board. The sampling and monitoring of nondomestic, industrial sources covered by pretreatment standards defined in 40 CFR 403 is required in the 1996-1997 Wastewater Discharge Permit (No. 1250) issued for the discharge of wastewater from LLNL into the City of Livermore sewer system. Permit 1250 discharge limits are listed in Table 6-1. These limits are applied at the site boundary before wastewater enters the LWRP collection system. The General Pretreatment Regulations establish both general and specific standards for the discharge of prohibited substances (40 CFR 403.5) that apply to all industrial users. Categorical 


\section{Sewerable Water}

standards are published by the Environmental Protection Agency (EPA) as separate regulations and contain numerical limits for the discharge of pollutants from specified processes (or industrial categories). The LWRP has identified specific LLNL wastewater generating processes that fall under the definition of two Categorical Standards: electrical and electronic components (40 CFR 469), and metal finishing (40 CFR 433).

Table 6-1. Limits under permit 1250 for discharges into the municipal sewer.

\begin{tabular}{|l|c|}
\hline \multicolumn{1}{|c|}{ Constituent } & Discharge limit \\
\hline Metals (mg/L) & 0.06 \\
Arsenic & 0.14 \\
Cadmium & 1.0 \\
Copper & 0.62 \\
Chromium (total) & 0.20 \\
Lead & 0.01 \\
Mercury & 0.61 \\
Nickel & 0.20 \\
Silver & 3.0 \\
Zinc & 0.04 \\
\hline Cyanide (mg/L) & 1.0 \\
\hline Toxic organics (total) & $5-10$ \\
\hline pH & \\
\hline
\end{tabular}

Previously, LLNL petitioned the EPA for an exemption from these two Categorical Standards, and formal monitoring and reporting requirements for these regulated processes were subsequently suspended. Quarterly and semiannual sampling of minor discharges was suspended and semiannual wastewater reports were not submitted to the LWRP, and the LWRP suspended its inspection schedule of the regulated processes at LLNL. This was done with the concurrence of both the LWRP and the Pretreatment Coordinator, EPA Region 9. During 1996, LLNL maintained compliance with categorical standard discharge limits for significant industrial processes that discharge to the sanitary sewer by reviewing retention-tank data prior to discharge and applying the appropriate categorical discharge limits. The analytical data and discharge records are available for review by regulatory agencies. In December 1996, LLNL was notified of EPA's decision regarding the request for exemption in a report of their 1995 Clean Water Act (CWA)/ NPDES inspection of LLNL's Livermore site. The EPA report stated that although they do exempt research laboratories from regulation under the categorical standards, they do not exempt operations in support of research, such as parts fabrication or waste handling. Therefore, LLNL resumed self-monitoring of its federally regulated discharges in 1997 as prescribed in the Wastewater Discharge Permit (No. 1250). 


\section{Sewerable Water}

Tables 6-2 and 6-3 show LLNL's internal discharge limits for wastewaters discharged to the sanitary sewer. Those processes that discharge to the sanitary sewer are subject to the pretreatment self-monitoring program specified in the Ground Water Discharge Permit issued by the LWRP. In 1996, nine exceptions to the pollutant limitations of the discharge permit were observed and are discussed below in the "Environmental Impact of Nonradioactive Liquid Effluents" section.

Table 6-2. Discharge limits for nonradioactive pollutants in wastewaters at point of discharge into LLNL sewer.

\begin{tabular}{|c|c|c|c|c|c|}
\hline \multirow[b]{2}{*}{ Parameter } & \multicolumn{5}{|c|}{ Discharge limits } \\
\hline & Internal(a) & $\begin{array}{c}\text { Metal } \\
\text { finishing(b) }\end{array}$ & $\begin{array}{c}\text { Electric } \\
\text { components }^{(b)}\end{array}$ & $\begin{array}{c}\text { Permit } \\
1508 \\
\end{array}$ & $\begin{array}{c}\text { Permit } \\
1510 \\
\end{array}$ \\
\hline \multicolumn{6}{|l|}{ Metals (mg/L) } \\
\hline Arsenic & $N A^{(c)}$ & NA & 0.83 & 0.06 & 0.06 \\
\hline Beryllium & 0.74 & -(d) $^{(d)}$ & -(d) $^{(d)}$ & -(d) $^{(d)}$ & -(d) $^{(\mathrm{c}}$ \\
\hline Cadmium & 0.9 & 0.26 & -(d) $^{(\mathrm{n}}$ & 0.14 & 0.14 \\
\hline Chromium (total) & 4.9 & 1.71 & -(d) $^{(\mathrm{n}}$ & 0.62 & 0.62 \\
\hline Copper & 1.0 & 2.07 & -(d) $^{(\mathrm{n}}$ & 1.00 & 1.00 \\
\hline Lead & 4.9 & 0.43 & -(d) & 0.20 & 0.20 \\
\hline Mercury & 0.05 & (d) $^{(\mathrm{d}}$ & -(d) $^{(\mathrm{n}}$ & 0.01 & 0.01 \\
\hline Nickel & 5 & 2.38 & -(d) $^{(\mathrm{n}}$ & 0.61 & 0.61 \\
\hline Silver & 1 & 0.24 & -(d) $^{(\mathrm{n}}$ & 0.20 & 0.20 \\
\hline Zinc & 15 & 1.48 & -(d) $^{(\mathrm{n}}$ & 3.00 & 3.00 \\
\hline \multicolumn{6}{|l|}{ Organics (mg/L) } \\
\hline $\mathrm{TTO}^{(\mathrm{e})}$ & 4.57 & 2.13 & 1.37 & 1.00 & 1.00 \\
\hline $\operatorname{BTEX}^{(\mathrm{f})}$ & NA & NA & NA & 0.25 & NA \\
\hline \multicolumn{6}{|l|}{ Other (mg/L) } \\
\hline Cyanide ${ }^{(g)}$ & 5 & 0.65 & -(d) $^{(\mathrm{n}}$ & 0.04 & 0.04 \\
\hline pH & $5-10$ & $5-10$ & $5-10$ & $6-9$ & $5-10$ \\
\hline
\end{tabular}

a These standards were established to meet the City of Livermore's requirements at the point of discharge to the Municipal Sewer (Building 196).

b These standards were specified by EPA. By regulation, the EPA or City of Livermore limit is used, whichever is lower. Internal limits apply where no standard is specified.

c $\mathrm{NA}=$ Not applicable.

d Noncategorical limits apply.

e Total toxic organics.

f Benzene, toluene, ethyl benzene, and xylene.

$g$ Limits apply to cyanide discharges other than cyanide salts. CN salts are classified by the State of California as "extremely hazardous waste" and cannot be discharged to the sewer. 
Table 6-3. LLNL's internal discharge limits for radioisotopes in wastewaters. There is no gross gamma limit; isotope-specific limits apply.

\begin{tabular}{|l|l|l|}
\hline \multicolumn{1}{|c|}{ Parameter } & \multicolumn{1}{|c|}{ Individual discharges } & \multicolumn{1}{c|}{ Total daily limit for site } \\
\hline Gross alpha & $11.1 \mathrm{~Bq} / \mathrm{L}(0.3 \mu \mathrm{Ci} / 1000 \mathrm{~L})$ & $185 \mathrm{kBq}(5.0 \mu \mathrm{Ci})$ \\
Gross beta & $111 \mathrm{~Bq} / \mathrm{L}(3.0 \mu \mathrm{Ci} / 1000 \mathrm{~L})$ & $1.85 \mathrm{MBq}(50.0 \mu \mathrm{Ci})$ \\
Tritium & $185 \mathrm{kBq} / \mathrm{L}(5.0 \mathrm{mCi} / 1000 \mathrm{~L})$ & $3.7 \mathrm{GBq}(100.0 \mathrm{mCi})$ \\
\hline
\end{tabular}

LLNL's ground water discharge permit (1510G, 1996-1997) allows ground water from hydraulic tests and VOC treatability studies to be discharged to the City of Livermore sanitary sewer in compliance with Table 6-1 effluent limitations taken from the Livermore municipal code. During 1996, over 1 ML of ground water from sitewide CERCLA cleanup activities was discharged to the sanitary sewer. Discharges were primarily from start-up operations associated with portable treatment unit construction and testing. Twenty-one separate discharges were sampled and discharged to the sewer during this period, all in compliance with the metals, total toxic organic, and self-monitoring permit provisions of self-monitoring permit 1510G. Concentrations of constituents of concern were all below discharge limits. Detections of regulated substances are summarized in Table 6-4. Complete monitoring data are in Volume 2.

\section{Radioactive Pollutants in Sewage Monitoring Results}

Determination of the total radioactivity released from tritium, alpha emitters, and beta emitters is based either on the measured radioactivity in the effluent or on the limit of sensitivity, whichever is higher (see Table 6-5). The 1996 combined releases of tritium and alpha and beta sources were $12.3 \mathrm{GBq}(0.33 \mathrm{Ci})$. The total is based on the results shown in Table 6-5; unlike previous years, the 1996 total does not include a contribution from SNL/California. SNL/California concluded all of its tritium research activities as of October 1994, and the cleanup activities at their former tritium research laboratories were completed by October 1995. The annual mean concentration of tritium in LLNL sanitary sewer effluent was $0.035 \mathrm{~Bq} / \mathrm{mL}(0.95 \mathrm{pCi} / \mathrm{mL})$. 


\section{Sewerable Water}

Table 6-4. Compounds detected in water discharged to the sanitary sewer in 1996 under permits 1508 and 1510 .

\begin{tabular}{|c|c|c|c|c|c|c|}
\hline \multirow[b]{2}{*}{ Parameter } & \multicolumn{6}{|c|}{ Discharge date } \\
\hline & $3 / 22$ & 4/11-12 & $4 / 23$ & $4 / 25$ & $6 / 4-12$ & $6 / 6$ \\
\hline \multicolumn{7}{|l|}{ Metals (mg/L) } \\
\hline Arsenic & -(a) & - (a) $^{\text {(a) }}$ & -(a) $^{(2)}$ & -(a) $^{(\mathrm{a})}$ & -(a) $^{(\mathrm{a})}$ & 0.0032 \\
\hline Chromium (total) & 0.005 & 0.005 & 0.009 & 0.008 & 0.0071 & 0.029 \\
\hline Chromium(VI) & -(a) & -(a) & 0.013 & 0.006 & -(a) $^{(\mathrm{n}}$ & (b) $^{(\mathrm{b})}$ \\
\hline Copper & 0.002 & - (a) $^{(2}$ & 0.008 & 0.011 & -(a) & 0.023 \\
\hline Lead & -(a) & - (a) $^{(a)}$ & -(a) $^{(\mathrm{a})}$ & -(a) $^{(\mathrm{a}}$ & 0.0029 & 0.0065 \\
\hline Mercury & -(a) & -(a) $^{\text {(a) }}$ & -(a) $^{(\mathrm{a}}$ & 0.0007 & -(a) $^{(\mathrm{a})}$ & -(a) $^{\text {(a) }}$ \\
\hline Nickel & -(a) & 0.002 & -(a) $^{(\mathrm{a}}$ & -(a) & -(a) & 0.031 \\
\hline Zinc & -(a) & -(a) $^{\text {(a) }}$ & -(a) & -(a) & -(a) & 0.022 \\
\hline
\end{tabular}

Table 6-4. Compounds detected in water discharged to the sanitary sewer in 1996 under permits 1508 and 1510 (concluded).

\begin{tabular}{|c|c|c|c|c|c|c|c|}
\hline & \multicolumn{7}{|c|}{ Discharge date } \\
\hline Parameter & $6 / 23$ & $6 / 25-28$ & $6 / 27$ & $7 / 10$ & 9/10-27 & $10 / 8-11$ & $10 / 15-18$ \\
\hline \multicolumn{8}{|l|}{ Metals (mg/L) } \\
\hline Arsenic & -(b) $^{(\mathrm{c}}$ & -(a) & -(a) & -(a) & -(a) $^{(\mathrm{a})}$ & -(a) $^{(\mathrm{a})}$ & -(a) $^{(a)}$ \\
\hline Chromium (total) & -(b) $^{(\mathrm{n}}$ & 0.014 & 0.010 & 0.028 & 0.040 & 0.008 & 0.010 \\
\hline Chromium(VI) & -(b) $^{(\mathrm{c}}$ & 0.014 & -(a) & -(a) & 0.025 & 0.010 & 0.015 \\
\hline Copper & - (b) $^{(2)}$ & -(a) & -(a) & 0.015 & 0.023 & -(a) $^{(\mathrm{a})}$ & -(a) $^{(2)}$ \\
\hline Lead & -(b) & -(a) & -(a) & 0.0058 & 0.031 & -(a) $^{(\mathrm{a}}$ & -(a) \\
\hline Mercury & - (b) $^{(\mathrm{n}}$ & -(a) & -(a) & 0.0068 & -(a) $^{\text {(a) }}$ & 0.00021 & - (a) $^{(2}$ \\
\hline Nickel & - (b) $^{(2)}$ & -(a) & -(a) & 0.020 & 0.003 & -(a) $^{\text {(a) }}$ & -(a) \\
\hline Zinc & - (b) $^{(2)}$ & - (a) $^{(2)}$ & -(a) & - (a) $^{(2)}$ & 0.04 & - (a) $^{\text {(a) }}$ & -(a) \\
\hline \multicolumn{8}{|l|}{ Organics ( $\mu \mathbf{g} / \mathbf{L})$} \\
\hline TTO(c) & -(a) & -(a) $^{(2)}$ & 2.4 & -(a) $^{(\mathrm{n}}$ & -(a) $^{(\mathrm{a}}$ & - (a) $^{(a)}$ & -(a) \\
\hline BTEX & 11.7 & -(a) & -(a) $^{(\mathrm{a}}$ & -(a) & -(a) & -(a) $^{(\mathrm{a})}$ & -(a) \\
\hline
\end{tabular}

\footnotetext{
a Not detected.

b Not analyzed

c Trichloroethylene

d Benzene, toluene, ethyl benzene, and xylene.
} 
Table 6-5. Estimated total radioactivity in LLNL sanitary sewer effluent, 1996.

\begin{tabular}{|l|c|c|}
\hline \multicolumn{1}{|c|}{$\begin{array}{c}\text { Radioactive } \\
\text { emitter }\end{array}$} & $\begin{array}{c}\text { Estimate based on effluent } \\
\text { activity (GBq) })^{(a)}\end{array}$ & $\begin{array}{c}\text { Limit of sensitivity } \\
(\mathbf{G B q})\end{array}$ \\
\hline Tritium & 12.0 & 3.7 \\
Alpha sources & 0.064 & 0.063 \\
Beta sources & 0.24 & 0.057 \\
\hline
\end{tabular}

a $37 \mathrm{GBq}=37 \times 10^{9} \mathrm{~Bq}=1 \mathrm{Ci}$.

The concentrations of ${ }^{239} \mathrm{Pu},{ }^{137} \mathrm{Cs}$, and tritium measured in the sanitary sewer effluent from LLNL and LWRP are presented in Table 6-6. The tritium numbers are based on the flow-weighted average of the individual daily sample results for a given month. The plutonium and cesium numbers are the direct result of analysis of monthly composite samples of LLNL and LWRP effluent, and quarterly composites of LWRP sludge. At the bottom of the table, the total activity released is given by radioisotope. This was calculated by multiplying each sample result by the total flow volume over which the sample was collected, and summing up over all samples. The total activity released for each radioisotope is a conservative value; the limit of sensitivity was used in the calculation when the limit of sensitivity was greater than the actual activity reported. Also included in the table are fractions of DOE and 10 CFR 20 limits, discussed in the Environmental Impact section of this chapter.

The historical trend in the monthly average concentration of tritium is shown in Figure 6-2. Also included in the figure is the DOE tritium limit ( $370 \mathrm{~Bq} / \mathrm{mL})$, discussed in the Environmental Impact section of this chapter. The trend plot in Figure 6-2 indicates a well-controlled tritium discharge, which is orders of magnitude below the DOE tritium limit.

Figure 6-3 shows the average monthly plutonium and cesium concentrations in sewage since 1985 . The annual mean concentration of ${ }^{137} \mathrm{Cs}$ was $12 \mu \mathrm{Bq} / \mathrm{mL}$ $\left(3.2 \times 10^{-4} \mathrm{pCi} / \mathrm{mL}\right)$; the annual mean ${ }^{239} \mathrm{Pu}$ concentration was $1.2 \mu \mathrm{Bq} / \mathrm{mL}$ $\left(3.2 \times 10^{-5} \mathrm{pCi} / \mathrm{mL}\right)$.

\section{Environmental Impact of Radioactive Pollutants in Sewage}

During 1996, no inadvertent releases exceeded any discharge limits for release of radioactive materials to the sanitary sewer system. 


\section{Sewerable Water}

Table 6-6. Various radionuclides in sanitary sewer effluents, LLNL and Livermore Water Reclamation Plant (LWRP), 1996.

\begin{tabular}{|c|c|c|c|c|c|c|c|}
\hline \multirow[t]{2}{*}{ Month } & \multicolumn{2}{|c|}{$\begin{array}{c}{ }^{3} \mathrm{H} \\
(\mathrm{mBq} / \mathrm{mL})^{(a)}\end{array}$} & \multicolumn{2}{|c|}{$\begin{array}{c}{ }^{137} \mathrm{Cs} \\
(\mu \mathrm{Bq} / \mathrm{mL})\end{array}$} & \multicolumn{2}{|c|}{$\begin{array}{c}{ }^{239} \mathrm{Pu} \\
(\mathrm{mBq} / \mathrm{mL})\end{array}$} & \multirow{2}{*}{\begin{tabular}{|c|}
$\begin{array}{c}{ }^{239} \mathrm{Pu} \\
\text { (mBq/dry g) }\end{array}$ \\
LWRP sludge ${ }^{(\mathrm{b}}$
\end{tabular}} \\
\hline & LLNL & LWRP & LLNL & LWRP & LLNL & LWRP & \\
\hline Jan & 3.5 & -0.16 & $0.88 \pm 0.37$ & $<0.41$ & $112 \pm 43$ & $9.0 \pm 16.7$ & \\
\hline Feb & 4.2 & 0.48 & $1.1 \pm 0.3$ & $<0.54$ & $414 \pm 74$ & $2.6 \pm 12.5$ & \\
\hline Mar & 8.4 & 0.36 & $88 \pm 2$ & $2.2 \pm 0.4$ & $2710 \pm 186$ & $20.2 \pm 13.7$ & $0.43 \pm 0.05$ \\
\hline Apr & $30 \pm 11$ & 0.43 & $18 \pm 1$ & $1.3 \pm 0.5$ & $2610 \pm 208$ & $13.6 \pm 13.3$ & \\
\hline May & $20 \pm 11$ & -0.16 & $5.6 \pm 0.7$ & $0.67 \pm 0.41$ & $1170 \pm 135$ & $20.0 \pm 14.4$ & \\
\hline Jun & 3.2 & 1.7 & $7.3 \pm 0.7$ & $<0.56$ & $1300 \pm 178$ & $10.8 \pm 15.0$ & $1.6 \pm 0.1$ \\
\hline Jul & $13 \pm 10$ & 10 & $2.4 \pm 0.7$ & $<0.56$ & $777 \pm 146$ & $10.4 \pm 11.4$ & \\
\hline Aug & $36 \pm 10$ & 4.2 & $6.6 \pm 0.6$ & $<0.44$ & $673 \pm 118$ & $-2.61 \pm 6.66$ & \\
\hline Sep & $36 \pm 10$ & 1.5 & $5.8 \pm 0.7$ & $<0.94$ & $3770 \pm 342$ & $20.9 \pm 13.9$ & $4.1 \pm 0.4$ \\
\hline Oct & $22 \pm 9$ & 1.7 & $1.8 \pm 0.5$ & $<0.57$ & $518 \pm 81$ & $-2.94 \pm 6.36$ & \\
\hline Nov & $107 \pm 10$ & $3.0 \pm 10.0$ & $1.60 \pm 0.03$ & $<0.37$ & $280 \pm 53$ & $6.9 \pm 12.4$ & \\
\hline Dec & $84 \pm 11$ & $1.4 \pm 10.6$ & $5.7 \pm 0.5$ & $<0.63$ & $681 \pm 93$ & $-2.19 \pm 8.18$ & $0.52 \pm 0.07$ \\
\hline Median & 21 & $<1.2$ & 5.6 & 0.56 & 729 & 9.7 & 1.0 \\
\hline \multirow[t]{2}{*}{$\operatorname{IQR}^{(\mathrm{c})}$} & 29 & $-^{(d)}$ & 5.0 & $-^{(d)}$ & 1140 & 13.8 & 1.7 \\
\hline & \multicolumn{6}{|c|}{$\mathrm{pCi} / \mathrm{mL}^{(\mathrm{e})}$} & $\mathrm{pCi} /$ dry g $^{(\mathrm{e})}$ \\
\hline Median & 0.57 & $<0.032$ & $1.5 \times 10^{-4}$ & $1.5 \times 10^{-5}$ & $2.0 \times 10^{-5}$ & $2.6 \times 10^{-7}$ & 0.028 \\
\hline \multirow[t]{3}{*}{ IQR } & 0.78 & -(d) $^{\text {(d) }}$ & $1.4 \times 10^{-4}$ & $-^{(d)}$ & $3.1 \times 10^{-5}$ & $3.7 \times 10^{-7}$ & 0.046 \\
\hline & \multicolumn{7}{|c|}{ Annual total discharges by radioisotope } \\
\hline & \multicolumn{2}{|c|}{${ }^{3} \mathbf{H}^{(\mathrm{f})}$} & \multicolumn{2}{|c|}{${ }^{137} \mathrm{Cs}$} & \multicolumn{2}{|c|}{${ }^{239} \mathrm{Pu}$} & Total $^{(\mathrm{f})}$ \\
\hline $\mathrm{Bq} / \mathrm{y}$ & \multirow{2}{*}{\multicolumn{2}{|c|}{$\begin{array}{c}1.2 \times 10^{10} \\
0.32\end{array}$}} & \multirow{2}{*}{\multicolumn{2}{|c|}{$\begin{array}{c}4.2 \times 10^{6} \\
1.1 \times 10^{-4}\end{array}$}} & \multirow{2}{*}{\multicolumn{2}{|c|}{$4.2 \times 10^{5}$}} & $1.2 \times 10^{10}$ \\
\hline \multirow[t]{2}{*}{$\mathrm{Ci} / \mathrm{y}$} & & & & & 1.1 & & 0.32 \\
\hline & \multicolumn{7}{|c|}{ Fraction of limit } \\
\hline DOE & \multirow{2}{*}{\multicolumn{2}{|c|}{$\begin{array}{c}9.4 \times 10^{-5} \\
0.065\end{array}$}} & \multirow{2}{*}{\multicolumn{2}{|c|}{$\begin{array}{l}2.2 \times 10^{-5} \\
3.3 \times 10^{-5}\end{array}$}} & \multirow{2}{*}{\multicolumn{2}{|c|}{$\begin{array}{l}3.3 \times 10^{-6} \\
1.7 \times 10^{-4}\end{array}$}} & $9.4 \times 10^{-5}$ \\
\hline 10 CFR 20 & & & & & & & - (g) \\
\hline
\end{tabular}

Note: Radionuclide results are reported $\pm 2 \sigma$; see Chapter 13, Quality Assurance.

a Ranges are only listed for activities that are above the limit of sensitivity.

b Sludge from LWRP digesters is dried before analysis. The resulting data indicate the plutonium concentration of the sludge prepared by LWRP workers for disposal at the Livermore Sanitary Landfill.

c Interquartile range.

d Because of the large number of nondetections, the interquartile range is omitted. See Chapter 13, Quality Assurance.

e $1 \mathrm{Ci}=3.7 \times 10^{10} \mathrm{~Bq}$.

f Does not include gross alpha and beta results shown in Table 6-5.

$\mathrm{g}$ The fraction of the 10 CFR 20 limit is not presented because tritium discharges have an annual limit and cesium and plutonium discharges have monthly concentration-based limits. See the individual fractions for each of these radioisotopes. 


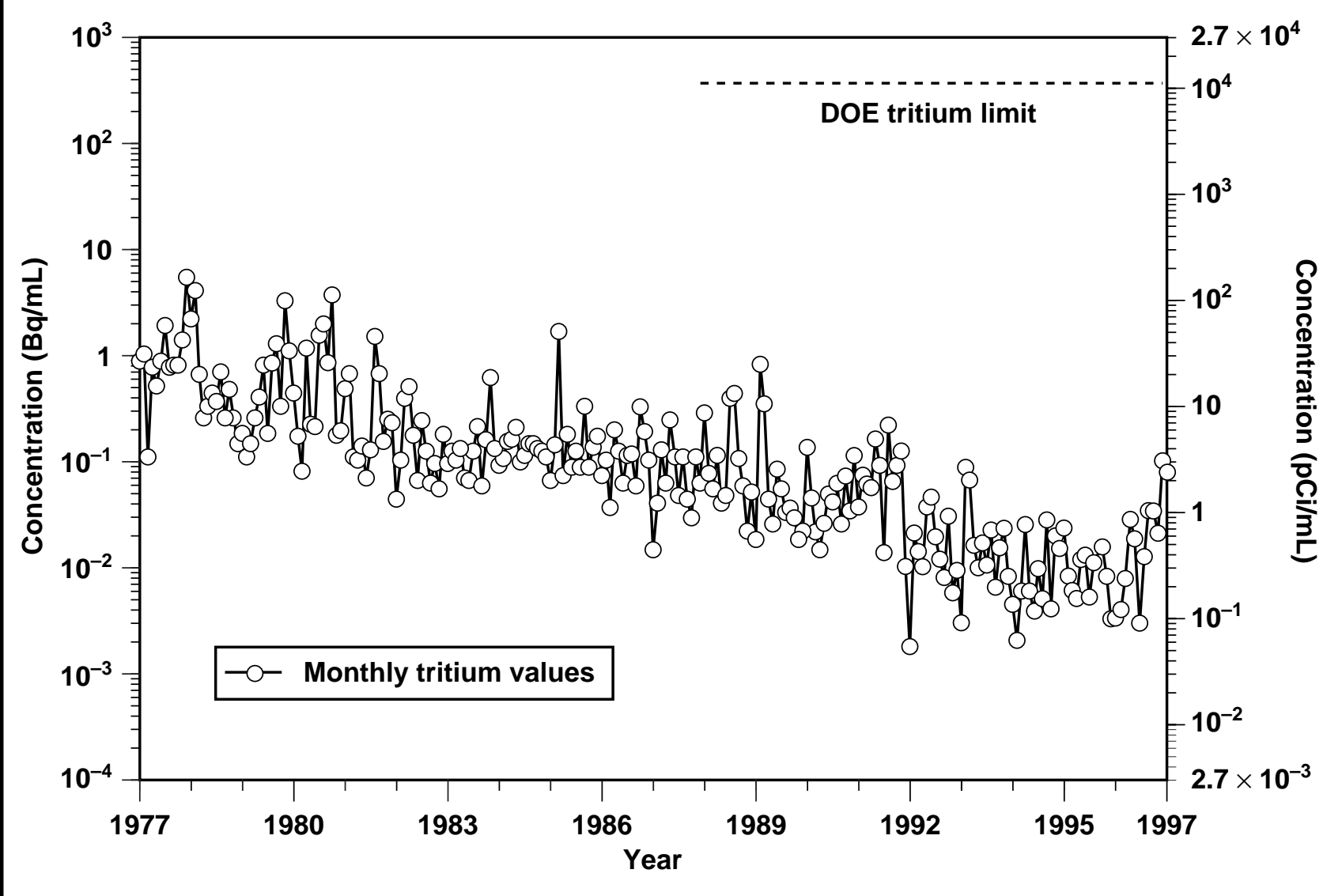

Figure 6-2. Historical trend in tritium concentration in LLNL sewage.

DOE Order 5400.5 established DOE policy requiring that radiological releases to the sanitary sewer comply with legally applicable local and state regulations and that LLNL implement standards generally consistent with those of the Nuclear Regulatory Commission. The most stringent of these limits was adopted in Title 17 of the California Code of Regulations. As a federal facility, LLNL is formally exempt from the requirements of state regulations but follows those requirements under the guidance of DOE. Title 17 contained a limit on discharges of radioactivity in sewage of $37 \mathrm{GBq}(1 \mathrm{Ci})$ each year; it also listed limits on the daily, monthly, and annual concentration for each specific radionuclide.

In 1994, the discharge requirements previously found in Title 17 were removed and the requirements in Title 10 of the Code of Federal Regulations, Part 20, incorporated by reference. Title 10 contains a limit for the total discharge activity of tritium (185 GBq or $5 \mathrm{Ci}$ ), carbon-14 (37 GBq or $1 \mathrm{Ci}$ ), and all other radionuclides combined (37 GBq or $1 \mathrm{Ci}$ ); in addition, it specifies that the discharge material must be soluble and lists limits on monthly concentrations. 


\section{Sewerable Water}

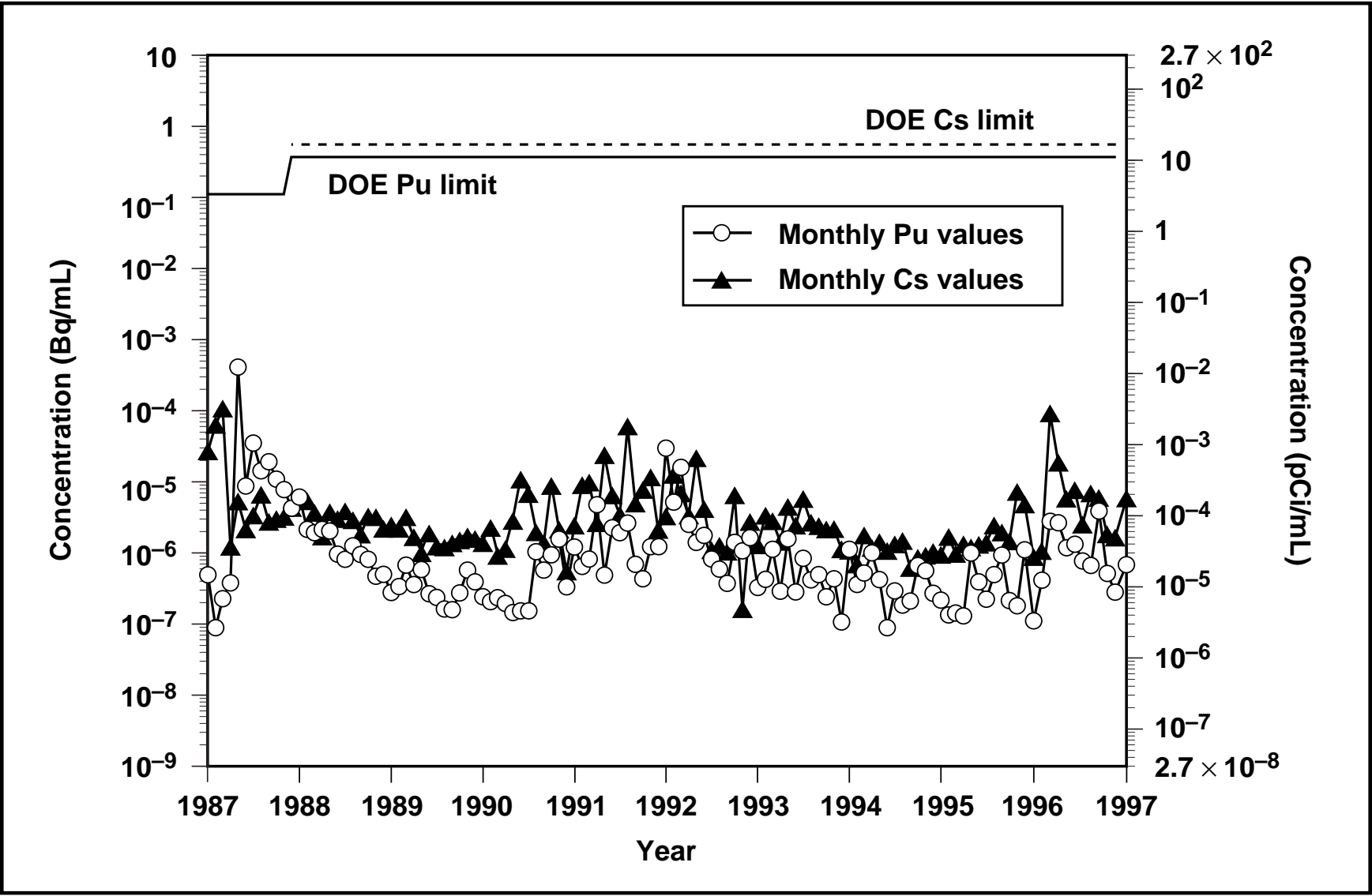

Figure 6-3. Historical trends in plutonium and cesium concentration in LLNL sewage.

Table 6-7 summarizes the discharge requirements of Title 10. Because Title 10 permits and therefore applies to only soluble discharges, and because the plutonium in LLNL effluent is in both the soluble and insoluble forms, the discharge requirement for ${ }^{239} \mathrm{Pu}$ is not directly applicable. This assumption is supported by our experience during the sewer system evaluation, when increased cleaning led to higher plutonium concentrations in LLNL sewage (Gallegos et al. 1992). This indicates that a portion of the soluble plutonium discharges from LLNL facilities is deposited on the sewer pipes, and when these deposits are liberated and discharged from the LLNL site, they are, by their nature, insoluble.

Table 6-7 also includes the total activity that could have been discharged by LLNL during a given period (monthly and annually) using 10 CFR 20 monthly concentrations in conjunction with the annual caps and assuming the 1996 average monthly flow rate. As the table shows, the Title 10 concentration limits for tritium for facilities such as LLNL that generate wastewater in large volumes are overridden by the limit on total tritium activity (18.5 GBq) dischargeable during a single year. In 1996, the total LLNL tritium release was $6.5 \%$ of the corresponding Title 10 limit. Total LLNL releases 
(Table 6-5), in the form of alpha and beta emitters (excluding tritium), were $0.82 \%$ of the corresponding Title 10 limit.

Table 6-7. Sewer discharge release limits for ${ }^{3} \mathrm{H},{ }^{137} \mathrm{Cs}$, and ${ }^{239} \mathrm{Pu}$.

\begin{tabular}{|l|c|c|c|}
\hline & ${ }^{3} \mathbf{H}$ & ${ }^{137} \mathbf{C s}$ & ${ }^{239} \mathbf{P u}$ \\
\hline 10 CFR 20 concentrations used to establish release limits $(\mathrm{Bq} / \mathrm{mL})$ & 370 & 0.37 & 0.0074 \\
10 CFR $20(\mathrm{GBq})$ & & & \\
Monthly & $185^{(\mathrm{a})}$ & 11 & 0.21 \\
Yearly & $185^{(\mathrm{a})}$ & $37^{(\mathrm{b})}$ & 2.6 \\
DOE annualized discharge limit for application of BAT(c) $(\mathrm{Bq} / \mathrm{mL})$ & 370 & 0.56 & 0.37 \\
\hline
\end{tabular}

a 10 CFR 20 imposes a 185-GBq (5-Ci) limit for the tritium radiation released.

b 10 CFR 20 imposes a 37-GBq (1-Ci) combined limit on the total of all radiation released (excluding tritium and $\mathrm{C}^{14}$, which have separate $10 \mathrm{CFR} 20$ limits of $185 \mathrm{GBq}$ and $37 \mathrm{GBq}$, respectively); i.e., the total release of all isotopes must not exceed $37 \mathrm{GBq}$. If a total of $37 \mathrm{GBq}$ of a particular isotope were released during the year, this would require that no other isotopes be released.

c The DOE annualized discharge limit for application of best available technology (BAT) is five times the Derived Concentration Guide (DCG; ingested water) for each radionuclide released.

DOE has also established criteria for the application of best available technology to protect public health adequately and minimize degradation of the environment. These criteria (the Derived Concentration Guides, or DCGs) limit the concentration of each specific radionuclide discharged to publicly owned treatment works. If a measurement of the monthly average concentration of a radioisotope exceeded its concentration limit, LLNL would be required to improve discharge control measures until concentrations were again below the DOE limits. Table 6-7 presents the DCGs for the specific radioisotopes of most interest at LLNL.

The annual average concentration of tritium in LLNL sanitary sewer effluent was $9.4 \times 10^{-5}$ (that is, $0.0094 \%$ ) of the DOE DCG (and the Title 10 limit); the annual average concentration of ${ }^{137} \mathrm{Cs}$ was $2.2 \times 10^{-5}(0.0022 \%)$ of the DOE DCG (and $3.3 \times 10^{-5}$ or $0.0033 \%$ of the Title 10 limit); and the annual average ${ }^{239} \mathrm{Pu}$ concentration was $3.3 \times 10^{-6}(0.00033 \%)$ of the insoluble ${ }^{239} \mathrm{Pu}$ DOE DCG, $2.3 \times 10^{-4}(0.023 \%)$ of the soluble ${ }^{239} \mathrm{Pu}$ DOE DCG, and $1.7 \times 10^{-4}(0.017 \%)$ of the Title 10 limit. The combined discharges were therefore within the range from $1.2 \times 10^{-4}(0.012 \%)$ to $3.5 \times 10^{-4}$ $(0.035 \%)$ of the DCG, corresponding to calculations incorporating an exclusively insoluble and soluble ${ }^{239} \mathrm{Pu}$ contribution, respectively. As discussed earlier in this section, the plutonium in LLNL effluent is assumed to be present both in the soluble and insoluble forms. 


\section{Sewerable Water}

LLNL also compares annual discharges with historical values to evaluate the effectiveness of ongoing discharge control programs. Table 6-8 summarizes the radioactivity in liquid effluent released over the past 10 years. During 1996, a total of 12.0 GBq (0.32 Ci) of tritium was discharged to the sanitary sewer. As indicated earlier in this chapter, this release does not include a contribution from SNL/California; LLNL therefore discharged $12.0 \mathrm{GBq}(0.32 \mathrm{Ci})$, an amount that is well within environmental protection standards and is comparable to the amounts reported for the last several years. Moreover, the total tritium released by LLNL in 1996 (and the years from 1992 through 1995) is below the range reported prior to 1992.

Table 6-8. Radioactive liquid effluent releases from the Livermore site, 1987-1996.

\begin{tabular}{|l|c|c|}
\hline \multirow{2}{*}{ Year } & \multicolumn{2}{|c|}{ Liquid effluents (GBq) } \\
\cline { 2 - 3 } & $\mathbf{3} \mathbf{H}$ & ${ }^{39} \mathbf{P u}$ \\
\hline 1987 & 52 & $2.6 \times 10^{-2}$ \\
1988 & 56 & $8.1 \times 10^{-4}$ \\
1989 & 59 & $1.8 \times 10^{-4}$ \\
$1990^{(a)}$ & 25 & $2.3 \times 10^{-4}$ \\
1991 & 32 & $6.1 \times 10^{-4}$ \\
1992 & 8 & $1.9 \times 10^{-3}$ \\
1993 & 13 & $2.6 \times 10^{-4}$ \\
$1994^{(b)}$ & 6.9 & $1.9 \times 10^{-4}$ \\
1995 & 6.0 & $1.2 \times 10^{-4}$ \\
$1996^{(c)}$ & 12 & $4.2 \times 10^{-4}$ \\
\hline
\end{tabular}

a The 1990 DOE Order 5400.5 required compliance with legally applicable local and state regulations such as California Title 17, which mandated a $37 \mathrm{GBq}(1 \mathrm{Ci})$ combined limit on the total of all radiation released.

b In 1994, the discharge requirements previously found in Title 17 were changed to correspond to the requirements in Title 10 of the Code of Federal Regulations, Part 20. Title 10 contains a limit for the total discharge activity of tritium (185 GBq or $5 \mathrm{Ci}$ ), carbon-14 (37 GBq or $1 \mathrm{Ci}$ ), and all other radionuclides combined (37 GBq or $1 \mathrm{Ci})$.

c The 1996 total for tritium does not include a contribution from SNL/California; in 1995, SNL/California ceased all tritium facility operations.

Figure 6-3 summarizes the ${ }^{239} \mathrm{Pu}$ monitoring data over the past 10 years. The historical levels observed since 1987 average $2 \mu \mathrm{Bq} / \mathrm{mL}\left(5 \times 10^{-5} \mathrm{pCi} / \mathrm{mL}\right)$, with the exception of a peak in 1987. Even this peak is well below the DOE DCG's for both the soluble and insoluble forms of ${ }^{239} \mathrm{Pu}$. Historically, levels generally are four-thousandths (0.004) and six-millionths (0.000006) of these soluble and insoluble limits, respectively. The greatest part of the plutonium discharged in LLNL effluent is ultimately concentrated in LWRP sludge, which is dried and disposed of at a landfill. The plutonium concentration observed in 1996 sludge (Table 6-6), $1.0 \mathrm{mBq} /$ dry g (0.027 pCi/dry g), 


\section{Sewerable Water}

is more than 400 times lower than the proposed EPA guideline for unrestricted use of soil (480 mBq/dry g).

As first discussed in the Environmental Report for 1991 (Gallegos et al. 1992), plutonium and cesium concentrations were slightly elevated during 1991 and 1992 over the lowest values seen historically. As was established in 1991, the overall upward trend was related to sewer cleaning with new, more-effective equipment. During 1993, as utility personnel worked to complete an assessment of the condition of the sewer system, cleaning activity around the site was less extensive, resulting in slightly lower plutonium and cesium concentrations in LLNL effluent. During 1994, in conjunction with the installation of the synthetic sock lining in the sewer system, the cleaning activity around the site was more extensive than in 1993. However, by the end of 1993 the new sewer cleaning equipment had been used on LLNL's entire sewer system; this was reflected in 1994 and the majority of 1995 by the continuation of the slightly lower plutonium and cesium concentrations that were observed in the 1993 effluent.

The 1996 plutonium and cesium concentrations are slightly higher than the concentrations observed over the past several years (1993 through 1995), and slightly lower than the observed concentrations of 1990 through 1992, with the exception of a cesium peak early in 1996. This peak, pictured in Figure 6-3 and reported in Table 6-6, is attributable to a controlled release from the LLNL retention tank system and is well below the applicable DOE DCG. The slightly higher plutonium and cesium concentrations of 1996 are well below applicable DOE DCG's and remain indicative of well-controlled discharges.

\section{Nonradioactive Pollutants in Sewage \\ Monitoring Results}

Table 6-9 presents monthly average metal concentrations in LLNL's sanitary sewer effluent. The averages were obtained by a flow-proportional weighting of the results from analysis of the weekly composite samples and the 24-hour composites collected each month. Each result was weighted by the total flow volume for the period during which the sample was collected. The results are quite typical of the values seen during the previous years, 1994 and 1995 (see Figure 6-4), with the exceptions of arsenic and mercury. The arsenic and mercury results are discussed below. Figure 6-5 compares daily and weekly concentrations of metals in LLNL sewage. 


\section{Sewerable Water}

Table 6-9. Monthly results for metals in LLNL sanitary sewer effluent (in mg/L), 1996 summary.

\begin{tabular}{|c|c|c|c|c|c|c|c|c|c|c|c|c|}
\hline Month & $\mathrm{Ag}$ & Al & As & $\mathrm{Be}$ & Cd & $\mathrm{Cr}$ & $\mathrm{Cu}$ & $\mathrm{Fe}$ & $\mathrm{Hg}$ & $\mathrm{Ni}$ & $\mathrm{Pb}$ & $\mathrm{Zn}$ \\
\hline Jan & 0.014 & 0.79 & 0.0032 & $<0.00050$ & $<0.0050$ & 0.020 & 0.13 & 1.7 & 0.00035 & 0.0083 & 0.017 & 0.26 \\
\hline Feb & 0.014 & 0.46 & $<0.0020$ & 0.00053 & $<0.0050$ & 0.011 & 0.12 & 1.1 & 0.00022 & 0.0073 & 0.017 & 0.17 \\
\hline Mar & $<0.0082$ & 0.70 & 0.0021 & $<0.00050$ & $<0.0041$ & 0.014 & 0.090 & 1.5 & 0.00036 & 0.0054 & 0.012 & 0.20 \\
\hline Apr & 0.012 & 0.65 & 0.0021 & $<0.00050$ & $<0.0050$ & 0.013 & 0.080 & 1.5 & 0.00037 & 0.0066 & 0.010 & 0.18 \\
\hline May & 0.011 & 0.92 & 0.0024 & $<0.00050$ & $<0.0050$ & 0.017 & 0.15 & 1.8 & 0.00045 & 0.0085 & 0.032 & 0.28 \\
\hline Jun & $<0.010$ & 0.48 & 0.0025 & $<0.00050$ & $<0.0050$ & 0.011 & 0.093 & 1.0 & 0.00022 & 0.0051 & 0.028 & 0.19 \\
\hline Jul & 0.011 & 0.45 & 0.0024 & $<0.00050$ & $<0.0050$ & 0.013 & 0.12 & 1.0 & 0.00024 & 0.0060 & 0.017 & 0.19 \\
\hline Aug & 0.010 & 0.64 & 0.0024 & $<0.00050$ & $<0.0050$ & 0.019 & 0.14 & 1.3 & 0.0012 & 0.0051 & 0.038 & 0.23 \\
\hline Sep & 0.011 & 0.59 & $<0.0020$ & $<0.00050$ & 0.0051 & 0.018 & 0.12 & 1.5 & 0.0020 & 0.0053 & 0.037 & 0.25 \\
\hline Oct & $<0.010$ & 0.39 & $<0.0020$ & $<0.00050$ & $<0.0050$ & 0.011 & 0.091 & 0.92 & 0.00048 & 0.0051 & 0.023 & 0.17 \\
\hline Nov & 0.010 & 0.61 & 0.0025 & $<0.00050$ & $<0.0050$ & 0.016 & 0.11 & 1.3 & 0.0019 & 0.0059 & 0.018 & 0.19 \\
\hline Dec & $<0.010$ & 0.44 & 0.0027 & $<0.00050$ & $<0.0050$ & 0.014 & 0.056 & 1.0 & 0.00086 & 0.0051 & 0.011 & 0.19 \\
\hline Median & 0.011 & 0.60 & 0.0024 & $<0.00050$ & $<0.0050$ & 0.014 & 0.11 & 1.3 & 0.00041 & 0.0056 & 0.018 & 0.19 \\
\hline $\operatorname{IQR}^{(a)}$ & 0.001 & 0.21 & 0.0004 & $-^{(b)}$ & -(b) $^{\text {(b) }}$ & 0.005 & 0.03 & 0.5 & 0.00062 & 0.0016 & 0.014 & 0.05 \\
\hline$E P L^{(c)}$ & 0.2 & $-^{(\mathrm{d})}$ & 0.06 & -(d) $^{\text {(d) }}$ & 0.14 & 0.62 & 1.0 & $-^{\text {(d) }}$ & 0.01 & 0.61 & 0.2 & 3.0 \\
\hline $\begin{array}{l}\text { Fraction } \\
\text { of EPL }\end{array}$ & 0.05 & $-^{(d)}$ & 0.04 & - (d) $^{(\mathrm{s})}$ & $<0.04$ & 0.02 & 0.11 & -(d) $^{(\mathrm{d})}$ & 0.04 & 0.01 & 0.09 & 0.06 \\
\hline
\end{tabular}

Note: Monthly values are presented with less than signs when all weekly and 24-hour composite sample results for the month are below the detectable concentration.

a Interquartile range.

b Because of the large number of nondetects, the interquartile range could not be calculated for these metals. See Chapter 13 , Quality Assurance.

C Effluent pollutant level (LLNL Wastewater Discharge Permit 1995-96 and 1996-97).

d No established limit for metal.

Detections of anions, metals, and organic compounds and data concerning other physical and chemical characteristics of the sanitary sewer effluent are provided in Table 6-10. Although the samples were analyzed for bromide, nitrite (as N), carbonate alkalinity (as $\left.\mathrm{CaCO}_{3}\right)$, hydroxide alkalinity (as $\left.\mathrm{CaCO}_{3}\right)$, the full suite of polychlorinated biphenyls, the full suite of organochlorine pesticides, and cyanide, those analytes were not detected in any sample acquired during 1996, and so are not presented in the table. The results are quite typical of those seen in previous years. 

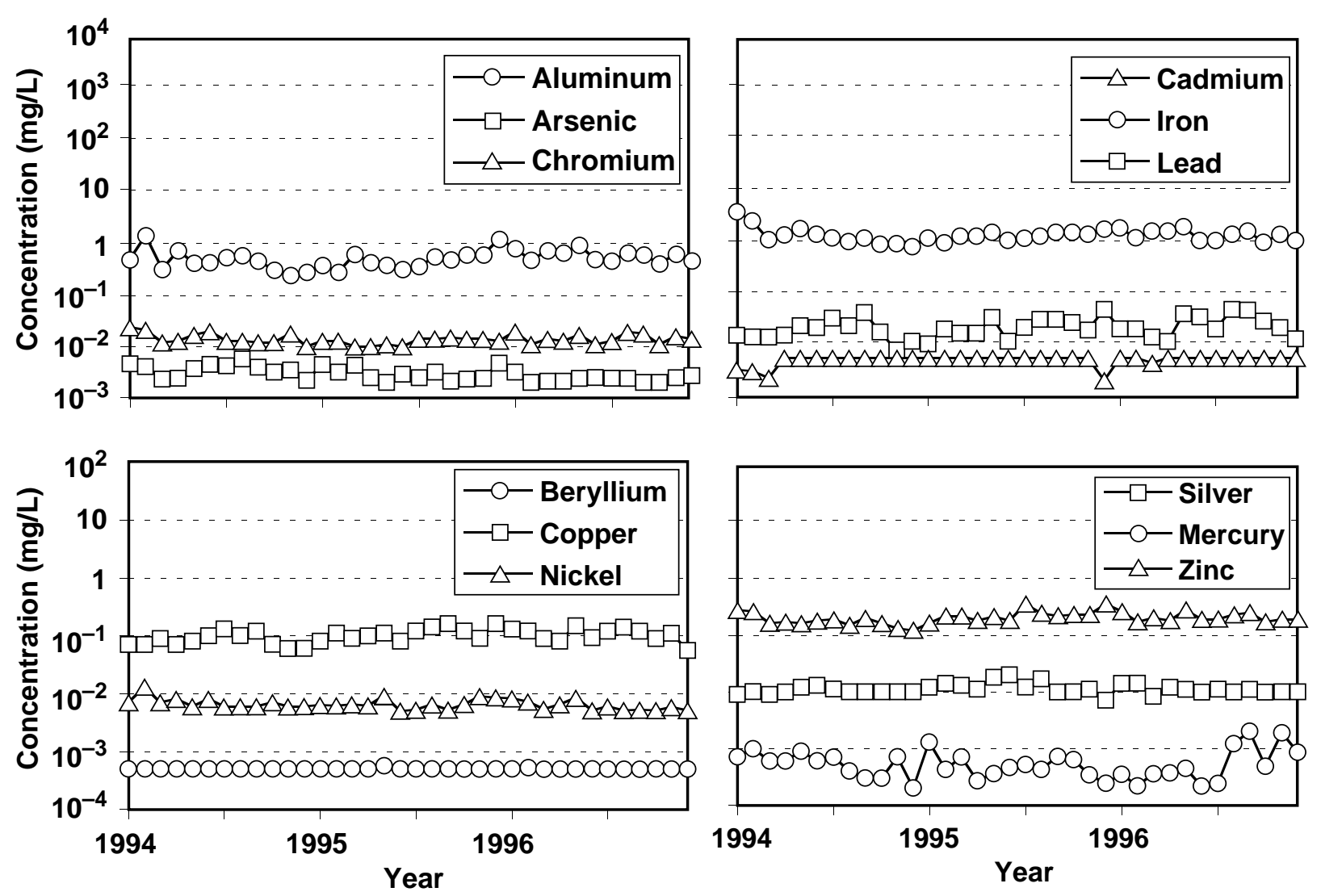

Figure 6-4. Average monthly concentrations of 12 metals in LLNL sanitary sewer effluent showing trends between 1994 and 1996. (Metals are plotted in groups of three for the sake of legibility only.)

\section{Environmental Impact of Nonradioactive Liquid Effluents}

In 1996, no inadvertent releases of metals warranted a sewer diversion. At the bottom of Table 6-9, the annual median concentration for each metal detected in LLNL's sanitary sewer effluent is compared to the discharge limit. The metals that approached closest to the discharge limits were copper and lead at $11 \%$ and $9 \%$, respectively.

Although well below discharge limits, slightly elevated arsenic levels were seen in 1992 through 1995. These levels did not continue in 1996. First discussed in the Environmental Report 1993 (Gallegos et al. 1994), the elevated arsenic levels were the subject of an extended investigation during 1993, which concluded that the presence of arsenic in the sewer was associated with the ground water cleanup at the gas pad along the southern border of the site. The gas pad cleanup operation was continued in 1994, 


\section{Sewerable Water}
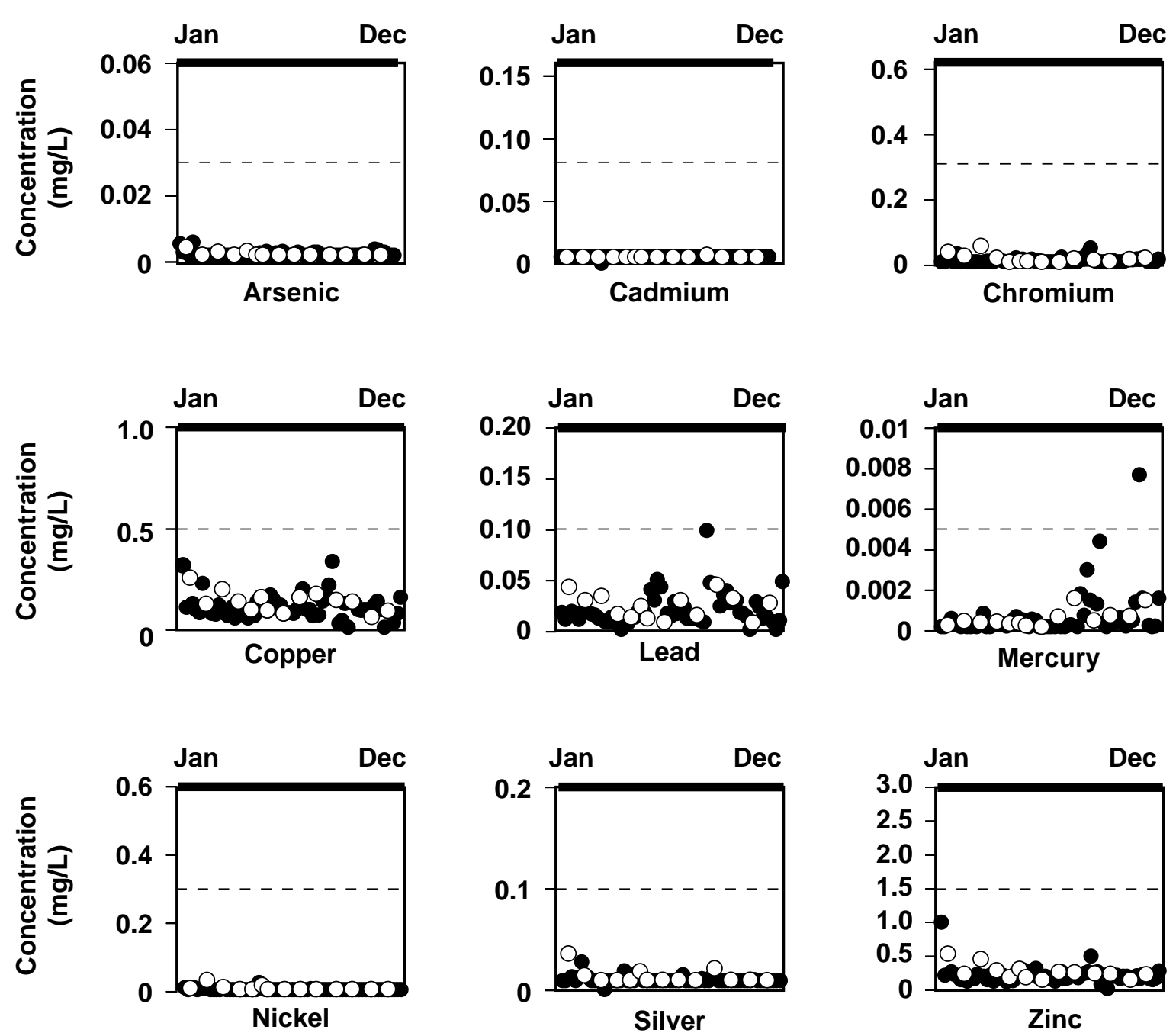

Figure 6-5. Concentrations of metals in 24-hour and weekly composite samples of LLNL sewage compared to effluent pollutant levels (EPLs) during 1996.

and the slightly elevated arsenic levels of 1993 continued in 1994. During 1995, the gas pad cleanup operations were reduced, and the slightly elevated arsenic levels were seen less frequently. In 1996, the gas pad operations were concluded, and arsenic levels returned to pre-1992 concentrations. 
Table 6-10. Positively detected physical and chemical parameters in LLNL sanitary sewer effluent, 1996.

\begin{tabular}{|c|c|c|c|c|c|}
\hline $\begin{array}{l}\text { Positively detected } \\
\text { parameter }\end{array}$ & $\begin{array}{l}\text { Detection } \\
\text { frequency(a) }\end{array}$ & Minimum & Maximum & Median & $\operatorname{IQR}^{(\mathbf{b})}$ \\
\hline \multicolumn{6}{|c|}{ 24-hour composite sample parameters (mg/L) } \\
\hline \multicolumn{6}{|l|}{ Oxygen demand } \\
\hline Biochemical oxygen demand & $12 / 12$ & 23.8 & 274 & 190 & 137 \\
\hline Chemical oxygen demand & $12 / 12$ & 54 & 820 & 240 & 320 \\
\hline \multicolumn{6}{|l|}{ Solids } \\
\hline Solid settling rate $(\mathrm{mL} / \mathrm{L} / \mathrm{h})$ & $12 / 12$ & 5 & 43 & 22 & 7.5 \\
\hline Total dissolved solids & $12 / 12$ & 180 & 450 & 240 & 88 \\
\hline Total suspended solids & $12 / 12$ & 94 & 460 & 230 & 140 \\
\hline Volatile solids & $12 / 12$ & 60 & 380 & 87 & 130 \\
\hline \multicolumn{6}{|l|}{ Anions } \\
\hline Chloride & $12 / 12$ & 36 & 63 & 51 & 11 \\
\hline Fluoride & $9 / 9$ & 0.082 & 0.9 & 0.13 & 0.08 \\
\hline Nitrate (as N) & $1 / 12$ & $<0.11$ & 5 & $<0.5$ & - \\
\hline Nitrate $\left(\right.$ as $\left.\mathrm{NO}_{3}\right)$ & $2 / 12$ & $<0.5$ & 9.9 & $<0.5$ & - \\
\hline Nitrite (as $\mathrm{NO}_{2}$ ) & $1 / 12$ & $<0.5$ & 5 & $<2$ & _- \\
\hline Orthophosphate & $8 / 9$ & 4.4 & 210 & 11 & 11 \\
\hline Sulfate & $12 / 12$ & 17 & 4800 & 19 & 12 \\
\hline \multicolumn{6}{|l|}{ Alkalinity } \\
\hline Bicarbonate alkalinity $\left(\right.$ as $\left.\mathrm{CaCO}_{3}\right)$ & $12 / 12$ & 130 & 240 & 200 & 15 \\
\hline Total alkalinity $\left(\right.$ as $\left.\mathrm{CaCO}_{3}\right)$ & $12 / 12$ & 130 & 240 & 200 & 15 \\
\hline \multicolumn{6}{|l|}{ Nutrients } \\
\hline Ammonia nitrogen (as $\mathrm{N}$ ) & $11 / 12$ & $<0.1$ & 51 & 40 & 14 \\
\hline Total Kjeldahl nitrogen & $12 / 12$ & 30 & 50 & 43 & 9 \\
\hline Total organic carbon & $11 / 11$ & 4.2 & 8.4 & 45 & 19 \\
\hline \multicolumn{6}{|l|}{ Total metals ${ }^{(c)}$} \\
\hline Calcium & $12 / 12$ & 10 & 20 & 16 & 4.5 \\
\hline Magnesium & $12 / 12$ & 2.5 & 4.8 & 3.5 & 1.4 \\
\hline Potassium & $12 / 12$ & 17 & 68 & 19 & 2.3 \\
\hline Selenium & $1 / 11$ & $<0.002$ & $<0.01$ & $<0.002$ & _- \\
\hline Sodium & $12 / 12$ & 26 & 44 & 38 & 8 \\
\hline
\end{tabular}




\section{Sewerable Water}

Table 6-10. Positively detected physical and chemical parameters in LLNL sanitary sewer effluent, 1996 (concluded).

\begin{tabular}{|c|c|c|c|c|c|}
\hline $\begin{array}{l}\text { Positively detected } \\
\text { parameter }\end{array}$ & $\begin{array}{l}\text { Detection } \\
\text { frequency }\end{array}$ & Minimum & Maximum & Median & $I_{Q} R^{(\mathbf{b})}$ \\
\hline \multicolumn{6}{|c|}{ Grab sample parameters } \\
\hline \multicolumn{6}{|l|}{ Volatile organic compounds $(\mu \mathrm{g} / \mathrm{L})$} \\
\hline Acetone & $12 / 12$ & 55 & 1400 & 170 & 79 \\
\hline Chloroform & $12 / 12$ & 6.4 & 22 & 11 & 3.3 \\
\hline Methylene chloride & $1 / 12$ & $<1$ & 160 & $<1$ & - \\
\hline Toluene & $1 / 12$ & $<1$ & 270 & $<1$ & - \\
\hline Trichloroethene & $1 / 12$ & $<0.5$ & 300 & $<0.5$ & - \\
\hline \multicolumn{6}{|l|}{ Semivolatile organic compounds ( $\mu \mathrm{g} / \mathrm{L})$} \\
\hline 2-Methyl phenol & $1 / 12$ & $<5$ & 21 & $<10$ & - \\
\hline Benzoic acid & $2 / 12$ & $<25$ & $<250$ & $<50$ & - \\
\hline Benzyl alcohol & $6 / 12$ & $<10$ & 270 & $<37$ & - \\
\hline Bis(2-ethylhexyl)phthalate & $7 / 12$ & $<5$ & 34 & 12 & 11 \\
\hline Butylbenzylphthalate & $1 / 12$ & $<5$ & $<20$ & $<7.5$ & - \\
\hline$m$ - and $p$-Cresol & $2 / 12$ & $<5$ & $<20$ & $<10$ & - \\
\hline Phenol & $2 / 12$ & $<5$ & $<20$ & $<9.1$ & - \\
\hline Total recoverable phenolics (mg/L) & $12 / 12$ & 0.027 & 0.3 & 0.18 & 0.18 \\
\hline Total oil and grease (average, mg/L) & $12 / 12$ & 7.5 & 26 & 17 & 8.3 \\
\hline
\end{tabular}

a The number of times an analyte was positively identified, followed by the number of samples that were analyzed (generally 12 , one sample for each month of the year).

b Interquartile range. Where the detection frequency is less than or equal to $50 \%$, the interquartile range is omitted.

c The 24-hour composite sample results incorporated in Table 6-7 are not represented in this section.

The monthly mercury values for the latter half of 1996 were higher than values reported for the previous two years. However, only one 1996 analytical result exceeded the action level in LLNL's Wastewater Discharge Permit, which states that archived daily composite samples must be analyzed for the pollutant of concern when the result for a weekly composite sample is $50 \%$ of, or greater than, the applicable effluent pollutant limit. This mercury analytical result $(0.0077 \mathrm{mg} / \mathrm{L})$, which exceeded the action level $(0.005 \mathrm{mg} / \mathrm{L})$, occurred in the latter half of 1996. The archived daily samples that corresponded to the appropriate weekly composite sampling period of November 26 through December 2 were submitted for mercury analysis. All of the analytical results for the daily samples were less than the effluent pollutant limit of $0.01 \mathrm{mg} / \mathrm{L}$, with the 


\section{Sewerable Water}

exception of the result for November 27. This analytical result of $0.013 \mathrm{mg} / \mathrm{L}$ exceeded the applicable effluent pollutant limitation, but LWRP, the regulatory agency, did not consider the value to be a violation of LLNL's Wastewater Discharge Permit because the mercury result fell within the range of uncertainty in the effluent pollutant limit.

All of the 1996 results for lead were well below the applicable action level and the applicable effluent pollutant limit, with the exception of the August 20 through 26 weekly composite sample. Even though the lead concentration for this sample $(0.099 \mathrm{mg} / \mathrm{L})$ was below the criterion for the action level, it was close enough that, as a best management practice, LLNL submitted the daily samples for lead analysis. All of the analytical results for these samples were less than the effluent pollutant limit. For 1996 as a whole, the monthly lead values presented in Table 6-9 are comparable to results reported in previous years.

Seven inadvertent discharges were detected in 1996 by the continuous monitoring system (Table 6-11). These incidents did not represent a threat to the integrity of the operations at the LWRP. All of the incidents, which occurred during normal working hours on weekdays, involved either an acid or a base and were reported to the LWRP; LLNL is not permitted by the LWRP to discharge effluent with a $\mathrm{pH}$ below 5 or above 10 . Five of the seven events were low $\mathrm{pH}$ incidents. Two of the seven events were above $\mathrm{pH} 10$ but not considered enforceable exceedances of permit conditions because they did not exceed the duration criteria (40 CFR 401.17). (Uncontained $\mathrm{pH}$ releases of sufficient concentration and duration outside of the effluent pollutant limit range could disrupt treatment plant operations or cause the treated wastewater to exceed allowable concentration limits for discharge to the San Francisco Bay.) Only one incident was of sufficient concentration and duration to warrant a sewage diversion. For comparison, 1, 1, 0, and 13 such diversions occurred in 1995, 1994, 1993, and 1992, respectively. Subsequent analysis of the diverted effluent showed that the average $\mathrm{pH}$ was acceptable for release of the wastewater back to the sanitary sewer.

As a result of these incidents, the LWRP issued two letters of concern. The letters stated that the LWRP did not issue a notice of violation (NOV) for any of the incidents for reasons that included the availability of data for retention tank releases and the short duration and relatively small volumes of the incidents. However, in the second letter of concern, the LWRP indicated that continued similar $\mathrm{pH}$ incidents would result in an NOV. To eliminate the source(s) of these incidents, LLNL embarked on an educational campaign intended to supplement the existing administrative, engineering, and educational programs for promoting acceptable wastewater disposal practices. These efforts, completed in October 1996, included articles in the Laboratory's newspaper and electronic news bulletin and the distribution of an environmental alert to all employees through the LLNL mail system. The $\mathrm{pH}$ incidents, which began in January and occurred 


\section{Sewerable Water}

at least once every other month until September, did not occur again in the final three months of 1996.

Table 6-11. Inadvertent discharges detected by the continuous monitoring system in 1996.

\begin{tabular}{|l|c|c|c|c|}
\hline Date & Contaminant & $\begin{array}{c}\text { Estimated } \\
\text { duration }^{(\mathbf{a})} \\
(\mathbf{m i n})\end{array}$ & $\begin{array}{c}\text { Estimated } \\
\text { volume(b) } \\
(\mathbf{L})\end{array}$ & $\begin{array}{c}\text { Minimum or } \\
\text { maximum } \\
\mathbf{p H}\end{array}$ \\
\hline $1 / 31$ & Acid & 3 & 4,300 & 3.5 \\
$3 / 22$ & Acid & 4 & 3,300 & 2.4 \\
$5 / 17^{(\mathrm{c})}$ & Base & 8 & 7,900 & 10.6 \\
$6 / 3^{(\mathrm{c}, \mathrm{d})}$ & Base & 30 & 35,000 & 10.8 \\
$8 / 12$ & Acid & 2 & 2,100 & 2.4 \\
$8 / 26^{(\mathrm{e})}$ & Acid & 2 & 2,400 & 2.8 \\
$9 / 11^{(\mathrm{e})}$ & Acid & 3 & 4,900 & 3.5 \\
\hline
\end{tabular}

a The estimated duration includes only the time that the $\mathrm{pH}$ of LLNL effluent was outside of its permitted range.

b The estimated volume includes only the volume of LLNL effluent that was outside of the permitted $\mathrm{pH}$ range.

c LWRP did not consider these events as enforceable exceedances because they did not exceed the duration criteria.

d This incident was of sufficient concentration and duration to warrant a sewer diversion; contained sewage was later returned to the sanitary sewer after analysis of the diverted effluent showed it had an acceptable $\mathrm{pH}$. The event comprised a 30 -minute excursion to $\mathrm{pH} 10.8$, followed by a 15-minute fluctuation to $\mathrm{pH} 10.4,25$ minutes later. The volume of the second discharge was estimated to be $75,600 \mathrm{~L}(20,000 \mathrm{gal})$.

e Based on a high sulfate concentration measured in an instantaneous sample acquired during the incident and the general usefulness of sulfuric acid in chemical work, the most probable cause for this incident is assumed to be sulfuric acid. 


\section{Surface Water}

Erich R. Brandstetter

Karen J. Folks

Shari L. Brigdon

Robert J. Vellinger

\section{Introduction}

Lawrence Livermore National Laboratory (LLNL) monitors surface water at the Livermore site, in surrounding regions of the Livermore Valley, and at Site 300 and vicinity in the nearby Altamont Hills. At the first two locales, LLNL monitors reservoirs and ponds, the Livermore site swimming pool, the Drainage Retention Basin (DRB), treated ground water discharges, rainfall, tap water, and storm water runoff. At Site 300 and vicinity, surface water monitoring encompasses rainfall, cooling tower discharges, and storm water runoff. The water samples are analyzed for radionuclides, high explosives, total organic carbon, total organic halides, total suspended solids, conductivity, $\mathrm{pH}$, chemical oxygen demand, total dissolved solids, oil and grease, metals, minerals, anions, and a wide range of organic compounds. In addition, fish bioassays are performed annually on water entering and leaving the Livermore site via the Arroyo Las Positas pathway, discharges from the DRB, and water contained in the DRB.

\section{Storm Water}

Storm water (runoff water) monitoring is driven by the requirements in the Environmental Regulatory Guide for Radiological Effluent Monitoring and Environmental Surveillance (U.S. Department of Energy 1991); DOE Orders 5400.1, General Environmental Protection Program, and 5400.5, Radiation Protection of the Public and the Environment; and two National Pollutant Discharge Elimination System (NPDES) permits issued under the authority of the Federal Clean Water Act and the Comprehensive Environmental Response, Compensation and Liability Act (CERCLA) Record of Decision (ROD).

Storm water comes in contact with a large number of potential pollution sources and has the potential to disperse contaminants across broad areas. To evaluate the overall impact of Livermore site and Site 300 operations on storm water quality, storm water flows are sampled where they leave the site. These samples provide information used to evaluate the effectiveness of LLNL's storm water pollution control program. The 


\section{Surface Water}

NPDES permits for storm water (WDR Order No. 95-174, NPDES Permit No. CA0030023 for the Livermore site and WDR Order No. 94-131, NPDES Permit No. CA0081396 for Site 300) require that LLNL conduct effluent sampling and visual inspections of the storm drainage system monthly during the wet season, whenever significant storms occur, and twice during the dry season to identify any dry weather flows. In addition, annual facility inspections are required to assure that the necessary management measures are adequate and implemented. The goals of the storm water monitoring program are to demonstrate compliance with permit requirements, aid in implementing the Storm Water Pollution Prevention Plan (SWPPP) (Eccher 1994), and measure the effectiveness of the best management practices (BMPs) in preventing contamination of storm water discharges.

LLNL first monitored storm water runoff at the Livermore site in 1975. The original monitoring network, designed to detect pesticides, was expanded in 1990 to cover new locations and additional water quality parameters (i.e., radioactivity, metals, and additional organic compounds). Additional changes during 1993 complied with the National Pollutant Discharge Elimination System General Industrial Activities Storm Water Permit (NPDES General Permit). In October 1993, also in response to the NPDES General Permit, LLNL established a new storm water monitoring program at Site 300. In 1995, the San Francisco Bay Region Water Quality Control Board (RWQCB) issued a Waste Discharge Requirements and National Pollutant Discharge Elimination System Permit (NPDES No. CA0030023, WDR 95-174) for the Livermore site, which replaced coverage under the Statewide General NPDES Permit for Storm Water Discharges Associated with Industrial Activities (Order No. 91-13-DWQ). The new permit includes specific monitoring and reporting requirements. The current list of analyses requested for storm water samples is given in Table 7-1. Flow patterns at the site are such that storm water at sampling locations includes components from other sources, such as neighboring agricultural land, parking lots, and landscaped areas. Because of this, and because wide-ranging activities are conducted at the Livermore site, it is necessary to analyze storm water for a wide variety of constituents at the Livermore site. In contrast, storm water at Site 300 is sampled at locations that target specific activities, and a smaller range of analyses is sufficient.

Currently, there are no numerical criteria that limit concentrations of specific constituents in storm water effluent. In the federal multisector permit, the Environmental Protection Agency (EPA) established benchmark values for 41 parameters but stressed that these concentrations were not intended to be interpreted as effluent limitations (see Table 7-2). Rather, they are levels that the EPA has used to determine if storm water discharged from any given facility merits further monitoring. Other water quality criteria developed by California and the federal 


\section{Surface Water}

Table 7-1. Requested analyses for storm water samples, 1996.

\begin{tabular}{|l|l|}
\hline \multicolumn{1}{|c|}{ Livermore site } & \multicolumn{1}{c|}{ Site $\mathbf{3 0 0}$} \\
\hline $\mathrm{pH}$ & $\mathrm{pH}$ \\
Total suspended solids & Total suspended solids \\
Specific conductance & Specific conductance \\
Oil and grease & Total organic carbon \\
Total organic carbon & Gross alpha and beta \\
Gross alpha and beta & Tritium \\
Tritium & Uranium \\
Chemical oxygen demand & Total organic halides \\
General minerals & Explosives \\
Anions & \\
Metals & \\
Herbicides-EPA Method 507 & \\
Glycophosphate-EPA Method 547 & \\
Diuron-EPA Method 632 & \\
Fish bioassay (fathead minnow) & \\
\hline
\end{tabular}

government were used as comparisons with LLNL storm water analysis results in this report. However, these criteria are defined for other purposes, and are therefore not directly applicable to storm water effluent. Nevertheless, use of a broad range of criteria can help to evaluate LLNL's storm water management program and to allow LLNL to ensure high quality in its storm water effluent.

Storm water sample results for the Livermore site were compared with criteria listed in the Water Quality Control Plan, San Francisco Bay Basin Region (San Francisco Bay RWQCB 1995), and results for Site 300 were compared with criteria listed in The Water Quality Control Plan (Basin Plan) for the California Central Valley RWQCB (Longley et al. 1994). Criteria in the Basin Plans include surface water quality objectives for the protection of aquatic life and water quality objectives for waters designated for use as domestic or municipal supply or agricultural supply. These criteria include, by reference, California Maximum Contaminant Levels (MCLs) for drinking water. In addition, results were compared with EPA MCLs and ambient water quality criteria (AWQC), as well as California AWQC. Criteria not specifically listed in the Basin Plans were obtained from A Compilation of Water Quality Goals (Marshack 1995). Criteria are summarized in Table 7-2. 
Table 7-2. Storm water nonradioactive comparison criteria, Livermore site, 1996.

\begin{tabular}{|c|c|c|c|}
\hline Parameter & $\operatorname{MCL}(a)$ & $A W Q C^{(b)}$ & Benchmark \\
\hline \multicolumn{4}{|l|}{ Materials (mg/L) } \\
\hline Aluminum & $1(\mathrm{CA})$ & 0.75 & 0.75 \\
\hline Antimony & $0.006(\mathrm{EPA})$ & 0.088 & 0.636 \\
\hline Barium & $1(\mathrm{CA})$ & none & none \\
\hline Chemical oxygen demand & none & none & 120 \\
\hline Chloride & 250 (EPA) & 860 & 860 \\
\hline Chromium & $0.05(\mathrm{CA})$ & $0.016^{(c)}$ & none \\
\hline Copper & 1 (EPA) & 0.027 & 0.063 \\
\hline Fluoride & $1.4(\mathrm{CA})$ & none & 1.8 \\
\hline Chromium(VI) & $0.05(\mathrm{CA})$ & 0.015 & none \\
\hline Iron & 0.3 (EPA) & 1 & 1 \\
\hline Lead & 0.015 (EPA) & 0.11 & 0.0816 \\
\hline Manganese & 0.5 (EPA) & none & 1 \\
\hline Nickel & 0.1 (EPA) & 2.15 & 1.417 \\
\hline Oil and grease & none & none & 15 \\
\hline Ortho-phosphate & none & none & $2^{(d)}$ \\
\hline Thallium & 0.002 (EPA) & none & none \\
\hline Total alkalinity (as $\mathrm{CaCO}_{3}$ ) & none (EPA) & 20 & none \\
\hline Total dissolved solids (TDS) & $500(\mathrm{CA})$ & none & \\
\hline Total suspended solids (TSS) & none & none & 100 \\
\hline Vanadium & none & none & none \\
\hline Zinc & 5 (EPA) & 0.175 & 0.117 \\
\hline \multicolumn{4}{|l|}{ General indicator parameters } \\
\hline $\mathrm{pH}$ & $6.5-8.5(\mathrm{EPA})$ & $6.5-9$ & $6-9$ \\
\hline Specific conductance ( $\mu \mathrm{mho} / \mathrm{cm})$ & $900(\mathrm{CA})$ & none & none \\
\hline \multicolumn{4}{|l|}{ EPA Method $507(\mu \mathrm{g} / \mathrm{L})$} \\
\hline Simazine & 4 (EPA) & none & none \\
\hline \multicolumn{4}{|l|}{ EPA Method $615(\mu \mathrm{g} / \mathrm{L})$} \\
\hline $2,4-D$ & 70 (EPA) & none & none \\
\hline \multicolumn{4}{|l|}{ EPA Method $625(\mu \mathrm{g} / \mathrm{L})$} \\
\hline Bis(2-ethylhexyl)phthalate & $4(\mathrm{CA})$ & 400 & none \\
\hline
\end{tabular}

a $\mathrm{MCL}=$ Maximum contaminant level.

b $\quad \mathrm{AWQC}=$ Ambient water quality criteria.

c Assumes $\mathrm{Cr}(\mathrm{VI})$.

d Total phosphorous. 
Although before 1995 Arroyo Las Positas only flowed when it rained, dry weather observations at the Livermore site noted that water flowed in Arroyo Las Positas throughout 1996. This water originated from two sources: natural flow of water from off site that entered LLNL property at the ALPO influent location (Figure 7-1), and permitted discharges from ground water treatment facilities. Dry weather inspections at Site 300 showed no indication of nonpermitted nonstorm water flows discharging from the site.

Each LLNL directorate inspected its facilities to verify that the best management practices (BMPs) identified in LLNL's Storm Water Pollution Prevention Plans (SWPPPs) were in place, properly implemented, and adequate. LLNL implements BMPs at construction sites and at facilities that use significant materials (as defined by the storm water regulations) to prevent storm water from being contaminated. The results of the inspections indicated that LLNL facilities were in compliance with the requirements of the SWPPPs and the provisions of the NPDES permits. LLNL submits annual storm water monitoring reports to the San Francisco Bay RWQCB and the Central Valley RWQCB reporting the results of sampling, observations, and inspections.

LLNL also meets the storm water compliance monitoring requirements authorized under the California General Construction Activity Storm Water Permit for construction projects disturbing 2 hectares of land or more. Monitoring for these construction projects included visual observation of sites before and after storms to assess the effectiveness of implemented BMPs. Three Livermore construction sites were inspected during 1996: Building 132; the DWTF project area; and the areas associated with the beneficial reuse of soils in the North Buffer Zone Regrading Project and landscaping throughout the developed areas of the Livermore site. As required by the California General Construction Activity Storm Water Permit, the construction managers annually certify compliance with the specific project SWPPP and the requirements of this general permit.

These projects were in compliance with their SWPPPs except for one grading project associated with the North Buffer Zone. Regrading was not inspected after May 17, 1996, rainfall, and the post-stabilization inspection was not documented. The project SWPPP was subsequently amended to augment the inspection requirements and an inspection checklist was developed. The DWTF construction project SWPPP was amended to address road cleaning. For the first time in 1996, the San Francisco Bay RWQCB requested the submission of Construction Status Compliance reports for the three construction projects at the Livermore site.

\section{Livermore Site}

The natural drainage at the Livermore site was altered by construction activities several times up to 1966 (Thorpe et al. 1990) so that the current northwest flow of Arroyo Seco 


\section{Surface Water}

and the north-then-west flow of Arroyo Las Positas do not represent historical flow paths. About $1.6 \mathrm{~km}$ to the west of the Livermore site, Arroyo Seco merges with Arroyo Las Positas, which continues to the west to eventually merge with Arroyo Mocho. An abandoned stream channel is visible on air-photo maps of the site east of the present alignment of Arroyo Seco (Carpenter et al. 1984). A drainage retention basin (DRB) for storm water diversion and flood control was excavated and constructed to the north and west of Building 551 and collects about one fourth of the surface water runoff from the site and a portion of the Arroyo Las Positas drainage (Figure 7-1). This basin was lined in 1990 to prevent infiltration in this area.

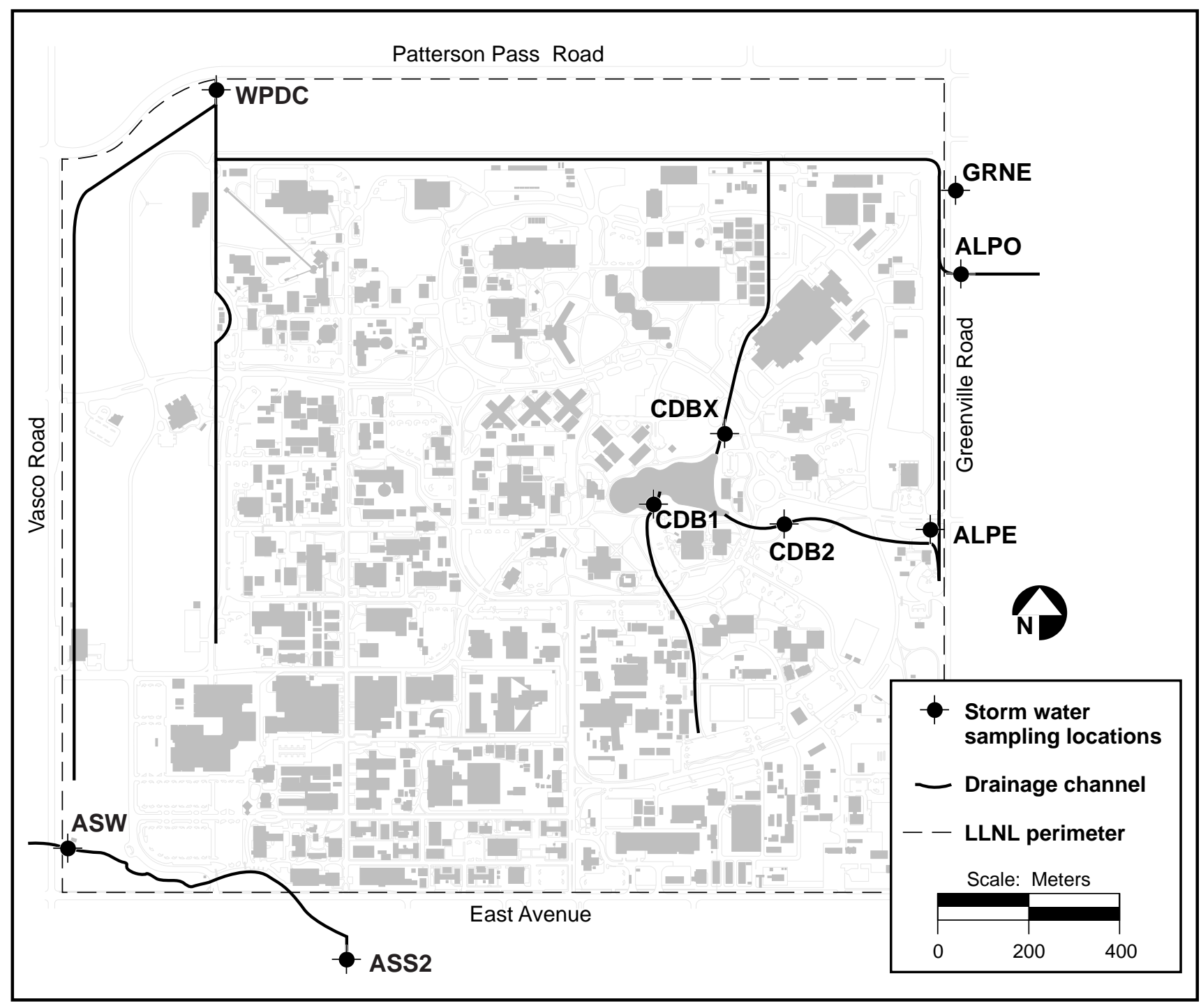

Figure 7-1. Storm water runoff sampling locations, Livermore site and vicinity, 1996. 
The DRB discharges to a culvert that leads to Arroyo Las Positas. The remainder of the site drains either directly or eventually into two arroyos by way of storm sewers and ditches. The two arroyos drain from east to west. Arroyo Seco cuts across the southwestern corner of the site. Arroyo Las Positas, diverted from its natural course, follows the northeastern and northern boundaries of the site and exits the site at the northwest corner.

In 1996, the Livermore site storm water sampling network consisted of nine locations (Figure 7-1). Six locations characterize storm water either entering (influent: ALPE, ALPO, GRNE, and ASS2) or exiting (effluent: WPDC and ASW) the Livermore site. Locations $\mathrm{CDB}$ and $\mathrm{CDB} 2$ characterize runoff from the southeastern quadrant of the Livermore site entering the DRB, and location CDBX characterizes water leaving the DRB.

Historically, LLNL has analyzed storm water for a wide range of organic constituents. A review of recent data (1991-1996), however, showed that no organic constituent specifically identified was detected in more than $25 \%$ of the samples. The most commonly detected organic constituents were acetone, in 6 out of 49 samples (12\%), bis(2-ethylhexyl)phthalate (4 detections, or 8\%), and Freon 113 (3 detections, or $6 \%$ ). All other organic constituents specifically identified were detected only once or twice in the 49 sampling events. Therefore, starting in the fall of 1996, organic analyses were selected to target pesticides known to be used at the Livermore site. Organic analyses now conducted are EPA 507 (herbicides), EPA 547 (glycophosphate), and EPA 632 (diuron).

LLNL collected storm water samples from four storm events in 1996. Samples were collected at all Livermore site locations on January 16, April 1, May 15, and October 29, 1996.

As required by LLNL's NPDES permit (WDR 95-174, NPDES No. CA0030023), LLNL conducted an annual fish bioassay. In this acute toxicity test, 96-hour survival of fathead minnow (Pimephales promelas) in undiluted storm water collected from effluent location WPDC is observed. The Regional Board has set a criteria of $20 \%$ survival compared with the control as an acceptable level. The testing laboratory provides water to use in the control sample. In addition, in agreement with Regional Board guidance, upgradient waters from influent locations ALPO, ALPE, and GRNE are used as added controls. Thus, a difference of more than $20 \%$ between location WPDC and the control sample with the lowest survival is considered a failed test. For example, if survival in the laboratory control is $95 \%$, and survival in water from ALPO, ALPE, and GRNE is $80 \%, 75 \%$, and $85 \%$, respectively, then survival of less than $55 \%$ in WPDC water would be a failed test. If the test is failed, LLNL is 


\section{Surface Water}

required to sample the next runoff event. If two consecutive tests are failed, LLNL is required to perform a toxicity reduction evaluation to identify the source of the toxicity. In this year's acute toxicity test, $95 \%$ of the minnows survived in the WPDC water. The survival rate in GRNE water was also 95\%, while the survival rate in ALPO, ALPE and the laboratory control water was $100 \%$.

Storm water gross alpha, gross beta, and tritium results are summarized in Table 7-3. Median activities were less than $10 \%$ of the respective MCLs. Figures 7-2 and 7-3 show the historical trend in storm water gross alpha and gross beta, respectively. In these and other storm water historical trend figures in this chapter, all available data for the influent and effluent locations of the two runoff pathways through the Livermore site have been aggregated. Also, data have been aggregated on a wet season basis-that is, October of one year through May of the next-rather than on a calendar year basis. Thus, data on storm plots labeled 95/96 represent October 1995 through May 1996, and data labeled 96 represent October through December 1996. The 1996 points represent a partial wet season, pending collection of 1997 data, and are based on only one sampling event for each location. Finally, plots include all available storm water influent and effluent data for each constituent. The gross alpha and gross beta data show no discernible pattern. The historical trend in tritium levels (Figure 7-4), which correlates with decreased emissions (see Chapter 5), indicates generally decreasing tritium levels in storm water from the 1988-89 to 1991-92 season, after which the curve is relatively flat.

Table 7-3. Radioactivity (in Bq/L) in storm water runoff, Livermore site, 1996.

\begin{tabular}{|l|c|c|c|}
\hline & Tritium & Gross alpha & Gross beta \\
\hline Median & 2.23 & 0.056 & 0.16 \\
Minimum & $<1.64$ & $<0.02$ & $<0.06$ \\
Maximum & 139.12 & 0.47 & 0.68 \\
Interquartile range & 4.06 & 0.050 & 0.11 \\
Maximum contaminant level (MCL) & 740 & 0.56 & 1.85 \\
\hline
\end{tabular}




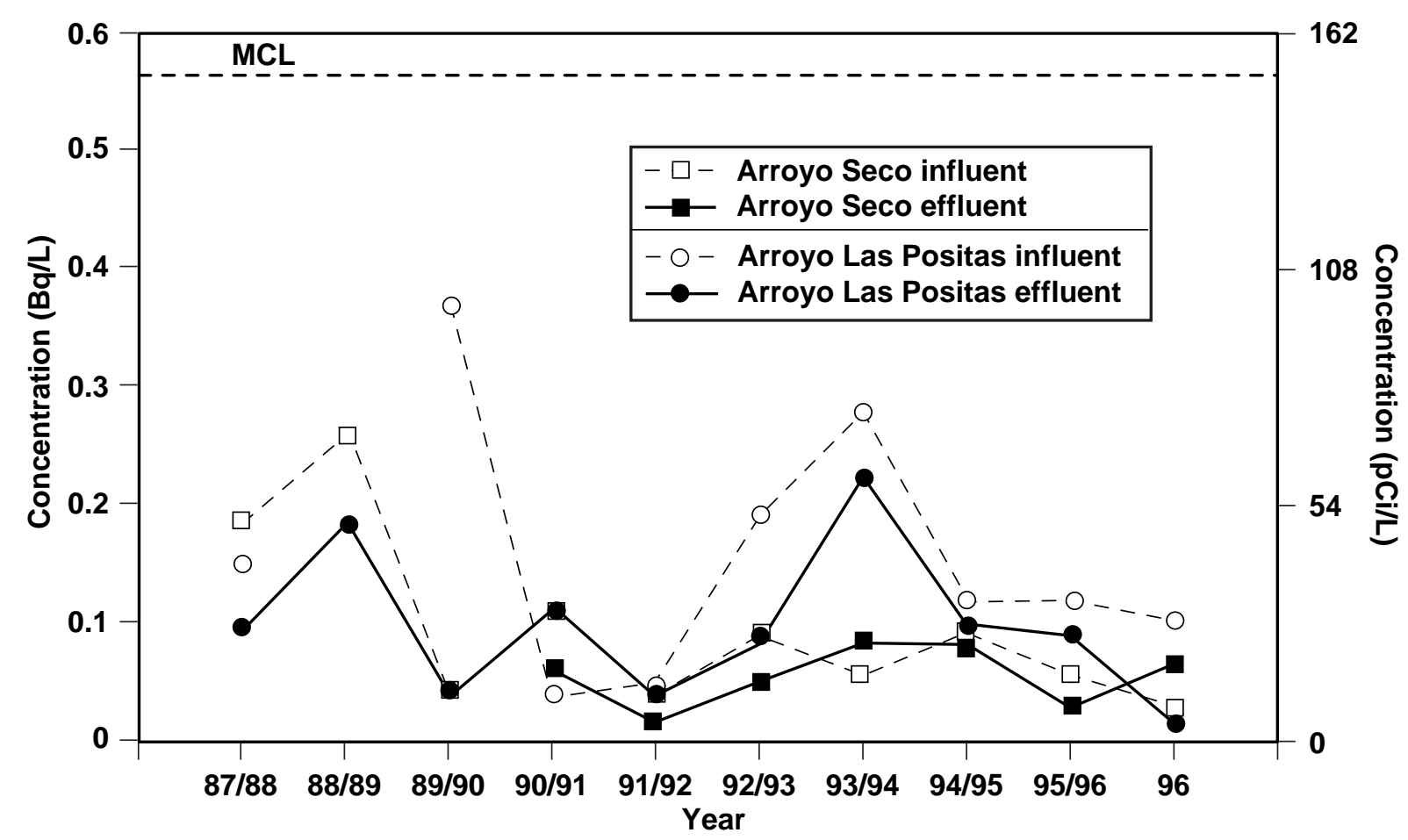

Figure 7-2. Annual median gross alpha in LLNL storm water compared with the maximum contaminant level (MCL).

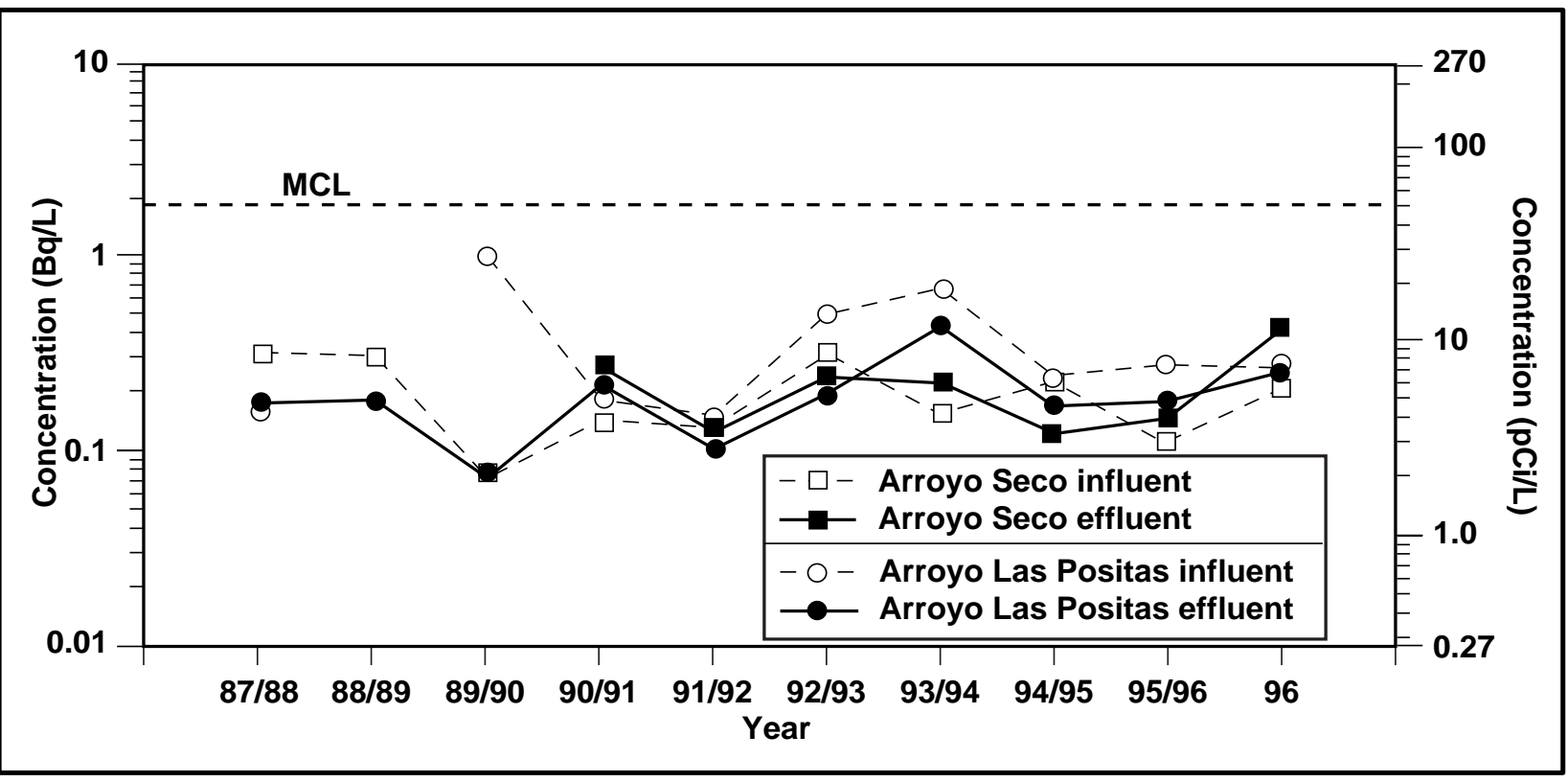

Figure 7-3. Annual median gross beta in LLNL storm water compared with the maximum contaminant level (MCL). 


\section{Surface Water}

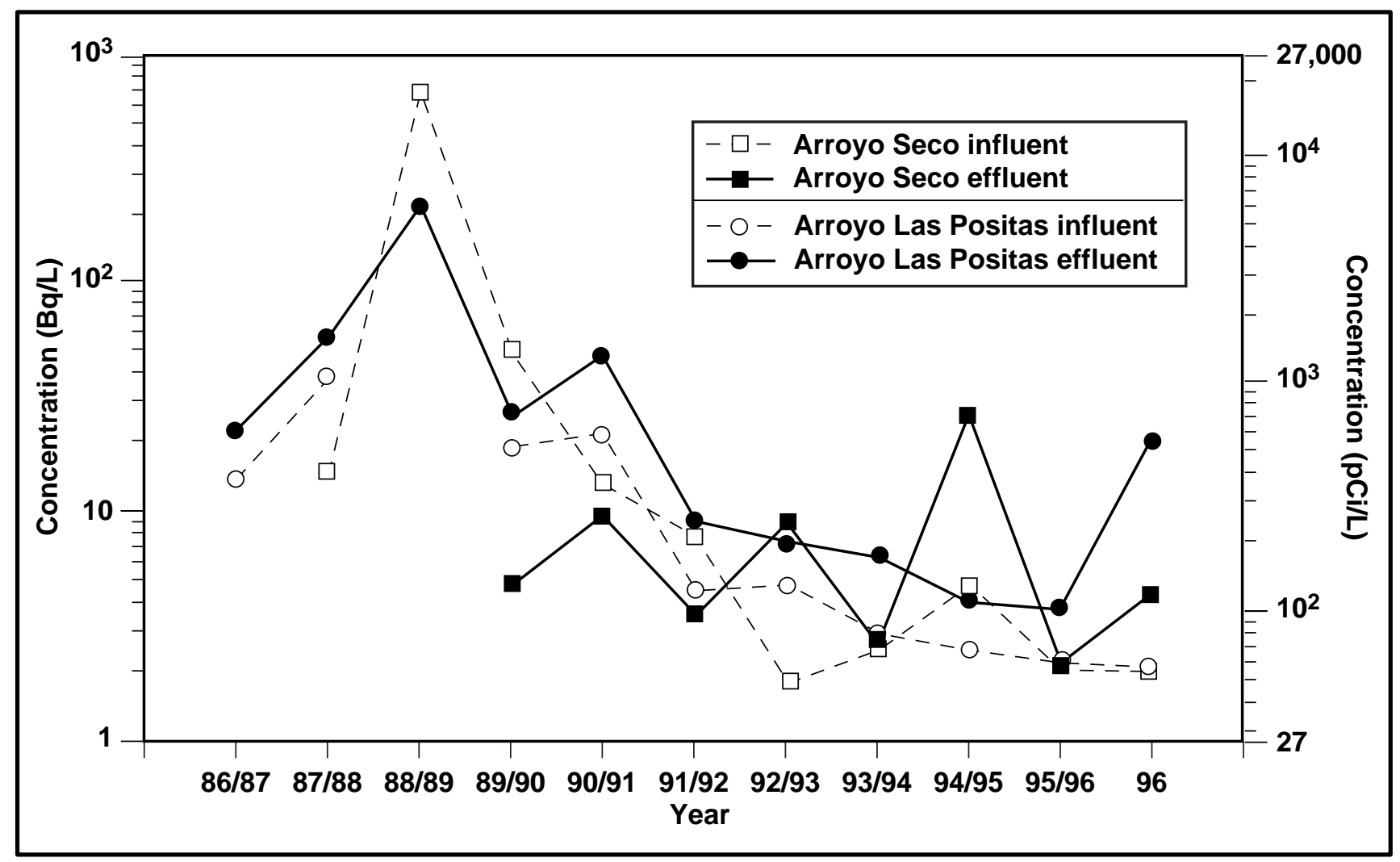

Figure 7-4. Annual median tritium concentrations in LLNL storm water.

Table 7-4 lists nonradioactive constituents found above comparison criteria in Livermore site storm water. Complete storm water results are presented in Table 7-2, Volume 2. Of greatest concern are constituents that exceeded comparison criteria at effluent points, but for which the influent concentrations were less than the corresponding effluent concentrations. This was the case for aluminum, chromium, copper, iron, manganese, nickel, and zinc. Historical trend plots seem to indicate that many of these constituents, for example, chromium, copper, and zinc, are increasing over time (Figures 7-5, 7-6, and 7-7). However, review of the data indicates that the apparent increases are primarily due to a shift from analyses that only recover dissolved metals to analyses that recover the total metal concentrations in the water (dissolved plus suspended). Next year, investigations are planned to determine how much of these metals are present in the liquid and how much in sediments being transported, for example, during high flow events. 
Table 7-4. Nonradioactive constituents above comparison criteria in storm water runoff, Livermore site, 1996.

\begin{tabular}{|c|c|c|c|c|c|c|c|c|c|}
\hline Parameter & $\begin{array}{c}\text { Storm } \\
\text { date }\end{array}$ & ALPE & ALPO & ASS2 & ASW & CDB & CDB2 & GRNE & WPDC \\
\hline \multicolumn{10}{|l|}{ Materials (mg/L) } \\
\hline \multirow[t]{6}{*}{ Aluminum } & $1 / 16$ & & & 0.87 & & & & & 1.7 \\
\hline & $4 / 1$ & 73 & 7.3 & 9.2 & 8.1 & 6.4 & 52 & 29 & 32 \\
\hline & $4 / 1$ & 65 & 6.2 & 8.7 & 8.8 & 8.6 & 38 & 28 & 31 \\
\hline & $5 / 15$ & 10 & 5.4 & 5.7 & 4.2 & 5.4 & 8.9 & 14 & 33 \\
\hline & $10 / 29$ & 3.1 & 5.5 & 5.6 & 13 & 4.4 & 4.6 & 36 & 5.4 \\
\hline & $10 / 29$ & 4.7 & 4.4 & 3.6 & 20 & 5.1 & 5.2 & 82 & 2.5 \\
\hline Antimony & $5 / 15$ & & & & & & 0.013 & & \\
\hline Barium & $10 / 29$ & & & & & & & 1.2 & \\
\hline Chemical oxygen demand & $10 / 29$ & 276 & & & 419 & 262 & 150 & & 190 \\
\hline \multirow[t]{2}{*}{ Chloride } & $4 / 1$ & & 300 & & & & & & \\
\hline & $4 / 1$ & & 300 & & & & & & \\
\hline \multirow[t]{4}{*}{ Chromium } & $1 / 16$ & 0.062 & & & & 0.018 & 0.019 & & 0.022 \\
\hline & $4 / 1$ & 0.16 & & 0.02 & 0.018 & 0.017 & 0.11 & 0.065 & 0.065 \\
\hline & $5 / 15$ & 0.029 & & & & & 0.026 & & 0.062 \\
\hline & $10 / 29$ & & & & 0.059 & 0.02 & 0.022 & 0.18 & \\
\hline \multirow[t]{5}{*}{ Copper } & $4 / 1$ & 0.081 & & & & & 0.063 & 0.037 & 0.042 \\
\hline & $4 / 1$ & 0.082 & & & & & 0.049 & 0.028 & 0.035 \\
\hline & $5 / 15$ & & & & 0.031 & & 0.044 & & 0.054 \\
\hline & $10 / 29$ & & & & 0.64 & 0.043 & 0.03 & 0.037 & 0.035 \\
\hline & $10 / 29$ & & & & & 0.045 & 0.039 & 0.086 & 0.037 \\
\hline \multirow[t]{3}{*}{ Fluoride } & $4 / 1$ & & 1.7 & & & & & & \\
\hline & $4 / 1$ & & 1.7 & & & & & & \\
\hline & $10 / 29$ & & 0.84 & & & & & & \\
\hline Chromium(VI) & $1 / 16$ & 0.093 & & & & & & & \\
\hline \multirow[t]{8}{*}{ Iron } & $1 / 16$ & 24 & 7 & 1.8 & 2.3 & 7.6 & 5.9 & 6.1 & 9.7 \\
\hline & $1 / 16$ & & & 0.63 & 0.4 & 0.43 & 0.43 & & 0.44 \\
\hline & $4 / 1$ & 78 & 5.6 & 8.2 & 7.1 & 5.5 & 45 & 27 & 26 \\
\hline & $4 / 1$ & 72 & 5.4 & 8.3 & 7.6 & 7.3 & 38 & 26 & 27 \\
\hline & $5 / 15$ & 11 & 4.1 & 6.1 & 4.8 & 5.3 & 7.8 & 10 & 30 \\
\hline & $5 / 15$ & & & & & 0.69 & & & \\
\hline & $10 / 29$ & 4.3 & 4.9 & 7 & 15 & 5.3 & 5 & 37 & 6.2 \\
\hline & $10 / 29$ & 5.7 & 4.1 & 4.6 & 24 & 6.2 & 5.8 & 84 & 3 \\
\hline Lead & $5 / 15$ & 0.016 & & & & & 0.021 & & \\
\hline
\end{tabular}




\section{Surface Water}

Table 7-4. Nonradioactive constituents above comparison criteria in storm water runoff, Livermore site, 1996 (continued).

\begin{tabular}{|c|c|c|c|c|c|c|c|c|c|}
\hline Parameter & $\begin{array}{c}\text { Storm } \\
\text { date }\end{array}$ & ALPE & ALPO & ASS2 & ASW & CDB & CDB2 & GRNE & WPDC \\
\hline \multirow[t]{7}{*}{ Manganese } & $1 / 16$ & 0.44 & 0.17 & & 0.036 & 0.15 & 0.09 & 0.093 & 0.18 \\
\hline & $4 / 1$ & 1.7 & 0.15 & 0.17 & 0.13 & 0.11 & 0.85 & 0.58 & 0.45 \\
\hline & $4 / 1$ & 1.6 & 0.13 & 0.17 & 0.14 & 0.15 & 0.75 & 0.55 & 0.46 \\
\hline & $5 / 15$ & 0.25 & 0.091 & 0.14 & 0.12 & 0.18 & 0.2 & 0.17 & 0.6 \\
\hline & $5 / 15$ & 0.078 & 0.078 & 0.048 & 0.069 & 0.19 & 0.12 & & 0.14 \\
\hline & $10 / 29$ & 0.31 & 0.13 & 0.19 & 0.51 & 0.37 & 0.18 & 0.72 & 0.28 \\
\hline & $10 / 29$ & 0.32 & 0.12 & 0.15 & 0.64 & 0.37 & 0.22 & 1.9 & 0.31 \\
\hline \multirow[t]{3}{*}{ Nickel } & $4 / 1$ & 0.18 & 0.15 & & & & 0.12 & 0.49 & 0.6 \\
\hline & $4 / 1$ & 0.16 & & & & & & & \\
\hline & $10 / 29$ & & & & & & & 0.19 & \\
\hline Oil and grease & $1 / 16$ & & & & & & 24 & & \\
\hline \multirow[t]{2}{*}{ Orthophosphate } & $10 / 29$ & & & & 2.7 & & & & \\
\hline & $10 / 29$ & & & & 2.7 & & & & \\
\hline Thallium & $10 / 29$ & & & & & & & 0.0024 & \\
\hline \multirow[t]{5}{*}{ Total alkalinity $\left(\right.$ as $\left.\mathrm{CaCO}_{3}\right)$} & $1 / 16$ & & & 15 & & 7.5 & 14 & & \\
\hline & $4 / 1$ & & & 9 & & 8 & 14 & & \\
\hline & $5 / 15$ & & & & & 1 & 19 & & \\
\hline & $10 / 29$ & & & 9.9 & & & 14.2 & & \\
\hline & $10 / 29$ & & & 11.3 & & 19.9 & 13.5 & & \\
\hline \multirow[t]{4}{*}{ Total dissolved solids (TDS) } & $1 / 16$ & 800 & 340 & 59 & 47 & 64 & 68 & 100 & 140 \\
\hline & $4 / 1$ & 120 & 1100 & 70 & 50 & 60 & 60 & 90 & 190 \\
\hline & $5 / 15$ & 110 & 190 & 94 & 81 & 92 & 130 & 150 & 150 \\
\hline & $10 / 29$ & 220 & 775 & 62 & 290 & 195 & 102 & 74 & 280 \\
\hline \multirow[t]{3}{*}{ Total suspended solids (TSS) } & $4 / 1$ & 500 & 230 & 130 & 150 & 340 & 440 & 380 & 650 \\
\hline & $5 / 15$ & 540 & 640 & 660 & 220 & 1300 & 1100 & 700 & 620 \\
\hline & $10 / 29$ & 143 & 161 & 296 & 480 & 120 & 186 & 2160 & \\
\hline \multirow[t]{2}{*}{ Vanadium } & $4 / 1$ & 0.17 & & & & & 0.11 & & \\
\hline & $10 / 29$ & & & & & & & 0.18 & \\
\hline \multirow[t]{7}{*}{ Zinc } & $1 / 16$ & & & & & & & & 0.13 \\
\hline & $4 / 1$ & 0.39 & & 0.27 & & & 0.25 & 0.16 & 0.26 \\
\hline & $4 / 1$ & 0.37 & & 0.28 & & & 0.21 & 0.15 & 0.26 \\
\hline & $5 / 15$ & & & 0.24 & 0.16 & 0.26 & 0.29 & & 0.6 \\
\hline & $5 / 15$ & & & 0.52 & 0.13 & 0.35 & 0.23 & & 1.1 \\
\hline & $10 / 29$ & 0.16 & & 0.45 & 0.31 & 0.9 & 0.34 & & 0.4 \\
\hline & $10 / 29$ & 0.17 & & 0.38 & 0.35 & 0.9 & 0.42 & 0.25 & 0.58 \\
\hline
\end{tabular}


Table 7-4. Nonradioactive constituents above comparison criteria in storm water runoff, Livermore site, 1996 (concluded).

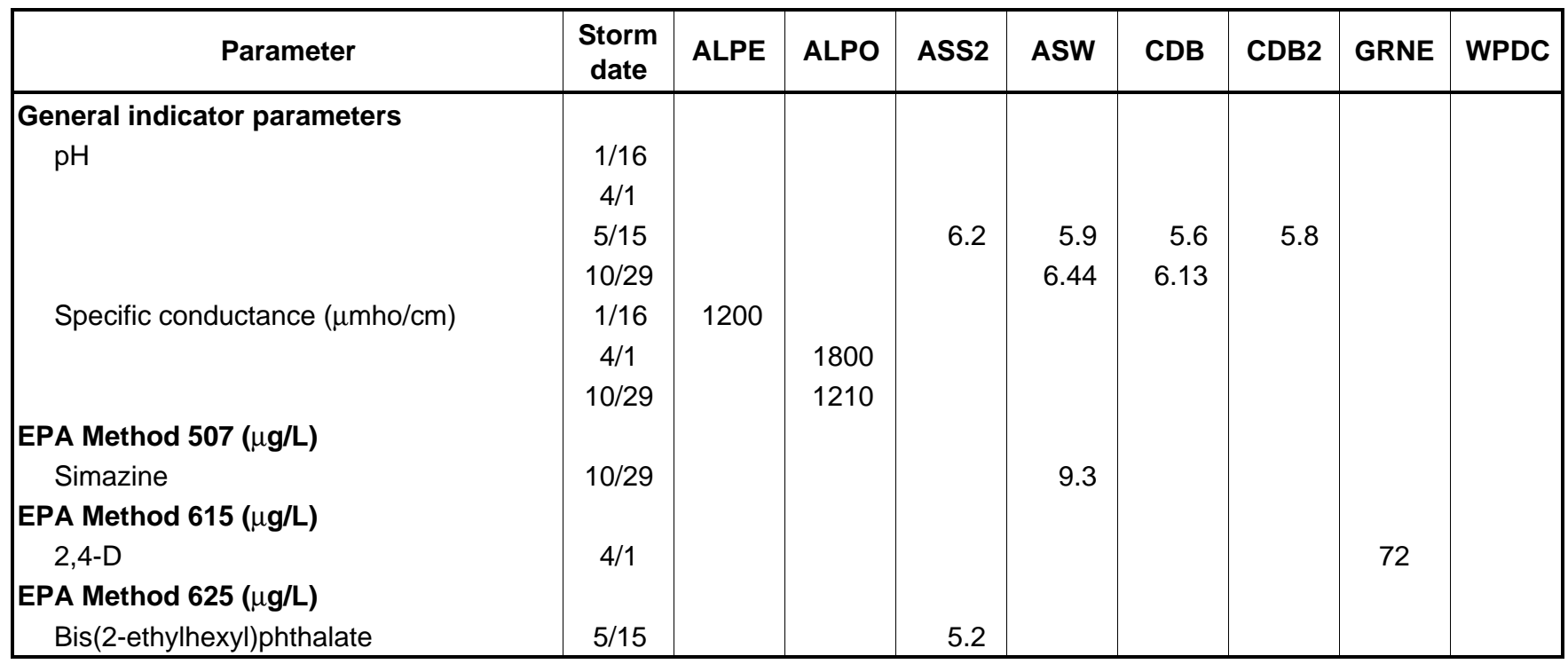

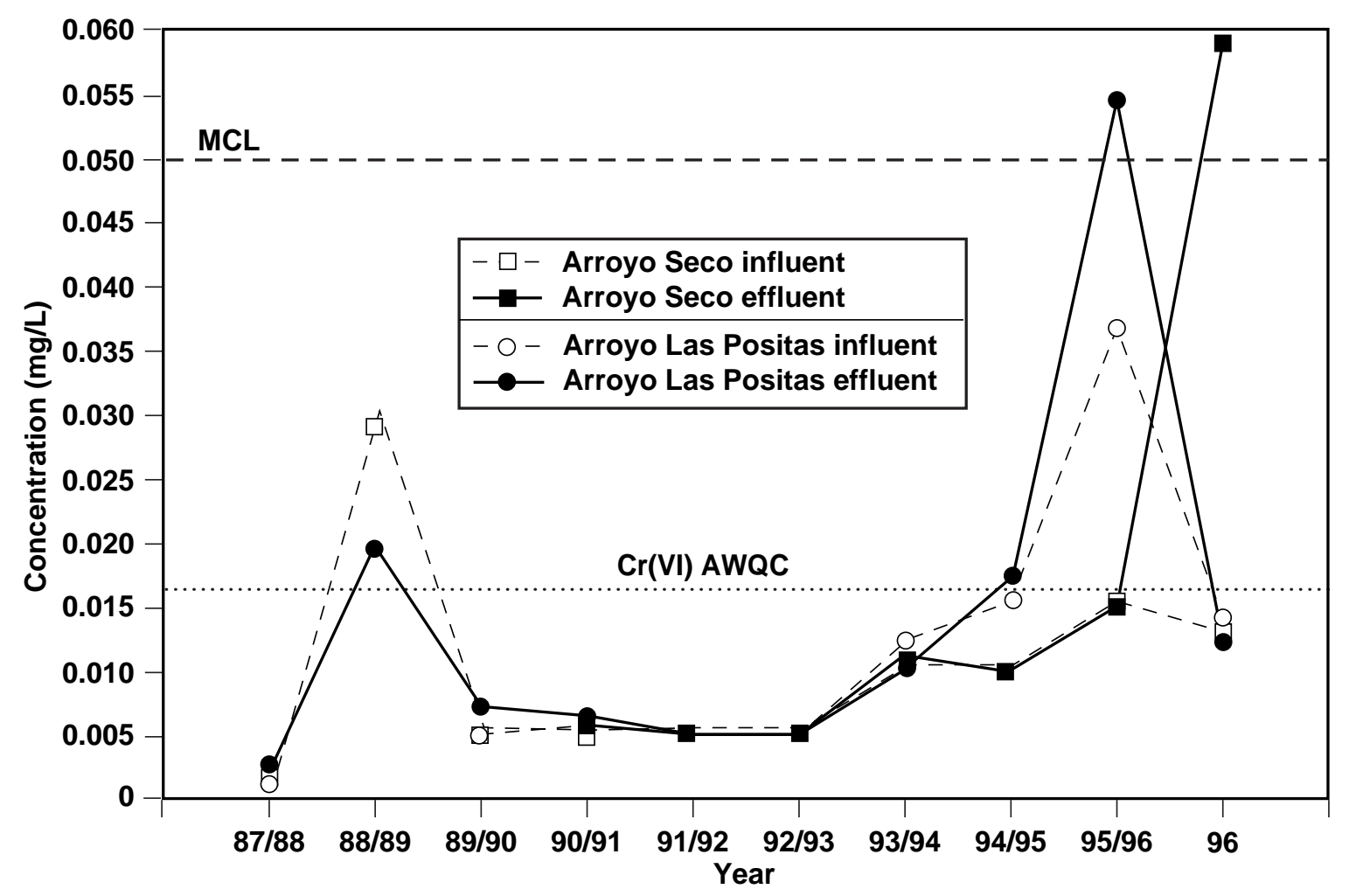

Figure 7-5. Chromium in LLNL storm water, compared with the maximum contaminant level (MCL) and ambient water quality criterion (AWQC) values. 


\section{Surface Water}

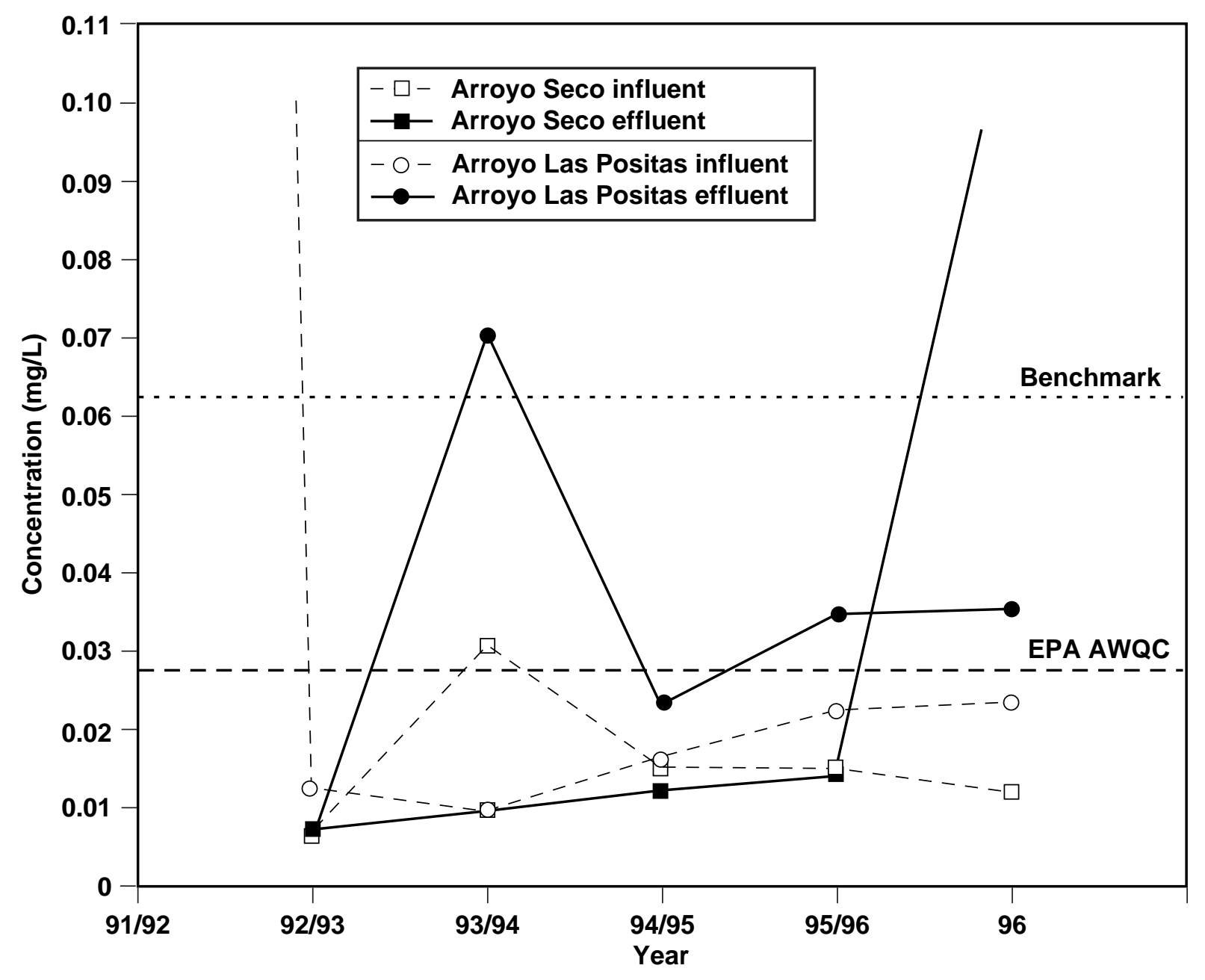

Figure 7-6. Annual median gross copper in LLNL storm water compared with the benchmark and ambient water quality criterion (AWQC) values. The concentration of copper in Arroyo Las Positas influent in 1991-92 was $0.97 \mathrm{mg} / \mathrm{L}$. In 1996-97, the copper concentration in Arroyo Seco effluent was $0.385 \mathrm{mg} / \mathrm{L}$. Both values are off the concentration scale in this figure.

Chromium, copper, and zinc are common constituents in urban runoff (Salomons et al. 1995). All three elements have been linked with automobile metal corrosion and emissions; copper and zinc concentrations have been correlated with traffic volume, and one study showed a zinc concentration of $0.37 \mathrm{mg} / \mathrm{L}$ in highway runoff. In addition, zinc is released from automobile tires (Salomons et al. 1995). Thus, it is likely that these types of nonindustrial sources are contributing metals to storm water runoff at the Livermore site. 


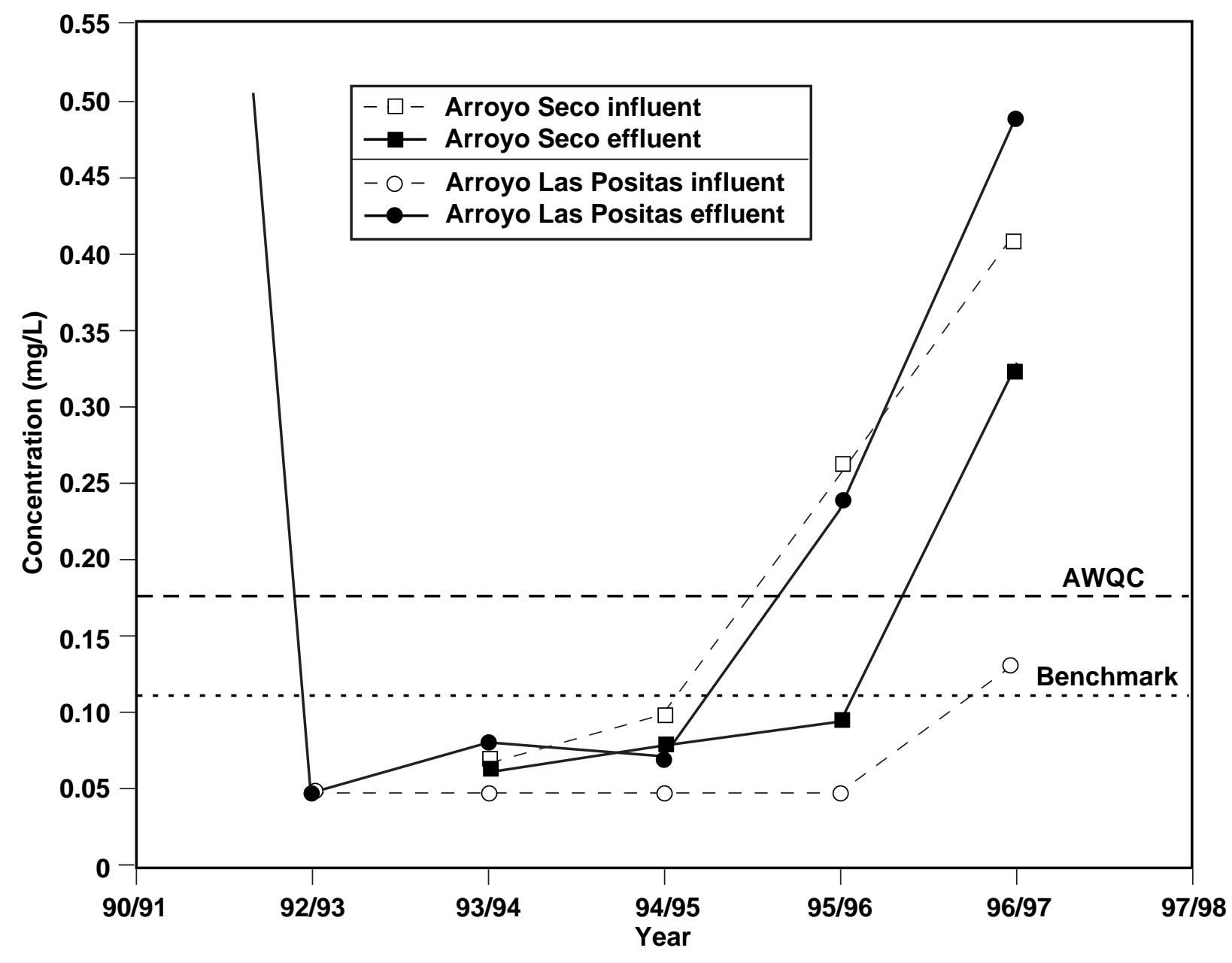

Figure 7-7. Annual median zinc concentrations in LLNL storm water compared with the benchmark and ambient water criterion (AWQC) values. The concentration of zinc in Arroyo Las Positas effluent in 1991-92 was $1.5 \mathrm{mg} / \mathrm{L}$, which is off the concentration scale in this figure.

Other constituents found (from 1-3 times) above comparison criteria at effluent points, and above the corresponding influent points, were total dissolved solids, total suspended solids, and the pesticide Simazine. In addition, two samples taken at the effluent point had $\mathrm{pH}$ values that were lower than the secondary MCL minimum $\mathrm{pH}$. The $\mathrm{pH}$ values of both samples were lower than $\mathrm{pH}$ values of samples taken at the influent point.

A number of other constituents in LLNL runoff were also above comparison criteria. In every case, however, when the concentration exceeded a criterion at an effluent point, 


\section{Surface Water}

there was a corresponding influent point with a higher concentration, indicating an offsite or possibly naturally occurring source. These constituents were antimony, barium, chemical oxygen demand, chloride, fluoride, hexavalent chromium, lead, oil and grease, ortho-phosphate, thallium, total alkalinity, specific conductance, vanadium, bis(2-ethylhexyl)phthalate, and 2,4-D (2,4-dichlorophenoxy acetic acid). Bromocil was the only other organic constituent detected in 1996 storm water runoff.

\section{Site 300}

The topography of Site 300 is much more irregular than that of the Livermore site; steep hills and ridges oriented along a generally northwest/southeast trend are separated by intervening ravines. The elevation ranges from approximately $150 \mathrm{~m}$ above sea level at the southeast corner of the site to approximately $538 \mathrm{~m}$ in the northwestern portion.

Surface water at Site 300 consists of seasonal stream runoff, springs, and natural and manmade ponds. Surface water sometimes occurs locally as a result of building discharges. The primary drainage in the Site 300 area is Corral Hollow Creek, an ephemeral stream that borders the site to the south and southeast. No continuously flowing streams are present in the Site 300 area. Elk Ravine is the major drainageway for most of Site 300; it extends from the northwest portion of the site to the east-central area. Corral Hollow and Elk Ravine drain eastward to the San Joaquin River Basin. Some smaller canyons in the northeast portion of the site drain to the north and east toward Tracy. A small portion of Site 300 drains to Alameda County, but is not included in the storm water sampling because there are no industrial activities in the associated drainages.

There are at least 23 springs at Site 300. Nineteen are perennial, and four are intermittent. Most of the springs have very low flow rates and are recognized only by small marshy areas, pools of water, or vegetation. Vegetation surrounding the springs includes cattails, nettles, willows, and grass. Only three of the springs have flow rates greater than $4 \mathrm{~L} / \mathrm{min}$. The significance of individual springs is discussed in the Final Site-Wide Remedial Investigation Report, Lawrence Livermore National Laboratory Site 300, hereafter referred to as the Final SWRI Report (Webster-Scholten 1994). A vernal pool is present in the northwest corner of Site 300. It is a perennial pool created by ponding of water in a natural depression.

Three artificial surface water bodies are present at Site 300. A sewage treatment pond is located in the southeast corner of the site in the General Services Area (GSA), and two lined High Explosives (HE) rinse water impoundments are located to the west in the Explosives Process Area. A residence pond at the Carnegie State Vehicular Recreation Area is located off site just east of Pit 6 at the mouth of Middle Canyon. In addition, four small off-site stock watering ponds are present in the area north of Site 300. 
Other surface water at Site 300 results from blowdown water from cooling towers in the East and West Firing Areas and other areas. Cooling tower discharges and their potential impact are discussed in the Final SWRI Report (Webster-Scholten 1994).

The Site 300 storm water sampling network began in 1994 with six locations and expanded to eight locations in 1995 (Figure 7-8). Location CARW was added to further characterize background conditions in Corral Hollow Creek, along with existing location NSTN. Location GEOCRK was formerly reported in Chapter 8 (which discusses ground water monitoring) because an upgradient spring contributes water representative of ground water. GEOCRK was transferred to storm water monitoring in order to utilize the location to characterize runoff in Corral Hollow Creek, downgradient of Site 300. The remaining five locations were selected to characterize storm water runoff at locations that could potentially be affected by specific Site 300 activities.

Samples were collected from some Site 300 locations on January 16, January 31, March 13, May 15, and October 29, 1996. Typically, a given storm will not produce runoff at all Site 300 locations because Site 300 receives relatively little rainfall and is largely undeveloped. Therefore, at many locations, a series of large storms is required to saturate the ground before runoff occurs.

The maximum tritium concentration in Site 300 storm water was $2.47 \mathrm{~Bq} / \mathrm{L}$ (66.7 pCi/L), or $0.3 \%$ of the $740 \mathrm{~Bq} / \mathrm{L}(20,000 \mathrm{pCi} / \mathrm{L}) \mathrm{MCL}$ (Table 7-5). Gross alpha was above its MCL $(0.56 \mathrm{~Bq} / \mathrm{L}$ or $15 \mathrm{pCi} / \mathrm{L})$ on January 31 at background locations CARW and NSTN, at on-site location NLIN, and at downgradient location GEOCRK; and on January 16 at location NPT6. In addition, on January 16, gross beta was above its MCL (1.85 Bq/L, or $50 \mathrm{pCi} / \mathrm{L})$ at location NPT6. The highest gross alpha and gross beta were at NPT6 on January 16, 4.26 and $7.55 \mathrm{~Bq} / \mathrm{L}$ (115 and $204 \mathrm{pCi} / \mathrm{L})$, respectively. Past studies, reported in Chapter 7 of the Environmental Report 1995 (Harrach et al. 1996), of storm water samples with high gross alpha and gross beta levels have shown that the apparent high levels of gross alpha and gross beta radiation were caused by high sediment loads (due to erosion typical of the region) and naturally occurring levels of potassium, thorium, and uranium, along with their daughter products, carried in that sediment. Furthermore, the gross alpha and gross beta in the solid phase were at background levels. A plot of sediment load vs gross alpha and gross beta radiation showed a clear relationship, and the 1996 high gross alpha and gross beta results follow the same pattern (Figure 7-9). Thus, these samples do not indicate that some new source has contributed to increased environmental gross alpha and gross beta radiation, but rather, only that more sediments are being transported in these storm events at these locations. There is no indication of an anthropogenic source of the gross alpha and gross beta levels. 


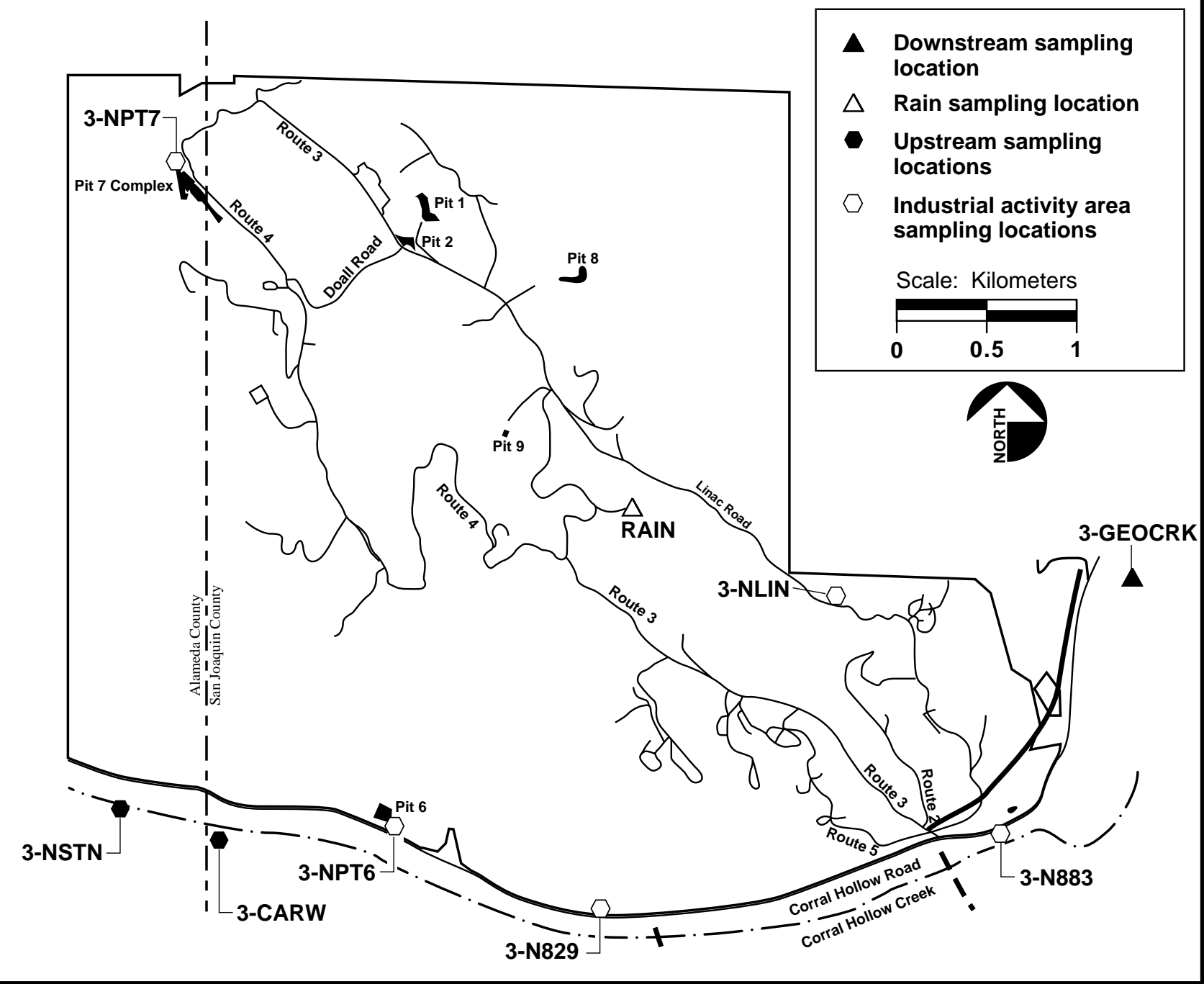

Figure 7-8. Rain and storm water runoff sampling locations, Site 300 and vicinity, 1996.

Two measurements of $\mathrm{pH}$ (6.12 and 6.4) were below the MCL minimum (6.5) at location N883, and one measurement (8.66) at location NPT7 was above the MCL maximum (8.5). Background specific conductance was above the California MCL $(900 \mu \mathrm{mho} / \mathrm{cm})$ at location NSTN $(1400 \mu \mathrm{mho} / \mathrm{cm})$. It was also above the MCL at the downgradient location (GEOCRK) in the same creek, but, at $1300 \mu \mathrm{mho} / \mathrm{cm}$, was slightly lower than at the upgradient location. Total suspended solids were above the EPA benchmark (100 mg/L) three times at background locations NSTN and CARW, twice at on-site location NSTN, and once at downgradient location GEOCRK. High values occurred at on-site location NPT6 (1900 mg/L) and background location CARW (1200 mg/L). Historically, background total suspended solids have been as high as 20,000 mg/L, indicating that these values are due to erosion typical of the region. 
Table 7-5. Radioactivity in storm water runoff at Site 300 (in Bq/L), 1996.

\begin{tabular}{|c|c|c|c|c|c|c|c|}
\hline Location & Date & Tritium & $\begin{array}{l}\text { Gross } \\
\text { alpha }\end{array}$ & $\begin{array}{c}\text { Gross } \\
\text { beta }\end{array}$ & $\begin{array}{r}234 U \\
\times 10^{-2}\end{array}$ & $\begin{array}{r}235 \mathrm{U} \\
\times 10^{-3}\end{array}$ & $\begin{array}{r}238 U \\
\times 10^{-2}\end{array}$ \\
\hline \multirow[t]{2}{*}{ CARW } & $\operatorname{Jan} 31$ & $2.36 \pm 2.20$ & $0.814 \pm 0.407$ & $1.21 \pm 0.31$ & $4 \pm 1$ & $2.6 \pm 2$ & $2.92 \pm 0.8$ \\
\hline & Mar 13 & -(a) $^{(\mathrm{a}}$ & $0.111 \pm 0.074$ & $0.222 \pm 0.15$ & -(a) $^{(a)}$ & -(a) & -(a) \\
\hline \multirow[t]{3}{*}{ GEOCRK } & $\operatorname{Jan} 31$ & $2.15 \pm 2.15$ & $0.925 \pm 0.444$ & $1.51 \pm 0.33$ & $8.66 \pm 1.4$ & $2.1 \pm 2$ & $6.88 \pm 1.3$ \\
\hline & Mar 13 & -(a) & $0.148 \pm 0.074$ & $0.148 \pm 0.148$ & -(a) & -(a) & -(a) \\
\hline & May 15 & $1.78 \pm 1.78$ & $0.329 \pm 0.144$ & $0.562 \pm 0.18$ & $4.7 \pm 1.1$ & $1.5 \pm 3$ & $4.29 \pm 1$ \\
\hline NLIN & $\operatorname{Jan} 31$ & $2.17 \pm 2.17$ & $0.629 \pm 0.407$ & $1.35 \pm 0.32$ & $3.48 \pm 1$ & $7.4 \pm 5$ & $4 \pm 1.1$ \\
\hline \multirow[t]{3}{*}{ N883 } & Jan 16 & $2.15 \pm 2.15$ & $0.047 \pm 0.031$ & $0.118 \pm 0.052$ & $01 \pm 0.4$ & $2.5 \pm 2$ & $0.35 \pm 0.3$ \\
\hline & $\operatorname{Jan} 31$ & $2.09 \pm 2.09$ & $0.013 \pm 0.027$ & $0.163 \pm 0.052$ & $0.85 \pm 0.5$ & $1.8 \pm 2$ & $0.59 \pm 0.4$ \\
\hline & Oct 29 & $2.43 \pm 2.43$ & $0.0123 \pm 0.033$ & $0.0181 \pm 0.13$ & $-0.2 \pm 0.4$ & $-1.5 \pm 2$ & $-0.2 \pm 0.3$ \\
\hline NPT6 & $\operatorname{Jan} 16$ & $2.18 \pm 2.18$ & $4.255 \pm 1.739$ & $7.55 \pm 1.33$ & $6.77 \pm 1.3$ & $15.5 \pm 6$ & $5.99 \pm 1.2$ \\
\hline \multirow[t]{3}{*}{ NPT7 } & $\operatorname{Jan} 16$ & $2.12 \pm 2.11$ & $0.0326 \pm 0.032$ & $0.167 \pm 0.056$ & $1.55 \pm 0.6$ & $1.5 \pm 2$ & $0.7 \pm 0.4$ \\
\hline & $\operatorname{Jan} 31$ & $2.08 \pm 2.08$ & $0.0333 \pm 0.063$ & $0.215 \pm 0.059$ & $2.89 \pm 0.8$ & $0 \pm 1$ & $2.29 \pm 0.7$ \\
\hline & Oct 29 & $2.47 \pm 2.47$ & $0.0256 \pm 0.037$ & $0.154 \pm 0.12$ & $0.61 \pm 0.4$ & $-1 \pm 3$ & $0.24 \pm 0.2$ \\
\hline \multirow[t]{2}{*}{ NSTN } & $\operatorname{Jan} 31$ & $2.11 \pm 2.11$ & $0.925 \pm 0.407$ & $1.39 \pm 0.26$ & $3.66 \pm 1.1$ & $9.6 \pm 6$ & $3.85 \pm 1.1$ \\
\hline & May 15 & $1.78 \pm 1.78$ & $0.141 \pm 0.104$ & $0.294 \pm 0.23$ & $6.92 \pm 1.2$ & $6.3 \pm 4$ & $4.66 \pm 1$ \\
\hline STN & Mar 13 & -(a) $^{(\mathrm{a}}$ & $0.185 \pm 0.074$ & $0.185 \pm 0.15$ & -(a) & -(a) & - (a) $^{(\mathrm{a})}$ \\
\hline
\end{tabular}

a Not sampled on March 13 on because sampling was an effort to resample only gross alpha and beta.

\section{Rainfall}

\section{Livermore Site}

Rainfall is sampled for tritium according to written procedures in Appendix A of the Environmental Monitoring Plan (Tate et al. 1995). Historically, the tritium activity measured in rainfall in the Livermore Valley has resulted primarily from atmospheric emissions of tritiated water vapor (HTO) from stacks at LLNL's Tritium Facility (Building 331), and Sandia National Laboratories/California's former Tritium Research Laboratory. The B343 rain sampling location is near the Tritium Facility (Building 331), where LLNL personnel have reduced operations in recent years and performed significant inventory reduction and cleanup activities. The total measured atmospheric emission of HTO from LLNL facilities in 1996 was 7.0 TBq, equal to 190 curies (Ci). 


\section{Surface Water}

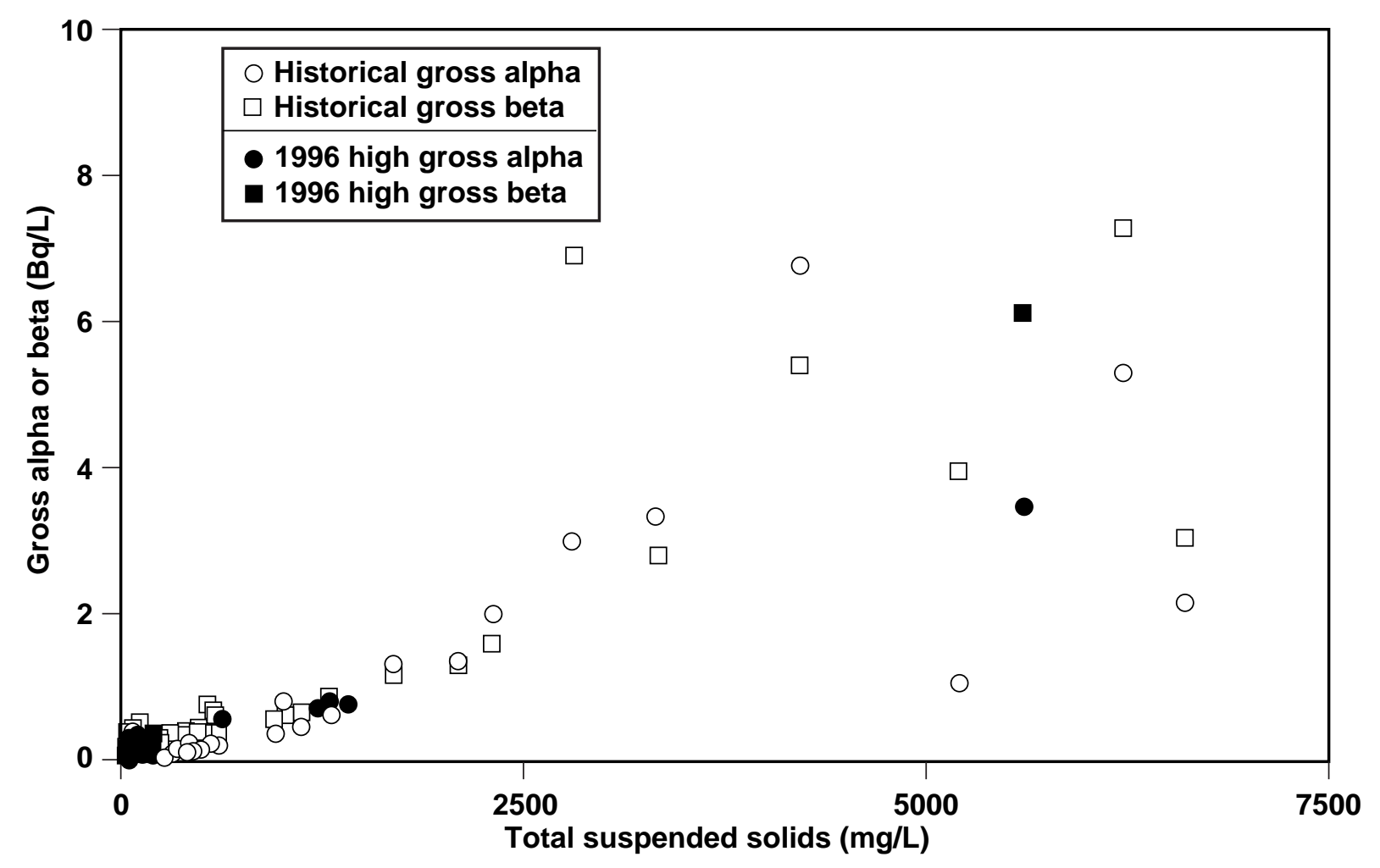

Figure 7-9. Relationship of storm water gross alpha and gross beta to total suspended solids.

The rain sampling station locations are shown on Figure 7-10. The fixed stations are positioned to record a wide spectrum of tritium activities in rainfall, from the maximum expected down to background levels.

Tritium activities measured in rainfall at the LLNL site and vicinity are summarized in Table 7-6. Complete data are shown in Volume 2, Table 7-4. The Livermore site rainfall has exhibited elevated tritium activities in the past (Gallegos et al. 1994). During 1996, however, measurements of tritium activity in rainfall were all far below the $740 \mathrm{~Bq} / \mathrm{L}(20,000 \mathrm{pCi} / \mathrm{L}) \mathrm{MCL}$ established by the EPA for drinking water. Rainfall samples were collected on January 17, April 1, April 18, May 16, and October 29, 1996. The highest overall activity was $170 \mathrm{~Bq} / \mathrm{L}$ (4590 pCi/L) measured on October 29 near Building 343, just to the north of the on-site Tritium Facility. This value is approximately $23 \%$ of the MCL for tritium. The highest off-site activity was $9.3 \mathrm{~Bq} / \mathrm{L}$ (250 pCi/L) recorded in a sample collected from station AQUE on April 18, 1996. This station is east of the former Tritium Research Laboratory at SNL/California and southeast of LLNL's Building 331. 


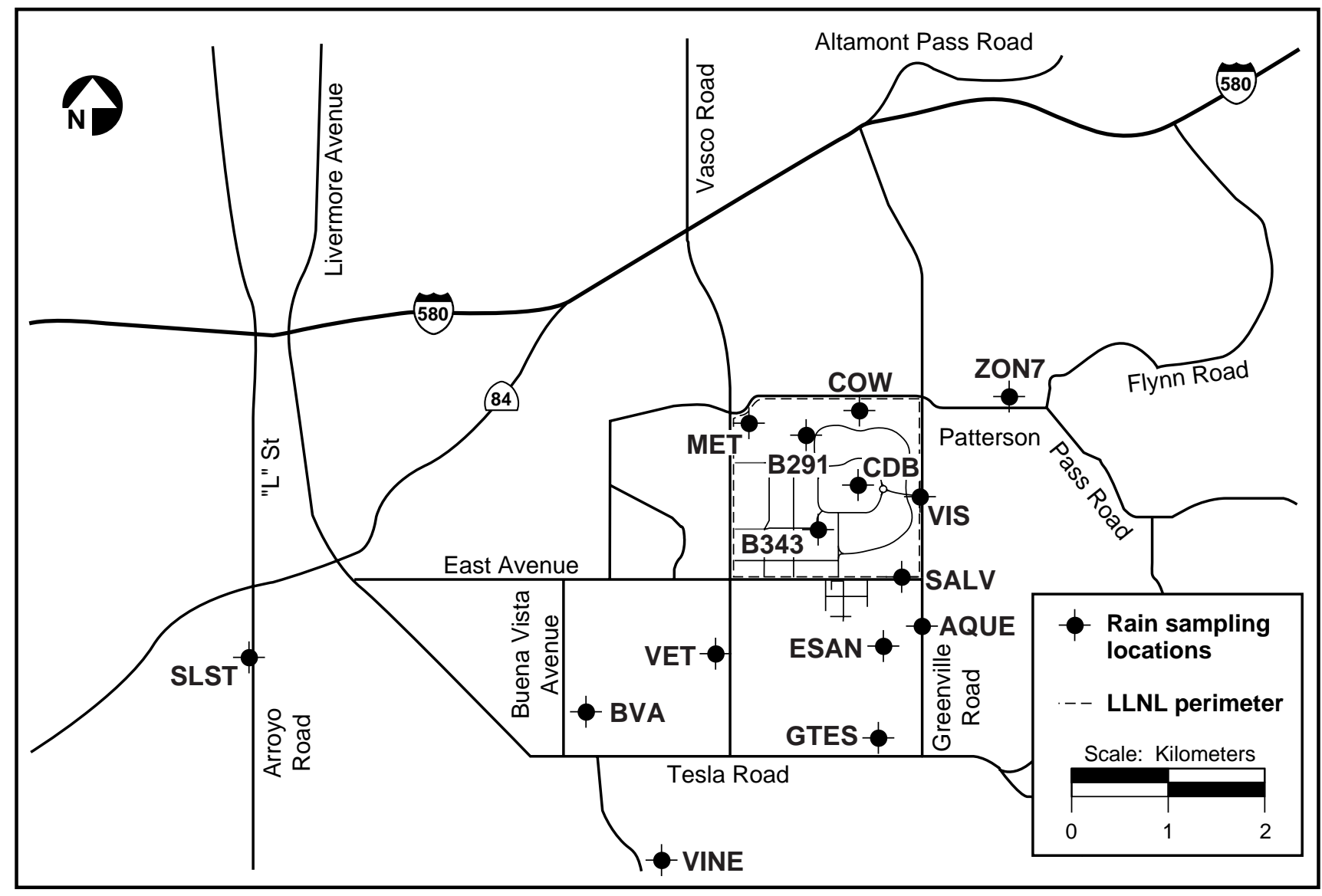

Figure 7-10. Rain sampling locations, Livermore site and Livermore Valley, 1996.

Table 7-6. Tritium activities (in Bq/L) in rainfall for the Livermore site and Livermore Valley.

\begin{tabular}{|l|c|c|c|}
\hline & Livermore site & Livermore Valley & Overall \\
\hline Median & 6.0 & 2.0 & 2.2 \\
Minimum & 1.6 & 1.7 & 1.6 \\
Maximum & 170 & 9.3 & 170 \\
Interquartile range & 9.6 & 0.71 & 4.2 \\
Number of samples & 35 & 40 & 75 \\
\hline
\end{tabular}

Tritium activity in rainfall at the Livermore site has decreased during the past 8 years. This decrease mirrors the downward trend in total HTO emissions from LLNL's Tritium Facility and SNL/California's former Tritium Research Laboratory. These trends are shown in Figure 7-11. Values for median tritium activity are derived from the six on-site rain sampling locations (B343, B291, CDB, SALV, VIS, and COW) that 


\section{Surface Water}

historically have given the highest activities. A nearly five-fold decrease in total HTO emissions has occurred since 1990, down from $34.9 \mathrm{TBq}$ (943 Ci) to 7.0 TBq (190 Ci). This decrease is mirrored by a more than tenfold decrease in median tritium activity measured in rainfall on site at LLNL: down from $65.9 \mathrm{~Bq} / \mathrm{L}(1780 \mathrm{pCi} / \mathrm{L})$ to $6.83 \mathrm{~Bq} / \mathrm{L}$, (185 pCi/L).

Site 300

One central location is used to collect rainfall for tritium activity measurements at LLNL's Experimental Test Site (Site 300) (Figure 7-8). Over the past 24 years, 155 measurements of rainfall samples collected at this location give a maximum tritium activity of only 9.1 Bq/L (250 pCi/L) and median of 2.3 Bq/L (62 pCi/L), with a standard deviation of $2.1 \mathrm{~Bq} / \mathrm{L}(57 \mathrm{pCi} / \mathrm{L})$. The tritium activity measured in rainfall at Site 300 has been indistinguishable from atmospheric background over the past 24 years. Because of a misunderstanding by Site 300 personnel, rain samples were not collected in 1996. Sample collection resumed in 1997.

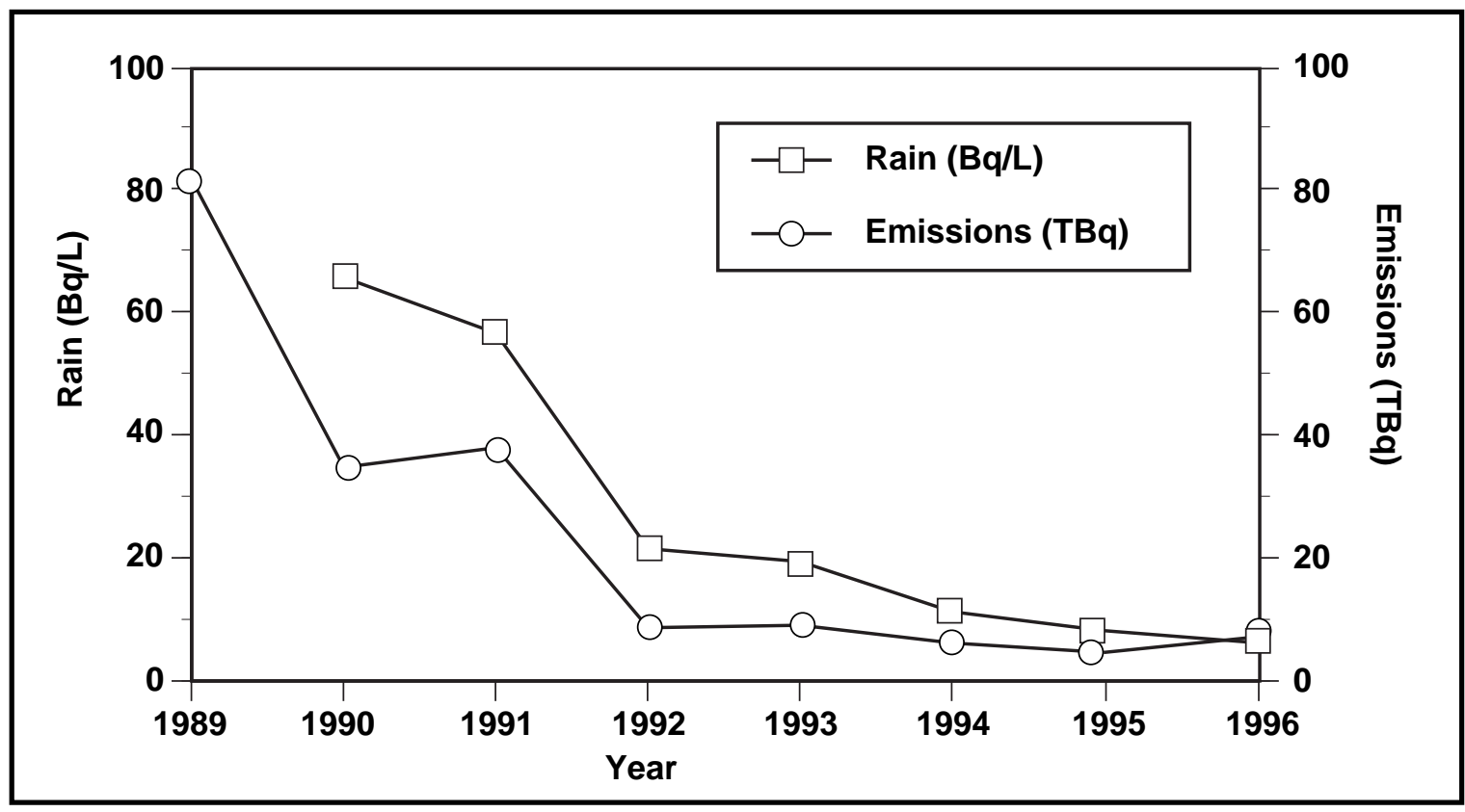

Figure 7-11. Trends of median tritium activity in rain and total stack emissions of HTO from LLNL and SNL/California, 1990 to 1996. (1996 emissions are only LLNL.) 


\section{Surface Water}

\section{Livermore Site Drainage Retention Basin}

The Drainage Retention Basin (DRB) came into being in 1992 when remedial action studies indicated that infiltration of storm water from the existing basin caused increased dispersal of ground water contaminants. Located in the center of the Livermore site, the DRB can hold approximately $53 \mathrm{ML}$ (43 acre-feet) of water.

After the basin was lined in 1992, LLNL adopted the Drainage Retention Basin Management Plan (The Limnion Corporation 1991). The focus of the management plan was to implement a long-term biological monitoring and maintenance program and to address water quality problems by bioremediation and reducing the nutrient load. The management plan identified two water sources to fill and maintain the level of the DRB. The primary water source was intended to be water reclaimed from ground water treatment units and discharged to the basin through the existing storm water collection system or piped directly to the DRB. The secondary water source was intended to be storm water runoff. However, since the start of operation in 1992, storm water runoff has been the primary source of water entering the DRB, with only small amounts of treated ground water being discharged to the DRB. In November 1996, Treatment Facility E began operation and became the first steady source of treated ground water entering the DRB.

The San Francisco Bay RWQCB regulates discharges from the DRB according to the Livermore site CERCLA Record of Decision (ROD) as modified by the letter from the RWQCB to DOE on August 15, 1996. The CERCLA ROD establishes discharge limits for all remedial activities at the Livermore site. In 1992, LLNL developed a sampling program for the DRB, which was approved by the San Francisco Bay RWQCB. The sampling program consists of sampling discharges from the DRB (location CDBX) and the site storm water outfall (location WPDC) during the first release from the DRB and a minimum of one additional storm (chosen in conjunction with storm water runoff monitoring). Sampling locations are shown in Figure 7-1. Samples are taken at CDBX to determine compliance with discharge limits. Sampling at WPDC is done at the direction of the RWQCB to identify any change in water quality as DRB discharges travel through the LLNL storm water drainage system and leave the site. Effluent limits established in the CERCLA ROD and the limits effective August 15, 1996, for discharges from the DRB, applied at CDBX, are found in Table 7-7. 


\section{Surface Water}

Table 7-7. Treated ground water and Drainage Retention Basin discharge limits identified in CERCLA ROD as amended for outfalls CDBX, TFB, TFC, TFD, TFE, TFF, TFG, TF406, and TF518.

\begin{tabular}{|c|c|c|c|}
\hline \multirow[b]{2}{*}{ Constituents } & \multirow{2}{*}{$\begin{array}{l}\text { Discharge limit } \\
\text { Jan-Aug } 1996\end{array}$} & \multicolumn{2}{|c|}{$\begin{array}{l}\text { New discharge limits } \\
\text { effective Aug } 15,1996\end{array}$} \\
\hline & & $\begin{array}{l}\text { Dry season } \\
\text { Apr } 1-\text { Nov } 30\end{array}$ & $\begin{array}{l}\text { Wet season } \\
\text { Dec 1-Mar } 31\end{array}$ \\
\hline \multicolumn{4}{|l|}{ Metals $(\mu \mathbf{g} / \mathbf{L})$} \\
\hline Antimony & 1460 & 6 & not applicable \\
\hline Arsenic & 20 & 50 & 10 \\
\hline Beryllium & 0.7 & 4 & not applicable \\
\hline Boron & 7000 & no change & no change \\
\hline Cadmium & 5 & 5 & 2.2 \\
\hline Chromium (total) & 50 & 50 & not applicable \\
\hline Chromium(VI) & 11 & not applicable & 22 \\
\hline Copper & 20 & 1300 & 23.6 \\
\hline Iron & 3000 & no change & no change \\
\hline Lead & 5.6 & 15 & 6.4 \\
\hline Manganese & 500 & no change & no change \\
\hline Mercury & 1 & 2 & $<1 \mathrm{~g} /$ day \\
\hline Nickel & 7.1 & 320 & 100 \\
\hline Selenium & 100 & 50 & 10 \\
\hline Silver & 2.3 & 100 & 8.2 \\
\hline Thallium & 130 & 2 & not applicable \\
\hline Zinc & 58 & not applicable & 220 \\
\hline \multicolumn{4}{|l|}{ Organics $(\mu \mathbf{g} / \mathbf{L})$} \\
\hline Volatile organic compounds (total) & 5 & no change & no change \\
\hline Benzene & 0.7 & no change & no change \\
\hline Tetrachloroethene & 4 & no change & no change \\
\hline Vinyl chloride & 2 & no change & no change \\
\hline 1,2-Dibromoethane & 0.02 & no change & no change \\
\hline Total petroleum hydrocarbons & 50 & no change & no change \\
\hline Polynuclear aromatic hydrocarbons & 15 & no change & no change \\
\hline $\begin{array}{l}\text { Base/neutral and acid extractable } \\
\text { compounds and pesticides }\end{array}$ & 5 & no change & no change \\
\hline \multicolumn{4}{|l|}{ Physical } \\
\hline $\mathrm{pH}$ & $6.5-8.5$ & no change & no change \\
\hline \multicolumn{4}{|l|}{ Toxicity } \\
\hline Aquatic survival bioassay (96 hours) & $\begin{array}{l}90 \% \text { survival median, } \\
90 \text { percentile value of not } \\
\text { less than } 70 \% \text { survival }\end{array}$ & no change & no change \\
\hline
\end{tabular}


By agreement with the San Francisco Bay RWQCB, every quarter LLNL summarizes weekly, monthly, quarterly, semiannual, and annual monitoring of the basin as specified in the Drainage Retention Basin Management Plan (The Limnion Corporation 1991). Sampling to determine whether water quality management objectives are met is conducted at several points within the DRB. Water at eight locations (Figure 7-12) is sampled for dissolved oxygen and the temperature measured. Because of limited variability among sampling locations, all samples, other than dissolved oxygen and temperature, are routinely collected from CDBE, located at the middle depth of the DRB. The routine management constituents are identified in Table 7-8. This year, LLNL added additional management constituents and increased monitoring frequencies for other constituents to better understand the dynamics within the DRB. Those constituents added or frequencies changed are highlighted in bold text within

Table 7-8.

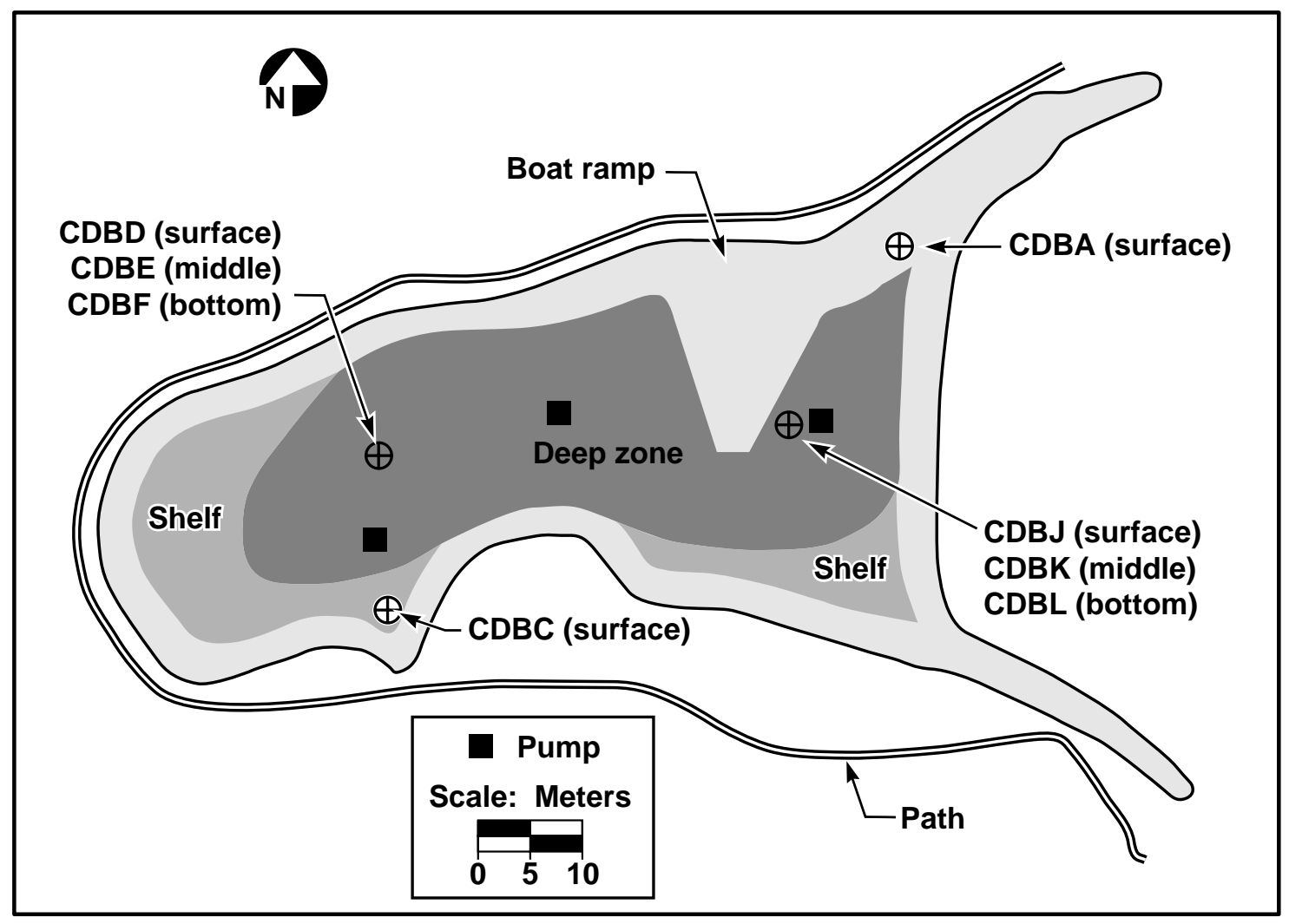

Figure 7-12. Sampling locations within the Drainage Retention Basin, 1996. 


\section{Surface Water}

Table 7-8. Routine water quality management levels for the Drainage Retention Basin. Constituents added or frequencies changed are displayed in bold-face type.

\begin{tabular}{|c|c|c|c|c|c|}
\hline \multirow[b]{2}{*}{ Constituents } & \multirow[b]{2}{*}{ Location } & \multirow[b]{2}{*}{ Frequency } & \multirow{2}{*}{$\begin{array}{c}\text { Management } \\
\text { action levels } \\
\text { Jan- } \\
\text { Aug } 1996 \\
\end{array}$} & \multicolumn{2}{|c|}{$\begin{array}{l}\text { New discharge limits } \\
\text { effective Aug 15, } 1996\end{array}$} \\
\hline & & & & $\begin{array}{c}\text { Dry season } \\
\text { Apr } 1-\text { Nov } 30\end{array}$ & $\begin{array}{l}\text { Wet season } \\
\text { Dec 1-Mar } 31\end{array}$ \\
\hline \multicolumn{6}{|l|}{ Physical } \\
\hline Dissolved oxygen (mg/L) & $\begin{array}{l}\text { CDBA, CDBC, } \\
\text { CDBD, CDBE, } \\
\text { CDBF, CDFJ, } \\
\text { CDBK, CDBL }\end{array}$ & Weekly & $\begin{array}{c}<80 \% \\
\text { saturation }\end{array}$ & no change & no change \\
\hline Temperature $\left({ }^{\circ} \mathrm{C}\right)$ & $\begin{array}{l}\text { CDBA, CDBC, } \\
\text { CDBD, CDBE, } \\
\text { CDBF, CDFJ, } \\
\text { CDBK, CDBL }\end{array}$ & Weekly & $<15$ and $>26$ & no change & no change \\
\hline $\begin{array}{l}\text { Total alkalinity }\left(\text { as } \mathrm{CaCO}_{3}\right) \\
(\mathrm{mg} / \mathrm{L})\end{array}$ & CDBE & Monthly & $<50$ & no change & no change \\
\hline Chlorophyll-a (mg/L) & CDBE & Monthly & $>10$ & no change & no change \\
\hline $\mathrm{pH}$ & $\begin{array}{l}\text { CDBA, CDBC, } \\
\text { CDBD, CDBE, } \\
\text { CDBF, CDFJ, } \\
\text { CDBK, CDBL }\end{array}$ & Weekly & $<6.0$ and $>9.0$ & no change & no change \\
\hline Total suspended solids (mg/L) & CDBE & Monthly & none & no change & no change \\
\hline Total dissolved solids (mg/L) & CDBE & Monthly & $>350$ & no change & no change \\
\hline Turbidity (m) & CDBE & Monthly & $<0.914$ & no change & no change \\
\hline $\begin{array}{l}\text { Chemical oxygen demand } \\
(\mathrm{mg} / \mathrm{L})\end{array}$ & CDBE & Quarterly & $>20$ & no change & no change \\
\hline Oil and grease $(\mathrm{mg} / \mathrm{L})$ & CDBE & Quarterly & $>15$ & no change & no change \\
\hline Conductivity ( $\mu \mathrm{mho} / \mathrm{cm})$ & CDBE & Monthly & $>900$ & no change & no change \\
\hline \multicolumn{6}{|l|}{ Nutrients (mg/L) } \\
\hline Nitrate & CDBE & Monthly & $>0.2$ & no change & no change \\
\hline Nitrite & CDBE & Monthly & $>0.2$ & no change & no change \\
\hline Ammonia nitrogen & CDBE & Monthly & $>0.1$ & no change & no change \\
\hline Phosphate (as phosphorous) & CDBE & Monthly & $>0.02$ & no change & no change \\
\hline \multicolumn{6}{|l|}{ Microbiological (MPN $(\mathrm{a}) / 0.1 \mathrm{~L})$} \\
\hline Total coliform & CDBE & Quarterly & $>5000$ & no change & no change \\
\hline Fecal coliform & CDBE & Quarterly & $>400$ & no change & no change \\
\hline
\end{tabular}


Table 7-8. Routine water quality management levels for the Drainage Retention Basin Constituents added or frequencies changed are displayed in bold-face type (continued).

\begin{tabular}{|c|c|c|c|c|c|}
\hline \multirow[b]{2}{*}{ Constituents } & \multirow[b]{2}{*}{ Location } & \multirow[b]{2}{*}{ Frequency } & \multirow{2}{*}{$\begin{array}{c}\text { Management } \\
\text { action levels } \\
\text { Jan- } \\
\text { Aug } 1996\end{array}$} & \multicolumn{2}{|c|}{$\begin{array}{l}\text { New discharge limits } \\
\text { effective Aug 15, } 1996\end{array}$} \\
\hline & & & & $\begin{array}{c}\text { Dry season } \\
\text { Apr 1-Nov } 30 \\
\end{array}$ & $\begin{array}{c}\text { Wet season } \\
\text { Dec 1-Mar } 31 \\
\end{array}$ \\
\hline \multicolumn{6}{|l|}{ Metals $(\mu \mathbf{g} / \mathbf{L})$} \\
\hline Antimony & CDBE & Monthly & $>1460$ & 6 & not applicable \\
\hline Arsenic & CDBE & Monthly & $>20$ & 50 & 10 \\
\hline Beryllium & CDBE & Monthly & $>0.7$ & 4 & not applicable \\
\hline Boron & CDBE & Monthly & $>7000$ & no change & no change \\
\hline Cadmium & CDBE & Monthly & $>5$ & 5 & 2.2 \\
\hline Chromium, total & CDBE & Monthly & $>50$ & 50 & not applicable \\
\hline Chromium(VI) & CDBE & Monthly & $>11$ & not applicable & 22 \\
\hline Copper & CDBE & Monthly & $>20$ & 1300 & 23.6 \\
\hline Iron & CDBE & Monthly & $>3000$ & no change & no change \\
\hline Lead & CDBE & Monthly & $>2$ & 15 & 6.4 \\
\hline Manganese & CDBE & Monthly & $>500$ & no change & no change \\
\hline Mercury & CDBE & Monthly & $>1$ & 2 & $<1$ g/day \\
\hline Nickel & CDBE & Monthly & $>7.1$ & 320 & 100 \\
\hline Selenium & CDBE & Monthly & $>100$ & 50 & 10 \\
\hline Silver & CDBE & Monthly & $>2.3$ & 100 & 8.2 \\
\hline Thallium & CDBE & Monthly & $>130$ & 2 & not applicable \\
\hline Zinc & CDBE & Monthly & $>58$ & not applicable & 220 \\
\hline \multicolumn{6}{|l|}{ Organics $(\mu \mathbf{g} / \mathbf{L})$} \\
\hline $\begin{array}{l}\text { Total volatile organic } \\
\text { compounds }\end{array}$ & CDBE & Semiannually & $>5$ & no change & no change \\
\hline Benzene & CDBE & Semiannually & $>0.7$ & no change & no change \\
\hline Tetrachloroethene & CDBE & Semiannually & $>4$ & no change & no change \\
\hline Vinyl chloride & CDBE & Semiannually & $>2$ & no change & no change \\
\hline Ethylene dibromide & CDBE & Semiannually & $>0.02$ & no change & no change \\
\hline Total petroleum hydrocarbons & CDBE & Semiannually & $>50$ & no change & no change \\
\hline $\begin{array}{l}\text { Polynuclear aromatic } \\
\text { hydrocarbons }\end{array}$ & CDBE & Semiannually & $>15$ & no change & no change \\
\hline $\begin{array}{l}\text { Base/neutral acid extractable } \\
\text { compounds }\end{array}$ & CDBE & Semiannually & $>5$ & no change & no change \\
\hline Pesticides and herbicides & CDBE & Quarterly & not applicable & not applicable & not applicable \\
\hline
\end{tabular}




\section{Surface Water}

Table 7-8. Routine water quality management levels for the Drainage Retention Basin Constituents added or frequencies changed are displayed in bold-face type (concluded).

\begin{tabular}{|c|c|c|c|c|c|}
\hline \multirow[b]{2}{*}{ Constituents } & \multirow[b]{2}{*}{ Location } & \multirow[b]{2}{*}{ Frequency } & \multirow{2}{*}{$\begin{array}{c}\text { Management } \\
\text { action levels } \\
\text { Jan- } \\
\text { Aug } 1996\end{array}$} & \multicolumn{2}{|c|}{$\begin{array}{l}\text { New discharge limits } \\
\text { effective Aug 15, } 1996\end{array}$} \\
\hline & & & & $\begin{array}{c}\text { Dry season } \\
\text { Apr } 1-\text { Nov } 30\end{array}$ & $\begin{array}{c}\text { Wet season } \\
\text { Dec 1-Mar } 31\end{array}$ \\
\hline \multicolumn{6}{|l|}{ Radiological (pCi/L) } \\
\hline Gross alpha & CDBE & Semiannually & $>15$ & no change & no change \\
\hline Gross beta & CDBE & Semiannually & $>50$ & no change & no change \\
\hline Tritium & CDBE & Semiannually & $>20,000$ & no change & no change \\
\hline \multicolumn{6}{|l|}{ Toxicity (\% survival/96-hour) } \\
\hline $\begin{array}{l}\text { Aquatic bioassay fathead } \\
\text { minnow }\end{array}$ & CDBE & Annually & $\begin{array}{l}90 \% \text { survival } \\
\text { median, } 90 \\
\text { percentile value } \\
\text { of not less than } \\
70 \% \text { survival }\end{array}$ & no change & no change \\
\hline $\begin{array}{l}\text { Chronic bioassay fathead } \\
\text { minnow }\end{array}$ & CDBE & Annually & not applicable & not applicable & not applicable \\
\hline $\begin{array}{l}\text { Chronic bioassay } \\
\text { selanastrum }\end{array}$ & CDBE & Annually & not applicable & not applicable & not applicable \\
\hline
\end{tabular}

a Most probable number.

During 1996, two of the thirteen discharges from the DRB were sampled at CDBX. Both samples exceed the amended discharge limits for iron (Table 7-9). Iron concentrations were also above the DRB discharge limit in samples collected at WPDC, the storm water outflow monitoring location at Arroyo Las Positas. Iron above discharge limits first

Table 7-9. Drainage Retention Basin monitoring event in which the concentration of metals exceeded discharge limits at CDBX shown with associated metal concentration at WPDC. Bold print denotes samples exceeding discharge limits in effect at the time the sample was collected.

\begin{tabular}{|c|c|c|c|c|c|c|c|}
\hline \multirow{3}{*}{$\begin{array}{l}\text { Constituents } \\
(\mu \mathrm{g} / \mathrm{L})\end{array}$} & \multicolumn{4}{|c|}{ Location, result $(\mu \mathrm{g} / \mathrm{L})$} & \multirow{3}{*}{$\begin{array}{c}\text { Discharge } \\
\text { limit } \\
\text { Jan-Aug } \\
1996 \\
(\mu \mathrm{g} / L)\end{array}$} & \multicolumn{2}{|c|}{$\begin{array}{c}\text { New discharge limits effective } \\
\text { August } 15,1996(\mu \mathrm{g} / \mathrm{L})\end{array}$} \\
\hline & \multicolumn{2}{|c|}{ January 16, 1996} & \multicolumn{2}{|c|}{ November 19, 1996} & & Dry & Wet \\
\hline & CDBX & WPDC & CDBX & WPDC & & Apr 1-Nov 30 & Dec 1-Mar 31 \\
\hline Iron & 3200 & 9700 & 3900 & 2900 & 3000 & no change & no change \\
\hline Lead & 4.1 & 7.7 & $<5$ & $<5$ & 5.6 & 15 & 6.4 \\
\hline Nickel & 9.7 & 21 & 13 & $<2$ & 7.1 & 320 & 100 \\
\hline Zinc & 51 & 130 & 110 & 96 & 58 & not applicable & 220 \\
\hline
\end{tabular}


appeared in DRB releases in the December 1995 sample. Previously, in samples of discharges from the DRB collected at CDBX from 1992 through 1994, iron was not present above discharge limits. However, because WPDC storm water includes flow from off site, other on-site locations, and from treatment facilities, data collected at this sampling location are not used to determine compliance with the discharge limits applied to the DRB releases. As stated earlier, WPDC sample are used to determine how the water quality changes as discharges flow through LLNL's storm drainage system before they eventually exit the Livermore site at WPDC.

January discharges from the DRB, which occurred before the implementation of the amended discharge limits, exceeded the discharge limit in effect at that time for nickel. Concurrent samples collected at WPDC exceeded the discharge limits in effect for zinc, lead, and nickel. Samples collected at the WPDC represent a combination of storm water running onto the Livermore site, storm water running off the site, NPDES-permitted treated ground water and process discharges, and the DRB release. Metals concentrations in the sample collected at location WPDC were generally higher than samples collected from the DRB discharge, showing that the presence of these metals at CDBX is consistent with typical storm water runoff from the site.

Samples collected during 1996 within the DRB at sample location CDBE did not meet the management action levels (MALs) as amended by the August 15, 1996, letter for alkalinity, nitrate, nitrite, ammonia, phosphorus, turbidity, temperature, alkalinity, and iron (Table 7-10). Prior to August 15, 1996, samples collected within the DRB at sample location CDBE also exceeded the MALs for arsenic, chromium(VI), lead, nickel, and zinc. No action was taken to adjust nutrient and metals levels. Monitoring frequencies for metals were increased from the required semiannual monitoring to monthly to more closely track concentration changes. Alkalinity monitoring was increased to weekly field measurements to more closely track water quality.

Dissolved oxygen concentrations varied around the MAL of at least $80 \%$ saturation of oxygen in the water. The concentration of dissolved oxygen in the DRB only occasionally dropped below the critical management action level of $5 \mathrm{mg} / \mathrm{L}$, and this was at location CDBL, which is located near the bottom of the DRB. Monthly average dissolved oxygen concentrations (Figure 7-13), however, were all well above $5 \mathrm{mg} / \mathrm{L}$. Dissolved oxygen levels were controlled manually with aeration pumps, which are started whenever oxygen levels at any level of the DRB drop close to or below the critical MAL of $5 \mathrm{mg} / \mathrm{L}$. Typically, these pumps are used continuously through the spring, summer, and fall months. During the winter, the pumps are started as needed. 


\section{Surface Water}

Table 7-10. Results of Drainage Retention Basin monitoring at sampling location CDBE. Events exceeding management action levels are in bold-face type. Discharge limits for some constituents were amended on August 15, 1996.

\begin{tabular}{|c|c|c|c|c|c|c|c|c|c|c|c|c|c|}
\hline Constituents & $\begin{array}{l}\text { Management } \\
\text { action level }\end{array}$ & Jan & Feb & Mar & Apr & May & Jun & Jul & Aug & Sep & Oct & Nov & Dec \\
\hline Temperature $\left({ }^{\circ} \mathrm{C}\right)$ & $\begin{array}{l}<15.6 \\
>26.7\end{array}$ & 11.7 & 16.6 & 13.1 & 16.4 & 19.1 & 22 & 23.7 & 23.4 & 20.7 & 18.8 & 11.2 & 11.5 \\
\hline $\begin{array}{l}\text { Turbidity (secchi } \\
\text { disk) }(m)\end{array}$ & $<0.914$ & 0.401 & 0.178 & 0.146 & 0.184 & 0.275 & 0.411 & 0.36 & 0.347 & 0.389 & 0.406 & 0.347 & 0.474 \\
\hline $\begin{array}{l}\text { Alkalinity (as } \\
\left.\mathrm{CaCo}_{3}\right)(\mathrm{mg} / \mathrm{L})\end{array}$ & $<50$ & 44 & 40 & 29 & 24 & 29 & 38 & 39.2 & 41.3 & 100 & 47.8 & 46.3 & 41.3 \\
\hline $\begin{array}{l}\text { Nitrate (as N) } \\
(\mathrm{mg} / \mathrm{L})\end{array}$ & $\geq 0.2$ & -(a) $^{(\mathrm{a})}$ & - (a) $^{(2)}$ & -(a) & 0.41 & $<0.5$ & $<0.5$ & 0.4 & 0.4 & $<0.5$ & 0.2 & 0.4 & 0.6 \\
\hline Nitrite (as N) (mg/L) & $\geq 0.2$ & $<0.5$ & $<0.5$ & $<0.05$ & $<0.05$ & $<0.5$ & $<0.5$ & $<0.1$ & $<0.1$ & $<0.5$ & $<0.1$ & $<0.1$ & $<0.1$ \\
\hline $\begin{array}{l}\text { Ammonia nitrogen } \\
(\mathrm{mg} / \mathrm{L})\end{array}$ & $>0.1$ & 0.18 & 3.9 & $<0.05$ & $<0.05$ & 0.3 & 0.1 & $<0.5$ & $<0.02$ & 0.2 & $<0.02$ & 0.06 & 0.02 \\
\hline $\begin{array}{l}\text { Phosphate (as P) } \\
(\mathrm{mg} / \mathrm{L})\end{array}$ & $\geq 0.02$ & 0.076 & 0.092 & 0.15 & 0.19 & 0.21 & 0.2 & 0.24 & 0.24 & 0.22 & 0.24 & 0.22 & 0.19 \\
\hline Arsenic $(\mu \mathrm{g} / \mathrm{L})^{(\mathrm{a})}$ & 20 & 3.9 & 21 & $<2$ & $<2$ & 2.7 & 2.1 & 3 & $<2$ & $<2$ & 3.3 & 3.5 & 2.2 \\
\hline $\begin{array}{l}\text { Chromium(VI) } \\
(\mu \mathrm{g} / \mathrm{L})^{(\mathrm{b})}\end{array}$ & 11 & - (c) $^{(1)}$ & -(c) $^{(\mathrm{c})}$ & $<2$ & $<2$ & 2 & 12 & $<2$ & $<2$ & 2 & 2 & $>2$ & $<2$ \\
\hline Iron $(\mu \mathrm{g} / \mathrm{L})$ & $>3000$ & 2100 & 6000 & 10000 & 5100 & 4400 & 4500 & 4080 & 3460 & 3900 & 3200 & 2390 & 2300 \\
\hline Lead $(\mu \mathrm{g} / \mathrm{L})^{(\mathrm{d})}$ & $>2$ & 2.6 & 3.4 & 3 & $<2$ & 2.8 & 2.7 & $<5$ & $<5$ & 4.2 & $<5$ & $<5$ & $<5$ \\
\hline Nickel $(\mu \mathrm{g} / \mathrm{L})^{(\mathrm{e})}$ & $>7.1$ & 7.7 & 16 & 18 & 13 & 8.7 & 12 & 10 & 12 & 10 & 22 & 8 & 7 \\
\hline $\operatorname{Zinc}(\mu \mathrm{g} / \mathrm{L})^{(\mathrm{f})}$ & $>58$ & 47 & 58 & 70 & 50 & 54 & 49 & 66 & 62 & $<20$ & 41 & 63 & 47 \\
\hline
\end{tabular}

a Discharge limit amended to $50 \mu \mathrm{g} / \mathrm{L}$ for wet season and $10 \mu \mathrm{g} / \mathrm{L}$ for dry season.

b Discharge limit amended to $22 \mu \mathrm{g} / \mathrm{L}$ for dry season.

c Not measured.

d Discharge limit amended to $15 \mu \mathrm{g} / \mathrm{L}$ for wet season and $16.4 \mu \mathrm{g} / \mathrm{L}$ for dry season.

e Discharge limit amended to $100 \mu \mathrm{g} / \mathrm{L}$ for wet season and $320 \mu \mathrm{g} / \mathrm{L}$ for dry season.

f Discharge limit amended to $220 \mu \mathrm{g} / \mathrm{L}$ for dry season.

Pump operation is probably responsible for the relatively uniform distribution of dissolved oxygen at the surface, middle, and bottom elevations seen throughout the 3 years of DRB operation. Adequate dissolved-oxygen levels prevent nutrient release back into the DRB water column by decaying organic matter in the bottom sediments. Temperature, the other important parameter in determining how much oxygen is dissolved in water, showed characteristic seasonal trends. The uniform distribution of temperature in the top, middle, and bottom elevations also reflects the uniform mixing achieved by the operation of the pumps. Without mixing, the water temperature would be expected to show seasonal stratification in addition to the changes in temperature with depth. 


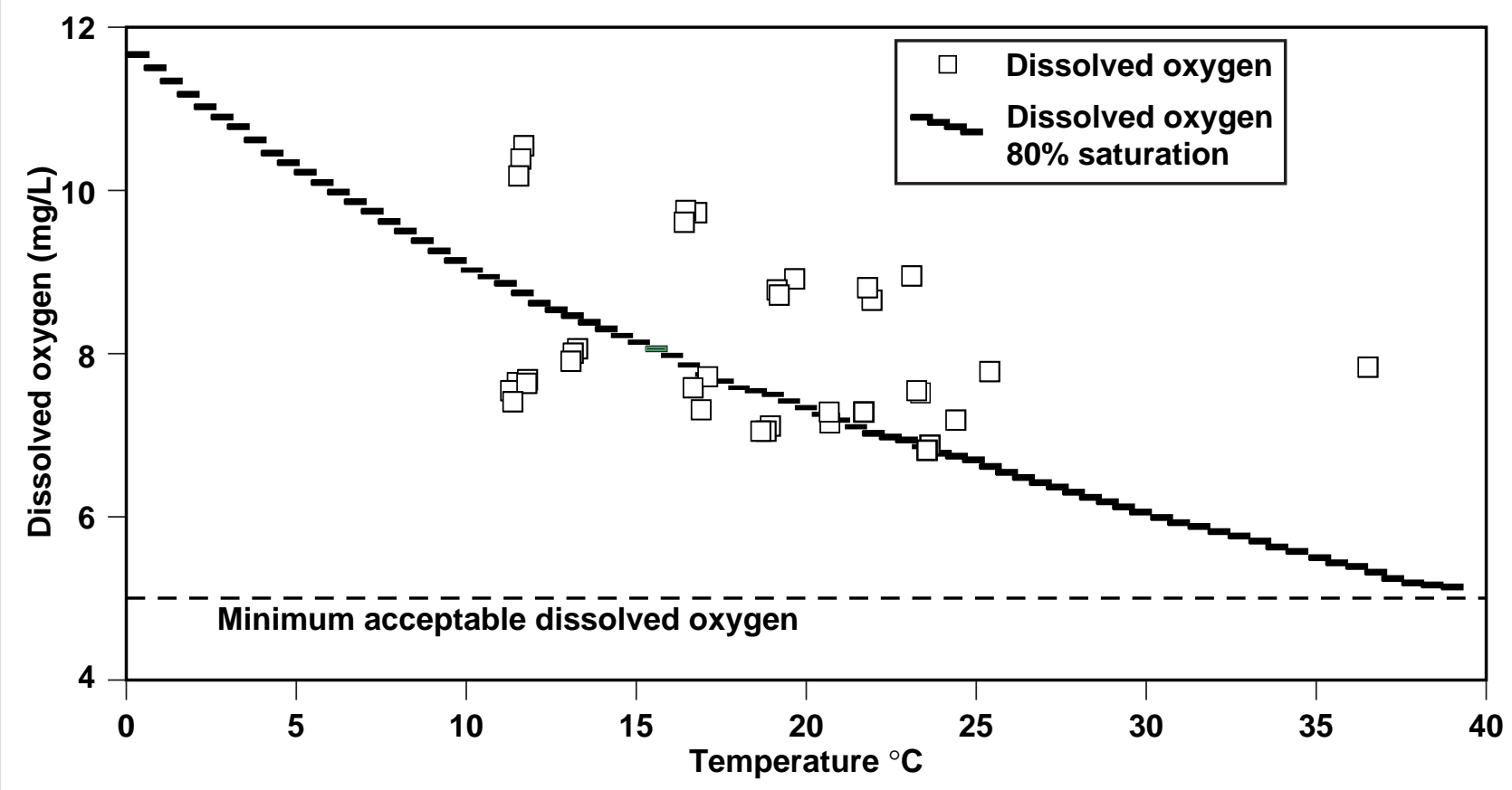

Figure 7-13. Monthly average dissolved oxygen vs temperature at each depth location in the Drainage Retention Basin from January through December 1996.

Turbidity rose above acceptable management levels during the 1993-1994 wet season, and throughout 1994 and 1995. Wet season turbidity probably results from sediments that pass through the sediment traps discharging into the DRB. Turbidity seen during the warmer summer months of 1994 was most likely the result of algae growth (Harrach et al. 1996). This was confirmed by high chlorophyll-a values and visual observations during the 1994 summer months. However, during 1995, though turbidity continued to be high, chlorophyll-a values were just above detection, indicating very little algae growth. This relationship continued through 1996 with visual observations made during sampling events, confirming that there was little or no algae growth. In January 1995, total alkalinity dropped below the MAL for the first time since June 1993 and continued mostly below the MAL throughout 1995 and 1996. Turbidity, alkalinity, and chlorophyll-a collected at sample location CDBE vary together, indicating that the chlorophyll-a varies with these two parameters (Figure 7-14). 


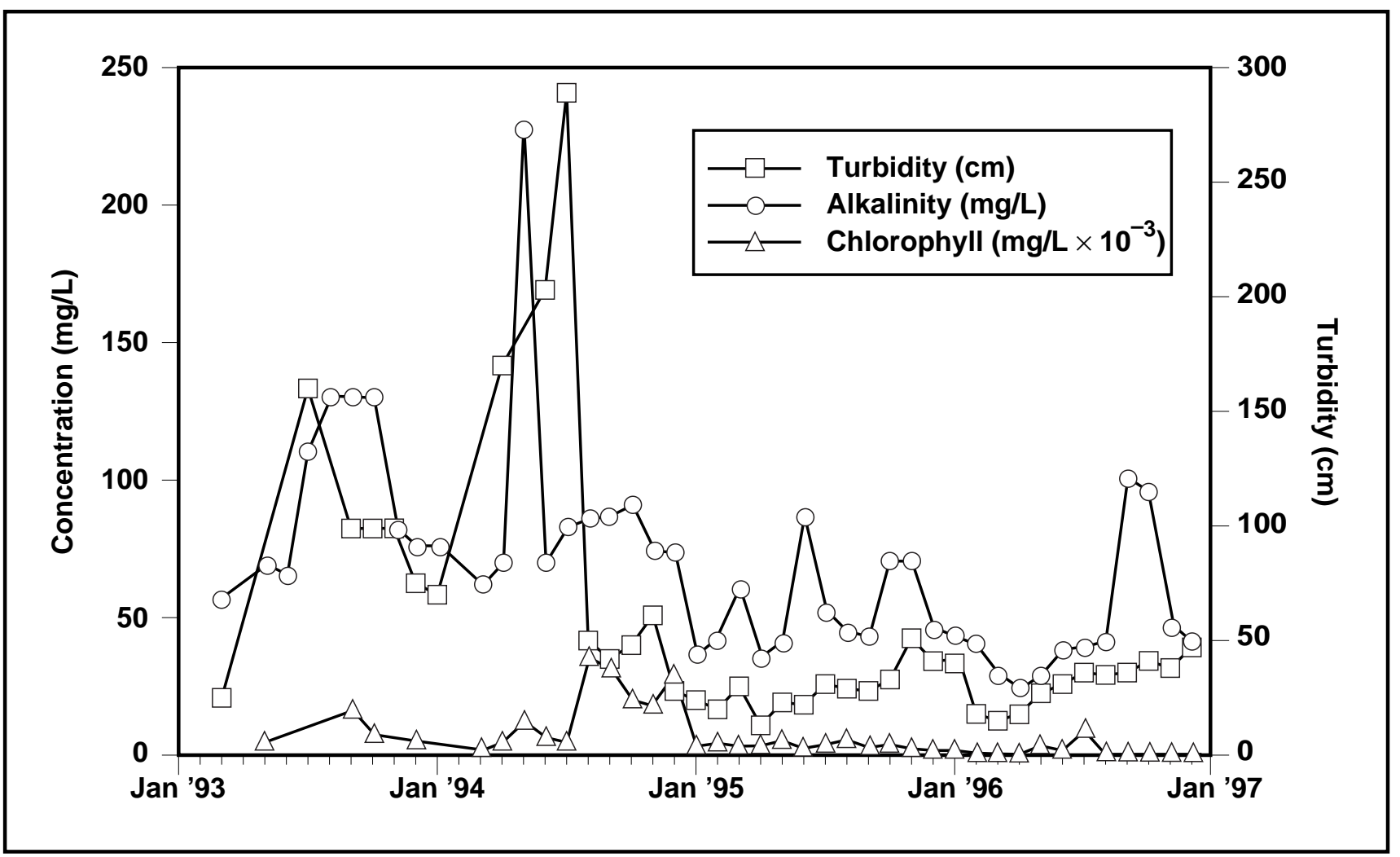

Figure 7-14. Correlation between concentration of chlorophyll-a and turbidity and alkalinity at monitoring point CDBE.

During September 1996, LLNL again conducted chronic toxicity tests on algae and fish to determine if the lack of algae growth was due to something other than the high turbidity, which would reduce light penetration in the water and limit the size of the photic zone where plant growth could occur. The results of the test using algae, Selanastrum capricornutum, indicated that algae growth in DRB water was actually enhanced above the control sample, a result that was different from the 1995 tests showing algae growth inhibition in the DRB sample. This test also was inconsistent with the chlorophyll-a results and visual observations, which indicated that the DRB water did not have a growth-enhancing affect on the algae. It is possible that the main cause of the reduced algae in the DRB in the fall of 1996 was the turbidity. The test using fathead minnow, Pimephales promelas, showed no chronic toxicity in 100\% DRB water.

LLNL is continuing to study the cause of the low algae growth within the DRB as well as investigating a means to remove the turbidity, increase the alkalinity of the DRB water, and establish a viable plant community within the DRB. 
LLNL began monitoring the flow discharging from the DRB in 1996 (see Figure 7-15). Discharges from the DRB occur during storm events and trail off as runoff enters and exits the DRB. Because storm water runoff accounts for the majority of the water entering the DRB, discharges occur only in the wet season, and all discharged water is associated with storm events. The volume of flow into the DRB from the only other contributing source, Treatment Facility E discharges, though continuous through the year is not enough to result in dry season discharges. A total of 105.8 ML (28 million gal) of water was discharged from the DRB in the months of January, February, March, May, November, and December. The largest single discharge occurred on December 21, 1996, when 13.6 ML (3.6 million gal) was released. Mass loadings can be determined for discharges from the DRB now that flow data is available. The data show that the total mass of metals and organics released from the DRB is small.

Data for maintenance monitoring at sampling locations CDBE , CDBX, and CDBA through $\mathrm{L}$ and for WPDC samples collected concurrent with DRB releases are presented in Tables 7-3, 7-4, and 7-5 in Volume 2.

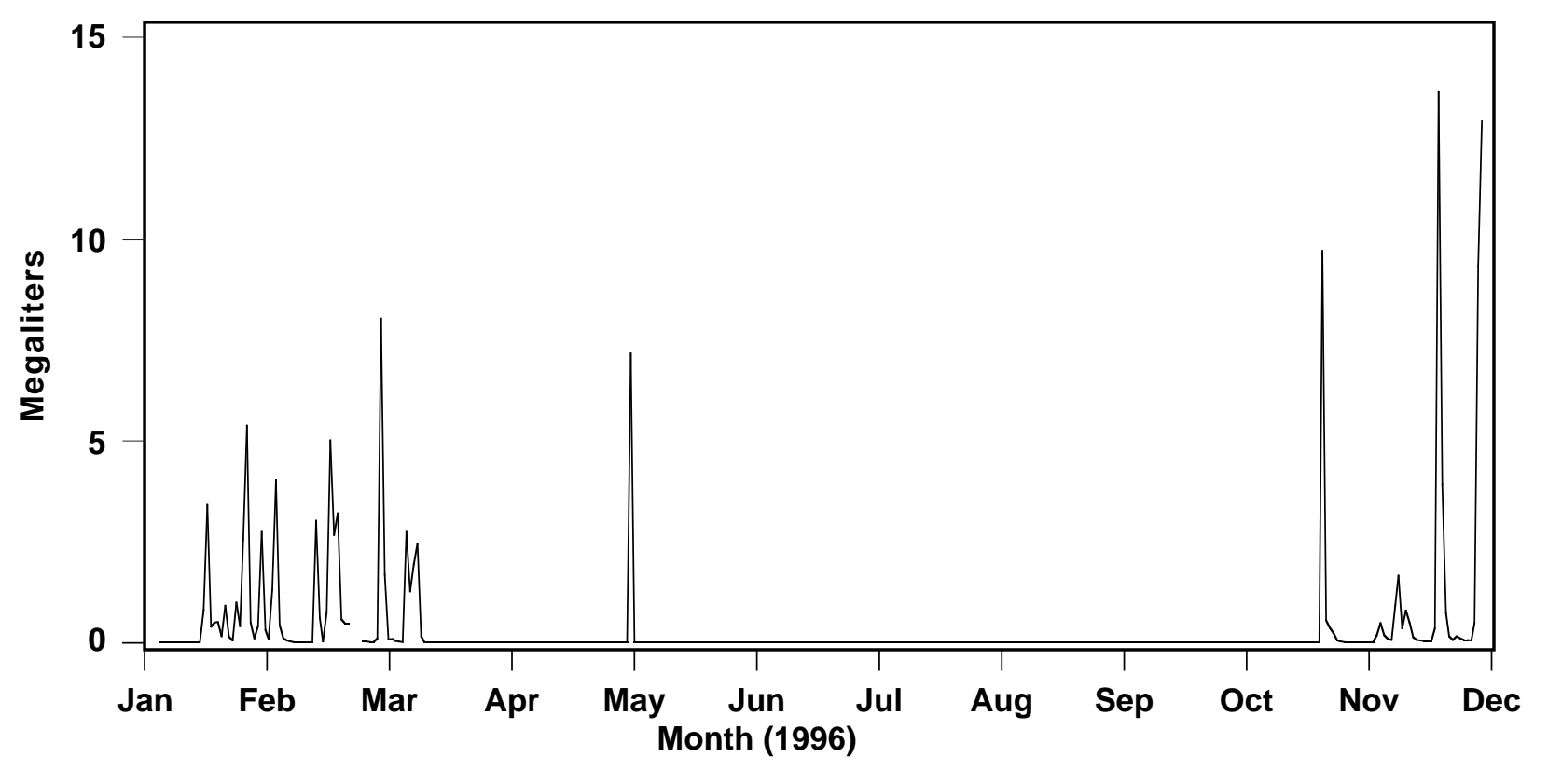

Figure 7-15. Water discharged from the Drainage Retention Basin in 1996. 


\section{Surface Water}

\section{Treatment Facilities}

The Livermore Site Ground Water Project (GWP) complies with provisions specified in a federal facility agreement (FFA) and in the CERCLA ROD entered into by the Environmental Protection Agency (EPA), DOE, the California EPA's Department of Toxic Substances Control (DTSC), and the San Francisco Bay Regional Water Quality Control Board (RWQCB). As required by the agreement, the project addresses compliance issues through investigations of potential contamination source areas (such as suspected old release sites, solvent handling areas, and leaking underground tank systems), continued monitoring of ground water, and remediation. The ground water constituents of concern are volatile organic compounds (VOCs), primarily trichloroethylene (TCE) and tetrachloroethylene (PCE). The primary treatment technology employed at the Livermore site to remediate contaminated ground water is ground water pump-and-treat. This technology employs a dense network of ground water extraction wells, monitoring wells, pipelines, and surface treatment facilities. At Site 300, ongoing remedial investigations, feasibility studies, engineering evaluation and cost analyses, and remedial actions are being performed by the Environmental Restoration Program and Division. Site 300 investigations and remedial actions are conducted under the joint oversight of the EPA, Central Valley RWQCB, and DTSC and the authority of an FFA for the site. (There are separate agreements for Site 300 and the Livermore site.) Similar pump-and-treat technology is utilized in the General Services Area of Site 300. Treatment facility operations and ground water extraction and cleanup activities that involve discharges to the surface are discussed in this section.

\section{Livermore Site}

Treatment Facility B (TFB). Treatment Facility B (TFB) is located along Vasco Road just north of Mesquite Way (Figure 7-16). TFB processes ground water contaminated with chromium and VOCs using a combination of $\mathrm{UV} / \mathrm{H}_{2} \mathrm{O}_{2}$ treatment and air-stripping technologies. TFB's treated waters are discharged into a drainage ditch at the west perimeter of the site that feeds into Arroyo Las Positas. TFB treated about $57 \mathrm{ML}$ of ground water in 1996, removing and destroying approximately $7.7 \mathrm{~kg}$ of VOCs. Between system startup in 1990 and 1996, TFB processed 180 ML of ground water and removed about $20.1 \mathrm{~kg}$ of VOCs from the subsurface.

Self-monitoring analytical results of TFB effluent samples indicate that the VOC discharge limit of $5 \mathrm{ppb}$ was not exceeded. Chromium(VI) is removed by reducing it with hydrogen peroxide, under controlled pH, to chromium(III). During part of 1996, water discharged from TFB contained chromium(VI) slightly in excess of the 0.011 parts per million discharge limit. Beginning in mid-July 1996, adjustments were made to the treatment process ( $\mathrm{pH}$ and hydrogen peroxide concentration) that reduced the chromium(VI) to less than the discharge limit. The exceedances were reported to and discussed with the regulatory agencies (USEPA, California DTSC, and California 


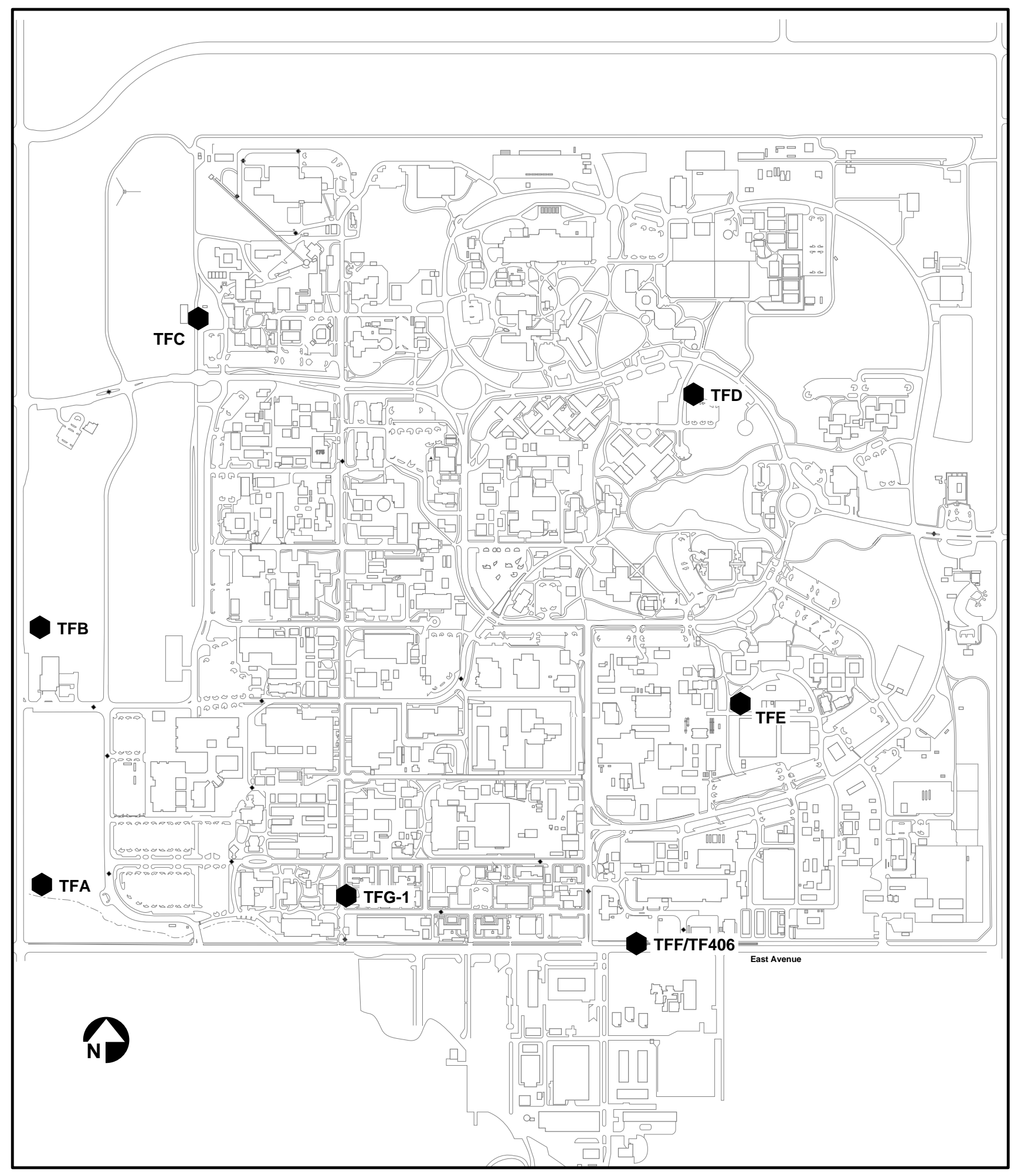

Figure 7-16. Location of water treatment facilities. 


\section{Surface Water}

RWQCB) at regularly scheduled CERCLA monthly Remedial Project Managers' meetings and documented in the minutes of those meetings. LLNL conducted samplings at TFB in accordance with the CERCLA ROD as amended (Table 7-7).

Treatment Facility C. Treatment Facility C (TFC) is located in the northwest quadrant of LLNL and uses air-stripping and ion-exchange technologies to process ground water contaminated with VOCs and chromium (Figure 7-16). In 1996, a total of $7.7 \mathrm{~kg}$ of VOCs was removed from approximately $57 \mathrm{ML}$ of ground water treated at TFC. Between system startup in October 1993 and 1996, TFC processed about 181.7 ML of ground water and removed about $20.1 \mathrm{~kg}$ of VOCs. The treated water from TFC is discharged into Arroyo Las Positas.

LLNL conducted samplings at TFC in compliance with the modified CERCLA ROD (Table 7-7). The self-monitoring analytical results of TFC effluent samples indicate that the VOC discharge limit of 5 ppb was not exceeded during 1996. All regulated metals parameters were below discharge limits designated in the CERCLA ROD as amended.

Treatment Facility D. Treatment Facility D (TFD) is located in the northeast quadrant of LLNL and uses air-stripping and ion-exchange technologies to process contaminated ground water (Figure 7-16). TFD was activated on July 14, 1994, and began operating on September 15, 1994. Since startup, TFD has processed nearly 49.2 ML of ground water and removed about $18 \mathrm{~kg}$ of VOC mass from the subsurface. In 1996, TFD processed about $41 \mathrm{ML}$ of ground water containing about $12.1 \mathrm{~kg}$ of VOCs. The treated water was discharged to a storm water drainage channel discharging into Arroyo Las Positas.

LLNL conducted samplings at TFD in compliance with the modified CERCLA ROD. The self-monitoring analytical results of TFD effluent samples indicated that metals and VOCs were within compliance discharge limits during 1996.

Treatment Facility E. Treatment Facility E (TFE) is located in the southeast quadrant of the Livermore site and will consist of multiple portable treatment units (PTUs) that use air stripping to treat ground water (Figure 7-16). The TFE East PTU was activated on November 25, 1996. Wells W-566 and W-1109 supplied $77 \mathrm{~L} / \mathrm{min}$ of ground water to the treatment facility, which operated for 6 hours each working day (Monday through Friday) during the first 2 weeks. From that point on, TFE East began operating 24 hours a day. Wells W-1109 and W-566 produce about 19 and $57 \mathrm{~L} / \mathrm{min}$ ground water from hydrostratigraphic units (HSUs) 2 and 5, respectively.

TFE East PTU processed about 1.9 ML of ground water through the end of 1996, and removed an estimated $0.8 \mathrm{~kg}$ of VOC mass from the subsurface. Water treated at TFE East is discharged to a north-flowing drainage ditch that ultimately empties into the 
Drainage Retention Basin. This requires compliance with regulatory requirements as set out in Table 7-7. During 1996, TFE was in compliance with the amended CERCLA ROD.

Treatment Facility F (TFF). TFF was located in the southeastern part of the Livermore site in the TF406 area (Figure 7-16), where hydrostratigraphic units 2,3A, and 3B had been impacted by a fuel hydrocarbon (FHC) spill (Dresen et al. 1986). Prior to remediation, significant FHC concentrations existed in both the unsaturated and saturated zones. Currently, low concentrations of VOCs exist in the FHC ground water plume beneath the TF406 area.

During 1996, passive bioremediation was implemented in the TFF area, which resulted in the permanent discontinuation of ground water extraction and treatment for residual dissolved FHCs from HSUs 3A and 3B. Before its permanent shutdown, TFF operation was interrupted for 194 days as a result of storm damage that occurred on December 8, 1995. During June 1996, ground water was extracted and treated at TFF for a total of 6 hours to evaluate FHC concentrations in ground water extracted from HSU 3B well GEW-816. No rebound of FHC concentrations was observed in ground water from GEW-816. Following submittal of Application for Containment Zone for the Livermore Site Hydrocarbon Impacted Zone at Treatment Facility F (Happel et al. 1996), "No Further Action" status was granted by the regulatory agencies on October 30, 1996 (SFBRWQCB 1996). As part of the terms of this agreement, HSU 3 wells in this area will be sampled and analyzed for FHCs on a semiannual basis.

Since the facility did not discharge to the surface during the 1996 period, there were no surface water compliance issues.

Treatment Facility 406 (TF406). Located in the southeastern part of the Livermore site (Figure 7-16), TF406 consists of a PTU that uses air stripping to treat ground water. TF406 is designed to treat VOCs extracted from HSUs 4 and 5 beneath the former TFF area.

TF406 began operating on August 27, 1996. TF406 processes ground water extracted from Well W-1114, which is positioned to clean up and hydraulically control a TCE plume in HSU 5. In the spring of 1997, LLNL plans to start treating ground water from HSU 4 extraction Well GSW-445.

During 1996, TF406 processed about 1.5 ML of ground water from Well W-1114 at flow rates between 38 and $60 \mathrm{~L} / \mathrm{min}$. The total VOC mass removed during 1996 was about $0.2 \mathrm{~kg}$. All treated ground water was discharged to a storm drain that leads to Arroyo Las Positas. There were no compliance violations associated with this discharge during 1996. 


\section{Surface Water}

Treatment Facility G (TFG-1). Treatment Facility G-1 (TFG-1) is located about $90 \mathrm{~m}$ (300 ft) north of East Avenue in the south-central part of the Livermore site (Figure 7-16). TFG-1 consists of a PTU that utilizes air stripping and ion exchange to treat ground water from HSU 2 extraction well W-1111.

During 1996, TFG-1 processed about 3.4 ML of ground water at an average flow rate of $30 \mathrm{~L} / \mathrm{min}$. TFG-1 has removed an estimated $0.2 \mathrm{~kg}$ of VOCs since operation began on April 11, 1996. All treated ground water has been discharged to a storm drain located about 15 m north of TFG-1, which empties into Arroyo Seco. There were no compliance violations associated with this discharge during 1996.

\section{Site 300}

\section{General Services Area}

The central GSA ground water treatment system is operating under Substantive Requirements for wastewater discharge issued by the Central Valley RWQCB. The central GSA treatment facility discharges to bedrock in the eastern GSA canyon, where the water percolates to the surface. The eastern GSA ground water treatment system operates under NPDES permit No. CA0082651, WDR 91-052 issued by the Central Valley RWQCB for discharges into Corral Hollow Creek. Effluent limitations for the central and eastern GSA ground water treatment system are listed in Table 7-11. Both the central and eastern GSA treatment systems operated in compliance with regulatory requirements during 1996. The GSA operable unit is located in the southeastern corner of Site 300. Since 1982, LLNL has conducted an intensive investigation in the GSA and off-site areas to locate VOC release points and to define the vertical and horizontal distribution of VOCs, primarily TCE and PCE, in the soil, rock, and ground water. According to the Final Site-Wide Remedial Investigation (Webster-Scholten 1994) and Draft Remedial Investigation (McIlvride et al. 1990) reports, VOCs in excess of drinking water MCLs have been identified in the shallow ground water beneath the GSA in two localities. Two small VOC plumes occur in the central GSA portion of the operable unit, and one VOC plume occurs in the eastern GSA section in the gravels of Corral Hollow Creek.

An air-sparging ground water treatment unit that removes VOCs from the eastern GSA ground water began operation in June 1991 as a CERCLA Removal Action and has been operated throughout 1996. The total volume of water treated here through December 1996 was about $300 \mathrm{ML} ; 4.6 \mathrm{~kg}$ of VOCs were removed from the water. The treated ground water was discharged off site to the Corral Hollow Stream Channel, in accordance with WDR Order No. 91-052, NPDES Permit No. CA0082651. 
Table 7-11. General Services Area ground water treatment system surface discharge effluent limitations.

\begin{tabular}{|c|c|c|}
\hline \multirow[b]{2}{*}{ Parameter } & \multicolumn{2}{|c|}{ Treatment facility } \\
\hline & Central General Services Area & Eastern General Services Area \\
\hline VOCs & Halogenated and aromatic VOCs & Halogenated VOCs \\
\hline Maximum daily & $5.0 \mu \mathrm{g} / \mathrm{L}$ & $5.0 \mu \mathrm{g} / \mathrm{L}$ \\
\hline Monthly median & $0.5 \mu \mathrm{g} / \mathrm{L}$ & $0.5 \mu \mathrm{g} / \mathrm{L}$ \\
\hline pH & $\begin{array}{l}\text { Between } 6.5 \text { and } 8.5 \text {, no receiving water } \\
\text { alteration greater than } \pm 0.5 \text { units }\end{array}$ & $\begin{array}{l}\text { Between } 6.5 \text { and } 8.5 \text {, no receiving water } \\
\text { alteration greater than } \pm 0.5 \text { units }\end{array}$ \\
\hline Temperature & $\begin{array}{l}\text { No alteration of ambient receiving water } \\
\text { conditions more than } 3^{\circ} \mathrm{C}\end{array}$ & $\begin{array}{l}\text { No alteration of ambient receiving water } \\
\text { conditions more than } 3^{\circ} \mathrm{C}\end{array}$ \\
\hline Mineralization & $\begin{array}{l}\text { Mineralization must be controlled to no } \\
\text { more than a reasonable increment }\end{array}$ & $\begin{array}{l}\text { Mineralization must be controlled to no } \\
\text { more than a reasonable increment }\end{array}$ \\
\hline $\begin{array}{l}\text { Methods and detection limits for } \\
\text { VOCs }\end{array}$ & $\begin{array}{l}\text { EPA Method } 601-\text { method detection limit } \\
\text { of } 0.5 \mu \mathrm{g} / \mathrm{L} \\
\text { EPA Method } 602-\text { method detection limit } \\
\text { of } 0.3 \mu \mathrm{g} / \mathrm{L}\end{array}$ & $\begin{array}{l}\text { EPA Method } 601-\text { method detection limit } \\
\text { of } 0.5 \mu \mathrm{g} / \mathrm{L}\end{array}$ \\
\hline
\end{tabular}

During 1996, the air sparging treatment system used to treat ground water in the eastern GSA was replaced by aqueous-phase carbon adsorption treatment units. The aqueousphase carbon adsorption units are less complex in both design and operation than air sparging technology and will incur lower operation and maintenance costs. Before cleanup was initiated, the portion of the plume with TCE concentrations in excess of the MCL ( $5 \mu \mathrm{g} / \mathrm{L})$ extended about $1400 \mathrm{~m}$ off site; it now extends only $60 \mathrm{~m}$ off site. LLNL estimates that 9 more years of ground water extraction and treatment will be required to achieve and maintain ground water VOC concentrations below MCLs at the eastern GSA.

The two VOC ground water plumes in the central GSA are present in alluvium and shallow bedrock and in deeper bedrock. Construction of an air-sparging ground water treatment system and vapor extraction and treatment unit for a CERCLA Removal Action to remove VOCs from the central GSA ground water and soil vapor was completed in 1993. During 1993, ground water extraction and treatment began. From 1993 through the end of 1996, about 2.6 ML of ground water containing $4.5 \mathrm{~kg}$ of VOCs was treated. The treated ground water was collected and batch discharged in a remote 


\section{Surface Water}

Site 300 canyon, in accordance with the Substantive Requirement for wastewater discharge. Following dewatering of bedrock through ground water extraction, soil vapor extraction and treatment of VOCs began in 1994. From 1994 through the end of 1996 , soil vapor was treated with carbon adsorption to remove $29.6 \mathrm{~kg}$ of VOCs. By 1996, VOC concentrations in soil vapor pumped from the central GSA soil vapor extraction (SVE) wells had been reduced from a historical high of $450 \mathrm{ppm}$ to less than 5 ppm (based on volume). Because VOC concentrations had been level at about 2 ppm for approximately one year, the SVE system was shut off to determine if VOC concentrations in soil vapor would increase or "rebound" during the shutdown period.

LLNL estimates that an additional 9 years of soil vapor extraction and 54 years of ground water extraction are required to achieve and maintain ground water VOC concentrations below MCLs at the central GSA.

The Draft Final and Final Proposed Plan for the General Services Area Operable Unit (LLNL $1996 \mathrm{~b}$ and c) were submitted to the regulatory agencies on February 15 and March 15, 1996, respectively, and describe the proposed remedial strategies for public evaluation. A Public Meeting was held on April 24, 1996, to provide a forum for public comment on the proposed remedial strategy (continued pump-and-treat) for the General Services Area operable unit. The Draft and Draft Final Records of Decision for the General Services Area Operable Unit (LLNL, 1996d and e) were submitted to the regulatory agencies on July 19 and December 1, 1996, respectively, and document the agreed remedial action.

\section{Cooling Towers}

LLNL samples cooling-tower wastewater discharges as required by the Self-Monitoring Program of WDR 94-131, NPDES permit CA0081396, and reports the results of the compliance sampling to the Central Valley Regional Water Quality Control Board (CVRWQCB) quarterly.

The cooling towers, used to cool buildings and equipment at Site 300, discharge noncontact cooling water to man-made and natural drainage courses (Figure 7-17). These drainage courses flow into Corral Hollow Creek, a tributary of the San Joaquin River.

WDR 94-131 establishes effluent limits for three parameters: (1) daily flow must not exceed the maximum design flow; (2) total dissolved solids (TDS) must not exceed a monthly average of $2000 \mathrm{mg} / \mathrm{L}$ or a maximum daily limitation of $2400 \mathrm{mg} / \mathrm{L}$; and (3) $\mathrm{pH}$ must not exceed 10. Along with effluent monitoring, when Corral Hollow Creek is flowing, the permit requires LLNL to collect $\mathrm{pH}$ samples upstream and downstream of 


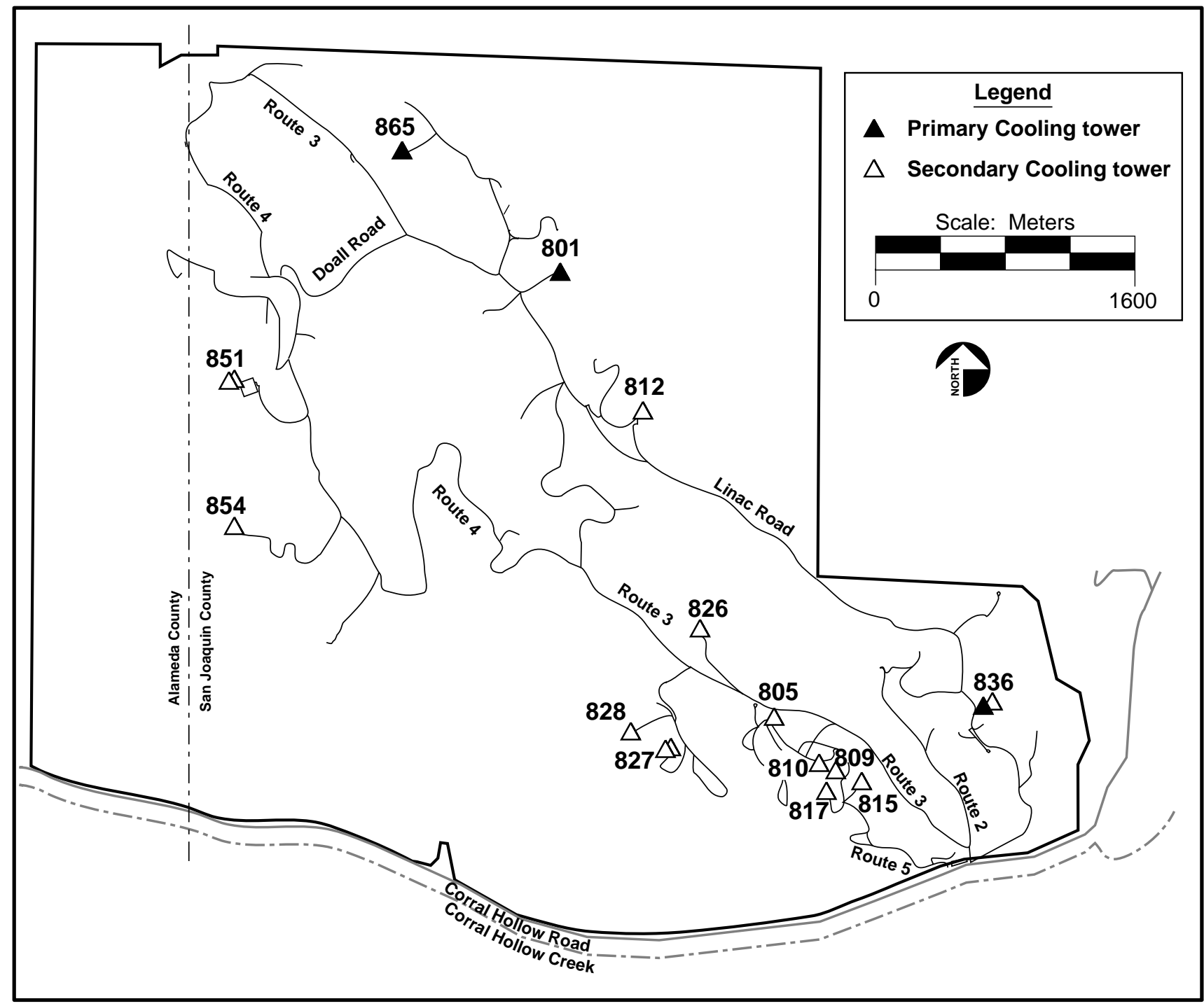

Figure 7-17. Site 300 cooling tower locations, 1996.

the cooling tower discharge points into the creek and to conduct visual observations of the creek. Cooling tower discharges must not raise the $\mathrm{pH}$ of Corral Hollow Creek above 8.5 or alter the ambient $\mathrm{pH}$ by more than 0.5 .

Two cooling towers, located at Buildings 801 and 836A, regularly discharge to surface water drainage courses. Fourteen other cooling towers routinely discharge to percolation pits under a waiver of waste discharge requirements from the Central Valley RWQCB. The permit establishes separate effluent limits for these 14 towers (dissolved solids must not exceed a monthly average of $2000 \mathrm{mg} / \mathrm{L}$ or $5000 \mathrm{mg} / \mathrm{L}$ daily; $\mathrm{pH}$ must not exceed 10) in the event that discharge to surface water drainage courses is necessary, 


\section{Surface Water}

such as during maintenance of the percolation pits. One such discharge occurred in June of 1996 when flow from the Building 812 cooling tower was diverted to the storm water drainage course for maintenance of the percolation pit. Flow returned to the percolation pit by July 1996. The Central Valley RWQCB was notified in May of 1996, and sample results of $920 \mathrm{mg} / \mathrm{L}$ TDS and $8.6 \mathrm{pH}$ demonstrated compliance with the permitted limits.

In August 1995, the cooling tower at Building 865 was taken off line. To preserve the tower for future use, components of the wooden tower were kept wet with the use of a sprinkler system to prevent the loss of structural integrity. LLNL informed the Central Valley RWQCB of the change in the tower status and continued to monitor the sprinkler water discharge according to the requirements of WDR 94-131 until August 1996, when the facility decided to decommission the tower and discontinued the use of the sprinkler system.

Monitoring results demonstrate that all cooling tower discharges were in compliance with all permitted limits, with the exception of one event in July, when the Building 801 tower exceeded its maximum permitted design flow by $155 \mathrm{~L}$. Subsequent sampling events demonstrated that the flow was once again below the limit. Occasional slight exceedances of the maximum permitted design flow are expected for this tower during the hottest months when evaporation is also highest; this is noted in Attachment B of the WDR 94-131.

Monitoring results are detailed in the quarterly reports to the Central Valley RWQCB and are summarized in Table 7-12 (compliance data) and Table 7-13 (operational data). LLNL reports operational values at the request of the Central Valley RWQCB, but they are not used to determine compliance. All pH samples collected from the cooling tower discharges were below the permitted maximum of 10. TDS concentrations are consistently below both the daily maximum and monthly average limits. During the 1996 reporting period, there was no continuous flow in Corral Hollow Creek; therefore no monitoring was required.

\section{Other Waters}

Additional surface water monitoring is driven by DOE Orders 5400.1, General Environmental Protection Program, and 5400.5, Radiation Protection of the Public and the Environment. Surface and drinking water near the Livermore site and in the Livermore Valley are sampled at locations shown in Figure 7-18 according to procedures set out in Appendix A of the Environmental Monitoring Plan (Tate et al. 1995). Sampling 
locations DEL, ZON7, DUCK, ALAG, SHAD, and CAL are surface water sources; BELL, GAS, PALM, and ORCH are drinking water outlets. LLNL samples these locations for gross alpha, gross beta, and tritium. In the past, LLNL sampled these locations quarterly. Because past monitoring has consistently showed background levels of these constituents, samples were taken semiannually in 1996. The on-site swimming pool and drinking water sources POOL and TAP were also sampled, as described above, for gross alpha, gross beta, and tritium. POOL is sampled monthly, TAP quarterly.

Table 7-12. Summary data from compliance monitoring of Site 300 primary cooling towers, 1996.

\begin{tabular}{|l|l|c|c|c|c|c|}
\hline \multicolumn{1}{|c|}{ Test } & Tower no. & Minimum & Maximum & Median & $\begin{array}{c}\text { Interquartile } \\
\text { range }\end{array}$ & $\begin{array}{c}\text { Number of } \\
\text { samples }\end{array}$ \\
\hline Total dissolved solids (mg/L)(a) & 801 & 920 & 1400 & 1300 & $-^{(\mathrm{f})}$ & 4 \\
& $836 \mathrm{~A}$ & 1200 & 1300 & 1300 & $--^{(\mathrm{f})}$ & 4 \\
& 865 & 670 & 1300 & 730 & $-^{(\mathrm{f})}$ & 3 \\
\hline \multirow{2}{*}{ Flow (L/day) } & $801^{(\mathrm{b})}$ & 0 & 16,430 & 3139 & 5955 & 26 \\
& $836 \mathrm{~A}^{(\mathrm{c})}$ & 0 & 2511 & 1010 & 1948 & 25 \\
& $865^{(\mathrm{d})}$ & 0 & 332 & 0.34 & 33 & 16 \\
\hline $\mathrm{pH}^{(\mathrm{e})}$ & 801 & 8.5 & 9.2 & 8.7 & $-^{(\mathrm{f})}$ & 4 \\
& $836 \mathrm{~A}$ & 8.5 & 8.7 & 8.6 & $--^{(\mathrm{f})}$ & 4 \\
& 865 & 7.9 & 8.7 & 8.2 & $--^{(\mathrm{f})}$ & 3 \\
\hline
\end{tabular}

a Maximum permitted total dissolved solids $=2400 \mathrm{mg} / \mathrm{L}$.

b Maximum permitted design flow $=16,276$ L/day.

c Maximum permitted design flow $=8138 \mathrm{~L} /$ day.

d Maximum permitted design flow $=90,840$ L/day.

e Maximum permitted $\mathrm{pH}=10$.

$f$ Not enough data points to determine.

Table 7-13. Summary data from operational monitoring of Site 300 primary cooling towers, 1996.

\begin{tabular}{|l|c|c|c|c|c|c|}
\hline \multicolumn{1}{|c|}{ Test } & Tower no. & Minimum & Maximum & Median & $\begin{array}{c}\text { Interquartile } \\
\text { range }\end{array}$ & $\begin{array}{c}\text { Number of } \\
\text { samples }\end{array}$ \\
\hline Total dissolved solids (mg/L) $)^{(a)}$ & 801 & 900 & 1450 & 1350 & 100 & 26 \\
& $836 \mathrm{~A}$ & 1050 & 1300 & 1200 & 50 \\
\hline $\mathrm{pH}^{(\mathrm{b})}$ & 801 & 8.7 & 9.0 & 8.9 & 0.1 & 26 \\
& $836 \mathrm{~A}$ & 8.6 & 9.1 & 8.8 & 0.2 & 26 \\
\hline
\end{tabular}

a Maximum permitted total dissolved solids $=2400 \mathrm{mg} / \mathrm{L}$.

b Maximum permitted $\mathrm{pH}=10$. 


\section{Surface Water}

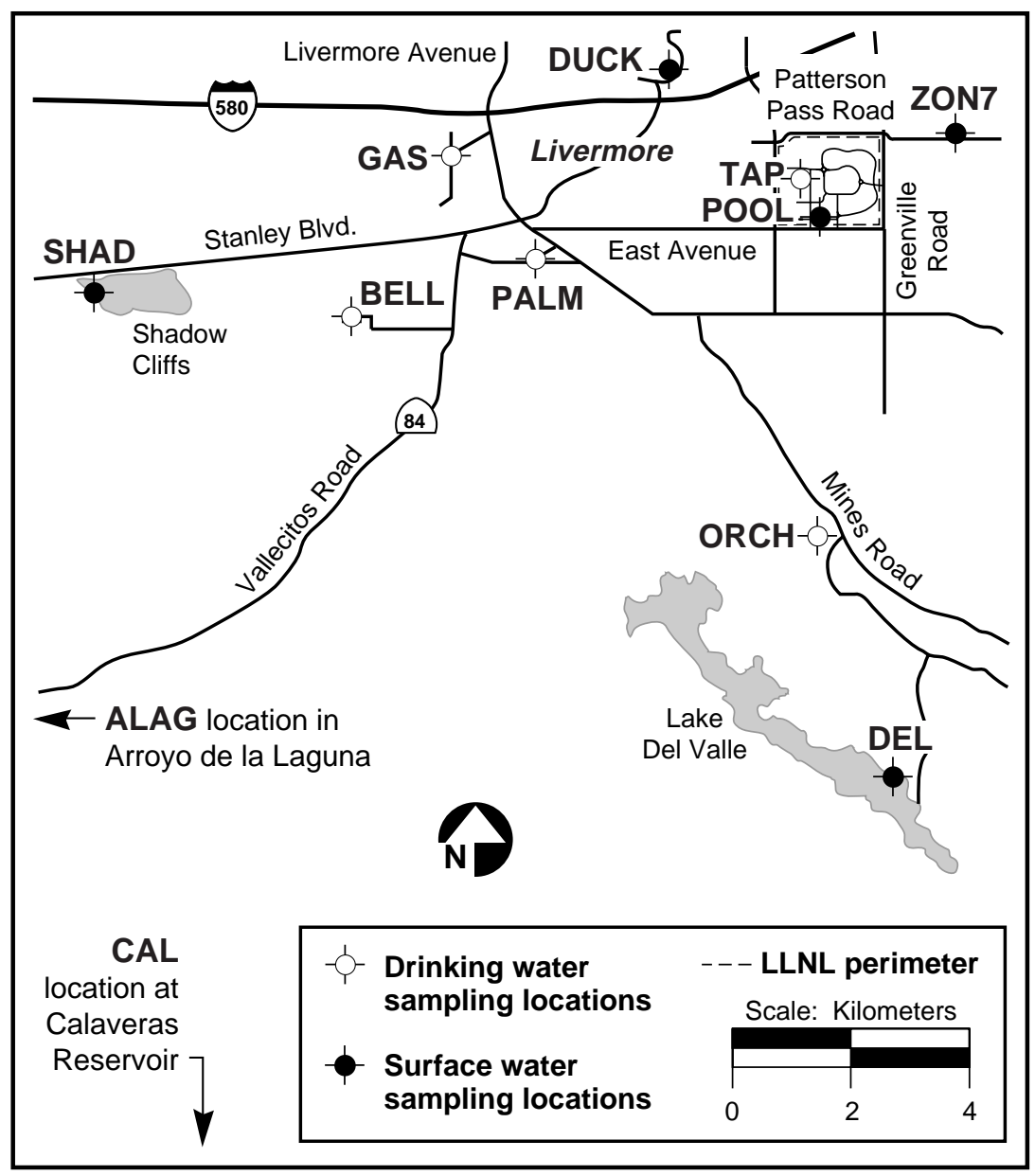

Figure 7-18. Surface and drinking water sampling locations, Livermore Valley, 1996.

Median activities for gross alpha and gross beta radiation in surface water samples are generally less than $10 \%$ of the drinking water maximum contaminant levels (MCLs). However, maximum activities detected for gross alpha and gross beta (both from location $\mathrm{ORCH}$ ) were $0.43 \mathrm{~Bq} / \mathrm{L}(11.6 \mathrm{pCi} / \mathrm{L})$ and $0.74 \mathrm{~Bq} / \mathrm{L}(20 \mathrm{pCi} / \mathrm{L})$, or $77 \%$ and $40 \%$ of their respective MCLs (see Table 7-14). Detailed data are in Volume 2, Table 7-8. Historically, gross alpha and gross beta radiation has fluctuated about the laboratory detection limits. At these very low levels, the error measurements are nearly equal to the measured values so that no trends are apparent in the data. 
Table 7-14. Radioactivity (in $\mathrm{Bq} / \mathrm{L}$ ) in surface and drinking water in the Livermore Valley, 1996.

\begin{tabular}{|l|c|c|c|}
\hline \multicolumn{1}{|c|}{ Location } & Tritium & Gross alpha & Gross beta \\
\hline Median & 2.24 & 0.050 & 0.088 \\
Minimum & 1.62 & 0 & 0. \\
Maximum & 5.51 & 0.43 & 0.74 \\
Interquartile range & 0.89 & 0.045954 & 0.14874 \\
Maximum contaminant level (MCL) & 740 & 0.56 & 1.85 \\
\hline
\end{tabular}

\section{Environmental Impacts}

With the exception of one event in July, when the Building 801 cooling tower slightly exceeded its design flow, all Site 300 cooling towers that discharge to surface were within their permitted flow limits. All cooling tower discharges were in compliance with permitted limits for $\mathrm{pH}$ and TDS. All discharges from treatment facilities that discharge to surface were within their compliance limits. Thus, data indicate no impact to surface waters from LLNL Livermore site and Site 300 cooling towers and treatment facilities.

There is no evidence of adverse environmental impact resulting from releases from the Drainage Retention Basin. Though internal measurements indicated that concentrations were above the management action levels for several constituents, only iron was discharged above amended limits established to protect receiving waters. In April 1997, the discharge limits established under CERCLA were again amended by the Remedial Project Managers, and the iron limit was determined to be not applicable and was completely dropped as a discharge limit because it had no aquatic life or human health protection water quality criteria.

Preliminary indications are that concentrations of some metals in storm water may be increasing; these levels may be related to suspended solids in the storm water. Further evaluation of the source of these metals has been planned. During the next wet season (1997-98), analysis will be conducted for both dissolved and total metals in both NPDESdriven (compliance) and DOE-order driven (surveillance) sampling. Although some 1996 storm water results were above criteria, there is no evidence that indicates any impact to off-site biota, and the acute fish toxicity test further supports the conclusion that LLNL storm water has no adverse effect on off-site biota. 


\section{Surface Water}

The environmental impact of tritium measured in rainfall samples from the Livermore site was negligible. The highest tritium activity measured in 1995 rainfall was $170 \mathrm{~Bq} / \mathrm{L}$ (4590 pCi/L), about $23 \%$ of the MCL for tritium (740 Bq/L). Tritium activities measured in Livermore site and Livermore Valley surface and drinking water were even lower, with a maximum of $5.51 \mathrm{~Bq} / \mathrm{L}(149 \mathrm{pCi} / \mathrm{L})$, or about $0.7 \%$ of the MCL. Maximum activities for gross alpha and gross beta in Livermore site and Livermore Valley surface and drinking water were also below MCLs. The maximum activities for gross alpha and gross beta were $0.43 \mathrm{~Bq} / \mathrm{L}(11.6 \mathrm{pCi} / \mathrm{L})$ and $0.74 \mathrm{~Bq} / \mathrm{L}(210 \mathrm{pCi} / \mathrm{L})$, or $77 \%$ and $40 \%$ of their respective MCLs.

LLNL maintains an extensive monitoring network for surface water, which includes treatment facility and cooling tower discharges, rain water, storm water, and both onsite and off-site drinking water and surface water. The sample data indicate that the impact of LLNL Livermore site and Site 300 operations on off-site surface water is negligible. 


\section{Ground Water}

Eric Christofferson

Richard A. Brown

Karen J. Folks

Erich R. Brandstetter

\section{Introduction}

Ground water in the Livermore Valley and in the Altamont Hills is monitored regularly by LLNL. The monitoring objectives are: to assess the progress of LLNL remediation efforts in areas of known ground water contamination; to assess the effectiveness of current LLNL activities, especially waste management practices, designed to protect the environment; and to conform with the requirements of the Ground Water Protection Management Program. Remediation efforts result from LLNL actions to comply with the Comprehensive Environmental Response, Compensation and Liability Act (CERCLA; see Chapter 2 for a summary of CERCLA activities). Operational monitoring complies with waste discharge requirements issued under California's Porter-Cologne Water Quality Act. Compliance monitoring is required by numerous federal, state, and local permits (see Chapter 2, Table 2-7 for a summary of LLNL permits). Surveillance monitoring of ground water is required by DOE Order 5400.1 as part of the U.S. Department of Energy's (DOE) commitment to protect the environment at DOE sites.

For surveillance monitoring purposes, LLNL determines the number and locations of surveillance wells, the constituents of concern (COCs) to be monitored, the frequency of sampling, and the analytical methods to be used. This allows LLNL to design a comprehensive, cost-effective monitoring program. A wide range of COCs is monitored in ground water to confirm that current LLNL operations do not significantly impact local water resources and to detect any slow-to-develop contamination due to past operations. Wells at the Livermore site, the Livermore Valley, and at Site 300 in the Altamont Hills are included in LLNL's surveillance monitoring plan. The surveillance networks include private wells and CERCLA wells.

Additional ground water wells are monitored regularly to comply with state-issued permits associated with closed landfills containing solid wastes from past LLNL operations and with continuing discharges of liquid waste from current operations. This compliance monitoring uses networks of water wells that are specifically positioned and constructed to meet regulatory requirements. 


\section{Ground Water}

LLNL's program of surveillance and compliance ground water monitoring follows an annual plan. Depending on their location and purpose, ground water wells are sampled quarterly, semiannually, or annually. Standard operating procedures (SOPs) are followed when taking samples of well water to minimize the effects of sampling on analytical results (Dibley and Depue 1996).

\section{Ground Water Regime Livermore Site}

\section{Physiographic Setting}

The Livermore Valley is the most prominent valley within the Diablo Range. It is an east-west trending structural and topographic trough bounded on the west by Pleasanton Ridge and on the east by the Altamont Hills. The valley is approximately $25-\mathrm{km}$ long and averages $11 \mathrm{~km}$ in width. The valley floor is $220 \mathrm{~m}$ at its highest elevation along the eastern margin and gradually dips to $92 \mathrm{~m}$ at the southwest corner. The valley floor is covered by alluvial, lake, and swamp deposits consisting of gravels, sands, silts, and clays with an average thickness of about $100 \mathrm{~m}$.

The Livermore Valley Ground Water Basin encompasses 17,000 hectares, including the uplands. The streams within the basin are ephemeral, flowing only during the October to May rainy season. The prominent streams are Arroyo del Valle, Arroyo Las Positas, Arroyo Seco, Arroyo Mocho, Alamo Creek, South San Ramon Creek, and Tassajara Creek. Arroyo del Valle and Arroyo Mocho drain the largest areas and are the largest streams. Arroyo Mocho now flows the entire year with water supplied by the Alameda County Flood Control and Water Conservation District Zone 7. The streams converge westward at Arroyo de la Laguna, which flows southward out of the valley into the Sunol Valley Ground Water Basin.

The Livermore Valley ground water system is a sequence of semiconfined aquifers. Ground water moves downslope from the valley uplands toward the east-west axis of the valley. It then flows generally westward toward the southwest portion of the basin. From there, ground water historically flowed south into the Sunol Valley Ground Water Basin. However, use of ground water within the basin has stopped the subsurface outflow since 1945. The largest quantities of ground water are pumped from the central and western portions of the Livermore Valley, where the valley fill is thickest.

The valley-fill sediments make up two aquifers: the Livermore Formation and its overlying alluvium. The Livermore formation averages about $1000 \mathrm{~m}$ in thickness and occupies an area of approximately $250 \mathrm{~km}^{2}$. The alluvium averages about $100 \mathrm{~m}$ in thickness. The alluvium is the principal water-producing formation within the valley. 
The quality of ground water in the Livermore Valley reflects the surface water that recharges the aquifers. The chemical character of the ground water ranges from excellent (low sodium, magnesium, or calcium bicarbonate content) to poor (high sodium chloride content). In the eastern part of the valley, poor quality ground water results from recharge via Altamont Creek, which drains marine sediments to the east of the valley. High concentrations of naturally occurring minerals there, especially boron, render this ground water unsuitable for irrigation.

\section{Drainage Retention Basin}

In 1990, a drainage basin was constructed near the center of the Livermore site to catch and retain storm water runoff. The Drainage Retention Basin (DRB) is lined to prevent infiltration in this area. Surface drainage at the Livermore site is discussed in detail in Chapter 7.

\section{Hydrogeology}

Sediment types at the Livermore site are grouped into four categories-clay, silt, sand, and gravel-based on dominant particle size. Ground water flow beneath the site is primarily in sand and gravel lenses and channels, bounded by the less permeable clays and silts. The alluvial setting has been mapped into seven hydrostratigraphic units beneath the Livermore site using data collected over the years. Hydrostratigraphic units (HSUs) can be defined as sedimentary sequences whose permeable layers show evidence of hydraulic connection. The HSUs of concern beneath the Livermore site are the Quaternary alluvial deposits of the upper Livermore member of the Livermore Formation. Hydrostratigraphic units 1B, 2, and 3A (in order of increasing depth, see Figure 8-1) contain contaminants, which are primarily solvents (Hoffman et al. 1997).

Based on borehole lithologic data, a series of buried sand and gravel-filled stream channels have been identified at the site. The sand and gravel deposits, which are highly permeable, are present in narrow bands at the site and are interpreted as braided stream deposits, similar to strata deposited by the present day Arroyo Mocho.

In 1996, the depth to ground water ranged from $40 \mathrm{~m}(130 \mathrm{ft})$ at the southeast corner of the site to $10 \mathrm{~m}(33 \mathrm{ft})$ at the northwest corner and $12 \mathrm{~m}(40 \mathrm{ft})$ at the northeast corner. Ground water levels have responded to variations in annual rainfall and resource use. Decreases in ground water use from the 1960s to 1985 caused the water table to rise. Heavy rains caused rises in 1986, 1993, 1994, 1995, and, 1996, while drier-than-normal winters caused declines between 1987 and 1991. 


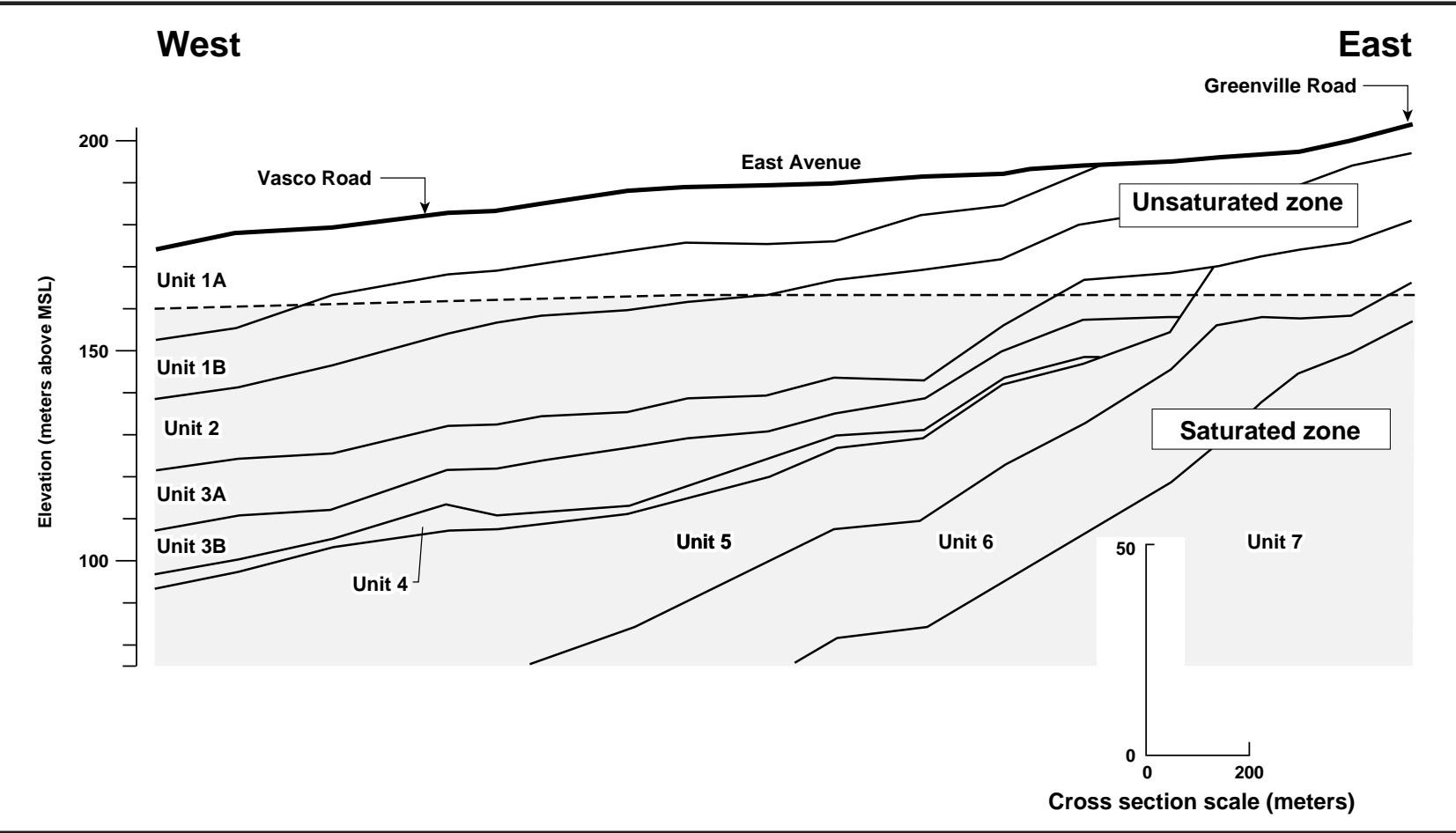

Figure 8-1. Hydrostratigraphic cross section for the Livermore site.

Ground water is recharged at the Livermore site mainly from nearby arroyos and from direct rainfall. Recharge enters primarily through the arroyos (see also Chapter 7). Ground water flow at the Livermore site is generally westward. The hydrogeology of the Livermore site is discussed in detail in the CERCLA Remedial Investigation Report for the LLNL Livermore Site (Thorpe et al. 1990) and Ground Water Project Reports.

The conceptual model presented in the CERCLA Remedial Investigation Report for the LLNL Livermore Site suggests that ground water generally flows towards two destinations from the Livermore site. Ground water from the north half flows west and northwest and eventually discharges to Arroyo Las Positas near First Street in Livermore, about $2 \mathrm{~km}$ northwest of the Livermore site. Ground water from the southern half flows generally westward toward the gap between the Mocho I and Mocho II subbasins, about $2 \mathrm{~km}$ west of the Livermore site. Ground water velocities at the Livermore site range from 15 to $20 \mathrm{~m}$ ( 49 to $66 \mathrm{ft}$ ) per year.

\section{Site 300}

\section{Physiographic Setting}

Site 300 is located in the Altamont Hills, which are part of the Coast Ranges Physiographic Province and separate the Livermore Valley to the west from the San Joaquin Valley to the east. 


\section{Ground Water}

Rocks exposed in the region are classified into three groups:

- Late Tertiary-Quaternary (0-5 million years ago)-Alluvium and semilithified sediments, mainly of continental origin.

- Early to late Tertiary (5-65 million years ago)—Shallow marine and continental sedimentary and volcaniclastic rocks.

- Jurassic-Cretaceous (65-180 million years ago)—Great Valley sequence (marine sedimentary rocks and ophiolites); Franciscan Complex (sheared and variably metamorphosed sedimentary and igneous rocks).

Distinctive blue-gray to brown weathering volcaniclastic sandstone and sandy siltstone, interbedded with light gray weathering tuffaceous claystone and conglomerate, are exposed extensively within Site 300. These rocks are mapped as the late Miocene Neroly Formation (Huey 1948; Dibblee 1980). The Neroly Formation is also present in the subsurface beneath the southeastern portion of Site 300 .

The Neroly Formation is the principal hydrologic unit within Site 300 and has therefore been the focus of the detailed geologic and hydrogeologic studies conducted during recent years (summarized in the Final Site-Wide Remedial Investigation Report, Lawrence Livermore National Laboratory Site 300, hereafter referred to as Final SWRI Report [Webster-Scholten 1994]). The Neroly Formation is about $150 \mathrm{~m}$ thick beneath Site 300.

The active floodplain of Corral Hollow Creek lies along the southern boundary of Site 300, underlying portions of the western and eastern General Services Area (GSA). The floodplain also makes small incursions into Site 300 in the vicinity of closed landfill Pit 6. Floodplain alluvium consists dominantly of coarse cobble and boulder-bearing gravel derived from sources to the south, with lenses and local cappings of sandy silt and silty clay.

The bedrock sequence within Site 300 has been slightly deformed into several gentle, low-amplitude folds. The locations and characteristics of these folds, in combination with the regional fault and fracture patterns, may locally influence ground water flow within the site and have therefore been studied as part of the CERCLA investigations.

\section{Hydrogeology}

Site 300 is generally underlain by gently dipping sedimentary bedrock dissected by steep ravines. The bedrock is made up primarily of interbedded sandstone, siltstone, and claystone (Figure 8-2). Most ground water occurs in the Neroly Formation upper blue sandstone $\left(\operatorname{Tnbs}_{2}\right)$ and lower blue sandstone (Tnbs 1$)$ aquifers. Significant ground water is also locally present in permeable Quaternary alluvium valley fill $\left(\mathrm{Qa}_{1}\right)$. Much less ground water is present in the Miocene Non-marine (Tps) unit, where it occurs as 


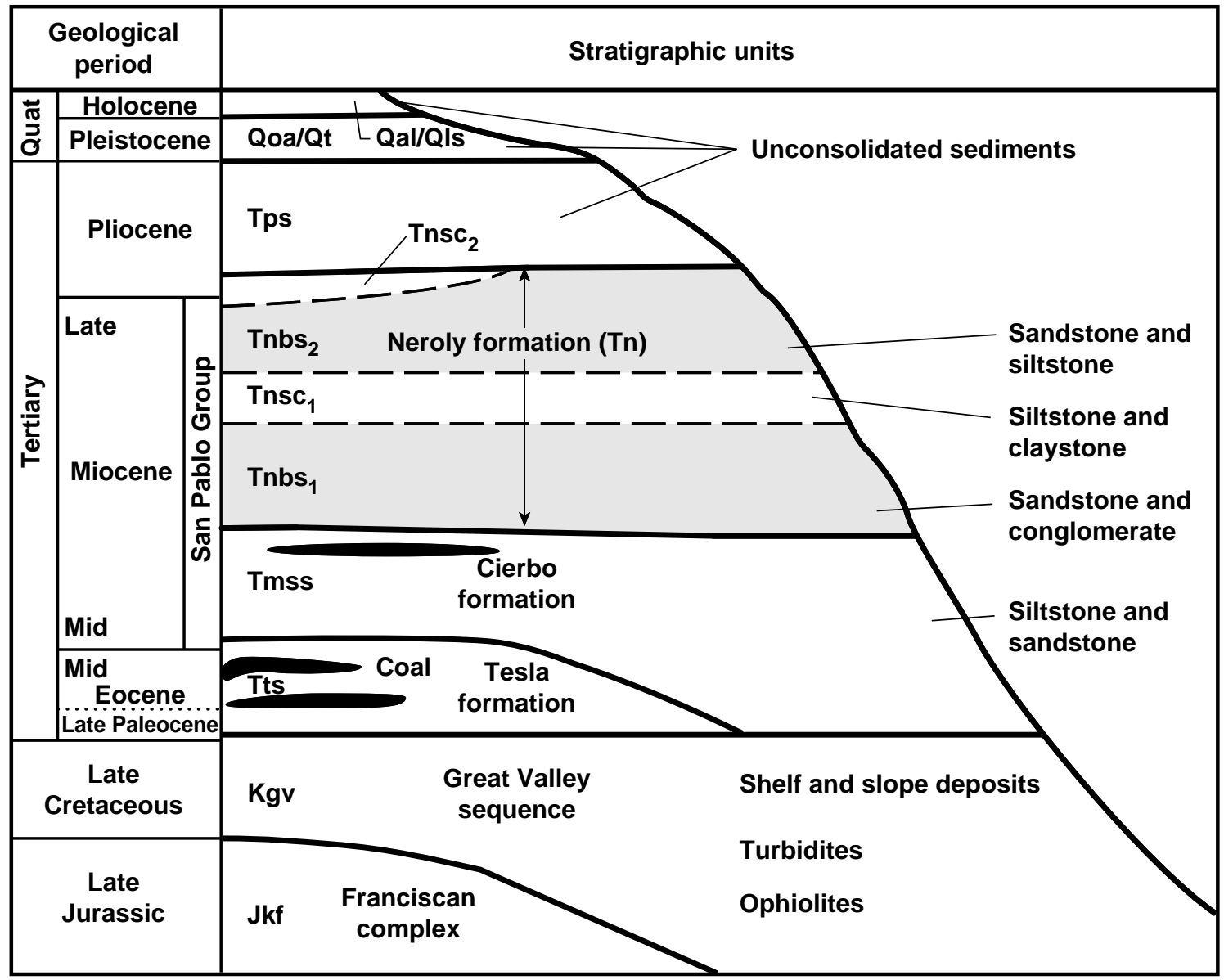

Figure 8-2. Site 300 stratigraphy. Stratigraphic codes are in standard geological notation (Webster-Scholten 1994). (For example, Tnbs 1 stands for tertiary Neroly lower blue sandstone.)

perched water-bearing zones beneath hilltops in the Buildings 833 and 834 areas, and more extensively in the Explosives Process Area. The perched water-bearing zone at Building 833 is ephemeral. Fine-grained siltstone and claystone interbeds act as aquitards, confining layers, or perching horizons. Ground water is present under confined conditions in parts of the deeper bedrock aquifers, but is generally unconfined elsewhere.

Recharge occurs predominantly in locations where saturated alluvium valley fill is in contact with underlying permeable bedrock, or where bedrock strata crop out because of structure or topography. Local recharge also occurs on hilltops, thus creating the perched water-bearing zones at Buildings 833 and 834. Low rainfall, high evapotranspiration, steep topography, and intervening aquitards generally preclude direct vertical recharge of the bedrock aquifers. 


\section{Ground Water}

Ground water flow in most aquifers follows the attitude of the bedrock. In the northwest part of Site 300 (north of the east-west trending Patterson anticline), bedrock ground water flows generally northeast, except where it is locally influenced by ground water in alluvium-filled ravines. In the southern half of the site, bedrock ground water flows roughly south-southeast, approximately coincident with the attitude of bedrock strata.

Ground water in the Tnbs 1 aquifer is unconfined in much of the northwestern part of Site 300. In the southern Explosives Process Area, several flowing artesian wells are present. Tnbs 2 beds are present throughout most of the southeastern part of Site 300, and locally in the northern part of the site. Prior to about 1980, this unit was used as a water-supply aquifer in the southern Explosives Process Area. In the northern part of the Explosives Process Area, the Tnbs 2 is unsaturated, but saturation increases downdip toward the south. Tnbs 2 ground water in the central Explosives Process Area is under phreatic (water table) conditions; the hydraulic head increases southward, resulting in local flowing artesian conditions in Tnbs 2 wells in the southern Explosives Process Area.

The Cierbo Formation (Tmss) is saturated beneath Doall Ravine, the Building 851 Area, and the southern part of the East Firing Area. The Tmss is unsaturated or does not otherwise yield water to wells in other parts of the East and West Firing Areas, and this may be the result of swelling clays in pore spaces. The thickness of the Cierbo Formation is not well known because most boreholes are not deep enough to completely penetrate this formation. Some of the deeper wells in the GSA penetrate the uppermost Tmss. Similar to the Tnbs 1 , the continuity of saturation between the northwest and southeast areas of Site 300 is undetermined. Ground water in the Tmss occurs under unconfined to artesian conditions.

The Tps unit is the youngest bedrock unit identified at Site 300 and is generally present only on hilltops. Where present, ground water is frequently perched, discontinuous, and/or ephemeral. The exception to this condition exists in the Explosives Process Area, where the extent of saturation in Tps sediments is significant. Ground water in the Tps unit is generally unconfined, although water under confined conditions does occur locally.

Quaternary alluvium $\left(\mathrm{Qa}_{1}\right)$ is present as valley fill in ravines throughout Site 300, but is saturated only in the Corral Hollow Creek stream channel, in Doall Ravine in the West Firing Area, and in southern Elk Ravine in the East Firing Area near a spring. Saturated Quaternary terrace alluvium deposits $(\mathrm{Qt})$ are present in the Pit 6 Area, GSA, and Building 833 study areas; some of these occurrences may be ephemeral. Small quantities of ground water are present in some local landslide (Qls) deposits. 


\section{Ground Water}

\section{Surveillance Ground Water Monitoring of Livermore Valley Livermore Site}

To complement the Livermore Ground Water Project, LLNL has redesigned the surveillance monitoring program to detect possible releases from beneath the Livermore site as a whole. Monitoring of the vadose zone is not feasible in this area because most of the area is paved. Therefore, surveillance monitoring of existing ground water wells was the method of choice. This program makes use of two upgradient monitoring wells (W-008 and W-221) in the eastern portion of the site, and seven downgradient monitoring wells near and past the western boundary of the site (Figure 8-3). These downgradient wells are located in the regions of Treatment Facility A (W-121, W-151, and 14B1), Treatment Facility B (W-571 and W1012), and Treatment Facility C (W-373 and W-556). This configuration was implemented in 1996 to monitor the uppermost aquifers (HSUs 1B and 2) within that area. The intent of this network is to monitor for possible contaminants other than volatile organic compounds (VOCs), which are handled under the Livermore Site Ground Water Project.

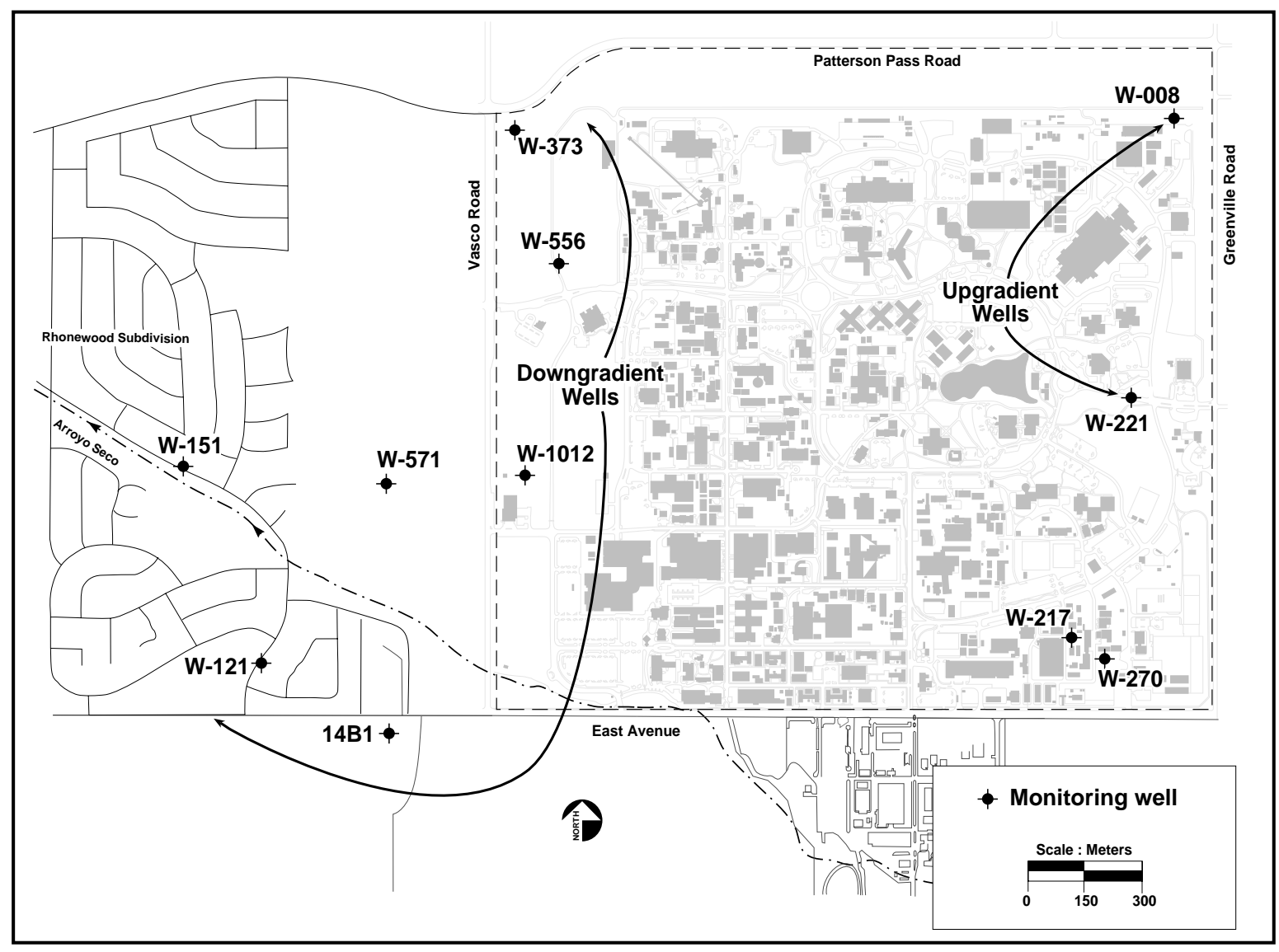

Figure 8-3. Locations of surveillance ground water monitoring wells at the Livermore site, 1996. 
These wells were sited to satisfy Resource Conservation and Recovery Act (RCRA) monitoring and California Code of Regulations Title 22 monitoring requirements.

For the Livermore Ground Water Project, the constituents of concern (COCs) are VOCs, primarily trichloroethylene (TCE) and tetrachloroethylene (PCE). Figure 8-4 shows the isoconcentration contours on total VOCs in HSU 2. The seven operating ground water treatment facilities (TFA, TFB, TFC, TFD, TFE, TFG1, and TF406) removed a total VOC mass of more than $40 \mathrm{~kg}$ by treating $470 \mathrm{ML}$ of ground water in 1996 (Hoffman et al. 1997).

The two upgradient wells were sampled and analyzed quarterly in order to obtain sufficient data for statistics; the seven downgradient wells were sampled and analyzed semiannually. Each well was sampled and analyzed for metals and minerals (except for ammonia as nitrogen and total Kjeldahl nitrogen), gross alpha and beta, tritium, and radium and uranium radioisotopes.

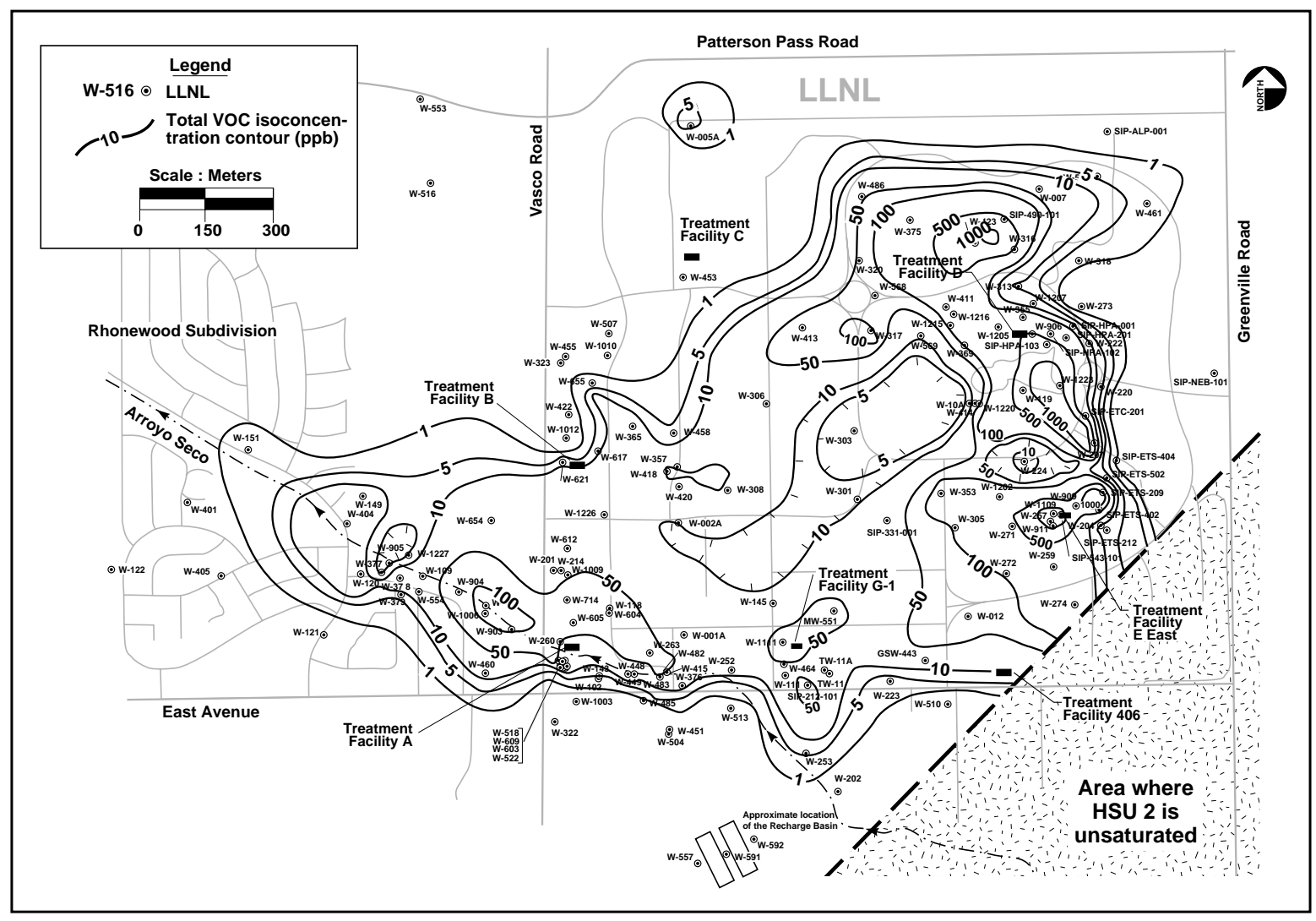

Figure 8-4. Map showing distribution of VOCs for 154 sampling locations in Hydrostratigraphic Unit 2 (HSU2), at Livermore site and vicinity, 1996. 
Examination of the City of Livermore drinking water wells revealed levels of radioactive radon gas up to $10.7 \mathrm{~Bq} / \mathrm{L}(290 \mathrm{pCi} / \mathrm{L})$. It was therefore decided to add analysis for radon-222 to the list of ground water analytes. Organic compounds, including semivolatile compounds (EPA Method 625) and chlorinated herbicides (EPA Method 615), were monitored during the first 6 months of the year. During the last 6 months of the year, EPA Methods 625,507,547, and 632 were used to monitor nitrogen-based and phosphorus-based pesticides and herbicides that are presently being used on site along with semivolatile compounds. Tables 8-1, 8-2, and 8-3 show the important water quality objectives for organic, inorganic, and radioactive compounds, respectively.

Table 8-1. Water quality objectives for organic compounds of concern, 1996.

\begin{tabular}{|c|c|c|c|c|}
\hline Analytes & EPA method & $\begin{array}{c}\text { CA or federal } \\
\text { MCLs }^{(a)} \\
(\mu \mathbf{g} / \mathbf{L})\end{array}$ & $\begin{array}{c}\text { Non-cancer } \\
\text { risk } \\
(\mu \mathrm{g} / \mathrm{L}) \\
\end{array}$ & $\begin{array}{c}\text { SFBRWQCB }^{(\mathbf{b})} \\
\text { Basin Plan } \\
(\mu \mathrm{g} / \mathrm{L}) \\
\end{array}$ \\
\hline Atrazine & 507 & 3.0 & 3 & 3 \\
\hline Benzo(a)pyrene & 625 & 0.2 & $0.002^{(\mathrm{c})}$ & 0.2 \\
\hline Bis(2-ethylhexyl)phthalate & 625 & 4 & $3^{(c)}$ & 4 \\
\hline Bromacil & 507 & $N A^{(d)}$ & 90 & NA \\
\hline $2,4-D$ & 615 & 70 & 70 & 70 \\
\hline Dalapon & 615 & 200 & 200 & 200 \\
\hline Diazinon & 507 & $14^{(\mathrm{e})}$ & 0.6 & NA \\
\hline Dicamba & 615 & NA & 200 & NA \\
\hline Diethylphthalate & 625 & NA & 5000 & NA \\
\hline Dimethoate & 507 & $140^{(e)}$ & NA & NA \\
\hline Diuron & 632 & NA & 10 & NA \\
\hline Glyphosate & 547 & 700 & 700 & 700 \\
\hline MCPA & 615 & NA & 11 & NA \\
\hline Metolachlor & 507 & NA & 100 & NA \\
\hline Molinate & 507 & 20 & 14 & 20 \\
\hline Propachlor & 507 & NA & 90 & NA \\
\hline Simazine & 507 & 4 & 4 & 4 \\
\hline $2,4,5-\mathrm{T}$ & 615 & NA & 70 & NA \\
\hline 2,4,5-TP & 615 & 50 & 50 & 50 \\
\hline Thiobencarb & 507 & 70 & 140 & 1 \\
\hline
\end{tabular}

a Maximum contaminant level.

b San Francisco Bay Regional Water Quality Control Board.

c Cancer risk from EPA.

d $\mathrm{NA}=$ Not applicable.

e California Department of Health Services Action Levels. 
Table 8-2. Water quality objectives for inorganic compounds of concern, 1996.

\begin{tabular}{|c|c|c|c|}
\hline Analyte & $\begin{array}{l}\text { CA or federal } \\
\operatorname{MCL}^{(a)}(\mathrm{mg} / \mathrm{L})\end{array}$ & $\begin{array}{c}\text { SFBRWQCB(b) } \\
\text { Basin Plan (mg/L) }\end{array}$ & $\begin{array}{c}\text { EPA health } \\
\text { advisory (mg/L) }\end{array}$ \\
\hline Aluminum & 1 & $1 / 0.2$ & NA \\
\hline Antimony & 0.006 & 0.006 & 0.003 \\
\hline Arsenic & 0.05 & 0.05 & 0.00002 \\
\hline Barium & 1 & 1 & 2 \\
\hline Beryllium & 0.004 & 0.004 & 0.000008 \\
\hline Boron & $N A^{(c)}$ & $0.5 / 2$ & 0.6 \\
\hline Cadmium & 0.005 & 0.005 & 0.005 \\
\hline Chloride & $250^{(d)}$ & 250 & NA \\
\hline Chromium(VI) & 0.05 & 0.05 & 0.1 \\
\hline Copper & $1^{(d)}$ & 1 & NA \\
\hline Cyanide & 0.2 & 0.2 & 0.2 \\
\hline Fluoride & $1.4-2.4$ & $0.8 / 1.7$ & NA \\
\hline Iron & $0.3^{(\mathrm{d})}$ & 0.3 & NA \\
\hline Lead & 0.015 & 0.05 & NA \\
\hline Manganese & $0.05^{(\mathrm{d})}$ & 0.05 & NA \\
\hline Mercury & 0.002 & 0.002 & 0.002 \\
\hline Molybdenum & NA & $0.01 / 0.05$ & 0.035 \\
\hline Nickel & 0.1 & 0.1 & 0.1 \\
\hline Nitrate $\left(\right.$ as $\left.\mathrm{NO}_{3}\right)$ & 45 & 45 & 45 \\
\hline Nitrite (as N) & 1 & 1 & 1 \\
\hline $\mathrm{pH}$ & $6.5-8.5^{(\mathrm{d})}$ & 6.5 & NA \\
\hline Selenium & 0.05 & 0.05 & NA \\
\hline Silver & $0.1^{(\mathrm{d})}$ & 0.05 & 0.1 \\
\hline Specific conductance $(\mu \mathrm{mho} / \mathrm{cm})$ & $900^{(d)}$ & 900 & NA \\
\hline Sulfate & $250^{(d)}$ & 250 & NA \\
\hline Total dissolved solids (TDS) & $500^{(d)}$ & 500 & NA \\
\hline Thallium & 0.002 & 0.002 & 0.0004 \\
\hline Vanadium & NA & $0.1 / 1$ & NA \\
\hline Zinc & $5^{(d)}$ & 5 & 2 \\
\hline
\end{tabular}

a Maximum contaminant level, as listed in U.S. Environmental Protection Agency (USEPA) Region IX Drinking Water Standards and Health Advisories Table, July 1994.

b San Francisco Bay Regional Water Quality Control Board.

c $\mathrm{NA}=$ Not applicable.

d U.S. Environmental Protection Agency (USEPA) and/or California Secondary MCL. 
Table 8-3. Water quality objectives for radioactive compounds.

\begin{tabular}{|l|c|c|c|}
\hline \multicolumn{1}{|c|}{ Radionuclide } & $\begin{array}{c}\text { CA or federal } \\
\text { MCL }\end{array}$ & $\begin{array}{c}\text { SFBRWQCB(b) } \\
\text { Sq/L) }\end{array}$ & $\begin{array}{c}\text { EPA health advisory } \\
\text { (Basin Plan } \mathbf{( B q} / \mathbf{L})\end{array}$ \\
\hline $\begin{array}{l}\text { Gross alpha (excluding } \\
\text { uranium and radon) }\end{array}$ & 0.56 & 0.56 & 0.0056 \\
Gross beta & 1.85 & 1.85 & $0.4 \mu \mathrm{Sv}(0.04 \mathrm{mrem}) / \mathrm{y}$ \\
Radium-226 & $0.185^{(\mathrm{c})}$ & $0.185^{(\mathrm{c})}$ & 0.0074 \\
Radium-228 & $0.185^{(\mathrm{c})}$ & $0.185^{(\mathrm{c})}$ & 0.0074 \\
Radon & $11.1^{(\mathrm{f})}$ & $\mathrm{NA}^{(\mathrm{e})}$ & 0.056 \\
Tritium & 740 & 740 & $\mathrm{NA}$ \\
Uranium-234 & $0.74^{(\mathrm{d})}$ & $0.74^{(\mathrm{d})}$ & $0.7 \mu \mathrm{g} / \mathrm{L}$ (total uranium) \\
Uranium-235 & $0.74^{(\mathrm{d})}$ & $0.74^{(\mathrm{d})}$ & $0.7 \mu \mathrm{g} / \mathrm{L}$ (total uranium) \\
Uranium-238 & $0.74^{(\mathrm{d})}$ & $0.74^{(\mathrm{d})}$ & $0.7 \mu \mathrm{g} / \mathrm{L}$ (total uranium) \\
\hline
\end{tabular}

a Maximum contaminant level.

b San Francisco Bay Regional Water Quality Control Board.

c For both radium-226 and -228.

d Isotopes of uranium are undifferentiated by the U.S. Environmental Protection Agency (USEPA) guidance documents.

e $\mathrm{NA}=$ Not applicable.

f Proposed MCL.

All surveillance monitoring analytical detections are presented in Volume 2 of this document (Tables 8-1 through 8-10). These first-year monitoring efforts will establish baseline conditions for future monitoring and establish the presence of any radioactive materials in the ground water at levels of concern to public health or to the environment.

\section{Monitoring Results}

Neither cyanide (via EPA Method 335.2), pesticides nor herbicides (via EPA Methods 507, 547, 615, and 632) were detected. However, bis(2-ethylhexyl)phthalate (DEHP), a ubiquitous plasticizer, was detected for the first time in samples collected in downgradient monitoring wells W-571 and W-1012. DEHP concentrations of 19 and $14 \mu \mathrm{g} / \mathrm{L}$ were found in W-571 ground water samples collected in March and August, respectively, and $21 \mu \mathrm{g} / \mathrm{L}$ of DEHP was found in a ground water sample collected from W-1012 in March. DEHP was not detected above the reporting limit of $5 \mu \mathrm{g} / \mathrm{L}$ in the August sample from W-1012. Because W-571 is located in a field in which housing construction began in 1996, sampling was not possible during the third and fourth quarters of 1996 and first quarter of 1997. When sampling of monitoring Well W-571 resumed in June 1997, no phthalates were detected. Another semivolatile compound, diethylphthalate, was detected in downgradient monitoring wells W-373 and W-556 at concentrations of 17 and $15 \mu \mathrm{g} / \mathrm{L}$, respectively, in ground water samples collected in 
March. However, diethylphthalate was also detected in the method blank sample at a concentration of $18 \mu \mathrm{g} / \mathrm{L}$, which indicates laboratory contamination. Because of the erratic sequence of detections and known potential contamination problems at the analytical laboratory, the phthalate detections are suspect.

Most of the inorganic compounds, including dissolved trace metals and minerals, are naturally occurring compounds. It should be noted that several mineralsbicarbonate, boron, bromide, chloride, and fluoride-are present at much higher concentrations in the upgradient wells than in the downgradient wells. Bicarbonate concentrations ranged from $230-330 \mathrm{mg} / \mathrm{L}$, boron from $1.8-19 \mathrm{mg} / \mathrm{L}$, bromide from $<0.5-1.6 \mathrm{mg} / \mathrm{L}$, chloride from $120-720 \mathrm{mg} / \mathrm{L}$, and fluoride from $0.74-1.3 \mathrm{mg} / \mathrm{L}$ in the upgradient wells. Corresponding downgradient concentrations were: bicarbonate 180-260 mg/L, boron from 0.52-1.8 mg/L, bromide from <0.50-0.71 mg/L, chloride from $76-160 \mathrm{mg} / \mathrm{L}$, and fluoride from $0.23-0.95 \mathrm{mg} / \mathrm{L}$. Chapter 3 of the CERCLA Remedial Investigation Report for the LLNL Livermore Site (Thorpe et al. 1990) documents the poor water quality in the upgradient portions of the site, especially near Well W-008.

Nitrate was detected at concentrations of 75 and $85 \mathrm{mg} / \mathrm{L}$ in March and September, respectively. Both concentrations are above the drinking water MCL of $45 \mathrm{mg} / \mathrm{L}$. Wells surrounding W-1012 are presently being sampled for nitrate.

Nickel was reported at $24 \mu \mathrm{g} / \mathrm{L}$ in the ground water sample collected from upgradient monitoring Wells W-221 in June. In samples collected in June, cadmium was detected at concentrations of $1.5 \mu \mathrm{g} / \mathrm{L}$ in upgradient Well W-008 (in the northeastern corner of LLNL) and at $0.5 \mu \mathrm{g} / \mathrm{L}$ (the reporting limit) in upgradient monitoring Wells W-221. Cadmium was again detected at $1.1 \mu \mathrm{g} / \mathrm{L}$ in the sample collected from Well W-008 in September.

Until 1990, total chromium was found in concentrations greater than $100 \mu \mathrm{g} / \mathrm{L}$ in downgradient monitoring Wells W-373, in the northwestern corner of LLNL. Since then concentrations of both total chromium and chromium(VI) in the ground water have been decreasing. Concentrations of dissolved chromium(VI) decreased to 76 and $56 \mu \mathrm{g} / \mathrm{L}$, respectively, in samples taken in March and August from this well. Ground water in the area of TFC has been treated since October 1993 (Chapter 7).

None of the ground water samples from surveillance wells had concentrations of radioactivity or radioisotopes that exceeded a drinking water MCL. The highest concentration of tritium found was $11.5 \mathrm{~Bq} / \mathrm{L}(311 \mathrm{pCi} / \mathrm{L})$, which is $1.6 \%$ of the MCL for tritium. 


\section{Off Site}

LLNL has monitored tritium in water hydrologically downgradient of LLNL since 1988; tritium is potentially the most mobile contaminant emanating from LLNL in ground water (Figure 8-5). Rain and storm water runoff in the Livermore Valley recharges local aquifers and contains small amounts of tritium from natural sources, past atmospheric nuclear weapons tests, and atmospheric emissions from LLNL and Sandia National Laboratories (SNL/California). (See Chapters 5 and 7 for further discussion of air emissions and rain.)

Measurements in water samples collected during the summer of 1996 from 21 wells in the Livermore Valley show tritium levels were very low compared with the $740 \mathrm{~Bq} / \mathrm{L}$ (20,000 pCi/L) MCL established by the State of California.

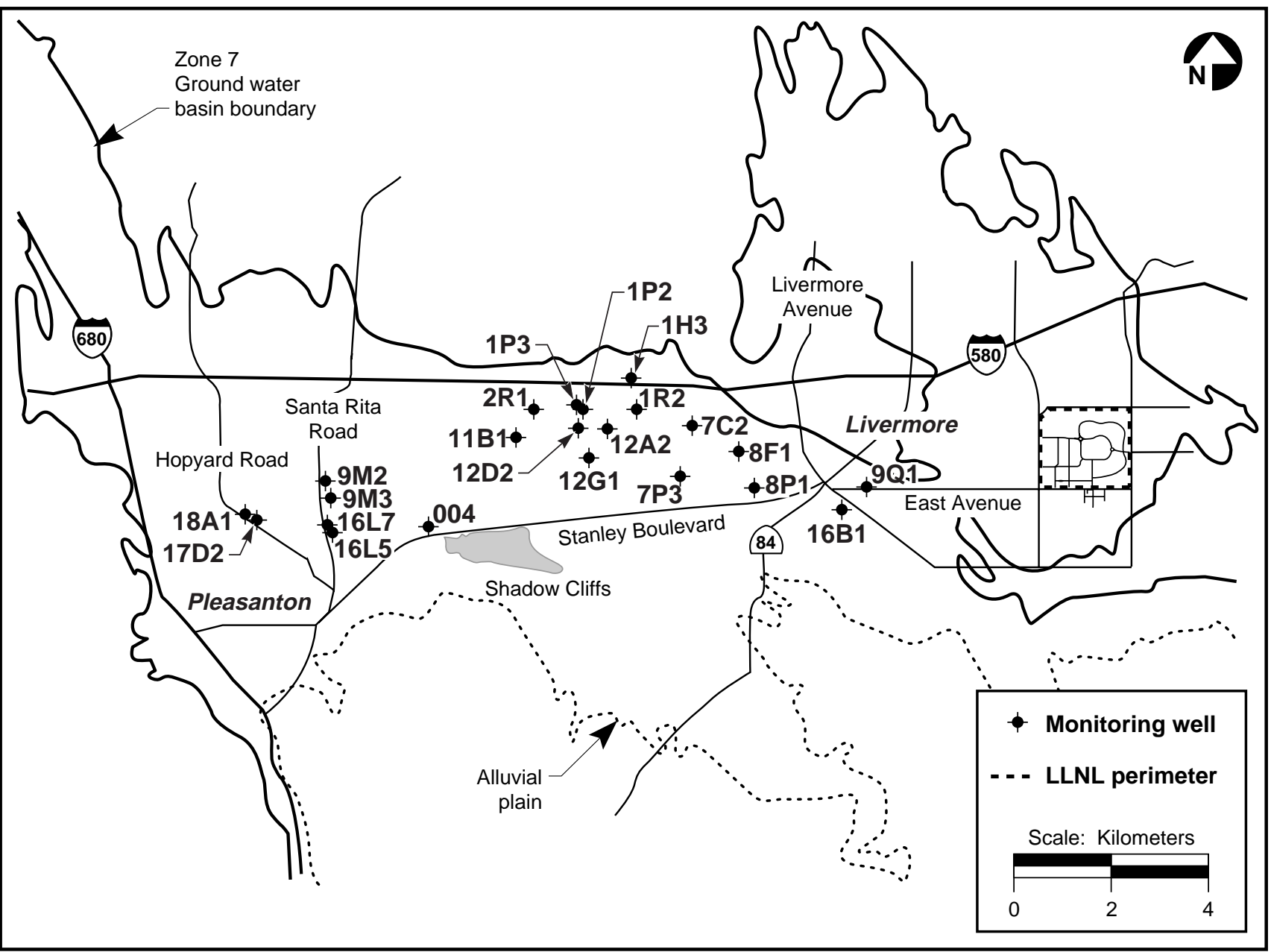

Figure 8-5. Locations of surveillance ground water monitoring wells in the Livermore Valley. 


\section{Ground Water}

As a further comparison, tritium was measured at $<1.19$ to $2.89 \mathrm{~Bq} / \mathrm{L}(0.044$ to $78.1 \mathrm{pCi} / \mathrm{L})$ in ground water samples from on-site upgradient monitoring wells and from $<1.66$ to $11.5 \mathrm{~Bq} / \mathrm{L}$ (44.9 to $310.8 \mathrm{pCi} / \mathrm{L}$ ) in on-site downgradient monitoring wells. As in previous years, the highest tritium activity measured was in a ground water sample from Well 11B1, located about $10 \mathrm{~km}$ west of LLNL. The activity in that sample in 1996 was $13.9 \mathrm{~Bq} / \mathrm{L}$ ( $377 \mathrm{pCi} / \mathrm{L})$, a decrease of $58 \%$ from its measurement of $33.0 \mathrm{~Bq} / \mathrm{L}(893 \mathrm{pCi} / \mathrm{L})$ in 1988 . This is a slightly greater decrease than can be accounted for by simple radioactive decay.

Tritium activity has shown a decreasing trend overall in Livermore Valley ground waters downgradient of LLNL. The median activities of tritium in ground water samples from these downgradient wells increased from 3.45 Bq/L (93.2 pCi/L) in 1988 to $4.59 \mathrm{~Bq} / \mathrm{L}$ (124 pCi/L) in 1989. By 1996, the median activity had dropped to 2.78 $\mathrm{Bq} / \mathrm{L}(75 \mathrm{pCi} / \mathrm{L})$. This decrease in median activity is approximately equal to that expected through radioactive decay of tritium, which has a half-life of 12.3 years.

\section{Surveillance Ground Water Monitoring of Site $\mathbf{3 0 0}$}

Surveillance monitoring of ground water at Site 300 requires samples from DOE on-site wells and from private off-site wells. Ground water samples are routinely measured for the following COCs: various elements, primarily metals; a wide range of organic compounds; general radioactivity (gross alpha and gross beta); and tritium activity. Analytical methods for COCs are selected for their sensitivity, that is, methods are chosen that have reporting limits (RLs) at, or below, toxic concentrations. Typically, drinking water maximum contaminant levels (MCLs) for COCs are referred to when selecting EPA methods for ground water analysis. (See Volume 2, Tables 8-11 and 8-12 for a complete list of COCs and the EPA methods, or other standard methods, used to measure COC concentrations in ground water.)

Figure 8-6 shows 31 surveillance and 2 compliance ground water sampling locations, which utilize a total of 24 wells and 3 springs. The primary water-bearing strata at Site 300 are the Neroly Formation upper and lower blue sandstones (Tnbs 1 and Tnbs2) and the underlying Cierbo Formation (Tmss) (see Figure 8-2). At some well locations there are as many as three distinct water-bearing zones separated by aquitards. Although most of the sampling locations at Site 300 take ground water from the shallowest waterbearing zone, four surveillance wells (K1-01, K1-02, K2-01, and K2-02) are fitted with a total of 10 Barcad devices that provide water samples from deeper water-bearing zones at those locations, one Barcad for each water-bearing zone. Nitrogen gas is admitted under pressure to the Barcad sampling devices to extract ground water for chemical analysis. 


\section{Ground Water}

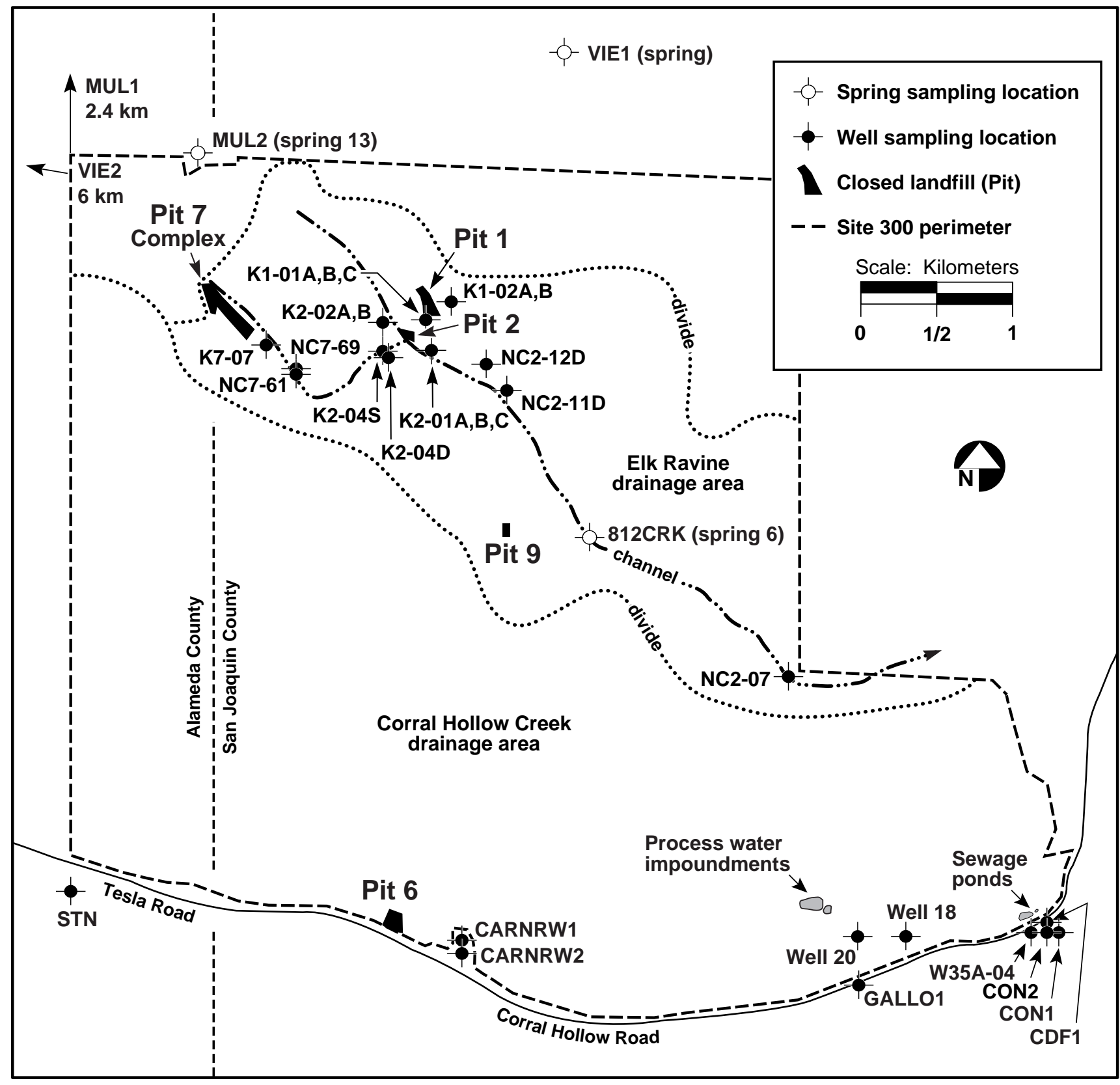

Figure 8-6. Locations of surveillance ground water wells and springs, Site 300, 1996.

Barcad samplers are identified according to depth in Figure 8-6 by the capital letters A, B, C, separated by commas at the end of a well's code name. For example, Barcad A always samples the deepest water-bearing zone. Barcads K1-01C and K1-02B at Pit 1 monitor the shallowest water-bearing zone for compliance purposes. 
Of the 31 surveillance sampling locations, 12 are off site. Three, including spring MUL2 and spring VIE1, are north of Site 300, where the Altamont hills slope down to the San Joaquin Valley. Well VIE2 lies $6 \mathrm{~km}$ west of Site 300 in the upper reaches of the Livermore Valley watershed. The remaining eight off-site surveillance locations are wells located south of Site 300 in the Corral Hollow Creek drainage area.

Twelve on-site surveillance wells are used to monitor three inactive landfills (closed pits). Six wells monitor Pit 6 (Figure 8-7). Four wells monitor Pit 9 (Figure 8-8). Six Barcads in three wells are used to monitor Pit 2 (K2-01A and B, K2-02A and B, and K1-01A and B in Figure 8-9). Nine on-site surveillance wells and one spring (812CRK) are located along the system of fault-marked ravines and arroyos that comprise the Elk Ravine drainage area (Figure 8-6). Surveillance monitoring includes two on-site water production wells, Well 18 and Well 20 (Figure 8-6). Well 20 provides potable water to Site 300 . Well 18 is maintained as a standby supply well.

Brief descriptions of the Site 300 surveillance areas and their monitoring wells are given below, together with ground water monitoring results for 1996. Detailed descriptions of Site 300 geology, hydrogeology, and the nature and extent of ground water contamination there can be found in the Final SWRI Report (Webster-Scholten 1994).

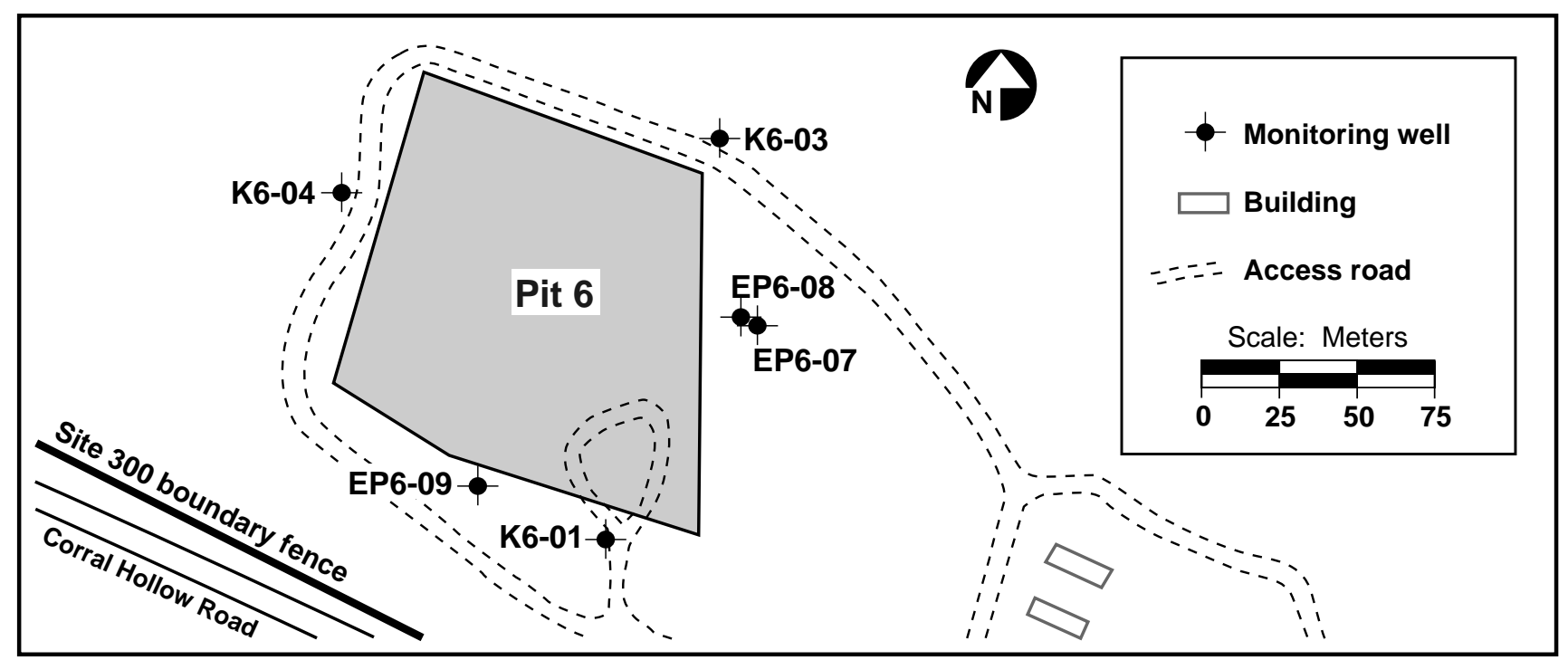

Figure 8-7. Locations of surveillance ground water monitoring wells, Pit 6, 1996. 

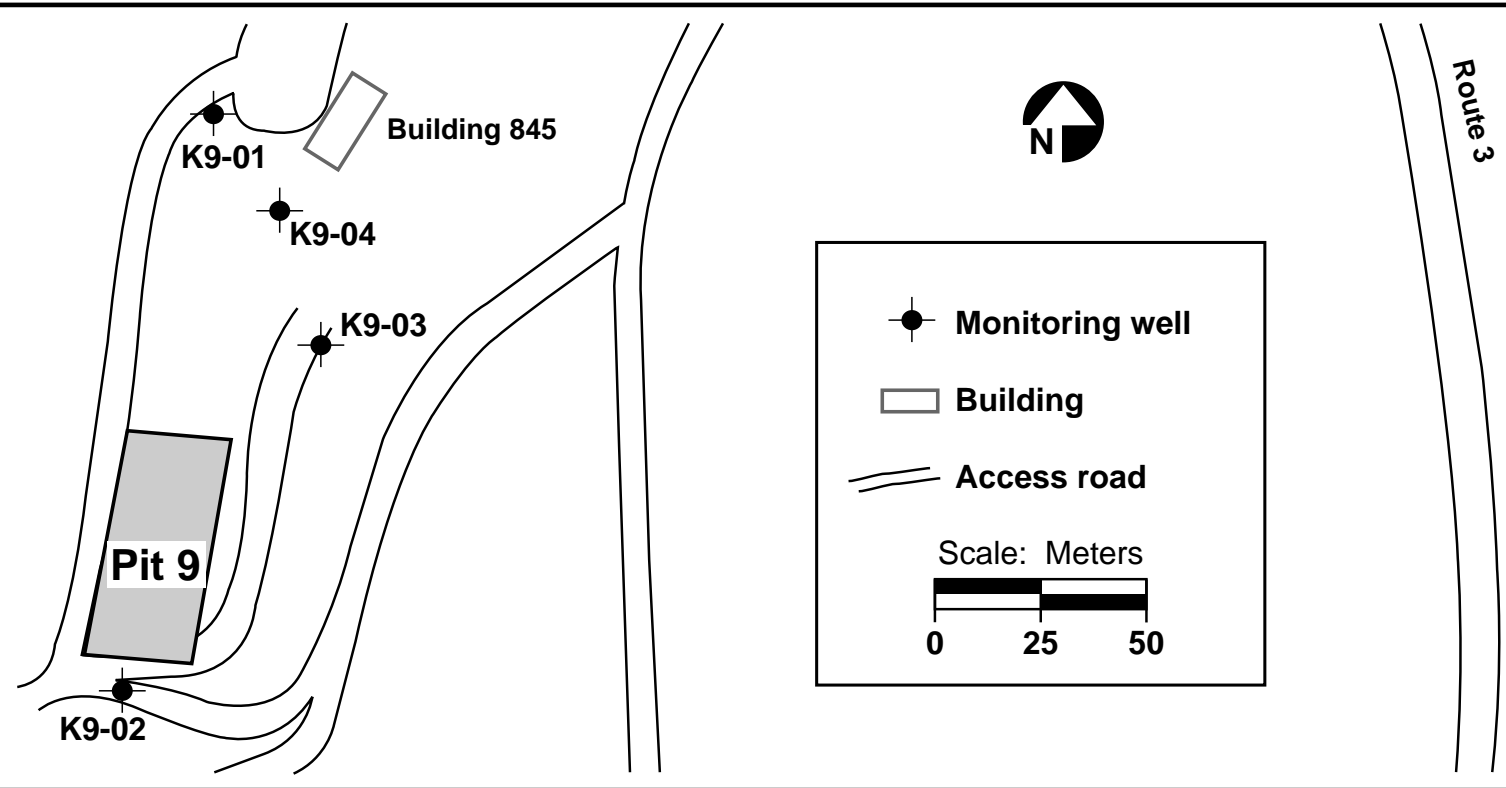

Figure 8-8. Locations of surveillance ground water monitoring wells, Pit 9, 1996.

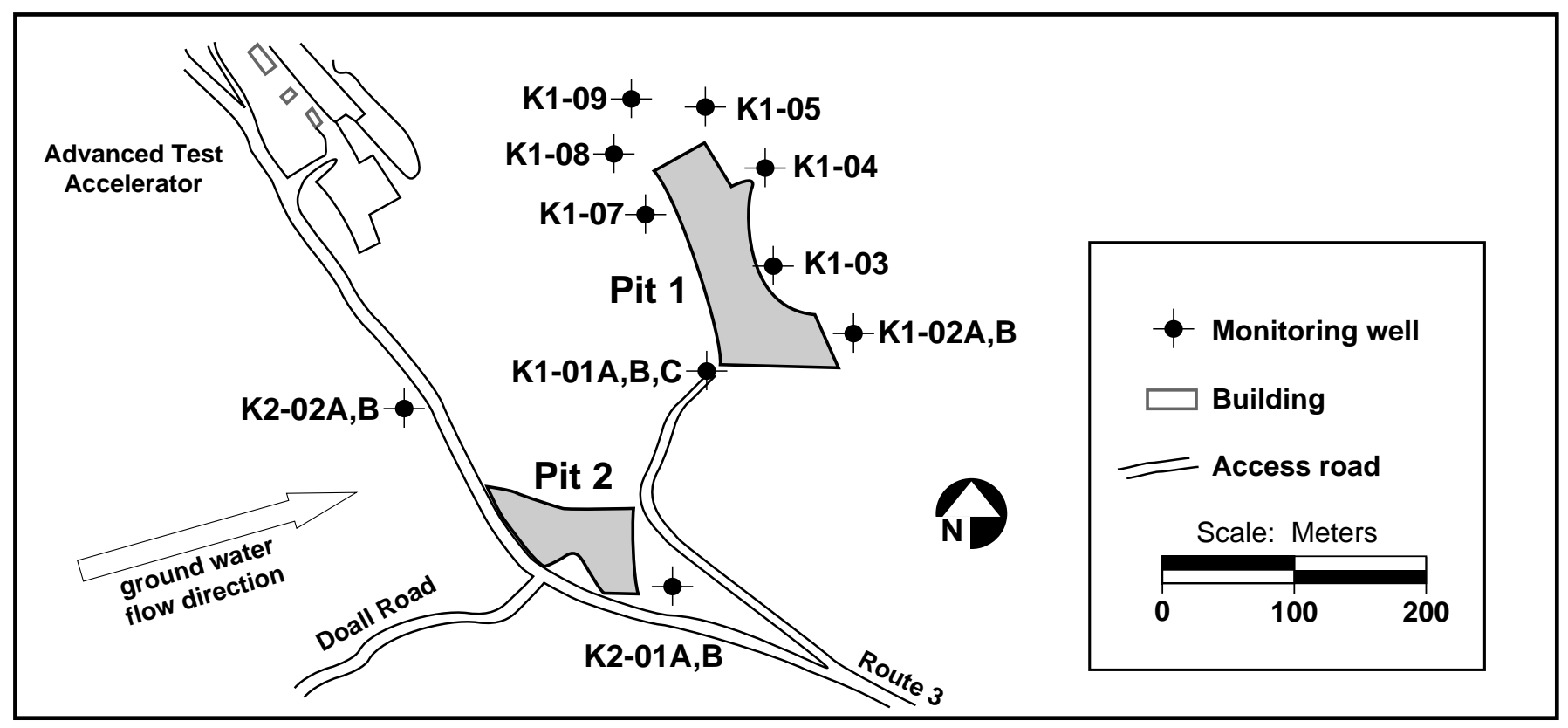

Figure 8-9. Locations of compliance ground water monitoring wells, Pit 1 (K1-01C, -07, -02B, -03, $-04,-05,-08$, and -09$)$ and $P$ it 2 surveillance wells (K1-01A and $B, K 1-02 A, K 2-01 A$ and B, and K2-02A and B), 1996. 


\section{Ground Water}

\section{Pit 6}

The unlined, closed, Pit 6 landfill lies at an average elevation of $210 \mathrm{~m}$ above sea level and covers an area of about 1 hectare adjacent to the southern boundary of Site 300 (Figures 8-6 and 8-7). From 1964 to 1973, about 1529 cubic meters (2000 cubic yards) of solid waste were buried in 9 separate trenches within the landfill. Three larger trenches contain about 1300 cubic meters (1700 cubic yards) of solid waste that includes empty drums, glove boxes, lumber, ducting, and capacitors. Six smaller trenches contain about 229 cubic meters (300 cubic yards) of biomedical waste, including animal carcasses and animal waste. A relatively small shallow plume of ground water containing TCE extends about 150 m eastward from Pit 6, parallel to Corral Hollow Road (see Chapter 2, Figure 2-2).

Pit 6 is sited in Quaternary terrace deposits (Qt; Figure 8-2) above and north of the Corral Hollow Creek flood plain. Tertiary Neroly sedimentary rocks (Tnbs 1 ; Figure 8-2) lie beneath the terrace deposits. Surface runoff from the pit area is southward to Corral Hollow Creek. Ground water flows southward beneath the pit, following the south-dipping sedimentary rocks. However, flow abruptly turns eastward beneath the southern margin of the landfill where movements along the Carnegie Fault have brought vertically dipping strata on the south into contact with the gently southward dipping strata to the north. A deposit of terrace gravel in a trough within the vertically dipping strata immediately south of the landfill acts as a channel for the ground water to flow eastward after it passes beneath Pit 6 (Webster-Scholten 1994).

Currently, six wells are used for surveillance monitoring of ground water in the vicinity of Pit 6 (Figure 8-7). With respect to the landfill and ground water flow, Well K6-03 is hydrologically upgradient, Wells K6-04, EP6-07, and EP6-08 are cross-gradient, and Wells EP6-09 and K6-01 are downgradient from Pit 6.

Ground water samples were collected twice during 1996 from the six monitoring wells. The samples were analyzed for various elements, mostly metals; volatile organic compounds, including pesticides; explosives compounds; general radioactivity (gross alpha and gross beta); and tritium $\left({ }^{3} \mathrm{H}\right)$ activity.

Data for COCs from the Pit 6 surveillance monitoring wells are presented for each of the six monitoring wells in Volume 2, Tables 8-13 through 8-18. Metals were generally not detected above RLs in Pit 6 well samples. Of the elements detected, none exceeded an MCL. Arsenic, barium, and selenium were detected at concentrations consistent with natural concentrations in the area ground water (Webster-Scholten 1994). Molybdenum, mercury, and silver were detected at extremely low concentrations. They do not represent the ground water and were probably introduced at the analytical laboratory. 


\section{Ground Water}

TCE was the only organic compound detected above its $5 \mu \mathrm{g} / \mathrm{L} \mathrm{MCL}$ in ground water from Pit 6. It was detected in Well EP6-09 at $14 \mu \mathrm{g} / \mathrm{L}$ (see Volume 2, Table 8-18). The concentration of TCE in the ground water sampled at Well EP6-09 was down 50\% from the $\mu \mathrm{g} / \mathrm{L}$ value $(28 \mu \mathrm{g} / \mathrm{L})$ in 1995 . This surveillance well specifically monitors the shallow plume of TCE-bearing ground water that extends a short distance eastward from Pit 6. The TCE plume is fully characterized and assessed in the Final SWRI Report (Webster-Scholten 1994). Conservative modeling indicates little or no risk to the environment from this slowly moving plume.

All radioactivity measurements during 1996 for gross alpha, gross beta, and tritium were below their respective MCLs in drinking water. Radioactivity of the ground water in the vicinity of Pit 6 was indistinguishable from natural background.

\section{Pit 2}

The unlined, closed, Pit 2 landfill primarily contains waste gravels and debris from experiments conducted at the Building 801 and 802 firing tables. The gravels contain debris from hydrodynamic tests of explosive devices. The waste material contains depleted uranium, or "D-38," a form of uranium consisting of the nonfissionable ${ }^{238} \mathrm{U}$ isotope. Trace amounts of beryllium, thorium, and tritium may also be present. The closed Pit 2 landfill lies in the upper portion of Elk Ravine, about $320 \mathrm{~m}$ above sea level (Figures 8-6 and 8-9). Surface runoff from the Pit 2 area is southerly into Elk Ravine. Subsurface water flow beneath the area is east-northeast, following the inclination (dip) of the underlying Miocene Tnbs 1 and Tmss sedimentary strata (Figure 8-2).

Multiple completion Well K1-01, which is downgradient of Pit 2, contains 3 Barcad devices (A, B, and C, see Figure 8-9) that sample three separate water-bearing intervals within the claystones and sandstones of the underlying Cierbo Formation (Tmss).

(Barcad K1-01C, which taps the shallowest water-bearing zone, also serves as one of two upgradient ground water monitoring points for the Pit 1 landfill to the northeast of Pit 2.) Multiple completion Wells K2-01 and K2-02 are hydrologically cross-gradient from Pit 2, but water samples from them are presumed to represent the upgradient ground water. Barcads K2-01A, K2-02A, and K2-02B are completed in Tmss. Barcad $\mathrm{K} 2-01 \mathrm{~B}$ is completed in Tnbs 1 .

For surveillance purposes at Pit 2, ground water samples from the three monitoring wells were taken twice (semiannually) during 1996. The samples were analyzed for various elements, mostly metals; volatile organic compounds; explosives compounds; general radioactivity (gross alpha and gross beta); and tritium $\left({ }^{3} \mathrm{H}\right)$ activity.

Constituents-of-concern data for the seven Pit 2 surveillance monitoring well Barcads are presented in Volume 2, Tables 8-19 through 8-25. Metals were generally not detected above reporting limits in Pit 2 well samples. None exceeded a drinking water MCL. 


\section{Ground Water}

The arsenic and barium concentrations measured are within the range of natural background concentrations found in ground waters elsewhere at Site 300 and throughout the Altamont Hills (Webster-Scholten 1994).

The radioactivity and radioisotope measurements show only low background activities for gross alpha and gross beta. Tritium activities were at low background levels in all water bearing zones near Pit 2 except for the shallow zone sampled by Barcad K2-01B. Although the maximum tritium activity measured in samples from Barcad K2-01B during 1996 was only $10 \mathrm{~Bq} / \mathrm{L}$, it is elevated relative to the activities measured in samples taken from the other Barcads and it is above background tritium activity in ground waters at Site 300 (1-2 Bq/L). This relatively elevated activity is associated with a plume of tritium-bearing water that originates beneath the Building 850 firing table, about $1 \mathrm{~km}$ upgradient (west) from Pit 2 (see Elk Ravine Drainage Section) (WebsterScholten 1994; Taffet et al. 1996). The plume appears to be confined to the Neroly formation lower blue sandstone (Tnbs 1 ) in the vicinity of Pit 2. The incursion of this tritium-bearing water into the Pit 2 area is also recorded in Barcad K1-02B ground water samples. That Barcad is a downgradient monitoring point for RCRA-closed landfill Pit 1. No measurements made on monitoring well samples suggest that any COCs were released from Pit 2 to ground water during 1996.

\section{Pit 9}

The inactive, closed, Pit 9 landfill is centrally located within Site 300 and lies at an average elevation of $340 \mathrm{~m}$ above sea level. Similar to Pit 2 , the closed Pit 9 landfill contains waste gravels and explosive experiment debris from the Building 845 firing table. Surface runoff from Pit 9 is northward into Elk Ravine. Subsurface ground water flow is north-northeast in the lower blue sandstone of the Neroly Formation (Tnbs 1 ).

Figure 8-8 shows the locations of the four surveillance wells used to monitor the ground water in the vicinity of Pit 9. Monitoring Well K9-02 is hydrologically upgradient from Pit 9. Wells K9-01, K9-03, and K9-04 are downgradient.

Well K9-02 is completed at the contact between Tnbs 1 and Tmss. Wells K9-01, K9-03, and K9-04 are completed and screened in Tmss, just below its contact with Tnbs 1 .

For surveillance purposes, Pit 9 monitoring Well K9-01, K9-02, and K9-03 were sampled once during 1996. The ground water samples were analyzed for various elements, mostly metals; nitrate; explosives compounds; volatile organic compounds; general radioactivity (gross alpha and gross beta); and tritium $\left({ }^{3} \mathrm{H}\right)$ activity.

Constituents of concern data for the four Pit 9 surveillance monitoring wells are presented in Volume 2, Table 8-26. No measurement exceeded an MCL for drinking water. No evidence for a release of any measured COC from Pit 9 was uncovered. All 


\section{Ground Water}

metals, explosives compounds, organic compounds, and radioisotopes were either not detected, or were indistinguishable from natural background concentrations.

\section{Elk Ravine Drainage Area}

The Elk Ravine drainage area includes most of northern Site 300, the area between the drainage divides shown in Figure 8-6. Surface runoff from closed landfills within the Elk Ravine drainage area (Pits 1, 2, 3, 4, 5, 7, and 9) is collected in arroyos. With sufficient seasonal rainfall, unconfined ground water can flow southeast on and within the Quaternary alluvial valley-fill deposits (Qal) that floor the Pit 7 Complex Valley. Surface runoff from the Pit 7 Complex Valley (containing the most elevated landfills) can flow southeast to Doall Road, where it is deflected northeastward into Doall Ravine by a landslide deposit (Q1s). At the northeastern end of Doall Ravine, this runoff combines with channeled runoff from the Advanced Test Accelerator (ATA) Building 865 area. From this confluence point, the arroyo trends southeasterly within Elk Ravine. Near Well NC2-07, channeled runoff turns easterly, away from the trend of the Elk Ravine fault, and flows off site for approximately $2 \mathrm{~km}$ to its confluence with Corral Hollow Creek. Except for Doall Ravine, the arroyos and valley-fill deposits traverse and follow faults, especially the extensive Elk Ravine Fault, that may provide pathways to the underlying ground water. Thus, ground waters from wells that lie within the Elk Ravine drainage area are monitored for COCs. The monitored wells are (from highest to lowest elevation) K7-07, NC7-61, NC7-69, K2-04D, K2-04S, K2-01C, NC2-12D, NC2-11D, and NC2-07. The 812CRK sampling location is a natural spring ( also known as Spring 6). It is located in the main Elk Ravine arroyo on the Elk Ravine Fault. Individual well locations are discussed below.

Well K7-07 is located in the Pit 7 Complex Valley. It is a shallow well completed in both Tnbs $_{1}$ and Qal. This well is downgradient from landfill Pits 3, 4, 5, and 7, with respect to unconfined flow in the valley-fill deposits (Qal) and to surface runoff. Wells NC7-61 and NC7-69 are completed in separate water-bearing zones beneath the upper reaches of Doall Ravine. Well NC7-61 is completed in Tnbs ${ }_{1}$ (shallower zone), and Well NC7-69 is completed in Tmss (deeper zone). Wells K2-04D and K2-04S and Barcad K2-01C are located near the join between Elk Ravine and Doall Ravine. They are all completed in Tnbs1. Wells NC2-12D and NC2-11D are located in Elk Ravine below its join with Doall Ravine. Well NC2-11D is completed at the contact between Tnbs 1 and Tmss. NC2-07 is the furthest downstream surveillance well in the Elk Ravine drainage area. It is completed in Tnbs 1 .

For surveillance purposes, ground water samples were taken at six-month intervals (semiannually) during 1996 from monitoring wells in Elk Ravine and from the 812CRK spring. The samples were analyzed for various elements, mostly metals; explosives compounds; volatile organic compounds; general radioactivity (gross alpha and gross beta); and tritium $\left({ }^{3} \mathrm{H}\right)$ activity. 


\section{Ground Water}

Surveillance analytical data for the ground water samples obtained during 1996 from monitoring wells in the Elk Ravine drainage area are given in Volume 2, Tables 8-27 through 8-36. Generally, no VOCs or HE compounds were detected. Arsenic, barium, molybdenum, selenium, and vanadium were detected at low concentrations consistent with natural sources for these elements in the rocks at Site 300. Except for tritium activity, gross alpha and beta activities were low and were indistinguishable from natural background. Tritium activity was above background in many of the ground water samples. Anomalous measurements for individual well samples are discussed below.

\section{Well K7-07}

Semiannual samples gave tritium activities of $238 \mathrm{~Bq} / \mathrm{L}$ and $139 \mathrm{~Bq} / \mathrm{L}$, considerably above tritium activity background (1-2 Bq/L). These results were expected. Well K7-07 lies within a known plume of tritium-bearing water.

LLNL remedial investigators have previously concluded that tritium, as tritiated water (HTO), is released occasionally from soil moisture in landfills and beneath the firing table at Building 150. Tritiated water is released from Pit 3 and Pit 5 during wetter-than-normal winters when ground water rises and contacts firing table wastes contained in these two unlined landfills. A major release of HTO occurred during the unusually wet winter of 1982-83 (Webster-Scholten 1994), and additional minor releases occurred during the wet winters of 1992-93 and 1994-95 (Taffet et al. 1996). HTO is also transported to ground water beneath the Building 150 firing table gravels by percolating water from rain and from dust-control spraying (Taffet et al. 1996). The configuration of the tritium-bearing ground water plume at Site 300, updated for 1996, is shown in Figure 8-10. The HTO plume is shallow and appears to be confined to the Neroly lower blue sandstone $\left(\operatorname{Tnbs}_{1}\right)$.

\section{Wells NC7-61 and NC7-69}

Well NC7-61 samples ground water from within the tritium plume near its source beneath the Building 850 firing table (Figure 8-10). The semiannual ground water samples from Well NC7-61 had elevated tritium activities of $6316 \mathrm{~Bq} / \mathrm{L}$ and $6543 \mathrm{~Bq} / \mathrm{L}$. The mean of the two activities, $6430 \mathrm{~Bq} / \mathrm{L}$, is $7.8 \%$ lower than the 1995 mean, $6975 \mathrm{~Bq} / \mathrm{L}$. The decay of tritium (12.3 year half-life) accounts for $5.5 \%$ of this decrease over the oneyear period. The remaining $2.3 \%$ decrease can be attributed to diffusion of HTO and downgradient movement of the plume. As in previous years, tritium activity in the underlying Cierbo Formation (Tmss) was very low, less than $1 \mathrm{~Bq} / \mathrm{L}$, as measured in the ground water samples from Well NC7-69. The marked difference in tritium activity between ground water samples from these two wells demonstrates that the HTO plume is confined to the shallow Neroly lower blue sandstone $\left(\operatorname{Tnbs}_{1}\right)$ in this area. 


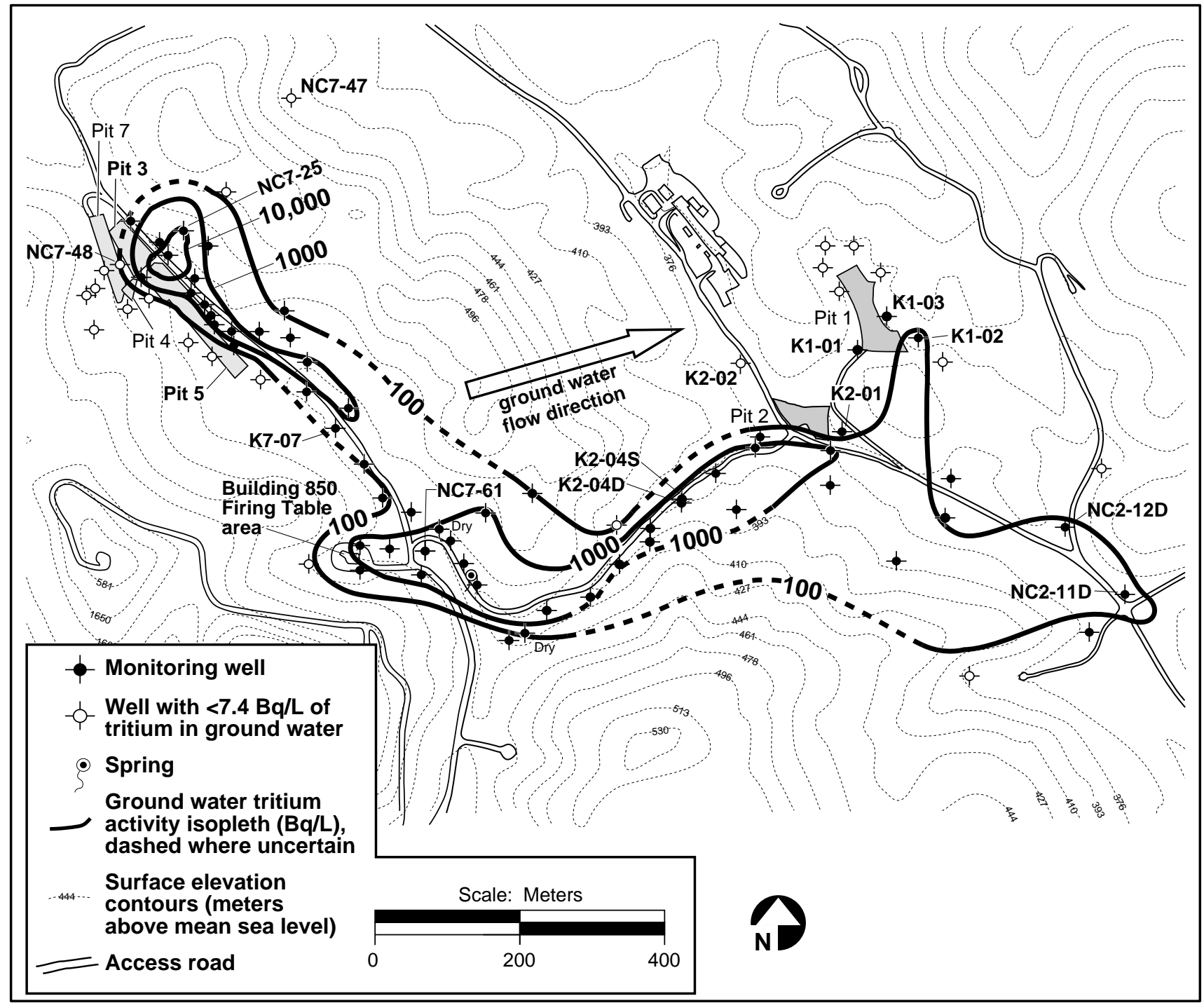

Figure 8-10. Map showing distribution of tritiated ground water extending from the Pit 7 Complex valley to Doall Ravine and Elk Ravine, 1996.

\section{Wells K2-04D, K2-04S, and K2-01C}

One antimony measurement $(10 \mu \mathrm{g} / \mathrm{L}$ in one ground water sample from monitoring Well K2-04D) exceeded the $6 \mu \mathrm{g} / \mathrm{L}$ drinking water MCL for antimony. However, the detection is questionable, because analysis of a duplicate quality control ground water sample taken from this well gave a nondetection for antimony $(<5 \mu \mathrm{g} / \mathrm{L})$.

Elevated tritium activity relative to background was measured in semiannual ground water samples from all three surveillance wells. These wells also monitor the plume of tritium-bearing ground water that extends from the Pit 7 Complex Valley through Doall Ravine into Elk Ravine (Figure 8-10). The 1996 mean tritium activity for Well K2-04D, 


\section{Ground Water}

$277 \mathrm{~Bq} / \mathrm{L}$, is $49 \%$ lower than the $540 \mathrm{~Bq} / \mathrm{L}$ mean activity for 1995 . The 1996 mean tritium activity for Well K2-04S, $1256 \mathrm{~Bq} / \mathrm{L}$, is approximately equal to the $1227 \mathrm{~Bq} / \mathrm{L}$ mean activity for 1995. The 1996 mean tritium activity for the Well K2-01C samples, $384 \mathrm{~Bq} / \mathrm{L}$, is $70 \%$ higher than the $227 \mathrm{~Bq} / \mathrm{L}$ mean for 1995 . The upgradient decrease and downgradient increase in tritium activity reflects continued eastward advection of the HTO plume.

\section{Wells NC2-11D and NC2-12D}

Elevated tritium activity relative to background was measured in semiannual ground water samples from both of these surveillance wells. These wells are situated near the leading edge of the tritium-bearing ground water that is moving slowly eastward in the Neroly lower blue sandstone (Tnbs 1 ) beneath Elk Ravine (Figure 8-10). The mean tritium activity for Well NC2-11D, $100 \mathrm{~Bq} / \mathrm{L}$, is slightly higher than the $88 \mathrm{~Bq} / \mathrm{L}$ mean for 1995, and the $216 \mathrm{~Bq} / \mathrm{L}$ mean for Well NC2-12D is 35\% higher than the $160 \mathrm{~Bq} / \mathrm{L}$ mean for 1995. These increasing activities reflect continuing downgradient movement (advection) of the tritium plume.

\section{CRK (Spring 6) and Well NC2-07}

Detections of arsenic, barium, and vanadium at these locations far below MCLs and near detection limits are consistent with natural sources in the rocks. A trace of mercury in the second ground water sample taken from Well NC2-07 during 1996 is not characteristic of the ground water there. Traces of mercury were also detected in a batch of ground water samples taken from other distant unrelated wells. Most likely, the mercury was introduced at the analytical laboratory. Gross alpha and gross beta activities are low at the two locations and cannot be distinguished from background activities. Tritium activity at the two locations is also very low. These sampling locations are distant from the slowly moving tritium plume beneath Elk Ravine, but they will eventually detect its arrival.

\section{Wells 18 and 20}

Well 20 supplied potable water at Site 300 during 1996, while Well 18 was maintained as a standby water supply well. The wells are located in the southeastern part of the site (Figure 8-6). Both are deep, high-production water wells that are completed in the Neroly Formation lower blue sandstone $\left(\operatorname{Tnbs}_{1}\right)$. The Well 18 completion zone extends upwards into a fine-grained aquitard ( $\left.\operatorname{Tnsc}_{1}\right)$ in the Neroly Formation that separates $\mathrm{Tnbs}_{1}$ from the overlying upper blue sandstone $\left(\mathrm{Tnbs}_{2}\right)$. Either well can produce up to $1500 \mathrm{~L} / \mathrm{min}$.

For surveillance purposes, ground water samples were taken at three-month intervals (quarterly) from these two on-site supply wells. Water samples from Well 20 were analyzed for various elements, mostly metals; nitrate; explosives compounds, volatile 


\section{Ground Water}

organic compounds; general radioactivity (gross alpha and gross beta); and tritium $\left({ }^{3} \mathrm{H}\right)$. Well 18 water samples were analyzed for volatile organic compounds; general radioactivity (gross alpha and gross beta); and tritium $\left({ }^{3} \mathrm{H}\right)$.

Surveillance analytical data for the two on-site potable water supply wells are presented in Volume 2, Tables 8-37 and 8-38. No metals of concern were detected in Well 20 during 1996, except molybdenum at $34 \mathrm{ppb}$ in the fourth quarter water sample. Like mercury, molybdenum appeared suddenly during the fourth quarter in trace amounts near the detection limit in several samples from wells distant from each other. Because the affected well samples were from widely separated ground waters, traces of molybdenum, like mercury (and probably silver), were probably introduced at the analytical laboratory during sample processing.

A clear instance of sample contamination occurred during 1996 when lead was unexpectedly measured in 19 well water samples. After LLNL questioned the results, the analytical laboratory discovered lead in their sample preparation equipment and removed it. The wells were sampled again and analyzed for lead. None was detected. The causes of some anomalous mercury, molybdenum, and silver detections could not, unfortunately, be determined with such certainty. It is suspected that routine cleaning of sample preparation and measurement equipment at the analytical laboratory removed evidence of contamination before LLNL's inquiries began.

Gross alpha, gross beta, and tritium activities in water samples from both production wells are very low and are indistinguishable from natural background activities.

\section{Off-Site Supply Wells}

For surveillance purposes during 1996, ground water samples were obtained from twelve off-site locations. Eleven of these locations are adjacent to Site 300. A distant well, VIE2, located at a private residence $6 \mathrm{~km}$ west of Site 300, is typical of clean water supply wells in the Altamont Hills. One cattle well, MUL1, and two cattle springs, MUL2 and VIE1, are adjacent to Site 300 on the north. Eight wells, CARNRW1, CARNRW2, CDF1, CON1, CON2, GALLO1, STN, and W-35A-04, are adjacent to the site on the south (Figure 8-6). W-35A-04 is a well installed by LLNL for monitoring only. Wells CARNRW2, GALLO1, and STN supply some water for human consumption. Well CDF1 is owned by the California Department of Forestry and supplies water for fire fighting. The remaining wells are used to water cattle or are used for irrigation.

Ground water samples were taken quarterly during 1996 at six off-site well locations. Of these, CARNRW1 and CON2 samples were analyzed only for volatile organic compounds, while CARNRW2, CDF1, CON1, and GALLO1 samples were analyzed for various elements, mostly metals; general parameters; explosives compounds; volatile organic compounds; inorganic compounds; general radioactivity (gross alpha and gross 


\section{Ground Water}

beta); and tritium $\left({ }^{3} \mathrm{H}\right)$ activity. Six off-site locations-MUL1, MUL2, STN, VIE1, VIE2, and W-35A-04-were sampled once (annually) during 1996 for various elements, mostly metals; nitrate; volatile organic compounds; explosives compounds; general radioactivity (gross alpha and gross beta); and tritium $\left({ }^{3} \mathrm{H}\right)$ activity. In addition to the analyses listed above, uranium isotope activities were determined for the MUL1 and STN ground water samples.

Surveillance analytical data for the 12 off-site water supply locations are presented in Volume 2, Tables 8-39 to 8-45. Arsenic and barium are widely detected at these locations, but their concentrations are below MCLs and are consistent with natural sources in the rocks. A few scattered detections of molybdenum, selenium, copper, lead, and zinc are observed at concentrations below MCLs.

Low concentrations of trihalomethanes (THMs) are detected in water samples from the W35A-04 monitoring well. The THMs were caused by chlorination of the well about one month before the annual surveillance sample was taken.

The concentration of TCE was near the reporting detection limit of $0.2 \mu \mathrm{g} / \mathrm{L}$ in the ground water samples taken from the GALLO1 surveillance well during 1996. The GALLO1 well is hydrologically upgradient from the nearest TCE contamination at Site 300, in the General Services Area (GSA; Figure 2-2, Chapter 2). LLNL remedial investigators concluded that the low concentration of TCE in the GALLO1 well water was probably due to a localized surface spill on the property, possibly from solvents used on a pump truck or another vehicle used to service the private well (WebsterScholten 1994). All radioactivity and tritium activities in ground water samples from the off-site surveillance wells are low and are indistinguishable from natural background activities in the Site 300 area.

\section{Compliance Ground Water Monitoring at Site $\mathbf{3 0 0}$}

Little flexibility is available to LLNL for compliance monitoring of ground water at Site 300, where requirements are specified in Waste Discharge Requirement (WDR) Orders, issued by the California Central Valley Regional Water Quality Control Board (CVRWQCB), and in post-RCRA-closure monitoring and reporting plans approved by the California EPA Department of Toxic Substances Control (DTSC). The WDRs and post-closure plans specify the wells to be monitored, the COCs to be measured, measurement frequency, analytical methodology, and the frequency and form of required reports.

Ground water compliance monitoring programs are carried out at Site 300 in response to LLNL Site 300 Resource Conservation and Recovery Act (RCRA) Closure and Post- 


\section{Ground Water}

Closure Plans for Landfill Pits 1 and 7 and WDR Order Nos. 93-100 and 96-248 (amending WDR 85-188). Compliance monitoring and reporting allow LLNL to evaluate operations of closed RCRA Landfill Pits 1 and 7, the Explosives Process Area Class II surface impoundments, and the sewage evaporation and percolation ponds and assure that they are consistent with regulatory requirements. WDR Order No. 93-100 and the post-closure monitoring plan developed within the RCRA Closure and PostClosure Plans establish the basis for the compliance monitoring network around Pits 1 and 7. Volume 2, Tables 8-46 to 8-49 list Pit 1 and 7 data pertaining to WDR 93-100 and post-closure monitoring. WDR Order No. 96-248 establishes the basis for compliance monitoring of the surface impoundments and sewage ponds. These monitoring programs include quarterly and semiannual monitoring of the ground water wells in each monitoring network, monitoring of various influent streams to the surface impoundments and the sewage ponds, semiannual monitoring, and quarterly visual observations of the sewage ponds. Each compliance monitoring network requires quarterly and annual self-monitoring reporting. Volume 2, Table 8-50 lists constituents of concern that show statistical evidence of having been released to ground water.

\section{Landfill Pits 1 and 7}

The Compliance Monitoring Program for Pits 1 and 7 includes ground water sampling and analysis, visual inspections, elevation surveys, and reporting of work performed. The work is specified in monitoring plans that accompany WDR 93-100, Revision 1, (CVRWQCB 1993, 1996), and the RCRA Closure and Post-Closure Plan (Rogers/Pacific Corporation, 1990). Samples of ground water are obtained quarterly from monitoring wells upgradient and downgradient from the two landfills. The samples are analyzed for COCs that may occur in the wastes buried in the unlined landfills. The wastes are mostly gravels from firing tables at Site 300 that contain debris from explosive experiments. In order to maintain the physical integrity of the two landfills, LLNL technical staff visually inspect them at least once a quarter and after major rainstorms. Each year, LLNL hires a Professional Engineer to inspect the two landfills and to provide a written report of findings. LLNL surveyors annually measure the elevations of fixed markers on the two landfill caps. The measurements are used to locate any settling that could adversely affect the integrity of the caps.

Brief descriptions of the compliance areas and their associated monitoring wells follow. More extensive descriptions can be found in the Final SWRI Report (Webster-Scholten 1994) and Addendum (Taffet et al. 1996).

\section{Pit 1 Area}

Figure 8-8 shows the RCRA-closed Pit 1 landfill and the eight compliance wells used to monitor the ground water in the vicinity of the inactive landfill. Pit 1 lies in the upper part of the Elk Ravine drainage area at an average elevation of $330 \mathrm{~m}$ above sea level. 


\section{Ground Water}

The RCRA cap constructed on Pit 1 in 1992 includes a layer of impermeable clay to prevent rainwater infiltration. A water-diversion channel made of concrete surrounds the landfill. Its purpose is to reduce local ground water recharge by collecting runoff from the cap and the surrounding area. The outfall of the diversion channel is at the southwest corner of Pit 1, where surface runoff flows to Elk Ravine.

Ground water flows in an east-northeast direction beneath Pit 1, following the dip of the underlying sedimentary rocks. The eight Pit 1 compliance monitoring wells are screened in the shallowest water-bearing zone, either in the Neroly Formation lower blue sandstone (Tnbs 1 ), or beneath Tnbs 1 in the Cierbo Formation (Tmss; Figure 8-2).

With respect to Pit 1 and the direction of ground water flow, Wells K1-01C and K1-07 are hydrologically upgradient, Wells K1-02B, K1-03, K1-04, and K1-05 are downgradient, and K1-08 and K1-09 are cross-gradient.

For compliance monitoring purposes, samples of ground water were taken quarterly from Pit 1 monitoring wells and were analyzed for COCs. Measurements were made for various elements, mostly metals; general radioactivity (gross alpha and gross beta); the radioisotopes tritium $\left({ }^{3} \mathrm{H}\right)$, radium $\left({ }^{226} \mathrm{Ra}\right)$, uranium $\left({ }^{234} \mathrm{U},{ }^{235} \mathrm{U}\right.$, and $\left.{ }^{238} \mathrm{U}\right)$, and thorium (228Th and ${ }^{232} \mathrm{Th}$ ); explosives compounds (cyclotetramethyltetramine [HMX], and hexahydro-1,3,5-trinitro-1,3,5-triazine [RDX]; total organic carbon (TOC); total organic halides (TOX); purgeable organic compounds (EPA Method 624); extractable organic compounds (EPA Method 625); pesticides (EPA Method 608); total dissolved solids (TDS); specific conductance; water temperature; $\mathrm{pH}$; and water table elevation.

Tables 8-46 and 8-47 in Volume 2 list the compliance COCs measured in ground water in the vicinity of Pit 1.

During the first quarter of 1996, no permitted concentration limit was exceeded by validated measurements (Christofferson and MacQueen 1996a). During the second quarter of 1996, a barium concentration of $28 \mu \mathrm{g} / \mathrm{L}$ in a ground water sample from Pit 1 monitoring Well K1-04 exceeded the $25 \mu \mathrm{g} / \mathrm{L}$ concentration limit for that well. (For reference, the MCL for barium in drinking water is $1000 \mu \mathrm{g} / \mathrm{L}$.) Additional sampling and analyses during the second quarter confirmed the presence of barium (Christofferson and MacQueen, 1996b). However, two subsequent quarterly analyses did not detect barium. Barium occurs naturally in ground water at Site 300 (WebsterScholten 1994; Taffet et al. 1996), and its presence in the vicinity of Pit 1 is most likely due to natural sources in the rocks.

During the third quarter of 1996, a total uranium activity of $0.23 \mathrm{~Bq} / \mathrm{L}$ exceeded the $0.13 \mathrm{~Bq} / \mathrm{L}$ concentration limit for ground water samples from monitoring Well K1-02B, and a tritium activity of $16.58 \mathrm{~Bq} / \mathrm{L}$ exceeded the $11.43 \mathrm{~Bq} / \mathrm{L}$ concentration limit for ground water samples from monitoring Well K1-03 (Christofferson and MacQueen, 


\section{Ground Water}

1996c). Previously conducted analyses of uranium by mass spectroscopy at LLNL show that the uranium activity in Pit 1 ground water is due to natural uranium. The tritium activity is related to the previously described tritium plume that originates in soil moisture beneath the Building 850 firing table, about $1 \mathrm{~km}$ upgradient from Pit 1 (Figure 8-10). The relatively elevated tritium activity measured in ground water from Pit 1 monitoring Well K1-03 signifies that the leading edge of the tritium plume has reached this well. Two other wells in the Pit 1 monitoring network are affected by the encroaching plume: K1-02B and the upgradient Well K1-01C.

During the fourth quarter of 1996, no concentration limits were exceeded by validated measurements. As in the past, 1,1,2-trichloro-1,2,2-trifluoroethane (Freon 113) appears in ground water samples from Pit 1 monitoring Wells K1-05 $(41 \mu \mathrm{g} / \mathrm{L}), \mathrm{K} 1-08(98 \mu \mathrm{g} / \mathrm{L})$, and K1-09 $(150 \mu \mathrm{g} / \mathrm{L})$. (For reference, the MCL for Freon 113 in drinking water is $1200 \mu \mathrm{g} / \mathrm{L}$.) The Freon is not from Pit 1. Rather, it is linked to past spills of Freon in the Advanced Test Accelerator area (Figure 8-9; Webster-Scholten 1994; Taffet et al. 1996). Although several COCs have shown statistically significant evidence of release from Pit 1 (Volume 2, Table 8-46), ground water monitoring has yet to produce compelling evidence for the release of any COC to ground water from Pit 1.

\section{Pit 7 Complex Area}

Nine compliance wells monitor the Pit 7 Complex comprising four adjacent closed landfills that are covered, but are unlined (Figure 8-11). Pits 3, 4, and 5 were closed before RCRA became effective. Pit 7 was closed under RCRA during 1992-93. The complex of closed landfills is located in the Pit 7 Complex Valley. From 1963 to 1988, the landfills received waste gravels from firing tables at Site 300. The gravels contained concrete, cable, plastic, wood, tritium, depleted uranium, beryllium, lead, and other metals in trace amounts. In 1988, 9440 cubic meters (12,350 cubic yards) of gravel were removed from six firing tables at Site 300 and were placed in Pit 7 (Lamarre and Taffet 1989). These were the last solid wastes to be placed in landfills at Site 300. (Since 1988, spent firing table gravels are shipped to LLNL's Nevada Test Site for disposal.)

RCRA closure of Pit 7 was completed in February 1993. Closure included construction of a cap, runoff diversion channels, and a ground water interceptor trench to reduce local ground water recharge from rain.

Ground water beneath the Pit 7 Complex Area flows east-northeast, following the dip of the underlying sedimentary rocks. 


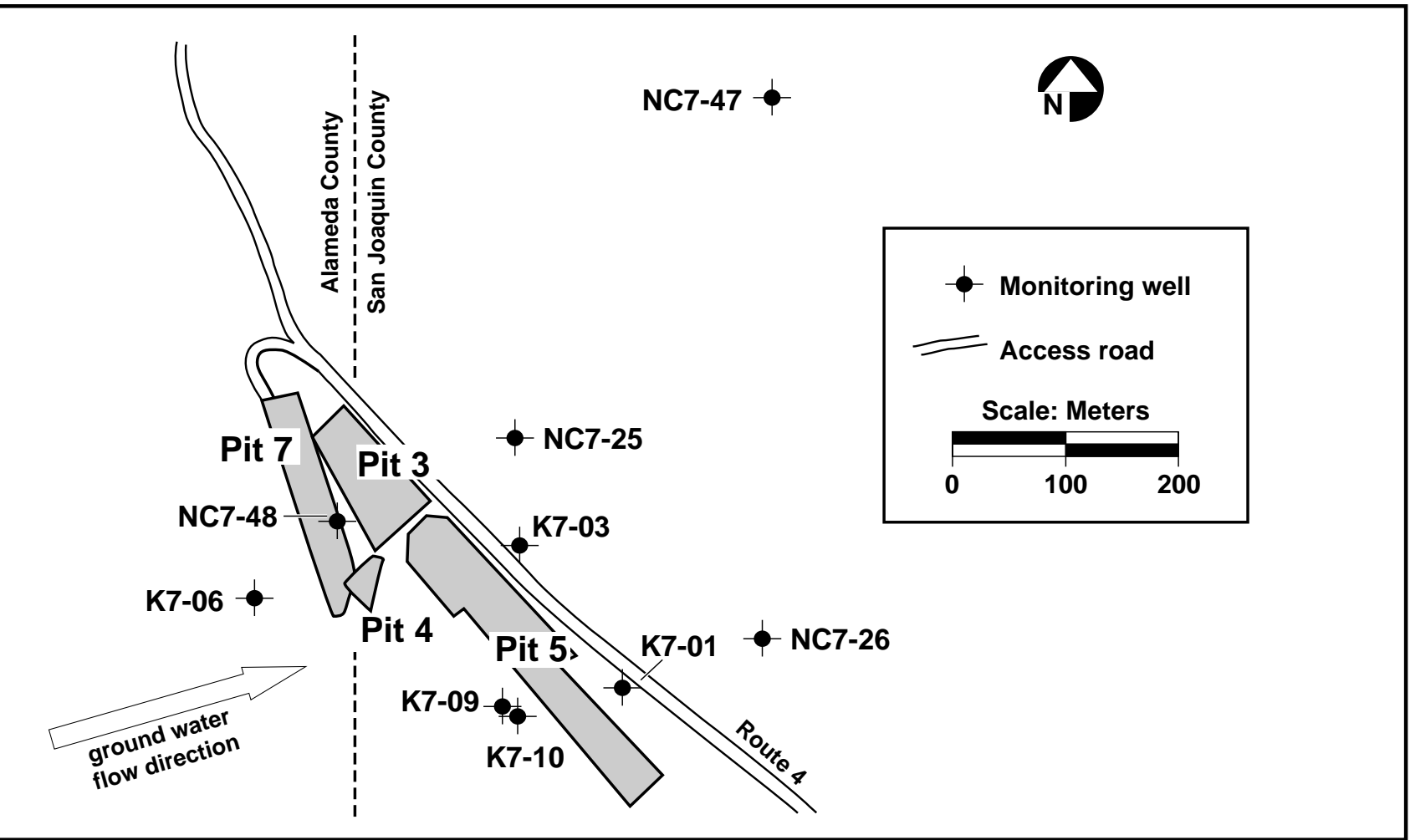

Figure 8-11. Locations of compliance ground water monitoring wells, Pit 7 Complex.

Monitoring Well K7-06 is hydrologically upgradient from Pit 7, Wells K7-09 and K7-10 are cross-gradient, and Wells K7-01, K7-03, NC7-25, NC7-26, NC7-47, and NC7-48 are downgradient. Wells K7-01, K7-10, and NC7-26 are completed in the Neroly lower blue sandstone $\left(\mathrm{Tnbs}_{1}\right)$.The remaining wells are completed beneath Tnbs 1 in the Cierbo claystones and sandstones (Tmss).

For compliance monitoring during 1996, ground water samples were taken quarterly from Pit 7 monitoring wells and were analyzed for COCs fulfilling the requirements of WDR Order No. 93-100 Revision 1 (CVRWQCB 1993, 1996) and the RCRA post-closure monitoring plan (Rogers/Pacific Corporation 1990). Measurements were made for various elements, mostly metals; general radioactivity (gross alpha and gross beta); the radioisotopes tritium $\left({ }^{3} \mathrm{H}\right)$, radium $\left({ }^{226} \mathrm{Ra}\right)$, uranium $\left({ }^{234} \mathrm{U},{ }^{235} \mathrm{U}\right.$, and $\left.{ }^{238} \mathrm{U}\right)$, and thorium (228Th and ${ }^{232} \mathrm{Th}$ ); explosives compounds (cyclotetramethyltetramine [HMX], and hexahydro-1,3,5-trinitro-1,3,5-triazine [RDX]; volatile organic compounds (EPA Method 601); and ground water elevation. The uranium isotope measurements were summed and are reported as total uranium. The Pit 7 compliance analytical data for 1996 are presented in Volume 2, Tables 8-48 and 8-49. 


\section{Ground Water}

During the first quarter of 1996, a nickel concentration of $5.6 \mu \mathrm{g} / \mathrm{L}$ in the ground water sample from monitoring Well K7-09 exceeded the $5 \mu \mathrm{g} / \mathrm{L}$ concentration limit for that well. Although one of two retest samples showed nickel above the concentration limit, three subsequent quarterly analyses during 1996 did not detect nickel. No third or fourth quarter analysis detected nickel in any ground water sample from Pit 7 monitoring wells.

During the second quarter of 1996, no concentration limits were exceeded by validated measurements. However, total uranium activity in the ground water samples from Wells NC7-25 (0.77 Bq/L) and NC7-48 (0.87 Bq/L), exceeded the 0.74 Bq/L MCL for drinking water.

A CERCLA uranium characterization of ground water at Site 300, begun in 1994, was completed in 1996 (Taffet et al. 1996). The characterization was undertaken to determine the extent of "depleted" uranium, or D-38, in the ground water across the northern half of Site 300. D-38 was discovered in 1993 in ground water samples from Pit 7 monitoring Well NC7-48 (Christofferson et al. 1993). The subsequent CERCLA uranium study identifies Pit 5, Pit 7, and the Building 850 firing table gravels as three likely sources of D-38 in the ground water (Taffet et al. 1996). The CERCLA study further concludes that D-38 was released from Pits 5 and 7 during the wetter-than-normal winter of 1982-1983, when above normal rainfall and local ground water recharge caused the water table to rise into contact with solid wastes in the two landfills.

The addition of small amounts of D-38 to ground water already containing considerable natural uranium has resulted in total uranium activities in excess of the $0.74 \mathrm{~Bq} / \mathrm{L}$ (20 pCi/L) California MCL for drinking water. Two small, shallow plumes of ground water with total uranium activity exceeding $0.74 \mathrm{~Bq} / \mathrm{L}$ are shown in Figure 8-12. Interestingly, spectroscopy measurements indicate that natural uranium is the primary source of total uranium activity in ground water at Well NC7-25, whereas D-38 is the major component of total uranium in the ground water at Well NC7-48. A substantial source of natural uranium is indicated in the aquifer rocks.

During the third quarter of 1996, a routine measurement of copper in the ground water sample from monitoring Well K7-03 exceeded the concentration limit for copper and was initially reported to the CVRWQCB as indicating "statistically significant evidence for a release." However, subsequent analyses showed copper concentration below the concentration limit (Christofferson and MacQueen 1996c). During the fourth quarter of 1996, no concentration limits were exceeded by validated measurements. 


\section{Ground Water}

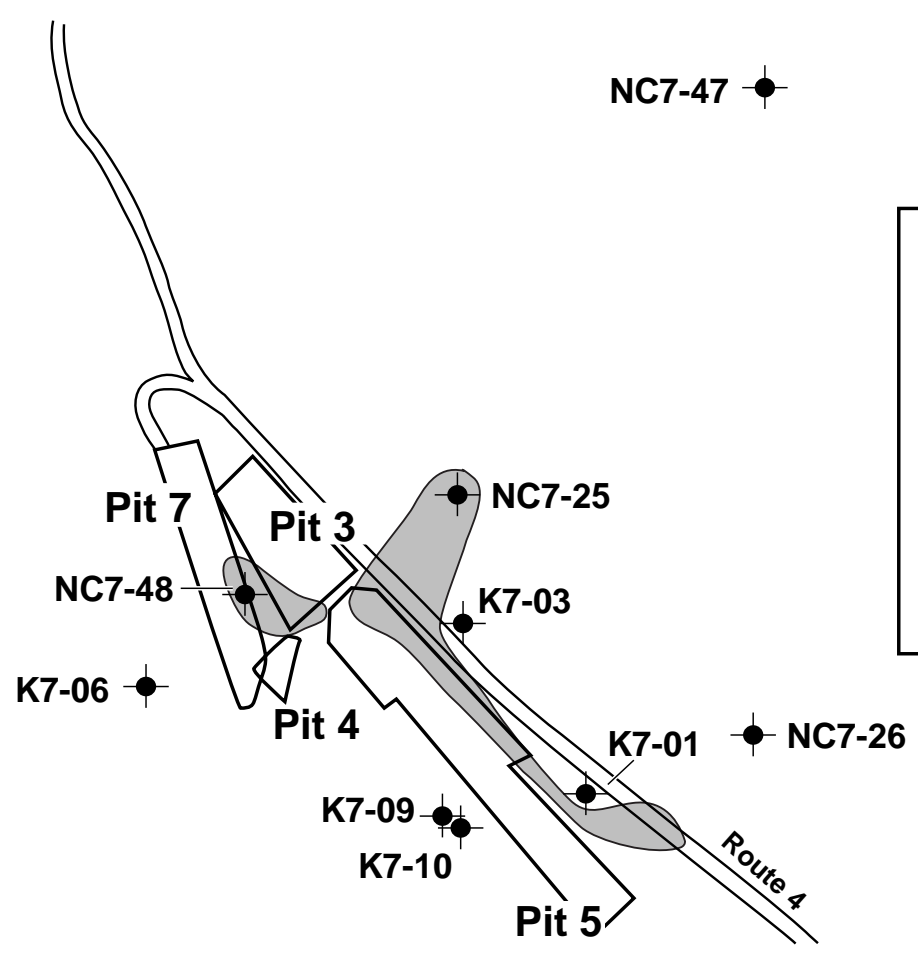

Figure 8-12. Map of the Pit 7 Complex showing two shallow ground water plumes where uranium is in excess of the California MCL for drinking water.

During all of 1996, as in the past, tritium activities in ground water samples from three Pit 7 wells exceeded the $740 \mathrm{~Bq} / \mathrm{L}$ drinking water MCL. These wells are K7-01, K7-03, and NC7-25. LLNL remedial investigators conclude that tritium was released during the unusually wet winter of 1982-83 from sources in Pits 3 and 5 (Webster-Scholten 1994) with additional minor releases occurring during the wet winters of 1992-93 and 1994-95 (Taffet et al. 1996). The highest tritium activity measured in 1996 was $13,900 \mathrm{~Bq} / \mathrm{L}$ in a third-quarter sample from monitoring Well NC7-25. This peak activity is $37 \%$ higher than the 10,175 Bq/L maximum activity measured in samples taken during 1995. The increasing activity supports other evidence that minor releases of tritium occurred from Pits 3 and 5 during recent wet winters. Monitoring Well NC7-25 is located close to tritium sources in Pits 3 and 5 (Figures 8-10 and 8-11). The 1996 peak tritium activity is 19 times the MCL for tritium in drinking water. However, none of the wells supplies water for drinking or irrigation in the area affected by the released tritium.

During 1996, as in previous years, TCE was detected below the $5 \mu \mathrm{g} / \mathrm{L} \mathrm{MCL}$ for drinking water in ground water samples from Wells K7-01 and K7-03. 1,1-DCE was detected below its $6 \mu \mathrm{g} / \mathrm{L}$ MCL in ground water samples from Well K7-03, and Freon 11 was detected at $1.1 \mu \mathrm{g} / \mathrm{L}$, far below its $150 \mu \mathrm{g} / \mathrm{L} \mathrm{MCL}$, in ground water samples from Well NC7-48. Freon 11 has been detected at similar low amounts in quarterly ground 


\section{Ground Water}

water samples from monitoring Well NC7-48 since the second quarter of 1992, when it was first reported (Fischer et al. 1992). Pit 7 is a potential source of the Freon 11, because it is the only landfill in the Pit 7 Complex that is monitored by Well NC7-48.

The RCRA Closure and Post-Closure Plan (Rogers/Pacific Corporation 1990) requires LLNL to maintain the structural integrity and effectiveness of Pit 1 and Pit 7 containment structures. Both pits were inspected by LLNL technical staff on February 21, May 22, August 29, November 20, December 23, and December 30, 1996. California Regulations (Title 22, Section 66264.228) require an independent annual inspection of RCRA-closed landfills by a state-certified engineer. Both pits were inspected on November 13, 1996, by a qualified engineer who provided a written report of findings. The engineer's findings do not differ significantly from LLNL's self-inspection findings of minimal degradation (Christofferson and MacQueen 1997). To detect uneven settling that might compromise the watertight integrity of the pit caps, the elevations fixed markers on the caps were measured by LLNL surveyors on December 17, 1996. The maximum measured settlement is $1 \mathrm{~cm}$ for the Pit $1 \mathrm{cap}$, and $2 \mathrm{~cm}$ for the Pit 7 cap.

\section{Surface Impoundments}

\section{Release Detection}

A three-tiered monitoring network is in place to any detect releases of chemicals from the surface impoundments in the Explosives Process Area. The primary means of release detection consists of weekly visual inspections for leachate flow at the outfalls of perforated pipes installed in a sand layer between the inner impermeable layer liner of high density polyethylene and an outer impermeable liner of compacted clay. Secondary release detection consists of quarterly remote operation of lysimeters installed beneath the clay liners. Monitoring wells comprise a tertiary release detection system and a means of estimating the environmental impact on ground water. Data pertaining to water in the surface impoundments are found in Volume 2, Tables 8-51 to $8-57$.

Leachate Collection. The two leachate collection and removal systems (LCRS) were monitored for the presence of liquids, which would indicate a leak in a surface impoundment liner. As previously reported (Harrach et al. 1996), a leak was discovered in the upper surface impoundment's polyethylene liner in June 1995. The leak allowed water to seep into a leachate collection pipe and from an outlet pipe into the lower surface impoundment. Although repairs to the system were completed in December 1995, water continued to flow from the upper surface impoundment's leachate collection system into September 1996. This residual leachate had collected in the sand layer between the two liners of the surface impoundment. From the highest leachate flow rate of 47 L/day on August 9, 1995, the leak rate fell to zero by October 3, 1996, and has remained at zero. 


\section{Ground Water}

Lysimeters. Five lysimeters installed in the vadose zone beneath the liners of the impoundments were operated quarterly during 1996 to extract water for analysis. No water was recovered. If water had been found in the lysimeters or the leachate collection systems, it would have been analyzed for aluminum, arsenic, barium, bicarbonate alkalinity, cadmium, calcium, carbonate alkalinity, chloride, chromium, cobalt, copper, fluoride, hydroxide alkalinity, iron, lead, magnesium, manganese, molybdenum, nickel, nitrate, $\mathrm{pH}$, potassium, RDX, HMX, silver, sodium, specific conductance, sulfate, total dissolved solids, total alkalinity, total hardness, and zinc.

Monitoring Wells. The Monitoring and Reporting Program for the surface impoundments (MRP 96-248) requires that ground water samples be collected quarterly from four monitoring wells and establishes concentration limits for COCs in ground water beneath the surface impoundments. MRP 96-248 became effective on September 20, 1996, amending the monitoring and reporting program previously required by MRP 85-188. The COCs and their concentration limits for ground water beneath the surface impoundments are listed in Volume 2, Table 8-52.

WDR 85-188, which was in effect through the first three quarters of 1996, required that ground water beneath the surface impoundments be monitored quarterly at one upgradient and four downgradient monitoring wells for the following COCs: total organic halogens (TOX), total organic carbon (TOC), $\mathrm{pH}$, electrical conductivity, nitrate, nitrite, high explosive compounds (HMX and RDX), nickel, selenium, silver, thallium, vanadium, zinc, molybdenum, antimony, arsenic, barium, beryllium, cadmium, chromium, cobalt, copper, lead, manganese, and mercury.

MRP 96-248 requires compliance monitoring of the ground water underlying the two connected surface impoundments (Figure 8-13). Four ground water monitoring wells are used. They are screened in the Neroly Formation upper blue sandstone layer $\left(\operatorname{Tnbs}_{2}\right)$. The direction of ground water flow is approximately southeasterly, following the local attitude (dip) of the formations. Well W-817-01 is hydrologically upgradient of the surface impoundments. Wells W-817-02, W-817-03, and W-817-04 are downgradient. Ground water samples are collected quarterly from these monitoring wells for analyses of the COCs specified in WDR 96-248. In addition, concentrations of ammonia, bromide, orthophosphate, and TATB will be measured six times during the first year to determine their statistical limits of concentration (SLs). All COC analyses under MRP 96-248 for the fourth quarter 1996, except for nondetections, are presented in Volume 2, Tables 8-57 and 8-58. 


\section{Ground Water}

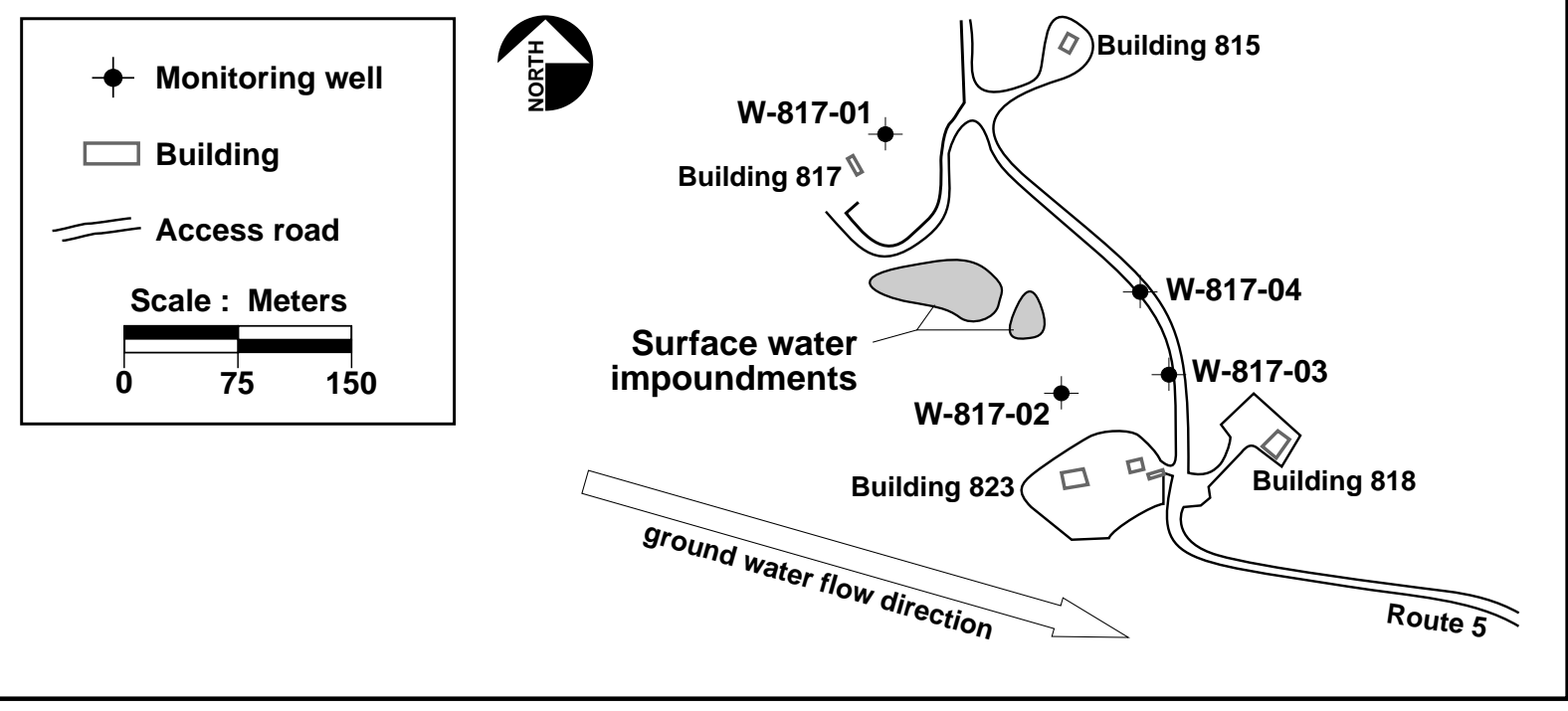

Figure 8-13. Locations of compliance ground water monitoring wells in the Explosives Process Area.

The High Performance Liquid Chromatography method (EPA Method 8330) is used to analyze for energetic compounds. Analyses of ground water from upgradient monitoring Well W-817-01 indicated HMX at concentrations between 14 and $35 \mu \mathrm{g} / \mathrm{L}$. HMX was not detected above the analytical reporting limit of 1 to $5 \mu \mathrm{g} / \mathrm{L}$ in any of the ground water samples from the downgradient monitoring wells. Ground water samples from three wells contained detectable concentrations of the energetic compound RDX above the analytical reporting limit of $0.85 \mu \mathrm{g} / \mathrm{L}$. The ground water samples containing RDX were from upgradient Well W-817-01 (from 21 to $85 \mu \mathrm{g} / \mathrm{L}$ ) and from downgradient Wells W-817-03 (5 to $8 \mu \mathrm{g} / \mathrm{L}$ ) and W-817-04 (4.4 to $8.7 \mu \mathrm{g} / \mathrm{L}$ ). RDX and HMX originate at closed disposal sites upgradient of the present surface impoundments (Raber and Carpenter 1983; Webster-Scholten 1994). The concentrations observed in the downgradient wells do not exceed their SLs. Additional compounds were detected by EPA Method 8330, but do not have SLs or MCLs.

Ground water concentrations of TCE continued to exceed the drinking water MCL of $5 \mu \mathrm{g} / \mathrm{L}$ in samples from Wells W-817-03 and W-817-04 during 1996. The TCE detected in ground water samples from these wells has migrated in the ground water from past spills at Building 815, upgradient of the impoundments (Webster-Scholten 1994). No SL was developed for TCE, because it has not been discharged to the surface impoundments.

Ground water analyses of metals were carried out using inductively coupled plasma and graphite-furnace atomic-absorption spectroscopy EPA methods. Analyses of other inorganics were carried out using other EPA-approved methods. Ground water 


\section{Ground Water}

concentrations of arsenic and nitrates continued to exceed drinking water MCLs in samples from all the surface impoundment monitoring wells during 1996. Concentrations of both arsenic and nitrates in ground water have historically exceeded their respective MCLs $(0.050 \mathrm{mg} / \mathrm{L}$ for arsenic and $45 \mathrm{mg} / \mathrm{L}$ for nitrates $)$ in this area. Background concentrations of arsenic in ground water monitoring wells upgradient from the surface impoundments have been measured at concentrations above the drinking water MCL (Webster-Scholten 1994). Because of the wide range of measured concentrations, arsenic is the only compound for which statistical analysis of variance (ANOVA) is used each quarter to determine if a significant increase has occurred. For ANOVA, four individual samples are collected from each well and analyzed for arsenic. To date, ANOVA indicates no significant differences in arsenic concentrations upgradient and downgradient from the surface impoundments. The distribution of arsenic over time and throughout the area suggests a natural source.

For the other COCs, analytical results are reported with the statistical method used, the SL, and the fourth quarter 1996 data in Volume 2, Tables 8-57 and 8-58.

Concentrations of zinc analyzed in ground water samples from monitoring Well $\mathrm{W}-817-02$ exceeded the SL of $0.076 \mathrm{mg} / \mathrm{L}$ for zinc during the fourth quarter. The concentration of zinc in the sample collected October 1 was $0.14 \mathrm{mg} / \mathrm{L}$. Two confirmation samples were collected in December. Zinc concentrations of 0.12 and $0.22 \mathrm{mg} / \mathrm{L}$ in these ground water samples confirmed the initial result.

However, the increase in zinc in ground water samples from monitoring Well W-817-02 could represent a release of zinc from sources other than the surface impoundments for the following reasons:

- Zinc was not detected above the analytical reporting limit of $0.02 \mathrm{mg} / \mathrm{L}$ in four separate samples of leachate taken from the upper surface impoundment LCRS in June 1995 (Christofferson and MacQueen 1995).

- Wastewater samples collected from within the upper surface impoundment on April 13 and June 30, 1995, indicated zinc concentrations of $<0.02 \mathrm{mg} / \mathrm{L}$ to $0.072 \mathrm{mg} / \mathrm{L}$, respectively; a sample taken from the lower surface impoundment on April 13, 1995, contained zinc at a concentration of $0.021 \mathrm{mg} / \mathrm{L}$ (Fisher 1995). These concentrations are below those found in the ground water samples from monitoring Well W-817-02 in October through December 1996.

- Historical monitoring data show zinc concentrations as high as $0.25 \mathrm{mg} / \mathrm{L}$ in ground water samples from background (or upgradient) monitoring Well W-817-01 in a sample collected in April 1988, and $0.21 \mathrm{mg} / \mathrm{L}$ in a sample collected in October 1989. Likewise, zinc concentrations of $1.0 \mathrm{mg} / \mathrm{L}$ and $0.75 \mathrm{mg} / \mathrm{L}$ were found in samples collected from ground water monitoring 


\section{Ground Water}

Wells W-817-02 and W-817-03, respectively, on February 6, 1989. These higher zinc concentrations indicate either natural variation or are the result of past human activities upgradient of this area. In either instance, they are not associated with the surface impoundments.

\section{Influent Monitoring}

Photographic Process Rinse Water Discharges. WDR 96-248 established new limits for discharges into the surface impoundments and required monitoring of the photoprocess and chemistry area wastewater retention tanks that discharge to the surface impoundments, as well as direct discharges occurring from the Explosives Process Area to the surface impoundments. Table 8-52 in Volume 2 identifies the limits applicable to discharges into the surface impoundments. During 1996, all discharges into the surface impoundments were consistent with these discharge limits.

Retention tanks containing photographic process rinse water from Buildings 801, 823, 850 , and 851 are sampled to confirm that discharges are consistent with the limitations specified in WDR 96-248. Discharges to the surface impoundments occur after samples are collected. Rinse water from the Building 823 retention tanks is discharged automatically to the surface impoundments. Monitored constituents for the photographic processes, as listed in Volume 2, Table 8-53, were all below discharge concentration limits (Volume 2, Table 8-54).

Chemistry Area Wastewater Discharges. Wastewater from the Chemistry Area (Buildings 825, 826, and 827 Complex) is held in retention tanks until analytical results indicate compliance with the WDR. Monitored constituents are listed in Volume 2, Table 8-53. Analyses of discharges from the Chemistry Area during 1996 are presented in Volume 2, Table 8-55. While all of the discharges during the first three quarters of 1996 occurred prior to the adoption of WDR 96-248, they met the requirements of WDR 96-248. In addition to discharges from retention tanks at the above facilities, wastewater from similar processes at these facilities was contained in drums and then discharged to the surface impoundments. These discharges also met the concentration requirements of WDR 96-248. (See Volume 2, Table 8-56.)

Explosives Process Area Discharges. Process water discharges to the Explosives Area impoundments are analyzed for constituents that have been found (or are likely to be found) in the process water from each specified building within the Explosives Process Area. As shown in Table 8-53, Volume 2, this monitoring program includes photographic process wastewater from Buildings 801, 823, 850, and 851; Chemistry Area wastewater from Buildings 825, 826, 827A, 827C, and 827E; and process area wastewater from Buildings 806/807, 809, and 817. 


\section{Ground Water}

Explosives Process Area discharges were not sampled in the final quarter of 1996.

WDR 96-248 requires annual analysis of this waste stream at Buildings 806/807, 809, and

817. Constituents to be analyzed include metals, VOCs, semivolatiles, and energetic compounds listed in Table 8-52 in Volume 2.

\section{Sewage Evaporation and Percolation Ponds}

The environmental monitoring required for the sewage evaporation and percolation ponds is also specified in MRP 96-248. In response to this permit, a new compliance network was formed that involves analyses of wastewater and ground water. Quarterly samples of wastewater flowing into the sewage evaporation pond are collected and analyzed for $\mathrm{pH}$, electrical conductivity, and dissolved oxygen. Observations of the pond are made at least monthly for freeboard, color, odor, and levee condition. All overflow discharges to the percolation pond are sampled and analyzed for biochemical oxygen demand, electrical conductivity, total and fecal coliform, and $\mathrm{pH}$. No overflow occurred during the fourth quarter of 1996.

Samples were collected from wastewater flowing into the evaporation pond and from the pond itself on December 19, 1996. All of the monitored constituents are in compliance with permitted limits.

Ground water monitoring includes semiannual sampling and analysis from upgradient monitoring Wells W-7E, W-7ES, and W-7PS; from cross-gradient ground water monitoring Well W-35A-04; and from downgradient ground water monitoring Wells W-26R-01, W-26R-11, W-26R-05, W-25N-20, and W-7DS (Figure 8-14). Monitoring Wells W-7PS, W-26R-11, and W-35A-04 are screened in Quaternary alluvium (Qal); Wells $\mathrm{W}-7 \mathrm{E}$ and $\mathrm{W}-26 \mathrm{R}-01$ are screened in the Tnbs 1 ; the four remaining wells are screened in both Qal and Tnbs1. Ground water samples were collected from the wells on November 5th and 14th and analyzed for electrical conductivity, nitrate, total and fecal coliform, and $\mathrm{pH}$, and general minerals. The ground water analytical data for the sewage pond monitoring network are presented in Volume 2, Table 8-58. All of the monitored constituents are in compliance with permitted limits. Background measurements for electrical conductivity and total dissolved solids exceed their respective California Secondary MCLs. Concentrations of TCE of $15 \mu \mathrm{g} / \mathrm{L}$ in ground water from monitoring Well W-26R-01 probably originated at an upgradient debris burial trench (Webster-Scholten 1994).

MRP 96-248 requires monthly inspections of the percolation pits at Buildings 806A, 827A, 827C, 827D, and 827E. It also requires sampling and analysis for metals if an overflow occurs. Inspections began in December 1996. No overflows or problems with pit operations were observed. 


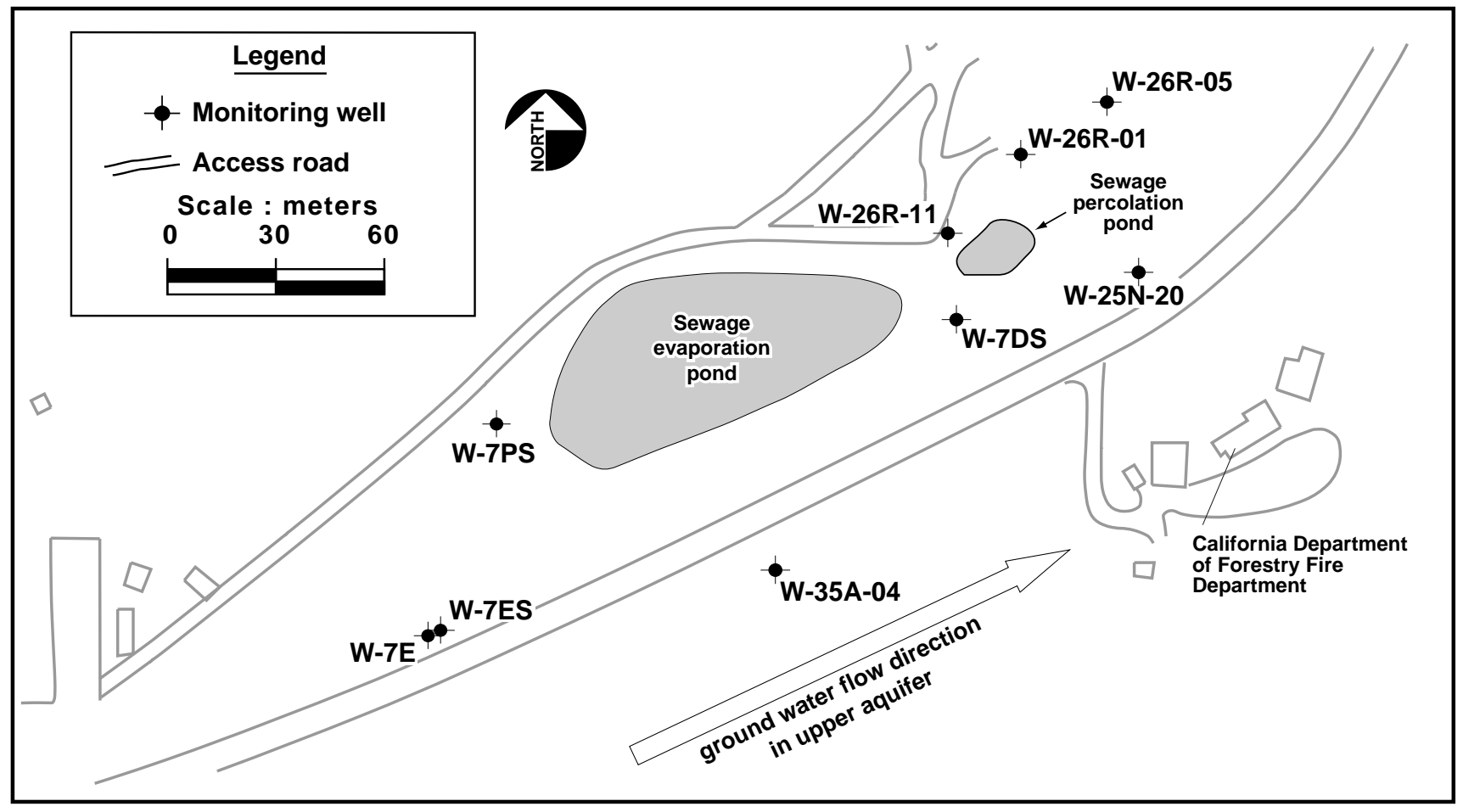

Figure 8-14. Locations of compliance ground water monitoring wells in the area of the sewage ponds.

\section{Ground Water Remediation}

This section discusses monitoring driven by permits or equivalent documents.

\section{Livermore Site}

Treatment Facility A (TFA) is located in the southwestern part of LLNL near Vasco Road (Figure 7-16, Chapter 7). At TFA, VOCs are removed from ground water using $\mathrm{UV} / \mathrm{H}_{2} \mathrm{O}_{2}$ treatment technology and an air stripper. Extracted vapors are removed using vapor extractor with granulated activated-carbon canisters. In operation since September 1989, TFA has treated more than $1000 \mathrm{ML}$ of ground water, removing about $75 \mathrm{~kg}$ of VOC mass from the subsurface. During 1996, TFA treated about $350 \mathrm{ML}$ of ground water containing an estimated $16.8 \mathrm{~kg}$ of VOCs. Treated ground water was discharged to the Recharge Basin located about $600 \mathrm{~m}$ southeast of TFA on DOE SNL/California property.

TFA is currently processing ground water at a rate of about $1136 \mathrm{~L} / \mathrm{min}$ from 18 extraction wells. Once TFA has been modified to treat ground water with air stripping only, its capacity will be increased to $1325 \mathrm{~L} / \mathrm{min}$. Modification of TFA is scheduled for spring 1997 (Hoffman et al. 1997). Other treatment facilities are discussed in Chapter 7. 


\section{Ground Water}

Waste Discharge Requirement (WDR) No. 88-075 requires a sampling program for this facility (Table 8-4). In 1996, new extraction wells were plumbed into TFA to accelerate the rate of ground water extraction and cleanup. However, because of the increased flow of ground water through the treatment facility, contaminants were not always completely destroyed. Self-monitoring analytical results of TFA effluent samples indicate that the VOC discharge limit of $5 \mathrm{mg} / \mathrm{L}$ was exceeded 12 times between July 10 and November 26, 1996, with total VOCs ranging from 5.5 to $7.5 \mathrm{mg} / \mathrm{L}$.

The solution was to scale back the flow rate through the treatment facility to enable us to meet the discharge limits. The exceedances were reported to and discussed with the CERCLA regulatory agencies (USEPA, California DTSC, and the California RWQCB) at regularly scheduled monthly CERCLA Remedial Project Managers' meetings and documented in the minutes of those meetings.

\section{Site 300}

Building 834 Complex. The Building 834 Complex is located in the eastern portion of Site 300. An isolated, perched, water-bearing zone that contains TCE in excess of the MCL of 5 ppb has been defined and reported (Bryn et al. 1990; Landgraf et al. 1994). The TCE remediation system at this site is operated as a Comprehensive Environmental Response, Compensation and Liability Act (CERCLA) Removal Action. Ground water treatment and discharge is monitored in compliance with the Regional Water Quality Control Board (RWQCB) Substantive Requirements for the B834 Removal Action. Air emissions are stipulated to be no greater than $6 \mathrm{ppm} / \mathrm{hr}$, and are regulated under an Authority to Construct permit from the San Joaquin Valley Unified Air Pollution Control District (SJVUAPCD). Limitations on effluents discharged from ground water treatment operations are listed in Table 8-5.

Techniques to remove TCE vapor from the vadose zone above the water table and from the shallow perched water have been evaluated and pilot-tested. Water was extracted by pumping from ground water extraction wells and from soil vapor extraction wells under vacuum. Pilot remediation began during 1993 at the Building 834 Complex, where about $300 \mathrm{~kg}$ of TCE was removed from the soil vapor in unsaturated sediments and ground water by extraction and treatment. Ground water has been treated by air sparging. Vapor-phase TCE is removed by adsorption on granular activated carbon, although experiments have been conducted at Building 834 to evaluate in-line destruction of TCE with ultraviolet flash lamps and an electron-beam accelerator. During 1993, the pilot extraction system was upgraded in preparation for a CERCLA Removal Action. Proof-of-system testing was conducted during 1994. During 1995, 9700 L of ground water were extracted to treat $0.36 \mathrm{~kg}$ of VOCs (primarily TCE) by air sparging. 
Table 8-4. Treated ground water discharge limits identified in WDR Order No. 88-075 for TFA.

\begin{tabular}{|c|c|}
\hline Constituent & Discharge limit ${ }^{(a)}$ \\
\hline \multicolumn{2}{|l|}{ Metals $(\mu \mathbf{g} / \mathbf{L})$} \\
\hline Antimony & 1460 \\
\hline Arsenic & 500 \\
\hline Beryllium & 0.68 \\
\hline Boron & 7000 \\
\hline Cadmium & 100 \\
\hline Chromium(III) & $1700 \times 10^{3}$ \\
\hline Chromium(VI) & 500 \\
\hline Copper & 2000 \\
\hline Iron & 3000 \\
\hline Lead & 500 \\
\hline Manganese & 500 \\
\hline Mercury & 20 \\
\hline Nickel & 134 \\
\hline Selenium & 100 \\
\hline Silver & 500 \\
\hline Thallium & 130 \\
\hline Zinc & 20,000 \\
\hline \multicolumn{2}{|l|}{ Volatile organic compounds ( $\mu \mathrm{g} / \mathrm{L}$ ) } \\
\hline Total volatile organic compounds & 5 \\
\hline \multicolumn{2}{|c|}{ Acid extractable organic compounds $(\mu \mathrm{g} / \mathrm{L})$} \\
\hline 2,4-Dimethylphenol & 400 \\
\hline Phenol & 5 \\
\hline 2,4,6-Trichlorophenol & 5 \\
\hline \multicolumn{2}{|c|}{ Base/neutral extractable organic compounds ( $\mu \mathrm{g} / \mathrm{L})$} \\
\hline 1,4-Dichlorobenzene & 5 \\
\hline Naphthalene & 620 \\
\hline Phenanthrene & 5 \\
\hline Pyrene & 5 \\
\hline
\end{tabular}

a These limits are instantaneous maximum values. 
Table 8-5. Site 300 Building 834 ground water treatment surface discharge effluent limitations.

\begin{tabular}{|c|c|}
\hline Parameter & Building 834 Treatment Facility \\
\hline \multicolumn{2}{|l|}{$\operatorname{VOCs}(a)$} \\
\hline Maximum daily (per compound) & $5.0 \mu \mathrm{g} / \mathrm{L}$ \\
\hline Monthly median & $0.5 \mu \mathrm{g} / \mathrm{L}$ \\
\hline pH & Between 6.5 and 8.5 \\
\hline Location discharge & $\begin{array}{l}\text { Treated effluent will be discharged by air } \\
\text { misting east of Building } 834 \text {. }\end{array}$ \\
\hline \multicolumn{2}{|l|}{ Total petroleum hydrocarbons } \\
\hline Daily maximum contaminant level & $100 \mu \mathrm{g} / \mathrm{L}$ \\
\hline Monthly median & $50 \mu \mathrm{g} / \mathrm{L}$ \\
\hline $\begin{array}{l}\text { Flow rate (30-day average daily dry weather } \\
\text { maximum discharge limit) }\end{array}$ & $7580 \mathrm{~L}$ \\
\hline Mineralization & $\begin{array}{l}\text { Mineralization must be controlled to no more } \\
\text { than a reasonable increment. }\end{array}$ \\
\hline \multicolumn{2}{|l|}{ Methods and detection limits } \\
\hline VOCs & Method EPA 601/602(b) \\
\hline Tetrabutyl orthosilicate (TBOS) & $\begin{array}{l}\text { Modified EPA Method 8015, discharge limit } \\
=100 \mu \mathrm{g} / \mathrm{L}(\mathrm{c})\end{array}$ \\
\hline
\end{tabular}

a The sum of VOC concentrations in a single sample shall not exceed $5.0 \mu \mathrm{g} / \mathrm{L}$.

b Confirmatory VOC identifications were sometimes required during treatment facility characterization, and EPA 624 analyses were requested in addition to the EPA 601/602 analyses.

c Detection limits for TBOS are currently $\sim 100 \mu \mathrm{g} / \mathrm{L}$ by a modified EPA 8015 procedure.

During 1996, 156,245 L of ground water were extracted to treat $10.7 \mathrm{~kg}$ of VOCs (96\% TCE). The resulting clean effluent water was discharged to air by an elevated mister network located immediately southeast of the Building 834 Complex. This unique design allows for the rapid evaporation of the clean effluent water and prevents surface erosion and ground water recharge.

The extraction system underwent extensive expansion and upgrading during 1996. Nine additional wells were plumbed into the manifold, bringing the total number of extraction wells to 15. A number of engineering modifications were implemented to simplify management of off-gas scrubbing and the associated monitoring. A sheltering roof was erected over the treatment apparatus to divert rainwater away from the area of highest subsurface contamination, greatly reducing recharge in that area. An economical plan was also developed for further drainage improvements and road surface repairs to further reduce recharge into the contaminated area. 


\section{Ground Water}

Collaborative research efforts with scientists and engineers at the Oregon State University Department of Civil Construction and Environmental Engineering began in 1996. The collaboration team will characterize the biological breakdown of VOCs in the area, surfactant behavior in local sediments, the use of naturally occurring radon gas as a tracer of residual hydrocarbons, the feasibility of promoting anaerobic TCE dechlorination by supplying electron acceptors, and existing biological processes in the subsurface.

During full scale operation of the treatment system, all compliance requirements for treated ground water and air emissions were met. Moreover, no organic compounds were detected for any effluent water samples during 1996.

\section{Ground Water Protection Management Program}

LLNL's Ground Water Protection Management Program (GWPMP) is a multifaceted effort to eliminate or minimize adverse impacts of LLNL operations on ground water (Failor and Isherwood 1994). U.S. Department of Energy (DOE) Order 5400.1 and the soon-to-be promulgated 10 CFR 834 require all DOE facilities to prepare a GWPMP that describes the site's ground water regime, programs to monitor the ground water and monitor and control potential sources of ground water contamination, and areas of known contamination and remediation activities. Much of the ground water monitoring and remediation at the Livermore site is carried out under Comprehensive Environmental Response, Compensation and Liability Act (CERCLA) restoration efforts, and the Livermore Site Ground Water Project and is summarized in Chapter 2 of this document. This section describes the site's ground water regime, programs to monitor the ground water and to monitor potential sources of ground water contamination, and programs to control potential sources of contamination.

\section{Areas of Special Concern}

The objectives of the GWPMP include monitoring the impact of current operations and eliminating or minimizing adverse impacts from ongoing operations on ground water. The approach is to detect contaminants before they can enter the ground water. To do this, areas have been identified that are contaminated or potentially contaminated with hazardous and/or radioactive waste, focusing on four areas:

- Geologic areas with rapid communication between surface water and ground water.

- Current processes and operations that could contaminate areas of rapid contamination. 


\section{Ground Water}

- $\quad$ Current and planned best management practices (BMPs) that minimize the risk of ground water contamination.

- Current and new monitoring to provide early warning of potential ground water contamination.

With these considerations, five areas have been identified as being at risk for ground water contamination:

- The arroyos (Arroyo Las Positas and Arroyo Seco) that cross the site.

- The storm drain system.

- $\quad$ Soil around underground storage tanks.

- $\quad$ Soil around the sanitary sewer systems.

- $\quad$ The ground water beneath the hazardous waste management (HWM) buildings, B514 and B612 that may be subject to spills.

\section{Soil and Sediment Surveillance Monitoring}

Soil monitoring in the arroyos and storm water network was one of the items targeted in the GWPMP surveillance monitoring because “...recharge of natural runoff through the stream beds of arroyos accounts for the majority (about $42 \%$ ) of resupply to the Livermore Valley ground water basin..." (Webster-Scholten 1994). Infiltrating rainwater may carry with it any dissolved constituents that may be present. Programs already exist that address the sanitary sewer system, the building drains, and underground storage tanks.

LLNL has developed background levels for total metals in soils and sediments and de minimis (or designated) concentration levels for soluble metals and organics (Marshack 1991). This designated level methodology (DLM) determines the soluble levels of contaminants that would not adversely impact ground water beyond its beneficial uses by application of a simple attenuation factor and specific water quality objectives. The San Francisco Bay Regional Water Quality Control Board (RWQCB) and LLNL agreed upon an attenuation factor of 100 except for certain metals; the attenuation factor for copper, lead and zinc is 1000. Any constituents with soluble concentrations above these de minimis levels may adversely impact the ground water beneath. LLNL has developed and the San Francisco Bay RWQCB has approved a site-specific DLM for beneficial reuse of soils generated from construction projects at the Livermore site. If the concentration of a constituent in soil is above its background level, the DLM can be used to determine if the concentration is protective of ground water quality. 


\section{Ground Water}

In 1996, LLNL sampled shallow vadose zones in the arroyos at two influent locations (ALPE and GRNE), and the two effluent locations (ASW and WPDC) corresponding to storm water sampling locations. In addition, sediment samples were collected from locations CDB and CDB2 in the settling basins upstream of the Drainage Retention Basin (see Figure 7-1, Chapter 7). Samples were analyzed for both total and soluble metals using California's Waste Extraction Test. For a description of methods and a discussion of 1996 arroyo sediment sampling radiological results, see Chapter 9 . The only constituent found above background was mercury at location CDB $(0.16 \mathrm{mg} / \mathrm{kg}$ compared to a background concentration of $0.11 \mathrm{mg} / \mathrm{kg}$ ). The DLM indicated that mercury was at levels that would not impact beneficial use of ground water. Thus, the sediment data indicate no adverse impact on ground water through the arroyos that cross the Livermore site.

\section{CERCLA Remedial Actions}

\section{Livermore Site}

An extensive investigation of the remediation options for the contaminated areas discussed above is summarized in the CERCLA Feasibility Study Report for the LLNL Livermore Site (Isherwood 1990). The Record of Decision (ROD) for Lawrence Livermore National Laboratory Livermore Site (U.S. Department of Energy 1992) documents the remedial options selected for implementation. The selected remedies for ground water contamination involve pumping the ground water to the surface for treatment with a combination of ultraviolet-light hydrogen peroxide, air stripping, and granulated activated carbon. The selected remedies for contaminants in the unsaturated zone are vacuum-induced venting with surface treatment of the vapors by catalytic oxidation or activated-carbon filtration. The goal of the remedial action is to clean the ground water to the levels specified in the applicable, relevant, and appropriate requirements developed for this project and outlined in the ROD. A description of the remediation efforts during 1996 can be found in Chapter 2 of this document.

\section{Site 300}

Investigation of the remediation options for the contaminated areas at Site 300 is discussed in the Final SWRI Report (Webster-Scholten 1994). It includes a thorough compilation of all pre-1992 ground water and soil investigation information for the entire site and contains a detailed assessment of potential human health and ecological hazards or risks resulting from contamination of soil, rock, and ground water. New characterization, summary, and feasibility study or engineering evaluation/cost analysis reports have been, or will be, prepared for portions of the individual study areas, where the Final SWRI Report or more recent studies indicate that unacceptable potential hazards or risks exist. A summary of the remediation efforts and studies conducted during 1996 can be found in Chapter 2 of this document. 


\section{Ground Water}

\section{Environmental Impacts}

The impact of LLNL Livermore site and Site 300 operations on off-site ground waters is minimal. With the exception of VOCs being remediated under CERCLA at both sites, LLNL operations appear to have little or no adverse effect on the surrounding ground waters.

\section{Livermore Site}

No ground water in any of the off-site wells monitored exceeded primary drinking water MCLs for any of the monitored constituents. A possible exception is bis (2-ethylhexyl)phthalate (DEHP), which was found in concentrations of 19 and $14 \mu \mathrm{g} / \mathrm{L}$ (above the drinking water MCL of $4 \mu \mathrm{g} / \mathrm{L}$ ) in March and August ground water samples from monitoring Well W-571. Since this compound is known to be a common laboratory contaminant, it is possible that it may have been introduced during chemical analysis. LLNL will determine the origin of DEHP in Well W-571 through further studies during 1997.

None of the radioactivity data exceeded MCLs. Of the potential radiological contaminants, radium in downgradient monitoring Well W-1012 was the closest (83\%) to its MCL. The maximum tritium activity $(13.95 \mathrm{~Bq} / \mathrm{L})$, about $1.9 \%$ of the MCL, was detected in the ground water sample from off-site Well 11B1.

Of the Livermore on-site monitoring wells, no inorganic data exceeded primary MCLs, with the exceptions of chromium in monitoring well W-373 and nitrates in monitoring well W-1012. Chromium(VI) in ground water in the vicinity of Monitoring Well W-373 is being treated in TFC, and this treatment is monitored separately. Chromium(VI) concentrations have been decreasing since TFC began operations (1993). An investigation to determine the source of nitrate in the vicinity of W-1012 is continuing. Although VOC discharge limits were exceeded at TFA, the environmental consequences were negligible.

\section{Site 300}

Compliance and surveillance monitoring at Site 300 and adjacent properties in the Altamont Hills leave little doubt that LLNL operations have minimal impact on ground water beyond the site boundaries.

Tritiated water and depleted uranium have been released to ground water from inactive landfills and from an active firing table at Site 300. The boundaries of the contaminated ground water lie entirely within the site boundaries. Fate and transport models predict that the tritium will decay naturally to an activity below the drinking water MCL before the tritium-bearing ground water reaches a site boundary (Webster-Scholten 1994;

Taffet et al. 1996). 
Maximum uranium activities that could reach potential exposure points (hypothetical ground water supply wells) at the northern boundary of Site 300 are estimated to be $0.08 \mathrm{~Bq} / \mathrm{L}$ from plumes originating at Pits 5 and 7 , and $0.05 \mathrm{~Bq} / \mathrm{L}$ at the eastern boundary of Site 300 from the plume originating at Building 850. These conservatively estimated maximum activities are small when compared with the $0.74 \mathrm{~Bq} / \mathrm{L}$ California MCL for uranium in drinking water. The predicted incremental lifetime cancer risks from the released uranium are less than one-in-a-million at the hypothetical exposure points on the Site 300 boundary (Taffet et al. 1996). The tritium and uranium in the ground water beneath Site 300 present no current health risks, because the water is neither used for agriculture nor consumed by people or cattle.

TCE has been released to ground water at numerous locations at Site 300 (see Chapter 2, Figure 2-2; Webster-Scholten 1994). With the exception of the plume extending off site from the Eastern GSA area, all of the TCE-bearing ground water is on site. This water is being pumped back to the site and quickly cleansed of TCE. 


\section{Soil and Sediment Monitoring}

Gretchen M. Gallegos

\section{Introduction}

Soil is weathered material, mainly composed of disintegrated rock and organic material, that will sustain growing plants. Soil can contain pollutants originally released directly to the ground, to the air, or through liquid effluents. DOE guidance for environmental monitoring (U.S. Department of Energy 1991) states that soil should be sampled to determine if there is measurable long-term buildup of radionuclides in the terrestrial environment and to estimate environmental radionuclide inventories. The guidance recommends that radionuclides specific to a particular operation or facility as well as those that occur naturally should be monitored. Particulate radionuclides are of major interest in the LLNL soil monitoring program because airborne particulate releases are the most likely pathway for LLNL-induced soil contamination.

Sediments are defined, for the purposes of this chapter, as finely divided solid materials that have settled out of a liquid stream or standing water. To evaluate current conditions, LLNL samples recent sediments in storm drainage channels and the two arroyos on site. The accumulation of radioactive materials in sediment could lead to exposure of humans through ingestion of aquatic species, through sediment resuspension into drinking water supplies, or as an external radiation source (U.S. Department of Energy 1991). Note, however, that the Livermore site and Site 300 do not have habitats for aquatic species that are consumed by people, nor do they have surface drainage that directly feeds drinking water supplies. In addition, subsurface sediment sampling is conducted to support the LLNL Ground Water Protection Management Program (Chapter 8).

Since 1971, surface soil sampling in the vicinity of the Livermore site and Site 300 has been part of a continuing LLNL monitoring program designed to measure any changes in environmental levels of radioactivity and to evaluate any increase in radioactivity that might have resulted from LLNL operations. These samples have been analyzed for plutonium and gamma-emitting radionuclides, such as depleted uranium, which is used in some high-explosives tests at Site 300. The inclusion of other gamma-emitting naturally occurring nuclides $\left({ }^{40} \mathrm{~K}\right.$ and ${ }^{232} \mathrm{Th}$ ) and the long-lived fission product ${ }^{137} \mathrm{Cs}$ provides background information and baseline data on global fallout from historical aboveground nuclear weapons testing. 


\section{Soil and Sediment Monitoring}

Similarly, sediment samples have been collected from selected arroyos and other drainage areas at and around the Livermore site since 1988; these locations largely coincide with selected storm water sampling locations (see Chapter 7). The number of sediment sampling locations was reduced in 1994 to correspond to reductions in storm water sampling locations. In addition, in 1991, LLNL began analyzing surface soil samples for beryllium, a potentially toxic metal used at both the Livermore site and Site 300. However, analysis for beryllium was discontinued at the Livermore site in 1995 , because beryllium was not ever measured above background values.

Location maps for soil and sediment sampling conducted during 1995 are provided in Figures 9-1 through 9-3. The locations were selected to represent background concentrations (distant locations unlikely to be affected by LLNL operations) as well as areas where there is the potential to be affected by LLNL operations. Areas with known contaminants, such as the Livermore Water Reclamation Plant (LWRP), are also sampled. In general, Site 300 soil sampling locations were established around firing tables and other areas of potential soil contamination. Arroyo and drainage channel sediment sampling locations were chosen to coincide with major Livermore site storm water drainages. All soil and sediment sampling locations have permanent location markers for reference.

\section{Methods}

Soil and sediment sampling is conducted according to written, standardized procedures (Tate et al. 1995, Appendix A). Soil samples are collected from undisturbed areas near the permanent sampling location marker. These areas generally are level, free of rocks, and are unsheltered by trees or buildings. All samples are collected from the top $5 \mathrm{~cm}$ of soil because surface deposition from the air is the primary pathway for potential contamination. Quality control duplicate samples are submitted with each batch of soil samples. At locations chosen for this sampling, two identical samples are collected.

Samples of recent sediment are collected annually from drainages at and around the Livermore site after the cessation of spring runoff. Sediment sampling location ASS2 was not sampled in 1996 because of problems with accessibility. For 1996, samples at the Livermore site were analyzed for radionuclides and samples for Site 300 were analyzed for radionuclides and beryllium. During 1996, additional subsurface sediment sampling supported the LLNL Ground Water Protection Management Program (Chapter 8). 


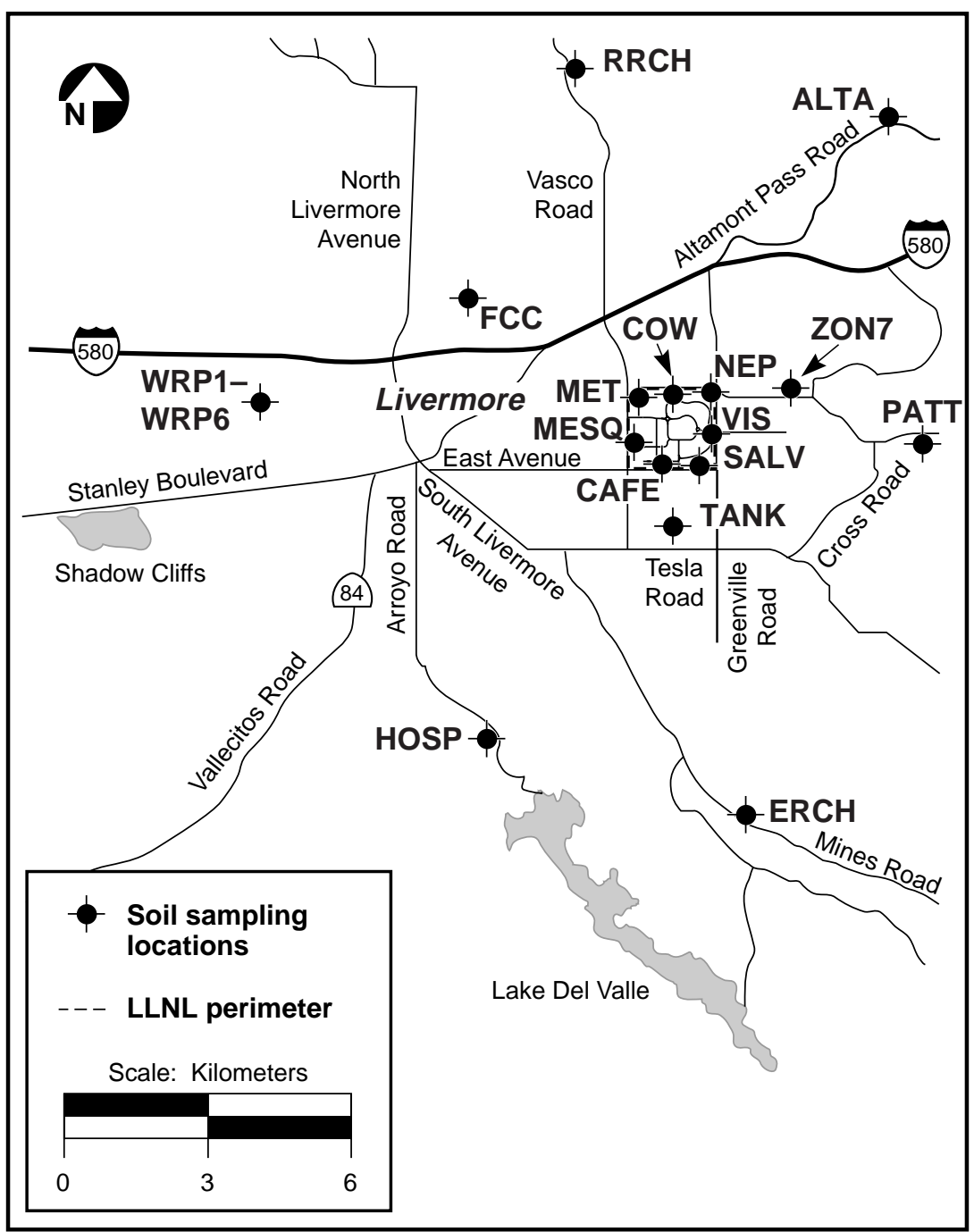

Figure 9-1. Soil sampling locations, Livermore Valley, 1996.

Soils and sediment samples are delivered to LLNL's Chemistry and Materials Science Environmental Services (CES) laboratory for analyses. Soil samples are dried, ground, sieved, and blended. The plutonium content of a sample aliquot is determined by alpha spectroscopy (Hall and Edwards 1994a, 1994b, and 1994c). Other sample aliquots (300 g) are analyzed for more than 150 radionuclides by gamma spectroscopy, using a highpurity germanium (HPGe) detector (Hall and Edwards 1994a, 1994b, and 1994c). The $10-\mathrm{g}$ subsamples for beryllium analyses are sent to a contract analytical laboratory and are analyzed by graphite-furnace atomic absorption spectroscopy. For sediment samples collected for tritium analyses, CES uses freeze-drying techniques to recover water from the samples and determines the tritium content of the water by liquidscintillation counting. Chain-of-custody procedures are followed throughout the sampling, delivery, and analytical processes. 


\section{Soil and Sediment Monitoring}

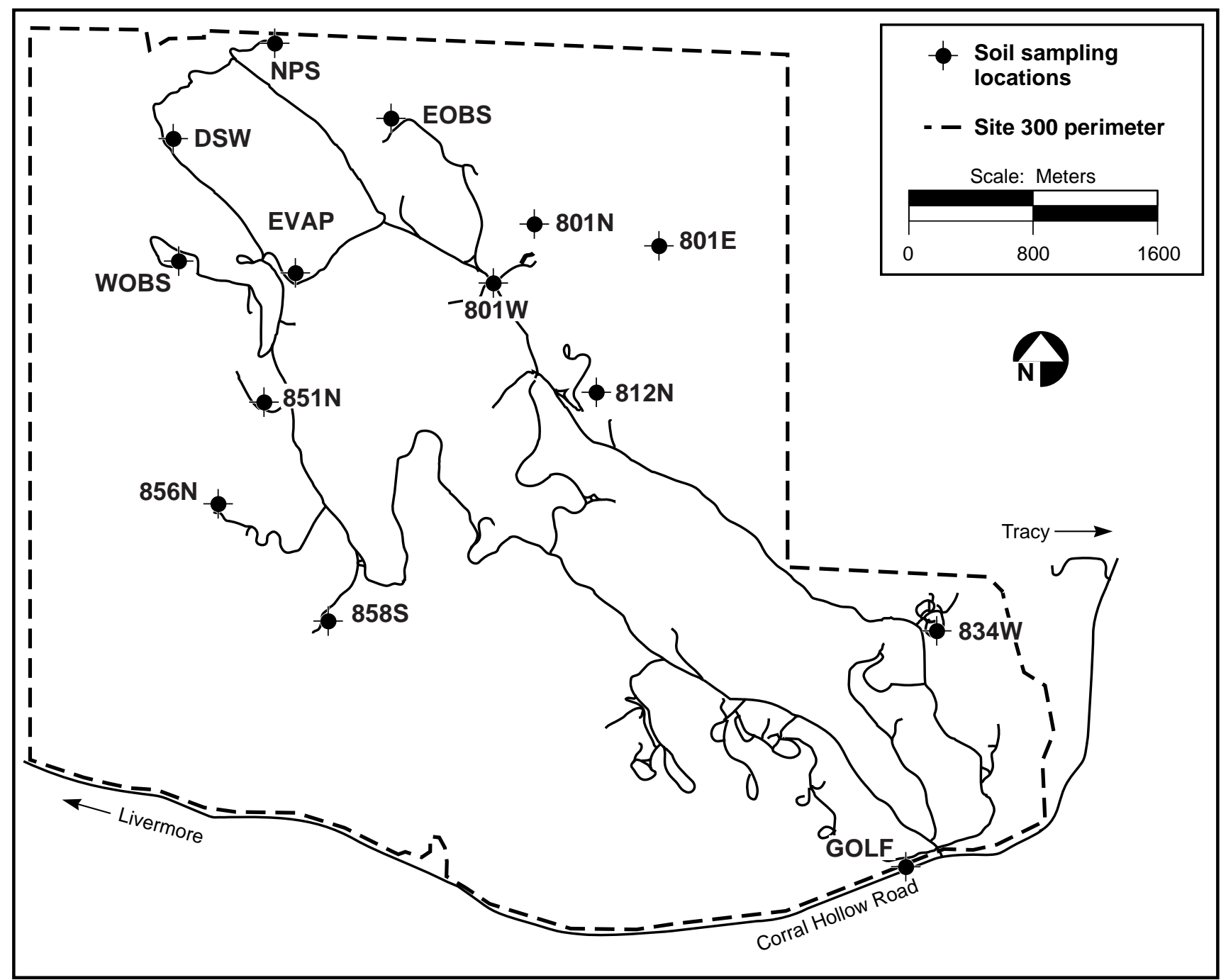

Figure 9-2. Site 300 soil sampling locations, 1996.

\section{Livermore Valley Results}

Table 9-1 presents summary data on the concentrations of ${ }^{239+240} \mathrm{Pu},{ }^{40} \mathrm{~K},{ }^{60} \mathrm{Co},{ }^{137} \mathrm{Cs}$, ${ }^{232} \mathrm{Th}, 235 \mathrm{U}$, and ${ }^{238} \mathrm{U}$ in surface soils from the Livermore Valley sampling locations. The complete data for 1996 soils and sediment sampling is presented in Table 9-1, Volume 2, of this report. The concentrations and distributions of all observed 


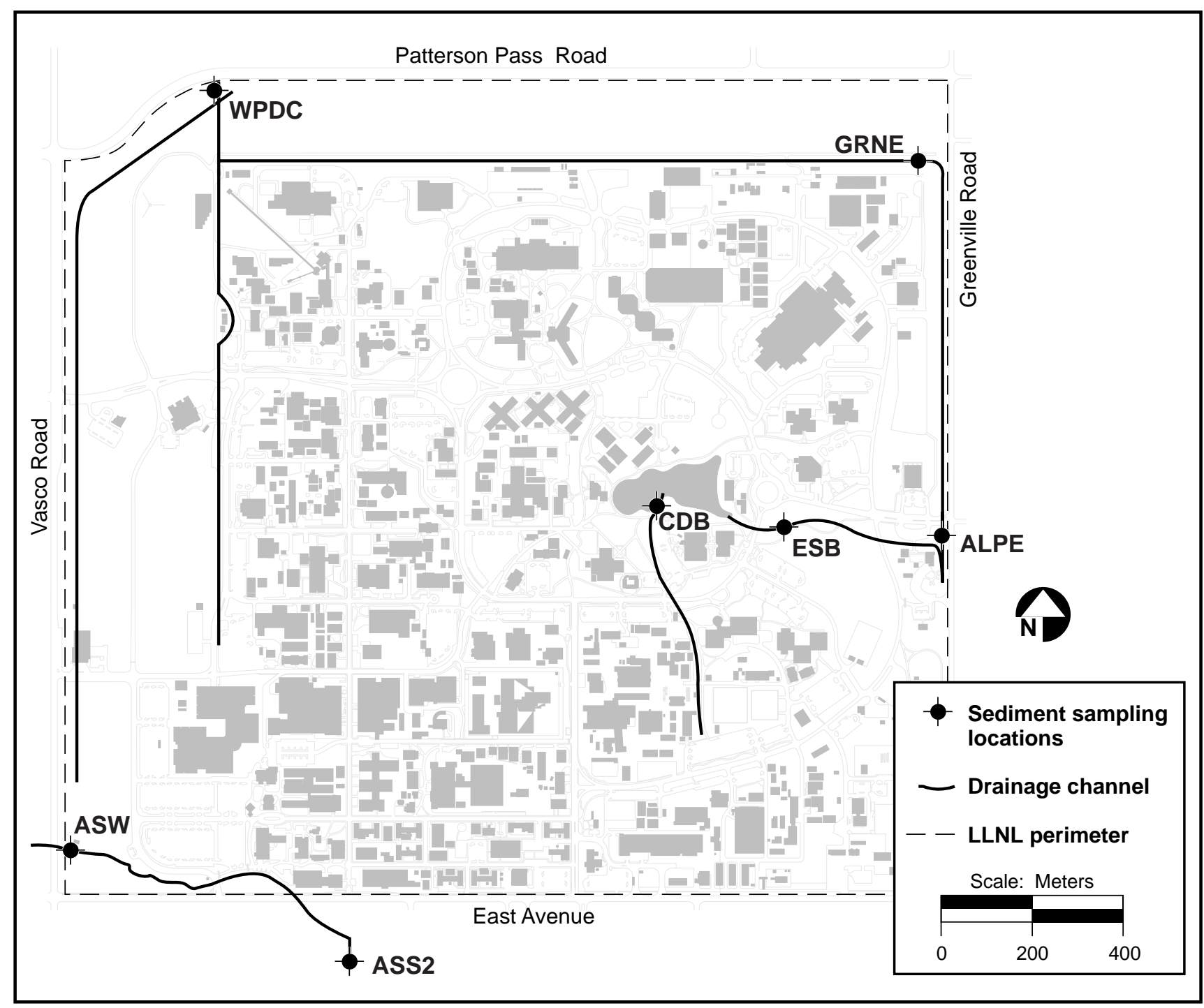

Figure 9-3. Arroyo and drainage basin sediment sampling locations, 1996.

radionuclides in soil for 1996 are within the ranges reported in previous years and generally reflect worldwide fallout and naturally occurring concentrations. The ratio of $235 \mathrm{U}$ to $238 \mathrm{U}$ generally reflects the natural ratio of $0.7 \%$; however, there is uncertainty in the ${ }^{235} \mathrm{U} /{ }^{238} \mathrm{U}$ ratio because of the difficulty in measuring small quantities of ${ }^{238} \mathrm{U}$ by gamma spectroscopy. 
Table 9-1. Summary of soils and sediment analytical data, 1996.

\begin{tabular}{|c|c|c|c|c|}
\hline $\begin{array}{c}\text { Analyte } \\
\text { and location }\end{array}$ & $\begin{array}{c}\text { Detection } \\
\text { frequency }(\mathrm{a})\end{array}$ & Median & $I_{Q}{ }^{(b)}$ & Maximum \\
\hline \multicolumn{5}{|l|}{${ }^{239+240} \mathrm{Pu}\left(10^{-3} \mathrm{~Bq} / \mathrm{dry} \mathrm{g}\right)$} \\
\hline Livermore Valley soils & $15 / 15$ & 0.11 & 0.25 & 0.61 \\
\hline LWRP(c) soils & $6 / 6$ & 3.5 & 8.0 & 24 \\
\hline Livermore site sediments & $6 / 6$ & 0.029 & 1.3 & 2.2 \\
\hline Site 300 soils & $14 / 14$ & 0.079 & 0.064 & 0.20 \\
\hline \multicolumn{5}{|l|}{${ }^{137} \mathrm{Cs}\left(10^{-3} \mathrm{~Bq} / \mathrm{dry} \mathrm{g}\right)$} \\
\hline Livermore Valley soils & $15 / 15$ & 3.1 & 1.7 & 7.1 \\
\hline LWRP soils & $6 / 6$ & 2.8 & 2.9 & 8.2 \\
\hline Livermore site sediments & $5 / 6$ & 0.40 & 0.42 & 0.94 \\
\hline Site 300 soils & $14 / 14$ & 2.4 & 1.9 & 6.4 \\
\hline \multicolumn{5}{|l|}{${ }^{40} \mathrm{~K}$ (Bq/dry g) } \\
\hline Livermore Valley soils & $15 / 15$ & 0.470 & 0.124 & 0.585 \\
\hline LWRP soils & $6 / 6$ & 0.437 & 0.031 & 0.503 \\
\hline Livermore site sediments & $6 / 6$ & 0.509 & 0.100 & 0.577 \\
\hline Site 300 soils & $14 / 14$ & 0.477 & 0.089 & 0.622 \\
\hline \multicolumn{5}{|l|}{${ }^{232}$ Th $(\mu \mathrm{g} / \mathrm{dry} \mathbf{g})^{(\mathrm{d})}$} \\
\hline Livermore Valley soils & $15 / 15$ & 6.2 & 1.1 & 8.6 \\
\hline LWRP soils & $6 / 6$ & 6.8 & 0.6 & 7.5 \\
\hline Livermore site sediments & $6 / 6$ & 5.9 & 1.6 & 7.6 \\
\hline Site 300 soils & $14 / 14$ & 8.7 & 1.5 & 11 \\
\hline \multicolumn{5}{|l|}{${ }^{235} \mathrm{U}(\mu \mathrm{g} / \mathrm{dry} \mathrm{g})^{(\mathrm{e})}$} \\
\hline Livermore Valley soils & $9 / 15$ & $<0.022$ & 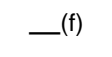 & 0.042 \\
\hline LWRP soils & $6 / 6$ & 0.025 & 0.002 & 0.029 \\
\hline Livermore site sediments & $6 / 6$ & 0.021 & 0.006 & 0.026 \\
\hline Site 300 soils ${ }^{(\mathrm{g})}$ & $13 / 18$ & 0.030 & 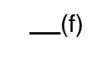 & 1.8 \\
\hline \multicolumn{5}{|l|}{${ }^{238} \mathrm{U}(\mu \mathrm{g} / \mathrm{dry} \mathrm{g})^{(\mathrm{h})}$} \\
\hline Livermore Valley soils & $9 / 15$ & 1.9 & -(f) $^{(\mathrm{n}}$ & 3.8 \\
\hline LWRP soils & $5 / 6$ & 2.0 & 0.4 & 2.3 \\
\hline Livermore site sediments & $3 / 6$ & $<1.3$ & $一^{(f)}$ & 1.7 \\
\hline Site 300 soils ${ }^{(\mathrm{g})}$ & $14 / 18$ & 3.6 & 6.1 & 840 \\
\hline
\end{tabular}


Table 9-1. Summary of soils and sediment analytical data, 1996 (concluded).

\begin{tabular}{|c|c|c|c|c|}
\hline $\begin{array}{c}\text { Analyte } \\
\text { and location }\end{array}$ & $\begin{array}{l}\text { Detection } \\
\text { frequency(a) }\end{array}$ & Median & $I Q R^{(b)}$ & Maximum \\
\hline \multicolumn{5}{|l|}{${ }^{3} \mathrm{H}\left(\mathrm{Bq} / \mathrm{L}\right.$ extracted water) ${ }^{(\mathrm{i})}$} \\
\hline Livermore site sediments & $5 / 6$ & 9.5 & 27 & 100 \\
\hline \multicolumn{5}{|l|}{${ }^{241} \mathrm{Am}\left(10^{-3} \mathrm{~Bq} / \mathrm{dry} \mathrm{g}\right)^{(\mathrm{j})}$} \\
\hline LWRP soils & $3 / 6$ & $<2.6$ & 一(f) $^{(\mathrm{f}}$ & 5.1 \\
\hline \multicolumn{5}{|l|}{${ }^{60} \mathrm{Co}\left(10^{-3} \mathrm{~Bq} / \mathrm{dry} \mathrm{g}\right)^{(\mathrm{j})}$} \\
\hline LWRP soils & $1 / 6$ & $<0.072$ & -(f) $^{(\mathrm{n}}$ & 0.25 \\
\hline \multicolumn{5}{|l|}{$\mathrm{Be}(\mathbf{m g} / \mathbf{k g})^{(\mathbf{k})}$} \\
\hline Site 300 soils $^{(\mathrm{f})}$ & $16 / 18$ & 1.3 & 0.7 & 53 \\
\hline
\end{tabular}

a Detection frequency is the number of samples with results above the detection limit/the number of samples.

b $\quad I Q R=$ interquartile range.

c $\quad$ LWRP $=$ Livermore Water Reclamation Plant.

d Thorium-232 activities in Bq/dry g can be determined by dividing the weight in $\mu \mathrm{g} / \mathrm{dry} \mathrm{g}$ by 247.3 , and $\mathrm{pCi} / \mathrm{dry} \mathrm{g}$ can be determined by dividing by 9.15 .

e Uranium-235 activities in Bq/dry g can be determined by dividing the weight in $\mu \mathrm{g} / \mathrm{dry} \mathrm{g}$ by 12.5 , and $\mathrm{pCi} / \mathrm{dry} \mathrm{g}$ can be determined by dividing by 0.463 .

f Insufficient number of detections to calculate IQR. (See Site 300 results for discussion.)

$\mathrm{g}$ Includes results from reanalysis of original sample and analysis of resample.

h Uranium-238 activities in Bq/dry g can be determined by dividing the weight in $\mu \mathrm{g} / \mathrm{dry} \mathrm{g}$ by 80.3 , and $\mathrm{pCi} / \mathrm{dry} \mathrm{g}$ can be determined by dividing by 2.97 .

i Tritium $\left({ }^{3} \mathrm{H}\right)$ analysis is only conducted on sediment samples.

j Cobalt-60 and Americium-241 are only detected in LWRP soil samples.

k Beryllium analysis is only conducted on soils sampled at Site 300; the analysis is a chemical, not a radiochemical analysis.

Plutonium has, in the past, been detected at levels above background at ZON7, the offsite soils sampling location near the LLNL site and in the prevailing downwind direction. Because of the high level of variability inherent in the measurement of soils, we do not always find plutonium above background levels at this location. As in 1991, 1994 , and 1995, 239+240 Pu was detected at background levels $-0.29 \times 10^{-3} \mathrm{~Bq} / \mathrm{g}$ $\left(7.8 \times 10^{-3} \mathrm{pCi} / \mathrm{g}\right)$ - at location ZON7 in 1996. Since 1973, soil samples in this area have generally shown $239+240 \mathrm{Pu}$ values that are higher than background. The slightly higher values near the Livermore site have been attributed to historic operations, which included the operation of solar evaporators for plutonium-containing liquid waste in the southeast quadrant (Silver et al. 1974). LLNL no longer operates the solar evaporators or engages in any other open-air treatment of plutonium-containing waste. Nonetheless, $239+240 \mathrm{Pu}$ from historic operations is carried off site by resuspension of soil by wind. 


\section{Soil and Sediment Monitoring}

Similarly, elevated levels of ${ }^{239+240} \mathrm{Pu}$, resulting from an estimated $1.2 \times 10^{9} \mathrm{~Bq}(32 \mathrm{mCi})$ plutonium release to the sewer in 1967 and first observed in soils near LWRP during the early 1970s, again were detected at LWRP sampling locations. As in 1990 through 1992 and 1995, 241Am was detected in LWRP samples; it is most likely caused by the natural decay of the trace concentrations of ${ }^{241} \mathrm{Pu}$ that were present in the release.

Historical plots of average ${ }^{239+240} \mathrm{Pu}$ concentrations in soil in the Livermore Valley, at Site 300, and at LWRP are shown in Figure 9-4. Livermore Valley and Site 300 concentrations have remained relatively constant over the past 10 years and generally are indicative of worldwide fallout (locations on site and ZON7 show activities greater than background). Greater variability in ${ }^{239+240} \mathrm{Pu}$ is seen at LWRP. However, six samples are evaluated to determine the median at LWRP. Moreover, the ${ }^{239+240} \mathrm{Pu}$ is likely to be present in discrete particles, so the random presence or absence of the particles will dominate the measured ${ }^{239+240} \mathrm{Pu}$ in any given sample.

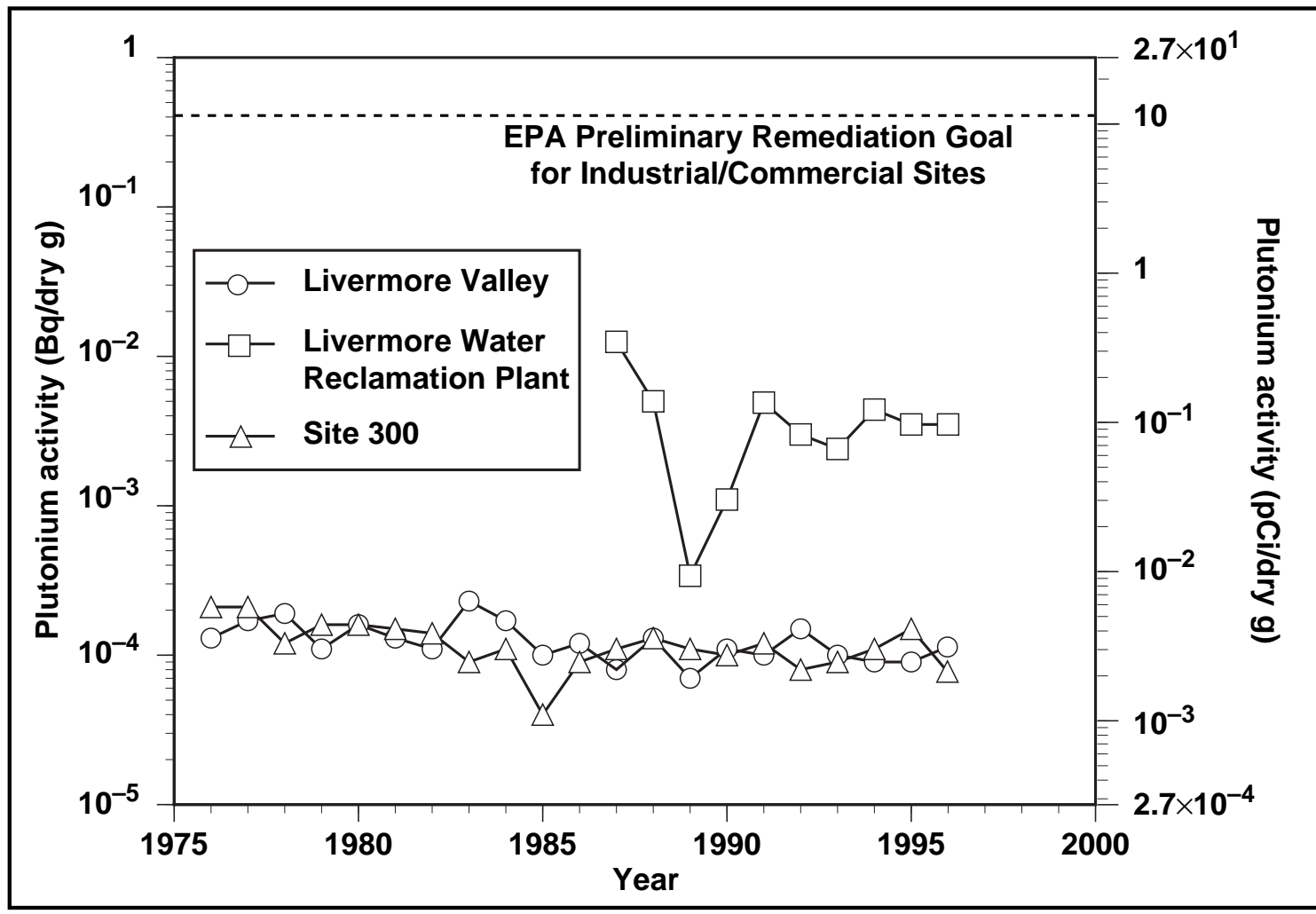

Figure 9-4. Median 239+240Pu activities in surface soils, 1976 to 1996. 
Low levels of ${ }^{60} \mathrm{Co}$ were detected at the LWRP. While ${ }^{60} \mathrm{Co}$ is in use at the Livermore site, it is only present in gram quantities in two facilities (Buildings 151 and 514) or in sealed sources. Low levels of ${ }^{60} \mathrm{Co}$, on the order of $0.0037 \mathrm{~Bq} / \mathrm{g}(0.1 \mathrm{pCi} / \mathrm{g})$, have also been detected intermittently in sewage sludge samples. If the Livermore site were the source of ${ }^{60} \mathrm{Co}$, this activity of ${ }^{60} \mathrm{Co}$ in the sludge would translate into about $1.5 \times 10^{-6}$ $\mathrm{Bq} / \mathrm{mL}\left(40 \times 10^{-6} \mathrm{pCi} / \mathrm{mL}\right)$ in the effluent leaving the site, which is below the detection limits of current analytical methods. This level is also well below the DOE effluent limit of $0.925 \mathrm{~Bq} / \mathrm{mL}(25 \mathrm{pCi} / \mathrm{mL})$. The reader should note that LLNL is not the only contributor to the waste stream that arrives at the LWRP and that ${ }^{60} \mathrm{Co}$ is used in a variety of medical, technical, and research applications. It is not possible to determine if LLNL is the source of ${ }^{60} \mathrm{Co}$ at LWRP. However, it can be concluded that LLNL controls on the release of ${ }^{60} \mathrm{Co}$ are sufficient to ensure that LLNL activities do not adversely affect LWRP applications.

Beryllium analysis for Livermore Valley soils was discontinued in 1995. The few LLNL operations that use beryllium are high-efficiency particulate air (HEPA) filtered. In addition, sampling data to date have shown no evidence of beryllium contamination in the Livermore Valley (Tate et al. 1995). Should beryllium usage change, LLNL's environmental monitoring staff would reevaluate the need for beryllium monitoring in soils.

Table 9-1 presents summary data on radionuclides detected in the sediment samples; a complete presentation of 1996 sediment data is found in Table 9-1, Volume 2, of this report. The levels of ${ }^{239+240} \mathrm{Pu}$ were generally at background concentrations, reflective of worldwide fallout. The slightly higher values at CDB and ESB may be attributed to historic activities in the southeast quadrant at LLNL; these locations are both in drainages for that area. Most other radionuclides were detected at levels similar to those reported from 1988 through 1995: 137Cs, a fission product, was found at worldwide background concentrations; and ${ }^{40} \mathrm{~K},{ }^{232} \mathrm{Th}, 235 \mathrm{U}$, and ${ }^{238} \mathrm{U}$-naturally occurring radionuclides-were detected at background concentrations. Tritium concentrations were within the range of previous data. The data show a slight increase, which can be explained by the increase in tritium emissions from the Tritium Facility (see Chapter 5, Air Effluent Monitoring). Median tritium values are shown in Figure 9-5. There is not a ready explanation for the low results obtained in 1993. The sediment sampling procedure was revised in that year so that samples for gamma analysis were collected at the surface ( $5 \mathrm{~cm}$ deep). However, the depth for taking samples for tritium analysis was retained at $15 \mathrm{~cm}$. Moreover, since samples were taken at the usual time, low values cannot be attributed to evaporative losses due to sampling delays. Tritium in sediments will continue to be evaluated. 


\section{Soil and Sediment Monitoring}

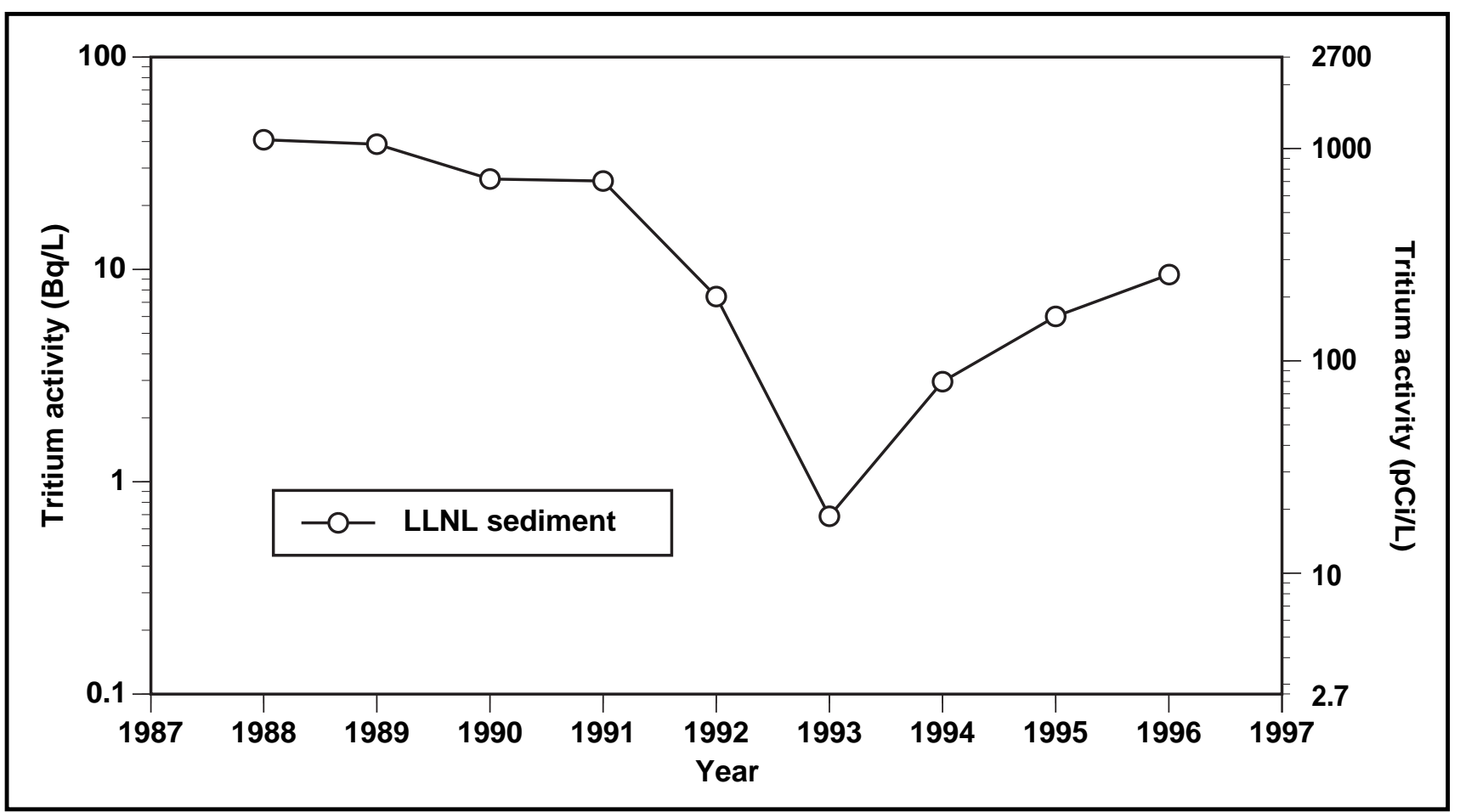

Figure 9-5. Median tritium concentrations in sediments (Bq/L of recovered water), 1988 to 1996.

\section{Site 300 Results}

Table 9-1 presents summary data on the concentrations of ${ }^{239+240} \mathrm{Pu},{ }^{40} \mathrm{~K},{ }^{137} \mathrm{Cs},{ }^{232} \mathrm{Th}$, ${ }^{235} \mathrm{U}$, and ${ }^{238} \mathrm{U}$ in soil from the Site 300 sampling locations; a complete presentation of 1996 soils data for Site 300 is found in Table 9-1, Volume 2, of this report. The concentrations and distributions of all observed radionuclides in Site 300 soil for 1996 lie within the ranges reported in all years since monitoring began, and, with the exceptions discussed below, reflect naturally occurring concentrations. The ratio of $235 \mathrm{U}$ to $238 \mathrm{U}$ generally reflects the natural ratio of $0.7 \%$. Historical trends of $238 \mathrm{U}$ concentrations from both the Livermore Valley and Site 300 are shown in Figure 9-6. Median values have remained relatively constant for both places. The highest values at Site 300 are caused by the use of depleted uranium in high-explosive tests.

During 1996, one sample from a region near a firing table $(812 N)$ had substantially higher than background concentrations of $238 \mathrm{U}$ and beryllium. The $235 \mathrm{U} / 238 \mathrm{U}$ ratios, at $0.2 \%$, confirm the presence of depleted uranium; the ratio in naturally occurring material is $0.7 \%$. To investigate the elevated ${ }^{238} \mathrm{U}$ and beryllium result at $812 \mathrm{~N}$, LLNL personnel 


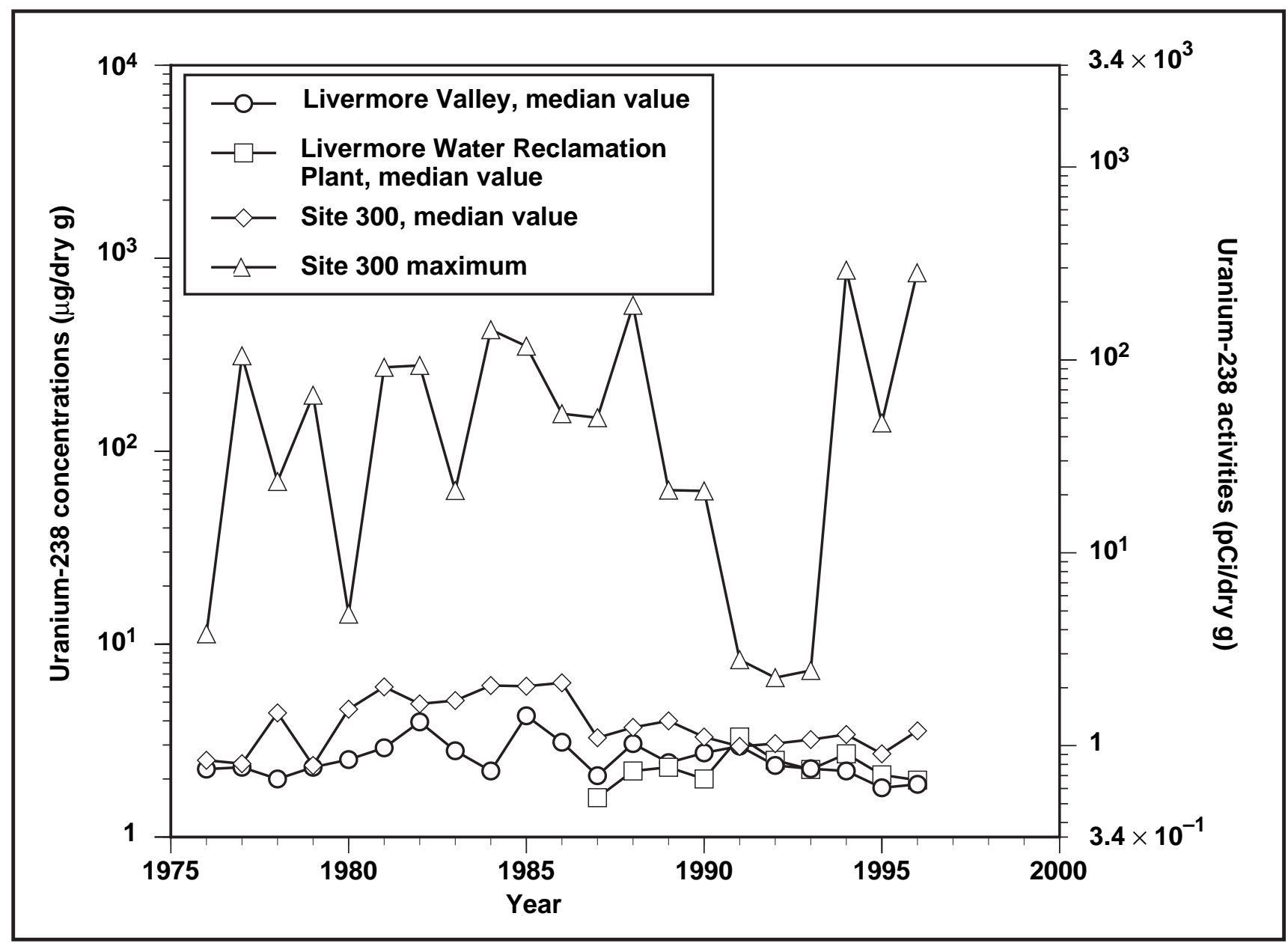

Figure 9-6. Uranium-238 activities in surface soils, 1976 to 1996.

resampled and analyzed the original sampling location. The high value of $32 \mu \mathrm{g} / \mathrm{g}$ of $238 \mathrm{U}$ in the original sample was confirmed by reanalysis; the results of resampling were $35,840,6$, and $140 \mu \mathrm{g} / \mathrm{g}$. This disparity in sampling results was to be expected considering the heterogeneous nature of the contamination.

The finding of beryllium above background was also confirmed by resampling. The initial sampling yielded a result of $53 \mathrm{mg} / \mathrm{kg}$. The results of resampling for beryllium were $<0.5,27,7.7$, and $<0.5 \mathrm{mg} / \mathrm{kg}$. Again, such heterogeneous results are expected because the contamination is not uniformly dispersed over the soil. 


\section{Soil and Sediment Monitoring}

\section{Environmental Impact}

This section discusses the environmental impacts at the Livermore site and Site 300 inferred from soil and sediment monitoring.

\section{Livermore Site}

Routine soil and sediment sample analyses indicate that the impact of LLNL operations on these media in 1996 has not changed from previous years and remains insignificant. Most analytes of interest or concern were detected at background concentrations, in trace amounts, or could not be measured above detection limits.

The highest value of $24 \times 10^{-3} \mathrm{~Bq} / \mathrm{g}(0.65 \mathrm{pCi} / \mathrm{g})$ for ${ }^{239+240} \mathrm{Pu}$ measured at LWRP during 1996 represents $6.5 \%$ of the EPA preliminary remediation goal for commercial or industrial sites of $0.37 \mathrm{~Bq} / \mathrm{g}(10 \mathrm{pCi} / \mathrm{g})$ (U.S. EPA 1991). Statistical analysis shows that all LWRP $239+240 \mathrm{Pu}$ soils data are lognormally distributed, and at LWRP there is no general increase or decrease in ${ }^{239+240} \mathrm{Pu}$ values with time. Moreover, all measured concentrations, regardless of location and year, have been a small fraction of the proposed EPA remediation goal, which is shown in Figure 9-4 for comparison. Sampling of soils for radiological materials will continue on an annual basis.

\section{Site 300}

With the exception of elevated concentrations of ${ }^{238} \mathrm{U}$ and beryllium at location $812 \mathrm{~N}$, the concentrations of radionuclides and beryllium observed in soil samples collected at Site 300 are representative of background or naturally occurring levels. In 1988, contaminated gravel from the firing table at Building 812 was removed to on-site landfills, and measured values for samples from this location have generally not exhibited elevated levels of $238 \mathrm{U}$ and beryllium. The elevated results for ${ }^{238} \mathrm{U}$ and beryllium indicate that areas outside the firing table may be contaminated by firing table debris. The investigation planned as part of the Site 300 CERCLA restoration efforts will clarify the nature and extent of the contamination in this area. 


\section{Vegetation and Foodstuff Monitoring}

Gretchen M. Gallegos

Kris A. Surano

\section{Introduction}

Because pollutants originally released to the soil, air, or water can be transported to vegetation, the sampling and analysis of native vegetation can provide information about the presence and movement of radionuclides in the environment. Vegetation can contribute a radiation dose to humans directly through ingestion or indirectly through human ingestion of products from animals that have consumed it. DOE guidance states that periodic sampling and analysis of vegetation should be performed to determine if there is measurable long-term buildup of radionuclides in the terrestrial environment (U.S. Department of Energy 1991).

Since 1972, vegetation and foodstuff sampling in the vicinity of LLNL and Site 300 has been part of a continuing LLNL monitoring program designed to measure any changes in environmental levels of radioactivity, to evaluate any increase in radioactivity that might have resulted from LLNL operations, and to calculate potential human doses resulting from direct and indirect ingestion of these products. During 1996, LLNL collected and analyzed samples of native vegetation and wine. Potential human doses from these foodstuffs are calculated using the monitoring data and dose models presented in Appendix B.

Tritium is the nuclide of major interest in the LLNL vegetation and foodstuff monitoring program because LLNL has historically released tritium to the air both accidentally and in the course of routine operations. Tritium is likely to move into the environment as tritiated water and can be assimilated easily into vegetation and foodstuff. It can contribute to human radiation dose burdens if it is inhaled or ingested directly or indirectly. Although other radionuclides are used at LLNL, our assessments show that only tritium could be present in vegetation in detectable concentrations.

\section{Methods}

Our methods for monitoring vegetation and wine are presented in the following sections. 


\section{Vegetation and Foodstuff Monitoring}

\section{Vegetation}

LLNL collects vegetation samples, usually annual grasses, quarterly from fixed locations in the Livermore Valley, San Joaquin Valley, and Site 300, and then analyzes them for tritium.

Location maps are provided in Figures 10-1 and 10-2. These locations have been selected so samples would represent vegetation from: (1) locations near LLNL that could be affected by LLNL operations, (2) background locations where vegetation was similar to that growing near LLNL but was unlikely to be affected by LLNL operations, and (3) areas of known or suspected LLNL-induced contamination. Sampling location NPER

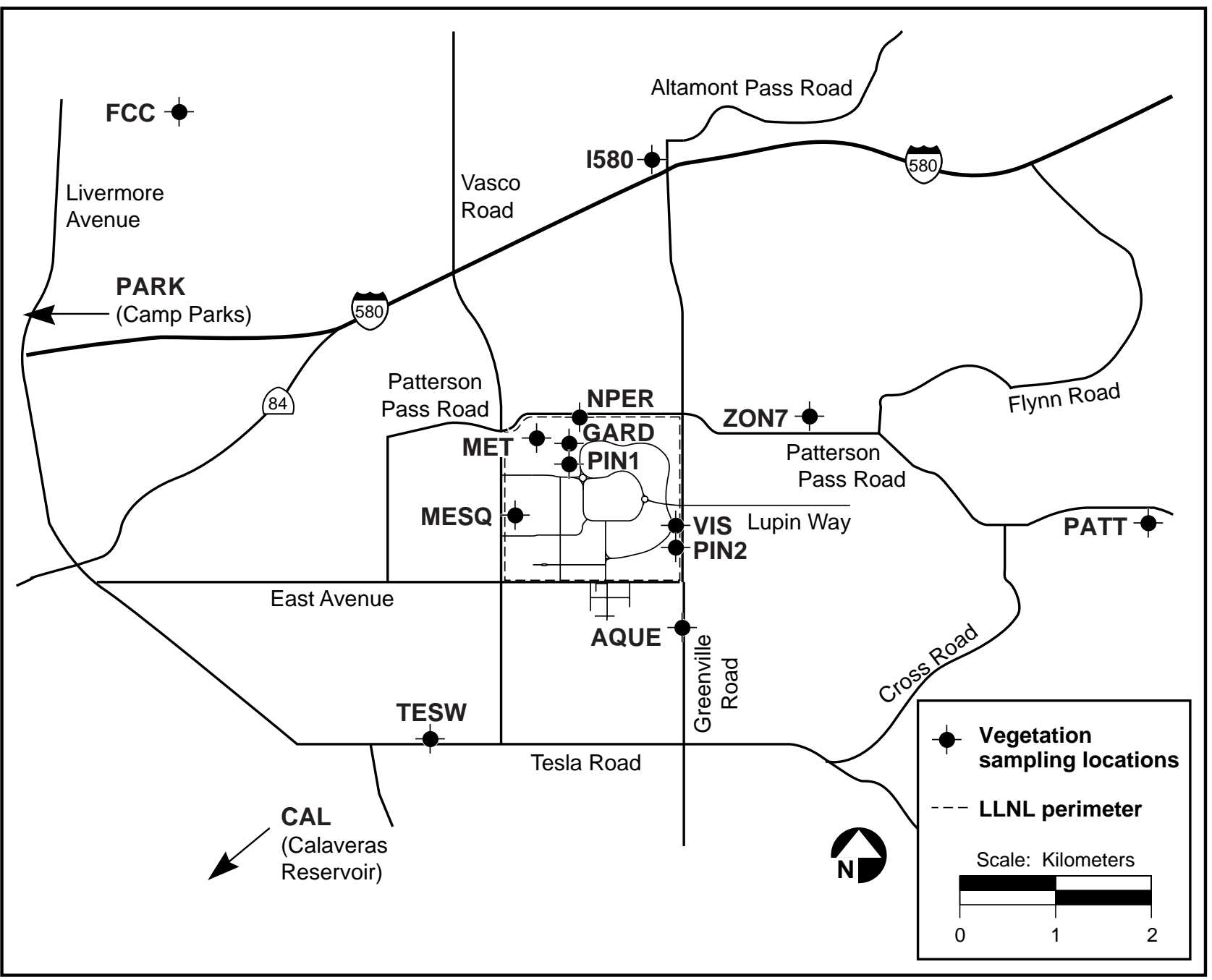

Figure 10-1. Livermore Valley vegetation sampling locations, 1996. 


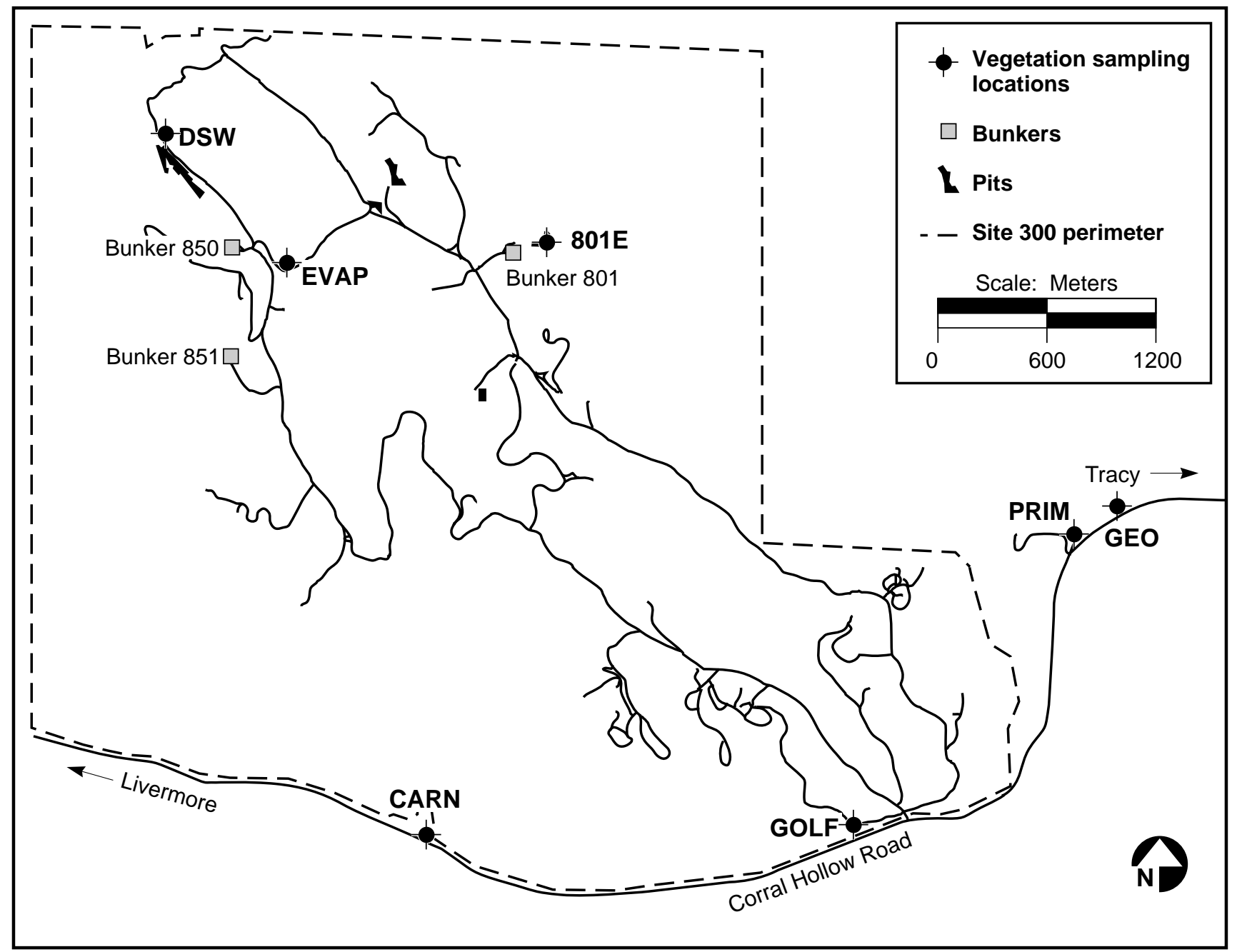

Figure 10-2. Site 300 vegetation sampling locations, 1996.

was added to the sampling network in the first quarter of 1996. It replaced location RAIL, which had become inaccessible. Sampling locations PIN1, PIN2, and PRIM were added in the fourth quarter of 1996. PIN1 and PIN2 were added to evaluate the emissions of tritium from a pine tree that is rooted in tritium-contaminated soil (PIN2 is a tree located in a background location). PRIM is located off site and downwind of Site 300.

All vegetation sampling is conducted according to written and approved standardized procedures (Tate et al. 1995). Approximately $10 \%$ of the sites are sampled in duplicate to comply with quality assurance protocols (Garcia and Failor 1993). 


\section{Vegetation and Foodstuff Monitoring}

\section{Wine}

Wine is the most important agricultural product in the Livermore Valley, representing an approximately \$30-million annual industry. Although the tritium concentrations in all wines are low, the data since monitoring began (in 1977) indicate that Livermore Valley wines contain statistically more tritium than do their California counterparts.

Three types of wine samples were collected and analyzed for tritium concentrations: wine produced from grapes grown in the Livermore Valley, wines produced from grapes grown in California outside the Livermore Valley, and wines produced from grapes grown in Europe (France, Germany, and Italy). The latter two groups were divided into 8 and 13 wine-producing regions, respectively, and were used as comparative samples.

The wine samples were purchased from local retailers in a variety of vintages and reflect the body of wines locally available to the general public during 1996. The resulting analytical data can be used to estimate the potential tritium dose received by consumers during the year of purchase. The 1996 sampling data cannot, however, be used to indicate how LLNL's operations affected wines produced in 1996. Some time-in some cases, several years - will have elapsed between the harvest of the grapes and the release of the vintage. However, wine sample data are decay-corrected to original tritium concentrations (given the number of months that have elapsed between wine production and LLNL analysis) to determine trends and to help determine the impact of LLNL operations during a particular vintage year.

The wine samples were submitted for analysis unopened to avoid airborne tritium contamination. Wines were analyzed for tritium using ${ }^{3} \mathrm{He}$ mass spectrometry in the LLNL Isotope Sciences Noble Gas Mass Spectrometry Laboratory (Surano et al. 1991). This highly sensitive method has a detection limit of less than $0.5 \mathrm{~Bq} / \mathrm{L}(13 \mathrm{pCi} / \mathrm{L})$, and is used to determine the small differences in the tritium content of the samples. Conventional scintillation detection systems typically have detection limits between 5 and $10 \mathrm{~Bq} / \mathrm{L}$ (150-300 pCi/L); therefore, the differences in the samples would not have been detected had conventional detection methods been used.

Approximately $10 \%$ of the total complement of wines was sampled in duplicate, $30 \%$ of all the samples were analyzed multiple times, and traceable standards were evaluated to comply with quality assurance protocols. 


\section{Results}

The results of vegetation and foodstuff monitoring for the Livermore site and Site 300 are presented below.

\section{Livermore site}

\section{Vegetation}

Table 10-1 shows summary tritium data for vegetation collected in the Livermore site vegetation monitoring program in 1996 (the individual sampling values are presented in Volume 2 of this document). In general, the 1996 tritium levels in vegetation were not significantly different than the levels measured in 1995.

Table 10-1. Tritium in vegetation (in Bq/L), 1996.

\begin{tabular}{|c|c|c|c|c|c|c|}
\hline \multirow[b]{2}{*}{ Location(a) } & \multirow{2}{*}{$\begin{array}{l}\text { Detection } \\
\text { frequency }\end{array}$} & \multirow[b]{2}{*}{ Median } & \multirow{2}{*}{$\begin{array}{l}\text { Interquartile } \\
\text { range }\end{array}$} & \multirow[b]{2}{*}{ Maximum } & \multicolumn{2}{|c|}{ Dose $(\mu \mathrm{Sv} / \mathrm{y})^{(\mathrm{b})}$} \\
\hline & & & & & Median & Maximum \\
\hline Livermore site near locations & $21 / 26$ & 5.5 & 13 & 96 & 0.027 & 0.46 \\
\hline Livermore site intermediate locations & $11 / 16$ & 3.2 & 3 & 9.2 & 0.015 & 0.044 \\
\hline Livermore site background locations & $1 / 12$ & $<1.9$ & —(c) & 2.3 & $<0.009$ & 0.011 \\
\hline Location DSW at Site $300^{(d)}$ & $3 / 4$ & 3.6 & 7.7 & 32 & 0.017 & 0.15 \\
\hline Location EVAP at Site 300(d) & $1 / 4$ & $<1.9$ & -(c) & 1360 & 0.009 & 6.7 \\
\hline All other locations at LLNL Site 300 & $1 / 17$ & $<1.9$ & -(c) & 2.0 & $<0.009$ & 0.009 \\
\hline
\end{tabular}

Note: Detection frequency means the fraction of samples taken having measured values above the detection limit.

a See Figures 10-1 and 10-2 for sampling locations.

b

Dose calculated based on conservative assumptions that an adult's diet is exclusively vegetables with this tritium concentration and that meat and milk is derived from livestock fed on grasses with the same concentration of tritium. See Appendix B, Methods of Dose Calculations.

c Insufficient number of detections to calculate IQR.

d Sampling location in known area of contamination.

The vegetation locations were put into three groups for statistical evaluation:

- Near-locations at or within $1 \mathrm{~km}$ of the Livermore site perimeter. Near locations include AQUE, NPER, GARD, MESQ, MET, PIN1, PIN2, and VIS.

- Intermediate-locations in the Livermore Valley further from the site (1 to $5 \mathrm{~km}$ from the Livermore site perimeter) but close enough and often downwind so that they are still potentially under the influence of tritium releases at the site. The intermediate locations were I580, TESW, ZON7, and PATT. 


\section{Vegetation and Foodstuff Monitoring}

- Far-locations unlikely to be affected by LLNL operations. One background location (CAL) is more than $25 \mathrm{~km}$ away. The other two (FCC and PARK) are in the Livermore Valley but are greater than $5 \mathrm{~km}$ from the Livermore site and are generally upwind, so they are unlikely to be affected by LLNL operations.

The changes in tritium levels between 1995 and 1996 for the vegetation from within each of the Near, Intermediate, and Far groups were statistically insignificant.

Because the data for tritium in vegetation were lognormally distributed, the means of the logarithms were compared, using the Tukey-Kramer honestly significant difference (HSD) test. This evaluation of the 1996 data showed a significant difference between the Near group and the other two groups; that is, the Near values are significantly different from the Intermediate and Far values, but the Intermediate values are not significantly different from the Far values. Figure 10-3 shows the historic averages for the three groups. The highest tritium results for individual vegetation sampling locations were found at PIN1, AQUE, and VIS. PIN1 is in a location of known contamination. AQUE and VIS are located downwind of the Livermore site and historically have exhibited higher values than other locations.

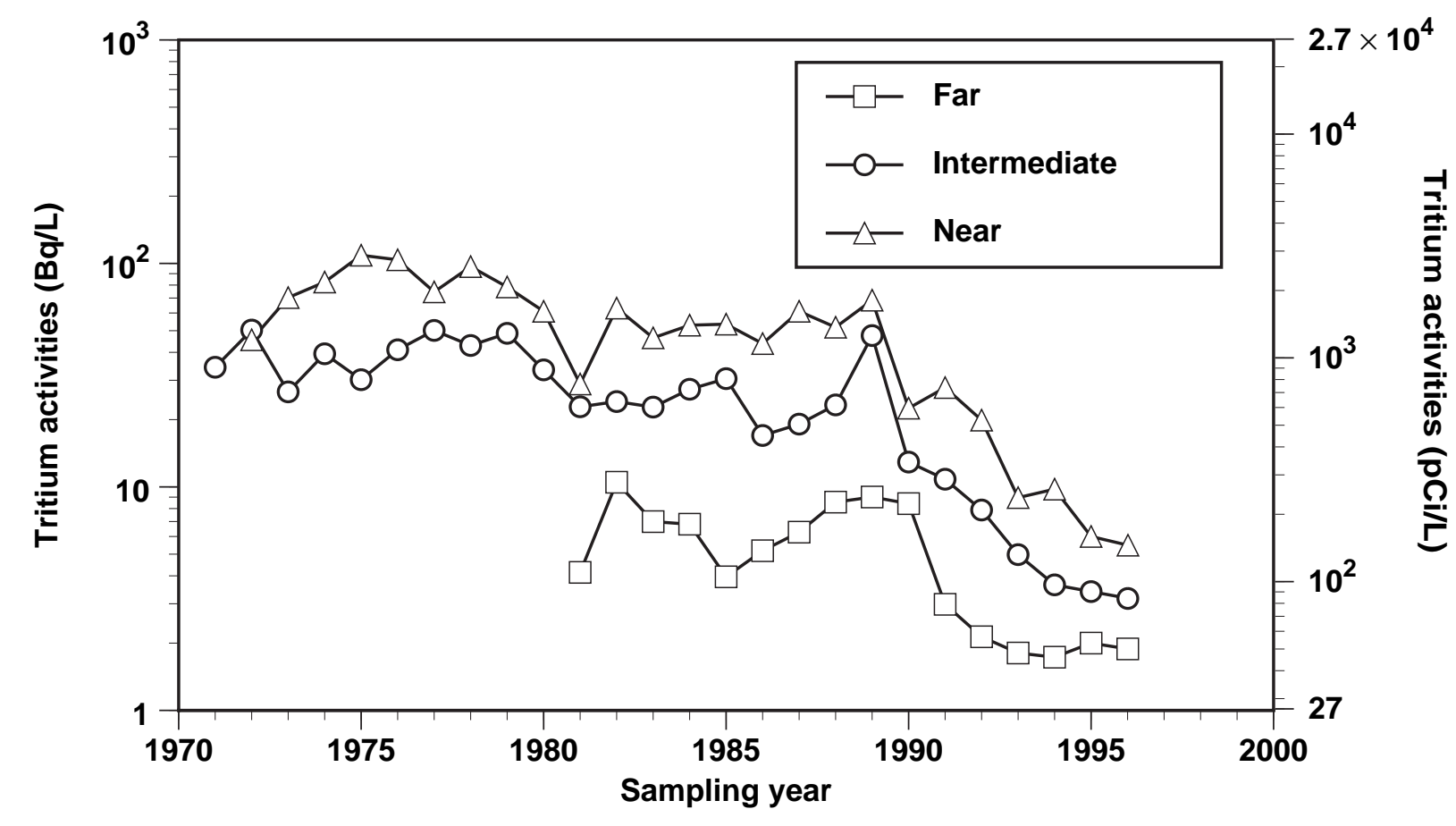

Figure 10-3. Median tritium activities in Livermore Valley vegetation samples, 1971 to 1996. 


\section{Wine}

The results from the 1996 wine tritium analyses are shown in Table 10-2. Tritium concentrations were within the range of those reported in previous years, and they remained low in wines from all areas.

Table 10-2. Tritium (Bq/L) in retail wine, 1996. (a)

\begin{tabular}{|l|c|c|c|c|c|c|}
\hline \multicolumn{1}{|c|}{ Region } & $\begin{array}{c}\text { Detection } \\
\text { frequency }\end{array}$ & Median & $\begin{array}{c}\text { Interquartile } \\
\text { range }\end{array}$ & Mean & Maximum & $\begin{array}{c}\mathbf{D o s e}^{(\mathbf{b})} \\
\mu \text { Sv/y (mrem/y) }\end{array}$ \\
\hline Livermore Valley & $12 / 12$ & 3.24 & 2.56 & 3.12 & 5.61 & $0.0028(0.00028)$ \\
California & $6 / 6$ & 0.58 & 0.19 & 0.63 & 0.93 & $0.0006(0.00006)$ \\
Europe & $4 / 4$ & 1.52 & 0.26 & 1.59 & 1.92 & $0.0014(0.00014)$ \\
\hline
\end{tabular}

a Wines from a variety of vintages were purchased and analyzed during 1996. The concentrations shown are not decay-corrected to vintage year.

b This dose is calculated from conservative assumption of drinking $52 \mathrm{~L}$ wine/year and using the mean concentration of sampled wines.

The data for the 1996 sampling year were analyzed using analysis of variance (ANOVA). The statistical analyses showed that the mean tritium concentration of the Livermore wines sampled was statistically greater than that of the California (other than Livermore) wines. The statistical analyses also indicated that there was no significant difference between the mean tritium values of the European and California wines sampled or between the Livermore and European wines. Multiple comparison tests indicated that the mean levels of the 1996 sampling year data from all areas were not significantly different from those reported for the 1994 and 1995 sampling years.

Figure 10-4, which shows the results of the wine analyses by sampling year since monitoring began, also shows that 1996 tritium concentrations are among the lowest for all reported Livermore wines.

During the review of historical data in 1995, it was discovered that the data being reported for the 1977 and 1979 sampling years were averages across multiple sampling years. These data have been corrected in Figure 10-4, and are the reason for differences observed when comparing this figure to those published before 1995.

Regression analyses and ANOVA of the wine data when decay-corrected and grouped by vintage year (1995 is the last sampled vintage) showed tritium concentrations have statistically decreased for all regions since 1984 (see Figure 10-5). Livermore wines, examined by vintage year, had statistically greater tritium concentrations from 1986 through 1994 than both European and California wines. However, the 1995 vintage Livermore wines exhibited slightly lower tritium concentrations than their European counterparts. Whether this is a statistical artifact of small sample size ( $n=2$ for 1995 Livermore wines) or an indication that tritium levels in Livermore wines have actually 


\section{Vegetation and Foodstuff Monitoring}

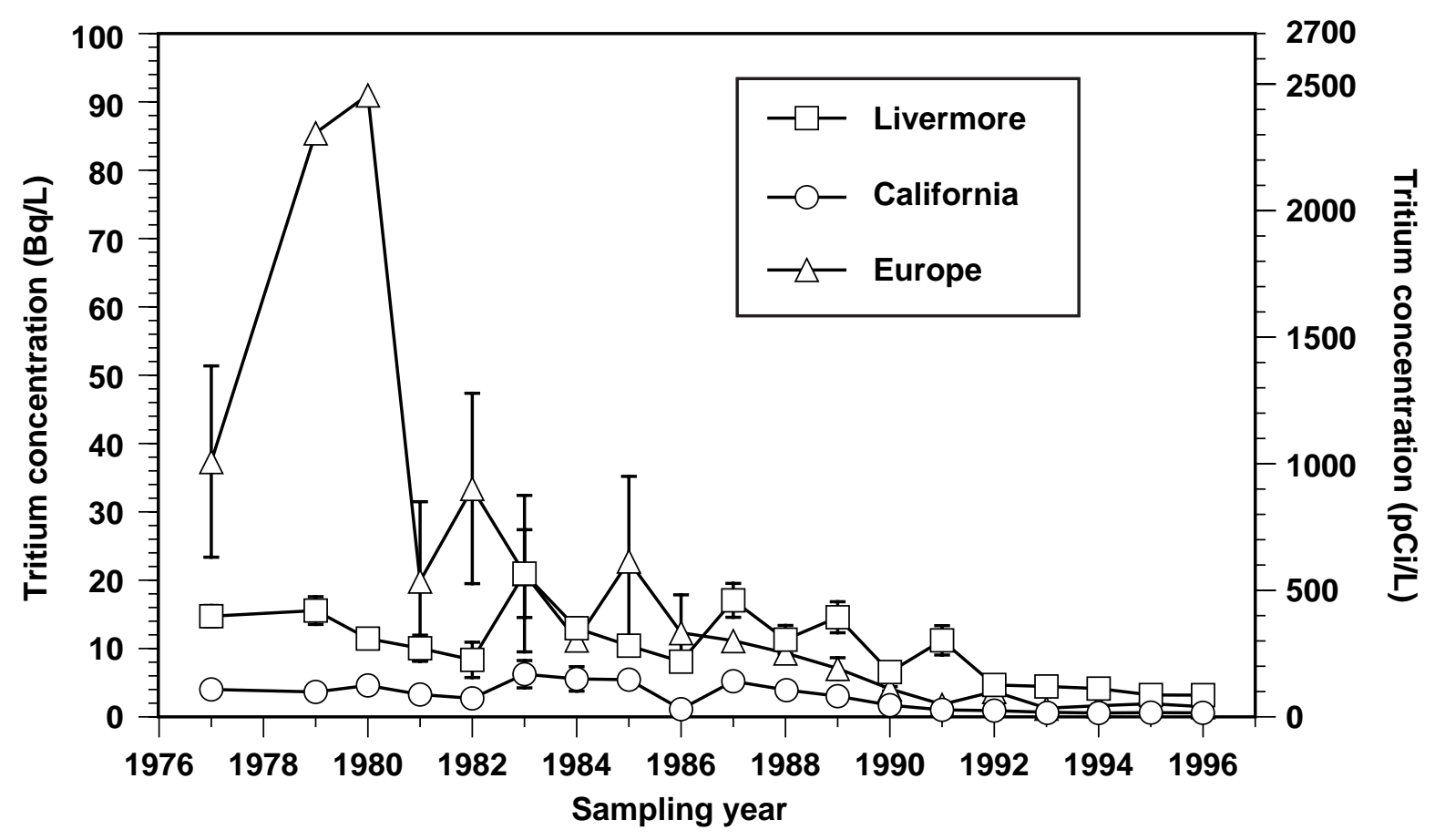

Figure 10-4. Mean tritium in retail wines, 1977 to 1996, plotted by sampling year (error bars are \pm 1 standard error).

decreased below that of European wines should be resolved in 1997 when additional 1995 vintage Livermore wines are available for analysis. Nevertheless, it is important to note the continued downward trend in the tritium concentrations of Livermore wines (when decay-corrected and grouped by vintage year) that has been observed since 1984 (when tritium operations at LLNL were scaled down and total amounts of tritium released were reduced).

Site 300

\section{Vegetation}

Table 10-1 shows summary tritium data for vegetation collected at Site 300 during 1996. Historic values for tritium at Site 300 sampling locations are shown in Figure 10-6. Of the six sampling locations at Site 300, four yielded results at or near the detection limits. Two locations, EVAP and DSW, yielded results above background. 


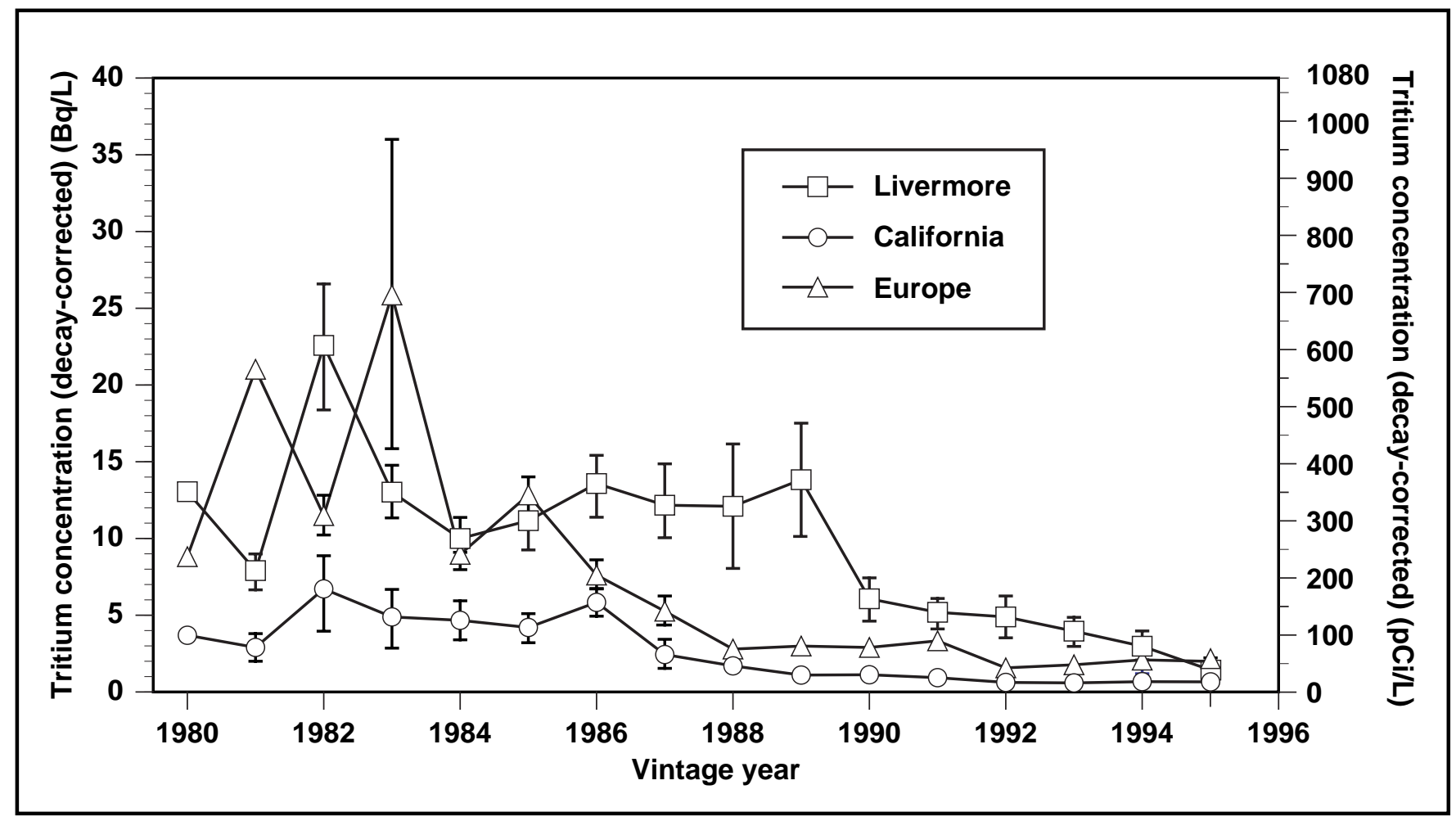

Figure 10-5. Mean tritium in retail wines, vintages 1980 to 1996 values are decay-corrected and plotted by vintage year (error bars are \pm 1 standard error).

With one exception, vegetation samples from location DSW contained the highest maximum tritium values detected (see Table 10-1). Tritium has been observed in the vegetation of the DSW sampling location since 1971; it is in an area presently being investigated under CERCLA for tritium contamination of ground water. This sampling location is adjacent to a landfill that contains debris contaminated with tritium from past experiments. The landfill area is under continued investigation for tritium in soil and ground water, as described in reports published as part of LLNL's Environmental Restoration Program (Lamarre 1989a, 1989b, and 1989c; Taffet et al. 1989a and 1989b; Taffet et al. 1991; Carlsen 1991a and 1991b; and Webster-Scholten 1994). The highest tritium result for a single vegetation sample occurred at the location EVAP. The sample was not the usual native grass, but a stinging nettle (Urtica dioica), which has a relatively long tap root. The location EVAP is near a spring where ground water flows near the surface and evaporates. The ground water in this area is contaminated with tritium which comes from three sources, Pit 3, Pit 5, and the firing table at Building 850 (see discussion of Wells NC7-61 and NC7-69 in Chapter 8, Ground Water). The root of the stinging nettle appears to have reached this ground water, causing the high measured result. Evaluation of the 1996 data using the Tukey-Kramer HSD test on the 


\section{Vegetation and Foodstuff Monitoring}

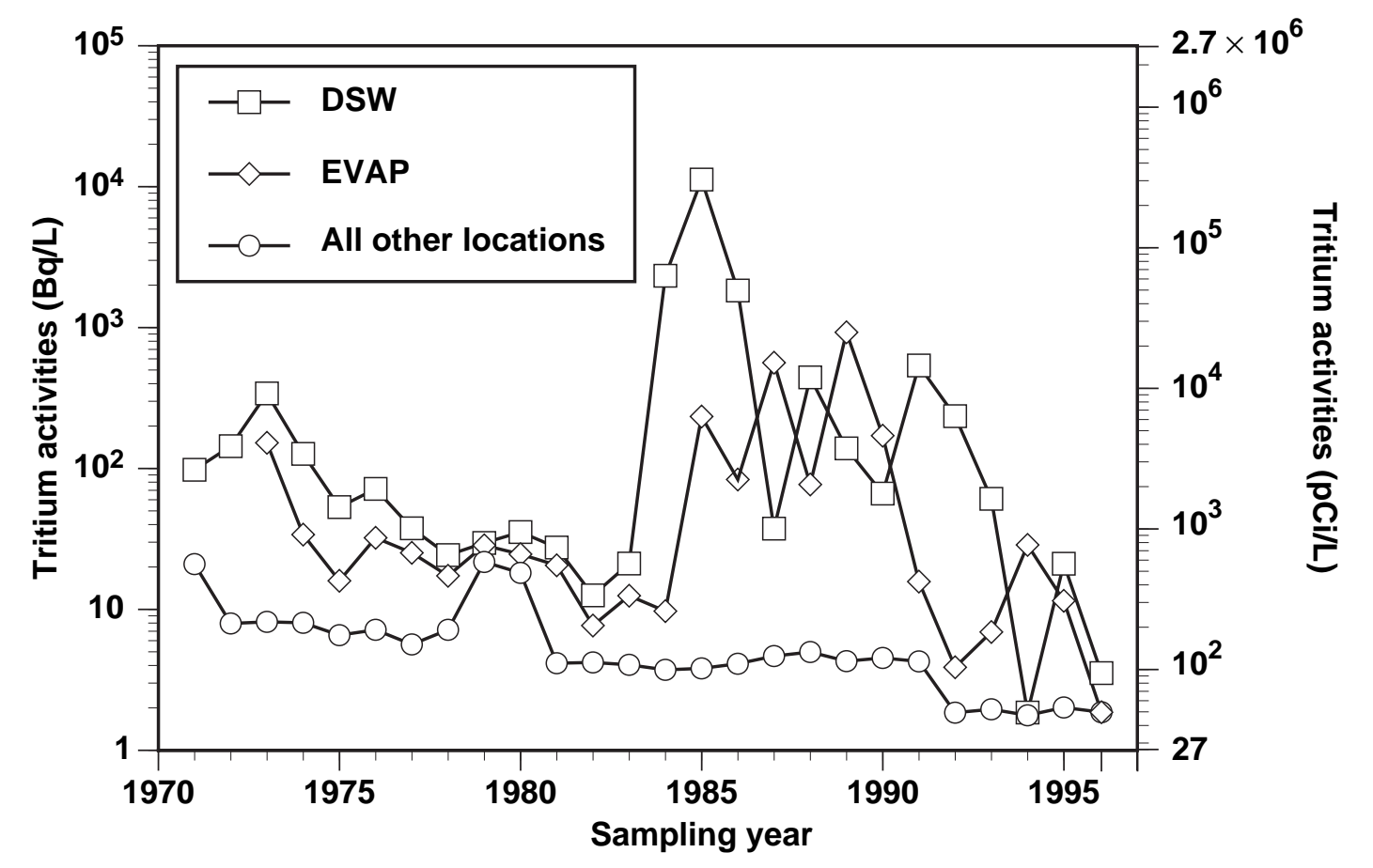

Figure 10-6. Median tritium activities in vegetation at Site 300 sampling locations, 1971 to 1996.

logarithms of the data yielded no significant differences among the various sampling locations; this is a result of the high variability of the data and the low number of data points. However, if the 1995 and the 1996 data are combined, a significant difference is found between the set of locations comprising GEO, CARN, GOLF, and 801E, and locations DSW and EVAP. This is a result of the fact that DSW and EVAP are located in areas of known tritium contamination.

\section{Environmental Impact}

The environmental impacts of LLNL operations on vegetation and foodstuff monitoring are small and are presented below for the Livermore site and Site 300.

\section{Livermore Site}

LLNL impacts on vegetation in the Livermore Valley remained minimal in 1996. The effective dose equivalents shown in Table 10-1 were derived using the dose conversion factors provided by DOE (U.S. Department of Energy 1988) and the dose pathway 
model from NRC Regulatory Guide 1.109 (U.S. Nuclear Regulatory Commission 1977). Appendix B provides a detailed discussion of dose calculation methods. The dose from tritium in vegetation is based on the conservative assumptions that an adult's diet consists exclusively of vegetables with the measured tritium concentration, and meat and milk derived from livestock fed on grasses with the same concentration. These assumptions are conservative because most vegetables consumed directly by an adult will not contain tritium at the levels reported (the tritium levels will actually be much lower), nor will the livestock actually consume vegetation with the reported levels of tritium. Based on these conservative assumptions, the maximum potential dose (from ingestion of affected vegetation) for 1996 for the Livermore site is $0.46 \mu \mathrm{Sv}$ (0.046 mrem).

No health standards exist for radionuclides in wine. However, all the wine tritium levels were far below drinking water standards. In fact, even the highest detected Livermore Valley value $(5.61 \mathrm{~Bq} / \mathrm{L}$ or $152 \mathrm{pCi} / \mathrm{L})$ represents only $0.8 \%$ of the California drinking water standard $(740 \mathrm{~Bq} / \mathrm{L}$ or $20,000 \mathrm{pCi} / \mathrm{L})$. Doses from wine consumption can be calculated according to methods for water ingestion, which are detailed in Appendix B.

The annual dose that corresponds to the highest detected 1996 Livermore Valley tritium value in wine $(5.61 \mathrm{~Bq} / \mathrm{L}$ [152 $\mathrm{pCi} / \mathrm{L}])$ is $0.070 \mu \mathrm{Sv}(0.0070 \mathrm{mrem})$, based on the extremely conservative assumption that wine is consumed in the same quantities as water $(730 \mathrm{~L} /$ year or $2 \mathrm{~L} /$ day). Using a more realistic wine consumption factor (52 L/year or $1 \mathrm{~L} /$ week of wine from a single area) and the mean tritium values detected in wines from the three sampling areas, the annual dose from Livermore wine would be $0.0028 \mu \mathrm{Sv}(0.00028 \mathrm{mrem})$, from European wine would be $0.0014 \mu \mathrm{Sv}$ (0.00014 mrem), and from California wine would be $0.0006 \mu \mathrm{Sv}(0.00006 \mathrm{mrem})$.

Compared with an annual background dose of approximately $3000 \mu \mathrm{Sv}$ (300 mrem), which includes radon, and a 100- $\mu$ Sv (10-mrem) dose from a typical chest x-ray (Shleien and Terpilak 1984), the potential dose from consuming wine from any area is minute. Therefore, although Livermore wines contained statistically more tritium than wines produced in other areas of California, the effects of the tritium are negligible.

\section{Site 300}

In general, LLNL impacts on vegetation at Site 300 for 1996 were insignificant. Tritium levels found in the Site 300 vegetation were comparable to those observed in previous years. With the exception of vegetation from previously identified sites of contamination, the levels were low, near the limits of detection. The areas where tritium is known to be present in the subsurface soil are well delineated and localized.

The calculated maximum potential annual dose from vegetation at sampling location EVAP, based on the maximum value of $1360 \mathrm{~Bq} / \mathrm{L}(38000 \mathrm{pCi} / \mathrm{L})$, is $6.7 \mu \mathrm{Sv}(0.67 \mathrm{mrem})$. 


\section{Vegetation and Foodstuff Monitoring}

This dose, which would never actually be received by anyone, is about 15 times less than a chest x-ray (Shleien and Terpilak 1984). This calculation uses the same conservative pathway modeling assumptions, as described above. In actuality, this dose never would be received because vegetation at Site 300 is not consumed by people or by grazing livestock. In comparison, the calculated potential annual dose from vegetation at all other locations at Site 300 had a median value of $<0.009 \mu \mathrm{Sv}(<0.0009 \mathrm{mrem}$; the value is a "less than" value because all measured tritium levels were less than the detection limit). Tritium levels in vegetation at Site 300 will continue to be monitored. 


\section{Environmental Radiation Monitoring}

Barbara C. Fields

\section{Introduction}

A variety of radioisotopes are used at LLNL for biomedical, general, and nuclear weapons research. These include transuranics, tritium, and mixed fission products. In accordance with federal regulations, DOE Orders 5400.1 and 5400.5, and Title 17, California Code of Regulations, Section 30250, LLNL monitors direct gamma radiation to establish background radiation levels in its vicinity and to determine the direct environmental radiological impact of its operations. Gamma radiation results from natural background sources of terrestrial or cosmic origin and from man-made sources, such as fallout from past nuclear weapons testing and any contribution from LLNL operations.

Because environmental radiological monitoring is used as one measure of the potential direct radiation dose the public receives as the result of LLNL operations, LLNL has developed an extensive radiological monitoring network for the Livermore site perimeter, the Livermore Valley, and the Site 300 perimeter. Direct gamma radiation has been measured at the Livermore site since 1973, and a direct environmental radiation monitoring program was implemented at Site 300 in 1988. Direct gamma radiation is measured using thermoluminescent dosimeters (TLDs), which provide a measure of the total amount of gamma radiation at a particular location. Environmental neutron monitoring, which was also started in 1973, was discontinued at the end of 1994. Currently, environmental exposure to neutrons is not a concern at LLNL. However, should it become necessary for LLNL to start up operations that produce neutrons at significant levels, environmental neutron monitoring can be resumed. As a result of a gamma network assessment, the number of monitoring locations was reduced in 1995 (Harrach et al. 1996).

\section{Monitoring Locations}

External doses from direct gamma radiation were monitored at 14 Livermore site perimeter locations (shown in Figure 11-1), and 23 Livermore Valley locations (Figure 11-2) in 1996. These off-site locations are used for background comparison with perimeter locations. Similarly, gamma doses were monitored at nine perimeter monitoring locations at Site 300 (Figure 11-3), 5 in areas near Site 300, and 2 locations in 


\section{Environmental Radiation Monitoring}

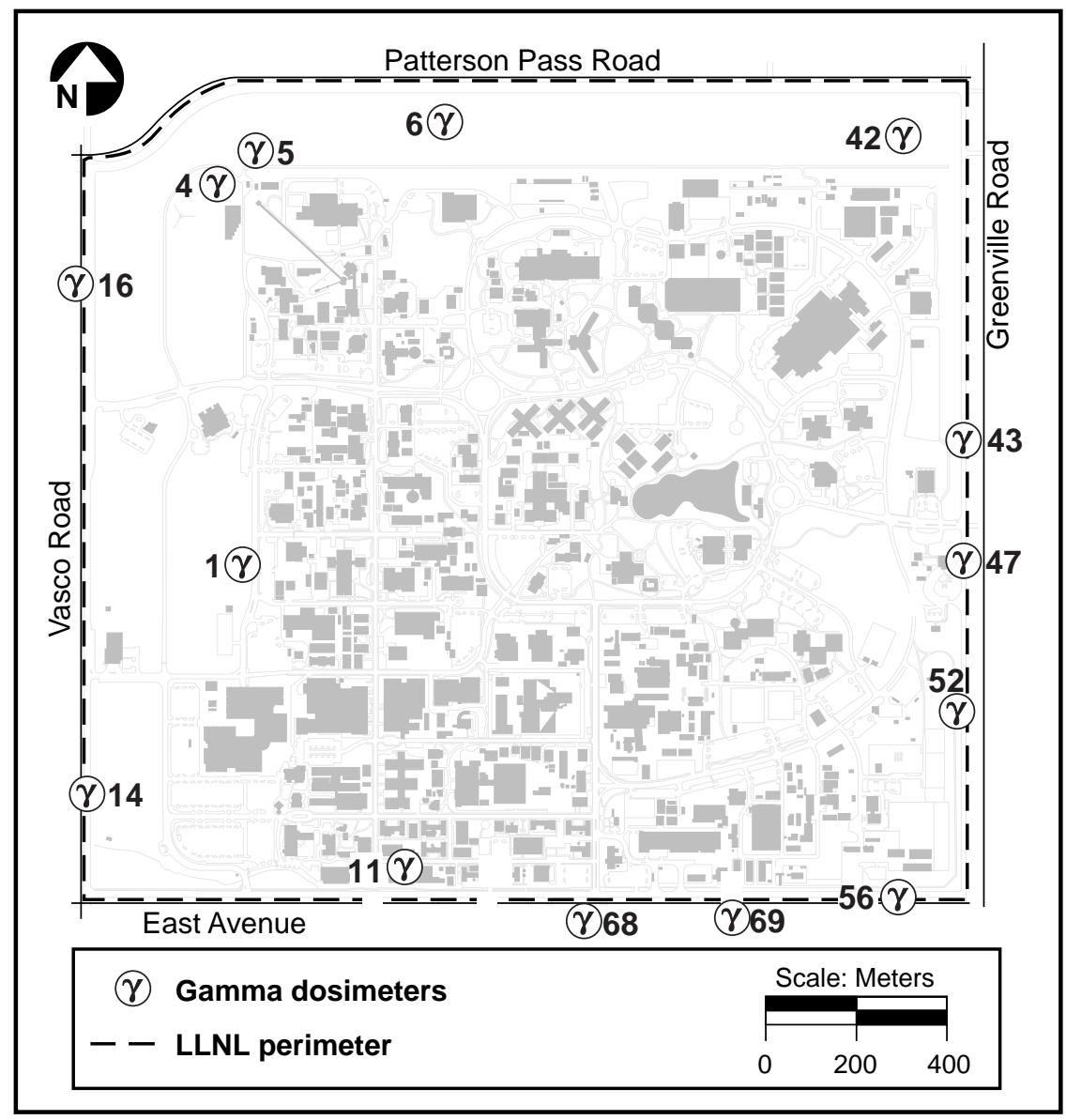

Figure 11-1. Gamma dosimeter locations, Livermore site, 1996.

nearby Tracy. Six monitoring locations near Site 300 were added as part of a special study in 1993. Monitoring has continued at these locations to provide data from areas not likely to be affected by LLNL operations. Sampling at locations 84 and 95 (Harrach et al. 1996) was discontinued in 1996.

\section{Results of Gamma Monitoring}

In 1995, all of the quarterly gamma radiation data points were normalized to standard 90-day quarters, as is the practice of the Nuclear Regulatory Commission (NRC) (Struckmeyer 1994). This practice was continued in the 1996 data processing and analyses. By using the same standard-quarter reporting method, data from other DOE and NRC facilities and data from intercomparison studies can be more easily compared. As shown in Figure 11-4, when our data are adjusted to standard quarters, the variability in exposures that was previously reported (Harrach et al. 1995) is reduced. 


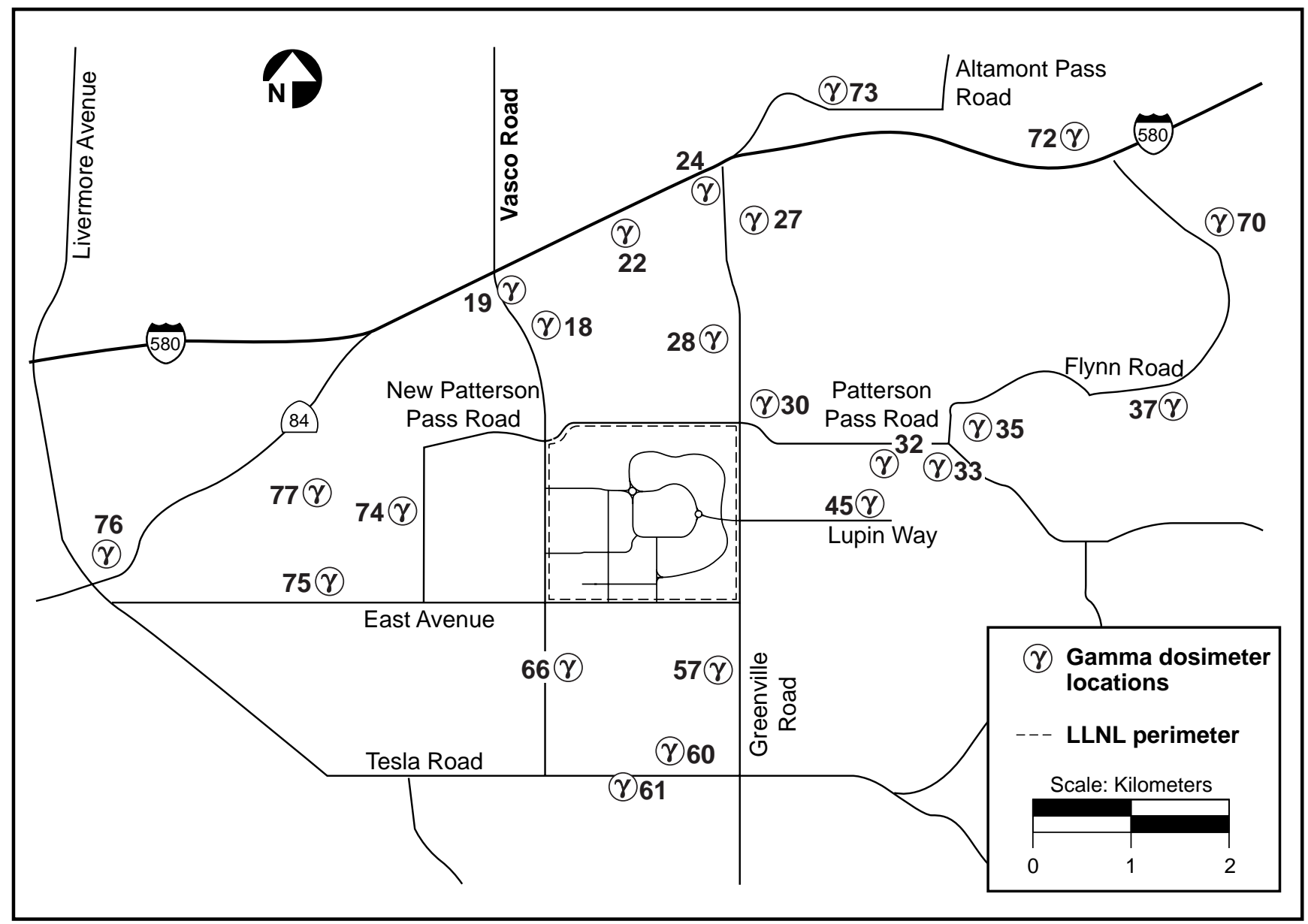

Figure 11-2. Gamma dosimeter locations, Livermore Valley, 1996.

\section{Livermore Site}

Table 11-1 presents a summary of the quarterly and annual TLD gamma radiation dose equivalents for the Livermore site perimeter locations and Livermore Valley off-site locations. The mean 1996 dose equivalent from external direct radiation exposure at the Livermore site perimeter, $0.55 \mathrm{mSv}$ ( $55 \mathrm{mrem}$ ), is about the same as background external dose measured in the Livermore Valley, $0.55 \mathrm{mSv}$ (55 mrem). Table 11-2 lists the yearly doses due to direct gamma radiation at the LLNL site perimeter. The data, normalized to 90-day standard quarters, show no significant variation from year to year.

Figure 11-5 presents the frequency distribution for external radiation dose measured at 23 Livermore Valley locations. See Chapter 11, Volume 2, of this report for a discussion of methods and more comprehensive presentation of the data. 


\section{Environmental Radiation Monitoring}

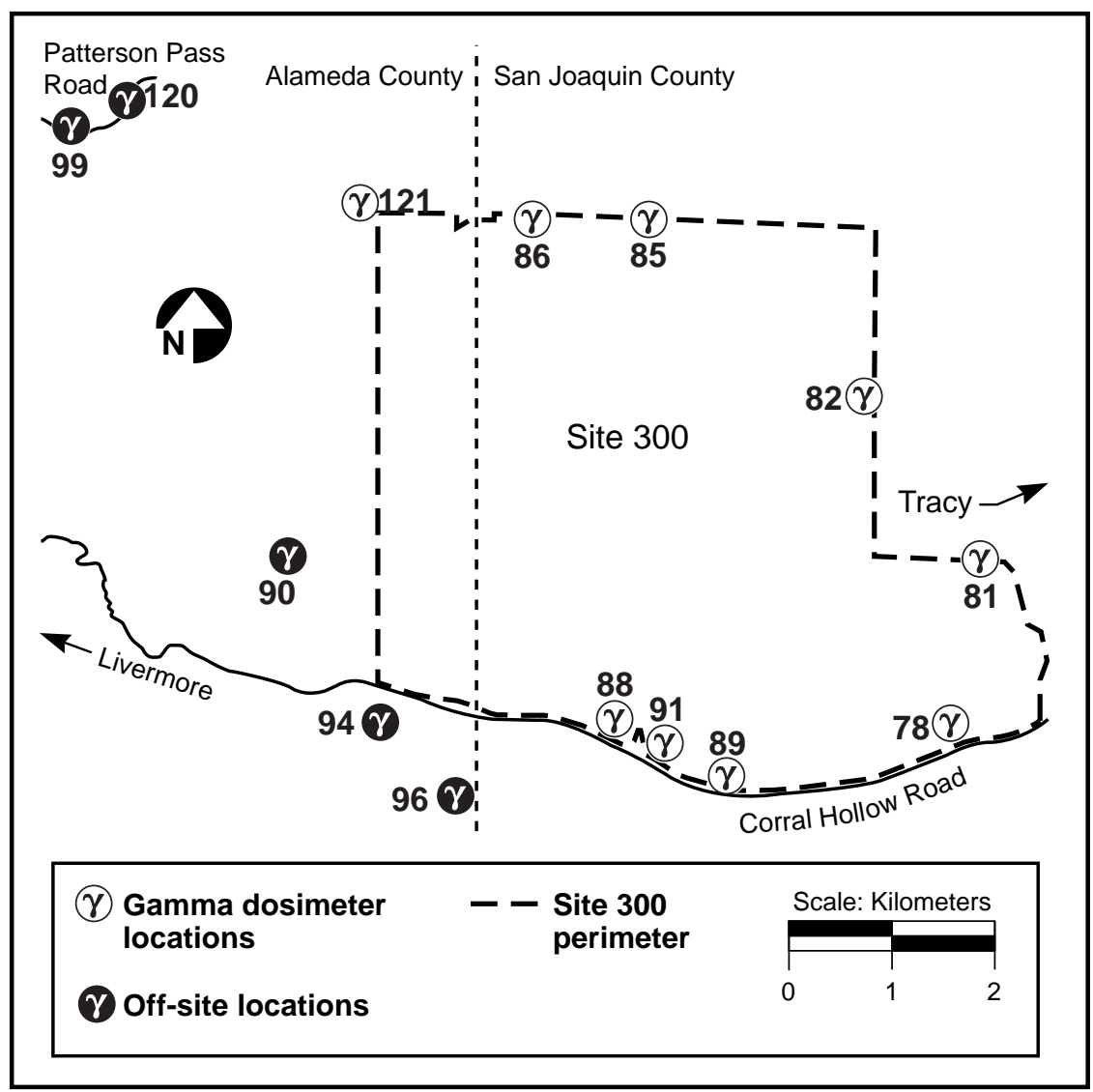

Figure 11-3. Gamma dosimeter locations, Site 300 and vicinity, 1996.

\section{Site 300}

As seen in Table 11-1, the measured Site 300 perimeter average dose in 1996 was $0.66 \mathrm{mSv}$ (66 mrem), the measured dose at the off-site locations near Site 300 was $0.71 \mathrm{mSv}(71 \mathrm{mrem})$, and the measured doses in and near Tracy were $0.63 \mathrm{mSv}$ (63 mrem). All doses are within the predicted range for background radiation, and no LLNL operational impacts are discernible.

At Site 300, the initial TLD network design limited monitoring to the Site 300 perimeter and two locations in and near the city of Tracy, which were chosen to represent background radiation levels. However, the Tracy locations are located on a geological substrate different from that at Site 300. The region around Site 300 has higher levels of naturally occurring uranium, which is present in the Neroly Formation. The mean dose measured in the off-site locations of the area around Site 300, which is used to represent the high end of background radiation from this formation, was $0.71 \mathrm{mSv}$ (71 mrem) and is greater than the Site 300 perimeter dose of $0.66 \mathrm{mSv}$ (66 mrem). The Tracy area, with a dose of $0.63 \mathrm{mSv}$ (63 mrem), is at a lower elevation, with geological constituents 
composed of alluvial deposits of clays, sands, and silts overlying the bedrock. The difference in doses can be directly attributed to the difference in geologic substrates.

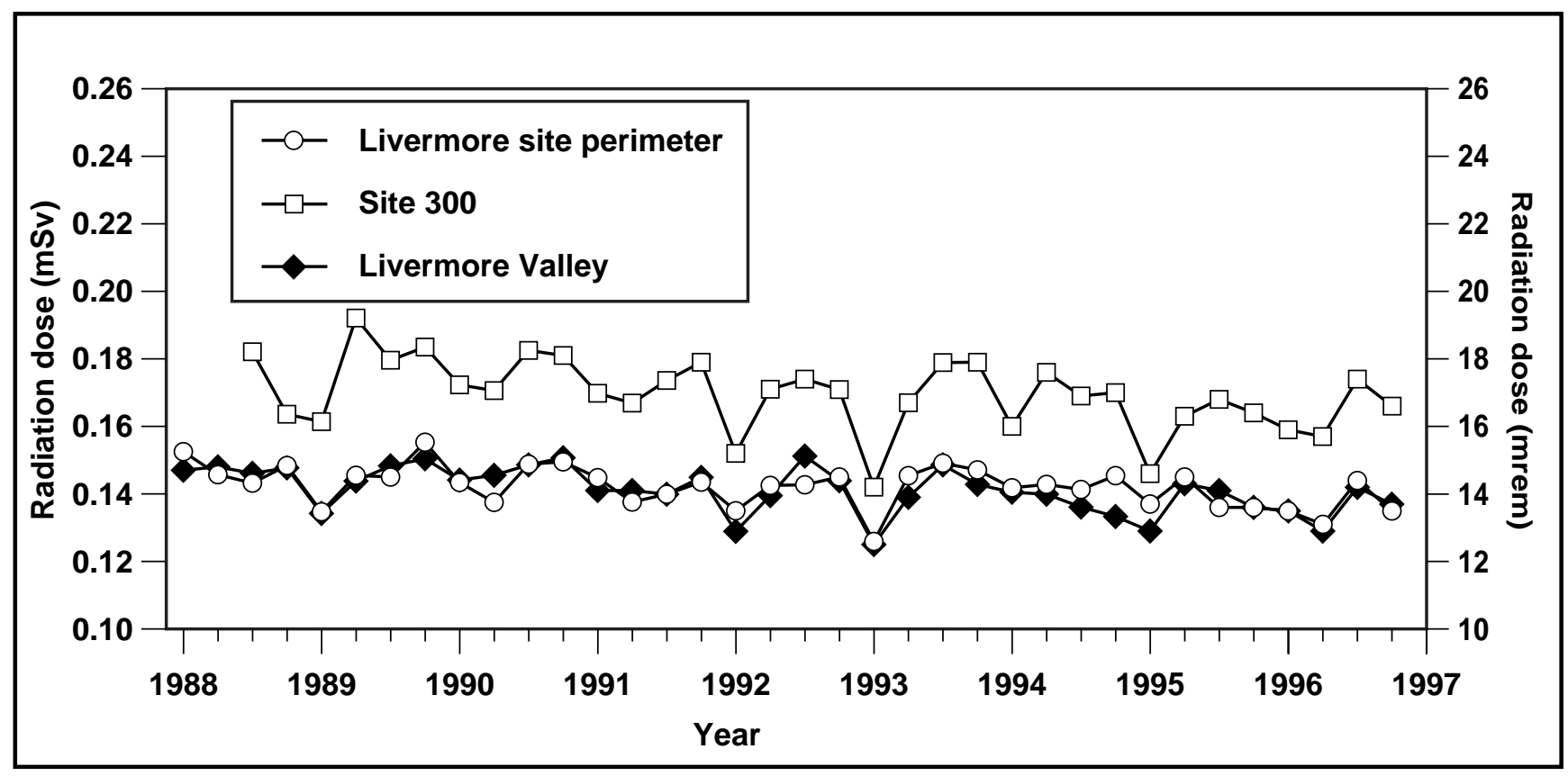

Figure 11-4. Gamma measurements at the Livermore site perimeter, Livermore Valley, and Site 300, 1988 to 1996.

Table 11-1. Summary statistics for gamma monitoring at all sites in 1996 (in mSv). (a)

\begin{tabular}{|c|c|c|c|c|c|c|c|c|c|c|}
\hline \multirow{3}{*}{ Quarter } & \multicolumn{10}{|c|}{ Location } \\
\hline & \multicolumn{2}{|c|}{ Livermore site } & \multicolumn{2}{|c|}{ Livermore Valley } & \multicolumn{2}{|c|}{ Site 300} & \multicolumn{2}{|c|}{ Tracy } & \multicolumn{2}{|c|}{ Off site } \\
\hline & Mean & Std. dev. & Mean & Std. dev. & Mean & Std. dev. & Mean & Std. dev. & Mean & Std. dev. \\
\hline First & 0.135 & 0.008 & 0.135 & 0.019 & 0.159 & 0.019 & 0.134 & 0.014 & 0.171 & 0.033 \\
\hline Second & 0.131 & 0.009 & 0.129 & 0.012 & 0.157 & 0.014 & —(b) & —(b) & 0.167 & 0.025 \\
\hline Third & 0.144 & 0.011 & 0.142 & 0.016 & 0.174 & 0.012 & 0.200 & 0.109 & 0.187 & 0.028 \\
\hline Fourth & 0.135 & 0.010 & 0.137 & 0.017 & 0.166 & 0.019 & 0.136 & 0.010 & 0.188 & 0.059 \\
\hline Total & 0.545 & & 0.547 & & 0.658 & & 0.625 & & 0.712 & \\
\hline
\end{tabular}

\footnotetext{
a $1 \mathrm{mSv}=100 \mathrm{mrem}$.

b Insufficient data for calculation.

c The total represents annual totals given in Volume II, which accounts for missing data by averaging data given for each site.
} 


\section{Environmental Radiation Monitoring}

Table 11-2. Annual dose by year at the Livermore site perimeter due to direct gamma radiation. (a)

\begin{tabular}{|c|c|c|}
\hline Year & mSv & mrem \\
\hline 1988 & 0.59 & 59 \\
1989 & 0.58 & 58 \\
1990 & 0.58 & 58 \\
1991 & 0.56 & 56 \\
1992 & 0.56 & 56 \\
1993 & 0.57 & 57 \\
1994 & 0.56 & 56 \\
1995 & 0.56 & 56 \\
1996 & 0.55 & 55 \\
\hline
\end{tabular}

a Data normalized to standard 90-day quarters (360-day years).

The adjusted doses at the Livermore site perimeter and in the Livermore Valley are comparable and lack significant trend from 1988 to 1996. However, while Site 300 doses are similarly without trend, they continue to measure slightly higher direct gamma doses than the Livermore site and the Livermore Valley, which is expected given the differences in geology between these sites.

In reviewing the trends of the standard quarter data as shown in Figure 11-4, it appears that seasonal variation can occur during the rainy season, most likely because of a decrease in radon emanation from the moist soil. As shown in the figure, the variation was absent during the severe drought years in Northern California (1990-1992) but is apparent when rainfall returned to normal (1994-1995) and above-normal levels (1993).

\section{Environmental Impact}

Based on past measurements (Lindeken et al. 1973), environmental terrestrial (geologic) radiation doses in the Livermore Valley vary from 0.25 to $0.60 \mathrm{mSv} / \mathrm{y}$ ( 25 to $60 \mathrm{mrem} / \mathrm{y})$. Cosmic radiation, as calculated for the local elevation and geomagnetic latitude according to the data of Lowder and Beck (1966), is about $0.35 \mathrm{mSv} / \mathrm{y}$ (35 mrem/y). This combination results in a typical total direct radiation dose level of 0.60 to $0.70 \mathrm{mSv} / \mathrm{y}$ (60 to $70 \mathrm{mrem} / \mathrm{y}$ ); however, local geological and meteorological factors will impact these dose levels. Direct radiation doses measured at the Livermore site perimeter in 1996 are near these predicted values and are statistically equivalent to the Livermore Valley doses, which are considered natural background levels. This indicates that any dose from LLNL operations is not large enough to be seen within the wide range of natural variation in background levels in different locations. 
Environmental Radiation Monitoring

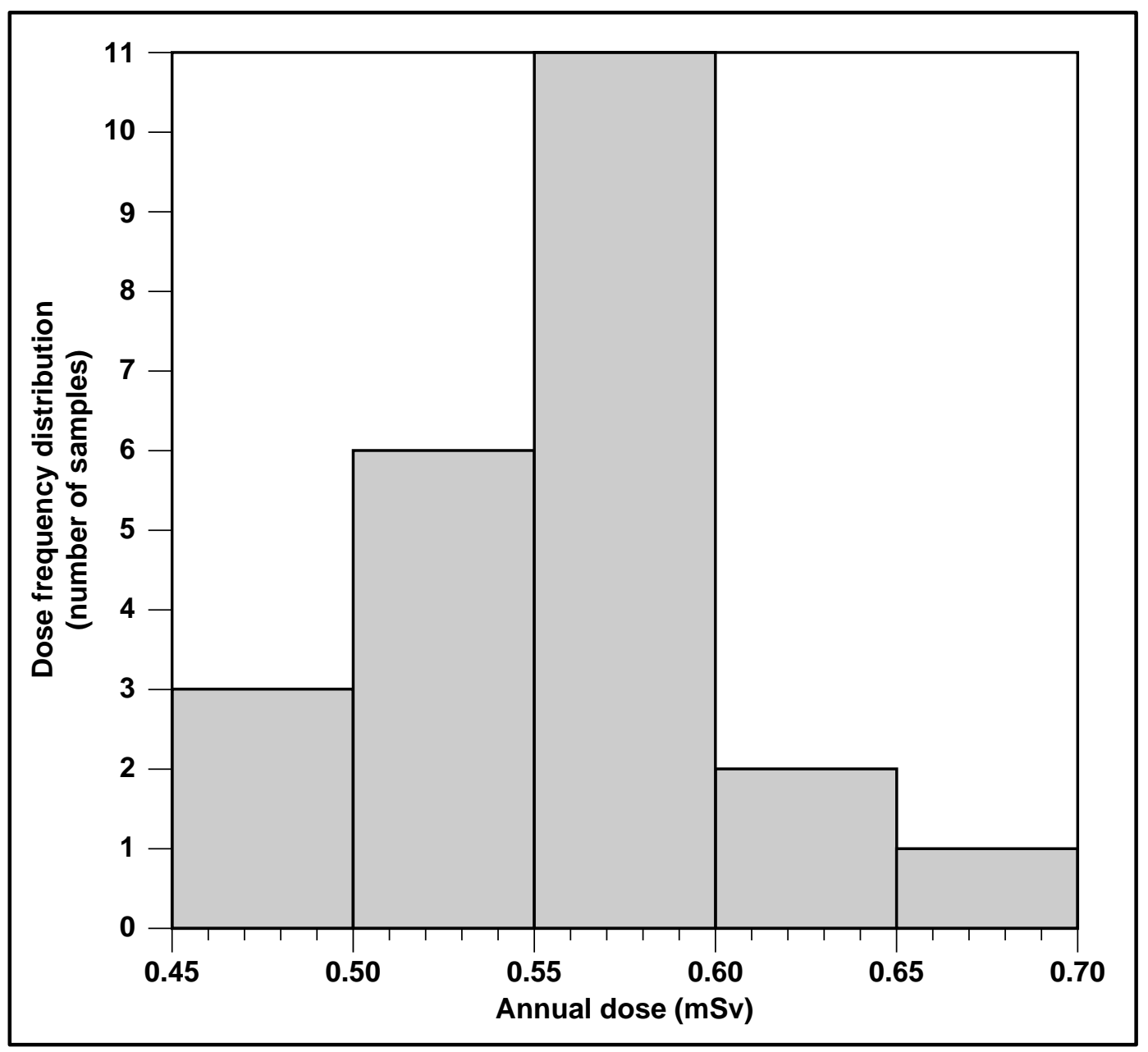

Figure 11-5. Frequency distribution of external gamma radiation at 23 Livermore Valley locations in 1996. 



\section{Radiological Dose Assessment}

Robert J. Harrach

Gretchen M. Gallegos

\section{Introduction}

Radiological doses to the public result from both natural and man-made radiation. The total dose to different populations can be determined by measurements and calculations. This chapter describes LLNL's radiological dose assessments, made to determine the impact of LLNL operations, and contains a discussion of the analyses we performed to demonstrate LLNL's compliance with the radiological National Emission Standards for Hazardous Air Pollutants (NESHAPs; 40 CFR 61 Subpart H).

Because this report has a diverse readership, we have included a brief tutorial on radiation-describing the different sources and types of radiation and the units used to quantify it, and providing some perspective on the wide range of radiation levels people commonly encounter - to enable the nonspecialist to understand more easily the radiological dose assessment information we report; see Supplement 12-1: "Radiation Basics," at the end of this chapter. The organization of the main text is to briefly summarize the federal standards for radiation protection, describe the basic models, data files, and concepts we use, comment on our facilities and the way potential and actual releases of radionuclides are determined, and present and put in context the main results from our radiological dose assessment for 1996 activities. Two additional supplements provide ancillary information; Supplement 12-2 describes LLNL's standard operating procedures that protect employees and the public from uncontrolled releases and unsafe levels of radiation, and Supplement 12-3 discusses modeling doses from explosives experiments at LLNL's Experimental Test Site, Site 300.

\section{Radiation Protection Standards}

DOE environmental radiation protection standards are provided in DOE Order 5400.5, Radiation Protection of the Public and the Environment and federal regulation 10 CFR 835, Occupational Radiation Protection, which incorporate standards for controlling exposures to the public from operations at DOE facilities. These standards are based on recommendations by the International Commission on Radiological Protection 


\section{Radiological Dose Assessment}

(ICRP 1977, 1980) and the National Council on Radiation Protection and Measurements (NCRP 1987a). The primary DOE radiation standards for protection of the public are $1 \mathrm{mSv} / \mathrm{y}$ (100 mrem/y) effective dose equivalent (EDE) for prolonged exposure, and $5 \mathrm{mSv} / \mathrm{y}$ (500 mrem/y) EDE for occasional exposure. (Radiation units and other terms are described in Supplement 12-1.) These limits are based on the dose to the maximally exposed individual in an uncontrolled area, and include all pathways of exposure. The limits apply to the sum of the EDE from external radiation and the committed (50-y) EDE from radioactive materials that may remain in the body for many years after being ingested or inhaled.

DOE and LLNL also comply with the EPA's standard for radiation protection, promulgated under Section 112 of the Clean Air Act, as amended. This EPA radiation dose standard, which applies only to air emissions, is defined in Subpart H of NESHAPs under 40 CFR 61. It limits to $0.1 \mathrm{mSv} / \mathrm{y}(10 \mathrm{mrem} / \mathrm{y})$ the whole-body EDE to members of the public from air emissions at DOE facilities under 40 CFR Part 61.92, Subpart H. Additionally, NESHAPs requires under Part 61.93 that any individual operation or activity that has the potential to produce an annual-averaged dose to a member of the public greater than or equal to $0.001 \mathrm{mSv} / \mathrm{y}(0.1 \mathrm{mrem} / \mathrm{y})$ (i.e., greater than or equal to one percent of the threshold level cited above for site-integrated emissions), allowing no credit for emission control devices, must be continuously monitored using EPAapproved methods.

Because the EPA standard is a low dose level, compared to doses from exposures to natural radioactivity (see Supplement 12-1) and doses caused by radionuclides released from DOE facilities are generally smaller still, it would be difficult to prove compliance with the standard by environmental measurements alone. EPA therefore developed computer codes that implement its approved dosimetry model and mandated that these codes be used to calculate potential doses to the public for compliance demonstrations. The models used in the regulatory codes to evaluate doses and risks contain conservative assumptions that are expected to result in calculated doses larger than ones actually received by members of the public. Calculations reported here primarily were performed using EPA's CAP88-PC code, described below.

\section{Modeling Code and LLNL Data Files}

The CAP88-PC code, developed under an Interagency Agreement between DOE and EPA and made available early in 1992, provides the capability to compute dose and risk to both exposed individuals and collective populations resulting from radionuclide emissions to air. The differences between CAP88-PC and earlier similar codes such as 
AIRDOS-PC are discussed in Appendix E of the User's Guide for CAP88-PC, Version 1.0 (Parks 1992). The mathematical models and explicit equations used in CAP88-PC are described in Chapter 8 of the User's Guide.

CAP88-PC uses a modified Gaussian plume equation to calculate the average dispersion of radionuclides released from up to six collocated sources. Plume rise can be driven by momentum, buoyancy, or set to a predetermined level. Flat terrain is assumed. CAP88-PC accommodates stack sources and area sources. For each stack, the key parameters to be specified are total emissions during the year (e.g., total number of becquerels [Bq] or curies [Ci] for each radionuclide), and stack flow rate, height, diameter, abatement devices, and location relative to site boundaries. Similar input data is required for area sources.

These source options are well-suited to LLNL's Livermore site, which has more than 200 stacks divided among several dozen buildings containing facilities where radioactive materials are used, stored, or where activation products occur, called Radioactive Materials Management Areas (RMMAs). Additionally, a dozen diffuse area sources have been identified at the Livermore site and Site 300 . The way these various sources are characterized for input to computer modeling runs is discussed below under the headings "Inventoried Sources" and "Monitored Sources." But the principal sources of radionuclide air emissions at Site 300 are not conventional; these are several "firing tables" where open-air explosive experiments are conducted, and their specification is more complicated (see Supplement 12-3 at the end of this chapter).

Up to 36 radionuclides can be included in a single run, chosen from a library of 265 radionuclides. Because CAP88-PC does not contain all the radionuclides present at LLNL, surrogate radionuclides were used in some cases to estimate EDEs. In selecting the surrogates, we used the most restrictive lung class (whether clearance from the lungs takes place in days, weeks, or years). When possible, we used a surrogate radionuclide with similar lung class chemistry and similar values for "annual limits of intake via inhalation and derived air concentration," as specified in the EPA guidance, Limiting Values of Radionuclide Intake and Air Concentration and Dose Conversion Factors for Inhalation, Submersion, and Ingestion (Eckerman et al. 1988).

CAP88-PC employs a circular grid, allowing up to 20 user-selected radial distances. Concentrations and doses are sector-averaged for each selected radius. For specifying populations, each area element in the sixteen $22.5^{\circ}$ compass sectors is bounded above and below by arcs with radii from the set of user-selected distances and on its sides by radial line segments separating the sectors. The code contains several modeling options regarding agricultural characteristics and land use, as established by the EPA. 


\section{Radiological Dose Assessment}

The population in each of these area elements can be set by a user-created population data input file. This file specifies the population distribution out to a radius of $80 \mathrm{~km}$ from a facility, considered by EPA to be the range of the exposed population. In 1996, we constructed improved versions of the population distributions centered on the two LLNL sites. These distributions are based on 1990 census data, as were the previous ones, but were made more accurate through use of commercially available, computermap-based population data and ArcView@ geographic information system software. The population for each sector area segment was determined by selecting census block level data for that segment. Key population centers affected by LLNL emissions are the relatively nearby communities of Livermore and Tracy, and the more distant metropolitan areas of Oakland, San Francisco, and San Jose, as well as the San Joaquin Valley communities of Modesto and Stockton. Within the $80-\mathrm{km}$ outer distance specified by the EPA, there are 6.3 million residents included for the Livermore site collective dose determination, and 5.2 million for Site 300. Our new population data files (distribution of population with distance and direction) are published in the LLNL NESHAPs 1996 Annual Report (Gallegos and Biermann 1997).

CAP88-PC accepts site-specific meteorological, as well as population, data files. Input data for the LLNL modeling are collected from on-site meteorological towers at both the Livermore site and Site 300. Wind speed and direction are sampled every few seconds, temperature every minute, and all are averaged into quarter-hour increments, timetagged, and computer-recorded for conversion into a CAP88-PC wind file. Data specifying the annual average precipitation, temperature, and average height of the atmospheric inversion layer are also put into the model. CAP88-PC computes results for each of seven Pasquill-Gifford atmospheric stability categories, specified as part of the wind file. Chapter 1, Site Overview, in this report discusses the LLNL meteorological data, and exhibits wind roses for both LLNL sites.

CAP88-PC computes radionuclide concentrations in air, rates of deposition on ground surfaces, concentrations in food, and intake rates to people from ingestion of food produced in the assessment area. The code contains the EPA's approved dosimetry model, allowing calculation of doses from each of the four principal exposure pathways: internal exposures from inhalation of air and ingestion of foodstuffs and drinking water, and external exposures through irradiation from contaminated ground and immersion in contaminated air. Dose and risk are tabulated as a function of radionuclide, pathway, spatial location, and body organ.

Dose and risk estimates from CAP88-PC are applicable only to low-level chronic exposures because the health effects and dosimetric data it uses are based on low-level chronic intakes. The code is not intended for modeling either short-term or high-level 
radionuclide intakes. The doses are expressed as whole-body effective dose equivalents (EDEs) in units of $\mathrm{mrem} / \mathrm{y}(1 \mathrm{mrem}=10 \mu \mathrm{Sv}=0.01 \mathrm{mSv})$.

\section{Maximally Exposed Individuals and Populations}

We report separate determinations of doses resulting from releases of radioactivity to air from the Livermore site and Site 300. Three potential doses are emphasized:

(1) the dose to the sitewide maximally exposed individual member of the public (denoted as SW-MEI and defined below), which integrates the effects of all emission points at a site; (2) the maximum dose to any member of the public, in any direction (generally occurring at the site boundary and commonly referred to as the maximum "fence line" dose), caused by each individual source of emissions on the site; and (3) the collective dose to the populations residing within $80 \mathrm{~km}$ of the Livermore site and Site 300 (treated separately), adding the products of individual doses received and the number of people receiving them. Dose to the SW-MEI (the first type above) is used to evaluate LLNL's compliance with the EPA standard limiting the total radionuclide emissions to air from DOE facilities to $100 \mu \mathrm{Sv} / \mathrm{y}(10 \mathrm{mrem} / \mathrm{y})$. In this evaluation, credit is taken in the dose model for any emission abatement devices, such as filters. The second type, or fence line dose, is calculated without taking credit for emission abatement devices; it is used to evaluate the need for continuous monitoring of individual emission points under the EPA's $1-\mu \mathrm{Sv} / \mathrm{y}(0.1-\mathrm{mrem} / \mathrm{y})$ standard on potential unabated emissions.

The SW-MEI is defined as the hypothetical member of the public (individual receptor at a residence, place of business, school, church, or similar public facility) who could receive the greatest LLNL-induced EDE from the combined effect of all sources at a single site. At the Livermore site, the SW-MEI is located at the UNCLE Credit Union, about $10 \mathrm{~m}$ outside the controlled eastern perimeter of the site. This location lies $0.95 \mathrm{~km}$ from LLNL's principal source of radionuclide emissions to air, the Tritium Facility (Building 331), in an east-northeast direction. At Site 300, the SW-MEI is located in an experimental area termed "Bunker 2" operated by PRIMEX/Physics International. Bunker 2 lies about 300 m outside the east-central boundary of Site 300. This bunker is $2.4 \mathrm{~km}$ east-southeast of the principal source of radionuclide emissions to air at Site 300, the firing table at Building 801.

It is possible for the location of the SW-MEI to change from year to year, e.g., with changing wind patterns, changing population distributions near site boundaries, or changing emission levels of sources. An illustration of the effect of different wind patterns on dose is given in the LLNL NESHAPs 1993 Annual Report (Harrach et al. 1994). 


\section{Radiological Dose Assessment}

Four prime candidates for the SW-MEI were evaluated for the Livermore site in confirming the UNCLE Credit Union location for 1995, as described in the LLNL NESHAPs 1995 Annual Report (Gallegos et al. 1996).

As stated above, this dose evaluation only pertains to air releases. Releases of radioactivity to the environment during LLNL operations occur via the water pathway as well as air. But radionuclides deposited into surface and ground waters by LLNL operations are not consumed by any individual, and of course releases to the sanitary sewer are not consumed. Therefore these releases to sewer, surface, and ground waters (which are discussed in Chapters 6, 7, and 8 of this report) do not represent a direct ingestion or inhalation pathway for radiation exposure of the public, and are excluded from our radiological dose assessment. Any possible indirect exposures to the public from releases to LLNL waters, e.g., inhalation dose from exposure to sludge containing sewered material, would be treated as special cases and clearly identified as such in reporting dose. Finally, no public exposures occurred via the direct radiation pathway from LLNL operations in 1996.

\section{Monitored and Inventoried Sources}

Accurate characterization of emission sources is crucial to credible air dispersion and dose modeling, and more generally to gauging the impacts of LLNL operations on workers, the public, and the environment. LLNL's sources are determined in three principal ways-by an inventory process, by direct measurement (monitoring) of the emission at the source, and by monitoring selected field points in and around the site.

\section{Inventoried Sources}

Earlier we defined Radioactive Materials Management Areas (RMMAs) as areas where radioactive materials are used or stored, or where activation products occur. Several RMMAs at the Livermore site have effluent monitoring systems in place in their exhaust pathways, as discussed below, allowing a direct measurement of their emission rates. For unmonitored or noncontinuously monitored RMMAs, source terms for potential releases are inferred from radionuclide inventories.

Inventory data is provided by experimenters and facility managers. A full inventory is not conducted each year; only the "key" Livermore site facilities, defined as those that accounted for $90 \%$ of the previous year's (1995) Livermore site radiological dose to members of the public, were reinventoried for 1996. (LLNL conducted a complete radionuclide-inventory update in 1994.) In addition, all new RMMAs (ones that 
commenced operations in 1996) were inventoried. Radionuclide inventories for all Site 300 explosives experiments were also updated in 1996.

For purposes of dose modeling, radionuclide inventory data is converted to potential release rates by means of EPA-specified multipliers for materials in different physical states-solid, liquid, powder, or gas-in accordance with 40 CFR Part 61, Subpart H, Appendix D. If the material was an unconfined gas, the release fraction 1.0 was used; for liquids and powders, $1.0 \times 10^{-3}$ was used; and for solids, $1.0 \times 10^{-6}$ was used.

In addition, for inventoried facilities credit was taken for radionuclide emission control devices when calculating total dose for evaluation under the $10 \mathrm{mrem} / \mathrm{y}(100 \mu \mathrm{Sv} / \mathrm{y})$ EPA standard. Similar to physical-state factors, EPA also specifies control-device abatement factors, associated with various emission-control devices, for use in dispersion and dose models: each high-efficiency-particulate-air (HEPA) filter stage is given a 0.01 emission-reduction factor, venturi scrubbers and electrostatic precipitators are each given a 0.05 factor, and each activated-charcoal filter is given a 0.1 factor. Emissions were assumed to be unabated for evaluations under the $1 \mu \mathrm{Sv} / \mathrm{y}$ (0.1 mrem/y) EPA standard for required continuous monitoring.

In summary, for unmonitored and noncontinuously monitored sources, estimated annual emissions for each radionuclide are based on the product of (1) radionuclide quantity from inventory data, (2) EPA potential-release fractions (physical-state factors), and (3) applicable emission-control-device abatement factors.

\section{Monitored Sources}

\section{Effluent Monitoring}

Actual measurements of radionuclides in air and effluent flow are the basis for reported emissions from continuously monitored sources (replacing the product of inventory data and release-to-air and emission-abatement factors above). There are currently nine buildings at the Livermore site that have continuously monitored discharge points: Buildings 166, 175, 231 (vault area), 251, 331, 332, 419, 490, and 491. These monitoring systems are described in the LLNL NESHAPS 1996 Annual Report (Gallegos and Biermann 1997). Taken together, these buildings feature 103 continuously-operating monitors. (See Chapter 5.)

The most significant monitored source is the Tritium Facility, Building 331, at the Livermore site. Each stack of this facility features both a continuous-monitoring alarm system and continuous molecular-sieve samplers. The sieve samplers, which can discriminate between tritiated-water vapor (HTO) and molecular tritium (HT), provide the values used for environmental reporting. The alarmed samplers provide real-time 


\section{Radiological Dose Assessment}

tritium concentration release levels (HT and HTO). Monitoring of these stacks provides an accurate measure of the total quantity (number of becquerels or curies) of tritium released to the environment, time-resolved over the course of the year, from stacks of known properties (height, flow rate, and diameter) into a wind field of continuously monitored properties (wind speed, direction, and fluctuation characteristics). This directly measured data on emission rates and wind field distributions significantly improves the quality and credibility of the air dispersion and dose assessment modeling.

Effluent monitoring in the other eight facilities is designed to detect radioactive particles. In contrast to monitoring unabated flow of tritium gas in the Building 331 stacks, air samples for particulate emissions are extracted downstream of HEPA filters and prior to the discharge point to the atmosphere. Particles are collected on membrane filters. Sample results are generally found to be below the minimum detectable concentration (MDC) of the analysis; sometimes as few as 1 to 4 samples (out of 25 to 50 per year) have concentrations greater than the MDC. Reporting zero values for this type of data can be justified; for details, see Chapter 5, Air Effluent Monitoring, in this report, and the previously cited 1996 NESHAPs Report.

Among the nine continuously monitored facilities at the Livermore site, none strictly requires monitoring under the EPA's $1 \mu \mathrm{Sv} / \mathrm{y}(0.1 \mathrm{mrem} / \mathrm{y})$ standard; each is continuously monitored for programmatic and other reasons. For example, continuous monitoring is maintained at the Tritium Facility to provide the most direct and accurate measure of its release of tritium to the atmosphere, and continuous monitoring is maintained at the Plutonium Facility (Building 332) and the seismically-hardened portion of Building 251 in lieu of undertaking a modeling and measurement effort that would be required to demonstrate that monitoring is not needed.

Dose calculations based on effluent monitoring data are expected to be more accurate than those using assumptions based on inventory data, physical state release fractions, and emission-control factors.

\section{Surveillance Monitoring}

Beyond the stack effluent monitoring, site-specific surveillance air monitors are placed in the vicinity of diffuse emission sources on site, in particular, those associated with Buildings 292, 331, 514, and 612 and in and around the southeast quadrant of the Livermore site. These special monitors measure the concentrations of radionuclides present in the air near the sources and allow a direct determination of their environmental impact. 


\section{Estimate of Total Radioactivity Released}

Source information obtained from effluent and surveillance monitoring and the inventory process provides an estimate of the total amount of radioactivity released from LLNL, with a breakdown by individual isotopes. As discussed in Chapter 5 of this report (see especially Table 5-3 and Figure 5-2), the total for 1996 was slightly higher than in 1995, but was below the range of earlier years.

\section{Calculations of Radiological Dose}

More than 200 point sources were included in the 1996 modeling runs, representing stack emissions from all RMMAs in which radiological operations took place.

In addition to these point sources, there are several diffuse sources at both sites. Building 514 and five other Livermore-site sources external to buildings, including the RMMA at the Building 612 Hazardous Waste Management Yard, were treated as diffuse-area sources, as were six Site 300 sources, including the ground area around the firing tables where surface and subsurface contamination exists. Finally, explosives experiments were conducted at two Site 300 explosives-testing facilities-the firing tables associated with Buildings 801 and 851-during 1996, and were modeled in our customary way (see Supplement 12-3), using inventory data and scaling laws for openair explosives experiments. This section presents the main results of our calculations. For further details, especially regarding the diffuse sources at the two sites, see the LLNL NESHAPs 1996 Annual Report (Gallegos and Biermann 1997).

\section{Dose Breakdown by Facility}

Table 12-1 lists all LLNL facilities and diffuse sources having the potential to release radioactivity into the environment during 1996. For each facility or building, the table gives the number of stacks discharging radionuclides, lists the dose to a public individual caused by the dominant emission point at each facility, and identifies the types of operations occurring in the building or facility, or the nature of the diffuse source, as the case may be. Corresponding data is included for the Site 300 explosive experiments. Facilities in which no operations using radionuclides took place in 1996 or in which any radionuclides present were encapsulated or sealed for the entire year are excluded from Table 12-1.

The principal feature shown in the table is that LLNL has a fairly large number of very small sources. As shown more clearly in subsequent tables, a few sources account for nearly all of the dose to members of the public, and the total dose is quite small compared to federal standards for radiation protection of the public. 


\section{Radiological Dose Assessment}

Table 12-1. Sources of radiation dose from LLNL releases to air: stacks (on buildings containing radioactive materials management areas) and diffuse area sources. $(a, b)$

\begin{tabular}{|c|c|c|c|c|}
\hline Bldg & Facility & $\begin{array}{c}\text { Potential } \\
\text { emission } \\
\text { points }\end{array}$ & $\begin{array}{l}\text { Maximum } \\
\text { EDE(c) } \\
(\mu \mathrm{Sv} / \mathrm{y})\end{array}$ & Operations \\
\hline 151 & $\begin{array}{l}\text { Isotope Sciences; Chemistry \& } \\
\text { Materials Science } \\
\text { Environmental Services Lab }\end{array}$ & 23 & $1.9 \times 10^{-4}$ & $\begin{array}{l}\text { Application of nuclear and isotope sciences to a wide } \\
\text { range of problems; sample analysis of waste streams } \\
\text { and environmental media for radionuclide content }\end{array}$ \\
\hline 166 & Laser Isotope Separation & 1 & $0.0^{(\mathrm{d})}$ & Conversion of uranium to halides and oxides \\
\hline 175 & Laser Isotope Separation & 1 & $2.3 \times 10^{-3}$ & Cleaning and refurbishing of uranium parts \\
\hline 177 & Laser Isotope Separation & 5 & $2.8 \times 10^{-2}$ & $\begin{array}{l}\text { Sample preparation, cleaning of parts, processing } \\
\text { uranium oxide powders, liquid uranium corrosion studies }\end{array}$ \\
\hline 212 & Physics \& Space Technology & 2 & $8.0 \times 10^{-11}$ & $\begin{array}{l}\text { Physics experiments; residual contamination from } \\
\text { previous operation of rotating target neutron source (no } \\
\text { longer operating) }\end{array}$ \\
\hline 222 & Chemistry \& Materials Science & 18 & $1.1 \times 10^{-6}$ & $\begin{array}{l}\text { Chemical analyses, cleaning equipment, waste samples } \\
\text { preparation and analysis, decontamination, } \\
\text { spectroscopy, gravimetric }\end{array}$ \\
\hline 224 & Chemistry \& Materials Science & 4 & $1.0 \times 10^{-4}$ & Chemical analysis, waste collection, sample digestion \\
\hline 226 & Chemistry \& Materials Science & 2 & $1.2 \times 10^{-9}$ & Sample preparation, scintillation counting \\
\hline 231 & $\begin{array}{l}\text { Chemistry \& Materials } \\
\text { Science, Engineering, } \\
\text { Safeguards \& Security }\end{array}$ & 13 & $2.8 \times 10^{-6}$ & $\begin{array}{l}\text { Materials research and testing, spin forming, heat } \\
\text { treatment, electron-beam welding, grinding/polishing, } \\
\text { casting, microscopy, sample preparation, storage }\end{array}$ \\
\hline \multirow[t]{3}{*}{251} & Heavy Elements & & & Storage of transuranic isotopes prior to disposal \\
\hline & Seismically Hardened area & 4 & $0.0^{(d)}$ & \\
\hline & Unhardened areas & 33 & $7.7 \times 10^{-4}$ & \\
\hline 253 & Hazards Control & 12 & $7.3 \times 10^{-9}$ & Radiochemical analyses \\
\hline 254 & Hazards Control & 5 & $5.6 \times 10^{-11}$ & $\begin{array}{l}\text { Radiochemical analyses of bioassays; analytical } \\
\text { services }\end{array}$ \\
\hline 255 & Hazards Control & 2 & $1.0 \times 10^{-4}$ & Radiation standards and instrument calibration \\
\hline 281 & Chemistry \& Materials Science & 8 & $2.1 \times 10^{-8}$ & Sample preparation; wet chemistry laboratory \\
\hline 282 & Physics \& Space Technology & 1 & 0.0 & Non-operational facility with tritium contamination \\
\hline 292 & Environmental Programs & 3 & $7.3 \times 10^{-5}$ & Tritium contamination from prior operations \\
\hline
\end{tabular}


Table 12-1. Sources of radiation dose from LLNL releases to air: stacks (on buildings containing radioactive materials management areas) and diffuse area sources $(a, b)$ (continued).

\begin{tabular}{|c|c|c|c|c|}
\hline Bldg & Facility & $\begin{array}{c}\text { Potential } \\
\text { emission } \\
\text { points }\end{array}$ & $\begin{array}{l}\text { Maximum } \\
\mathrm{EDE}^{(\mathrm{c})} \\
(\mu \mathrm{Sv} / \mathrm{y})\end{array}$ & Operations \\
\hline 298 & Laser Fusion & 2 & $1.1 \times 10^{-4}$ & Laser fusion targets research and development \\
\hline 321 & Materials Fabrication & 4 & $4.2 \times 10^{-6}$ & Forming, machining, and manufacturing of uranium parts \\
\hline 322 & Mechanical Engineering & 1 & $8.0 \times 10^{-8}$ & Cleaning and plating of depleted uranium \\
\hline 327 & Mechanical Engineering & 1 & $1.3 \times 10^{-8}$ & Nondestructive ultrasonic material evaluation \\
\hline 331 & Tritium & 2 & $4.2 \times 10^{-1(d)}$ & $\begin{array}{l}\text { tritium research; decontamination and decommissioning } \\
\text { operations }\end{array}$ \\
\hline 332 & Plutonium & 7 & $0.0^{(\mathrm{d})}$ & Plutonium research \\
\hline 361 & $\begin{array}{l}\text { Biological and Biotechnology } \\
\text { Research }\end{array}$ & 15 & $1.1 \times 10^{-5}$ & $\begin{array}{l}\text { Radiolabeling; biological dosimetry; DNA sequencing, } \\
\text { hybridization, and repair; human genome; enzyme } \\
\text { assay; radioactive probes }\end{array}$ \\
\hline 362 & $\begin{array}{l}\text { Biological and Biotechnology } \\
\text { Research }\end{array}$ & 1 & $2.2 \times 10^{-7}$ & Dose preparation for animal experiments \\
\hline 363 & $\begin{array}{l}\text { Biological and Biotechnology } \\
\text { Research }\end{array}$ & 1 & $1.9 \times 10^{-5}$ & Dispensing samples \\
\hline 364 & $\begin{array}{l}\text { Biological and Biotechnology } \\
\text { Research }\end{array}$ & 2 & $6.3 \times 10^{-5}$ & DNA labeling; isolation and purification \\
\hline 365 & $\begin{array}{l}\text { Biological and Biotechnology } \\
\text { Research }\end{array}$ & 1 & $6.4 \times 10^{-12}$ & Housing research animals \\
\hline 378 & $\begin{array}{l}\text { Health and Ecological } \\
\text { Assessment }\end{array}$ & 2 & $1.5 \times 10^{-9}$ & $\begin{array}{l}\text { Chemical and radiological sample preparation for } \\
\text { environmental analyses; analysis of environmental } \\
\text { samples }\end{array}$ \\
\hline 381 & Laser Fusion & 1 & $2.7 \times 10^{-13}$ & Tritium handling for laser target research \\
\hline 391 & NOVA Laser & 1 & $3.5 \times 10^{-4}$ & Housing of high-energy laser; fusion target irradiation \\
\hline $412 W$ & $\begin{array}{l}\text { Health and Ecological } \\
\text { Assessment }\end{array}$ & 1 & $2.3 \times 10^{-12}$ & Sample preparation for measurement of $\mathrm{Ni}-59$ and $\mathrm{Ni}-63$ \\
\hline 419 & $\begin{array}{l}\text { Hazardous Waste } \\
\text { Management }\end{array}$ & 2 & $1.0 \times 10^{-3(d)}$ & Decontamination and decommissioning \\
\hline 490 & Laser Isotope Separation & 1 & $0.0^{(\mathrm{d})}$ & $\begin{array}{l}\text { U.S. Enrichment Corporation isotope separation } \\
\text { operations, including vaporization of uranium for } \\
\text { enrichment }\end{array}$ \\
\hline 491 & Laser Isotope Separation & 1 & $0.0^{(d)}$ & $\begin{array}{l}\text { U.S. Enrichment Corporation isotope separation } \\
\text { operations }\end{array}$ \\
\hline 513 & $\begin{array}{l}\text { Hazardous Waste } \\
\text { Management }\end{array}$ & 1 & $3.8 \times 10^{-7}$ & Drum repacking and sludge stabilization \\
\hline 514 & See diffuse sources below & & & \\
\hline 612 & $\begin{array}{l}\text { Hazardous Waste } \\
\text { Management }\end{array}$ & 1 & $6.3 \times 10^{-5}$ & Waste repackaging for shipment offsite \\
\hline
\end{tabular}




\section{Radiological Dose Assessment}

Table 12-1. Sources of radiation dose from LLNL releases to air: stacks (on buildings containing radioactive materials management areas) and diffuse area sources $(a, b)$ (concluded).

\begin{tabular}{|c|c|c|c|c|}
\hline Bldg & Facility & $\begin{array}{c}\text { Potential } \\
\text { emission } \\
\text { points }\end{array}$ & $\begin{array}{c}\text { Maximum } \\
\text { EDE(c) } \\
(\mu \mathrm{Sv} / \mathrm{y})\end{array}$ & Operations \\
\hline 801 & Site 300 Firing Table at 801 & -(e) & $1.8 \times 10^{-1}$ & Detonation of explosives \\
\hline \multirow[t]{2}{*}{851} & Site 300 Firing Table at 851 & -(e) & $1.5 \times 10^{-1}$ & Detonation of explosives \\
\hline & $\begin{array}{l}\text { Livermore site diffuse } \\
\text { sources }^{(f)}\end{array}$ & 6 & $\begin{array}{l}\text { See next six } \\
\text { entries below }\end{array}$ & Storage areas and contaminated ground \\
\hline 292 & Underground storage tank & 1 & $3.6 \times 10^{-6}$ & Tank leakage of tritiated water; transpired by plants \\
\hline 331 & Tritium Facility (external) & 1 & $3.1 \times 10^{-2}$ & Outdoor waste accumulation area \\
\hline 514 & $\begin{array}{l}\text { Hazardous Waste } \\
\text { Management Tank Farm }\end{array}$ & 1 & $3.0 \times 10^{-1}$ & Liquid waste processing, treatment, and storage \\
\hline 612 & $\begin{array}{l}\text { Hazardous Waste } \\
\text { Management }\end{array}$ & 1 & $2.5 \times 10^{-1}$ & Storage of low-level waste \\
\hline \multirow[t]{2}{*}{-} & $\begin{array}{l}\text { Southeast quadrant of } \\
\text { Livermore site }\end{array}$ & 1 & $9.4 \times 10^{-3}$ & Contaminated ground \\
\hline & Site 300 diffuse sources $(f)$ & 6 & $\begin{array}{l}\text { See next six } \\
\text { entries below }\end{array}$ & Contaminated ground and water \\
\hline- & Pit 7 Complex & 1 & $3.0 \times 10^{-4}$ & Contaminated ground and purge water \\
\hline 802 & Site 300 & 1 & $5.4 \times 10^{-7}$ & Contaminated ground \\
\hline 850 & Site 300 & 1 & $5.7 \times 10^{-5}$ & Contaminated ground \\
\hline 851 & Site 300 & 1 & $1.8 \times 10^{-7}$ & Contaminated ground \\
\hline- & Well 8 Spring & 1 & $1.3 \times 10^{-6}$ & Contaminated spring water \\
\hline - & All Site 300 land area & 1 & $4.1 \times 10^{-3}$ & Contaminated ground \\
\hline
\end{tabular}

a LLNL NESHAPs 1996 Annual Report (Gallegos and Biermann 1997).

b RMMAs in which no operations using radionuclides took place in 1996 or in which all radionuclides were encapsulated or sealed for the entire year are not included in this table. Table entries refer to routine operations, not unplanned releases.

c The maximum effective dose equivalent to the sitewide maximally exposed individual (SW-MEI) member of the public from a single discharge point, among all discharge points modeled for the indicated facility or building. The SW-MEI is defined in the section on Maximally Exposed Individuals and Populations.

d The effluents from the facility are monitored. Zeroes refer to monitored values below the minimum detectable concentration, as discussed in the Monitored Facilities section.

e Open air dispersal in 1996.

f Diffuse sources are described briefly in the section on specifications of source terms, and more fully in the LLNL 1996 NESHAPS Annual Report cited in footnote a. 


\section{Unplanned Releases}

The foregoing discussion, as well as all entries in Table 12-1, refer to releases occurring during the course of normal operations. Unplanned or accidental releases must be accounted for, as well, in determining the total dose to the public from LLNL activities. As noted in Chapter 2 of this report (in the subsection on "National Emission Standards for Hazardous Air Pollutants"), there was one unplanned atmospheric radionuclide release from the Livermore site in 1996, involving leakage of $1.5 \mathrm{~L}$ of oil contaminated with depleted uranium from a 55-gal drum in the Building 514 yard. The calculated dose to the SW-MEI from this event was extremely small: $4.9 \times 10^{-8} \mu \mathrm{Sv}$ $\left(4.9 \times 10^{-9} \mathrm{mrem}\right)$. There were no unplanned atmospheric releases at Site 300 in 1996.

\section{Doses to Sitewide Maximally Exposed Individuals}

The 1996 calculated EDE to the SW-MEI from Livermore-site point sources was $0.48 \mu \mathrm{Sv}$ (0.048 mrem). Emissions from the two 30-meter stacks at the LLNL Tritium Facility (Building 331) accounted for $0.45 \mu \mathrm{Sv}$ (0.045 mrem). In 1995, emissions from the Tritium Facility resulted in a modeled dose of $0.17 \mu \mathrm{Sv}(0.017 \mathrm{mrem})$. The relative increase in 1996 in emissions and dose occurred primarily as a result of glovebox decontamination and decommissioning activities. For the Livermore site, the dose calculated for the SW-MEI from diffuse emissions in 1996 was $0.45 \mu \mathrm{Sv}$ (0.045 mrem). When point and diffuse sources were combined, the total annual dose was $0.93 \mu \mathrm{Sv}(0.093 \mathrm{mrem})$, divided $52 \% / 48 \%$ between point and diffuse source emissions.

The calculated EDE to the SW-MEI at Site 300 was $0.33 \mu$ Sv (0.033) mrem from pointsource emissions. All of this EDE resulted from Building 801 and Building 851 firingtable emissions in the course of explosives experiments- $55 \%$ from the former and $45 \%$ from the latter. This is an increase over the $0.20 \mu \mathrm{Sv}(0.020 \mathrm{mrem})$ dose modeled for 1995; the larger dose resulted from an increase in the amount of depleted uranium used in experiments at the site. Table 12-2 shows the dose values attributed to firing table experiments for 1990 through 1996, correlated with the total amounts of depleted uranium and the total quantity of high explosives used in the experiments. (Only experiments that included depleted uranium are considered; most have none.) The data show that variations from year to year in these doses mainly reflect differences in the amount of depleted uranium used in the tests. For Site 300, only $0.0045 \mu \mathrm{Sv}$ (0.00045 mrem), or 1\%, was contributed by diffuse sources. Resuspension of LLNLcontributed uranium in surface soils throughout Site 300 was responsible for nearly all of this dose from diffuse sources. 


\section{Radiological Dose Assessment}

Table 12-2. Annual dose to the SW-MEI from explosives experiments on firing tables at Site 300, 1990-1996, related to the total quantity of depleted uranium used in the experiments and the total quantity of high explosives (HE) driving the detonations.

\begin{tabular}{|c|l|c|c|c|}
\hline \multirow{2}{*}{ Year } & \multicolumn{2}{|c|}{ Dose to SW-MEI } & \multirow{2}{*}{$\begin{array}{c}\text { Total depleted U used in } \\
\text { experiments } \mathbf{( k g})\end{array}$} & $\begin{array}{c}\text { Total HE used in depleted } \\
\text { U experiments }(\mathbf{k g})\end{array}$ \\
\cline { 2 - 3 }$(\boldsymbol{\mu} \mathbf{S v})$ & $(\mathbf{m r e m})$ & 272 & 112 \\
1996 & 0.33 & 0.033 & 165 & 199 \\
1995 & 0.20 & 0.020 & 230 & 134 \\
1994 & 0.49 & 0.049 & 99 & 74 \\
1993 & 0.11 & 0.011 & 151 & 360 \\
1992 & 0.21 & 0.021 & 221 & 330 \\
1991 & 0.44 & 0.044 & 340 & 170 \\
1990 & 0.57 & 0.057 & & \\
\hline
\end{tabular}

Table 12-3 lists the facilities that were primarily responsible for the LLNL dose; the contributions from all emission points at each facility have been summed. These facilities accounted for approximately $99.8 \%$ of the total EDE resulting from Livermore site operations and practically 100\% of the total EDE from Site 300 operations. The dominant radionuclide(s) are indicated for each facility. Tritium was the overall dominant radionuclide at the Livermore site, accounting for more than two-thirds of the Livermore site dose. At Site 300, practically the entire dose was due to the isotopes present in depleted uranium having atomic numbers 238, 235, and 234.

The relative significance of inhalation and ingestion is different for tritium and uranium and depends on the assumptions made about the origin of food consumed by a person receiving the dose. For the conditions we assumed when assessing individual doses, namely that milk is imported while the remainder of the food is produced locally, ingestion accounted for $81 \%$ of the dose in the case of tritium, versus $19 \%$ for inhalation. For uranium, these numbers are nearly reversed: $17 \%$ by the ingestion pathway, versus $83 \%$ via inhalation. For both uranium and tritium, external doses from air immersion and ground irradiation were negligible.

The trends in dose to the SW-MEI from emissions at the Livermore site and Site 300 over the last 7 years are shown in Figure 12-1 and Table 12-4. No diffuse emissions were reported at Site 300 for years before 1993, so comparison for total dose can only be made with the values for 1993, 1994, and 1995; in addition, diffuse source doses were not reported separately from the total dose for the Livermore site for 1990 and 1991. As noted earlier, the increased point source contribution to dose for the Livermore site for 1996 compared to 1995 is attributed to glovebox decontamination and decommissioning operations at Building 331. The increased diffuse source contribution to dose is attributed to increased treatment of legacy waste at the Building 514 Tank Farm. 
Table 12-3. Major contributors to LLNL's radiation dose via airborne emissions, 1996.

\begin{tabular}{|c|c|c|c|}
\hline \multirow{2}{*}{$\begin{array}{l}\text { Facility or } \\
\text { operation(a) }\end{array}$} & \multirow{2}{*}{$\begin{array}{c}\text { Dominant } \\
\text { radionuclide(s) }\end{array}$} & \multicolumn{2}{|c|}{ EDE at SW-MEI(b) } \\
\hline & & $\mu \mathrm{Sv} / \mathbf{y}$ & mrem/y \\
\hline \multicolumn{4}{|l|}{ Livermore site } \\
\hline B331/Tritium Facility & ${ }^{3} \mathrm{H}$ & 0.45 & 0.045 \\
\hline B612 Yard Area ${ }^{(\mathrm{c})}$ & ${ }^{3} \mathrm{H}$ & 0.25 & 0.025 \\
\hline B514/Tank Farm ${ }^{(\mathrm{c})}$ & ${ }^{238} \mathrm{U},{ }^{228} \mathrm{Th},{ }^{239} \mathrm{Pu},{ }^{137} \mathrm{Cs},{ }^{234} \mathrm{U}$ & 0.16 & 0.016 \\
\hline B331/Exterior $(\mathrm{c})$ & ${ }^{3} \mathrm{H}$ & 0.031 & 0.0031 \\
\hline B177/U-AVLIS & ${ }^{238} U,{ }^{234} U,{ }^{235} U$ & 0.028 & 0.0028 \\
\hline S.E. Quadrant & ${ }^{239} \mathrm{Pu}$ & 0.0092 & 0.00092 \\
\hline Sum of all other sources & Various & 0.0018 & 0.00018 \\
\hline Total & & $0.93^{(d)}$ & $0.093^{(d)}$ \\
\hline \multicolumn{4}{|l|}{ Site 300} \\
\hline B801/firing table & ${ }^{238} U,{ }^{234} U,{ }^{235} U$ & 0.18 & 0.018 \\
\hline B851/firing table & ${ }^{238} U,{ }^{234} U,{ }^{235} U$ & 0.15 & 0.015 \\
\hline Soil resuspension ${ }^{(\mathrm{c})}$ & ${ }^{238} U,{ }^{234} U,{ }^{235} U$ & 0.0041 & 0.00041 \\
\hline Total & & $0.33^{(d)}$ & $0.033^{(d)}$ \\
\hline
\end{tabular}

a The facilities cited here are discussed in the text of this report and in more detail in the NESHAPs annual reports.

b These doses represent the sum of all emission points from a given facility (for example, both stacks on Building 331), in contrast to the dose values in Table 12-1, which represent the dose from the single largest emission point on each facility. The sitewide maximally exposed individual (SW-MEI) member of the public is defined in the section on Maximally Exposed Individuals and Populations.

C Diffuse sources (see text).

d These Livermore site and Site 300 totals represent $0.9 \%$ and $0.3 \%$, respectively, of the federal standard.

\section{Collective Doses to Exposed Populations}

Population doses, or collective EDEs, for both LLNL sites were calculated out to a distance of $80 \mathrm{~km}$ in all directions from the site-centers using CAP88-PC. As noted earlier, CAP88-PC evaluates the four principal exposure pathways: ingestion through food and water consumption, inhalation, air immersion, and irradiation by contaminated ground surface. The collective EDE due to 1996 Livermore-site operations was 1.1 person-rem (0.011 person-Sv), of which 0.88 person-rem (0.0088 person-Sv), or $80 \%$, was from point-source emissions, and the remaining $20 \%$ from diffuse sources. This value is greater than the 1995 result of 0.59 person-rem ( 0.0059 person-Sv). The reason is the increased stack releases in 1996. Stacks release effluents at considerable speed high above the ground, allowing contaminants to be more readily transported toward population centers downwind. 


\section{Radiological Dose Assessment}

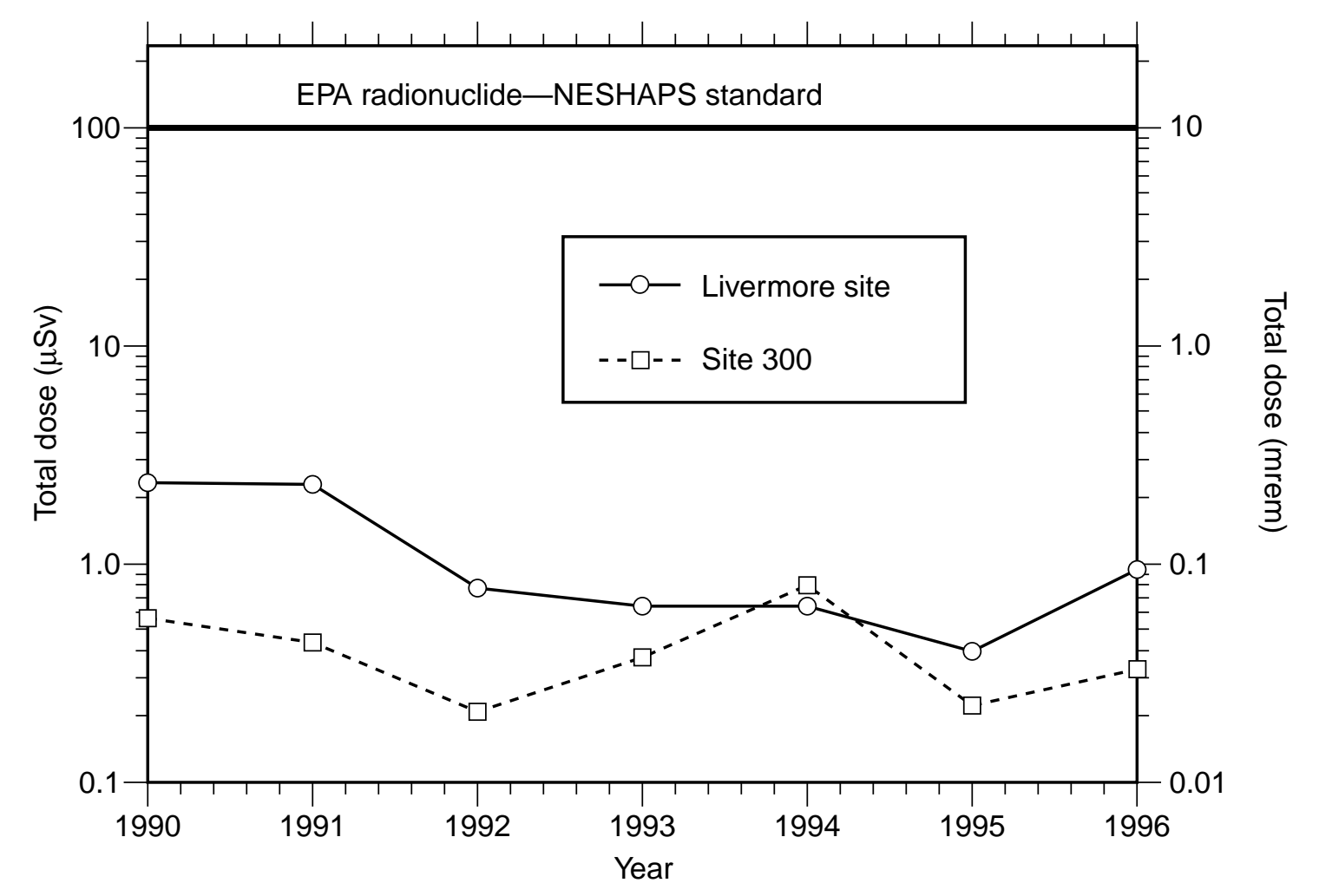

Figure 12-1. Dose to the sitewide maximally exposed individual member of the public, 1990 to 1996.

The corresponding collective EDE from Site 300 operations in 1996 was 10.0 person-rem (0.100 person-Sv), due almost entirely to explosives experiments (classified as pointsource emissions). The total collective EDE value is very similar to the 1995 value of 7.7 person-rem ( 0.77 person-Sv). These differences are the result of differences in the amounts of high explosives and depleted uranium used each year in explosives experiments.

As shown in Table 12-5, these population doses caused by LLNL operations are several thousand times smaller than ones from natural background radiation. 
Table 12-4. Doses (in $\mu \mathrm{Sv}$ ) calculated for the site-wide maximally exposed individual for the Livermore site and Site 300, 1990 to 1996.

\begin{tabular}{|c|c|c|c|}
\hline Year & Total dose & Point source dose & Diffuse source dose \\
\hline Livermore site & & & \\
1996 & 0.93 & 0.48 & 0.45 \\
1995 & 0.41 & 0.19 & 0.22 \\
1994 & 0.65 & 0.42 & 0.23 \\
1993 & 0.66 & 0.40 & 0.26 \\
1992 & 0.79 & 0.69 & 0.10 \\
1991 & 2.3 & $-^{(a)}$ & - (a) $^{(a)}$ \\
1990 & 2.4 & $-^{(a)}$ & \\
Site 300 & & & 0.0045 \\
1996 & 0.33 & 0.33 & 0.03 \\
1995 & 0.23 & 0.20 & 0.32 \\
1994 & 0.81 & 0.49 & 0.26 \\
1993 & 0.37 & 0.11 & $-_{(\mathrm{b})}^{(\mathrm{a})}$ \\
1992 & 0.21 & 0.21 & $-^{(\mathrm{b})}$ \\
1991 & 0.44 & 0.44 & (b) $^{(\mathrm{b})}$ \\
1990 & 0.57 & 0.57 & \\
\hline
\end{tabular}

a Diffuse source doses were not reported separately from the total dose for the Livermore site for 1990 and 1991.

b No diffuse emissions were reported at Site 300 for years prior to 1993.

The larger value for Site 300 compared to the Livermore site is traceable primarily to the highly conservative assumptions we make about the Site 300 explosives experiments, especially regarding the fraction of radioactive material that is aerosolized and the height and trajectory of the explosive-debris cloud. This conservative modeling methodology over-predicts the quantity of radionuclides released to air by at least a factor of five, we believe, and over-estimates the longrange dispersal of material in these experiments (see Supplement 12-3). 


\section{Radiological Dose Assessment}

Table 12-5. Comparison of background and LLNL radiation doses, 1996.

\begin{tabular}{|c|c|c|c|c|}
\hline \multirow{2}{*}{$\begin{array}{l}\text { Location/ } \\
\text { Source }\end{array}$} & \multicolumn{2}{|c|}{ Individual dose $\mathrm{e}^{(\mathrm{a})}$} & \multicolumn{2}{|c|}{ Population dose $\mathrm{e}^{(\mathrm{b})}$} \\
\hline & $(\mu \mathrm{Sv})$ & (mrem) & (person-Sv) & (person-rem) \\
\hline \multicolumn{5}{|l|}{ Livermore site sources } \\
\hline Atmospheric emissions & 0.93 & 0.093 & 0.011 & 1.1 \\
\hline \multicolumn{5}{|l|}{ Site 300 sources } \\
\hline Atmospheric emissions & 0.33 & 0.033 & 0.10 & 10 \\
\hline \multicolumn{5}{|l|}{ Other sources $^{(c)}$} \\
\hline \multicolumn{5}{|l|}{ Natural radioactivity $(\mathrm{d}, \mathrm{e})$} \\
\hline Cosmic radiation & 300 & 30 & 1,900 & 190,000 \\
\hline Terrestrial radiation & 300 & 30 & 1,900 & 190,000 \\
\hline Internal (food consumption) & 400 & 40 & 2,500 & 250,000 \\
\hline Radon & 2000 & 200 & 12,500 & $1,250,000$ \\
\hline $\begin{array}{l}\text { Medical radiation (diagnostic } \\
\text { procedures) })^{(\mathrm{e})}\end{array}$ & 530 & 53 & 3,300 & 330,000 \\
\hline Weapons test fallout $(\mathrm{e})$ & 11 & 1.1 & 68 & 6,800 \\
\hline Nuclear fuel cycle & 4 & 0.4 & 25 & 2,500 \\
\hline
\end{tabular}

a For LLNL sources, this dose represents that experienced by the sitewide maximally exposed individual member of the public.

b The population dose is the collective (combined) dose for all individuals residing within an $80-\mathrm{km}$ radius of LLNL (approximately 6.3 million people for the Livermore site and 5.2 million for Site 300), calculated with respect to distance and direction from each site.

c From National Council on Radiation Protection (NCRP 1987a and 1987b).

d These values vary with location.

e This dose is an average over the U.S. population.

\section{Summary and Conclusion}

The annual radiological dose from all emissions at the Livermore site and Site 300 in 1996 was found to be well below the applicable standards for radiation protection of the public, in particular the NESHAPs standard for DOE facilities, which limits total annual emissions of radionuclides to the ambient air to $100 \mu \mathrm{Sv} / \mathrm{y}(10 \mathrm{mrem} / \mathrm{y})$. Using EPAmandated computer models, actual LLNL meteorology, and population distributions appropriate to the two sites, the dose to the LLNL sitewide maximally exposed members of the public from 1996 operations were:

- Livermore site: $0.93 \mu \mathrm{Sv}$ (0.093 mrem) (45\% from point-source emissions, $55 \%$ from diffuse-source emissions); 
- $\quad$ Site 300: $0.33 \mu \mathrm{Sv}$ (0.033 mrem) (99\% from explosive experiments, classified as point-sources, $1 \%$ from diffuse-source emissions).

The major radionuclides accounting for the doses were tritium at the Livermore site and the three isotopes in depleted uranium $\left({ }^{238} \mathrm{U},{ }^{235} \mathrm{U}\right.$, and $\left.{ }^{234} \mathrm{U}\right)$ at Site 300.

The collective effective dose equivalent or population dose attributable to LLNL operations in 1996 was estimated to be 0.011 person-Sv (1.1 person-rem) for the Livermore site and 0.10 person-Sv (10 person-rem) for Site 300 . These doses include exposed populations of 6.3 million people for the Livermore site and 5.2 million for Site 300, living within a distance of $80 \mathrm{~km}$ from the site centers, based on 1990 census data.

Table 12-5 compares the individual and collective radiation doses from atmospheric releases at LLNL to other sources of radioactivity to which the U.S. population is exposed. The dose to the maximally exposed member of the public resulting from Livermore site and Site 300 operations is seen to be about 3000 times smaller than the doses from background radiation (see also Figure 12-2 in Supplement 12-1 below), and the population dose from LLNL operations is about 200,000 times smaller than those caused by natural radioactivity in the environment.

We conclude that the potential radiological doses from LLNL operations were well within regulatory standards and very small compared to doses normally received by these populations from natural background radiation sources, even though highly conservative assumptions were used in the determinations of LLNL doses. Thus, the maximum credible doses show that LLNL's use of radionuclides had no significant impact on public health during 1996. 


\section{Chapter 12 Supplements}

\section{Supplement 12-1: Radiation Basics}

Natural and Man-Made Radiation: By far the greatest part of radiation received by the world's population comes from natural sources-primarily cosmic rays that impinge on the earth's atmosphere from space and radionuclides naturally present in our environment, such as radioactive materials in soil and rocks. Among these terrestrial sources are carbon-14, potassium-40, rubidium-87, uranium-238, thorium-232, and radioactive elements, such as radon, that arise from decay of uranium and thorium. The source of human exposure to natural radiation can be external (from substances staying outside the body) or internal (from substances inhaled in air or ingested in food and water). Individual doses vary with location. The level of cosmic radiation increases with altitude, because there is less air overhead to act as a shield, and the earth's poles receive more cosmic radiation than the equatorial regions, because the earth's magnetic field diverts the radiation. The levels of terrestrial radiation differ from place to place around the United States and around the world, mainly owing to variations in soil and rock composition.

Adding to this pervasive natural or background radiation is man-made radiation from radionuclides used in medicine, consumer products, the production of energy, and the production of nuclear weapons. Exposure to man-made sources can be controlled more readily than exposure to most natural sources. However, nuclear explosives tested in the atmosphere in the 1950s and 1960s spread radioactivity across the surface of the globe, and the nuclear reactor accident at Chernobyl in 1986 affected a large area. At present, medical treatment is the largest common source of public exposure to manmade radiation. Individual medical doses vary enormously-someone who has never had an x-ray examination may receive zero medical dose while patients undergoing treatment for cancer may receive many thousands of times the annual average dose they would receive from natural radiation. Another source of public exposure to man-made radiation is consumer products, including luminous-dial watches, smoke detectors, airport $\mathrm{x}$-ray baggage inspection systems, and tobacco products.

Radioactivity: Generally, naturally occurring isotopes are stable, but notable exceptions include carbon-14, potassium-40, thorium-232, uranium-235, and uranium-238, which occur naturally but are radioactive. Nuclear decay divides into three main categories: alpha, beta, and gamma. Alpha decay is the spontaneous emission of an alpha particle (a bound state of two protons and two neutrons - the nucleus of a helium atom) from a nucleus containing a large number of protons (most commonly 82 or more). Beta decay is the spontaneous conversion of a neutron to a proton in the nucleus with the emission 
of an electron, and gamma decay is the spontaneous emission of high-energy photons (high-frequency electromagnetic radiation) by nuclei.

Radioisotopes decay at quite different rates; the "half-life," or length of time for half of the atoms to decay, spans a wide range from small fractions of a second to millions of years. For example, tritium (the radioactive form of hydrogen) has a 12.3-year half-life, compared to 24,131 years for plutonium-239.

Some radioisotopes decay by forming radioisotopes that in turn decay into other radioisotopes until a stable state is achieved. For example, an atom of uranium-238 can undergo alpha decay, leaving behind a daughter, thorium-234, which is also radioactive. The transformations of the decay chain continue, ending with the formation of lead-206, which is a stable isotope.

Radioactivity can be hazardous because radiation (alpha particles, beta particles, or gamma rays) can be released with great energy. This energy is capable of altering the electronic configuration of atoms and molecules, especially by stripping one or more electrons off the atoms of the irradiated material, thereby disrupting the chemical activity in living cells. If the disruption is severe enough to overwhelm the normal restorative powers of the cell, the cell may die or become permanently damaged. Cells are exposed to many naturally occurring sources of disruption, including naturally toxic chemicals in food, microbes that cause disease, high-energy radiation from outer space (cosmic rays), and heat and light (including the sun's rays, which can cause sunburn and skin cancer). Consequently, cells and living organisms have evolved the capacity to survive limited amounts of damage, including that caused by radioactivity.

Three main factors determine the radiation-induced damage that might be caused to living tissue: the number of radioactive nuclei that are present, the rate at which they give off energy, and the effectiveness of energy transfer to the host medium, i.e., how the radiation interacts with the tissue. Alpha radiation can be halted by a piece of paper and can scarcely penetrate the dead outer layers of skin. Radioisotopes that give off alpha radiation are generally not health hazards unless they get inside the body through an open wound or are ingested or inhaled. In those cases, alpha radiation can be especially damaging because its disruptive energy can be deposited within a small distance, resulting in significant energy deposition in a few cells. Beta radiation from nuclear decay typically penetrates a centimeter or two of living tissue. It therefore deposits energy over many cells, decreasing the damage to any single cell. Gamma radiation is extremely penetrating and can pass through most materials, only being significantly attenuated by thick slabs of dense materials, such as lead. 


\section{Radiological Dose Assessment}

Measurement of Radioactivity and Dose: The rate at which a nucleus decays is expressed in units of becquerels, abbreviated $\mathrm{Bq}$, where 1 becquerel is one decay per second, or alternatively in curies, $\mathrm{Ci}$, where 1 curie equals $3.7 \times 10^{10}$ (37 billion) decays per second, or $3.7 \times 10^{10} \mathrm{~Bq}$ (approximately equal to the decay rate of 1 gram of pure radium). Becquerels and curies are not measures of the effect of radiation on living tissue. This depends on the efficiency of energy deposition as the radiation traverses matter.

The amount of energy deposited in living tissue is called the "dose." The amount of radiation energy absorbed per gram of tissue is called the "absorbed dose," and is expressed in units of rads or grays (Gy), where 1 Gy equals 100 rads. Because an absorbed dose produced by alpha radiation is more damaging to living tissue than the same dose produced by beta or gamma radiation, the absorbed dose is multiplied by a quality factor to give the dose equivalent. The quality factor for alpha radiation is 20; for beta and gamma, 1 . The dose equivalent is measured in units of rem or sieverts (Sv); $1 \mathrm{~Sv}$ equals $100 \mathrm{rem}$. Also commonly used are the millirem (mrem) and the millisievert $(\mathrm{mSv})$, which are one-thousandth of a rem and sievert, respectively.

Just as one type of radiation can be more damaging than others, some parts of the body are potentially more vulnerable to radiation damage than others, so the different parts of the body are given weightings. For example, a given radiation dose from iodine-131 is more likely to cause cancer in the thyroid than in the lung. The reproductive organs are of particular concern because of the potential risk of genetic damage. Once particular organs are weighted appropriately, the dose equivalent becomes the "effective dose equivalent," also expressed in rem or sievert.

The effective dose equivalent (EDE) describes doses to individuals. When individual effective dose equivalents received by a group of people are summed, the result is called the "collective effective dose equivalent," often referred to as the "population dose," and is expressed in person-sievert or person-rem. Finally, to account for the long-term effects of radionuclides as they continue to decay and affect generations of people, we calculate the dose over many years, summing the effect over time. This is termed the "collective effective dose equivalent commitment." Most of our discussion in this chapter deals with the effective dose equivalent and the collective effective dose equivalent.

Doses from Natural and Man-Made Radioactivity: The average radiation dose from natural sources in the United States, according to the National Council on Radiation Protection and Measurement (NCRP 1987b), is $3.0 \mathrm{mSv} / \mathrm{y}$ (300 mrem/y). Approximately $0.3 \mathrm{mSv} / \mathrm{y}$ (30 mrem/y) of this exposure comes from high energy radiation from outer space (cosmic rays). Terrestrial sources, mainly radionuclides in 
rock and soil, also account for approximately $0.3 \mathrm{mSv} / \mathrm{y}$ ( $30 \mathrm{mrem} / \mathrm{y})$ of the average natural dose. Another significant part of the dose comes from radionuclides we ingest through food and drink, resulting in approximately $0.4 \mathrm{~m} \mathrm{~Sv} / \mathrm{y}$ (40 mrem/y).

Potassium-40 and carbon-14 are common radionuclides in food.

The remaining $2.0 \mathrm{mSv} / \mathrm{y}$ ( $200 \mathrm{mrem} / \mathrm{y}$ ) or $67 \%$ of the average dose from natural sources in the United States comes from radon gas. Radon is one of the major radionuclides produced by uranium decay, and our inhalation dose is dominated by radon's short-lived decay products. Figure 12-2 shows the distribution of annual radiation doses from natural and other common sources.

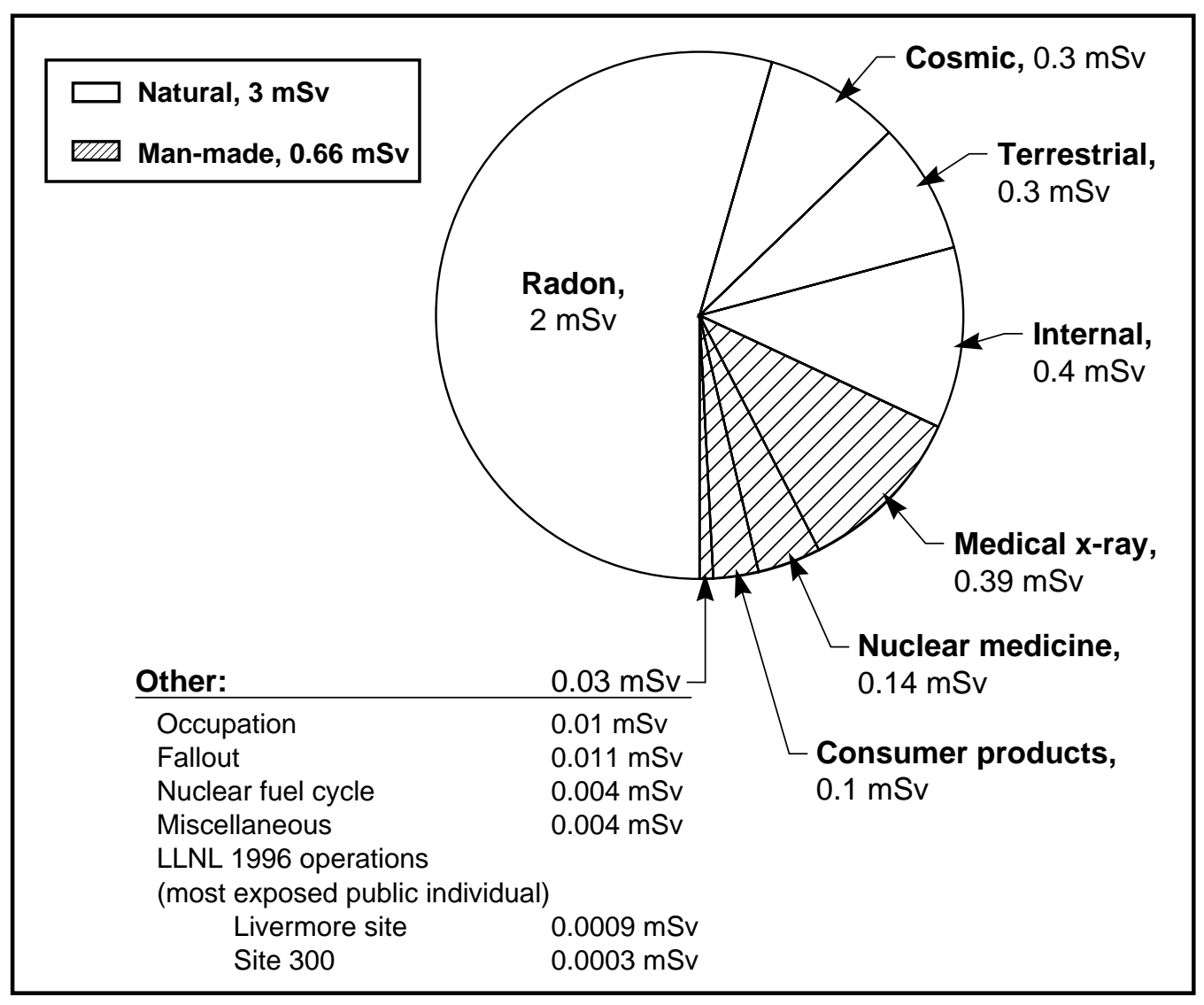

Figure 12-2. Typical annual radiation doses from natural and man-made sources (NCRP 1987b).

Radon dose varies significantly with geographic location. Levels several times higher than the average occur in some regions of the United States, while at LLNL and its environs doses as low as half the average are typical. Radon gas seeps out of the earth worldwide. Radon in water and natural gas provide additional but less important 


\section{Radiological Dose Assessment}

sources of radon in homes. The United States Environmental Protection Agency (EPA) has instituted a major program to educate the public regarding the effects of naturally occurring radon (U.S. Environmental Protection Agency and U.S. Department of Health and Human Services 1986).

The dose received by any particular individual from natural background sources depends on other lifestyle choices or conditions besides place of residency, eating habits, and occupation. For example, the dose from cosmic radiation received in a one-way airplane flight between New York and Los Angeles is about 2.5 mrem; two U.S. coast-tocoast round trip flights give about the same radiation exposure as a standard chest $\mathrm{x}$-ray.

We noted earlier that medical treatment is the largest common source of public exposure to man-made radiation, and most of it is delivered as medical x-rays. These contribute $0.39 \mathrm{mSv}$ (39 mrem) to the average whole-body annual dose in the United States, but individual doses vary enormously. For example, a typical dental x-ray series results in a skin dose (not whole body) of approximately $2.5 \mathrm{mSv}$ (250 mrem). Nuclear medicine contributes $0.14 \mathrm{mSv}(14 \mathrm{mrem})$ to the average dose, and consumer products add $0.1 \mathrm{mSv}$ (10 mrem). For a typical member of the public, radiation from medical procedures and consumer products result in a dose of approximately $0.63 \mathrm{mSv} / \mathrm{y}$ (63 mrem/y). The average dose from other man-made sources, including fallout from nuclear testing, is less than $0.03 \mathrm{mSv}$ ( $3 \mathrm{mrem}$ ). As described in this chapter, the contributions from LLNL operations to the dose of even the most affected resident are on the order of $0.1 \mathrm{mrem} / \mathrm{y}$ or less, and would not be discernible on the scale shown in Figure 12-2; LLNL's contributions are listed under "Other" in the figure.

\section{Supplement 12-2: Radiation Control Measures at LLNL}

Radioisotopes used at LLNL include uranium, transuranics, biomedical tracers, tritium, and mixed fission products. Protection of employees and the public from the uncontrolled release of radioactive materials into the environment is a primary consideration for LLNL. This effort takes several forms, as summarized here.

When an operation or facility is designed, a thorough assessment of potential radiation hazards is conducted, and radioisotope-handling procedures and work enclosures are determined for each project, depending on the isotope, the quantity being used, and the type of operations being performed. Radioisotope handling and working environments include glove boxes, exhaust hoods, and laboratory bench tops. The controls might include limiting physical access and using shielding, filters, and remote handling equipment. Exhaust paths to the atmosphere include HEPA 
(high-efficiency particulate air)-filtered stacks, stacks lacking abatement devices, roof vents, and ordinary room air ventilation channels. Facility Safety Analysis Reports and Facility Safety Procedures are written to document the need for specific measures and to spell out the requirements for maintenance, training, emergency response, and other administrative control measures.

When a facility is occupied for use, an Operational Safety Procedure (OSP) is written that specifies actions to be taken in conducting a research or development project. This procedure is reviewed by environmental analysts, industrial hygienists, and health physicists to assess the safety of the operation, its compliance with current occupational health and environmental standards, and the adequacy of proposed engineering and administrative controls. The OSP also specifies training requirements for personnel. This part of the control program enables LLNL personnel who work with radiation and radioactivity to recognize and prevent the execution of unsafe operations.

Another form of LLNL's radiation control program involves direct monitoring of the workplace environment. This includes sampling of the air and surfaces in facilities where radioactive materials are handled, and includes personal dosimetry and bioassay programs used to monitor potential worker exposure to direct radiation and radioactive isotopes. This monitoring program helps to determine the effectiveness of a facility's radiation control program as well as providing information on worker exposures.

The surveillance and effluent monitoring of radiation in air, water, soils, vegetation, and sewage, as discussed in Chapters 2 and 4 through 11 of this report, play an important role in LLNL's program to control radiation releases. These measurements can signal anomalous releases, should they occur, and directly gauge the degree of success of LLNL's radionuclide discharge control program in limiting exposures of the public.

Development of the Livermore Valley and the San Joaquin Valley has enlarged the populations and decreased the distance between sources of emissions and the residents who might be exposed. People live and work within several hundred meters of LLNL's boundaries. It is therefore increasingly important that our assessments provide the best information possible regarding the radiological impact of LLNL operations. 


\section{Radiological Dose Assessment}

\section{Supplement 12-3: Modeling Explosives Experiments at Site 300}

Modeling releases to the atmosphere from explosive tests at Site 300 requires special attention compared to conventional stack or area sources. During experiments, an explosive device containing depleted uranium is placed on an open-air firing table and detonated. A cloud of explosive decomposition products promptly forms over the firing table, and disperses as it is carried downwind. (The uranium does not contribute to the explosive energy, which is entirely of chemical origin.) In the absence of measurements of the properties of the cloud, we assume for modeling purposes that it reaches an initial height and size governed by known empirical scaling laws for detonations, in which the scaling parameter is the TNT-equivalent explosive mass. Isotopic ratios for depleted uranium are used. The masses of the three uranium isotopes with atomic weights 238, 235, and 234 (occurring in depleted uranium in the weight-percentages 99.8, 0.2, and $5 \times 10^{-4}$, respectively) are multiplied by their respective specific activities to get the total number of curies for each isotope in the cloud.

LLNL's modeling of these Site 300 explosive tests to determine the resultant off-site doses is based on the CAP88-PC code. CAP88-PC simulates each explosive experiment or shot as a low-level, steady-state (year-long), stack-type emission occurring over flat terrain with meteorological data appropriate to annual average conditions at Site 300. An alternative modeling methodology that treats these transient explosive events as short-duration puffs, and that incorporates some of the effects of the hilly terrain at Site 300, was submitted for approval in 1992 (LLNL NESHAPs Project Quarterly Progress Report, Biermann et al. 1993), but LLNL was directed by EPA to use the CAP88-PC code for these calculations despite the recognized difficulties.

Several conservative assumptions are made in the absence of detailed data on the explosive experiments. We assume that: (1) 100\% of the depleted uranium present in the experiment is completely aerosolized and dispersed as a cloud; (2) the median particle size is the CAP88-PC default value of 1 micrometer; (3) the lung clearance class for inhaled material is class $Y$. (Note: Clearance of inhaled material from the lung to the blood or to the gastrointestinal tract depends on the chemical form, e.g., $\mathrm{U}_{3} \mathrm{O}_{8}$, of the radionuclide, and is classified as $\mathrm{D}, \mathrm{W}$, and $\mathrm{Y}$, respectively, for clearance times of order days, weeks, and years.) These assumptions may produce a dose that is too high by a factor of 10 or more. We believe a more realistic release-to-air fraction for the uranium is no greater than 0.2 , but we lack sufficient documentation to use a value other than 1.0. Also, the median particle size may be much larger than $1 \mu \mathrm{m}$ and a sizable fraction of the aerosolized particles might be more properly characterized by lung clearance class $\mathrm{D}$, which produces a dose by inhalation of depleted uranium that is smaller by a factor of about 16 compared to class $Y$. 


\section{Quality Assurance}

Lucinda M. Garcia

Donald H. MacQueen

\section{Introduction}

Quality assurance (QA) is a system of activities and processes put in place to ensure that monitoring and measurement data meet user requirements and needs. Quality Control (QC) consists of procedures used to verify that prescribed standards of performance in the monitoring and measurement process are attained. QA requirements for environmental monitoring of DOE facilities are mandated by DOE Orders and guidance. DOE Order 5400.1 identifies QA requirements for radiological effluent and surveillance monitoring and specifies that a QA program consistent with DOE Order 5700.6 be established. The latter Order sets forth policy, requirements, and responsibilities for the establishment and maintenance of plans and actions that assure quality achievement in DOE programs. The DOE Environmental Regulatory Guide for Radiological Effluent Monitoring and Environmental Surveillance (U.S. Department of Energy 1991) requires that an Environmental Monitoring Plan be prepared that contains a QA section discussing the applicable elements of the American National Standards Institute/American Society of Mechanical Engineers (ANSI/ASME) NQA-1, Quality Assurance Program Requirements for Nuclear Facilities (ASME 1989).

LLNL conducted QA activities in 1996 at the Livermore site and Site 300 in accordance with a plan based on DOE Order 5700.6C. DOE Order 5700.6C prescribes a risk-based, graded approach to QA. This process promotes the selective application of QA and management controls based on the risk associated with each activity, maximizing the effectiveness and efficiency in resource use.

LLNL environmental sampling is conducted according to procedures published in Appendix A of the LLNL Environmental Monitoring Plan (Tate et al. 1995). Environmental monitoring samples are analyzed by LLNL or commercial laboratories using EPA standard methods when available. When EPA standard methods are not available, custom analytical procedures, usually developed at LLNL, are used. The radiochemical methods used by LLNL laboratories are described in procedures unique to the laboratory performing the analyses. When analyses are performed by independent contractors, LLNL requires that their laboratories be certified by the State of California for the analyses performed for LLNL. In addition, LLNL requires all analytical laboratories to maintain adequate QA programs and documentation of methods. 


\section{Quality Assurance}

\section{Quality Assurance Activities}

During 1996, 106 Nonconformance Reports (NCRs) related to environmental monitoring were written. The major sources of NCRs continued to be air particulate sampling equipment failures and analytical laboratory problems. Air particulate sampling equipment was upgraded prior to November 1996 and a significant reduction in the number of NCRs related to that network occurred after those improvements were completed. This trend is expected to continue.

Of 44 NCRs related to analytical laboratories, 26 were associated with one contract laboratory. LLNL personnel were unable to resolve all the issues with that laboratory, and as a result, much of the sample load scheduled to go to that laboratory was diverted to another laboratory pending demonstration of the implementation of effective corrective action. The remaining NCRs written for analytical laboratories resulted from minor start-up or communications problems and were easily resolved.

\section{Analytical Laboratories}

In March of 1996, LLNL and Lawrence Berkeley National Laboratory (LBNL) began using new contracts with six off-site analytical laboratories-three for nonradiological analyses of environmental samples, and three for nonradiological analyses of waste samples and radiological analyses of waste and environmental samples. The six initial off-site analytical laboratories were reduced to four as the year progressed because of decreased sample volumes at LLNL and LBNL and changes in key capabilities of two laboratories.

A joint LLNL/LBNL committee called the Analytical Contract Management Team (ACMT) was formed to manage contracts with the analytical laboratories. In addition, an analytical contract forum was created to provide an opportunity for ongoing discussion of contract issues at the worker level. Issues that arise at monthly forum meetings can be raised to the ACMT for resolution. Additionally, contract laboratory representatives are often invited to forum meetings to improve communication and resolve problems.

No analytical laboratory audits were performed in 1996. All off-site analytical laboratories will be audited in early 1997.

\section{Participation in Laboratory Intercomparison Studies}

The LLNL Chemistry and Materials Science Environmental Services Environmental Monitoring Radiation Laboratory (CES EMRL) and the Hazards Control Department's 
Analytical Laboratory (HCAL) participated in both the EPA's Environmental Monitoring Systems Laboratory (EMSL) intercomparison studies program and the DOE Environmental Monitoring Laboratory (EML) intercomparison studies program in 1996.

A review of the EMSL data indicates that 41 of 42 analyses performed by the CES EMRL fell within established acceptance control limits, and 7 of 8 sample results from HCAL fell within control limits. Review of the EML results shows that 71 of 71 results from HCAL submitted by the CES EMRL and 10 of 10 results submitted by the HCAL were within the established acceptance control limits. The HCAL also participated in four EPA Water Pollution and Water Supply intercomparison studies for metals during 1996. Seventy-two of 73 determinations of metals in LLNL sewage samples fell within established acceptance control limits.

The intercomparison study results, as well as the follow-up explanation and response for data that fell outside the acceptance control limits are presented in Volume 2, Table 13-4. Contract laboratories are also required to participate in laboratory intercomparison programs; however, permission to publish their results for comparison purposes was not granted for 1996.

The potential effects of unacceptable intercomparison study results on routine data have not been fully determined or evaluated. A joint EPD/CES performance evaluation committee has been formed to create a systematic process for evaluating laboratory performance using traceable standards. A method for evaluating the results of intercomparison studies will be developed by that committee.

\section{Duplicate Analyses}

Duplicate or collocated samples are samples collected independently, as close as possible to the same point in space and time, and are intended to be identical in all respects. Collocated samples processed and analyzed by the same organization provide intralaboratory precision information for the entire measurement system, including sample acquisition, homogeneity, handling, shipping, storage, preparation, and analysis. Collocated samples processed and analyzed by different organizations provide interlaboratory precision information for the entire measurement system (U.S. Environmental Protection Agency 1987). Collocated samples may also be used to identify errors-for example, mislabeled samples and data entry errors.

Tables 13-1 through 13-3 present data generated by collocated sample pairs, grouped by sample matrix and analyte. Samples from both the Livermore site and Site 300 are included. Tables 13-1 and 13-2 contain data pairs in which both values are above the 


\section{Quality Assurance}

detection limit and all radiological results for which a reported value was available. The tables exclude radiological values for which only a minimum detectable activity was reported. In addition, Table 13-2 excludes radiological results for which the reported value was negative. Table 13-3 contains data pairs in which either or both values are below the detection limit.

If there were more than eight data pairs with both results above the detection limit, precision and regression analyses were performed; the results are presented in

Table 13-1. Precision is measured by the percent relative standard deviation (\%RSD); see the EPA Data Quality Objectives for Remedial Response Activities: Development Process, Section 4.6 (U.S. Environmental Protection Agency 1987).

Acceptable values for \%RSD vary greatly with matrix, analyte, and analytical method; however, values above $30 \%$ are common. The results for \%RSD given in Table 13-1 are the 75th percentile of the individual precision values. Regression analysis consists of fitting a straight line to the collocated sample pairs. Good agreement is indicated when the data lie close to a line with slope equal to one and intercept equal to zero, as illustrated in Figure 13-1. Allowing for normal analytical variation, the slope of the fitted line should be between 0.7 and 1.3, and the absolute value of the intercept should be less than the detection limit. The coefficient of determination $\left(\mathrm{r}^{2}\right)$ should be $>0.8$.

If there are eight or fewer data pairs with both results above the detection limit, the ratios of the individual duplicate sample pairs are averaged; the average, minimum, and maximum ratios for selected analytes are given in Table 13-2. The mean ratio should be between 0.7 and 1.3 .

If one of the results in a pair is below the detection limit, then the other result should be less than two times the detection limit. Table 13-3 identifies the sample media and analytes for which at least one pair failed this criterion. Analytes with fewer than four pairs total are omitted from the table.

These analyses show generally good agreement between routine samples and quality assurance duplicates: approximately $84 \%$ of the pairs have a precision better than $30 \%$. Data sets not meeting our precision criteria generally fall into one of two categories. The first category, outliers, can occur because of data transcription errors, measurement errors, or real but anomalous results. Of 34 data sets reported in Table 13-1, five did not meet the criterion for acceptability because of outliers. Figure 13-2 illustrates a set of collocated pairs with two outliers. The other category of results that does not meet the criterion for acceptability consists of data sets in which there is a lot of scatter. This tends to be typical of measurements at extremely low concentrations as illustrated in Figure 13-3. 
Table 13-1. Quality assurance duplicate sampling. Summary statistics for analytes with more than eight pairs in which both results were above the detection limit.

\begin{tabular}{|c|c|c|c|c|c|c|}
\hline Medium & Analyte & $N^{(a)}$ & $\% \mathrm{RSD}^{(\mathrm{b})}$ & Slope & $r^{2(c)}$ & Intercept \\
\hline \multirow[t]{5}{*}{ Air } & Beryllium(d) & 10 & 18.4 & 0.733 & 0.41 & $2.7\left(\mathrm{pg} / \mathrm{m}^{3}\right)$ \\
\hline & Gross alpha(d) $^{(d)}$ & 96 & 73.1 & 0.125 & 0.013 & $2.80 \times 10^{-7}(\mathrm{pCi} / \mathrm{L})$ \\
\hline & Gross beta $(\mathrm{e})$ & 96 & 27.8 & 0.869 & 0.78 & $1.089 \times 10^{-6}(\mathrm{pCi} / \mathrm{L})$ \\
\hline & Plutonium-239(e) & 12 & 88.7 & 3.10 & 0.67 & $-97 \times 10^{-12}(\mathrm{pCi} / \mathrm{L})$ \\
\hline & Tritium & 41 & 22.7 & 0.983 & 0.97 & $-0.000139(\mathrm{pCi} / \mathrm{L})(\mathrm{air})$ \\
\hline \multirow{26}{*}{$\begin{array}{l}\text { Radiation dose } \\
\text { Ground water }\end{array}$} & Radiation dose & 32 & 4.43 & 0.875 & 0.89 & 1.70 (mrem) \\
\hline & Arsenic & 19 & 9.43 & 0.930 & 0.99 & $0.000022(\mathrm{mg} / \mathrm{L})$ \\
\hline & Barium & 13 & 3.72 & 1.00 & 0.87 & $0.006314(\mathrm{mg} / \mathrm{L})$ \\
\hline & Bicarbonate alkalinity $\left(\right.$ as $\left.\mathrm{CaCO}_{3}\right)$ & 9 & 11.3 & 1.24 & 0.83 & $-62.3(\mathrm{mg} / \mathrm{L})$ \\
\hline & Calcium & 9 & 2.21 & 0.958 & 1.0 & $1.18(\mathrm{mg} / \mathrm{L})$ \\
\hline & Chloride & 11 & 18.4 & 0.827 & 0.96 & $13.1(\mathrm{mg} / \mathrm{L})$ \\
\hline & Fluoride $(\mathrm{e})$ & 11 & 1.63 & 0.715 & 0.76 & $0.196(\mathrm{mg} / \mathrm{L})$ \\
\hline & Gross alpha(d) $^{(1)}$ & 25 & 63.3 & 0.557 & 0.62 & $0.476(\mathrm{pCi} / \mathrm{L})$ \\
\hline & Gross beta $(\mathrm{d})$ & 25 & 45.4 & 0.751 & 0.51 & $1.23(\mathrm{pCi} / \mathrm{L})$ \\
\hline & Magnesium & 9 & 3.82 & 0.924 & 0.99 & $0.231(\mathrm{mg} / \mathrm{L})$ \\
\hline & Nitrate $(\text { as } N)^{(e)}$ & 15 & 28.3 & 1.30 & 0.48 & $-2.11(\mathrm{mg} / \mathrm{L})$ \\
\hline & Nitrate $\left(\text { as } \mathrm{NO}_{3}\right)^{(\mathrm{e})}$ & 17 & 13.1 & 0.694 & 0.71 & $5.52(\mathrm{mg} / \mathrm{L})$ \\
\hline & Potassium & 9 & 3.82 & 0.924 & 0.99 & $0.231(\mathrm{mg} / \mathrm{L})$ \\
\hline & Radium-226(d) & 13 & & 1.14 & 0.68 & $0.135 \mathrm{pCi} / \mathrm{L})$ \\
\hline & Sodium & 10 & 3.93 & 0.985 & 0.99 & $0.291(\mathrm{mg} / \mathrm{L})$ \\
\hline & Specific conductance & 11 & 3.82 & 0.981 & 0.94 & $52.7(\mu \mathrm{mho} / \mathrm{cm})$ \\
\hline & Sulfate & 11 & 4.04 & 0.943 & 1.0 & $1.39(\mathrm{mg} / \mathrm{L})$ \\
\hline & TDS & 9 & 1.63 & 1.01 & 1.0 & $-11.5(\mathrm{mg} / \mathrm{L})$ \\
\hline & Total alkalinity (as $\left.\mathrm{CaCO}_{3}\right)$ & 9 & 11.3 & 1.24 & 0.83 & $-62.3(\mathrm{mg} / \mathrm{L})$ \\
\hline & Total hardness $\left(\right.$ as $\left.\mathrm{CaCO}_{3}\right)$ & 9 & 5.41 & 0.986 & 1.0 & $-5.99(\mathrm{mg} / \mathrm{L})$ \\
\hline & Tritium & 9 & 35.2 & 0.994 & 1.0 & $3.68(\mathrm{pCi} / \mathrm{L})$ \\
\hline & Uranium-234 and uranium-233 & 12 & 17.8 & 0.866 & 0.93 & $0.329(\mathrm{pCi} / \mathrm{L})$ \\
\hline & Uranium-235 and uranium-236(d) & 12 & 32.2 & 0.788 & 0.72 & $0.0375(\mathrm{pCi} / \mathrm{L})$ \\
\hline & Uranium-238 & 12 & 18.0 & 0.786 & 0.99 & $0.367(\mathrm{pCi} / \mathrm{L})$ \\
\hline & Vanadium & 10 & 2.48 & 0.967 & 0.99 & $0.001448(\mathrm{mg} / \mathrm{L})$ \\
\hline & $\mathrm{pH}^{(\mathrm{d})}$ & 9 & 0.975 & 0.494 & 0.52 & 3.87 Units \\
\hline
\end{tabular}




\section{Quality Assurance}

Table 13-1. Quality assurance duplicate sampling. Summary statistics for analytes with more than eight pairs in which both results were above the detection limit (concluded).

\begin{tabular}{|l|l|c|c|c|c|c|}
\hline \multicolumn{1}{|c|}{ Medium } & \multicolumn{1}{|c|}{ Analyte } & $\mathbf{N}^{(\mathbf{a})}$ & \%RSD $^{(\mathbf{b})}$ & Slope & $\mathbf{r}^{2(\mathbf{c})}$ & Intercept \\
\hline Sewer & Gross alpha $^{(\mathrm{d})}$ & 52 & 94.8 & 0.500 & 0.17 & $0.684(\mathrm{pCi} / \mathrm{L})$ \\
& Gross beta & 52 & 17.4 & 0.898 & 0.97 & $2.10(\mathrm{pCi} / \mathrm{L})$ \\
& Tritium & 52 & 65.6 & 1.00 & 1.0 & $18.2(\mathrm{pCi} / \mathrm{L})$ \\
\hline
\end{tabular}

a Number of duplicate pairs included in regression analysis.

b 75th percentile of percent relative standard deviation (\%RSD), where $\% R S D=\left(\frac{200}{\sqrt{2}}\right)\left(\frac{\left|x_{1}-x_{2}\right|}{x_{1}+x_{2}}\right)$ and $x_{1}$ and $x_{2}$ are the reported concentrations of each routine-duplicate pair.

c Coefficient of determination.

d Outside acceptable range of slope or $\mathrm{r}^{2}$ due to variability.

e Outside acceptable range of slope or $r^{2}$ due to outliers.

Table 13-2. Quality assurance duplicate sampling. Summary statistics for selected analytes with eight or fewer pairs in which both results were above the detection limit.

\begin{tabular}{|c|c|c|c|c|c|}
\hline Media & Analyte & $N^{(a)}$ & $\begin{array}{c}\text { Mean } \\
\text { ratio }\end{array}$ & $\begin{array}{l}\text { Minimum } \\
\text { ratio }\end{array}$ & $\begin{array}{l}\text { Maximum } \\
\text { ratio }\end{array}$ \\
\hline \multirow[t]{3}{*}{ Aqueous } & Gross alpha ${ }^{(b)}$ & 2 & 1.6 & 0.43 & 2.8 \\
\hline & Gross beta & 4 & 0.96 & 0.12 & 1.8 \\
\hline & Tritium & 2 & 0.95 & 0.88 & 1.0 \\
\hline \multirow[t]{3}{*}{ Ground water } & Chromium & 8 & 0.99 & 0.46 & 1.3 \\
\hline & Thorium-232(b) & 2 & 4.8 & 0.77 & 8.8 \\
\hline & Trichloroethene & 7 & 0.95 & 0.77 & 1.1 \\
\hline Rain & Tritium & 3 & 1.3 & 0.87 & 2.1 \\
\hline \multirow[t]{3}{*}{ Runoff (from rain) } & Gross alpha ${ }^{(b)}$ & 7 & 150 & 0.37 & 1000 \\
\hline & Gross beta(b) & 7 & 2.5 & 0.92 & 8.3 \\
\hline & Tritium & 3 & 1.2 & 1.1 & 1.3 \\
\hline \multirow[t]{3}{*}{ Soil } & Beryllium & 1 & 1.7 & 1.7 & 1.7 \\
\hline & Cesium-137 & 4 & 0.82 & 0.30 & 1.1 \\
\hline & Plutonium-239 & 4 & 0.92 & 0.65 & 1.2 \\
\hline Vegetation & Tritium & 6 & 0.80 & 0.15 & 1.7 \\
\hline VG & Tritium, per gram dry weight & 6 & 0.69 & 0.12 & 1.5 \\
\hline
\end{tabular}

a Number of data pairs.

b Outside acceptable range of $0.7-1.3$, for mean ratio. 
Table 13-3. Quality assurance duplicate sampling. Summary statistics for analytes with at least four pairs in which one or both results were below the detection limit.

\begin{tabular}{|l|l|c|c|c|}
\hline \multicolumn{1}{|c|}{ Medium } & \multicolumn{1}{|c|}{$\begin{array}{c}\text { Number of } \\
\text { inconsistent } \\
\text { pairs }\end{array}$} & $\begin{array}{c}\text { Number } \\
\text { of pairs }\end{array}$ & $\begin{array}{c}\text { Percent of } \\
\text { inconsistent } \\
\text { pairs }\end{array}$ \\
\hline Other water & Zinc & 1 & 4 & 25 \\
Ground water & Arsenic & 2 & 7 & 29 \\
& Chromium & 1 & 16 & 69 \\
& Copper & 1 & 27 & 4 \\
& Lead & 1 & 38 & 3 \\
& Nickel & 1 & 26 & 4 \\
& Nitrate $\left(\right.$ as $\left.\mathrm{NO}_{3}\right)$ & 1 & 5 & 20 \\
& Orthophosphate & 1 & 7 & 14 \\
Soil & Selenium & 1 & 19 & 5 \\
& Tritium & 1 & 16 & 6 \\
& Cobalt-60 & 1 & 4 & 25 \\
\hline
\end{tabular}

Low concentrations of radionuclides on particulates in air highlight this effect even more because one or two radionuclide-containing particles on an air filter can significantly impact results. Another cause of high variability is sampling and analytical methodology. Analyses of total organic carbon and total organic halides in water are particularly difficult to control. Of the 34 data sets in Table 13-1, eight show sufficient variability in results to make them fall outside of the acceptable range.

\section{Deviations and Changes to the Sampling Program}

The sections that follow summarize changes to the environmental sampling effort made during 1996, deviations from planned environmental sampling, and omissions of data expected from regularly scheduled samples.

\section{Changes to Environmental Monitoring Networks}

Changes that were made to environmental monitoring networks in 1996 are summarized in Table 13-4. 


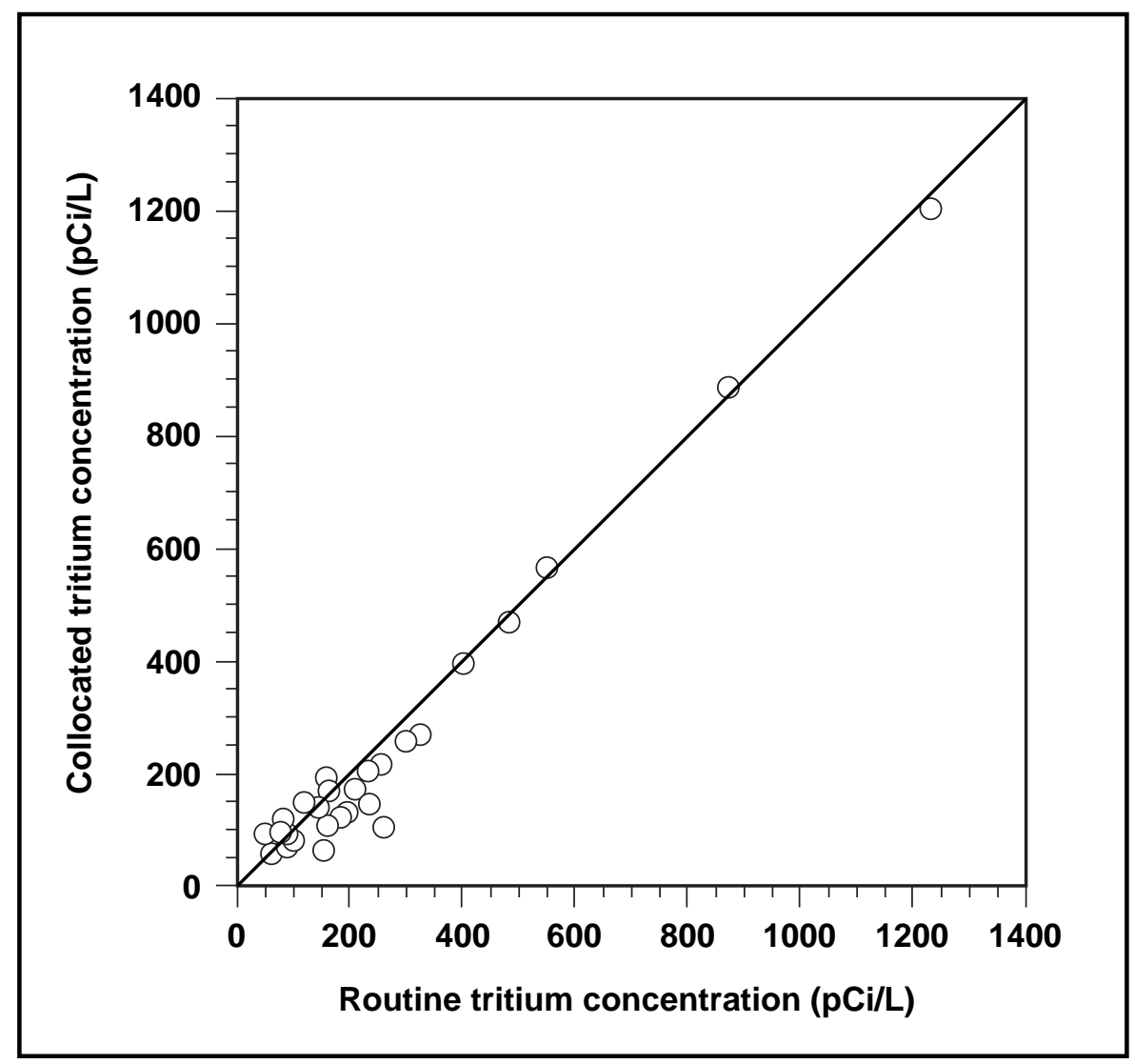

Figure 13-1. Tritium concentration in air from collocated samples. Data are shown with a line having a slope equal to one and an intercept equal to zero. The measure of acceptability is determined by how well the data fall on the line.

The LLNL environmental monitoring program uses alphanumeric location designator codes to define sampling locations. Tables 13-1 to 13-3 in Chapter 13, Volume 2 decode these sampling location designators and provide a cross-reference between current designators and those used in previous years. Changes made in 1996 are noted on those tables.

Air tritium sampling location L-HOSP was added to replace a location that was previously monitored by SNL/California. LLNL decided to continue sampling at that location to ensure complete monitoring of environmental tritium in and around the Livermore site. 


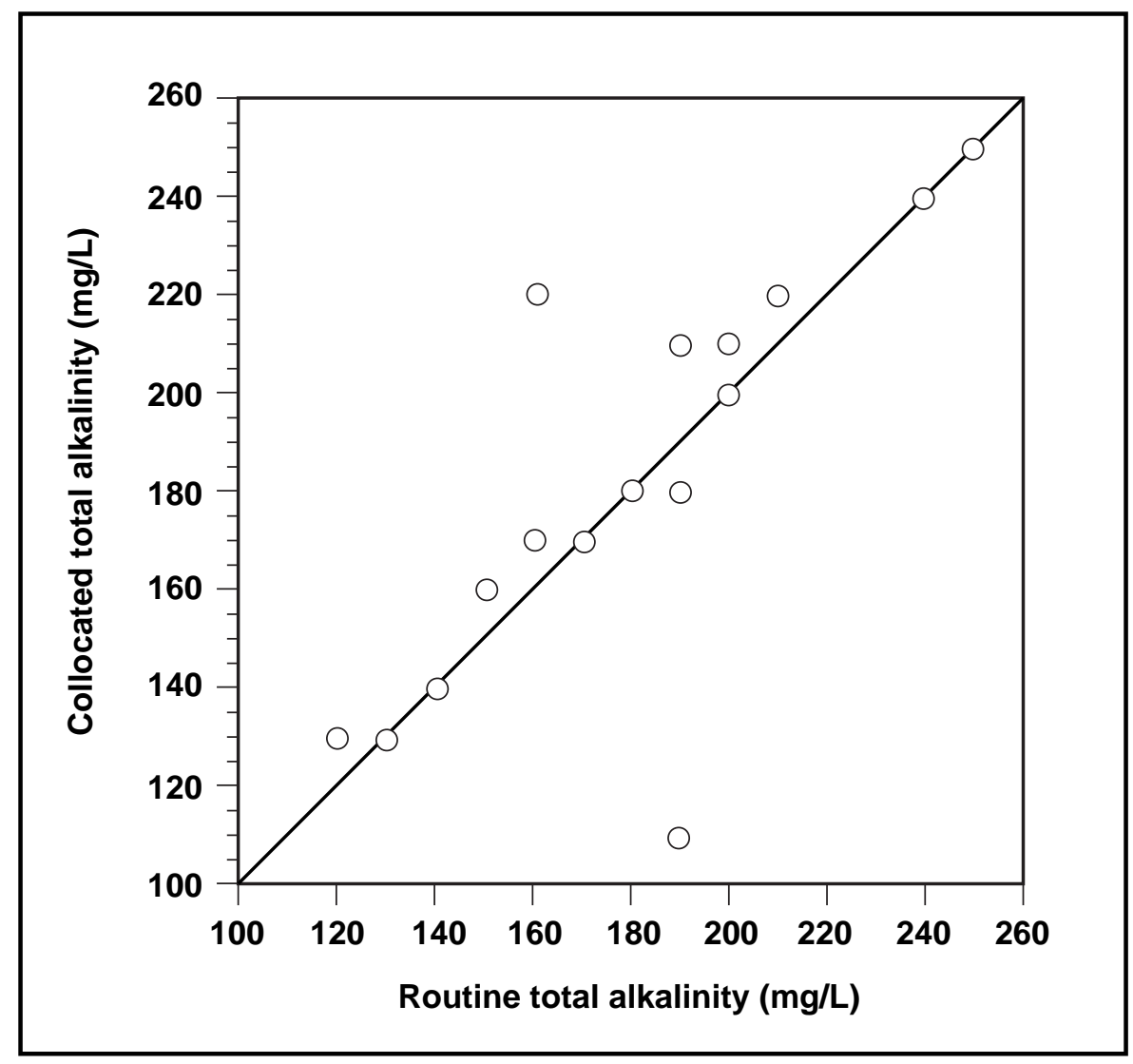

Figure 13-2. Total alkalinity concentration in ground water from collocated samples. Data are shown with a line having a slope equal to one and an intercept equal to zero. This data illustrates the case where the data fit the line well, except for two outliers.

Vegetation sampling location L-RAIL was replaced with location L-NPER in the first quarter of 1996 because of difficulty in accessing the RAIL site. Vegetation sampling began at the 3-PRIM location at Site 300 during the fourth quarter of 1996. 3-PRIM vegetation data will improve LLNL's ability to evaluate the dose to the public by complementing air sampling (to be added in 1997) at PRIMEX/Physics International, location of the sitewide maximally exposed individual (see Chapter 12).

Twelve cooling towers were removed from the monitoring network during 1996. This was done because these towers are currently operating under a waiver and have been dropped from the NPDES permit because they are being discharged to percolation pits. If discharge from these towers to surface waters resumes, they will be included in the monitoring network. 


\section{Quality Assurance}

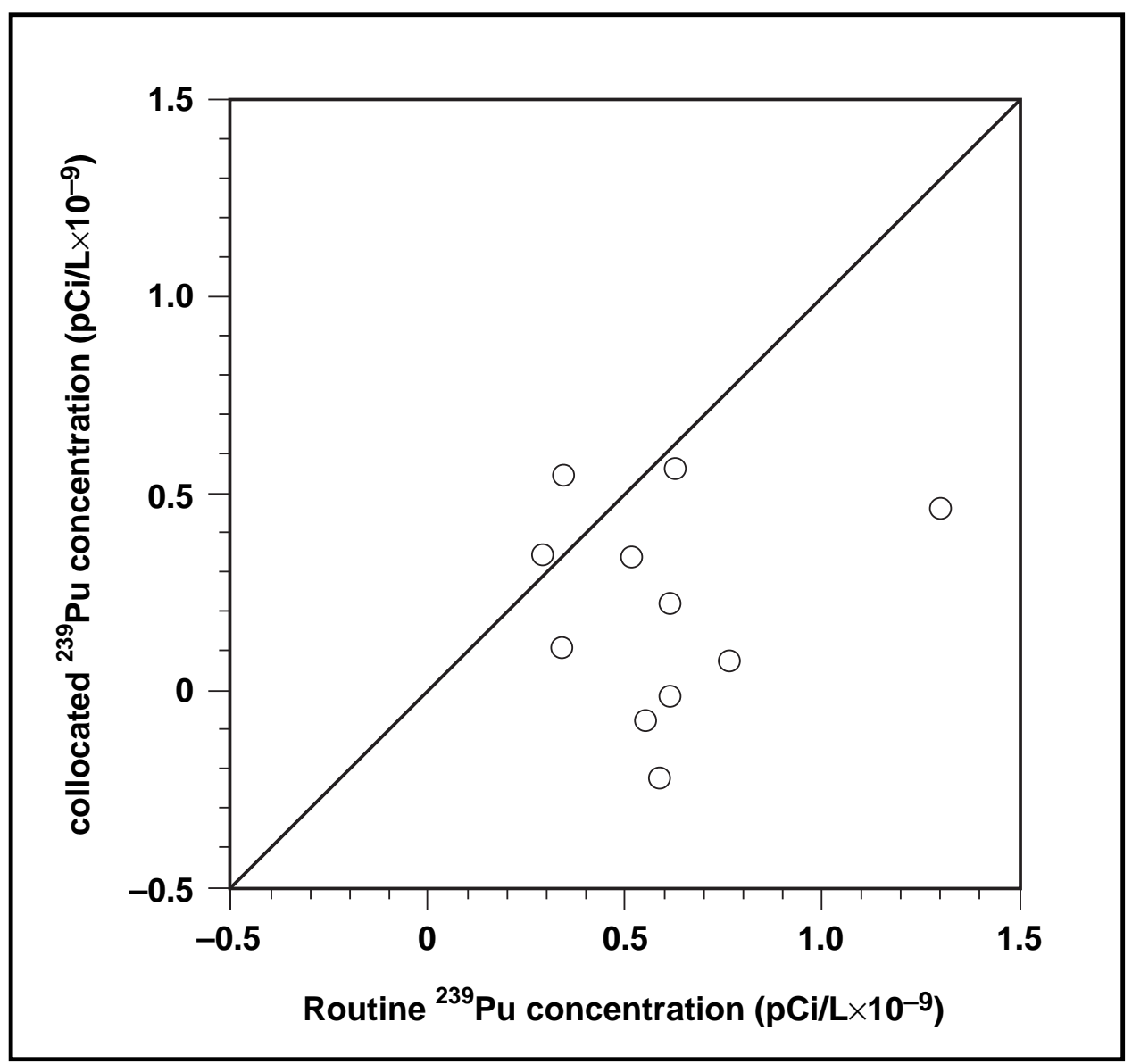

Figure 13-3. Plutonium-239 concentration on air filters from collocated samples. Data are shown with a line having a slope equal to one and an intercept equal to zero. This data illustrates the inherent variability of measurements at extremely low concentrations.

The WDR-96-248 monitoring network was created in response to monitoring requirements specified in 1996 amendments to an existing permit.

\section{Explanation of Missing Samples}

Planned samples and actual samples collected and analyzed in 1996 are summarized in Table 13-5. 
Table 13-4. Changes to environmental monitoring networks in 1996.

\begin{tabular}{|c|c|c|}
\hline Environmental medium & Livermore site & Site 300 \\
\hline Air particulate & No changes & No changes \\
\hline Air tritium & Added location L-HOSP in $11 / 96$ & Not sampled \\
\hline Soil & No changes & No changes \\
\hline Arroyo sediment & No changes & Not sampled \\
\hline Vegetation & $\begin{array}{l}\text { Dropped location L-RAIL prior to } \\
\text { the beginning of } 1996 \text { and } \\
\text { replaced it with L-NPER }\end{array}$ & $\begin{array}{l}\text { Added location 3-PRIM in fourth } \\
\text { quarter of } 1996\end{array}$ \\
\hline & $\begin{array}{l}\text { Added locations PIN1 and PIN2 } \\
\text { in the 4th quarter. }\end{array}$ & \\
\hline Wine & No changes & Not sampled \\
\hline Rain & No changes & No changes \\
\hline Storm water runoff & No changes & $\begin{array}{l}\text { Renamed 3-CARN to 3-CARW } \\
\text { during } 1996\end{array}$ \\
\hline Drainage Retention Basin & No changes & Not applicable \\
\hline Other surface water & No changes & No changes \\
\hline Ground water & No changes & WDR 96-248 changes \\
\hline Cooling towers & Not sampled & $\begin{array}{l}\text { Dropped } 12 \text { towers prior to the } \\
\text { beginning of } 1996\end{array}$ \\
\hline Sewage & No changes & Now sampling under WDR 96-248 \\
\hline Thermoluminescent dosimeters & No changes & No changes \\
\hline Process wastewater & Not sampled & $\begin{array}{l}\text { Added new monitoring network } \\
\text { during } 1996 \text { (WDR 96-248) }\end{array}$ \\
\hline
\end{tabular}

Loss of samples for the air particulate network was caused by a number of factors: tripped ground fault interrupt (GFI) circuits (33\%), motor problems (30\%), flow out of acceptable range (17\%), movement of the QC duplicate sampler at the incorrect time $(7 \%)$, and access or power problems (6\%). Lost samples for the air tritium network were due to motor problems (25\%), broken flasks (17\%), tripped GFI circuits (17\%), flow out of acceptable range (8\%), and undetermined causes (33\%).

Drainage Retention Basin field measurements were missed because of equipment failure or workload and scheduling problems. Field measurements are less important than sampling results for this medium, so the low value of completeness is not a major concern. The lost sample for the Drainage Retention Basin was a QC duplicate that was inadvertently omitted. 


\section{Quality Assurance}

Table 13-5. Sampling completeness in 1996, Livermore site and Site 300.

\begin{tabular}{|c|c|c|c|}
\hline Environmental medium & $\begin{array}{l}\text { Number of } \\
\text { samples } \\
\text { planned }\end{array}$ & $\begin{array}{c}\text { Number of } \\
\text { samples analyzed }\end{array}$ & $\begin{array}{l}\text { Completeness } \\
\text { (percent) }\end{array}$ \\
\hline \multicolumn{4}{|l|}{ Air particulate } \\
\hline Gross alpha/beta & 1421 & 1378 & 97.0 \\
\hline Plutonium & 264 & 264 & 100 \\
\hline Gamma & 24 & 24 & 100 \\
\hline Uranium & 84 & 84 & 100 \\
\hline Beryllium & 228 & 228 & 100 \\
\hline Air tritium & 475 & 463 & 97.5 \\
\hline \multicolumn{4}{|l|}{ Soil } \\
\hline Livermore & 46 & 46 & 100 \\
\hline Site 300 & 30 & 30 & 100 \\
\hline Arroyo sediment (Livermore only) & 54 & 42 & 77.8 \\
\hline \multicolumn{4}{|l|}{ Vegetation } \\
\hline Livermore & 60 & 60 & 100 \\
\hline Site 300 & 29 & 29 & 100 \\
\hline Wine & 22 & 22 & 100 \\
\hline \multicolumn{4}{|l|}{ Rain } \\
\hline Livermore & 80 & 80 & 100 \\
\hline Site 300 & 7 & 0 & 0 \\
\hline \multicolumn{4}{|l|}{ Storm water runoff } \\
\hline Livermore & 490 & 434 & 88.6 \\
\hline Site 300 & 240 & 115 & 47.9 \\
\hline \multicolumn{4}{|l|}{ Drainage Retention Basin } \\
\hline Field measurements & 416 & 320 & 76.9 \\
\hline Samples & 107 & 106 & 99.1 \\
\hline Other surface water (Livermore only) & 70 & 70 & 100 \\
\hline \multicolumn{4}{|l|}{ Ground water } \\
\hline Livermore & 422 & 422 & 100 \\
\hline Site 300 & 2250 & 2250 & 100 \\
\hline Sewage & 656 & 649 & 98.9 \\
\hline \multicolumn{4}{|l|}{ Thermoluminescent dosimeters } \\
\hline Livermore & 172 & 170 & 98.8 \\
\hline Site 300 & 72 & 63 & 87.5 \\
\hline Cooling towers (Site 300 only) & 34 & 34 & 100 \\
\hline
\end{tabular}


The primary cause of sample loss for storm water runoff sampling, both at Livermore and at Site 300, was insufficient flow. One Livermore sampling did not have adequate flow for sampling during three of the four storms sampled. At Site 300, four of seven locations did not exhibit sufficient flow during the first storm sampled, one of seven was not flowing during the second storm, five of seven were not flowing during the third storm, and five of seven were not flowing during the fourth storm. In addition, one Livermore and two Site 300 runoff sample bottles were found to be broken upon receipt at the analytical laboratory.

No Site 300 rain samples were collected during 1996. Site 300 personnel are supposed to collect composite samples that are picked up monthly by environmental monitoring personnel. Due to communication and scheduling problems, the samples were neither collected nor picked up, and the problem was not discovered until after the end of the rainy season. Collection of rain samples at Site 300 will resume in 1997.

Sewer sample losses were caused by equipment problems (57\%), over-chlorination of samples (29\%), and sampling technologist error (14\%).

Thermoluminescent dosimeters were lost when they were destroyed by vandals or eaten by cows. Because the majority of these samples are located off site, it is difficult to protect them from people or animals. Unfortunately, these dosimeters have proven to be particularly appetizing to cows.

\section{Statistical Methods}

Statistical methods used in this report have been implemented pursuant to the Environmental Monitoring Plan (Tate et al. 1995). These methods reduce the large volumes of monitoring data to summary concentration estimates that are suitable for both temporal and spatial comparisons. Attention is given to estimating accuracy, bias, and precision of all data.

Data review and analyses are conducted in accordance with the Environmental Monitoring Plan and the Environmental Monitoring Section's Data Analysis Procedure. These documents contain detailed information regarding the acceptability of data and the procedures that are followed for the identification, notification, and correction of suspect data. 


\section{Quality Assurance}

\section{Radiological Data}

The precision of radiological analytical results is displayed in the Volume 2 data tables as the $2 \sigma$ counting error. The counting errors are not used in any summary statistic calculations. By convention, any radiological result exhibiting a $2 \sigma$ counting error greater than or equal to $100 \%$ is considered to be indistinguishable from zero. The reported concentration is derived from the number of sample counts minus the number of background counts. A sample with a low or zero concentration may therefore be reported to have a negative value; such results are reported in the tables and used in the calculation of summary statistics and statistical comparisons. Some analytical laboratory reports provide a minimum detectable activity rather than a reported value when the radiological result is below the detection criterion. In this case, the result is presented in the tables with a less-than symbol $(<)$ to indicate its status.

\section{Nonradiological Data}

Nonradiological data that are reported as being below the analytical detection limit also are displayed in the tables with a less-than symbol. The actual detection limit values are used in the calculation of summary statistics as explained below.

\section{Statistical Comparisons}

Standard comparison techniques (such as regression, t-tests, and analysis of variance) have been used where appropriate to determine the statistical significance of trends or differences between means. All such tests of significance have been performed at the 0.05 level. When such a comparison is made, it is explicitly stated in the text as being "statistically significant" or "not statistically significant." Other uses of the word "significant" in the text do not imply that statistical tests have been performed. These uses instead relate to the concept of practical significance and are based on professional judgment.

\section{Summary Statistics}

Determinations of measures of central tendency and associated measures of dispersion are calculated according to the Environmental Monitoring Plan (Tate et al. 1995). For data sets not containing values below the detection criterion, the measures of central tendency and dispersion are the median and interquartile range (IQR). The IQR is the range that encompasses the middle $50 \%$ of the data set. Radiological data sets that include values less than zero may have an IQR greater than the median.

For data sets with one or more, but fewer than one half, values below the detection criterion, the measure of central tendency is the median. If the values of the detection limits and the number of values below the detection limit permit (determined on a caseby-case basis), dispersion is reported as the IQR. Otherwise, no measure of dispersion 
is reported. Statistics are calculated using the reported detection limit value for nonradiological data or the reported value for radiological data.

For data sets with one half or more of the values below the detection criterion, the central tendency is reported as less than the median value. Dispersion is not reported.

\section{Radiation Units}

Data for 1995 have been reported in Système Internationale (SI) units to conform with standard scientific practices and federal law. Values in the text are reported in becquerels (Bq) and millisieverts (mSv); equivalent values in picocuries (pCi) and millirems (mrem) are given in parentheses. 



\section{Appendix A 1996 EPD Publications}

Abri, M. (1996), Interim Status Modifications for Hazardous Waste Treatment and Storage Facilities, Livermore Site, Vols. I-III, Lawrence Livermore National Laboratory, Livermore, CA (UCRL-AR-121025).

Abri, M. (1996), Interim Status Modifications for Hazardous Waste Treatment and Storage Facilities, Livermore Site, Vols. I-IV, Lawrence Livermore National Laboratory, Livermore, CA (UCRL-AR-123728-96).

Abri, M. (1996), Interim Status Modifications for Hazardous Waste Treatment and Storage Facilities, Part A, Livermore Site, Lawrence Livermore National Laboratory, Livermore, CA (UCRL-AR-123728-96a).

Abri, M. (1996), Part A Permit Application for Hazardous Waste Treatment and Storage Facilities, Livermore Site, Lawrence Livermore National Laboratory, Livermore, CA (UCAR-10275-93a Rev. 1).

Adamson, M. G., and P. J. Densley (1996), Expedited Technology Demonstration Project Baseline Revision 3.0, Lawrence Livermore National Laboratory, Livermore, CA (UCRL-ID-125487).

Allenby, B. (1996), Industrial Ecology, Lawrence Livermore National Laboratory, Livermore, CA (UCRL-LR-124625).

Allenby, B. R., M. A. Gonzales, and E. Raber (1996), Implementing Industrial Ecology and Design for Environment at a National Laboratory, Lawrence Livermore National Laboratory, Livermore, CA (UCRL-JC-123020).

Allenby, B. R., and J. Richardson (1996), Implementing Industrial Ecology and Design for Environment at Lawrence Livermore National Laboratory, Part II, Lawrence Livermore National Laboratory, Livermore, CA (UCRL-JC-123020 Rev. 1).

Allenby, B. R., and J. Richardson (1996), Implementing Industrial Ecology and Design for Environment at Lawrence Livermore Laboratory: Part II, Lawrence Livermore National Laboratory, Livermore, CA (UCRL-JC-124633). 
Bainer, B., S. Bahowick, R. Blake, L. Berg, K. Folks, A. Happel, F. Hoffman, G. Howard, G. Kumamoto, M. Maley, C. Noyes, M. Ridley, S. Shukla, T. Vogele, and A. Watts (1996), LLNL Ground Water Project, 1995 Annual Report, Lawrence Livermore National Laboratory, Livermore, CA (UCRL-AR-122596).

Barrett, D. P. (1996), Onsite Hazardous Materials Packaging and Transportation Safety Manual, Lawrence Livermore National Laboratory, Livermore, CA (UCRL-MA-108269 Rev. 1).

Bishop, D. (1996), Site Characterization of the Gasoline Spill at Lawrence Livermore National Laboratory, Lawrence Livermore National Laboratory, Livermore, CA (UCRL-AR-118089).

Brandstetter, E. R., D. C. Littlefield, and M. Villegas (1996), Post-Rehabilitation Flow Monitoring and Analysis of the Sanitary Sewer System at Lawrence Livermore National Laboratory, Lawrence Livermore National Laboratory, Livermore, CA (UCRL-ID-122594).

Brigdon, S. (1996), Retention-Tank System: A Unique Operating Practice for Managing Complex Waste Streams at Research and Development Facilities, Lawrence Livermore National Laboratory, Livermore, CA (UCRL-JC-122997).

Brigdon, S. (1996), Wastewater Discharge Permit Application 1996-1997, Lawrence Livermore National Laboratory, Livermore, CA (UCRL-AR-106905-96).

Brown, R. A. (1996), LLNL Experimental Test Site 300 Compliance Monitoring Program for HE Process Area Surface Impoundments, Lawrence Livermore National Laboratory, Livermore, CA (UCRL-AR-125915-96-3).

Brumburgh, G., R. W. Myers, and J. E. Neuman (1996), Preliminary Safety Analysis Report for Phase $3 A$ of the Decontamination and Waste Treatment Facility, Lawrence Livermore National Laboratory, Livermore, CA (UCRL-AR-124341DR).

Brumburgh, G., R. W. Myers, and J. E. Neuman (1996), Preliminary Safety Analysis Report for Phase $3 A$ of the Decontamination and Waste Treatment Facility, Lawrence Livermore National Laboratory, Livermore, CA (UCRL-AR-124341).

Campbell, B. (1996), Spill Prevention Central and Countermeasure (SPCC) Plan, Livermore Site, Lawrence Livermore National Laboratory, Livermore, CA (UCRL-MA-105699 Rev. 1). 


\section{Appendix A. 1996 EPD Publications}

Campbell, B. (1996), Spill Prevention Central and Countermeasure (SPCC) Plan, Site, 300, Lawrence Livermore National Laboratory, Livermore, CA (UCRL-MA-105700 Rev. 1).

Cantwell, E., J. Celeste, and D. Dobie (1996), Strategy for Complying with SB14 Hazardous Waste Source Reduction and Management Review Act of 1984-Livermore Site, Lawrence Livermore National Laboratory, Livermore, CA (UCRL-AR-122184).

Chase, D. (1996), Contingency Plan for the Building 611 Anti-Freeze Recycling Unit, Lawrence Livermore National Laboratory, Livermore, CA (UCRL-AR-124323).

Chase, D. (1996), Contingency Plan for Waste Accumulation Areas, Lawrence Livermore National Laboratory, Livermore, CA (UCRL-AR-110233-96).

Chase, D. M., and S. Mancieri (1996), Contingency Plan for Hazardous and Mixed Waste Retention Tank Systems, Lawrence Livermore National Laboratory, Livermore, CA (UCRL-AR-119569 Rev. 1).

Christofferson, E., and D. M. MacQueen (1996), LLNL Experimental Test Site 300 Compliance Monitoring Program for RCRA-Closed Landfill Pits 1 and 7, Lawrence Livermore National Laboratory, Livermore, CA (UCAR-10191-96-3).

Coleman, S., and D. Graser (1996), Guidelines for Retention Tank Systems, Lawrence Livermore National Laboratory, Livermore, CA (UCRL-AR-115851 Rev. 1).

Dibley, V., and R. Depue (1996), LLNL Livermore Site and Site 300 Environmental Restoration Project Standard Operating Procedures (SOPS), Lawrence Livermore National Laboratory, Livermore, CA (UCRL-MA-109115 Rev. 2).

Dobie, D., M. Gonzales, J. Celeste, and B. Cantwell (1996), Strategy for Complying with SB14 Hazardous Waste Source Reduction and Management Review Act of 1984Site 300, Lawrence Livermore National Laboratory, Livermore, CA (UCRL-AR-122185).

Eagan, E., K. Otsuki, T. Kato, and M. Taffet (1996), Environmental and Exposure Assessment for Site 300 Explosives Waste Treatment Facility, Lawrence Livermore National Laboratory, Livermore, CA (UCRL-AR-113869 Rev. 2).

Eagan, E., K. Otsuki, T. Kato, M. Taffet, F. Gouveia, R. Berger, and L. Green (1996), Environmental and Exposure Assessment for Site 300 Explosives Waste Treatment Facility, Lawrence Livermore National Laboratory, Livermore, CA (UCRL-AR-113869 Rev. 1). 
Fields, B. C. (1996), Measurements of Environmental Radon Using TLDs Revisited, Lawrence Livermore National Laboratory, Livermore, CA (UCRL-JC-122250 Abs, Rev. 1).

Finley, D., and D. Wheatcraft (1996), Turning Inspection Regulations into Training Tools, Lawrence Livermore National Laboratory, Livermore, CA (UCRL-JC-122615).

Gagner, S. D., and A. B. Crockett (1996), Compositing and Sub Sampling of Media Related to Waste Management Activities, Lawrence Livermore National Laboratory, Livermore, CA (UCRL-JC-124193).

Gallegos, G. M., R. J. Harrach, A. H. Biermann, P. J. Tate, F. J. Gouveia, B. C. Fields, and K. A. Surano (1996), LLNL NESHAPs Project, 1995 Annual Report, Lawrence Livermore National Laboratory, Livermore, CA (UCRL-ID-113867-96).

Gouveia, F., G Laguna, and D. Lager (1996), LLNL Meteorological Data on the World Wide Web, Lawrence Livermore National Laboratory, Livermore, CA (UCRL-MI-125279).

Graham, S. (1996), Environmental Restoration at LLNL, Lawrence Livermore National Laboratory, Livermore, CA (UCRL-MI-125484).

Haendler, B., A. Andrade, and R. Fischer (1996), Waste Certification Program Sampling and Analysis Plan, Lawrence Livermore National Laboratory, Livermore, CA (UCRL-AR-121797 Rev. 1).

Hainebach, K. (1996), Transuranic Waste Characterization Quality Assurance Project Plan, Lawrence Livermore National Laboratory, Livermore, CA (UCRL-AR-119486).

Happel, A. M, W. W. McNab, J. K. MacDonald, and C. M. Noyes (1996), Application for Containment Zone for the Livermore Site Hydrocarbon Impacted Zone at Treatment Facility F, Lawrence Livermore National Laboratory, Livermore, CA (UCRL-AR-123385).

Happel, A. M. (1996), Evaluation of Actinide Biosorption by Microorganisms, Lawrence Livermore National Laboratory, Livermore, CA (UCRL-ID-124223).

Happel, A. M., W. W. McNab, J. K. MacDonald, and C. M. Noyes (1996), LLNL Ground Water Project Draft Comprehensive Site Evaluation and Proposed Containment Plan for the LLNL Gasoline Contaminated Zone at Treatment Facility F, Lawrence Livermore National Laboratory, Livermore, CA (UCRL-AR-123385DR). 
Happel, A., E. Beckenbach, L. Savalin, H. Temko, R. Rempel, B. Dooher, and D. Rice (1996), Analysis of the Distribution of Dissolved Benzene Plumes and Methyl Tertiary Butyl Ether (MTBE) Plumes in Ground Water Leaking Underground Fuel Tank (LUFT) Sites, Lawrence Livermore National Laboratory, Livermore, CA (UCRL-JC-125633).

Happel, A., E. Beckenbach, R. Rempel, and D. Rice (1996), Evaluation of MTBE Analytical Field Results and Analysis of MTBE Plumes at California LUFT Sites, Lawrence Livermore National Laboratory, Livermore, CA (UCRL-JC-125178 Abs).

Harrach, R. J., R. A. Failor, G. M. Gallegos, P. J. Tate, E. Christofferson, E. R. Brandstetter, J. M. Larson, A. H. Biermann, R. A. Brown, B. C. Fields, L M. Garcia, and A. R. Grayson (1996), Environmental Report 1995, Lawrence Livermore National Laboratory, Livermore, CA (UCRL-50027-95, Vols. I and II).

Harrison, A. R., B. Cantwell, J. Celeste, D. Dobie, M. Meltzer, and K. Wilson (1996), Pollution Prevention Group Home Page, Lawrence Livermore National Laboratory, Livermore, CA (UCRL-MI-123269).

Heffner, B. (1996), Environmental Community Letter, Lawrence Livermore National Laboratory, Livermore, CA (UCRL-AR-112812-96-1).

Heffner, B. (1996), Site 300 Fact Sheet Number 3, January 1996, Lawrence Livermore National Laboratory, Livermore, CA (UCRL-TB-110590-96-1).

Heffner, B., and T. Berry (1996), Environmental Community Letter, Lawrence Livermore National Laboratory, Livermore, CA (UCRL- AR-112812-96-2).

Hoffman, F. (1996), New Conceptual Model and Remediation Strategy for VOCs in Low Organic Carbon Unconsolidated Sediments, Lawrence Livermore National Laboratory, Livermore, CA (UCRL-JC-125199).

Hoppes, W. G., and K. A. Surano (1996), Environmental Monitoring and Modeling Expert Meeting and Workshop, Lawrence Livermore National Laboratory, Livermore, CA (UCRL-MI-124836).

Hoyt, D. (1996), Building 233 Facility Contingency Plan, Lawrence Livermore National Laboratory, Livermore, CA (UCRL-AR-113859 Rev. 3).

Hoyt, D. (1996), Building 514 Facility Contingency Plan, Lawrence Livermore National Laboratory, Livermore, CA (UCRL-AR-109117 Rev. 4). 
Hoyt, D. (1996), Building 612 Facility Contingency Plan, Lawrence Livermore National Laboratory, Livermore, CA (UCRL-AR-109118 Rev. 4).

Hoyt, D. (1996), Building 693 Facility Contingency Plan, Lawrence Livermore National Laboratory, Livermore, CA (UCRL-AR-109119 Rev. 4).

Hoyt, D. (1996), Building 883 Container Storage Area Contingency Plan, Lawrence Livermore National Laboratory, Livermore, CA (UCRL-AR-119738 Rev. 1).

Hoyt, D. (1996), Waste Matters, Lawrence Livermore National Laboratory, Livermore, CA (UCRL-AR-110229-96-1).

Hoyt, D. (1996), Waste Matters, Lawrence Livermore National Laboratory, Livermore, CA (UCRL-AR-110229-96-2).

Hoyt, D. (1996), Waste Matters, Lawrence Livermore National Laboratory, Livermore, CA (UCRL-AR-110229-96-3).

Hunt, C. E. (1996), Classification and Storage of Wastewater from Floor Finish Removal Operations, Lawrence Livermore National Laboratory, Livermore, CA (UCRL-LR-124062).

Isherwood, W. F., G. D. Rambach, and J. F. Cooper (1996), Sustainable Energy for the Arctic, Lawrence Livermore National Laboratory, Livermore, CA (UCRL-JC-125603 Abs).

Johnson, V. M., and L. L. Rogers (1996), Poor Man's Parallelism in a Design Optimization Problem, Lawrence Livermore National Laboratory, Livermore, CA (UCRL-ID-123639).

Kato, T. T., G. D. Warrick, and B. R. Rose (1996), Spatial Ecology of Blunt-Nosed Leopard Lizards, Lawrence Livermore National Laboratory, Livermore, CA (UCRL-JC-124613).

Kato, T. T., G. D. Warrick, and B. R. Rose (1996), Home Range and Habitat Use of the Blunt-Nosed Leopard Lizard, Lawrence Livermore National Laboratory, Livermore, CA (UCRL-MI-123689).

Knight, D. (1996), Contingency Plan for Site 300-Waste Accumulation Area 883 North, Lawrence Livermore National Laboratory, Livermore, CA (UCRL-AR-123749). 


\section{Appendix A. 1996 EPD Publications}

Knight, D. (1996), Contingency Plan for Site 300-Waste Accumulation Area M71, Lawrence Livermore National Laboratory, Livermore, CA (UCRL-AR-123750).

Lamarre, A. (1996), Management Summary Environmental Restoration at Lawrence Livermore National Laboratory, Livermore Site, Livermore, California, Lawrence Livermore National Laboratory, Livermore, CA (UCRL-AR-122289 Rev. 1).

Lamarre, A. (1996), Management Summary Environmental Restoration at Lawrence Livermore National Laboratory, Livermore Site, Livermore, California, Lawrence Livermore National Laboratory, Livermore, CA (UCRL-AR-122289 Rev. 2).

Lamarre, A. L., L. L. Berg, E. N. Folsom, M. D. Dresen, and R. W. Bainer (1996), Draft Explanation of Significant Differences for Treatment Facilities A and B, Lawrence Livermore National Laboratory, Livermore Site, Lawrence Livermore National Laboratory, Livermore, CA (UCRL-AR-125555DR).

Landgraf, R., and L. Rueth (1996), Draft Final Proposed Plan for Remediation of the Lawrence Livermore National Laboratory Site 300 General Services Plan, Lawrence Livermore National Laboratory, Livermore, CA (UCRL-AR-122585DR Rev. 1).

Landgraf, R., and L Rueth (1996), The United States Department of Energy Presents the Proposed Plan for Remediation of the Lawrence Livermore National Laboratory Site 300 General Services Area, Lawrence Livermore National Laboratory, Livermore, CA (UCRL-AR-122585).

Landgraf, R., B. A. MacDonald, K. S. Obenauf, and T. Berry (1996), Title I Conceptual Design for Pit 6 Landfill Closure, Lawrence Livermore National Laboratory Site 300, Lawrence Livermore National Laboratory, Livermore, CA (UCRL-CR-124994-I).

Landgraf, R., T. Berry, L. Berg, R. Depue, C. Dibble, R. Ferry, L. Hall, and J. Orloff (1996), Addendum in the Pit 6 Engineering Evaluation/Cost Analysis, Lawrence Livermore National Laboratory Site 300, Lawrence Livermore National Laboratory, Livermore, CA (UCRL-AR-113861, Add. 1).

Landgraf, R., T. Berry, L. Berg, R. Depue, C. Dibble, R. Ferry, L. Hall, and J. Orloff (1996), Addendum in the Pit 6 Engineering Evaluation/Cost Analysis, Lawrence Livermore National Laboratory Site 300, Lawrence Livermore National Laboratory, Livermore, CA (UCRL-AR-113861, Add. 1DR). 


\section{Appendix A. 1996 EPD Publications}

Landgraf, R., T. Berry, L. Berg, R. Depue, C. Dibble, R. Ferry, L. Hall, K. Heyward, D. MacQueen, J. Orloff, and M. Ridley, Addendum to the Pit 6 Engineering Evaluation/Cost Analysis Lawrence Livermore National Laboratory Site 300, Lawrence Livermore National Laboratory, Livermore, CA (UCRL-AR-113861 Add. 1, Rev. 1).

Lane, M. (1996), Management Summary Environmental Restoration at Lawrence Livermore National Laboratory, Site 300, Livermore, California, Lawrence Livermore National Laboratory, Livermore, CA (UCRL-AR-122292).

Mathews, S. (1996), 1996 National Storm Water Control Program Excellence Awards, Lawrence Livermore National Laboratory, Livermore, CA (UCRL-AR-123898).

McKereghan, P. F., L. L. Berg, M. D. Dresen, R. W. Bainer, E. N. Folsom, A. L. Lamarre, R. O. Devany, F. Hoffman, J. D. Hoffman, M. P. Maley, C. M. Noyes, and T. J. Vogele (1996), Contingency Plan for the Lawrence Livermore National Laboratory Site, Lawrence Livermore National Laboratory, Livermore, CA (UCRL-AR-123370).

McKereghan, P. F., L. L. Berg, M. D. Dresen, R. M. Bainer, E. N. Folsom, A. L. Lamarre, R. O. Devany, F. Hoffman, J. D. Hoffman, M. P. Maley, C. M. Noyes, and T. J. Vogele (1996), Draft Contingency Plan for the Lawrence Livermore National Laboratory Livermore Site, Lawrence Livermore National Laboratory, Livermore, CA (UCRL-AR-123370DR).

McNab, W. (1996), Simulation of Reactive Geochemical Transport in Groundwater Using a Semi-Analytical Screening Model, Lawrence Livermore National Laboratory, Livermore, CA (UCRL-JC-125040).

McNab, W., and B. P. Dooher (1996), Critique of a Steady-State Analytical Method for Estimating Contaminant Degradation Rates, Lawrence Livermore National Laboratory, Livermore, CA (UCRL-JC-126016).

McNab, W., and B. P. Dooher (1996), Uncertainty Analyses of Fuel Hydrocarbon Bioattenuation Signatures in Groundwater by Probabilistic Modeling, Lawrence Livermore National Laboratory, Livermore, CA (UCRL-JC-126015).

McNab, W., D. W. Rice, B. P. Dooher, M. C. Kavanaugh, P. C. Johnson, S. J. Cullen, W. E. Kastenberg, M. C. Small, and L. Everett, (1996), Draft Final Assessment of Appropriate Fuel Hydrocarbon Cleanup Strategies for George Air Force Base, Victorville, California, Using a Risk-Based Approach, Lawrence Livermore National Laboratory, Livermore, CA (UCRL-AR-125619DR). 


\section{Appendix A. 1996 EPD Publications}

Meltzer, M. (1996), International Pollution Prevention Partnership with USAID, Lawrence Livermore National Laboratory, Livermore, CA (UCRL-JC-124327).

Meltzer, M., and H. Gregg (1996), In-Progress Cleaning Analysis, Lawrence Livermore National Laboratory, Livermore, CA (UCRL-JC-122883).

Meltzer, M., and H. Gregg (1996), New Tool for Contamination Analysis, Lawrence Livermore National Laboratory, Livermore, CA (UCRL-JC-124326).

Neuman, J. E., R. W. Myers, and C. Van Warmerdam (1996), Application of the Necessary and Sufficient Approach for Lawrence Livermore National Laboratory Site 300, Lawrence Livermore National Laboratory, Livermore, CA (UCRL-JC-123206 Abs).

Neuman, J. E., S. G. Lane, and C. Van Warmerdam (1996), Implementation of the Single Container Inventory Limit Method for Hazardous Waste Chemicals at the Lawrence Livermore National Laboratory, Lawrence Livermore National Laboratory, Livermore, CA (UCRL-JC-123207 Abs).

Nichols, E. M., M. D. Berg, M. D. Dresen, R. J. Gelinas, R. W. Bainer, and E. N. Folsom (1996), Draft Final Compliance Monitoring Plan for the Lawrence Livermore National Laboratory Livermore Site, Lawrence Livermore National Laboratory, Livermore, CA (UCRL-AR-120936DR Rev. 1).

Nichols, E. M., M. D. Berg, M. D. Dresen, R. J. Gelinas, R. W. Bainer, E. N. Folsom, and A. L. Lamarre (1996), Compliance Monitoring Plan for the Lawrence Livermore National Laboratory Livermore Site, Lawrence Livermore National Laboratory, Livermore, CA (UCRL-AR-120936).

Nitao, J. J., T. J. Vogele, A. Klulresthra, K. Lee, M. D. Dresen, E. M. Nichols, R. J. Gelinas, R. W. Bainer, and P. F. McKereghan (1996), Simulation of Soil Vapor Extraction at Building 518, Lawrence Livermore National Laboratory Livermore Site, Lawrence Livermore National Laboratory, Livermore, CA (UCRL-AR-124995).

Pearson, H. E. (1996), TSDF Audit Report, No. 95IR-1: Environmental Systems Company, Inc., January 31, 1996, Lawrence Livermore National Laboratory, Livermore, CA (UCRL-AR-121533-96-5).

Pearson, H. E. (1996), TSDF Audit Report No. 95IR-2: Rollons Environmental Services (TX), Inc., February 2, 1996, Lawrence Livermore National Laboratory, Livermore, CA (UCRL-AR-121533-96-6). 


\section{Appendix A. 1996 EPD Publications}

Pearson, H. E. (1996), TSDF Audit Report No. 96IR-5: NSSI/Sources and Services, Inc., June 11, 1996, Lawrence Livermore National Laboratory, Livermore, CA (UCRL-AR-121533-96-9).

Pearson, H. E. (1996), TSDF Audit Report No. 95IR-6: Perma Fix Environmental Services, June 13, 1996, Lawrence Livermore National Laboratory, Livermore, CA (UCRL-AR-121533-96-10).

Pearson, H. E. (1996), TSDF Audit Report: No. 96IR-7: California Asbestos Moonfill (CAM), October 3, 1996, Lawrence Livermore National Laboratory, Livermore, CA (UCRL-AR-121533-96-11).

Pearson, H. E. (1996), TSDF Audit Report \#95IR-8: Diversified Scientific Services, Inc., Lawrence Livermore National Laboratory, Livermore, CA (UCRL-AR-121533-96-1).

Pearson, H. E. (1996), TSDF Audit Report \#95IR-9: Scientific Ecology Group, Inc., Lawrence Livermore National Laboratory, Livermore, CA (UCRL-AR-121533-96-2).

Pearson, H. E. (1996), TSDF Audit Report \#95IR-11, November 16, 1995, Lawrence Livermore National Laboratory, Livermore, CA (UCRL-AR-121533-96-4).

Pearson, H. E. (1996), TSDF Audit Report \#95IR-100, November 15, 1995, Lawrence Livermore National Laboratory, Livermore, CA (UCRL-AR-121533-96-3).

Pearson, T. (1996), Why and How to TSDF Audits, Lawrence Livermore National Laboratory, Livermore, CA (UCRL-MI-124624).

Raber, E. (1996), Technologies for Environmental Protection and Remediation, Lawrence Livermore National Laboratory, Livermore, CA (UCRL-MI-124347).

Rogers, L., V. Johnson, and W. Bosl (1996), 3-D Field-Scale Remediation Optimization at Lawrence Livermore National Laboratory, Lawrence Livermore National Laboratory, Livermore, CA (UCRL-JC-125196 Abs).

Rueth, L., and J. Ziagos (1996), Draft Record of Decision for the General Services Area Operable Unit, Lawrence Livermore National Laboratory Site 300, Lawrence Livermore National Laboratory, Livermore, CA (UCRL-AR-124061DR).

Salvo, V. (1996), Contingency Plan for Building 231 Resin Mixing Unit for B-231, Rooms 116 and 1128, Lawrence Livermore National Laboratory, Livermore, CA (UCRL-AR-125618). 


\section{Appendix A. 1996 EPD Publications}

Salvo, V. (1996), Contingency Plan for Building 322 Rinsewater Vaporization Facility, Lawrence Livermore National Laboratory, Livermore, CA (UCRL-AR-125621).

Sims, J. M., A. Ladran, and E. Jones (1996), Hazard and Risk Analysis for Selecting Safety Standards: Experience from the Necessary and Sufficient Pilot Demonstration at Lawrence Livermore National Laboratory, Lawrence Livermore National Laboratory, Livermore, CA (UCRL-JC-123272 Abs).

Sims, J. M., A. Ladran, and E. Jones (1996), Hazard and Risk Analysis for Selecting Safety Standards: Experience from the Necessary and Sufficient Pilot Demonstration at Lawrence Livermore National Laboratory, Lawrence Livermore National Laboratory, Livermore, CA (UCRL-JC-123272 Sum).

Sizemore, F., and M. Abri (1996), Part B Permit Application for Hazardous Waste Treatment and Storage Facilities, Livermore Site, Lawrence Livermore National Laboratory, Livermore, CA (UCAR-10275-96DR).

Steenhoven, J. (1996), Environmental Impact Report, Addendum for the Continued Operation of Lawrence Livermore National Laboratory (LLNL), Lawrence Livermore National Laboratory, Livermore, CA (UCRL-CR-125546).

Taffet, M. J., L. Green-Horner, L. C. Hall, T. M. Carlsen, and J. A. Orberdorfer (1996), Addendum to Site-Wide Remedial Investigation Report, Lawrence Livermore National Laboratory Site 300, Lawrence Livermore National Laboratory, Livermore, CA (UCRL-AR-108131, Add. 1).

Van Warmerdam, C. (1996), Hazardous Waste Management Facilities Final Safety Analysis Report, Lawrence Livermore National Laboratory, Livermore, CA (UCRL-CR-113523).

Vonder Haar, S. P., C. Webster-Scholten, and N. B. Crow (1996), Environmental Restoration Acronyms and Abbreviations, Lawrence Livermore National Laboratory, Livermore, CA (UCRL-AR-122176).

Vukelich, J. (1996), Environmental Compliance Manual, Lawrence Livermore National Laboratory, Livermore, CA (UCRL-MA-118090 Rev. 2).

Wilkinson, C. (1996), New Approach for Environmental Justice Impact, Lawrence Livermore National Laboratory, Livermore, CA (UCRL-JC-123630). 


\section{Appendix A. 1996 EPD Publications}

Wilkinson, C. H. (1996), Environmental Justice Impact Assessment-Key Components and Energy Issues, Lawrence Livermore National Laboratory, Livermore, CA (UCRL-JC-125342).

Wilson, K. (1996), Methodology of Recent Solid Waste Stream Assessments and Summary of Current Recyling Endeavors at Lawrence Livermore National Laboratory (LLNL), Lawrence Livermore National Laboratory, Livermore, CA (UCRL-JC-123649).

Wilson, K. (1996), Recycling at LLNL, Lawrence Livermore National Laboratory, Livermore, CA (UCRL-TB-120696 Rev. 1).

Ziagos, J., R. Gelinas, S. Doss, and R. Nelson (1996), Adaptive Simultaneous Forward-Inverse Galerkin Method for Strongly Constrained Parameter Estimation, Lawrence Livermore National Laboratory, Livermore, CA (UCRL-JC-125188 Abs). 


\section{Appendix B Methods of Dose Calculations}

\section{Introduction}

Radiological doses calculated from measured activities are a principal indicator of the potential impact of LLNL operations on surrounding populations. The doses from ingestion of water and locally produced foodstuff are based on actual measurements of radionuclide concentrations in the various media, determined by sampling, as described in Chapters 7 through 11. Data needed to evaluate potential doses from the inhalation and immersion pathways are provided by air surveillance monitoring, as described in Chapter 4 .

The data on radionuclide concentrations or activities in these media are necessary inputs to the dose-rate equations described here. The examples presented below concern dose assessments for significant agricultural products of the Livermore Valley, including wine, and general vegetation, and in particular describe the forage-cow-milk pathway for ingestion of tritium in vegetation. The rate equations can also be used to estimate doses that would occur from ingestion of water at each of the Livermore Valley and Site 300 water sampling locations, though none of these is actually a primary source of drinking water.

\section{Dose Calculation Methods}

The dose calculation methods given here for the ingestion, inhalation, and immersion pathways are based on the NRC Regulatory Guide 1.109, Calculation of Annual Doses to Man from Routine Releases of Reactor Effluent (U.S. Nuclear Regulatory Commission 1977). The dose and dose-rate conversion factors used in these calculations were obtained from the committed dose equivalent tables for DOE dose calculations and are consistent with those specified in ICRP 30, Limits of Intakes of Radionuclides by Workers (International Commission on Radiological Protection [ICRP] 1980).

The calculations use conventional activity units of picocuries (pCi) and dose units of millirem (mrem). The conversion constants that apply when converting to Système International (SI) activity units of becquerels (Bq) and dose units of sieverts (Sv) are:

$$
\begin{gathered}
1 \mathrm{pCi}=\left(3.7 \times 10^{-2}\right) \mathrm{Bq} \\
1 \mathrm{mrem}=\left(1 \times 10^{-5}\right) \mathrm{Sv}=10 \mu \mathrm{Sv}=1 \times 10^{-2} \mathrm{mSv}
\end{gathered}
$$


The annual whole-body dose rate from ingestion of a particular food or drink is expressible as a product of three factors: the rate the food or drink is consumed (e.g., in $\mathrm{L} / \mathrm{y}$ ), the radionuclide concentration (e.g., in $\mathrm{pCi} / \mathrm{L}$ ) in the food or drink, and the dose rate conversion factor (e.g., in $\mathrm{mrem} / \mathrm{pCi}$ ) for the radionuclide. In the following subsections, equations of this type are used to estimate the annual dose from tritium in water and milk (directly consumed), from tritium ingested by humans via the foragecow-milk pathway, and, more generally the annual dose from radionuclides in meat, liquids, and leafy vegetables. Similar formulas are given for the inhalation dose and immersion dose, with HTO and HT, respectively, used as specific examples.

Generally, the concentrations are measured, while the appropriate consumption-rate factors are taken from the literature. The water and milk consumption rates are estimated to be $730 \mathrm{~L} / \mathrm{y}$ and $310 \mathrm{~L} / \mathrm{y}$, respectively, in Appendix 1 of the NRC Regulatory Guide 1.109 (U.S. Nuclear Regulatory Commission 1977). In the absence of consumption data on locally produced wine, we employ the conservative (high dose) assumption that the intake rate for wine is the same as that for water. The resultant dose is expected to be several times too high for wine but well below levels of health concern.

LLNL's first use of these dose-rate formulas in our environmental annual reports is described by Silver et al. (1980).

\section{Annual Dose from Potable Water}

Based on the assumption that all water sampled is available as drinking water, the annual whole-body dose for tritium in mrem/y is calculated using the following equation:

$D_{\text {whole body }}(\mathrm{mrem} / \mathrm{y})=C_{\mathrm{w}} \times U_{\mathrm{w}} \times D_{\mathrm{w}}$

where

$$
\begin{aligned}
C_{\mathrm{W}}= & \text { concentration of tritium in water }(\mathrm{pCi} / \mathrm{L}) \\
U_{\mathrm{w}}= & \text { water consumption rate }(\mathrm{L} / \mathrm{y})=730 \mathrm{~L} / \mathrm{y} \text { for maximally exposed } \\
& \text { individual } \\
D_{\mathrm{w}}= & \text { dose conversion factor }(\mathrm{mrem} / \mathrm{pCi}) \\
= & 6.3 \times 10^{-8} \mathrm{mrem} / \mathrm{pCi} \text { for tritium for the whole-body ingestion } \\
& \text { pathway for an adult (similarly, for } 40 \mathrm{~K} \text { the dose conversion factor is } \\
& \left.1.88 \times 10^{-5} \mathrm{mrem} / \mathrm{pCi} \text {, and for } 137 \mathrm{Cs}, \text { it is } 2.17 \times 10^{-7} \mathrm{mrem} / \mathrm{pCi}\right) \\
D_{\text {whole body }}= & \text { effective dose equivalent }(\text { mrem } / \mathrm{y}) \text { from ingestion of } 730 \mathrm{~L} \text { of } \\
& \text { potable water with tritium concentration } C_{\mathrm{w} .}
\end{aligned}
$$




\section{Annual Dose from Forage-Cow-Milk Pathway for Tritium in Vegetation}

Based on the assumption that all feed for the cattle was pasture grass, the effective dose equivalent per $\mu \mathrm{Ci} / \mathrm{mL}$ of tritiated water (HTO) for the maximally exposed individual is calculated using the following equation:

$D_{\text {whole body }}(\mathrm{mrem} / \mathrm{y})=D_{\text {veg }}+D_{\text {meat }}+D_{\text {milk }}$

where

$$
\begin{aligned}
D_{\text {veg }} & =\text { mrem } / \mathrm{y} \text { dose from ingestion of vegetables } \\
D_{\text {meat }} & =\mathrm{mrem} / \mathrm{y} \text { dose from ingestion of meat } \\
D_{\text {milk }} & =\mathrm{mrem} / \mathrm{y} \text { dose from ingestion of milk. }
\end{aligned}
$$

\section{Vegetation}

$D_{\text {veg(leafy) }}=U_{\text {veg }} \times C_{\text {veg }} \times D_{\text {HTO }}$

where

$$
\begin{aligned}
U_{\mathrm{veg}}= & \text { intake rate }(\mathrm{kg} / \mathrm{y}): 64 \mathrm{~kg} / \mathrm{y} \text { for maximally exposed individual } \\
C_{\mathrm{veg}}= & \text { concentration }(\mathrm{pCi} / \mathrm{kg}): 10^{9} \frac{\mathrm{pCi} / \mathrm{kg}}{\mu \mathrm{Ci} / \mathrm{mL}} \\
& \times\left(C_{\text {veg }}[\mu \mathrm{Ci} / \mathrm{mL} \text { measured }]\right) \\
D_{\mathrm{HTO}}= & \text { dose factor }(\mathrm{mrem} / \mathrm{pCi}): 6.3 \times 10^{-8} \mathrm{mrem} / \mathrm{pCi} \text { for }{ }^{3} \mathrm{H} \text { for the adult } \\
& \text { wholebody ingestion pathway. }
\end{aligned}
$$

The tritium dose from ingestion of vegetation is then

$$
D_{\text {veg }}(\mathrm{mrem} / \mathrm{y})=\left(0.40 \times 10^{4}\right) \times\left(C_{\mathrm{veg}}[\mu \mathrm{Ci} / \mathrm{mL} \text { measured }]\right) .
$$

Note: In this and some of the following equations, the dimensions associated with a multiplicative factor are not shown explicitly; the dimensions of the dependent variable and measured quantity are shown explicitly. For example, the above factor $\left(0.40 \times 10^{4}\right)$ carries units of $\frac{(\mathrm{mL} \cdot \mathrm{mrem})}{(\mathrm{y} \cdot \mu \mathrm{Ci})}$.

\section{Meat}

$$
D_{\text {meat }}(\mathrm{mrem} / \mathrm{y})=U_{\text {meat }} \times C_{\text {meat }} \times D_{\text {HTO }}
$$

where

$$
\begin{aligned}
& U_{\text {meat }}=\text { intake rate }(\mathrm{kg} / \mathrm{y}): 110 \mathrm{~kg} / \mathrm{y} \text { for maximally exposed individual } \\
& C_{\text {meat }}=\left(F_{\mathrm{f}}\right) \times\left(Q_{\mathrm{f}}\right) \times\left(C_{\mathrm{veg}}\right) \times\left(\mathrm{e}^{\left[-\lambda_{\mathrm{i}} \mathrm{s}\right]}\right)
\end{aligned}
$$




$$
\begin{aligned}
D_{\mathrm{HTO}}= & \text { dose factor }(\mathrm{mrem} / \mathrm{pCi}): 6.3 \times 10^{-8} \text { mrem } / \mathrm{pCi} \text { for }{ }^{3} \mathrm{H} \text { for the } \\
& \text { adult whole-body ingestion pathway } \\
F_{\mathrm{f}}= & \text { fraction of daily intake of nuclide per kilogram of animal } / \text { fish } \\
& (\mathrm{pCi} / \mathrm{kg} \text { in meat per } \mathrm{pCi} / \mathrm{d} \text { ingested by the animal })(\mathrm{d} / \mathrm{kg}): \\
& 1.2 \times 10^{-2} \mathrm{~d} / \mathrm{kg} \\
Q_{\mathrm{f}}= & \text { amount of feed consumed }(\mathrm{kg} / \mathrm{d}): 50 \mathrm{~kg} / \mathrm{d} \\
C_{\mathrm{veg}}= & \text { concentration }(\mathrm{pCi} / \mathrm{kg}): 10^{9} \frac{\mathrm{pCi} / \mathrm{kg}}{\mu \mathrm{Ci} / \mathrm{mL}} \\
& \times\left(C_{\text {veg }}[\mu \mathrm{Ci} / \mathrm{mL} \text { measured }]\right) \\
\lambda_{\mathrm{i}}= & \text { radiological decay constant }(\mathrm{d}-1): 1.5 \times 10^{-4} \mathrm{~d}^{-1} \\
t_{\mathrm{s}}= & \text { time between slaughter to consumption }(\mathrm{d}): 20 \mathrm{~d} \\
C_{\mathrm{meat}}= & \left(1.2 \times 10^{-2} \mathrm{~d} / \mathrm{kg}\right) \times(50 \mathrm{~kg} / \mathrm{d}) \times\left(C_{\mathrm{veg}}[\mu \mathrm{Ci} / \mathrm{mL}]\right) \\
& \times\left(10^{9} \frac{\mathrm{pCi} / \mathrm{kg}}{\mu \mathrm{Ci} / \mathrm{mL}}\right) \times\left(\exp \left[\left\{-1.5 \times 10^{-4}\right\} \times\{20\}\right]\right) \\
= & \left.0.6 \times 10^{9} \frac{\mathrm{pCi} / \mathrm{L}}{\mu \mathrm{Ci} / \mathrm{mL}}\right) \times\left(C_{\mathrm{veg}}[\mu \mathrm{Ci} / \mathrm{mL} \text { measured }]\right) .
\end{aligned}
$$

The tritium dose rate from meat consumption is then

$$
\begin{aligned}
\mathrm{D}_{\text {meat }}(\mathrm{mrem} / \mathrm{y})= & (110 \mathrm{~kg} / \mathrm{y}) \times\left(0.6 \times 10^{9} \frac{\mathrm{pCi} / \mathrm{kg}}{\mu \mathrm{Ci} / \mathrm{mL}} \times \mathrm{C}_{\mathrm{veg}}[\mu \mathrm{Ci} / \mathrm{mL} \text { measured }]\right) \\
& \times\left(6.3 \times 10^{-8} \mathrm{mrem} / \mathrm{pCi}\right) \\
= & \left(0.41 \times 10^{4}\right) \times\left(C_{\text {veg }}[\mu \mathrm{Ci} / \mathrm{mL} \text { measured }]\right)
\end{aligned}
$$

\section{Milk}

$$
D_{\text {milk }}(\mathrm{mrem} / \mathrm{y})=U_{\text {milk }} \times C_{\text {milk }} \times D_{\mathrm{HTO}}
$$

where

$$
\begin{aligned}
U_{\text {milk }}= & \text { intake rate }(\mathrm{L} / \mathrm{y}): 310 \mathrm{~L} / \mathrm{y} \text { for maximally exposed individual } \\
D_{\mathrm{HTO}}= & \text { dose factor }(\text { mrem } / \mathrm{pCi}): 6.3 \times 10^{-8} \mathrm{mrem} / \mathrm{pCi} \text { for }{ }^{3} \mathrm{H} \text { for the adult } \\
& \text { whole-body ingestion pathway } \\
C_{\text {milk }}= & \left(F_{\mathrm{m}}\right) \times\left(Q_{\mathrm{f}}\right) \times\left(C_{\mathrm{veg}}\right) \times\left(\mathrm{e}^{[-\lambda i t \mathrm{f}]}\right) \\
F_{\mathrm{m}}= & \text { fraction of daily intake of nuclide per liter of milk }(\mathrm{pCi} / \mathrm{L} \text { in milk } \\
& \text { per pCi } / \mathrm{d} \text { ingested by the animal })(\mathrm{d} / \mathrm{L}): 1.0 \times 10^{-2} \mathrm{~d} / \mathrm{L} \\
Q_{\mathrm{f}}= & \text { amount of feed consumed by the animal }(\mathrm{kg} / \mathrm{d}): 50 \mathrm{~kg} / \mathrm{d}
\end{aligned}
$$




$$
\begin{aligned}
C_{\text {veg }}= & \text { concentration }(\mathrm{pCi} / \mathrm{kg}):\left(10^{9} \frac{\mathrm{pCi} / \mathrm{kg}}{\mu \mathrm{Ci} / \mathrm{mL}}\right) \\
& \times\left(C_{\text {veg }}[\mu \mathrm{Ci} / \mathrm{mL} \text { measured }]\right) \\
\lambda_{\mathrm{i}}= & \text { radiological decay constant }\left(\mathrm{d}^{-1}\right): 1.5 \times 10^{-4} \mathrm{~d}^{-1} \\
t_{\mathrm{f}}= & \text { time from milking to milk consumption }(\mathrm{d}): 2 \mathrm{~d} \\
C_{\text {milk }}= & \left(1.0 \times 10^{-2} \mathrm{~d} / \mathrm{L}\right) \times(50 \mathrm{~kg} / \mathrm{d}) \times\left(C_{\mathrm{veg}}[\mu \mathrm{Ci} / \mathrm{mL}]\right) \\
& \times\left(10^{9} \frac{\mathrm{pCi} / \mathrm{L}}{\mu \mathrm{Ci} / \mathrm{mL}}\right) \times\left(\exp \left[\left\{-1.5 \times 10^{-4}\right\} \times\{2\}\right]\right) \\
= & \left(0.5 \times 10^{9} \frac{\mathrm{pCi} / \mathrm{L}}{\mu \mathrm{Ci} / \mathrm{mL}}\right) \times\left(C_{\mathrm{veg}}[\mu \mathrm{Ci} / \mathrm{mL} \text { measured }]\right) .
\end{aligned}
$$

The tritium dose rate from directly consumed milk is then

$$
\begin{aligned}
D_{\text {milk }}(\mathrm{mrem} / \mathrm{y})= & (310 \mathrm{~L} / \mathrm{y}) \times\left(\left[0.5 \times 10^{9} \frac{\mathrm{pCi} / \mathrm{kg}}{\mu \mathrm{Ci} / \mathrm{mL}}\right] \times\left[C_{\text {veg }}\{\mu \mathrm{Ci} / \mathrm{mL}\right.\right. \\
& \text { measured }\}]) \times\left(6.3 \times 10^{-8} \mathrm{mrem} / \mathrm{pCi}\right) \\
= & \left(0.97 \times 10^{4}\right) \times\left(C_{\text {veg }}[\mu \mathrm{Ci} / \mathrm{mL} \text { measured }]\right) .
\end{aligned}
$$

\section{Whole Body}

$$
\begin{aligned}
D_{\text {whole body }}(\mathrm{mrem} / \mathrm{y}) & =\left(\left[0.40 \times 10^{4}\right] \times\left[C_{\mathrm{veg}}\{\mu \mathrm{Ci} / \mathrm{mL} \text { measured }\}\right]\right) \\
+ & \left(\left[0.41 \times 10^{4}\right] \times\left[C_{\text {veg }}\{\mu \mathrm{Ci} / \mathrm{mL} \text { measured }\}\right]\right) \\
+ & \left(\left[0.97 \times 10^{4}\right] \times\left[C_{\text {veg }}\{\mu \mathrm{Ci} / \mathrm{mL} \text { measured }\}\right]\right) .
\end{aligned}
$$

The total annual dose rate from the forage-cow-milk pathway for tritium in vegetation is then

$D_{\text {whole body }}(\mathrm{mrem} / \mathrm{y})=\left(\left[1.78 \times 10^{4}\right] \times\left[C_{\text {veg }}\{\mu \mathrm{Ci} / \mathrm{mL}\right.\right.$ measured $\left.\left.\}\right]\right)$.

\section{Inhalation/ Immersion Dose}

Doses due to inhalation of and immersion in radionuclide-contaminated air can be estimated in an analogous way to the preceding treatment of ingestion doses. The starting point is to evaluate the radionuclide concentration in air, $\chi\left(\mathrm{Ci} / \mathrm{m}^{3}\right)$ at the location of interest. $\chi$ can be directly measured, or calculated using a Gaussian dispersion air transport model. In the latter approach, the calculated quantity is the atmospheric dispersion parameter, $\chi / Q$, which is the product of the radionuclide 
concentration in air $\chi\left(\mathrm{Ci} / \mathrm{m}^{3}\right)$ at all locations of interest and the source release rate $\mathrm{Q}(\mathrm{Ci} / \mathrm{s})$.

For inhalation dose, once $\chi$ or the product $(\chi / Q) \times(Q)$ is evaluated, it is multiplied by the inhalation rate of a human to obtain the number of curies of radioactive material inhaled by the human body. Dose and dose-rate conversion factors provided by the DOE (U.S. Department of Energy 1988), which are consistent with those specified in ICRP 30 (International Commission on Radiological Protection 1980), are used to relate the intake of radioactive material into the body to dose commitment. These dose factors provide estimates of 50-year dose from a one-year intake of radioactivity.

The inhalation dose is expressible as

$D_{\text {whole body }}(\mathrm{mrem} / \mathrm{y})=U_{\text {inhalation }} \times C_{\text {radionuclide }} \times D_{\text {radionuclide }}$

where

$$
\begin{aligned}
U_{\text {inhalation }}= & \text { air intake rate }(\mathrm{L} / \mathrm{y}): 8,400 \mathrm{~m}^{3} / \mathrm{y} \text { for an adult } \\
D_{\text {radionuclide }}= & \text { dose conversion factor }(\mathrm{mrem} / \mathrm{pCi}) \text { for the radionuclide of } \\
& \text { interest }\left[\text { for } \mathrm{HTO} \text { this factor is } 1.5 \times 6.4 \times 10^{-8} \mathrm{mrem} / \mathrm{pCi}=9.6\right. \\
& \times 10^{-8} \mathrm{mrem} / \mathrm{pCi} \text { for the adult whole-body inhalation pathway, } \\
& \text { where the factor } 1.5 \text { accounts for absorption through the skin; for } \\
& \text { other radionuclides, see Table } 2.1 \text { in Eckerman et al. (1988)] } \\
C_{\text {radionuclide }=} & (F) \times(\chi / \mathrm{Q}) \times(\mathrm{Q})=\text { radionuclide concentration at the receptor } \\
& \left(\mathrm{pCi} / \mathrm{m}^{3}\right) \\
F= & \frac{1 \times 10^{12} \mathrm{pCi} / \mathrm{Ci}}{3.15 \times 10^{7} \mathrm{~s} / \mathrm{y}}=3.17 \times 10^{4}(\mathrm{pCi} / \mathrm{Ci}) /(\mathrm{s} / \mathrm{y}) \\
\mathrm{Q}= & \text { radionuclide release rate }(\mathrm{Ci} / \mathrm{y}) \\
\chi / \mathrm{Q}= & \text { diffusion parameter }\left(\mathrm{s} / \mathrm{m}^{3}\right) ; \text { calculated. }
\end{aligned}
$$

The wholebody inhalation dose rate is then

$$
\begin{aligned}
D_{\text {whole body }}(\mathrm{mrem} / \mathrm{y})= & \left(3.17 \times 10^{4}[\mathrm{pCi} / \mathrm{Ci}] /[\mathrm{s} / \mathrm{y}]\right) \times(\chi / \mathrm{Q})\left(\mathrm{s} / \mathrm{m}^{3}\right) \times(\mathrm{Q}[\mathrm{Ci} / \mathrm{y}]) \\
& \times\left(8.4 \times 10^{3} \mathrm{~m}^{3} / \mathrm{y}\right) \times D_{\text {radionuclide }}(\mathrm{mrem} / \mathrm{pCi})
\end{aligned}
$$

The immersion dose is similarly expressible as

$D_{\text {whole body }}(\mathrm{mrem} / \mathrm{y})=C_{\text {radionuclide }} \times(D R F)$ 


\section{Appendix B. Methods of Dose Calculations}

where

$$
\begin{aligned}
C_{\text {radionuclide }=} & (F) \times(\chi / \mathrm{Q}) \times(\mathrm{Q})=\text { radionuclide concentration at the receptor } \\
& \left(\mathrm{pCi} / \mathrm{m}^{3}\right) \\
F= & \frac{1 \times 10^{12} \mathrm{pCi} / \mathrm{Ci}}{3.15 \times 10^{7} \mathrm{~s} / \mathrm{y}}=3.17 \times 10^{4}(\mathrm{pCi} / \mathrm{Ci}) /(\mathrm{s} / \mathrm{y}) \\
\mathrm{Q}= & \text { radionuclide release rate }(\mathrm{Ci} / \mathrm{y}) \\
\chi / \mathrm{Q}= & \text { diffusion parameter }\left(\mathrm{s} / \mathrm{m}^{3}\right), \text { calculated } \\
D R F= & \text { the external dose-equivalent rate factor per unit radionuclide } \\
& \text { concentration }(\mathrm{mrem} / \mathrm{y}) /\left(\mathrm{pCi} / \mathrm{m}^{3}\right)\left[\text { for elemental }{ }^{3} \mathrm{H} \text { this factor } \mathrm{DRF}\right. \\
& \text { is } 3.9 \times 10^{-8}(\text { mrem } / \mathrm{y}) /\left(\mathrm{pCi} / \mathrm{m}^{3}\right) ; \text { for the short-lived isotopes } 13 \mathrm{~N} \\
& \text { and } 15 \mathrm{O} \text { it equals } 5.1 \times 10^{-3}\left(\mathrm{mrem}^{15}\right) /\left(\mathrm{pCi} / \mathrm{m}^{3}\right) ; \text { for other } \\
& \text { radionuclides see Table } 2.3 \mathrm{in} \mathrm{Eckerman} \mathrm{et} \mathrm{al.}(1988)] .
\end{aligned}
$$





\section{References}

American Society of Mechanical Engineers (ASME) (1989), NQA-1 Quality Assurance Program Requirements for Nuclear Facilities, New York, NY.

Bainer, B., S. Bahowick, R. Blake, L. Berg, K. Folks, A. Happel, F. Hoffman, G. Howard, G. Kumamoto, M. Maley, C. Noyes, M. Ridley, S. Shukla, T. Vogele, and A. Watts (1996), LLNL Ground Water Project, 1995 Annual Report, Lawrence Livermore National Laboratory, Livermore, CA (UCRL-AR-122596).

Berry, T.R. (1996), Addendum to the Pit 6 Engineering Evaluation/Cost Analysis, Lawrence Livermore National Laboratory Site 300, Lawrence Livermore National Laboratory, Livermore, CA (UCRL-AR-113861 Add 1).

Bessette Rochette, M. (1996), Letter from Michael Bessette Rochette, RWQCB Project Manager, to Paul Ko, DOE Project Manager, stating approval of changes to metals discharge limits and sampling frequencies, dated August 15, 1996.

Biermann, A. H., R. J. Harrach, R. L. Berger, and K. A. Surano (1993), LLNL NESHAPs Project Quarterly Progress Report, March 31, 1993, Lawrence Livermore National Laboratory, Livermore, CA (UCRL-AR-108419-93-1).

Bryn, S. M., R. K. Landgraf, and S. E. Booth (1990), Draft Remedial Investigation and Feasibility Study for the Lawrence Livermore National Laboratory Site 300 Building 834 Complex, Lawrence Livermore National Laboratory, Livermore, CA (UCRL-ID103963 DR, Vols. 1 and 2.

California RWQCB (1996), Case Closure Letter from Loretta Barasmian, Executive Officer, to Mr. Paul Ko of DOE regarding Petroleum Hydrocarbon Impacted Zone at Treatment Facility F.

Carlsen, T. M. (1991a), LLNL Site 300 Environmental Investigations Quarterly, JanuaryMarch 1991, Lawrence Livermore National Laboratory, Livermore, CA (UCAR-10194-91-1).

Carlsen, T. M. (1991b), LLNL Site 300 Environmental Investigations Quarterly, April-June 1991, Lawrence Livermore National Laboratory, Livermore, CA (UCAR-10194-91-2). 


\section{References}

Carpenter, D. W., J. J. Sweeney, P. W. Kasameyer, N. R. Burkhard, K. G. Knauss, and R. J. Shelmon (1984), Geology of the Lawrence Livermore National Laboratory Site and Adjacent Areas, Lawrence Livermore National Laboratory, Livermore, CA (UCRL-53316).

Celeste, J. (1995), Reassessment of LLNL Waste Generation for Calendar Year 1995, Lawrence Livermore National Laboratory, Livermore, CA (UCRL-AR-125047).

Celeste, J. (1997), FY97 Pollution Prevention Plan: A Strategy for the Future, Lawrence Livermore National Laboratory, Livermore, CA (UCRL-AR-127073).

Central Valley Regional Water Quality Control Board (RWQCB) (1993), Waste Discharge Requirements for University of California Lawrence Livermore National Laboratory Site 300 and U.S. Department of Energy, Landfill Pits 1 and 7, San Joaquin County (Order No. 93-100), June 25, 1993.

Central Valley Regional Water Quality Control Board (RWQCB) (1996), Waste Discharge Requirements for University of California Lawrence Livermore National Laboratory Site 300 and U.S. Department of Energy, Landfill Pits 1 and 7, San Joaquin County, Rev. 1 (Order No. 93-100), June 25, 1993.

Christofferson, E., D. H. MacQueen, N. L. Hankla, and W. G. Hoppes (1993), LLNL Site 300 Ground Water Monitoring Program, Quarterly Report, July-September 1993, Lawrence Livermore National Laboratory, Livermore, CA (UCAR-10191-93-3).

Christofferson, E. and D. H. MacQueen (1995), LLNL Experimental Test Site 300 Compliance Monitoring Program for RCRA-Closed Landfill Pits 1 and 7 and Process Water Surface Impoundments, Second Quarter Report, April-June 1995, Lawrence Livermore National Laboratory, Livermore, CA (UCAR-10191-95-2).

Christofferson, E. and D. H. MacQueen (1996a), LLNL Experimental Test Site 300 Compliance Monitoring Program for RCRA-Closed Landfill Pits 1 and 7 and Process Water Surface Impoundments, Fourth Quarter Report, October-December 1995, Lawrence Livermore National Laboratory, Livermore, CA (UCAR-10191-95-4).

Christofferson, E. and D. H. MacQueen (1996b), LLNL Experimental Test Site 300 Compliance Monitoring Program for RCRA-Closed Landfill Pits 1 and 7, Annual Report for 1995, Lawrence Livermore National Laboratory, Livermore, CA (UCAR10191-95-5). 
Christofferson, E. and D. H. MacQueen (1996c), LLNL Experimental Test Site 300 Compliance Monitoring Program for RCRA-Closed Landfills Pit 1 and Pit 7, Third Quarter Report, July-September 1996, Lawrence Livermore National Laboratory, Livermore, CA (UCAR-10191-96-3).

Christofferson, E. and D. H. MacQueen (1997), LLNL Experimental Test Site 300 Compliance Monitoring Program for RCRA-Closed Landfills Pit 1 and Pit 7, Annual Report for 1996, Lawrence Livermore National Laboratory, Livermore, CA (UCAR-10191-96-4).

Crow, N. B., and A. L. Lamarre (1990), Remedial Investigation of the High-Explosives (HE) Process Areas, LLNL Site 300, Lawrence Livermore National Laboratory, Livermore, CA (UCID-21920).

Devany, R., R. Landgraf, and T. Berry (1994), Final Feasibility Study Report for the Pit 6 Operable Unit, Lawrence Livermore National Laboratory, Livermore, CA (UCRL-AR-113861).

Dibblee, T. W., Jr. (1980), Preliminary Geologic Map of the Midway Quadrangle, Alameda and San Joaquin Counties, California, USGS Open File Report 80-535.

Dibley, V., and R. Depue (1996), LLNL Livermore Site and Site 300 Environmental Restoration Project Standard Operating Procedures (SOPs), Lawrence Livermore National Laboratory, Livermore, CA (UCRL-MA-109115 Rev. 2).

Dresen, M. D., F. Hoffman, and S. Lovejoy, Jr. (1986), Subsurface Distribution of Hydrocarbons in the Building 403 Area at LLNL, Lawrence Livermore National Laboratory, Livermore, CA (UCID-20787).

Dresen, M. D., J. P. Ziagos, A. J. Boegel, E. M. Nichols, K. Anderson, R. O. Devany, E. N. Folsom, J. L. Iovenitti, J. K. McDonald, P. F. McKereghan, and C. N. Noyes (1993), Remedial Action Implementation Plan for the LLNL Livermore Site, Livermore, $C A$, Lawrence Livermore National Laboratory, Livermore, CA (UCRL-AR-110532).

Eccher, B. (1994), Storm Water Pollution Prevention Plan Livermore Site, Lawrence Livermore National Laboratory, Livermore, CA (UCRL-AR-110573-94). 
Eckerman, K. F., A. B. Wolbarst, and A. C. B. Richardson (1988), Limiting Values of Radionuclide Intake and Air Concentration and Dose Conversion Factors for Inhalation, Submersion, and Ingestion, U.S. Environmental Protection Agency, Washington, DC (Federal Guidance Report No. 11, EPA-520/1-88-020).

Failor, R. A. and W. F. Isherwood (1994), Lawrence Livermore National Laboratory Livermore Site and Site 300 Ground Water Protection Management Program, Lawrence Livermore National Laboratory, Livermore, CA (UCRL-AR-118435).

Fischer, K. G., W. G. Hoppes, and D. H. MacQueen (1992), LLNL Site 300 Groundwater Monitoring Program Quarterly Report, April-June 1992, Lawrence Livermore National Laboratory, Livermore, CA (UCAR-10191-92-2).

Fisher, Dennis K. (1995), Amended Report of Waste Discharge, Waste Discharges Permit Number 85-188, Lawrence Livermore National Laboratory Experimental Test Site (Site 300), Alameda and San Joaquin Counties, November 13, 1995.

Gallegos, G. M., and A. H. Biermann (1997), LLNL NESHAPs 1996 Annual Report, Lawrence Livermore National Laboratory, Livermore, CA (UCRL-ID-113867-96).

Gallegos, G. M., B. K. Balke, K. A. Surano, W. G. Hoppes, P. J. Tate, J. C. Steenhoven, B. C. Fields, L. M. Garcia, and K. C. Lamson (1992), Environmental Report for 1991, Lawrence Livermore National Laboratory, Livermore, CA (UCRL-50027-91).

Gallegos, G. M., P. J. Tate, B. K. Balke, E. Christofferson, R. J. Harrach, W. G. Hoppes, R. A. Failor, S. Wander, B. C. Fields, L. M. Garcia, and A. R. Grayson (1994), Environmental Report for 1993, Lawrence Livermore National Laboratory, Livermore, CA (UCRL-50027-93).

Gallegos, G. M., R. J. Harrach, A. H. Biermann, F. J. Gouveia, P. J. Tate, B. C. Fields, and K. Surano (1996), LLNL NESHAPs 1995 Annual Report, Lawrence Livermore National Laboratory, Livermore, CA (UCRL-ID-113867-95).

Garcia, L. M., and R. A. Failor (1993), Environmental Monitoring Section Quality Assurance Plan, Lawrence Livermore National Laboratory, Livermore, CA (UCRL-AR-114318).

Gouveia, F., and K. R. Chapman (1989), Climatology of Lawrence Livermore National Laboratory, Lawrence Livermore National Laboratory, Livermore, CA (UCID-21686). 
Grandfield, C. H. (1989), Guidelines for Discharges to the Sanitary-Sewer System, Lawrence Livermore National Laboratory, Livermore, CA (UCAR-10235).

Hall, H. L., and W. L. Edwards (1994a), Radiation Analytical Sciences Quality Assurance Plan, Quality Implementing Procedures and Quality Assurance Project Plans, Vol. 1, Lawrence Livermore National Laboratory, Livermore, CA (M-078-142).

Hall, H. L., and W. L. Edwards (1994b), Radiation Analytical Sciences Integrated Software Documentation, Vols. 2a, 2b, and 3, Lawrence Livermore National Laboratory, Livermore, CA (UCRL-MA-116560).

Hall, H. L. and W. L. Edwards (1994c), Technical Implementing Procedures, Radiation Analytical Sciences, Vol. 2a, Lawrence Livermore National Laboratory, Livermore, CA (UCRL-MA-116560).

Happel, A. M, W. W. McNab, J. K. MacDonald, and C. M. Noyes (1996), Application for Containment Zone for the Livermore Site Hydrocarbon Impacted Zone at Treatment Facility F, Lawrence Livermore National Laboratory, Livermore, CA (UCRL-AR-123385).

Harrach, R. J., K. A. Surano, A. H. Biermann, F. J. Gouveia, B. C. Fields, and P. J. Tate, (1994), LLNL NESHAPS 1993 Annual Report, Lawrence Livermore National Laboratory, Livermore, CA (UCRL-ID-113867-94).

Harrach, R. J ., G. M. Gallegos, R. A. Failor, E. Christofferson, P. J. Tate, E. R.

Brandstetter, J. M. Larson, J. R. McIntyre, B. C. Fields, R. A. Brown, L. M. Garcia, and A. R. Grayson (1995), Environmental Report for 1994, Vols. I \& II, Lawrence Livermore National Laboratory, Livermore, CA (UCRL-50027-94), http:/ / www.llnl.gov/saer /

Harrach, R. J., R. A. Failor, G. M. Gallegos, P. J. Tate, E. Christofferson, E. R. Brandstetter, J. M. Larson, A. H. Biermann, R. A. Brown, B. C. Fields, L. M. Garcia, and A. R. Grayson (1996), Environmental Report 1995, Vols. I \& II, Lawrence Livermore National Laboratory, Livermore, CA (UCRL-50027-95), http:/ / www.llnl.gov/saer /

Heffner, B. (1996), Site 300 Fact Sheet Number 3, January 1996, Lawrence Livermore National Laboratory, Livermore, CA (UCRL-TB-110590-96-1). 
Hoffman, J., P. McKereghan, B. Qualheim, R. Bainer, E. Folsom, and M. Dresen (1997), LLNL Ground Water Project 1996 Annual Report, Lawrence Livermore National Laboratory, Livermore, CA (UCRL-AR-126020).

Huey, A. S. (1948), "Geology of the Tesla Quadrangle, California," California Division of Mines and Geology, Bulletin 140.

International Commission on Radiological Protection (ICRP) (1977), Recommendations of the International Commission on Radiological Protection, Publication 26 (Pergamon Press, New York, NY).

International Commission on Radiological Protection (ICRP) (1980), Limits for Intakes of Radionuclides by Workers, Publication 30 (Pergamon Press, New York, NY).

Isherwood, W. F., C. H. Hall, M. D. Dresen, and A. J. Boegel (1991), CERCLA Feasibility Study Report for the LLNL Livermore Site, Lawrence Livermore National Laboratory, Livermore, CA (UCRL-AR-104040).

Ko, P., M. D. Gill, B. R. Feather, and M. Bessette Rochette (1996), Consensus Statement for Environmental Restoration of Lawrence Livermore National Laboratory (LLNL) Livermore Site, dated September 19, 1996.

Ko, P., and A. L. Lamarre (1996), Letter Report: LLNL Livermore Site July 2, 1996, Remedial Program Manager's Meeting Summary and Second Quarter SelfMonitoring Report, dated August 29, 1996.

Lamarre, A. L., ed. (1989a), LLNL Site 300 Environmental Investigations Quarterly, JulySeptember 1989, Lawrence Livermore National Laboratory, Livermore, CA (UCAR-10194-89-3).

Lamarre, A. L., ed. (1989b), LLNL Site 300 Environmental Investigations Quarterly, OctoberDecember 1989, Lawrence Livermore National Laboratory, Livermore, CA (UCAR-10194-89-4).

Lamarre, A. L. (1989c), Lawrence Livermore National Laboratory Site 300 Environmental Restoration Work Plan, Lawrence Livermore National Laboratory, Livermore, CA (UCAR-10247 Rev. 1).

Lamarre, A. L., and M. J. Taffet (1989), Firing Table Gravel Cleanup at Lawrence Livermore National Laboratory Site 300, Lawrence Livermore National Laboratory, Livermore, CA (UCAR-10282). 
Landgraf, R., E. Miner, and T. Berry (1994), Final Feasibility Study Report for the Building 834 Operable Unit, Lawrence Livermore National Laboratory Site 300, Lawrence Livermore National Laboratory, Livermore, CA (UCRL-AR-113863).

Landgraf, R., and L. Rueth (1996a), Draft Final Proposed Plan for Remediation of the Lawrence Livermore National Laboratory Site 300 General Services Plan, Lawrence Livermore National Laboratory, Livermore, CA (UCRL-AR-122585DR Rev. 1).

Landgraf, R., and L Rueth (1996b), The United States Department of Energy Presents the Proposed Plan for Remediation of the Lawrence Livermore National Laboratory Site 300 General Services Area, Lawrence Livermore National Laboratory, Livermore, CA (UCRL-AR-122585).

Limnion Corporation, The (1991), Drainage Retention Basin Management Plan, Lawrence Livermore National Laboratory, Livermore, CA.

Lindeken, C. L., R. O. Morgin, and K. F. Petrock (1963), “Collection Efficiency of Whatman-41 Filter Paper for Submicron Aerosols," Health Physics 9, 305-308.

Lindeken, C. L., P. H. Gudiksen, J. W. Meadows, K. O. Hamby, and L. R. Anspaugh (1973), Environmental Levels of Radioactivity in Livermore Valley Soils, Lawrence Livermore National Laboratory, Livermore, CA (UCRL-74424).

Littlejohn, J. and A. L. Lamarre (1996), Letter Report: LLNL Livermore Site September 18, 1996 Remedial Program Manager's Meeting Summary and Third Quarter Self-Monitoring Report, dated November 27, 1996.

Littlejohn, J. and A. L. Lamarre (1997), Letter Report: LLNL Livermore Site December 10, 1996 Remedial Program Manager's Meeting Summary and Fourth Quarter Self-Monitoring Report, dated February 27, 1997.

LLNL (1995), Draft Proposed Plan for the General Services Area Operable Unit, Lawrence Livermore National Laboratory Site 300, Lawrence Livermore National Laboratory, Livermore, CA (UCRL-AR-122585DR), December 15, 1995.

LLNL (1996a), "Tritium Geochemistry and Ground Water Treatment Technology for the Building 850/Pit 7 Complex Operable Unit," Letter Report to Robert Feather (DTSC), Lida Tan (EPA), and Susan Timm (Central Valley RWQCB), Lawrence Livermore National Laboratory, Livermore, CA, February 15, 1996. 
LLNL (1996b), Draft Final Proposed Plan for the Site 300 General Services Area, Lawrence Livermore National Laboratory Site 300, Lawrence Livermore National Laboratory, Livermore, CA (UCRL-AR-122585 DR), February 15 , 1996.

LLNL (1996c), Final Proposed Plan for the Site 300 General Services Area, Lawrence Livermore National Laboratory Site 300, Lawrence Livermore National Laboratory, Livermore, CA (UCRL-AR-122585), March 15, 1996.

LLNL (1996d), Draft Record of Decision for the General Services Area, Lawrence Livermore National Laboratory Site 300, Lawrence Livermore National Laboratory, Livermore, CA (UCRL-AR-124961DR), July 191996.

LLNL (1996e), Draft Final Record of Decision for the General Services Area, Lawrence Livermore National Laboratory Site 300, Lawrence Livermore National Laboratory, Livermore, CA (UCRL- AR-124961DR), December 1, 1996.

LLNL (1996f), Pit 6 EE/CA Fact Sheet, Lawrence Livermore National Laboratory, Livermore, CA, December 1996.

LLNL (1996g), The Environmental, Safety, and Health Program at Lawrence Livermore National Laboratory, Lawrence Livermore National Laboratory, Livermore, CA (UCRL-AR-119618 Rev 1). Accessible from LLNL home page at http//www.llnl.gov.

Longley, K. E., H. V. Johns, and H. Abraham et al. (1994), The Water Quality Control Plan (Basin Plans) for the California Regional Water Control Board, Central Valley Region, Central Valley Regional Water Control Board, Sacramento, CA.

Lowder, W. M., and H. L. Beck (1966), "Cosmic Ray Ionization in the Lower Atmosphere," J. Geophys. Res. 71, 4661-4668.

Marshack, J. B. (1991), The Designated Level Methodology for Waste Classification and Cleanup Level Determination, a summary of the Staff Report of the Central Valley RWQCB.

Marshack, J. B. (1995), A Compilation of Water Quality Goals, Central Valley Regional Water Quality Control Board, Sacramento, CA.

McConachie W. A. and M. G. Brown (1996), Letter Report: LLNL Livermore Site March 21, 1996 Remedial Program Manager's Meeting Summary and First Quarter Self-Monitoring Report, dated May 29, 1996. 
McIlvride, W. A., R. A. Ferry, S. P. Vonder Haar, W. M. Wade, and L. L. Glick (1990), Remedial Investigation of the General Services Area (GSA), Lawrence Livermore National Laboratory Site 300, May 1990, Lawrence Livermore National Laboratory, Livermore, CA (UCRL-AR-103161).

McKereghan, P. F., L., L. Berg, M. D. Dresen, R. W. Bainer, E. N. Folsom, A. L. Lamarre, R. O. Devany, F. Hoffman, J. D. Hoffman, M. P. Maley, C. M. Noyes, and T. J. Vogele (1996), Contingency Plan for the Lawrence Livermore National Laboratory Site, Lawrence Livermore National Laboratory, Livermore, CA (UCRL-AR-123370).

National Council on Radiation Protection and Measurements (NCRP) (1987a), Recommendations on Limits of Exposure to Ionizing Radiation, Report No. 91, National Council on Radiation Protection and Measurements, Washington, DC.

National Council on Radiation Protection and Measurements (NCRP) (1987b), Ionizing Radiation Exposure of the Population of the United States, Report No. 93, National Council on Radiation Protection and Measurements, Washington, DC.

Nichols, E. M., M. D. Berg, M. D. Dresen, R. J. Gelinas, R. W. Bainer, E. N. Folsom, and A. L. Lamarre (1996), Compliance Monitoring Plan for the Lawrence Livermore National Laboratory Livermore Site, Lawrence Livermore National Laboratory, Livermore, CA (UCRL-AR-120936).

Parks, B. S. (1992), User's Guide for CAP88-PC, Version 1.0, U.S. Environmental Protection Agency, Office of Radiation Programs, Las Vegas, NV (EPA 402-B-92-001).

Raber, E., and D. W. Carpenter, eds. (1983), An Evaluation of the Hydrogeology and Groundwater Chemistry Associated with Landfills at LLNL's Site 300, Lawrence Livermore National Laboratory, Livermore, CA (UCRL-53416).

Rogers/Pacific Corporation (1990), Lawrence Livermore National Laboratory Site 300 Resource Conservation and Recovery Act Closure and Post-Closure Plans-Landfill Pits 1 and 7, Vols. I and II, Van Nuys, CA (California EPA No. CA2890090002).

Rueth, L., and J. Ziagos (1996), Draft Record of Decision for the General Services Area Operable Unit, Lawrence Livermore National Laboratory Site 300, Lawrence Livermore National Laboratory, Livermore, CA (UCRL-AR-124061DR).

Salomons, W., U. Forstner, and P. Mader (1995), Heavy Metals: Problems and Solutions, Springer-Verlag, New York, NY. 
San Francisco Bay Regional Water Quality Control Board (RWQCB) (1982a), Water Quality Control Plan, San Francisco Bay Basin, State of California, Oakland, CA.

San Francisco Bay Regional Water Quality Control Board (RWQCB) (1982b), Waste Discharge Requirements and National Pollutant Discharge Elimination System (NPDES) Storm Water Permit for: U.S. Department of Energy and Lawrence Livermore National Laboratory, State of California, Oakland, CA (Order No. 95-174, NPDES No. CA030023).

San Francisco Bay Regional Water Quality Control Board (RWQCB) (1995), Water Quality Control Plan, San Francisco Bay Basin, State of California, Oakland, CA.

San Francisco Bay Regional Water Quality Control Board (RWQCB) (1996), Case closure letter from Loretta Barasmian, Executive Officer, to Mr. Paul Ko of DOE regarding "Petroleum Hydrocarbon Impacted Zone at Treatment Facility F," October 30, 1996.

Shleien, B., and M. S. Terpilak (1984), The Health Physics and Radiological Health Handbook, Nucleon Lectern Associates, Inc., Olney, MD.

Silver, W. J., C. L. Lindeken, J. W. Meadows, W. H. Hutchin, and D. R. McIntyre (1974), Environmental Levels of Radioactivity in the Vicinity of the Lawrence Livermore Laboratory, 1973 Annual Report, Lawrence Livermore National Laboratory, Livermore, CA (UCRL-51547).

Silver, W. J., C. L. Lindeken, J. H. White, and R. W. Buddemeir (1980), Environmental Monitoring at the Lawrence Livermore Laboratory, 1979 Annual Report, Lawrence Livermore National Laboratory, Livermore, CA (UCRL-50027-79).

Stone, R., and M. R. Ruggieri (1983), Ground-Water Quality and Movement at Lawrence Livermore National Laboratory, Lawrence Livermore National Laboratory, Livermore, CA (UCRL-53474).

Struckmeyer, R. (1994), NRC TLD Direct Radiation Monitoring Network, Progress Report, July-September, 1994, Nuclear Regulatory Commission, Washington, DC (NUREG-0837, Vol. 14, No. 3).

Surano, K. A., G. B. Hudson, R. A. Failor, J. M. Sims, R. C. Holland, S. C. MacLean, and J. C. Garrison (1991), “Helium-3 Mass Spectrometry for Low-Level Tritium Analysis of Environmental Samples," J. Radioanal. Nucl. Chem, 6, 443-453. 
Taffet, M. J., A. L. Lamarre, and W. A. McIlvride (1989a), LLNL Site 300 Environmental Investigations Quarterly, January-March 1989, Lawrence Livermore National Laboratory, Livermore, CA (UCAR-10194-89-1).

Taffet, M. J., J. A. Oberdorfer, and W. A. McIlvride (1989b), Remedial Investigation and Feasibility Study for the Lawrence Livermore National Laboratory Site 300 Pit 7 Complex, Lawrence Livermore National Laboratory, Livermore, CA (UCID-21685).

Taffet, M. J., J. R. Copland, and R. A. Ferry (1991), Draft Feasibility Study for Landfill Pit 6, Lawrence Livermore National Laboratory Site 300, Lawrence Livermore National Laboratory, Livermore, CA (UCRL-AR-106307DR).

Taffet, M. J., L. Green-Horner, L. C. Hall, T. M. Carlsen, and J. A. Orberdorfer (1996), Addendum to Site-Wide Remedial Investigation Report, Building 850/Pit 7 Complex Operable Unit, Lawrence Livermore National Laboratory Site 300, Lawrence Livermore National Laboratory, Livermore, CA (UCRL-AR-108131, Add. 1).

Tate, P., S. Brigdon, G., Gallegos, B. Balke, A. Biermann, F. Gouveia, L. Garcia, D. MacQueen, N. Hankla, S. Mathews, E. Christofferson, R. Brown, E. Brandstetter, R. Harrach, A. Grayson, B. Fields, J. Larson, R. Vellinger, R. Failor, K. Surano, W. Hoppes, P. Althouse, and B. Ward (1995), Environmental Monitoring Plan, Lawrence Livermore National Laboratory, Livermore, CA (UCRL-ID-106132 Rev. 1).

Thorpe, R. K., W. F. Isherwood, M. D. Dresen, and C. P. Webster-Scholten (1990), CERCLA Remedial Investigation Report for the LLNL Livermore Site, Vols. 1-5, Lawrence Livermore National Laboratory, Livermore, CA (UCAR-10299).

U.S. Department of Energy (1988), External Dose-Rate Conversion Factors for Calculation of Dose to the Public, U.S. Department of Energy, Washington, DC (DOE/EH-0070).

U.S. Department of Energy (1991), Environmental Regulatory Guide for Radiological Effluent Monitoring and Environmental Surveillance, U.S. Department of Energy, Washington, DC (DOE/EH-0173T).

U.S. Department of Energy (1992), Record of Decision for the Lawrence Livermore National Laboratory Livermore Site, Lawrence Livermore National Laboratory, Livermore, CA (UCRL-AR-109105). 
U.S. Department of Energy (1996a), "Addendum 2 to the Site 300 Federal Facility Agreement and Appendix A: FFA Schedule of Deliverables," Letter with enclosures to Daniel Opalski (EPA), Barbara Cook (DTSC), and William H. Crooks (Central Valley RWQCB), San Francisco Operations Office, Oakland, CA, November 15, 1996.

U.S. Department of Energy, Office of the Secretary (1996b), Pollution Prevention Program Plan, 1996, U.S. Department of Energy, Washington, DC (DOE/S-0118).

U.S. Department of Energy and University of California (1992a), Environmental Impact Statement and Environmental Impact Report Executive Summary, Lawrence Livermore National Laboratory, Livermore, CA (DOE/EIS-0157, SCH90030847).

U.S. Department of Energy and University of California (1992b), Final Environmental Impact Statement and Environmental Impact Report Executive Summary, Lawrence Livermore National Laboratory, Livermore, CA (DOE/EIS-0157).

U.S. Environmental Protection Agency (1987), Data Quality Objectives for Remedial Response Activities: Development Process, U.S. Environmental Protection Agency, Office of Emergency and Remedial Response, Washington, DC (EPA 540/G-87/003, OSWER Directive 9355-0).

U.S. Environmental Protection Agency (1991), Risk Assessment Guidance for Superfund: Volume I-Human Health Evaluation Manual (Part B, Development of Risk-based Preliminary Remediation Goals), U.S. Environmental Protection Agency, Office of Emergency and Remedial Response, Washington, DC.

U.S. Environmental Protection Agency and U.S. Department of Health and Human Services (1986), A Citizen's Guide to Radon: What It Is and What To Do About It, U.S. Environmental Protection Agency, Office of Air Public Awareness, Washington, DC (Pamphlet Number OPA 86-004).

U.S. Nuclear Regulatory Commission (1977), Calculation of Annual Doses to Man from Routine Releases of Reactor Effluent for the Purpose of Evaluation Compliance with 10 Code of Federal Regulations, Part 50, Appendix 1, Washington, DC (Regulatory Guide 1.109).

Vogele, T. J., A. Kulresthra, J. J. Nitao, and K. Lee (1996), Simulation of Soil Vapor Extraction at Building 518, Lawrence Livermore National Laboratory Livermore Site, Lawrence Livermore National Laboratory, Livermore, CA (UCRL-AR-124995). 
Webster-Scholten, C. P., and C. H. Hall (1988), Work Plan, Lawrence Livermore National Laboratory, Livermore Site: CERCLA/SARA Remedial Investigations/Feasibility Studies, Lawrence Livermore National Laboratory, Livermore, CA (UCAR-10225).

Webster-Scholten, C. P., Ed. (1994), Final Site-Wide Remedial Investigation Report, Lawrence Livermore National Laboratory Site 300, Lawrence Livermore National Laboratory, Livermore, CA (UCRL-AR-108131). 



\section{Glossary}

\section{Acronyms and Abbreviations}

A

ACEHS

Alameda County Environmental Health Services.

ACG Ambient concentration guide.

ACMT Analytical Contract Management Team.

ACOE Army Corps of Engineers.

ALARA As low as reasonably achievable.

ANOVA Analysis of variance (see Technical Terms).

ANSI American National Standards Institute.

ASME American Society of Mechanical Engineers.

AST Aboveground storage tank.

ATA Advanced Test Accelerator.

AWQC Ambient water quality criteria.

B BAAQMD Bay Area Air Quality Management District. The local agency responsible for regulating stationary air emission sources (including the Livermore site) in the San Francisco Bay Area.

BAT Best available technology.

BETX (or BTEX) Benzene, ethyl benzene, toluene, and xylene.

BMP Best management practice.

$\mathrm{Bq} \quad$ Becquerel (see Technical Terms).

C Cal/EPA California Environmental Protection Agency. 


\section{Glossary}

CAM Continuous air monitor.

CAP88-PC Computer code required by the EPA for modeling air emissions of radionuclides.

CAREs (Tri-Valley) Citizens Against a Radioactive Environment.

CCR California Code of Regulations. Codification of regulations promulgated by the State of California.

CDFG California Department of Fish and Game.

CEPRC Chemical Emergency Planning and Response Commission.

CEQA California Environmental Quality Act of 1970. CEQA requires that all California state, local, and regional agencies document, consider, and disclose to the public the environmental implications of their actions.

CERCLA/SARA Comprehensive Environmental Response, Compensation and Liability Act of 1980. Administered by EPA, this program, also known as Superfund, requires private parties to notify the EPA after the release of hazardous substances and undertake short-term removal and long-term remediation. If conditions exist that could create the threat of hazardous substances being released, the Act also requires the remediation of those conditions. In 1986, the Superfund Amendments and Reauthorization Act (SARA) was enacted, which amended and reauthorized CERCLA for five years at a total funding level of $\$ 8.5$ billion.

CES Chemistry and Materials Science Environmental Services. An LLNL laboratory that analyzes environmental samples.

CFC Chlorofluorocarbon (see Technical Terms).

CFF Contained Firing Facility.

CFR Code of Federal Regulations. A codification of all regulations promulgated by federal government agencies.

ChemTrack Computerized chemical inventory and tracking system.

CHP California Highway Patrol. 
Ci Curie (see Technical Terms).

COC Constituent of concern.

CRMP Cultural Resource Management Plan.

CRWQCB California Regional Water Quality Control Board.

CVRWQCB Central Valley Regional Water Quality Control Board.

CWG Community Work Group.

D DCG Derived Concentration Guide (see Technical Terms).

DEHP Bis(2-ethylhexyl)phthalate.

DfE Design for Environment.

DEP Diethylphthalate.

DLM Designated level methodology.

DoD U.S. Department of Defense.

DOE U.S. Department of Energy. The federal agency that is responsible for conducting energy research and regulating nuclear materials used for weapons production.

DOT U.S. Department of Transportation.

DRB Drainage Retention Basin. Man-made, lined pond used to capture storm water runoff and treated water at the Livermore site.

DTSC California Environmental Protection Agency, Department of Toxic Substances Control.

DWTF Decontamination and Waste Treatment Facility.

E EA Environmental Assessment. An environmental review document that identifies environmental impacts from any federally approved or funded project. If an EA shows significant impact, an EIS is required. 


\section{Glossary}

EDE

EDO

EEA

$\mathrm{EE} / \mathrm{CA}$

EFA

EIR

EIS

EML

EMRL

EMSL

EO

EOG

EPA

EPCRA
Effective dose equivalent (see Technical Terms).

Environmental Duty Officer.

Environmental and Exposure Assessment.

Engineering evaluation/cost analysis.

East Firing Area (LLNL Site 300).

Environmental Impact Report. A detailed report prepared pursuant to CEQA on the environmental impacts from any action carried out, approved, or funded by a California state, regional, or local agency.

Environmental Impact Statement. A detailed report, required by the National Environmental Policy Act, on the environmental impacts from a federally approved or funded project. An EIS must be prepared by a federal agency when a "major" federal action that will have "significant" environmental impacts is planned.

U.S. Department of Energy Environmental Measurements Laboratory.

Environmental Monitoring Radiation Laboratory.

Environmental Monitoring Systems Laboratory.

Executive Order.

Environmental Operations Group.

U.S. Environmental Protection Agency. The federal agency responsible for enforcing federal environmental laws. Although some of this responsibility may be delegated to state and local regulatory agencies, EPA retains oversight authority to ensure protection of human health and the environment.

Emergency Planning and Community Right-to-Know Act of 1986. EPCRA requires facilities that produce, use, or store hazardous substances to report releases of reportable quantities or hazardous substances to the environment. 
EPD Environmental Protection Department (LLNL).

EPL Effluent pollutant level.

ERD Environmental Restoration Division of the Environmental Protection Department at LLNL.

ES\&H Environmental, Safety, and Health.

EST Environmental Support Team.

EWTF Explosives Waste Treatment Facility.

F FFA Federal facility agreement. A negotiated agreement that specifies required actions at a federal facility as agreed upon by various agencies (e.g., EPA, RWQCB, and DOE).

FHC Fuel hydrocarbon.

FONSI Finding of no significant impact.

Freon 113 1,1,2-trichloro-1,2,2-trifluoroethane.

G $\mathrm{g}$ Gram. The standard metric measure of weight approximately equal to 0.035 ounce.

GAC Granulated activated carbon.

GBq Gigabecquerel. $1 \times 10^{9}$ Becquerel.

GFI Ground fault interrupt.

GSA General Services Area (LLNL Site 300).

GWP Ground Water Project.

GWPMP Ground Water Project Management Program.

GWTF Ground water treatment facility. 


\section{Glossary}

Gy

H HCAL

HCD

HDPE

HE

HEPA

HMX

HPGe

HSD

HSU

HT

HTO

HWCA

HWM

I ICRP

IQR
Gray. The SI unit of measure for absorbed dose. It is the quantity of energy imparted by ionizing radiation to a unit mass of matter such as tissue. One gray corresponds to 1 joule per kilogram and equals 100 rads.

Hazards Control Department Analytical Laboratory.

Hazards Control Department.

High density polyethylene.

High explosives. Materials that release large amounts of chemical energy when detonated.

High-efficiency particulate air (filter).

Cyclotetramethyltetramine, a high-explosive compound. Also referred to as octahydro-1,3,5,7-tetranitro-1,3,5,7-tetrazocine.

High-purity germanium.

(Tukey-Kramer) honestly significant difference (test).

Hydrostratigraphic unit.

Tritiated hydrogen gas. Tritium is the hydrogen isotope with one proton and two neutrons in the nucleus. It emits a low-energy beta particle and has a half-life of 12.3 years.

Tritiated water and water vapor (see HT).

California Hazardous Waste Control Act. This legislation specifies requirements for the management of hazardous wastes in California.

Hazardous Waste Management Division of the Environmental Protection Department at LLNL.

International Commission on Radiological Protection. An international organization that studies radiation, including its measurement and effects.

Interquartile range (see Technical Terms). 
ISD Interim status document.

ISMS Integrated safety management system.

ISO International Standards Organization.

L LBNL Lawrence Berkeley National Laboratory.

LCRS Leachate collection and removal system.

LEPC Local Emergency Planning Committee.

LLNL Lawrence Livermore National Laboratory.

LOC Letter of concern.

LOS Limit of sensitivity (detectability).

LUFT Leaking underground fuel tank.

LWRP Livermore Water Reclamation Plant. The City of Livermore's municipal wastewater treatment plant, which accepts discharges from the LLNL Livermore site.

M MAL Management action level.

MCL Maximum contaminant level in drinking water established by EPA or DTSC.

MDC Minimum detectable concentration.

MDL Minimum detection limit.

MEI Maximally exposed individual member of the public.

ML Megaliter. $10^{6}$ liters.

$\mathrm{mL} \quad$ Milliliter. $10^{-3}$ liter $=1 \mathrm{~cm}^{3}$.

MOLE Miniature Optical Lair Explorer. 


\section{Glossary}

$\mathrm{mR} \quad$ Milliroentgen. $10^{-3}$ roentgen.

mrem $\quad$ Millirem. $10^{-3}$ rem.

MSDS Material Safety Data Sheet.

mSv Millisievert. $10^{-3}$ sievert.

N NBZ

North Buffer Zone (Livermore site).

NCR

Nonconformance Report.

NCRP

National Council on Radiation Protection.

NEPA National Environmental Policy Act. This federal legislation, enacted in 1969 , requires all federal agencies to document and consider environmental impacts from federally funded or approved projects. DOE is responsible for NEPA compliance at LLNL.

NESHAPs National Emission Standards for Hazardous Air Pollutants. These standards are found in the Clean Air Act and set limits for hazardous air pollutants.

NHPA National Historical Preservation Act.

NIF National Ignition Facility.

NIST National Institute for Standards and Technology. The federal agency, formerly known as the National Bureau of Standards, responsible for reference materials against which laboratory materials are calibrated.

NOI Notice of intent.

NOV Notice of violation.

NPDES National Pollutant Discharge Elimination System. This federal regulation, under the Clean Water Act, requires permits for discharges into surface waterways. 
NRC Nuclear Regulatory Commission. The federal agency charged with oversight of nuclear power and nuclear machinery and applications not regulated by DOE or the Department of Defense.

O ORAD

Operations and Regulatory Affairs Division of the Environmental Protection Department at LLNL.

OSHA Occupational Safety and Health Act.

OSP Operational Safety Procedure.

$\mathbf{P} \quad \mathrm{P} 2$

Pollution Prevention.

PCB Polychlorinated biphenyl.

PCE Tetrachloroethylene (or perchloroethylene).

pCi Picocurie $1 \times 10^{-12} \mathrm{Ci}$.

PeerRP Peer Review Panel.

PEIS Programmatic Environmental Impact Statement.

PM Performance measure.

\%RSD Percent relative standard deviation, a measure of precision.

$\mathrm{ppb} \quad$ Parts per billion. A unit of measure for the concentration of a substance in its surrounding medium. For example, one billion grams of water containing one gram of salt has a salt concentration of one part per billion.

PPG Pollution Prevention Group of Environmental Protection Department at LLNL.

ppm Parts per million. A unit of measure for the concentration of a substance in its surrounding medium. For example, one million grams of water containing one gram of salt has a salt concentration of one part per million.

PPOA Pollution Prevention Opportunity Assessment.

PRG Preliminary remediation goal. 


\section{Glossary}

PTU

Q QA

QC

R $\quad \mathrm{R}$

RAIP

RCRA

RDX

RL

RML

RMMA

ROD

ROI

RWQCB

SARA

SDWA

SERC
Portable treatment unit.

Quality assurance.

Quality control.

Roentgen, (see Technical Terms).

Remedial Action Implementation Plan.

Resource Conservation and Recovery Act of 1976. RCRA is a program of federal laws and regulations that govern the management of hazardous wastes. RCRA is applicable to all entities that manage hazardous wastes.

Hexahydro-1,3,5-trinitro-1,3,5-triazine, a high-explosive compound.

Reporting limit.

Radiological Measurements Laboratory.

Radioactive Materials Management Area.

Record of Decision.

Return on investment.

Regional Water Quality Control Board. The California regional agency responsible for water quality standards and the enforcement of state water quality laws within its jurisdiction. California is divided into a number of RWQCBs; the Livermore site is regulated by the San Francisco Bay Region, and Site 300 is regulated by the Central Valley Region.

Superfund Amendment and Reauthorization Act of 1986 (see CERCLA/SARA).

Safe Drinking Water Act.

State Emergency Response Commission. 
SI

Site 300

SJCHD

SJCPHS

SJVUAPCD

SL

SMCL

SNL/California

SOP

SPCC

SSM

STAR

STLC

STP

SVE

SW-MEI

SWPPP
Système International d'Unités. An international system of physical units. Units of measure in this system include meters (length), kilogram (mass), kelvin (temperature), becquerel (radioactivity), gray (radioactive dose), and sievert (dose equivalent).

LLNL's Experimental Test Site, located approximately $24 \mathrm{~km}$ east of the Livermore site.

San Joaquin County Health District. The local agency that enforces underground-tank regulations in San Joaquin County, including Site 300.

San Joaquin County Public Health Services.

San Joaquin Valley Unified Air Pollution Control District. The local agency responsible for regulating stationary air emission sources (including Site 300) in San Joaquin County.

Statistical limit.

Secondary maximum contaminant level.

Sandia National Laboratories, California.

Standard operating procedure.

Spill Prevention Control and Countermeasures (Plans).

Stockpile Stewardship and Management.

Sample tracking and receiving (computer system).

Soluble threshold limit concentration. A value that can be used to determine if a waste is hazardous.

Site Treatment Plan.

Soil vapor extraction.

Sitewide maximally exposed individual member of the public.

Storm Water Pollution Prevention Plan. 


\section{Glossary}

SWRCB California State Water Resources Control Board.

TBOS Tetrabutyl orthosilicate.

TBq Terabecquerel. $1 \times 10^{12}$ Becquerel.

TCE Trichloroethylene.

TCLP Toxicity Characteristic Leaching Procedure.

TDS Total dissolved solids. The portion of solid material in a waste stream that is dissolved and passed through a filter.

THM Trihalomethane.

TLD Thermoluminescent dosimeter. A device used to measure external beta or gamma radiation levels. TLDs contain a material that after exposure to beta or gamma radiation emits light when processed and heated.

TNT Trinitrotoluene.

TOC Total organic carbon. The sum of the organic material present in a sample.

TOX Total organic halides. The sum of the organic halides present in a sample.

TRI Toxic Chemical Release Inventory.

TRU Transuranic waste.

TSDF Treatment, storage, and disposal facility.

TSS Total suspended solids.

TTLC Total threshold limit concentration. A value that can be used to determine if a waste is hazardous.

TWMS Total Waste Management System.

U UC University of California.

USEPA U.S. Environmental Protection Agency. 
UST Underground storage tank.

VOC Volatile organic compound. Liquid or solid organic compounds that have a high vapor pressure at normal pressures and temperatures and thus tend to spontaneously pass into the vapor state.

VPP Voluntary Protection Program.

W WAA Waste accumulation area. An officially designated area that meets current environmental standards and guidelines for temporary (less than 90 days) storage of hazardous waste before pickup by the Hazardous Waste Management Division for off-site disposal.

WDR Waste Discharge Requirements. Issued by the California Regional Water Quality Control Board.

WFA West Firing Area (LLNL Site 300).

WQO Water quality objective.

WSS Work Smart Standards.

WTF Working Task Force.

\section{Technical Terms}

A Absorbed dose

The amount of energy deposited by radiation in a given amount of material. The units of absorbed dose are the rad or gray.

Accuracy The closeness of the result of a measurement to the true value of the quantity measured.

Action Level Defined by regulatory agencies, it is the level of pollutants which, if exceeded, requires regulatory action.

Aerosol

A gaseous suspension of very small particles of liquid or solid.

Alluvium Sediment deposited by flowing water. 


\section{Glossary}

Alpha particle A positively charged particle emitted from the nucleus of an atom. It has a mass and charge equal to those of a helium nucleus (two protons and two neutrons).

Ambient air The surrounding atmosphere, usually the outside air, as it exists around people, plants, and structures. It is not considered to include the air immediately adjacent to emission sources.

Analyte A constituent that is being analyzed.

Anion A negatively charged ion, for example $\mathrm{Cl}^{-}$.

ANOVA Analysis of variance. A test of whether two or more sample means are statistically different.

Aquifer A saturated layer of rock or soil below the ground surface that can supply usable quantities of ground water to wells and springs. Aquifers can be a source of water for domestic, agricultural, and industrial uses.

Aquitard Low permeability bed that bounds an aquifer.

Atom The smallest particle of an element capable of entering into a chemical reaction.

Atomic absorption Abbreviated AA. A method used to determine the elemental spectroscopy composition of a sample. In this method, the sample is vaporized and its light absorbance measured.

B Barcad Device that samples water in a well. Water, collected in a discrete water bearing zone, is forced to the surface by pressurized nitrogen.

$\mathrm{Bq} \quad$ Becquerel. The SI unit of activity of a radionuclide, equal to the activity of a radionuclide having one spontaneous nuclear transition per second.

Beta particle A negatively charged particle emitted from the nucleus of an atom. It has a mass and charge equal to those of an electron.

Biochemical A measure of the amount of dissolved oxygen that microorganisms need (biological) oxygen to break down organic matter in water. It is used as an indicator of water demand quality. 
C Categorical

discharge

CFC

Chain-of-custody

Chlorocarbon

Curie

Collective dose equivalent

Collective effective dose equivalent

Committed dose equivalent

Committed effective dose equivalent

Cosmic radiation

D Daughter nuclide
Discharge from a process regulated by EPA rules for specific industrial categories.

Chlorofluorocarbon. A compound that has fluorine and chlorine atoms on a carbon backbone. Freons are common CFCs.

A method for documenting the history and possession of a sample from the time of its collection, through its analysis and data reporting, to its final disposition.

A compound of carbon and chlorine, or carbon, hydrogen, and chlorine, such as carbon tetrachloride, chloroform, and tetrachloroethylene.

A unit of measurement of radioactivity, defined as the amount of radioactive material in which the decay rate is $2.22 \times 10^{12}$ disintegrations per minute $\left(3.7 \times 10^{10}\right.$ disintegrations per second). One $\mathrm{Ci}$ is approximately equal to the decay rate of one gram of pure radium.

The sums of the dose equivalents of all individuals in an exposed population within a certain radius, expressed in units of person-rem (or person-sievert).

The sums of the effective dose equivalents of all individuals in an exposed population within a certain radius, expressed in units of personrem (or person-sievert).

The predicted total dose equivalent to a tissue or organ over a 50-year period after known intake of a radionuclide into the body. It does not include contributions from external dose. Committed dose equivalent is expressed in units of sievert (or rem).

The sum of the committed dose equivalents to various tissues, each multiplied by the appropriate weighting factor. Committed effective dose equivalent is expressed in units of sievert (or rem).

Radiation with very high energies, originating outside the earth's atmosphere. Cosmic radiation is one source contributing to natural background radiation.

A nuclide formed by the radioactive decay of another nuclide, which is called the parent. 


\section{Glossary}

Depleted uranium Uranium having less ${ }^{235} \mathrm{U}$ than is found in natural uranium.

DCG Derived Concentration Guide. Concentrations of radionuclides in water and air that could be continuously consumed or inhaled (365 days/y) and not exceed the DOE primary radiation protection standard to the public (100 mrem/y effective dose equivalent).

Dose

The energy imparted to matter by ionizing radiation. The unit of absorbed dose is the rad, equal to 0.01 joules per kilogram for irradiated material in any medium.

Dose commitment The dose which an organ or tissue would receive during a specified period of time (e.g., 50 or 70 years) as a result of 1 year's intake of one or more radionuclides.

Dose equivalent The product of the absorbed dose (rad) in tissue and a quality factor. Dose equivalent is expressed in units of rem (or sievert). The dose equivalent to an organ, tissue, or whole body in a year will be that received from the direct exposure plus the committed dose equivalent received from radionuclides taken into the body during the year.

Dosimeter

A portable detection device for measuring the total accumulated exposure to ionizing radiation.

Dosimetry

The theory and application of the principles and techniques involved in the measurement and recording of radiation doses. Its practical aspect is concerned with the use of various types of radiation measurement instruments.

Downgradient In the direction of ground water flow from a designated area; analogous to downstream.

E EDE

Effective dose equivalent. An estimate of the total risk of potential effects from radiation exposure. It is the sum of the committed effective dose equivalent from internal deposition and the effective dose equivalent from external penetrating radiation received during a calendar year. The committed effective dose equivalent is the sum of the individual organ committed dose equivalents multiplied by weighting factors that represent the proportion of the total random risk that each organ would receive from uniform irradiation of the whole body. 
Effluent A liquid or gaseous waste discharged to the environment.

Evapotranspiration Process by which water is transferred from the soil to the air by plants that take the water up through their roots and give it off through their leaves and other aboveground tissue.

F Federal facility A facility that is owned or operated by the federal government. Federal facilities are subject to the same requirements as other responsible parties once placed on the Superfund National Priorities List.

Federal Register A document published daily by the federal government containing notification of government agency actions. The Federal Register contains notification of EPA and DOE actions, including notification of EPA and DOE decisions concerning permit applications and rule-making.

G Gamma ray

High-energy, short-wavelength electromagnetic radiation emitted from the nucleus of an atom. Gamma radiation frequently accompanies the emission of alpha or beta particles.

Ground water All subsurface water.

H Half-life (radiological)

The time required for one-half the radioactive atoms in a given amount of material to decay. After 1 half-life, 50 out of 100 atoms (on average) will have decayed; during the next half-life, 25 more will decay, and so on, exponentially.

Hazardous waste Wastes exhibiting any of the following characteristics: ignitability, corrosivity, reactivity, or EP-toxicity (yielding toxic constituents in a leaching test). In addition, EPA has listed as hazardous other wastes that do not necessarily exhibit these characteristics. Although the legal definition of hazardous waste is complex, the term more generally refers to any waste that EPA believes could pose a threat to human health and the environment if managed improperly.

Hydraulic gradient In an aquifer, the rate of change of total head (water-level elevation) per unit distance of flow at a given point and in a given direction.

Hydrology The science dealing with the properties, distribution, and circulation of natural water systems. 


\section{Glossary}

I Inorganic compounds

In situ

Interim status

IQR

Isotopes

L Liter

Less than detection limits

Low-level waste

Lower limit of detection

Lysimeter

M Mixed waste
Compounds that either do not contain carbon or do not contain hydrogen along with carbon. Inorganic compounds include metals, salts, and various carbon oxides (carbon monoxide, carbon dioxide).

A term that can be used to refer to the treatment of contaminated areas in place, i.e., without excavation or other removal, as in the in situ treatment of soils through biodegradation of contaminants on site.

A legal classification that applies to hazardous waste incinerators or other hazardous waste management facilities that were under construction or in operation by November 19,1980, and can meet other interim status requirements. Interim status facilities may operate while EPA considers their permit application.

Interquartile range. The distance between the top of the lower quartile and the bottom of the upper quartile. The IQR provides a measure of the spread of data.

Forms of an element having the same number of protons in their nuclei but differing numbers of neutrons.

The SI measure of capacity approximately equal to 1.057 quart.

A phrase indicating that a chemical constituent was either not identified or not quantified at the lowest level of sensitivity of the analytical method being employed by the laboratory. Therefore, the chemical constituent either is not present in the sample, or it is present in such a small concentration that it cannot be measured by the analytical procedure.

Waste defined by DOE Order 5820.2A. Low-level waste contains transuranic nuclide concentrations less than $100 \mathrm{nCi} / \mathrm{g}$.

The smallest concentration or amount of analyte that can be detected in a sample at a $95 \%$ confidence level.

An instrument for measuring the water percolating through soils and determining the dissolved materials.

Waste that has the properties of both hazardous and radioactive waste. 
N Nonpoint source

Nuclide

O Off site

On site

P Part B permit

Perched aquifer

Performance standards (incinerators)

Piezometer

Pliocene

$\mathrm{pH}$

Point source

Pretreatment
Any nonconfined area from which pollutants are discharged into a body of water (e.g., agricultural runoff, construction runoff, and parking-lot drainage), or into air (e.g., a pile of uranium tailings).

A species of atom characterized by the constitution of its nucleus. The nuclear constitution is specified by the number of protons, number of neutrons, and energy content; or, alternatively, by the atomic number, mass number, and atomic mass. To be regarded as a distinct nuclide, the atom must be capable of existing for a measurable length of time.

Outside the boundaries of the LLNL Livermore site and Site 300 properties.

Within the boundaries of the LLNL Livermore site or Site 300 properties.

The second, narrative section submitted by generators in the RCRA permitting process. It covers in detail the procedures followed at a facility to protect human health and the environment.

Aquifer that is separated from another water-bearing stratum by an impermeable layer.

Specific regulatory requirements established by EPA limiting the concentrations of designated organic compounds, particulate matter, and hydrogen chloride in incinerator emissions.

Instrument for measuring fluid pressure. Generally used to measure the elevation of the water table in a small, nonpumping well.

Geological epoch of the Tertiary period, starting about 12 million years ago.

A measure of hydrogen-ion concentration in an aqueous solution. Acidic solutions have a $\mathrm{pH}$ from 0 to 6 , basic solutions have a $\mathrm{pH}$ greater than 7 , and neutral solutions have a $\mathrm{pH}$ of 7 .

Any confined and discrete conveyance (e.g., pipe, ditch, well, or stack).

Any process used to reduce a pollutant load before it enters the sewer system. 


\section{Glossary}

Pretreatment regulations

Priority pollutants

Q QA

QC

Quality factor

Quaternary

R $\quad \operatorname{Rad}$

Radioactivity

Radionuclide

Rem
National wastewater pretreatment regulations, adopted by EPA in compliance with the 1977 amendments to the Clean Water Act, which required that EPA establish pretreatment standards for existing and new industrial sources.

A set of organic and inorganic chemicals identified by EPA as indicators of environmental contamination.

Quality assurance. A system of activities whose purpose is to provide the producer or user of a product or service the assurance that it meets defined standards of quality with a stated level of confidence.

Quality control. Procedures used to verify that prescribed standards of performance are attained.

The factor by which the absorbed dose (rad) is multiplied to obtain a quantity that expresses, on a common scale for all ionizing radiation, the biological damage to exposed persons. It is used because some types of radiation, such as alpha particles, are more biologically damaging than others.

The geologic era encompassing the last 2-3 million years.

The unit of absorbed dose. It is the quantity of energy imparted by ionizing radiation to a unit mass of matter such as tissue. One rad equals 0.01 joule per kilogram.

Radioactive decay The spontaneous transformation of one radionuclide into a different radioactive or nonradioactive nuclide, or into a different energy state of the same radionuclide.

The spontaneous emission of radiation, generally alpha or beta particles, or gamma rays, from the nucleus of an unstable isotope.

An unstable nuclide. See nuclide and radioactivity.

A unit of radiation dose equivalent. The product of the absorbed dose $(\mathrm{rad})$, quality factor $(\mathrm{Q})$, distribution factor, and other necessary modifying factors. It describes the effectiveness of a type of radiation to produce biological effects ( 1 rem $=0.01$ sievert). 
Risk assessment

Roentgen

S Sampling and Analysis Plan

Sanitary waste

Saturated zone

Sensitivity

Sewerage

Sievert (Sv)

Specific conductance

Superfund
The use of established methods to measure the risks posed by an activity such as hazardous waste treatment. Risk assessments evaluate (1) the relationship between exposure to toxic substances and the subsequent occurrence of health effects and (2) the potential for that exposure.

Unit of measurement used to express radiation exposure in terms of the amount of ionization produced in a volume of air.

A detailed document describing the procedures used to collect, handle, and analyze ground water samples. The plan details quality control measures that will be implemented to ensure that sample-collection, analysis, and data-presentation activities meet the prescribed requirements.

Most simply, waste generated by routine operations that is not regulated as hazardous or radioactive by state or federal agencies.

A subsurface zone below which all rock pore-space is filled with water; also called the phreatic zone.

The capability of methodology or instrumentation to discriminate between samples having differing concentrations or containing varying amounts of analyte.

The system of sewers.

A unit of radiation dose equivalent and effective dose equivalent. It describes the ability of a type of radiation to produce biological effects. A sievert is the SI unit that corresponds to the rem; $1 \mathrm{~Sv}=100 \mathrm{rem}$.

Measure of the ability of a material to conduct electricity. Also called conductivity.

The common name used for the Comprehensive Environmental Response, Compensation and Liability Act of 1980 (CERCLA). California has also established a "State Superfund" under provisions of the California Hazardous Waste Control Act. 


\section{Glossary}

Surface

impoundment

T Tritium

Transuranic waste

Material contaminated with alpha-emitting transuranium nuclides, which have an atomic number greater than 92 (e.g. ${ }^{239} \mathrm{Pu}$ ), half-lives longer than 20 years, and are present in concentrations greater than $100 \mathrm{nCi} / \mathrm{g}$ of waste.

U Unsaturated zone

V Vadose zone

W Wastewater treatment system

Water table

Weighting factor

Wind rose

A facility or part of a facility that is a natural topographic depression, man-made excavation, or diked area formed primarily of earthen materials, although it may be lined with man-made materials. The impoundment is designed to hold an accumulation of liquid wastes, or wastes containing free liquids, and is not an injection well. Examples of surface impoundments are holding, storage, settling and aeration pits, ponds, and lagoons.

Tritium is the hydrogen isotope with one proton and two neutrons in the nucleus. It emits a low-energy beta particle and has a half-life of 12.3 years.

That portion of the subsurface in which the pores are only partially filled with water. The direction of water flow is vertical in this zone; which is also referred to as the vadose zone.

The partially saturated or unsaturated region above the water table that does not yield water to wells.

A collection of treatment processes and facilities designed and built to reduce the amount of suspended solids, bacteria, oxygen-demanding materials, and chemical constituents in wastewater.

The water-level surface below the ground at which the unsaturated zone ends and the saturated zone begins. It is the level to which a well that is screened in the unconfined aquifer would fill with water.

A value used to calculate dose equivalents. It is tissue-specific and represents the fraction of the total health risk resulting from uniform, whole-body irradiation that could be contributed to that particular tissue. The weighting factors used in this report are recommended by the ICRP (Publication 26).

A diagram that shows the frequency and intensity of wind from different directions at a particular place. 
Z Z Zone 7

The common name for the Alameda County Flood Control and Water Conservation District. Zone 7 is the water management agency for the Livermore-Amador Valley with responsibility for water treatment and distribution. Zone 7 is also responsible for management of agricultural and surface water and the ground water basin. 



\section{External Distribution}

Air Resources Board

J. Morgester

Compliance Division

P.O. Box 2815

Sacramento, CA 95812

Alameda County Department of Environmental Health

Robert Weston

Environmental Protection Division

1131 Harbor Bay Parkway, 2nd Floor

Alameda, CA 94502

Alameda County Flood Control and Water

Conservation District, Zone 7

David Lunn

5997 Parkside Drive

Pleasanton, CA 94566

Alameda County Water District

E. L. Lenahan

43885 S. Grimmer Blvd.

Fremont, CA 94537

Argonne National Laboratory

Norbert Golchert

9700 S. Cass Avenue

Building 200, Room B-117

Argonne, IL 60439

Argonne National Laboratory

Michael Lazaro

9700 S. Cass Avenue

Building 200, Room B-900

Argonne, IL 60439

Assistant Administrator for Air Radiation

(ANR-443)

U.S. Environmental Protection Agency

401 "M" Street, S.W.

Washington, DC 20460
Association of Bay Area Governments

T. Bursztynsky

P.O. Box 2050

Oakland, CA 94604

Bay Area Air Quality

Management District

Milton Feldstein

939 Ellis Street

San Francisco, CA 94109

Biomedical \& Environmental

Sciences Lab

Dr. O.R. Lunt, Director

University of California

900 Veteran Avenue

Los Angeles, CA 90024

Brookhaven National Laboratory

Robert Miltenberger

G. L. Schroeder

Bldg. 535A

Upton, NY 11973

Brookhaven National Laboratory

J. Naidu

Safety \& Environmental Protection

Bldg. 535A

Upton, NY 11973

California Department of Energy

Barbara J. Byron

Executive Office

1515 - 9th Street/MS-36

Sacramento, CA 95814 


\section{External Distribution}

California Department of Health Services

Dorice Bailey

Edgar D. Bailey

K. Jackson

DHS/EMB, MS-178

601 N. 7th Street, Box 942732

Sacramento, CA 95814

California Environmental

Protection Agency

C. Williams

Department of Toxic Substances Control

700 Heinz Avenue, Bldg. F

Berkeley, CA 94710

California Environmental

Protection Agency

Robert Feather

Department of Toxic Substances Control,

Region 2

700 Heinz Avenue, Suite 200

Berkeley, CA 94710-2737

California Regional Water Quality Control

Board

S. Timm

Central Valley Region

3443 Routier Road

Sacramento, CA 95827-3098

California Regional Water Quality Control

Board

M. Bessette

L. Barsamian

San Francisco Bay Region

2101 Webster Street \#500

Oakland, CA 94612

California State Water Resources Control Board

W. Pettit

J. Diaz, Chief

Division of Water Quality

901 "P" Street

Sacramento, CA 95814
CDM Federal

Christina Thelen

2301 Buena Vista SE

Albuquerque, NM 87106

Continuous Electron Beam

Accelerator Facility

Bob May

Radiation Control

12000 Jefferson Avenue

Newport News, VA 23606

Chow Engineering

Sam Kreitem

770 Edgewater Dr., \#729

Oakland, CA 94621

EG \& G Mound Applied Technologies

Daniel G. Carfagno

P.O. Box 3000

Miamisburg, OH 45343

EG \& G Rocky Flats, Inc.

Keith Anderson

Environmental Operations

P.O. Box 464

Golden, CO 80402-0464

EG \& G Rocky Flats, Inc.

Catherine Madore

Environmental Protection

Management

P.O. Box 464

Golden, CO 80402-0464

EG\&G Rocky Flats, Inc.

Laura Tyler

RMRS/ Document Services

P.O. Box 464

Golden, CO 80402

EG\&G Rocky Flats, Inc.

Joan Novy

RMRS/Technical Publications

P.O. Box 464

Golden, CO 80402-0464 
EG\&G Rocky Flats, Inc.

George H. Setlock

P.O. Box 464

Golden, CO 80402-0464

Environmental Measurements Lab

Edward P. Hardy, Jr., Director

Environmental Studies Division

U.S. Department of Energy

376 Hudson Street

New York, NY 10014-3621

FERMCO

P. A. Kraps

Allan Lydic

Xenos J. Sroka

Site Restoration Services

P.O. Box 538704

Cincinnati, $\mathrm{OH}$ 45253-8704

FERMCO

Caran Siefert

Environmental Protection

P.O. Box 538704

Cincinnati, $\mathrm{OH}$ 45253-8704

Fermilab

Sam Baker

Paul Kesich

P.O. Box 500, MS-119

Batavia, IL 60510

Hanford Environmental Health Foundation Joseph K. Samuels

Environmental Health Services

P.O. Box 100, H1-78

Richland, WA 99352

Lawrence Berkeley Laboratory

David Balgobin

Ron Pauer

Environmental Monitoring Group

One Cyclotron Road, MS-E75B

Berkeley, CA 94720
Lawrence Berkeley Laboratory

Henry Tran, MS - B75B-101

University of California

One Cyclotron Road

Berkeley, CA 94720

Livermore Water Reclamation Plant

W. Adams

101 West Jack London Blvd.

Livermore, CA 94550

Lockheed Idaho Technologies Co.

Leah Street

Environmental Protection

P.O. Box 1625

Idaho Falls, ID 83415-4110

Los Alamos National Laboratory

Tom Buhl

Doris Garvey

Environmental Assessments and Resource

Evaluation

Section HSE-8, MS-K490

Los Alamos, NM 87545

Los Alamos National Laboratory

Bruce Gallahar

Steven Rae

ESH Division

MS-K497, ESH-18

P.O. Box 1663

Los Alamos, NM 87545

Los Alamos National Laboratory

Keith Jacobson

Air Quality Division

P.O. Box 1663, ESH-17, MS-J978

Los Alamos, NM 87544

Los Alamos National Laboratory

Julie Johnston

Environment, Safety, \& Health Div.

P.O. Box 1663, ESH-20, MS-M887

Los Alamos, NM 87545 


\section{External Distribution}

Los Alamos National Laboratory John M. Puckett, Division Leader Health Safety \& Environmental Div. University of California P.O. Box 1663

Los Alamos, NM 87545

Los Alamos National Laboratory Lars Soholt

Environmental Surveillance Group MS-K490

P.O. Box 1663

Los Alamos, NM 87545

Mountain Environmental

Dr. Katherine Hunninen

P.O. Box 1010

Silver Plume, CO 80476

Nevada Operations Office

Bruce W. Church

Asst. Manager for Environment, Safety and Health

P.O. Box 98518

Las Vegas, NV 89193-8518

Oak Ridge National Laboratory

Frank O'Donnell

Building 4500 S., MS-6102

Oak Ridge, TN 37831-6102

Oak Ridge National Laboratory

John B. Murphy

Head, Environmental Surveillance

and Protection Section

Building 4500N, MS-6198

Oak Ridge, TN 37831-6198

Oak Ridge National Laboratory

Laury Hamilton

Building 4500S, MS-6137

Oak Ridge, TN 37831-6137
Oakridge National Laboratory

Mark Tardiff

Office of Environmental Compliance and

Documentation

Building 4500N, MS-6198

Oak Ridge, TN 37831-6198

Pacific Northwest Laboratory

W. W. Laity, General Manager

Environmental Mgmt. Operations

Battelle Blvd.

P.O. Box 999

Richland, WA 99352

Pacific Northwest Laboratory

P. Evan Dresel

Stuart Luttrell

Earth and Environmental Sciences

P.O. Box 999

Richland, WA 99352

Pacific Northwest Laboratory

Richard Jaquish

Office of Health and Environment

P.O. Box 999

Richland, WA 99352

Radiobiology \& Environmental

Health Laboratory

Dr. Sheldon Wolff, Director

University of California

Medical Center

San Francisco, CA 94143

REECO

Stuart C. Black

Health Physics Department

P.O. Box 98521, MS-708

Las Vegas, NV 89193-8521

REECO

Wayne M. Glines

Alan Latham

Analytical Services Department

P.O. Box 98521

Las Vegas, NV 89193-8521 
San Joaquin Valley Unified Air Pollution

Control District

Anthony Mendes

Engineering Manager

4230 Kiernan Avenue, Suite 130

Modesto, CA 95356

Sandia National Laboratories

H.S. Hwang

F. Ghanbari

Lih-Jenn Shyr

Dept. 7575

P.O. Box 5800, MS-1311

Albuquerque, NM 87185

Sandia National Laboratories

Marion McDonald

Dept. 6500, MS-1143

P.O. Box 5800

Albuquerque, NM 87185

Sandia National Laboratories, California

Tricia Larson

P.O. Box 969

Livermore, CA 94551-0969

Sandia National Laboratories, California

D. Brekke

P.O. Box 969, MS-9222

Livermore, CA 94551

San Joaquin County Public Health Services

Donna Heran, Director

Environmental Health Division

P.O. Box 388

Stockton, CA 95201

San Joaquin Local Health District

V. V. Williams

P.O. Box 388

Stockton, CA 95201
Savannah River Plant

Dennis Stevenson, Chief Supervisor,

Tim Jannic

Health Protection Department

Building 735A

Aiken, SC 29808

Robert L. Schlegel

12321 Tampico Way

Silver Spring, MD 20904

Stanford Linear Accelerator Center

Michael P. Grissom

ESH, MS-84

2575 Sand Hill Road

Menlo Park, CA 94025-7015

Stanford University

H. Gusterson

Anthropology Department

Stanford, CA 94305

TetraTech, Inc.

John Nash

5203 Leesburg Pike, Suite 900

Falls Church, VA 22041

U.S. Department of Energy

Brookhaven Area Office

Gerald Granzen

Environmental Programs Division

Bldg. 464

Upton, NY 11973-5000

U.S. Department of Energy

Eddie Chew

785 Department of Energy Place

Idaho Falls, ID 83401-4149

U.S. Department of Energy

Office of Scientific \& Technical Information

P.O. Box 62

Oak Ridge, TN 37831 


\section{External Distribution}

U.S. Department of Energy

Rocky Flats Area Office

James K. Hartmen

Environmental Program Branch

P.O. Box 928

Golden, CO 80402-0928

U.S. Department of Energy

Rocky Flats, Site Support Division

Brent Evans

P.O. Box 928, Bldg. T115A

Golden, CO 80402-0928

U.S. Environmental Protection Agency

S. Rosenblum, AIR-6

P. Wood, AIR-6

Region IX

75 Hawthorne Street

San Francisco, CA 94105

U.S. Environmental Protection Agency

K. Silva, WTR-7

M. Gill, SFD-8

Region IX

75 Hawthorne Street

San Francisco, CA 94105

West Valley Nuclear Services Co., Inc.

Anthony Nagel

Environmental, Safety, Health

and Quality Assurance

10282 Rock Springs Road

P.O. Box 191

West Valley, NY 14171-0191

Westinghouse Hanford Co.

Austin R. Johnson

P.O. Box 1970, H6-30

Richland, WA 99352

Westinghouse Savannah River Co.

James Heffner

Pete Fledderman

Environmental Protection

P.O. Box 616, Bldg. 735A

Aiken, SC 29802 


\section{Environmental Report \\ Reader Survey}

To Our Readers:

Each annual Environmental Report publishes the results of environmental monitoring at the Lawrence Livermore National Laboratory and documents our compliance with environmental regulations. In providing this information, our goal is to give our readership-whether they be regulators, scientists, or the public-a clear accounting of the range of environmental activities we undertake, the methods we employ, and the degree of accuracy of our results.

It is important that the information we provide is easily understood, is of interest, and communicates LLNL's effort to protect human health and the environment. We would like to know from you, our readers, whether we are successful in these goals. Your comments are welcome.

1. Is the technical level $\square$ too high? $\square$ too low? $\square$ uneven? $\square$ just right?

2. Is the writing $\square$ too concise? $\square$ too verbose? $\square$ uneven? $\square$ just right?

3. Do the illustrations help you understand the text better?

Are there enough?

Too few?

Too many?

4. Is the background information sufficient?

5. Are the methodologies being described understandable? Interesting?

6. Are the glossaries and appendices useful?

7. Are the data tables of interest?

Would you prefer short summaries of data trends instead?

Other comments:

A business reply envelope has been attached for returning these surveys to the Laboratory. Laboratory staff may simply send their survey forms through Lab mail to Bob Harrach, L-629.

OPTIONAL

Name: Occupation:

Address: 




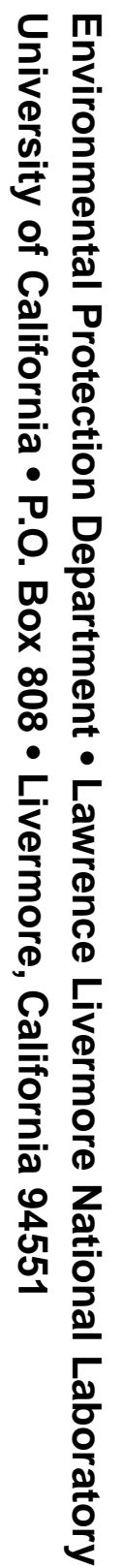

